\title{
E-BOOK
}

\section{EDUCAÇÃO NA CONTEMPORANEIDADE}

Organizadores

Luciano Luan Comes Paiva

Dayana Lúcia Rodrigues de Freitas

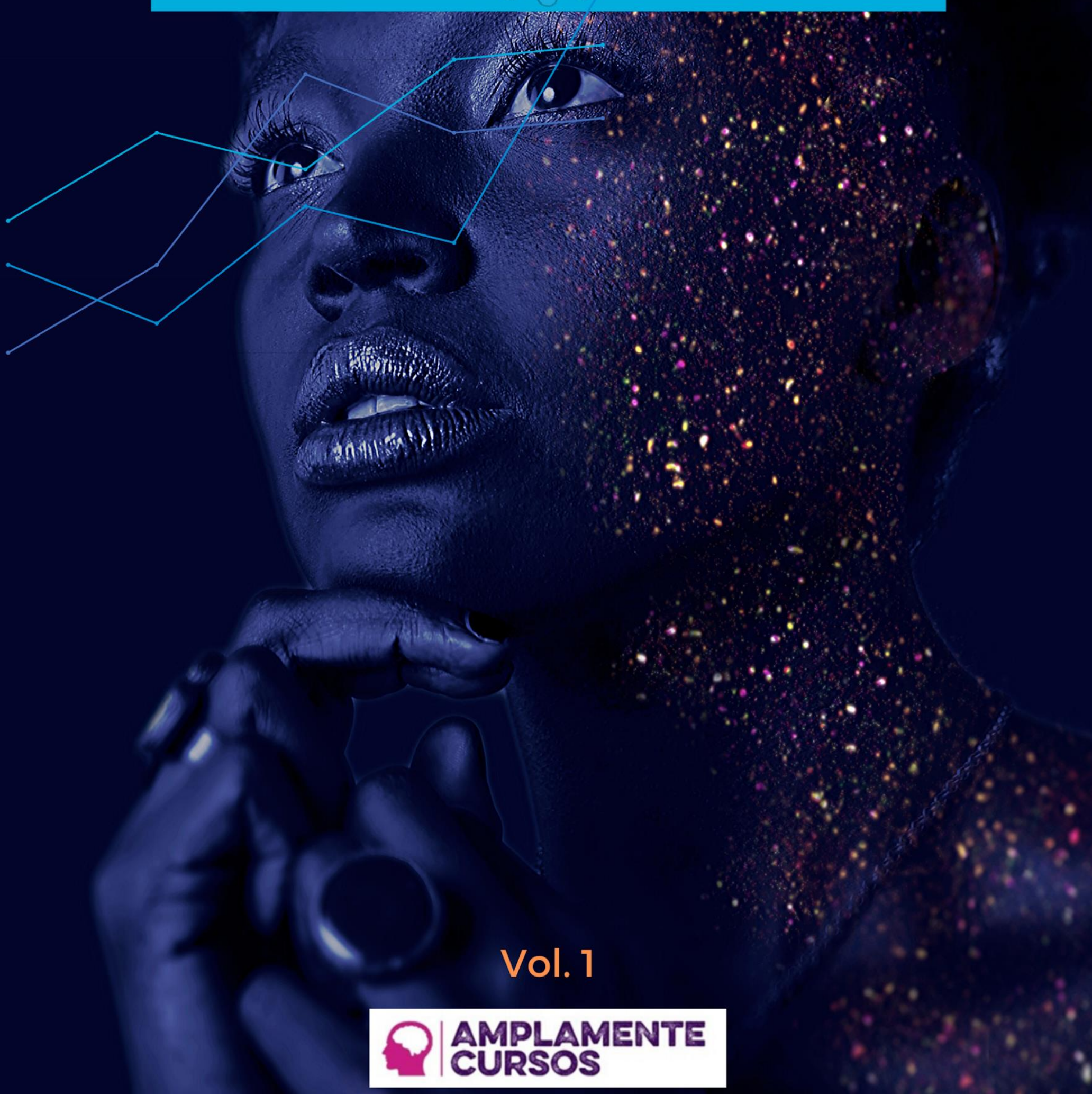




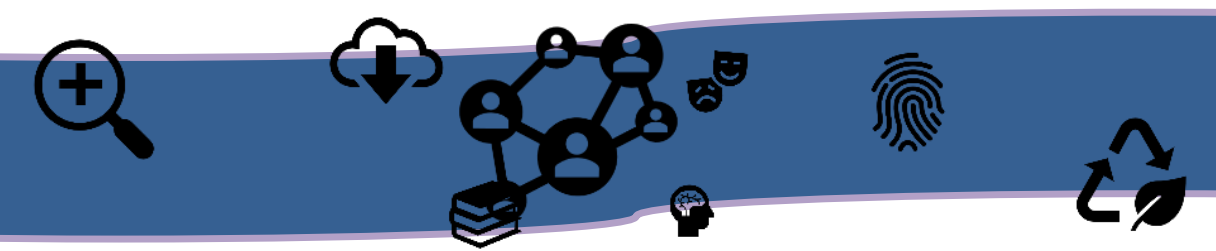

E-BOOK

$1^{a}$ Edição. Volume 01.

AMPLAMENTE: EDUCAÇÃO NA CONTEMPORANEIDADE

\author{
ORGANIZADORES \\ Luciano Luan Gomes Paiva \\ Dayana Lúcia Rodrigues de Freitas
}

COLABORADORA

Caroline Rodrigues de Freitas Fernandes

AMPLAMENTE CURSOS

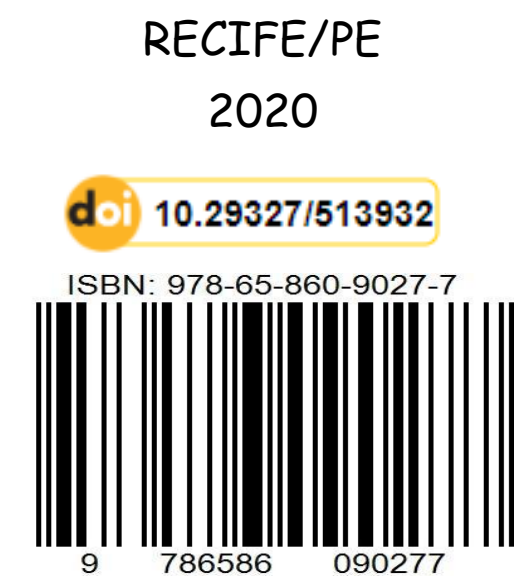


Dados Internacionais de Catalogação na Publicação (CIP) (Even3 Publicaç̃es, PE, Brasil)

A526 Amplamente: Educação na Contemporaneidade / Luciano Luan Gomes Paiva e Dayana Lucia Rodrigues de Freitas. - Vol. 1 - 1. ed. - Recife: Even3 Publicações, 2020.

1 livro digital ; $399 \mathrm{p}$.

Bibliografia.

ISBN: 978-65-86090-27-7

DOI: $10.29327 / 513932$

1. Educação. 2. Formação de Professores. 3. Pesquisa em Educação,

\section{Título}




\title{
- Amplamente Cursos e Formação Continuada
}

$1^{a}$ Edição. Volume 01. (E-BOOK)

\author{
Capa/Projeto gráfico \\ Luciano Luan Gomes Paiva \\ Dayana Lúcia Rodrigues de Freitas
}

\begin{abstract}
E-BOOK (online)
Este e-book possui textos nacionais e internacionais. Todos os direitos reservados. Partes desta obra podem ser utilizadas ou reproduzidas desde que sejam devidamente citadas e referenciadas. Cada autor é inteiramente responsável por seu(s) respectivo(s) texto(s), isentando a Amplamente Cursos e Formação Continuada de qualquer problema ou erro.
\end{abstract}

Editado por: Amplamente Cursos e Formação Continuada

ISBN: $978-65-860-9027-7$

$10.29327 / 513932$

Amplamente Cursos e Formação Continuada

CNPJ: 35.719.570/0001-10

Tel.: (84) 99707-2900 


\section{SUMÁRIO}

APRESENTAÇÃO. 6

A CONTRIBUIÇÃO DA TEORIA DA APRENDIZAGEM SIGNIFICATIVA NA CONSTRUÇÃO DO JOGO 'TABULEIRO DAS COMPETÊNCIAS SOCIAIS' PARA CRIANÇAS DE 9 A 11 ANOS.

A DEFICIÊNCIA INTELECTUAL NA EDUCAÇÃO INFANTIL: O DESAFIO DA INCLUSÃO.

A DISCIPLINA DE INTRODUÇÃO À LOGÍSTICA NAVAL NA FORMAÇÃO SUPERIOR DA MARINHA: CAMINHOS INICIAIS...

A FAMÍLIA E A ESCOLA: CONDICIONAMENTO DE RELAÇÕES PARA UMA INTEGRAÇÃO PEDAGÓGICA DE SUCESSO NA EDUCAÇÃO INFANTIL .......... 49

A IMPORTÂNCIA DA ATUAÇÃO DOS PROFESSORES NA EDUCAÇÃO INFANTIL.

A IMPORTÂNCIA DA PRÁTICA DE CONJUNTO NA ESCOLA ESPECIALIZADA EM MÚSICA. 74

A IMPORTÂNCIA DE CONHECER O NIM. 90

A IMPORTÂNCIA DO AEE PARA UMA EDUCAÇÃO INCLUSIVA 101

A MONITORIA ACADÊMICA COMO UM INSTRUMENTO DE FORMAÇÃO DOCENTE E PROFISSIONAL NA DISCIPLINA DE METODOLOGIA DO ENSINO DE CIÊNCIAS . 109

ABORDAGENS DIFERENCIADAS NO ENSINO FUNDAMENTAL: O PAPEL DO PROFESSOR NA RELAÇÃO COM O ALUNO. 122

ACESSIBILIDADE E INCLUSÃO DE CRIANÇAS COM DEFICIÊNCIA FÍSICA NAS ESCOLAS: COMO ACONTECE? 132

AS CONSEQUÊNCIAS DA AGRESSIVIDADE FAMILIAR NA EDUCAÇÃO ESCOLAR DOS FILHOS NOS ANOS INICIAIS

AS INTERVENÇÕES PSICOPEDAGÓGICAS PARA A SUPERAÇÃO DAS DIFICULDADES DE APRENDIZAGEM NAS SÉRIES INICIAIS . 158

AUTISMO, MEDIAÇÃO ESCOLAR, FORMAÇÃO DOCENTE E FAMÍLIA PARTICIPATIVA: UM OLHAR VOLTADO PARA AS POLÍTICAS PÚBLICAS QUANTO À INCLUSÃO NA EDUCAÇÃO INFANTIL 173 


\section{APRESENTAÇÃO}

O E-book Amplamente: Educação na Contemporaneidade consiste em uma coletânea de artigos científicos, representando a realidade educacional de diversos Estados e Municípios do Brasil, assim como traz algumas pesquisas internacionais para contribuir com o debate. Os textos são oriundos de teorias e práticas pedagógicas dos diversos contextos de ensino $e$ aprendizagem educacional, principalmente incorporados às novas demandas que a Educação vem exigindo. Nesse sentido, os personagens desta trama já não são mais os mesmos que outrora, a estrutura educacional não precisa se manter conservada, assim como as políticas públicas voltadas à Educação precisam das condições necessárias para efetivar seu funcionamento.

Pensar em uma Educação na Contemporaneidade é considerar todas as possibilidades de práxis, nas diversas modalidades de transmissão e troca de conhecimento, sobretudo a partir das novas concepções educativas que rompem os paradigmas criados ao longo da história. Desta forma, a construção de conhecimento pode acontecer de maneira mais diversa $e$ significativa, motivando os alunos - por estarem gostando do processo - $e$ contornando de uma Educação menos burocrática para uma Educação mais participativa, descentralizada e condizente com a realidade social do aluno.

É nesse sentido que, o E-book Amplamente: Educação na Contemporaneidade traz (em seus volumes 1 e 2) diversos artigos científicos escritos por professores e pesquisadores, nas modalidades de Pesquisa Concluída, Pesquisa em Andamento, Ensaio Acadêmico e Relato de Experiência, objetivando suscitar um debate consistente para os 

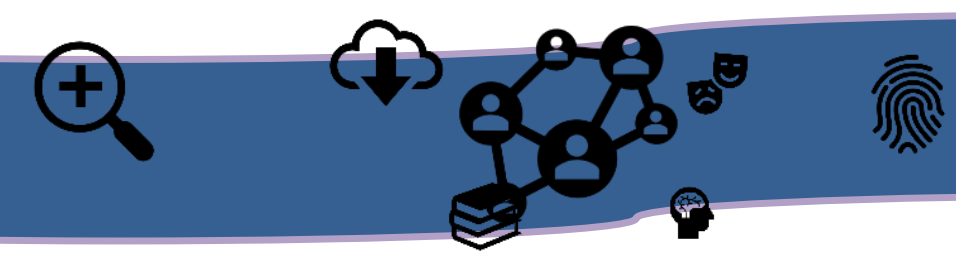

professores das diferentes áreas de atuação. Neste E-book, há uma multiplicidade de realidades educacionais distintas, que mesmo tendo uma intensa disparidade contextual, convergem para um caminho: pensar a Educação atual para construir um futuro melhor e pensar nas gerações futuras para construir uma Educação na Contemporaneidade.

Assim, em nome da Amplamente Cursos e Formação Continuada, convido a todos para leitura no debate científico da Educação na Contemporaneidade, com propostas, apontamentos, análises, reflexões entre outras questões pertinentes para conter neste material e para 0 campo educacional. Boa leitura!

Luciano Luan Gomes Paiva 


\title{
A CONTRIBUIÇÃO DA TEORIA DA APRENDIZAGEM SIGNIFICATIVA NA CONSTRUÇÃO DO JOGO 'TABULEIRO DAS COMPETÊNCIAS SOCIAIS' PARA CRIANÇAS DE 9 A 11 ANOS
}

\author{
MASSAGLI, Silvia Carla Conceição ${ }^{1}$ \\ LOPES, Francisca Patrícia da Silva ${ }^{2}$ \\ SOUSA, Paulo Ricardo Cordeiro de ${ }^{3}$ \\ OLIVEIRA JÚNIOR, Alexandre Tiago de ${ }^{4}$
}

\section{RESUMO:}

Este relato de experiência apresenta os resultados iniciais do projeto apresentado ao Programa Institucional de Voluntários de Iniciação Científica (PIVIC), submetido ao Programa de Bolsas de Extensão (PROBEX), na Universidade Federal de Campina Grande do Campus de Cajazeiras (PB) e vincula-se ao Laboratório de Tecnologias de Informação e Comunicação em Saúde (LATICS), da Universidade Federal de Campina Grande (UFCG-Cajazeiras-PB), na linha de Pesquisa Tecnologias CuidativoEducacionais na Infância e Adolescência. O estudo objetiva demonstrar o jogo e a sua construção, bem como a contribuição da teoria da aprendizagem significativa de Ausubel (1973), como abordagem propícia na utilização de jogos cuidativoeducacionais. O jogo visa verificar os desempenhos habilidosos ou não habilidosos dos sujeitos em relações sociais, de modo a favorecer o desenvolvimento de competências sociais que permitam as crianças (re)estruturem relações intra e interpessoais saudáveis como prevenção ao sofrimento psíquico. Primeiramente foi realizado um levantamento das principais categorias de análise das habilidades sociais, que orientou às competências sociais que permitam as crianças (re)estruturem relações intra e interpessoais saudáveis como prevenção ao sofrimento psíquico. Primeiramente foi realizado um levantamento das principais categorias de análise das habilidades sociais, que orientou à construção do jogo. Foram utilizadas as Categorias e Escalas de Del Prette \& Del Prette (2005), a saber: Habilidades de Empatia e Civilidade, Habilidades de Assertividade de Enfrentamento, Habilidades de Autocontrole, e Habilidades de Participação. Trata-se de um estudo descritivo com abordagem qualitativa que visa identificar como a utilização de um jogo pode promover uma aprendizagem significativa proposta por Ausubel para criar e aperfeiçoar habilidades sociais em crianças de 9 a 11 anos. Quanto aos resultados iniciais pode-se verificar a importância da construção de jogos cuidativo-educacionais que estimulem o desenvolvimento das

\footnotetext{
${ }^{1}$ Doutora em educação pela Faculdade de Educação da Universidade de São Paulo (FEUSP). Professora da Universidade Federal de Campina Grande (UFCG-Cajazeiras). E-mail: silvia.carla@ufcg.edu.br

2 Acadêmica do Curso de graduação em Enfermagem da Universidade Federal de Campina Grande (UFCG). E-mail: patysilvasjp@ hotmail.com

3 Acadêmico do Curso de graduação em Enfermagem da Universidade Federal de Campina Grande (UFCG). E-mail: cspauloricardo2013@gmail.com

4 Acadêmico do Curso de graduação em Enfermagem da Universidade Federal de Campina Grande (UFCG). E-mail: alextiol_jr@ hotmail.com
} 
habilidades sociais, encorajando os participantes a proporem e resolverem problemas, desenvolvendo o pensamento crítico e favorecendo relações sociais saudáveis que promovam sua a saúde psíquica, pois os sujeitos que participaram deste jogo vivenciaram novos desafios pertinentes aos relacionamentos interpessoais num ambiente criativo.

PALAVRAS-CHAVE: Competências Sociais. Aprendizagem Significativa. InfantoJuvenil. Saúde Psíquica. Tecnologias Cuidativo-educacionais

\section{INTRODUÇÃO}

O fato de vivermos em uma era tecnológica já não é uma novidade no mundo globalizado. As mudanças sociais são inegáveis, há alguns anos ninguém imaginava que o ensino romperia as paredes das salas de aula, hoje a internet leva o ensino aos cantos mais remotos do mundo permitindo que, cada vez mais, pessoas tenham acesso à informação. Entretanto, o exagerado acesso à tecnologia pode afetar de maneira direta a saúde mental e física dos indivíduos, principalmente às crianças. Segundo Paiva e Costa (2015) o uso de tecnologias de forma indiscriminada pode acarretar problemas de ordem afetiva, física, cognitiva e social, levando a quadros de isolamento social, embotamento afetivo, ansiedade e depressão. Desta forma, ações que visem prevenção do sofrimento mental e o desenvolvimento de habilidades sociais se faz de extrema importância.

Neste sentido, são exigidos cada dia mais a utilização de comportamentos em situação social (Habilidades sociais), seja de Empatia e civilidade, Assertividade de enfrentamento, Autocontrole ou participação, como categorizaram Dell Prette e Dell Prette (2005). Estas habilidades podem ser aprendidas, melhoradas ou modificadas ao longo da vida, desde que sejam feitas as intervenções corretas em tempo oportuno. No entanto, a infância é uma fase crucial para isso, porque é nesta fase em que acontece grande crescimento e desenvolvimento. Esta fase comprometeria às demais do ciclo vital. Também, déficits de habilidades sociais estão relacionados a problemas psicossociais, como baixa autoestima, ansiedade, depressão, estresse, interferindo negativamente no autoconceito.

O desenvolvimento de habilidades sociais por meio da educação afetivoemocional através da utilização de jogos, permite que a criança experimente e conheça a si, ao próximo e ao mundo, aliando aprendizagem e desenvolvimento, construindo um fator de proteção à saúde. Segundo Scheller, Viali e Lahm (2014), o método como 
muitos foram ensinados no passado não serve mais para ser utilizado com os estudantes de hoje. Os professores, na maioria, foram pegos pela revolução digital, enquanto seus estudantes já nasceram na mesma.

Portanto, é importante a utilização de novos métodos que permitam que o ensino ocorra de maneira mais efetiva, como é a teoria da aprendizagem significativa de Ausubel (1973). Segundo esta teoria, um novo conhecimento pode ser melhor assimilado quando estudante tem um conhecimento prévio (subsunçor) e, deste modo, o conhecimento prévio do educando interage, de forma significativa, com o novo conhecimento que lhe é apresentado, provocando mudanças em sua estrutura cognitiva.

É neste contexto que o Tabuleiro das Competências Sociais, uma tecnologia cuidativo-educacional, se torna um instrumento para promover saúde e empoderar, pautado pelo uso de tecnologias leves para promover suporte sociais e na Teoria da Aprendizagem Significativa, para desenvolver nas crianças comportamentos habilidosos no contexto social.

Deste modo, o estudo objetiva demonstrar o jogo e sua construção, bem como a contribuição da teoria da aprendizagem significativa de Ausubel como abordagem propícia na utilização de jogos cuidativo-educacionais.

\section{METODOLOGIA}

Trata-se de um estudo descritivo com abordagem qualitativa que visa identificar como a utilização de um jogo, nomeado como o Tabuleiro das Competências Sociais, pode promover uma aprendizagem para criar e aperfeiçoar habilidades sociais em escolares de 9 a 11 anos e, desta forma, prevenir o sofrimento psíquico e favorecer suporte social. A pesquisa foi desenvolvida em 3 etapas: Fase exploratória, Fase de ação, Fase de avaliação, logo após a realização de um levantamento das principais categorias de análise das habilidades sociais, que orientou à construção do jogo, com as crianças. Foram utilizadas as Categorias e Escalas de Del Prette \& Del Prette (2005).

Durante a fase exploratória foi realizada uma roda de conversa com crianças de 9 a 11 anos, que coincidiu com os escolares do $6^{\circ}$ ano fundamental. Então, as crianças sentiram-se seguras e empoderadas para dialogarem conosco sobre a utilização de jogos educativos, a rotina escolar e os principais eventos recorrentes na sala de aula e na 
escola de maneira geral, subsidiando as situações problema que seriam posteriormente exploradas pelo jogo.

Durante a fase de ação foi realizada a pré-testagem e estão sendo realizadas as intervenções pedagógicas com as crianças por meio do Tabuleiro das Competências Sociais, objetivando que elas expressem verdadeiramente o comportamento que assumiriam na vivência das situações propostas pelo jogo.

Durante a fase de avaliação realizada segundo aspectos qualitativos e quantitativos, foi verificado como as crianças se encontram em relação a expressão de comportamentos sociais habilidosos e a sua evolução ao longo das intervenções, segundo as categorias e escalas de Del Prette \& Del Prette (2005) e análise de conteúdo de Bardin (1977). Sendo possível, porque as intervenções da fase de ação foram gravadas em áudio e vídeo e transcritas para análise.

\section{RESULTADOS E DISCUSSÃO}

Inicialmente, foi feita a definição das situações problema do jogo, segundo as informações conosco compartilhadas, a respeito das principais situações vivenciadas pelos escolares quanto a utilização de jogos educativos, a rotina escolar e os principais eventos recorrentes na sala de aula e na escola de maneira geral. As situações foram bastante diversificadas e envolveram: Barulho na sala de aula, quebra de objetos emprestados, brincadeiras maldosas, xingamentos, furar fila, colar na prova, perder em jogos, dividir refeições com os colegas, diferença de notas entre os colegas, ajudar os colegas, trabalho em grupo, convite para festa dos colegas.

As situações foram registradas e discutidas entre o grupo de pesquisa em uma de suas reuniões semanais, foram então selecionadas as 20 situações mais recorrentes e dispostas 5 situações para cada uma das 4 categorias de Del Prette \& Del Prette (2005), e as demais situações foram exploradas na forma de desafio. Assim, durante os meses de setembro a novembro, o jogo físico foi confeccionado e suas regras estabelecidas. $\mathrm{O}$ tabuleiro das competências sociais conta com casas marcadas por números e emojis, sendo que:

1- Os participantes deverão jogar juntos e chegar ao final coletivamente.

2- Somente 1 marcador (peça) será usado e cada criança jogará uma vez a cada rodada. 
3- O grupo que tirar a maior numeração no dado inicia o jogo.

4- Os jogadores deverão andar o número de casas indicadas pelo dado.

5- Se a casa em que o marcador parar corresponder a um número, o jogador deverá escolher uma carta dentre as 4 categorias apresentadas e que estão divididas por cores.

6- Se a casa em que o marcador parar corresponder a um emoji, o jogador deverá cumprir com o desafio proposto.

7- Se a casa em que o marcador parar corresponder a um presente, o jogador deverá escolher um cartão na caixa de presentes e seguir com o que estiver indicado no cartão.

8- As cartas que forem utilizadas durante a partida não devem ser recolocadas no baralho, devendo ser guardadas em um local separado.

9- Se a resposta escolhida pelo jogador representar um comportamento habilidoso, o jogador andará duas casas.

10- Se a resposta escolhida pelo jogador representar um comportamento não habilidoso ativo ou passivo, o jogador voltará uma casa.

11- Os jogadores deverão ouvir com atenção as respostas dos colegas.

12- Os jogadores deverão ser sinceros ao responderem as questões propostas nas cartas.

13- Não é permitido escolher na caixa de cartões, um cartão referente a mesma habilidade sucessivamente. Deste modo, se um jogador escolher um cartão representado pela cor vermelha, o próximo jogador deverá escolher um cartão de outra cor.

14- Os jogadores devem ter respeito uns com os outros e respeitar a vez de cada participante, sendo convidado a se retirar qualquer jogador que apresente uma postura inadequada.

As pré-testagens foram realizadas, sendo a primeira com um grupo reduzido de 4 escolares e outra com um grupo de 20 escolares. Na primeira pré-testagem a escolha das crianças que participaram do jogo foi feita segundo a faixa etária que o projeto abrange e a demanda em sala de aula, sendo as 4 crianças escolhidas pelo professor, utilizando como critério aquelas que não ficaram em recuperação da disciplina, evitando ociosidade destes. Na segunda pré-testagem, toda a turma de escolares do $6^{\circ}$ ano 
participou e se autodividiu em 4 grupos de 5 crianças, revezando em cada partida aquele que era responsável por jogar o dado e escolher a carta.

Como resultado das duas pré-testagens, obteve-se que: Em relação a habilidade de participação, as crianças demonstraram envolvimento e souberam trabalhar bem em grupo, compartilhando a liderança e presentes recebidos ao longo da jogada por vontade própria. A respeito da habilidade de autocontrole, os participantes escolheram respostas que demonstraram um controle emocional satisfatório. No tocante à habilidade de empatia e civilidade, as crianças escolheram respostas baseadas nos princípios de solidariedade e companheirismo. E em relação a habilidade de assertividade de enfrentamento, demonstraram saber enfrentar situações de confronto de maneira saudável e com defesa de seus direitos.

Deste modo, pode-se destacar que a utilização do tabuleiro das competências sociais, com todo o seu potencial significativo, permite que as crianças relacionem as situações e atitudes do jogo com os conceitos subsunçores da sua estrutura cognitiva, permitindo que elas atribuam novos significados acerca das habilidades sociais. Desta forma, podem reconstruir suas práticas, através dos novos saberes agregados pela autorreflexão sobre suas ações, reflexão acerca da resposta dos colegas e debates ao final de cada jogada, realizando a assimilação obliteradora e sendo cada vez mais difícil dissociar o conhecimento prévio ao que foi aprendido com a utilização da tecnologia cuidativo-educacional. Assim, contribuindo também, com os estudos de Carvalho, et al. (2015), Castro e Costa (2011), Silva e Schirlo (2014), que demonstram bons resultados na construção de conhecimento com o alinhamento entre tecnologias e a teoria de aprendizagem.

Os estudos de Moreira (2006), Pelizzari, et al. (2002) e Sousa, et al. (2015) refletem acerca de pontos que são fundamentais para que a Aprendizagem Significativa aconteça, como disposição do aluno e relevância do conteúdo. Assim, a utilização do Tabuleiro das Competências Sociais incentiva a disposição do aluno pela dinamização do jogo como uma tecnologia leve, focada nas relações sociais. Tornando o conteúdo relevante para as crianças, ao passo em que integra múltiplas áreas do conhecimento, como a educação, saúde, tecnologia, comunicação, cidadania, já que as Habilidades Sociais envolvem indivíduos em todos os contextos sociais. 
Ao darem foco à importância da história de vida de cada indivíduo na construção de uma aprendizagem de fato significativa, Pelizzari et al. (2002) e Prado, Rodrigues e Almeida (2011), chegam de encontro à tipologia do presente trabalho, uma pesquisaação, onde através do diálogo em roda de conversa, as crianças puderam expor o que sabiam e viviam em relação a utilização de jogos educativos, a rotina escolar e os principais eventos na sala de aula e na escola. Assim como, subsidiando as situações problema do jogo através de suas próprias experiências, ou seja, seus conceitos subsunçores desenvolvidos conforme suas experiências de vida em diferentes ambientes. Além disso, vai de encontro ao protagonismo infantil, ao qual este trabalho se propõe a dar destaque, colocando as crianças como sujeitos ativos e atores principais das práticas relacionadas a sua vida.

Pesquisas realizadas por Prado, Rodrigues e Almeida (2011) e as reflexões de Carril, Natário e Zoccal (2017), permitem constatar que o que é aprendido significativamente permite ampliar, avaliar, atualizar e reconfigurar a informação anterior, transformando-a em nova, através da diferenciação progressiva dos subsunçores e da reconciliação integrativa. É neste contexto que aprender sobre Habilidades Sociais através de um jogo pautado na teoria da Aprendizagem Significativa vem a amplificar e reajustar ideias existentes na mente, à medida que novos conhecimentos são agregados aos subsunçores e as ideias a eles são relacionadas, empoderando-se para fazer novas associações em todos os contextos. Sendo que, quanto maior o número de elos formados com base nas 4 categorias de Dell Prette e Dell Prette (2005), mais alicerçado foi o aprendizado.

Deste modo, as vantagens de aprender sobre habilidades sociais a partir do tabuleiro das competências sociais, são: $\mathrm{O}$ conhecimento adquirido será lembrado por mais tempo; A capacidade de aprender outros conteúdos relacionados à temática será muito mais fácil, porque passará a funcionar como subsunçor; Mesmo que futuramente seja esquecido, será muito mais fácil de ser resgatada a aprendizagem.

\section{CONSIDERAÇÕES FINAIS}

A elaboração e aplicação desta tecnologia proporcionou uma integralização das habilidades sociais e comportamentos para o público-alvo nas mais variadas situações 
do cotidiano, em que são expostos e consolidou sua relevância nesses procedimentos habituais, corroborado pelas Categorias e Escalas de Del Prette \& Del Prette (2005).

A metodologia utilizada propiciou uma cooperação mútua com as crianças na construção do tabuleiro e acentuou a importância desta temática para a promoção do cuidado, possibilitando a construção de novas tecnologias no assunto ou em outros que promovam a indispensabilidade desse cuidar.

Destaca-se que, apesar dos resultados se demonstrarem potencialmente positivos, é imprescindível a aplicação consecutiva do jogo a longo prazo, tendo em vista as mais inúmeras realidades e particularidades onde encontram-se as crianças.

\section{REFERÊNCIAS}

AUSUBEL, D. P. Algunos aspectos psicológicos de la estrutuctura del conocimiento. Buenos Aires: El Ateneo, 1973.

BARDIN, L. Análise de conteúdo. Lisboa: Edições 70 Ltda, 1977.

CARRIL, M.G.P.; NATÁRIO, E.G.; ZOCCAL, S. Considerações sobre Aprendizagem Significativa, a partir da visão de Freire e Ausubel - uma reflexão teórica. Revista Multidisciplinar de Ensino, Pesquisa, Extensão e Cultura do Instituto de Aplicação Fernando Rodrigues da Silveira, Rio de Janeiro, v.6, n. ${ }^{\circ}$ 13, p. 68-79, dez., 2017.

CARVALHO, D.P.S.R.P. et al. Teoria da Aprendizagem Significativa como proposta para inovação no ensino de Enfermagem: experiência dos estudantes. Revista de Enfermagem UFSM, Santa Maria, v.5, n. ${ }^{\circ}$ 1, p. 186-192, Jan-Mar, 2015.

CASTRO, B.J.; COSTA, P.C.F. Contribuições de um jogo didático para o processo de ensino e aprendizagem de Química no Ensino Fundamental segundo o contexto da Aprendizagem Significativa. Revista electrónica de investigación en educación en Ciências, v.6, n. ${ }^{\circ}$ 2, dezembro, 2011.

Del Prette, Z. A. P.; Del Prette, A. Sistema Multimídia de Habilidades Sociais para Crianças. $3^{\mathrm{a}}$ ed. São Paulo: Casa do Psicólogo, 2005.

MOREIRA, M.A. Aprendizagem significativa subversiva. Série-Estudos - Periódico do Mestrado em Educação da UCDB, Campo Grande, n. ${ }^{\circ}$ 21, p.15-32, jan. - jun., 2006.

PAIVA, N.M.N.; COSTA, J.S. A influência da tecnologia na infância: Desenvolvimento ou ameaça? Revista Psicologia. PT, p. 1-12, jan. 2015. 
PELIZZARI, A. et al. Teoria da Aprendizagem Significativa segundo Ausubel. Rev. PEC, Curitiba, v.2, n. ${ }^{\circ}$ 1, p.37-42, jul., 2002.

PRADO, C.; RODRIGUES, V.D.; ALMEIDA, D.M. Teoria da Aprendizagem Significativa: elaboração e avaliação de aula virtual na plataforma Moodle. Revista Brasileira de Enfermagem, Brasília, v. 64, n. o 6, p. 1114-1121, nov.-dez., 2011.

SCHELLER, M. VIALI, L. LAHM, R.A. A aprendizagem no contexto das tecnologias: Uma reflexão para os dias atuais. Revista RENOTE, Porto Alegre, v. 12, no 2, dez., 2014.

SILVA, S.C.R.; SCHIRLO, A.C. Teoria da Aprendizagem Significativa de Ausubel: Reflexões para o ensino de Física ante a nova realidade social. Imagens da Educação, v. 4, n. ${ }^{\circ}$ 1, p. 36-42, 2014.

SOUSA, A.T.O. et al. A utilização da teoria da aprendizagem significativa no ensino da Enfermagem. Rev Bras Enferm, Brasília, v.68, n. ${ }^{\circ} 4$, p.713-22, jul.-ago., 2015. 


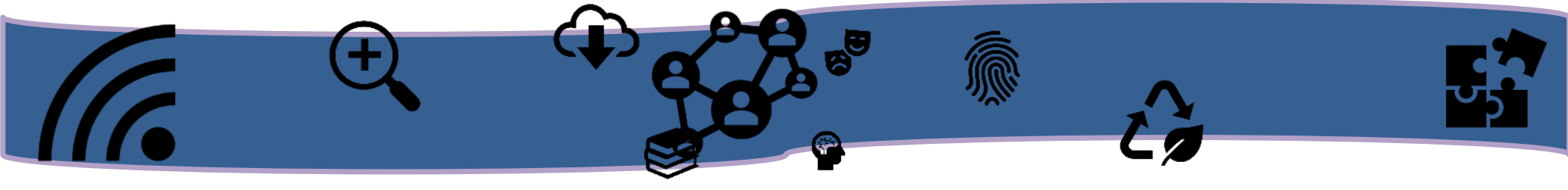

A DEFICIÊNCIA INTELECTUAL NA EDUCAÇÃO INFANTIL: O DESAFIO DA INCLUSÃO

\author{
SIMÃO, Kelly Freire ${ }^{5}$ \\ SIMÃO, Gleika Magaly Freire ${ }^{6}$ \\ SILVA, Rozenilda Maria Silva da ${ }^{7}$
}

\title{
RESUMO:
}

Esse trabalho visa refletir sobre a inclusão de crianças com deficiência intelectual no espaço escolar da Educação Infantil. Diante da insegurança do professor para contribuir para inclusão escolar (MANTOAN, 2003), a escola oferece condições favoráveis para que haja adaptação de crianças com capacidade limitada para exercer atividades essenciais à vida, como é o caso das crianças com deficiência intelectual. Ao considerar a leitura de alguns autores acerca da inclusão desses alunos na sala de aula comum, compreendemos que apesar de todas as pessoas com deficiência serem iguais perante a lei, a escola de Educação Infantil não oferece condições reais de adaptação e aprendizagem para as crianças especiais. A lei obriga a matrícula, mas não capacita o professor para cumpri-la. A família, além de não dispor do conhecimento necessário para colaborar com a inclusão de suas crianças, também não acredita no potencial da escola. Acreditamos que o professor da Educação Infantil comprometido pode promover um ambiente escolar inclusivo, mas para isso, ele precisa de formação, precisa conhecer o aluno, sua família, suas características, interesses particulares, seu meio social, suas dificuldades e potencialidades. Desta forma, ele poderá planejar estratégias de ensino que considerem as diferentes formas e ritmos de aprendizagem que possibilitem a construção coletiva do próprio conhecimento, promovendo para as crianças com deficiência intelectual a aquisição de habilidades adaptativas na rotina diária: conversar com as pessoas, ler e escrever, alimentar-se e hábitos de higiene pessoal. Certamente, isso é possível, se lhes for concedida a oportunidade de aprenderem com outras crianças.

PALAVRAS-CHAVE: Inclusão. Deficiência intelectual. Professor de Educação Infantil.

\section{INTRODUÇÃO}

\footnotetext{
${ }^{5}$ Mestranda no curso de Ciências da Educação pelo Centro de Educação Continuada e Aperfeiçoamento Profissional (CECAP). Professora da Educação Básica do município de Pendências/RN. E-mail: gleicekelly2019@gmail.com

${ }^{6}$ Mestranda no curso de Ciências da Educação pelo Centro de Educação Continuada e Aperfeiçoamento Profissional (CECAP). Professora da Educação Básica do município de Pendências/RN e Guamaré/RN. E-mail: gleikamagaly@ hotmail.com

${ }^{7}$ Mestranda no curso de Ciências da Educação pelo Centro de Educação Continuada e Aperfeiçoamento Profissional (CECAP). Professora da Educação Básica dos municípios de Guamaré/RN e Assú/RN. Email: rozenildamaria07@ hotmail.com
} 
A deficiência intelectual caracteriza-se pela limitação, seja de raciocínio, aprendizagem ou de adaptação para realização de atividades cotidianas. De acordo com a lei, as crianças com deficiência intelectual têm direito à educação formal na escola de ensino regular. Já que a Educação Infantil é considerada a primeira etapa escolar, e a criança, como todo ser humano, é um sujeito social, acredita-se que se as crianças com deficiência intelectual tiverem acesso à escola desde esta etapa escolar terão mais chance de adaptação e aprendizagem.

Nos últimos anos, houve um aumento considerável de matrículas de crianças com necessidades educacionais especiais nas salas de aula comuns. Sabe-se, porém, que apenas a realização da matrícula dessas crianças não garante a inclusão escolar, isto é, não é garantia que elas terão oportunidade de aprendizagem.

Sendo assim, o objetivo deste trabalho é verificar se o professor da Educação Infantil oferece condições de favorecer a inclusão de crianças cujo intelecto necessite de um trabalho pedagógico diferenciado. Por tratar-se de uma pesquisa bibliográfica, buscamos respostas em leituras de livros e artigos publicados, como: Honora e Frizanco (2008); Cunha (2014); Mantoan (2008) entre outros.

Para Honora e Frizanco, por exemplo, não existem "receitas" prontas para o trabalho com alunos, tanto com deficiência intelectual ou com outra deficiência. Cunha (2014) acredita que o bom preparo profissional possibilita as condições necessárias para avaliar a conduta do aluno e conduzir as intervenções em caso de não obter resultados no trabalho realizado pela escola. Mantoan (2008) acredita que o ensino precisa de reestruturação no sentido de compatibilizar suas intenções inclusivas com suas propostas de trabalho pedagógico e com o aprimoramento do processo educativo de todos os alunos. Para autora, a escola adultera o sentido de inclusão escolar, quando matrícula essas crianças sem o compromisso pedagógico de identificar e vencer suas dificuldades.

$\mathrm{O}$ assunto em questão despertou nosso interesse porque temos vivenciado a realidade nas escolas públicas do ensino regular, em que as crianças portadoras de deficiência intelectual são inseridas no Ensino Fundamental sem nenhuma adaptação ou aprendizado.

Assim sendo, a revisão de literatura deste trabalho expõe o conceito de deficiência intelectual, suas características contextualizam o assunto de forma breve na 
história. Na terceira parte, apresenta fatores relevantes para a inclusão de crianças com deficiência intelectual na Educação Infantil, como: a base legal que sustenta a inclusão de crianças com necessidades educacionais especiais, a necessidade de professores preparados para esse fim, e a importância dos pais como aliados no favorecimento da inclusão escolar. Certamente, o bom funcionamento destes três fatores pode tornar a escola um espaço inclusivo para essas crianças socialmente ignoradas por tanto tempo.

Acreditamos, portanto, na relevância deste trabalho, haja vista se tratar de um assunto que deveria ser elementar para todos os docentes, e, no entanto, existe uma carência de conhecimento nos profissionais que deveriam favorecer a inclusão dessas crianças no espaço escolar.

\section{FUNDAMENTAÇÃO TEÓRICA}

\section{Definindo Deficiência Intelectual}

A inclusão escolar de crianças com deficiência intelectual constitui um grande desafio para a escola regular. Tanto é que, a grande parte dos profissionais da Educação não sabe sequer sua definição. A Convenção de Guatemala, em 1999, em consonância com nossa Constituição, através do Decreto 3.956/2001, no artigo $1^{\circ}$, definiu deficiência como uma restrição física, mental ou sensorial, de natureza permanente ou transitória que limita a capacidade de exercer uma ou mais atividades essenciais da vida diária, causada ou agravada pelo ambiente econômico e social.

A Associação Americana em deficiência Intelectual e do desenvolvimento manteve a definição de 2002, mas incorporou a mudança do termo "retardo/deficiência mental" para deficiência intelectual, como explica Schalock et al (2010, p. 6):

Deficiência intelectual é uma incapacidade caracterizada por
limitações significativas tanto no funcionamento intelectual
(raciocínio, aprendizado, resolução de problemas) quanto no
comportamento adaptativo, que cobre uma gama de habilidades
sociais e práticas do dia a dia. Esta deficiência se origina antes da
idade de 18.

\section{Contextualizando a deficiência intelectual na história}

Em meados do século XX, as pessoas com algum tipo de deficiência começaram a ser vistas de forma diferente, isto é, diferente de como eram vista em séculos 
anteriores. No século XIX podia-se visualizar um atendimento apenas ao nível da medicina, mas o indivíduo com qualquer deficiência era considerado inapto, inválido para realizar qualquer tarefa produtiva que fosse para a sociedade.

Mazzota (2009) destaca dois períodos distintos para compreendermos melhor essa história, a qual deu início em 12 de setembro de 1854. Quando Dom Pedro II fundou o Imperial Instituto dos Meninos Cegos no Rio de Janeiro, o qual atendia, educacionalmente, as pessoas com deficiência visual. Em setembro de 1857, Dom Pedro II funda o Imperial Instituto dos Surdos-Mudos, também na cidade do Rio de Janeiro e em 1874, o Hospital Estadual de Salvador passa a dar assistência aos deficientes intelectuais. Possivelmente, tratavam-se apenas de atendimentos médicos.

Considerando o tratamento a que as pessoas com deficiência eram submetidas antes, quando eram marginalizados em séculos anteriores, pode-se visualizar um avanço, ainda que não seja em grandes proporções, mas bastante significativo. De acordo Sassaki (1997, p. 1) "algumas culturas simplesmente eliminavam as pessoas deficientes, outras adotaram a prática de interná-las em grandes instituições de caridade, junto com doentes e idosos." Segundo Nogueira (2008) no século XX, os indivíduos com deficiência passam a ser vistos como cidadãos com direitos e deveres de participação na sociedade, mas sob uma ótica assistencial e caritativa.

Em 1948 surge a primeira diretriz política desta nova visão por meio da Declaração Universal dos Direitos Humanos que diz que todo ser Humano tem direito à educação. Nos anos 60, surgem as primeiras críticas à segregação. A partir daí teóricos passam a defender a adequação da pessoa com deficiência à sociedade para permitir sua integração.

A Educação Especial no Brasil surge, pela primeira vez, na Lei de Diretrizes e Bases - LDB 4.024, de 1961. A lei aponta que a educação dos excepcionais deve, no que for possível, enquadrar-se no sistema geral de educação (Nogueira, 2008, p.10). Nos anos seguintes, o Brasil aprova o Estatuto da Criança e do Adolescente - ECA, que reitera os direitos garantidos na Constituição Federal - CF (atendimento educacional especializado para pessoas com deficiência preferencialmente na rede regular de ensino) e em 1994 dirigentes de mais de oitenta países se reúnem na Espanha e assina a Declaração de Salamanca, um dos mais importantes documentos de compromisso de garantia de direitos educacionais. 
Sob o regime da lei Constitucional de 1988 e no artigo 205 desta, propõe-se o avanço no que tange à inclusão escolar. "A educação, direito de todos e dever do Estado e da família, será promovida e incentivada com a colaboração da sociedade, visando ao pleno desenvolvimento da pessoa, seu preparo para o exercício da cidadania e sua qualificação para o trabalho". Mantoan (2003, p. 21) faz a seguinte ressalva sobre esse assunto:

A Constituição elege como um dos princípios para o ensino "a igualdade de condições de acesso e permanência na escola" (art. 206, inciso I), acrescentando que o " "dever do Estado com a educação será efetivado mediante a garantia de acesso aos níveis mais elevados do ensino, da pesquisa e da criação artística, segundo a capacidade de cada um.

\section{Características da Deficiência Intelectual}

Segundo o Manual de Diagnóstico e Estatística dos Transtornos Mentais DSM-V, publicado pela Associação Americana de Psicologia em 2014, a deficiência intelectual é caracterizada pelo seu início, que sempre ocorre durante o período de desenvolvimento. Os déficits de raciocínio, planejamento, solução de problemas, pensamento abstrato, aprendizagem escolar e compreensão são características inerentes da deficiência intelectual.

São peculiares também os déficits no funcionamento adaptativo nos domínios conceitual, que se relaciona com aquisição da leitura e da escrita, raciocínio matemático, aptidão na resolução de problemas etc. Já o domínio social refere-se ao déficit no que tange à empatia, discernimento, habilidade de se comunicar com outras pessoas, processar informações e o domínio prático envolve o aprendizado pessoal, capacidade de cuidar de si mesmo e organização de tarefas.

A Associação Americana de Retardo Mental reforça o seguinte:

A deficiência mental é concebida como uma incapacidade caracterizada por limitações significativas no funcionamento intelectual e no comportamento adaptativo e está expresso nas habilidades práticas, sociais e conceituais, originando-se antes dos dezoito anos de idade (AAMR, 2006, p. 20).

Segundo Honora e Frizanco (2008), existe uma grande variação de capacidades e necessidades dos indivíduos com deficiência intelectual, podendo apresentar 
diferenças em quatro áreas: motora - dificuldade em motricidade fina; cognitiva dificuldades de aprendizagem de conceitos abstratos, resolução de problemas etc.; de comunicação - acarreta dificuldade nas relações; e sócio educacional - ocorre às vezes, discrepância entre idade mental e a idade cronológica.

Vemos, então, que a deficiência intelectual apresenta peculiaridades que exigem do professor uma avaliação acurada para que ele possa desenvolver um plano de ação diferente para cada criança, visando atender a necessidade de cada uma delas. Esta avaliação também ajudará o professor não rotular as crianças com dificuldades de aprendizagem como "doente mental" e facilitará a adaptação das crianças com dificuldade no intelecto, principalmente se tiverem acesso à escola desde a Educação Infantil.

\section{O DESAFIO DA INCLUSÃO DE CRIANÇAS COM DEFICIÊNCIA INTELECTUAL NA EDUCAÇÃO INFANTIL}

De acordo com Soto e Soares $(2009$, p. 45) “[...] o processo de inclusão pode ser visto como o primeiro passo numa operação de reconhecimento do outro enquanto sujeito de direitos, pois é na aproximação com o mesmo que se estabelece algum saber acerca desse diferente". Para que este processo de inclusão seja real, existem alguns fatores que consideramos relevantes para a inclusão dos alunos com deficiência intelectual entre os quais citaremos a seguir:

\section{Base legal que sustenta a inclusão escolar desde a Educação Infantil}

A Constituição Federal de 1988, em seu Artigo 205, reconhece a educação como direito fundamental compartilhado entre Estado, família e sociedade ao determinar que a educação, direito de todos e dever do Estado e da família, será promovida e incentivada com a colaboração da sociedade, visando ao pleno desenvolvimento da pessoa, seu preparo para o exercício da cidadania e sua qualificação para o trabalho (BRASIL, 1988 apud BNCC, 2017, p. 7). Segundo a Declaração de Salamanca (1994), o conceito de inclusão é um desafio para a educação, uma vez que estabelece que o direito à educação é para todos e não só para aqueles que apresentam necessidades educacionais especiais, como explica no texto abaixo: 
As escolas devem acolher todas as crianças, independentemente de suas condições físicas, intelectuais, sociais, emocionais, linguísticas ou outras. Devem acolher crianças com deficiência e crianças bem dotadas; crianças que vivem nas ruas e que trabalham; crianças de populações distantes ou nômades; crianças de minorias linguísticas, étnicas ou culturais e crianças de outros grupos ou zonas desfavorecidas ou marginalizadas. (DECLARAÇÃO DE SALAMANCA, 1994).

Antes da Declaração de Salamanca (1994), tivemos a Declaração Mundial de Educação para Todos - Conferência de Jontiem (1990). Em 1996, foi promulgada a Lei de Diretrizes e Bases Nacional da Educação (LDB) n 9.394/96 que em seu artigo 58 entende a educação especial como modalidade da educação escolar devendo ser oferecida preferencialmente na rede regular de ensino, garantindo que os sujeitos dessa ação tenham currículo, método, técnicas, recursos e organizações específicas, adequadas às suas necessidades (BRASIL, 1996).

Tivemos, ainda, a Convenção de Guatemala (1999), promulgada pelo Decreto $3.956 / 01$, foram criados com o intuito de possibilitar que todas as crianças sejam atendidas nas escolas sem exclusão. Convenção Internacional sobre o direito das Pessoas com Deficiência (2007). Em 2010, o CNE promulgou novas DCNs, ampliando e organizando o conceito de contextualização como "a inclusão, a valorização das diferenças e o atendimento à pluralidade e à diversidade cultural, resgatando e respeitando às várias manifestações de cada comunidade", conforme destaca o Parecer CNE/CEB nº 7/2016, e, conforme estabelecido na Lei Brasileira de Inclusão da Pessoa com Deficiência, igualmente, requer o compromisso com os alunos com deficiência, reconhecendo a necessidade de práticas pedagógicas inclusivas e de diferenciação curricular. O Estatuto da Pessoa com Deficiência que garante no Art. $7^{\circ}$ que:

Todas as pessoas com deficiência são iguais perante a lei e não sofrerão nenhuma espécie de discriminação. $\S 1^{\circ}$ Considera-se discriminação em razão da deficiência, todas as formas de discriminação ou qualquer distinção, restrição ou exclusão, por ação ou omissão, que tenha o propósito ou efeito de prejudicar, impedir ou anular o reconhecimento, gozo ou exercício dos direitos e liberdades fundamentais dessas pessoas, incluindo a recusa de adaptação razoável (2013).

Todas as leis e documentos que regem a inclusão das crianças de nosso país, como o Plano Nacional de Educação (2011-2020), consideram como público alvo da 
educação inclusiva, os educandos com deficiência intelectual, física, auditiva, visual e múltipla, alunos com transtorno global do desenvolvimento (TGD) e altas habilidades. O fato é que essas leis ainda não dispõem de força necessária para fazer funcionar no sentido da aplicabilidade, de forma para que a inclusão de crianças com deficiência intelectual seja real.

A Lei $n^{\circ}$ 12.796, de 4 de abril de 2013, que altera a LDB n. 9394/96, diz que as crianças com 4 anos devem ser matriculadas na Educação Infantil. Com isso, a Educação Infantil passa a fazer parte da Educação Básica. Isso significa que todas as crianças desde a Educação Infantil têm o direito de serem incluídas na escola.

\section{A capacitação dos professores versus a inclusão de crianças com deficiência}

\section{Intelectual na Educação Infantil}

Um dos maiores problemas para inclusão escolar é a falta de formação dos professores, sobretudo na Educação Infantil. Como esta é a primeira etapa da vida escolar das crianças é fundamental que os educadores tenham o conhecimento necessário de como lidar e incluir todas as crianças, especialmente aquelas com necessidades educacionais especiais, já que elas podem gozar desse direito por lei.

De acordo com Mantoan (2003), os professores resistem à inclusão sob o argumento de não estarem ou não terem sido preparados para esse trabalho. Independente das dificuldades ou limitações, todas as crianças se desenvolvem com o contato direto com outras crianças, contudo, essa interação social por meio da qual a criança aprende apenas a escola reúne as condições de oferecê-la. E isso "requer o compromisso com os alunos com deficiência, reconhecendo a necessidade de práticas pedagógicas inclusivas e de diferenciação curricular, conforme estabelecido na Lei Brasileira de Inclusão da Pessoa com Deficiência” (Lei nº 13.146/2015, apud BRASIL, 2017, p. 13). O Conselho Nacional de Educação (2001) concorda que:

A Educação Básica deve ser inclusiva, no sentido de atender a uma política de integração dos alunos com necessidades educacionais especiais nas classes comuns dos sistemas de ensino. Isso exige que a formação dos professores das diferentes etapas da Educação Básica inclua conhecimentos relativos à educação desses alunos. (BRASIL, 2001, p. 25-26). 
A normatização da escolarização da criança deficiente intelectual na escola regular, a Lei $\mathrm{n}^{\mathrm{o}} 12.796$ de 04 de abril de 2013, em seu Art. 62, estabelece que: "a formação de docentes para atuar na educação básica far-se-á em nível superior, em curso de licenciatura, de graduação plena, em universidades e institutos superiores de educação [...]" (BRASIL, 2013). Apesar da lei, a maioria dos profissionais da Educação Infantil da escola pública do ensino regular não sabe o que fazer com as crianças que apresentam diferenças daquelas que aprendem normalmente, sem planejamento diferenciado e busca ansiosamente uma "receita" que tenha o "modo de fazer" para trabalhar com essas crianças. Ao relacionar a necessidade de formação de professores no que tange às crianças com deficiência intelectual, ressalta que:

Não existem "receitas" prontas para o trabalho com alunos tanto com deficiência intelectual, ou com outra deficiência, quanto com os sem deficiência. Devemos ter em mente que cada aluno é um e que suas potencialidades, necessidades e conhecimentos ou experiências prévias devem ser levados em conta, sempre. (HONORA; FRIZANCO, 2008, p. 107).

De acordo com Referencial Curricular para Educação Infantil, “compreender, conhecer e reconhecer o jeito particular das crianças serem e estarem no mundo é o grande desafio da educação infantil e de seus profissionais” (1998, p. 22). Por isso Concordamos com Cunha (2014, p. 90) quando ele coloca que: “O bom preparo profissional possibilita ao educador a isenção necessária para avaliar a conduta do aluno e da família no auxílio da recondução das intervenções, quando elas não alcançam os resultados esperados no ambiente familiar ou na escola".

Existem muitas barreiras para que as crianças com deficiência intelectual tenham o acesso escolar propriamente dito. Como já citado, o professor despreparado não será capaz de propiciar um ambiente de aprendizagem na sala de aula do ensino regular. Embora as universidades mantenham em suas grades curriculares conhecimentos valiosos para colaborar com os aspectos psíquico, cognitivo e social do universo infantil, ainda assim são insuficientes para os professores da Educação Infantil desenvolverem um trabalho eficaz com todas as crianças, respeitando seus diferentes ritmos de aprendizagem.

O professor precisa planejar sua atuação em situações de atendimento individual ou coletivo. Desta forma, ele poderá proporcionar práticas educativas respeitando suas 
deficiências e possibilidades de aprendizagem. Concordamos que a educação dessas crianças

[...] deve ser pensada de forma diferente, não a partir daquilo que uma deficiência determina como limitação, mas, neste caso em particular, em se tratando de deficiência intelectual, a partir das diferenças de abstração do pensamento. Aprender é um ato singular que requer criatividade, investimento e credibilidade por parte de quem ensina (PAN, 2008, p. 126-127).

A verdade, porém, é que "os alunos com deficiências estão chegando hoje na sala regular, e a maioria esmagadora dos professores não sabe o que fazer com eles". (OLIVEIRA, 2007). E por causa da limitação das crianças com deficiência intelectual, elas são vistas pela escola como crianças incapazes, o que tem levado os educadores a propor atividades pedagógicas que as inferiorizam, desfavorecendo assim a aprendizagem e o avanço delas, seja cognitivo, seja de ordem social que poderiam ser adquirido no espaço escolar.

Acreditamos, no entanto, que se o problema da falta formação para os professores seja resolvido, eles poderão assumir uma prática pedagógica condizente com as limitações delas. Para isso é essencial que o professor conheça o aluno, sua família, suas características e seus interesses particulares, seu meio social e seu processo de aprendizagem (dificuldades e potencialidades); trabalhe coletivamente ao possibilitar entre si e os alunos sistemas de cooperação, podendo compreender melhor as dificuldades de aprendizagem de cada estudante; valorize as diferenças por meio de planejamento de estratégias de ensino que considerem as diferentes formas e ritmos de aprendizagem e que possibilitem a construção coletiva do próprio conhecimento; vise à aprendizagem significativa ao articular o interesse do educando com o saber que já possui (HILÁRIO, s/d, p. 17-22).

\section{A participação dos pais no processo a inclusão de crianças com deficiência intelectual na primeira infância}

É essencial a participação ativa dos pais no processo de aprendizagem escolar das crianças, desde a idade mais tenra, como é o caso da Educação Infantil. Certamente, quando se trata de crianças com deficiência intelectual, mais ainda. Para Mittler (2003, 
p. 210), "pais e mães são os primeiros, os principais e os mais duradouros educadores de suas crianças". Ele ainda afirma que:

Quando pais e profissionais trabalham juntos durante a infância, os resultados têm um impacto positivo no desenvolvimento da criança e na sua aprendizagem. Então, cada etapa do desenvolvimento deve buscar uma parceria afetiva com os pais. [...] a parte passada e futura desempenhada pelos pais na educação de suas crianças é reconhecida e é explicitamente encorajada. (MITTLER, 2003, p. 210).

Evidentemente, mesmo que a escola disponha de professores com formação adequada e dos recursos materiais necessários que favoreçam à inclusão de alunos com deficiência intelectual, não terá sucesso sem a motivação, sem a ajuda dos pais, e, para eles possam ajudar, precisam também de ajuda. Muitos pais não sabem lidar com os filhos especiais porque são ignorantes em relação à deficiência dos filhos. É comum as famílias carentes, por exemplo, mandar a criança para escola, sobretudo no período da Educação Infantil, em virtude do Benefício de Prestação Continuada (BPC), um tipo de ajuda mensal equivalente a um salário mínimo que o INSS (Instituto Nacional do Seguro Social) proporciona a: idosos com 65 anos ou mais; pessoas com deficiência e incapacitadas para o trabalho. Acreditamos que o descaso de alguns pais em relação à educação formal dos filhos com deficiência é porque são desinformados e não acreditam que eles vão aprender, pois além de conhecerem bem suas limitações, não acreditam no trabalho realizado pela escola.

Por outro lado, quando os pais têm conhecimento das leis que garantem o direito de aprendizagem de seus filhos, independente das dificuldades deles, esses pais são presentes no ambiente escolar e batalham para que suas crianças usufruam o direito adquirido. Mantoan (2003, p. 30) acredita que "os pais podem ser nossos grandes aliados na reconstrução da nova escola brasileira. São uma força estimuladora e reivindicadora dessa tão almejada recriação da escola". O problema reside no fato da maioria dos pais não terem conhecimento real da deficiência dos filhos e não acreditarem que a escola pode mudar a vida deles.

\section{CONSIDERAÇÕES FINAIS}

As instituições de Educação Infantil, como um espaço de aprendizagem inclusiva, têm o dever de propiciar uma prática educativa, que permita a inclusão de 
todas as crianças, incluindo as crianças com deficiência intelectual e outras. Esse direito é garantido pela Carta Magna de nosso país, a Constituição (1988), quando garante a todos o direito à educação e o acesso à escola.

Percebe-se, entretanto, que apesar de ser um direito garantido por lei, há uma acentuada falta de conhecimento no que tange a educação das crianças com deficiência intelectual no ambiente escolar. Essa precariedade de conhecimento gera, inclusive, falta de sensibilidade e insegurança dos professores. Isso significa que ao matricular as crianças com necessidades educacionais especiais na escola regular, cumpre-se a lei, mas ela é descumprida quando a criança chega à escola e o professor não tem a formação adequada para acolhê-la e prover a adaptação e aprendizagem a que tem direito. Elas são matriculadas no ensino regular, contudo, a escola não realiza nenhum projeto de ação para trabalhar de acordo com suas limitações. O professor sequer conhece as dificuldades e limitações que lhe são impostas, desfavorecendo, assim, um ambiente escolar inclusivo.

A Educação Infantil, como a primeira etapa escolar, é responsável principalmente pela adaptação da criança no espaço escolar. Especialistas no assunto referente à educação especial apontam para a necessidade de formação dos professores para que eles ofereçam as condições de favorecer não apenas socialização, mas também propiciar o desenvolvimento cognitivo e social.

No que tange à deficiência intelectual, o professor deve desenvolver nas crianças habilidades para cuidarem de si mesmas em atividades cotidianas, que aprendam a ler e escrever, a raciocinar, se relacionar com outras crianças. A escola adultera o sentido de inclusão escolar, quando matricula essas crianças sem o compromisso pedagógico de identificar e vencer suas dificuldades (MANTOAN, 2003).

Consideramos, também, que o educador precisa da ajuda familiar. Com certeza, o envolvimento dos pais durante a infância em um trabalho em conjunto com a escola proporcionará resultados de impacto positivo no desenvolvimento da aprendizagem da criança (MITTLER, 2003). Certamente, a colaboração de toda comunidade escolar tornará possível os meios para que professor identifique as limitações das crianças com deficiência intelectual e desenvolva atividades planejadas e coerentes com às suas necessidades, favorecendo assim, a inclusão delas no espaço escolar. 


\section{REFERÊNCIAS}

ASSOCIAÇÃO AMERICANA DE RETARDO MENTAL - AAMR. Retardo mental - definição, classificação e sistemas de apoio (2002). 10ª edição. (tradução Magda França Lopes). Editora: ARTMED, Porto Alegre, 2006.

BRASIL. LDB. Lei de Diretrizes e Bases da Educação. Lei n ${ }^{\circ} 9424$, de dezembro de 1996.

BRASIL. Lei n ${ }^{\circ}$ 12.764/2012, de 27 de dezembro de 2012. Política Nacional de Proteção dos Direitos da Pessoa com Transtorno do Espectro Autista. Brasília, 2012. Disponível em: <http://www.planalto.gov.br/ccivil_03/_ato201-

2014/2012/lei/112764.htm> acesso em 25/05/2019.

BRASIL. Conselho Nacional de Educação. Resolução CNE/CEB n 2, de 11 de fevereiro de 2001b. Disponível em: <

http://portal.mec.gov.br/seesp/arquivos/pdf/resolucaocne.pdf>. Acesso em 25/05/2019.

BRASIL. Política Nacional de Educação Especial na Perspectiva da Educação Inclusiva. Inclusão: R. Educ. esp., Brasília, v.4, n.1, p. 7-17, jan./jun. 2008a.

CUNHA, Eugênio. Autismo e Inclusão: psicopedagogia e práticas educativas na escola e na família. 5.ed, Rio de Janeiro: Wak Ed, 2014.

DECLARAÇÃO DE SALAMANCA, 1994. Disponível em< http //www.portal.mec.gov.br>. Acesso em 25/05/2019.

GLAT, R. Inclusão Total: mais uma utopia? Revista Integração. Brasília, ano 08, n 20, 1998. p. 26-28.

JULIANA C. BARCELli. Desafios E Estratégias De Ensino Para Alunos Com

Deficiência Intelectual. Disponível em: <https://fce.edu.br/blog/desafios-e-estrategiasde-ensino-para-alunos-com-deficiencia-intelectual/>. Acesso em: 13/04/2020.

OLIVEIRA Eloiza da S. Gomes. Adaptação Curricular. 2007 -Texto obtido através do site: http://aceitandodiferencas.blogspot.com/2007/10/adaptao-curricular.html. Acesso em 25/05/2019.

GUATEMALA. Assembleia Geral, 29Ü período ordinário de sessões, tema 34 da agenda. Convenção interamericana para a eliminação de todas as formas de discriminação contra as pessoas portadoras de deficiência (original em espanhol), 1999.

HONORA, M. FRIZANCO, M. L. Esclarecendo as deficiências: Aspectos teóricos e práticos para contribuir com uma sociedade inclusiva. Ciranda Cultural, 2008. 
MANTOAN, M. T. E. Inclusão escolar: o que é? por quê? como fazer? São Paulo: Moderna, 2003. (Coleção cotidiano escolar).

Mantoan. Maria Teresa Eglér Inclusão escolar : o que é? por quê? como fazer? — São Paulo : Moderna, 2003.

MAZZOTA M. J. S., Educação Especial no Brasil: História e Políticas Públicas. São Paulo: Cortez, 2009.

MITTLER, Peter. Educação Inclusiva: contextos sociais. Porto Alegre, Artmed: 2003.

NOGUEIRA, C. de. M. A história da deficiência: tecendo a história da assistência a criança deficiente no Brasil. Tese de mestrado. Programa de pós-graduação de mestrado em políticas públicas e formação humana. Centro de Educação e Humanidades e Centro de Ciências Sociais. Universidade do Estado do Rio de Janeiro. Rio de janeiro, 2008. Acesso em 28/05/2019.

PAN, Mirian Aparecida Graciano de Souza. O direito à diferença: uma reflexão sobre deficiência intelectual e educação inclusiva. Curitiba: Ibpex, 2008.

SASSAKI, Romeu Kazumi, Inclusão, Construindo uma Sociedade para Todos. Rio de Janeiro: WVA, 1997.

SCHALOCK, R. et al. Intellectual Disability - Definition, Classication ad Systems of supports, 11th Edition, Washington, DC: AAIDD, 2010.

SOTO, Ana Paula de Oliveira Moraes., SOARES, Marcia Torres Neri. Currículo, Identidade e diferenças: perspectivas para uma escola inclusiva. In:

MARQUEZINE, Maria Cristina et al (Org.). Re'discutindo a inclusão. Londrina: ABPEE, 2009, p. 41 - 46. (Série Estudos Multidisciplinares de Educação Especial, n. $4)$.

TÉDDE, Samantha. Crianças com Deficiência Intelectual: a aprendizagem e a inclusão. Americana: Centro Universitário Salesiano de São Paulo, 2012. Disponível em:http://unisal.br/wpcontent/uploads/2013/03/Disserta\%C3\%A7\%C3\%A3o_Samantha -T\%C3\%A9dde.pdf. Acesso em 30/05/2019.

VIGOTSKI, Lev. A construção do pensamento e da linguagem. $2^{\mathrm{a}}$ ed. São Paulo: WMF Martins Fontes, 2009. 


\section{A DISCIPLINA DE INTRODUÇÃO À LOGÍSTICA NAVAL NA FORMAÇÃO SUPERIOR DA MARINHA: CAMINHOS INICIAIS}

HONORATO, Hercules Guimarães ${ }^{8}$

\section{RESUMO:}

O objetivo deste artigo é apresentar ao meio acadêmico como foi construída a disciplina de Introdução à Logística Naval (ILN), que passou a fazer parte do currículo da Escola Naval (EN) a partir de 2016. O estudo é uma pesquisa teórica, de cunho qualitativo, com pesquisas bibliográfica e documental. A pergunta deste estudo: em que medida a Disciplina de ILN contribuirá para uma melhor formação dos Oficiais da Marinha oriundos da EN de acordo com o perfil desejado? O artigo é apresentado em duas seções principais: a primeira trata do marco teórico e dos principais conceitos envolvidos na construção da disciplina, a saber: o currículo; as disciplinas escolares, a Logística, as metodologias ativas e aprendizagem significativa; e a segunda seção apresenta a disciplina, sua ementa, suas metodologias de ensino e avaliação. A conclusão não é fácil, quando pretendemos incluir uma disciplina em uma matriz acadêmica superior e militar, caracterizada por um ensino tradicional e tecnicista, de aprendizagem mecânica e com foco no docente. Os caminhos iniciais, contudo, foram abertos para uma formação em que os discentes se tornassem sujeitos ativos da própria aprendizagem e sintonizados também com o tempo em que estamos vivendo.

PALAVRAS-CHAVE: Currículo. Ensino Superior Militar. Introdução à Logística Naval.

\section{INTRODUÇÃO}

"Em qualquer espécie de projeto duas coisas devem ser consideradas: primeiramente a qualidade absoluta do projeto; em segundo lugar a facilidade de execução"

(Jean-Jacques Rousseau)

A competição da Era Industrial se transformou na competição da Era da Informação e Globalização. Verificamos que estamos imersos em um mundo de rápidas mudanças em diversos contextos, principalmente motivadas pela chamada revolução das tecnologias de informação e conhecimento, advindas em especial da grande rede e dentro de uma sociedade complexa e diversificada. O homem plural, dentro desse meio incerto e globalizante, procura crescer e buscar sua melhor formação,

\footnotetext{
${ }^{8}$ Doutor e Mestre em Política e Estratégia Marítimas pela Escola de Guerra Naval/RJ (EGN). Integrante do corpo docente da Escola Superior de Guerra/RJ (ESG). E-mail: $\underline{\text { hghhhma@gmail.com }}$
} 
instrumentalizando sua transformação social. Contudo, concordando com Zygmunt Bauman em entrevista a Alba Porcheddu (2009, p. 667), que a “[...] arte de viver em um mundo ultrassaturado de informações ainda deve ser aprendida, assim como a arte ainda mais difícil de educar o ser humano neste novo modo de viver".

É notório que para o profissional do século XXI, as escolas (como instituição formadora do homem cidadão e trabalhador) e o seu currículo sofrem influências poderosas, positivas ou negativas, de todas as modificações do mundo em que vivemos, recebendo constantes desafios da sociedade, da comunidade onde está inserida, do seu ambiente externo e interno, dos professores, alunos e demais componentes educacionais, e, em especial, quando começam a ser idealizadas, construídas.

Nesse caminho da formação desse sujeito social, histórico e político que opta pelo ensino superior militar em uma das academias militares, visando, ao final, uma formação de qualidade acadêmica e profissional. Compostas pela Escola Naval (EN), Academia Militar das Agulhas Negras (AMAN) e Academia da Força Aérea (AFA), estas Instituições de Ensino Superior (IES) militares têm como tarefa principal a formação dos seus oficiais para os primeiros postos da carreira militar. Os oficiais formados obtêm a certificação em áreas específicas do seu emprego como Força Armada, se tornando, ao término da graduação, bacharéis em ciências militares, com reconhecimento do Ministério da Educação (MEC) como graduação superior.

A partir dessas colocações iniciais, este professor da EN, que teve sua especialização em Logística pelo Instituto COPPEAD de Administração, recebeu a tarefa do Superintendente de Ensino, responsável pela gestão acadêmica da instituição, de elaborar a ementa de uma nova disciplina na área de Logística, com foco no ambiente marítimo-naval, que faria parte do currículo da instituição e que deveria ser para todo o corpo discente de um determinado ano de formação do ciclo escolar.

A ideia de uma nova disciplina surgiu da verificação pela Alta Administração Acadêmica da instituição de construir conhecimentos a partir da constatação, com outras disciplinas já integrantes da formação do oficial da Marinha, da falta de conteúdos que tratassem de um tema muito importante para o campo do conhecimento militar e em especial nos dias atuais, ou seja, a Logística. O nome escolhido para a disciplina foi "Introdução à Logística Naval” (ILN).

O estudo em questão é uma pesquisa teórica, de cunho qualitativo, que teve 
como metodologia as pesquisas bibliográfica e documental como técnicas exploratórias iniciais. A escolha da pesquisa qualitativa teve como escopo a ênfase na interpretação, "na compreensão das motivações, culturas, valores, ideologias, crenças e sentimentos que movem os sujeitos, que dão significado à realidade estudada e não aos fatos observáveis e passíveis de serem medidos estatisticamente" (IVENICKI; CANEN, 2016, p. 11). Conforme esses mesmos autores, a análise documental é um exemplo da metodologia qualitativa, onde este pesquisador mergulhou sobre fontes escritas e destinou-se a interpretação do material levantado para a nossa investigação.

Assim exposto surgiu a inquietação inicial deste pesquisador para a montagem da referida disciplina, que culminou com a seguinte pergunta síntese deste estudo: em que medida a adoção da Disciplina de ILN contribuirá para uma melhor formação dos Oficiais da Marinha oriundos da EN de acordo com o perfil desejado?

Espera-se que este estudo seja relevante na medida em que é mais uma ferramenta no plano ontológico e epistemológico do continuum estabelecido quando da apresentação da práxis interdisciplinar em 2016 e posterior, na procura de uma ação ativa, construtiva e reconstrutiva dos saberes que serão despertados e conquistados, em especial no campo do ensino superior militar, e na complementação de uma formação ampla de um jovem oficial da MB na preparação para sua vida profissional.

O artigo completo é apresentado em duas seções principais, além da Introdução e das Considerações Finais. A primeira trata do marco teórico e dos principais conceitos envolvidos na construção do referencial teórico estruturante da disciplina em tela, a saber: o currículo; as disciplinas escolares, a Logística do seu aspecto amplo ao militarnaval, as metodologias ativas e aprendizagem significativa. Ao final, é apresentada a disciplina criada em 2014 e integrante do currículo de formação do oficial da Marinha a partir de 2016, sua ementa, suas metodologias de avaliação e os seus caminhos iniciais nos dois anos de sua aplicação efetiva.

\section{O MARCO TEÓRICO}

Neste capítulo são apresentados os principais conceitos envolvidos para a construção da disciplina em estudo. Este autor se alinha com o pensamento de Morán (2015, p. 31), quando "todos os processos de organizar o currículo, as metodologias, os 
tempos, os espaços precisam ser revistos e isso é complexo, necessário e um pouco assustador, porque não temos modelos prévios bem sucedidos para aprender".

\section{O currículo}

Em relação à conceituação de currículo, podemos listar até 50 definições que são apresentadas pela literatura, o que nos dá uma ideia do quanto as concepções são variáveis e diferentes quanto ao seu significado e às suas funções. Schmidt (2003) pondera que não existe uma definição certa ou totalmente exata, e sim a mais atual. Quando se escolhe um pensador ou teorizador do currículo, está-se definindo por uma determinada concepção, que inclui compromissos sociais, políticos e ideológicos.

Segundo o Dicionário de Educação (VAN ZANTEN, 2011, p. 163), “a noção de currículo, numa acepção restrita, designa o conteúdo de ensino (os conhecimentos, as competências, as aptidões etc.) e a ordem da sua progressão no decorrer do tempo". Partindo-se de um aspecto mais amplo, o currículo é um instrumento que é utilizado por diferentes sociedades para se desenvolver ou mesmo para sua conservação, transformando e renovando os conhecimentos que são historicamente construídos e acumulados para serem socializados às gerações mais jovens (MOREIRA, 2009).

Young (2011) deixa claro que currículo é mais amplo do que um mero depositório de disciplinas e conteúdos, sendo considerados com importância as notas e os resultados avaliativos, uma forma de prestar contas em vez de um guia para os professores. O currículo precisa ser visto como tendo uma finalidade própria, o desenvolvimento intelectual dos discentes, refletindo o "conhecimento que um país considera importante que esteja ao alcance de todos os estudantes" (YOUNG, 2011, p. 612), e no nosso caso, a Marinha do Brasil (MB) na formação de seus oficiais.

Um conceito simples e direto é apresentado por Silva (2016, p. 15): “é sempre o resultado de uma seleção: de um universo mais amplo de conhecimentos e saberes seleciona-se aquela parte que vai constituir". Ainda apresentado como uma seleção, Schmidt (2003, p. 60) argumenta que o currículo “[...] é o próprio fundamento de qualquer sistema de ensino, ele é o elemento nuclear do projeto pedagógico da escola, viabilizando o processo de ensino e aprendizagem".

Uma matriz curricular atual e no estado da arte da formação superior militar para os dias atuais foi o desejado pela EN. 


\section{As disciplinas escolares}

André Chervel (1988), pesquisador francês, apresenta a disciplina, para nós, "em qualquer campo que se a encontre, um modo de disciplinar o espírito, quer dizer de lhe dar os métodos e as regras para abordar os diferentes domínios do pensamento, do conhecimento e da arte", o que pode ser resumido "a aquilo que se ensina e ponto final". Pinto (2014) assevera que as disciplinas são concebidas como um produto cultural, constituídas pelo aparato didático-pedagógico que guia o ensino. Segundo ainda Santomé (1998, grifo nosso), uma determinada disciplina é uma maneira de organizar e delimitar um território de trabalho, as fronteiras do conhecimento, concentrando as experiências dentro de um determinado ângulo de visão.

Em suma, a organização disciplinar traduz conhecimentos que são entendidos como legítimos de serem ensinados às gerações mais novas, organizam as atividades, o tempo e o espaço no trabalho escolar, a forma como diversos professores ensinam, em sucessivos anos, a milhares de alunos. "Uma disciplina deverá, antes de tudo, estabelecer e definir suas fronteiras constituintes.". (JAPIASSU, 1976, p. 61).

\section{Metodologias ativas e aprendizagens significativas}

As metodologias ativas é o processo de ensino e aprendizagem que são centrados no estudante, tornando-o protagonista na construção do seu próprio conhecimento, por intermédio de processos interativos individuais ou coletivos com a finalidade precípua de encontrar soluções para um determinado problema, quer seja real ou fictício (SANTOS; ALMEIDA, 2018). Diesel, Baldez e Martins (2017, p. 271) ratificam e complementam que no método ativo "os estudantes ocupam o centro das ações educativas e o conhecimento é construído de forma coletiva.”.

O aluno passa a possuir um sentimento de pertencimento e coparticipação, assumindo uma postura ativa, onde o docente passa a ser um mediador, facilitador e ativador, deixando para trás a concepção bancária quando o “educador é o que sabe e os educandos, os que não sabem; o educador é o que pensa e os educandos, os pensados; o educador é o que diz a palavra e os educandos, os que escutam docilmente [...]" (GADOTTI, 2004, p. 69). Reforça-se, assim, a frase de Paulo Freire (2008, p. 23) que "não há docência sem discência, as duas se explicam e seus sujeitos apesar das 
diferenças que os conotam, não se reduzem á condição de objeto, um do outro.”.

Morán (2015) afirma que devam existir problemas e situações reais, o mais próximo da realidade, que os discentes passarão a vivenciar em sua vida profissional, de forma antecipada e durante o curso, para a efetivação das metodologias ativas de aprendizagem. Seria, em síntese, a prática caminhando lado a lado, ou até mesmo, antecipadamente, à teoria. Poderíamos citar algumas metodologias ativas, porém, vamos conceituar apenas naquela que foi empregada na nova disciplina, ou seja, a aprendizagem baseada em problemas (Problem Based Learning - PBL), onde os discentes desenvolvem competências e habilidades de resoluções de problemas, "provendo um ambiente propício para o desenvolvimento meta-cognitivo dos estudantes" (ROCHA; LEMOS, 2014, p. 3). A PBL significa que os alunos são apresentados aos problemas reais ou criados e têm que tentar caminhar no sentido de resolvê-los, por intermédio dos conteúdos apresentados.

A noção de aprendizagem significativa veio com a ideia de ruptura com a aprendizagem mecânica, onde a informação é armazenada arbitrariamente, e considerada como necessária para um ensino-aprendizagem que está sintonizado apenas na voz do professor, sem respaldo e retorno via conhecimentos prévio dos discentes e uma preparação apenas para uma avaliação somativa, onde o resultado final está em uma boa nota e não na retenção de novos conhecimentos. Moreira e Masini (1982, p. 7) argumentam que a aprendizagem se torna significativa "quando a nova informação ancora-se em conceitos relevantes preexistentes na estrutura cognitiva de quem a aprende", onde existem abstrações da experiência dos alunos.

\section{A Logística e a Logística Naval}

A base da bibliografia básica tinha que ser decidida para a construção de uma nova disciplina que seria explorada pelos Aspirantes (como são denominados os discentes da EM). Por isso mesmo, alguns conceitos principais são expostos nesta subseção sobre a Logística, no seu sentido amplo, chegando até a Logística Naval, escopo da nossa disciplina.

Segundo Ballou (2006, p. 27, grifo nosso), podemos conceituar o termo Logística como o "[...] ramo da ciência militar que lida com a obtenção, manutenção e transporte de material, pessoal e instalações.”. A Logística teve sua origem no ambiente 
das guerras, no militar, e posteriormente foi caminhando para outras áreas do conhecimento. $\mathrm{O}$ que para este autor significaria, em simples palavras e levando para o setor empresarial, atender ao cliente, disponibilizando o produto ou serviço desejado e certo, no tempo certo e, principalmente, na hora certa.

A MB, segundo o seu Manual de Logística (BRASIL, 2003, p. 1-3, grifo nosso), adota o seguinte conceito para a Logística: “[...] é a componente da arte da guerra que tem como propósito obter e distribuir às Forças Armadas os recursos de pessoal, material e serviços em quantidade, qualidade, momento e lugar por elas determinados, satisfazendo as necessidades na preparação e na execução de suas operações exigidas pela guerra.".

Cada uma das três Forças Armadas tem as suas especificidades, porém, é conceituada de forma ampla a Logística Naval, como sendo: "O ramo da logística militar concernente aos meios, efetivos e organizações de comando, controle, comunicações e apoio empregados pela Marinha para atender às necessidades das forças navais”. (BRASIL, 2003, p. 1-3, grifo nosso). Ao final, pincelando apenas o que está grifado nos conceitos, podemos ter a certeza de que esta nova disciplina está bem justificada para fazer parte de uma matriz curricular de uma IES militar e de formação naval.

\section{O currículo escolar e os seus desafios}

É notório que qualquer ambiente educacional de qualquer nível e o seu currículo acadêmico sofre influências poderosas, que podem ser positivas ou negativas, de todas as modificações do mundo em que vivemos, globalizado e tecnologicamente, recebendo constantes desafios para o que seja ensinando aos seus alunos esteja atual e preparandoo para a sua formação acadêmica e para o mundo do trabalho. O que Freire (2008, p. 26) afirma que a produção do saber que se deseja deva "[...] reforçar a capacidade crítica do educando, sua curiosidade, sua insubmissão.".

Segundo Oliveira (2008, p. 542, grifo nosso), já em 1922, Émile Durkheim em sua obra Éducation et Sociologie, chamava a atenção para que nós, os educadores, voltássemos para a sociedade, esta que experimenta transformações profundas, hoje em dia aceleradas, e que leva consigo a educação, uma de suas componentes principais. Este mesmo autor realçava que: 
É a sociedade, pois, que devemos interrogar, são as suas necessidades que devemos conhecer, porquanto a elas é que nos cumpre atender. Limitar-nos a olhar para dentro de nós mesmos, seria desviar nossos olhos da realidade que nos importa atingir, e isso nos colocaria na impossibilidade de nada compreender do movimento que arrasta o mundo, ao redor de nós e nós próprios com ele [...].

O currículo não é neutro como na teoria de Ralph Tyler, ele se liga ao poder, "à homogeneização ou diferenciação da escola, e por isso os educadores precisam estar alertas às suas implicações sociológicas e culturais quando de sua estruturação" (OLIVEIRA, 2008, p. 545). Ele é intencionalmente pensado ou deveria ser a partir da definição de pessoa que se quer formar, relacionando aos perfis de demanda social e, em específico, à demanda de trabalho, e no caso deste estudo, a profissionalização do militar da Marinha.

Não é tarefa fácil estabelecer o que a sociedade atual exige da educação, e viceversa, essencialmente, numa sociedade tecnológica em constante mutação, em que as repercussões da técnica e a ciência impõem novos desafios à educação. O que nos deixa claro que a escola estandardizada, segundo Morán (2015, p. 16) “[...] ignora que a sociedade do conhecimento é baseada em competências cognitivas, pessoais e sociais, que não se adquirem da forma convencional e que exigem proatividade, colaboração, personalidade e visão empreendedora.”.

\section{A DISCIPLINA DE INTRODUÇÃO A LOGÍSTICA NAVAL}

"A Logística é tudo ou quase tudo, no campo das atividades militares, exceto o combate".

(Barão de Jomini ${ }^{9}$ ).

A Escola Naval (EN), considerada a instituição de ensino superior mais antiga do Brasil, visto que veio com a família real portuguesa fugida do jugo do Imperador francês Napoleão Bonaparte, em 1808. Esta IES militar é o estabelecimento de ensino da Marinha responsável pelo Curso de Graduação na área de Ciências Navais, formando Oficiais de Marinha para os Corpo (coletivo de militares da MB com determinada formação profissional) da Armada (CA), de Fuzileiros Navais (CFN) e de Intendentes da Marinha (CIM), habilitados em eletrônica, mecânica, sistemas de armas e

\footnotetext{
${ }^{9}$ Antoine-Henri Jomini, o Barão de Jomini, estrategista militar do início do século XIX.
} 
administração, com o propósito de capacitá-los para o pleno exercício de atividades operativas e funções técnico-administrativas, seja a bordo, em terra ou em unidades de tropa, inerentes aos primeiros postos da carreira militar-naval (ESCOLA NAVAL, 2017). Com base no perfil estabelecido e desejado, retirado da Sinopse Geral do Curso de graduação da EN, determinadas competências e habilidades, específicas e comuns, que em síntese e com o foco neste estudo formam as bases no início da construção de uma disciplina que atenderia, entre outros aspectos:

[...] Analisar os dados disponíveis e tomar decisões corretas, oportunas e adequadas, mesmo em situações difíceis ou sob condições de tensão (capacidade de decisão); Executar diversas tarefas cumulativamente, atendendo às demandas de forma prática, sem se perder em aspectos pouco relevantes, atuando de maneira eficiente e eficaz (objetividade); Planejar as atividades de seu setor ordenando de maneira sistemática e eficiente as etapas a serem realizadas ou ideias explanadas (organização). Prever os meios necessários e esquematizar as etapas a serem cumpridas, antecipando alternativas para solucionar possíveis dificuldades (capacidade de planejamento); Trabalhar em harmonia e boa vontade com outras pessoas para o mesmo fim, considerando os outros e respeitando aos seus interesses legítimos, necessidades e pontos de vista (cooperação); e Aplicar continuamente sua capacidade de resolução de problemas, orientando, assim, as ações a serem tomadas (capacidade de tomar decisão); [...] (ESCOLA NAVAL, 2017, p. 2-3, grifo nosso).

E assim, tendo por base o perfil desejado aos oficiais da MB para os primeiros postos da carreira e em consonância com uma disciplina atual para uma matriz curricular contemporânea, começamos a nossa caminhada pela estruturação de uma nova disciplina, com foco na Marinha, na qual o discente fosse também um ator principal na relação professor-aluno e na construção coletiva do seu conhecimento.

\section{A construção da Disciplina de ILN}

A determinação para a construção de uma nova disciplina, no caso específico da Logística, deveria contar com alguns pontos que não poderíamos esquecer, sendo o principal, o parco número de horas-aula, ou seja, apenas 33 tempos de 45 minutos que foram, à princípio, disponibilizados. Tal limitador foi muito importante para as escolhas do que deveríamos transmitir a todos os Aspirantes do $3^{\circ}$ ano, independente da escolha do seu corpo de formação, ou seja, Corpos da Armada, Fuzileiros Navais e Intendentes. 
O que isso representava: que a ementa teria que ser direta, objetiva, ampla e que atendesse a formação de um oficial de uma maneira geral, sem esquecermos o perfil desejado.

Outro fator considerado na escolha dos conteúdos da ementa foi que não houvesse, quer na própria instituição ou mesmo durante a formação continuada dos seus egressos, conteúdos repetidos ou desatualizados. Partimos então para uma verificação no currículo da própria EN e verificamos que existe uma disciplina de Administração do Material e Logística, com uma unidade de ensino denominada "Gestão Eficaz de Operações e Logística", de 12 horas-aula, apenas para o terceiro ano do Corpo de Intendentes e com foco apenas na Logística Empresarial. Por conseguinte, a nova disciplina tinha o seu espaço no currículo, pois o foco era uma Logística Naval e para todos os alunos do $3^{\circ}$ ano, não deveria haver superposição de conteúdos a serem ministrados.

A decisão por uma bibliografia simples e objetiva veio de encontro aos manuais existentes tanto no Ministério da Defesa (MD) e da Marinha no Brasil, ou seja, o MD20 (BRASIL, 2002) e o EMA-400 (BRASIL, 2003), que normatizam o tema Logística Militar e Naval dentro da própria estrutura de formação profissional. Porém, havia um conteúdo que este professor resolveu incorporar, que seria dar as noções básicas de Mobilização Nacional, considerada importante atualmente e, em especial, por exemplo, em situações de calamidades climáticas.

Porém, ainda carecia de uma sedimentação dessa nova disciplina com os currículos das academias congêneres, ou seja, as Academias Militar das Agulhas Negras (AMAN) e da Força Aérea (AFA). Por isso mesmo, foram verificados e analisados os seus currículos, onde verificamos que já existia uma disciplina de Logística e com foco no ambiente militar específico a cada Força. Em suma, a Disciplina de ILN estava pronta para ser estruturada e ratificava a sua necessidade.

\section{A ementa e as unidades de estudos}

A nova disciplina teria que ter o seu foco no ambiente naval, ou seja, na MB. Por isso mesmo, os seguintes objetivos foram propostos: (i) Apresentar a evolução da Logística ao longo do tempo, seus conceitos, classificação e seu relacionamento com outras atividades essenciais ao emprego do Poder Militar; (ii) Descrever a estrutura 
básica da Logística na MB; (iii) Apresentar o ciclo logístico na MB; (iv) Descrever as funções logísticas na MB; (v) Introduzir o apoio logístico é desenvolvido na MB; (vi) Definir as responsabilidades pela Logística e seu planejamento na MB; e (vii) Apresentar os principais custos e problemas Logísticos na MB.

A especialização deste autor em Logística pelo Instituto COPPEAD de Administração em 2009, desvelou ainda alguns conteúdos que deveriam ser apresentados com fulcro em uma melhor formação e na amplitude dos conhecimentos importantes para os graduandos, como a discussão sobre a Terceirização e os Provedores de Serviços Logísticos. Como comentado anteriormente, julgamos também importante e necessário que introduzíssemos a temática da Mobilização Nacional para os futuros oficiais da Marinha.

Assim exposto, estes objetivos foram transformados em unidades de estudo, como preconizado nas normas de formação de uma disciplina para o Sistema de Ensino Naval (SEN) da MB. Contudo, não poderíamos afastar da sala de aula a experiência do docente, militar com 32 anos de serviço ativo na área de Logística, muito menos relegar a um segundo plano à vivência, mesmo que pouca, dos discentes, enquanto desenvolvem outras atividades não acadêmicas na Escola Naval, como exemplo, as viagens de veleiros para participarem de competições, onde a atividade logística é empregada do início ao fim.

Outro ponto a ressaltar e trabalhando fora do currículo estipulado para ILN são os dez minutos finais de cada tempo de aula, onde este docente contava sua experiência profissional no campo da Logística, como oficial Intendente, além de sua vivência como cidadão integrante da nossa sociedade, onde também era liberado para toda e qualquer troca de informações dos discentes em relação ao seu dia a dia em uma IES militar, quando passam a semana em aquartelamento, em situações de cunho logístico.

\section{A avaliação e seus resultados}

A escola padronizada, que ensina e avalia a todos de forma igual e exige resultados previsíveis, "ignora que a sociedade do conhecimento é baseada em competências cognitivas, pessoais e sociais, que não se adquirem da forma convencional e que exigem proatividade, colaboração, personalização e visão empreendedora" (MORÁN, 2015, p. 16). Foi com este pensamento desse autor que a 
metodologia de avaliação para esta disciplina foi proposta, saindo das tradicionais provas e testes estandardizados.

As normas de avaliação dessa IES militar preveem testes e provas, sendo um teste e uma prova por semestre. Como a disciplina só conseguiu 33 tempos de aulas e acreditando numa avaliação mais formativa do que somativa, este autor resolveu utilizar no lugar do teste um trabalho de grupo (TG), nos mesmos moldes dos que são praticados nos demais cursos de carreira da MB, ou seja, os alunos em graduação ainda estariam sendo preparados para a sua formação continuada no SEN.

A atividade de TG foi apresentada em sala de aula, no primeiro dia efetivo de aula, e seguindo um roteiro impresso e distribuído em quantidade suficiente para cada grupo, que já estava distribuído com seus integrantes, com um mínimo de cinco e no máximo oito discentes, de acordo com o número de alunos por cada turma.

Foram disponibilizados sete temas em Logística para que os grupos explorassem, independentes dos conteúdos ministrados pelo docente. A quantidade de temas foi devido ao número maior de grupos em uma mesma sala de aula. No total, contando sala de aulas e grupos, foram 39 grupos em 2016 e 43 grupos em 2017. Os temas foram: Logística: o estado da arte; a terceirização logística; a Mobilização nacional; Custos Logísticos; Funções Logísticas; a Logística Reversa; e o Apoio Logístico Integrado. O caminho a ser seguido em relação ao trabalho do grupo era de responsabilidade dos grupos, porém, foram disponibilizados na ementa quatro tempos para as reuniões dos grupos em sala de aula e para que as dúvidas surgidas fossem sanadas com este docente-orientador.

Os grupos, obrigatoriamente, foram divididos internamente da seguinte maneira:

- Dirigente - um dos discentes, o mais bem classificado, conhecido como mais antigo, exerceria a função de "Dirigente" do grupo, ou seja, o responsável pela coordenação e distribuição das tarefas inerentes ao grupo, sendo também a ligação com a docência, este responsável pela orientação dos trabalhos;

- Relator - seria um dos integrantes do grupo e responsável pela organização escrita do estudo propriamente dito. Faria também a entrega do trabalho em meio físico e envio por meio digital ao docente para avaliação. A escolha do relator ficaria a cargo do próprio grupo; e 
- Apresentador - discente escolhido também no seio do próprio grupo, para fazer a apresentação do trabalho à turma e em data prevista no calendário de trabalho desta atividade avaliativa.

O critério de avaliação do trabalho seria: Conteúdo do TG - 7 (sete) pontos; apresentação do TG em sala de aula - um ponto; a criatividade do grupo - um ponto; e a forma/ABNT - um ponto. A apresentação seria livre para os grupos, podendo usar o data-show disponível em sala de aula ou outra metodologia que o grupo achar melhor, porém, o tempo disponível será de 15 (quinze) minutos para cada grupo.

A nota final do grupo foi um total de pontos que seria distribuído pelos seus próprios integrantes como nota do teste. Interessante situação ocorreu, onde tivemos grupos que distribuíram igualmente os pontos, dividindo-o pelo número de componentes e outros que distribuíram de acordo com o trabalho que o discente desenvolveu no grupo.

Tivemos grupos onde todos os seus integrantes tiraram graus iguais e outros, por exemplo, em que um discente recebeu 10,0 e outro componente ficou 6,0 (seis) de nota de teste no mesmo grupo. Tal metodologia procurou avaliar, além dos conteúdos estudados, a relação desenvolvida de distribuição de tarefas e estudos dentro dos grupos, além da liderança que deveria ser exercida e esperada pelo aluno dirigente.

A qualidade dos trabalhos apresentados foi considerada muito boa, sendo que três deles foram escolhidos para publicação na Revista de Villegagnon de $2017^{10}$, periódico institucional com tiragem anual, impresso e eletrônico, da Escola Naval. Os seguintes estudos foram publicados: “A impressora 3D como ferramenta logística na MB"; "Voo Air France 447: um estudo de caso sob a ótica logística"; e "Forças Armadas e Defesa Civil: atuação conjunta”.

Em relação à prova, que é requisito para a nota final do Aspirante e que tem peso dois na média final, a metodologia utilizada foi uma prova discursiva, com apenas uma questão de correlacionar colunas. $\mathrm{O}$ discente teria que responder as questões abertas com suas palavras, em função dos conceitos apreendidos em sala de aula e dos estudos realizados. Um exemplo de questão com maior pontuação, dois pontos, foi a seguinte:

\footnotetext{
${ }^{10}$ Disponível para baixar:

<https://www.marinha.mil.br/sites/www.marinha.mil.br.en/files/upload/REVISTA_VILLEGAGNON_20 17.pd>. Acesso em: 07 set. 2019.
} 
"De acordo com os conhecimentos adquiridos na Disciplina de Introdução à Logística Naval (ILN) conceitue Logística, Logística Militar e Logística Naval.", onde era determinado que a resposta teria que ter um mínimo de dez e máximo de 20 linhas.

Uma das questões integrantes da nota da prova, que valia um ponto, foi o chamado "teste surpresa". No primeiro dia de aula, todos os discentes receberam um artigo, "A logística militar nas forças armadas russas: ensinamentos”, de dez laudas, de autoria de Marco Antônio de Freitas Coutinho e Konitskaia, publicado no Anuário da Academia Militar das Agulhas Negras, em 2015. O artigo desenvolve, na prática, todas as situações logísticas enfrentadas pela antiga União das Repúblicas Socialistas Soviéticas (URSS) durante a segunda Grande Guerra. Foram estipuladas oitos questões, sendo uma para cada sala de aula, onde a turma escolhia a pergunta que seria respondida em uma hora de teste.

Nas metodologias ativas de aprendizagem, o aprendizado se dá a partir de problemas e situações reais; os mesmos que os alunos vivenciarão depois na vida profissional, de forma antecipada, durante o curso (MORÁN, 2015, p. 19). Foi esse o caminho procurado por este docente, contextualizar a disciplina de ILN com a profissão que irão trabalhar pelos próximos anos. Ao final, as médias finais das turmas de $2016 \mathrm{e}$ de 2017 foram, respectivamente, 7,5 e 7,8, consideradas boas.

\section{CONSIDERAÇÕES FINAIS}

Ao assumirmos a tarefa de construir uma disciplina do zero e para uma IES militar, cujo foco deveria ser a Marinha, ou seja, o objetivo central deveria ser a Logística Naval, a que é praticada pela Força Armada, e alguns pontos merecem destaques: (i) o pouco tempo de sala de aula disponibilizado para a nova disciplina, apenas 33 horas-aula; (ii) obrigatoriedade das avaliações com graus somativos ao final da carga de conteúdos; (iii) a formação em Logística empresarial do autor e a sua experiência profissional; (iv) o uso de casos logísticos reais (PBL) e aprendizagem significativa; (v) o discente no centro da relação ensino-aprendizagem. Tudo isso foram ingredientes importantes colocados no caldeirão de uma ementa que melhor traduzisse tudo que o jovem e futuro oficial da MB deveria conhecer, ou pelo menos, saber onde procurar se desejasse. 
Ao escolhermos o caminho da avaliação formativa, onde o Aspirante colocaria os seus conceitos e o que tinha compreendido dos conteúdos ministrados e estudados, da pontuação por criatividade no trabalho de grupo, dos diversos estudos de casos que foram disponibilizados, quer impressos ou mesmo em vídeos, como forma de aprendizagem baseada em problemas, associava ainda o que acontecia no seu dia a dia dentro da Escola Naval, emitia sua análise e questionava os caminhos que foram tomados pelos decisores e, assim, construía o seu próprio conhecimento, a sua própria aprendizagem significativa, para além da sala de aula, para sua profissão e para sua vida.

Diferente dos graduandos das instituições civis, que terão no mercado de trabalho a real destinação dos conhecimentos apreendidos em sua graduação, onde serão selecionados ou não, os jovens formados no ensino superior militar já possuem emprego garantido, serão designados para assumirem cargos em organizações militares em todo o Brasil, quer organizações em terra, mar ou rios. Por isso mesmo, deveremos formar bem os nossos futuros oficiais, é a nossa principal responsabilidade como docentes, tanto para a profissão que exercerão, quanto para serem integrantes ativos e participativos em nossa sociedade.

A conclusão não é fácil, talvez a aplicação seja ainda mais difícil, quando pretendemos incluir uma disciplina em uma matriz acadêmica superior e militar, caracterizada por um ensino tradicional e tecnicista, de aprendizagem mecânica e com foco no docente, detentor de todos os conteúdos, e que deva estar sintonizado também com o tempo em que estamos vivendo. No mesmo momento pretende-se que as implicações sociais e a realidade do mundo contemporâneo sejam refletidas e conscientizadas pelos alunos, aproximando-os da sociedade e da comunidade onde estão inseridos, preparando-os para enfrentarem os novos desafios do séc. XXI. Relembrando que este estudo tem por base a formação superior militar, um ensino que tem evoluído, em certa medida, rápido com o advento das novas tecnologias da arte da guerra.

Ao final, acreditamos que o início está sendo promissor em relação ao ensino e aprendizagem da disciplina criada em 2014, que iniciou sua participação na matriz curricular da Escola Naval em 2016, ainda é uma criança de dois anos, que cabe ainda muitos anos para o seu amadurecimento, mas a base curricular foi lançada. Terminamos, assim, esta apresentação com uma frase de Pablo Neruda que retrata com 
clareza o que procuramos realizar com a Disciplina de "Introdução à Logística Naval": "Escrever é fácil. Você começa com uma letra maiúscula e termina com um ponto final. No meio você coloca ideias".

\section{REFERÊNCIAS}

BALLOU, R. H. Gerenciamento da cadeia de suprimentos/logística empresarial. Tradução de Raul Rubenich. 5. ed. Porto Alegre: Bookman, 2006.

BRASIL. Marinha do Brasil. Estado-Maior da Armada. EMA-400. Manual de Logística da Marinha. Brasília, DF, 2003.

$\overline{\mathrm{DF}, 2002 .}$

Ministério da Defesa. MD42-M-02. Doutrina de Logística Militar. Brasília,

CHERVEL, A. História das disciplinas escolares: reflexões sobre um campo de pesquisa. Tradução de Guacira Lopes Louro. Histoire de l'éducation, n. 38, maio 1988.

COUTINHO, M. A. de F.; KONITSKAIA, J. A Logística Militar nas Forças Armadas Russas: ensinamentos. Anuário da Academia Militar das Agulhas Negras, ano 5, n. 5. Resende, RJ: Academia Militar das Agulhas Negras, 2015.

DIESEL, A.; BALDEZ, A. L. S.; MARTINS, S. N. Os princípios das metodologias ativas de ensino: uma abordagem teórica. Revista Themo, v.14, n.1, Lajeado, RS, p.268-288, 2017.

ESCOLA NAVAL. Currículo: curso de graduação de oficiais. Rio de Janeiro, 2017.

FREIRE, P. Pedagogia da Autonomia: saberes necessários à prática educativa. 37. ed. São Paulo: Paz e Terra, 2008. (Coleção Leitura).

GADOTTI, M. Convite à leitura de Paulo Freire. 2. ed. São Paulo: Scipione, 2004.

IVENICKI, A.; CANEN, A. G. Metodologia da Pesquisa: rompendo fronteiras curriculares. Rio de Janeiro: Ciência Moderna, 2016.

JAPIASSÚ, H. Interdisciplinaridade e patologia do saber. Rio de Janeiro: Imago, 1976. (Série Logoteca).

MORÁN, J. Mudando a educação com metodologias ativas. SOUZA, C. A. de; MORALES, O. E. T. (Org.). Convergências Midiáticas, Educação e Cidadania: aproximações jovens. Ponta Grossa, PR: Foca-PROEX/UEPG, 2015. (Coleção Mídias Contemporâneas, v.2). 
MOREIRA, M. A.; MASINI, E. F. S. Aprendizagem significativa: a teoria de David Ausubel. São Paulo: Ed. Moraes, 1982.

MOREIRA, A. F. B. (Org.). Currículo: questões atuais. 15. ed. Campinas, SP: Papirus, 2009. (Coleção Magistério: Formação e Trabalho Pedagógico).

OLIVEIRA, Z. M. F. de. Currículo: um instrumento educacional, social e cultural. Rev. Diálogo Educ., Curitiba, v. 8, n. 24, p. 535-548, maio/ago. 2008. Disponível em: $<$ http://docplayer.com.br/9818888-Curriculo-um-instrumento-educacional-social-ecultural.html>. Acesso em: 20 jul. 2018.

PINTO, N. B. História das disciplinas escolares: reflexão sobre aspectos teóricometodológico de uma prática historiográfica. Revista Diálogo Educacional. Curitiba, v.14, n.41, p.125-142, jan./abr. 2014.

PORCHEDDU, A. Zigmunt Bauman: entrevista sobre a educação. Desafios pedagógicos e modernidade líquida. Tradução: Neide Luzia de Resende e Marcello Bulgarelli. Cadernos de Pesquisa, São Paulo, v.39, n.137, p.661-684, maio/ago. 2009. Disponível em: <http://www.scielo.br/scielo.php?script=sci_arttext\&pid=S010015742009000200016>. Acesso em: 20 ago. 2018.

ROCHA, H. M.; LEMOS, W. de M. Metodologias Ativas: do que estamos falando? Base conceitual e relato de pesquisa em andamento. In: IX SIMPÓSIO PEDAGÓGICO E PESQUISAS EM EDUCAÇÃO, São Paulo, de 02 a 04 set. 2014, Faculdade de Filosofia, Ciências e Letras Dom Bosco. Anais eletrônicos... São Paulo, 2018. Disponível em: <https://www.aedb.br/wp-content/uploads/2015/05/41321569.pdf >. Acesso em: 17 ago. 2018.

SANTOMÉ, J. T. Globalização e Interdisciplinaridade: o currículo integrado. Porto Alegre: Artmed, 1998.

SANTOS, P. C.; ALMEIDA, M. E. B. T. M. P. de. Formação discente e as metodologias ativas: o caso de uma intuição de ensino superior. In: CONGRESSO INTERNACIONAL DE EDUCAÇÃ̃ E TECNOLOGIAS E ENCONTRO DE PESQUISADORES EM EDUCAÇÃO A DISTÂNCIA (CIET:ENPED:2018), 26 jun. a 13 jul. 2018, Universidade Federal de São Carlos. Anais eletrônicos..., São Carlos, SP, 2018. Disponível em:

<http://cietenped.ufscar.br/submissao/index.php/2018/article/view/39>. Acesso em: 17 ago. 2018.

SCHMIDT. E. S. Currículo: uma abordagem conceitual e histórica. Publ. UEPG Ci.

Hum., Ci. Soc. Apl., Ling., Letras e Artes, Ponta Grossa, v.11, n.1, p.59-69, jun.

2003. Disponível em: <

http://www.revistas2.uepg.br/index.php/humanas/article/view/492>. Acesso em: 20 jul. 2018. 
SILVA, T. T. Documentos de Identidade: uma introdução às teorias do currículo. 3. ed; 8. reimp. Belo Horizonte: Autêntica, 2016.

VAN ZANTEN, A. (Coord.). Dicionário de Educação. São Paulo: Editora Vozes, 2011.

YOUNG, M. F. D. O futuro da educação em uma sociedade do conhecimento: o argumento radical em defesa de um currículo centrado em disciplinas. Tradução de Laura Beatriz Áreas Coimbra. Revisão Técnica de Antônio Flavio Barbosa Moreira. Revista Brasileira de Educação, v. 16, n. 48, set./dez. 2011. 
A FAMÍliA E A ESCOLA: CONDICIONAMENTO DE RELAÇÕES PARA UMA INTEGRAÇÃO PEDAGÓGICA DE SUCESSO NA EDUCAÇÃO INFANTIL

\author{
PASSOS, Geillany Aurina da Silva ${ }^{11}$ \\ JULIÃO, Marcia Aparecida Da Silva Oliveira ${ }^{12}$ \\ VIRGÍNIO, Regina Maria Araújo ${ }^{13}$ \\ AGUIAR, Marileyde Leôncio de Moura ${ }^{14}$
}

\title{
RESUMO:
}

O presente trabalho de conclusão de curso apresenta uma reflexão do tema: a família e a escola: condicionamentos e relações para uma integração pedagógica na educação infantil, relatando o quanto é importante a parceria família e escola na vida escolar do filho-aluno. Tradicionalmente a família tem sido apontada como parte fundamental do sucesso ou fracasso escolar, em que se pode observar que o comportamento escolar depende do relacionamento dos pais para com os filhos em casa e o relacionamento dos alunos e professores na rotina diária da escola. É na família em que ocorrem os primeiros ensinamentos e experiências emocionais que o discente tem como referência para a vida, especialmente no escolar. Assim sendo, o objetivo principal da Educação hoje é favorecer uma participação que gere compromisso da família com a aprendizagem e o sucesso escolar do seu aluno e compromisso da escola. Este trabalho está dividido em quatro partes principais, ficando dividido da seguinte forma, respectivamente: a função da escola na formação do aluno, o papel dos pais na educação dos alunos, a importância da relação da família na escola, e por fim, o papel do professor na Educação Infantil. O embasamento teórico que sustenta as reflexões neste trabalho foi defendido por Reis (2007), Piaget (1972), Freire (1999), Cury (2008) entre outros. Sendo assim, conclui-se que a escola e a família devem estar sempre unidas, uma dependendo da outra na tentativa de alcançar um melhor futuro para o filho e educando e, automaticamente, para toda a sociedade.

PALAVRAS-CHAVE: Escola. Família. Educação. Interação. Professor.

\section{INTRODUÇÃO}

\footnotetext{
${ }^{11}$ Especialista em Educação Infantil pela Faculdade de Tecnologia Módulo Paulista/SP. Professora da Educação Básica do RN. E-mail: geillanypassos@outlook.com

${ }^{12}$ Especialista em Educação Infantil pela Faculdade de Tecnologia Módulo Paulista/SP. Professora da Educação Básica dos municípios de Macau/RN e Guamaré/RN. E-mail: marcia2005_pedagoga@hotmail.com

${ }^{13}$ Mestranda em Ciências da educação pelo Centro de Educação Continuada e Aperfeiçoamento Profissional (CECAP). Professora da Educação Básica do município de Guamaré/RN. E-mail: reginnavirginio@gmail.com

${ }^{14}$ Especialista em Gestão Escolar e Coordenação Pedagógica pelo Instituto Superior de Educação de Pesqueira/PE. Professora da Educação Básica do RN. E-mail: marileydepedagogia@ hotmail.com
} 
O presente trabalho discute sobre a integração da família e escola, uma parceria de sucesso para a obtenção da qualidade de ensino, estabelecendo a importância de uma escola participativa. A educação como direito de todos e dever da família e do Estado, tem por obrigação incentivar a colaboração da sociedade, visando ao pleno desenvolvimento da pessoa, seu preparo para o exercício da Cidadania e sua qualificação para o trabalho.

A influência da família neste processo é um desafio para pais e professores e diversas escolas brasileiras, sendo, atualmente, um tema muito debatido e preocupante no meio educacional.

É necessário e essencial ressaltar que o foco Central deste estudo é a integração da família na escola, que gera um desafio para os professores, pois os alunos, primeiro aprendem em casa para depois vir a escola. É no ambiente familiar que os alunos devem aprender as regras para depois sistematizar na escola e seu aprendizado ser mais favorável.

Conforme afirma Weil (1984, p. 47)

[...] o comportamento das crianças no ambiente escolar e em casa é, na verdade, uma reação as atitudes de seus pais. Foi constatado que a maioria dos problemas de comportamento como ausência de atenção e agressividade, é reflexa da conduta dos Pais. Uma criança, por exemplo, que não consegue, em sala de aula, ficar parada em momento nenhum, mostrando-se sempre nervosa, brigona, agressiva com os colegas, sempre mal arrumada, cadernos rasgados, pode ser uma das causas para que tudo isso seja uma relação conflituosa com a família ou a relação, também conflituosa, entre os pais os quais brigam o tempo todo na frente dos filhos e acabam descontando na criança com desprezo ou indiferença, com agressões físicas ou verbais. Este fenômeno tão comum leva a criança a pedir ajuda demonstrando e isso de várias maneiras inclusive chamando a atenção para si no ambiente escolar.

Neste sentido, a relação da família na escola é importante para influenciar a conduta e os comportamentos são de extrema necessidade nesse processo, até porque na escola não é diferente, nela também a criança apresenta ou não esses comportamentos vivenciados no ambiente familiar. Enfim, este acompanhamento e a relação desenvolvida são indispensáveis para que o aluno fique inserido na instituição escolar sem problemas. 
Nesta perspectiva, com base no conhecimento das famílias, se não houver um interesse em detectar e resolver esses problemas, a escola e o professor podem se sentir impedidos de intervir para o sucesso do educando, portanto, o interesse e a participação da família são fundamentais para o desenvolvimento do educando.

É no aconchego da família e da escola que a criança vai construindo sua consciência/caráter, se socializando, se educando para enfrentar a realidade e as dificuldades na sociedade, tornando-se uma pessoa consciente e crítica.

Para Aries (1978, p. 25) "os bons pedagogos ensinam não apenas as letras, mas também os bons costumes e as maneiras decentes". Acreditamos que a família e a escola vão influenciando nas atitudes de vida das crianças. Elas buscam respeito como gente que pensa, age, ama e sofre.

Convém ressaltar que a relação família/escola propiciará às crianças uma maior capacidade para enfrentar as dificuldades no processo de aprendizagem, principalmente em nosso tempo. Quando o ensino se moderniza, a cada instante e alguns educandos não conseguem aprender de forma satisfatória. Pode-se afirmar que nos dias atuais a escola não pode viver sem a família e a família não pode viver sem a escola, pois é através da interação desse trabalho em conjunto, que tem como objetivo o desenvolvimento do bem-estar e da aprendizagem do educando, os quais contribuirão na formação integral do mesmo.

É nesse sentido que a participação dos pais na aprendizagem escolar é necessária e fundamental, não só na parceria, como também dividindo as responsabilidades, contribuições e limites do educando entre ambas. Hoje, para a família é cobrada uma participação na escola, mas essa participação deve ser constante e consciente. A família e a escola formam uma equipe. É fundamental que ambas sigam os mesmos princípios e critérios, bem como a mesma direção em relação aos objetivos que desejam atingir. E a parceria da Família com a escola sempre será fundamental para o sucesso da Educação de todo indivíduo. Portanto, pais e educadores necessitam serem grandes e fiéis companheiros nessa nobre caminhada da formação educacional do ser humano.

Assim, a participação dos pais no processo de aprendizagem na Educação Infantil facilita a prática pedagógica dos professores. Isso evidencia a responsabilidade que a escola tem em incentivar e apoiar sem articulação família-escola. Por isso, a 
questão da parceria entre família e escola reúne importantes pontos que nos convidam a refletir sobre os benefícios a serem alcançados nessa relação.

\section{FUNÇÃO DA ESCOLA NA FORMAÇÃO DOS ALUNOS}

É papel das escolas ensinar e conceituar para que possamos aprender diferentes disciplinas, são partes de teorias que buscam explicar e comprovar os fenômenos da natureza e os fatos sociais. A escola é para a sociedade, é uma extensão da família, pois é através dela que se consegue desenvolver indivíduos críticos e conscientes de seus direitos e deveres.

A escola tem encontrado dificuldade em assimilar as mudanças sociais e familiares e incorporar as novas tarefas que à ela tem sido delegada, embora isso não seja um processo recente. Entretanto, a escola precisa ser pensada como um caminho entre a família e a sociedade, pois, tanto a família quanto a sociedade voltam seus olhares exigentes sobre ela.

Como diz Szymanski (2001, p. 90), a escola tem um papel preponderante na contribuição do sujeito, tanto do ponto de vista de seu desenvolvimento pessoal e emocional, quanto da constituição da identidade, além de sua inscrição futura na sociedade.

$\mathrm{Na}$ escola, a criança e o adulto interagem numa relação social específica na relação de ensino, com a finalidade de ensinar e aprender, para que seus participantes que, nela ocupam lugares sociais diferentes, a criança no papel de aluno é colocada diante da tarefa de compreender as bases dos conceitos sistematizados ou científicos e o professor é encarregado de orientá-la.

$\mathrm{Na}$ verdade, encontrar formas de modo a favorecer um ambiente conveniente e favorável a todos, constitui-se num grande desafio para a escola. Diante dessas premissas, percebe-se que o papel da escola supera a simples condição de mera transmissora de conhecimento.

Para Reis (2007, p. 6), a escola nunca educa sozinha, de modo que a responsabilidade educacional da família jamais cessará. Uma vez escolhida a escola, a relação com ela apenas começa. É preciso o diálogo entre escola, pais e filhos.

O dever da escola é propiciar situações de aprendizado, porém o sujeito do aprendizado é o aluno, ou seja, ele é quem busca seu conhecimento, através do 
incentivo do professor. A escola não é a única responsável pela educação do aluno, sua família também tem grande responsabilidade. Mas, cabe a escola orientar em todos os âmbitos, a fim de formar cidadãos.

$\mathrm{Na}$ escola, os alunos devem entender-se cidadãos ativos no processo ensinoaprendizagem, socializando conhecimentos e construindo um olhar crítico frente a qualquer assunto em estudo, quer seja ou não por eles vivenciados. O papel da escola passa a ser mais significativo ainda, uma vez que lida com um saber que muitas vezes precisa ser repensado, reavaliado e reestruturado.

A escola e a família, cada qual com seus valores e objetivos específicos na educação de uma criança adolescente, constituindo uma estrutura intrínseca, em que quanto mais diferentes são, mais necessitam uma da outra.

Como diz Paro, (1993, p. 30):

A escola deve utilizar todas as oportunidades de contato com os pais, para passar informações relevantes sobre seus objetivos, recursos, problemas e também sobre as questões pedagógicas. Só assim, a família irá se sentir comprometida com a melhoria da qualidade escolar e com o desenvolvimento de seu filho como ser humano.

Nesta perspectiva, a escola por sua maior aproximação às famílias constitui-se em instituição social importante na busca de mecanismos que favoreçam um trabalho avançado, em favor de uma atuação que mobilize os integrantes, tanto da escola, quanto da família, em direção a uma maior capacidade de dar respostas aos desafios que são impostos pela sociedade.

Partindo desse pressuposto, espera-se que a escola cumpra o seu papel social, que é preparar o aluno para enfrentar as dificuldades, seja ela cognitiva ou comportamental. Sendo assim, a expectativa em relação ao desempenho escolar é esperada com muita ansiedade pela família, que atribui à mesma tal função.

É importante que a escola Busque estreitar as relações com a família em nome do bem-estar do aluno. Tem como tarefa árdua educar a criança para que ela tenha uma vida plena e realizada, além de formar o profissional, contribuindo assim para melhoria da sociedade em questão. Como afirma Torres (2008, p. 29): “[...] uma das funções sociais da escola é preparar o cidadão para o exercício da cidadania, vivendo como profissional e cidadão. 


\section{O PAPEL DOS PAIS NA EDUCAÇÃO DOS FILHOS}

A família é a base da sociedade. Neste sentido cabe aos pais um papel fundamental na educação dos filhos. Os pais são os primeiros educadores, e, desde o início, estão incumbidos do sustento material, cultural e espiritual das crianças.

Para pensar em uma educação de qualidade hoje é preciso ter em mente que a família esteja presente na vida escolar de todos os alunos, em todos os sentidos, ou seja, é preciso uma interação entre escola e família. Neste sentido, a escola e a família possuem uma grande tarefa, pois nelas é que se formam os primeiros grupos sociais de uma criança.

Além de ensinar os princípios de tudo em casa, os pais devem estimular a aprendizagem dos filhos na escola também. É comprovado que desta forma as crianças aprendem com mais facilidade e mostram um desempenho ainda melhor. A família deve participar das atividades escolares, tanto na escola quanto em casa, ajudando nos deveres e trabalhos.

Envolver os familiares na elaboração da proposta pedagógica pode ser a meta da escola que pretende ter um equilíbrio, no que diz respeito à educação de seus educandos. A sociedade moderna vive uma crise de valores éticos e morais. Essa é uma constatação que norteia os arredores dos setores educacionais, pois é na escola que essa crise pode aflorar mais, ficando em maior evidência.

Compreendemos com Bock (1989, p. 143) que:

A importância da primeira educação é tão grande na formação da pessoa que podemos compará-la ao alicerce da construção de uma casa. Depois, ao longo da sua vida, viram novas experiências que continuaram a construir a casa/indivíduo, relativizando o poder da família.

Os pais têm muita importância na educação dos filhos, pois são responsáveis pelos conhecimentos e valores adquiridos pelas crianças no processo de aprendizagem da criança. Exercem, portanto, importante mediação na relação da criança com o mundo. Pais que valorizam a formação científica e cultural tendem a influenciar positivamente a relação estabelecida entre os filhos e o processo de aprendizagem. 
A participação ativa no processo educacional indica esse interesse. Quando os pais se aproximam dos conteúdos aprendidos na escola e demonstram interesse, essa atitude reflete diretamente no comportamento dos filhos. O papel dos pais na educação dos filhos é, portanto, emocional. Assim, a escola, deve sempre envolver a família dos educandos em atividades escolares.

É comum ver algumas famílias deixando toda a responsabilidade de educar os filhos para a escola, esquecendo ser o papel dos pais na educação. É preciso ter clareza que o processo educativo de uma pessoa é definido pelo seu desenvolvimento intelectual, físico e moral, proporcionando assim a socialização e a adaptação com os outros indivíduos.

Quando se fala em vida escolar e sociedade, não há como não citar o mestre Paulo Freire (1999, p. 18), quando diz que:

A educação sozinha não transforma a sociedade, sem ela tampouco a sociedade muda. Se opção é progressista, se não se está a favor da vida e não da morte, da equidade e não da Injustiça, do direito e não do arbítrio, da convivência com o diferente e não de sua negação, não se tem outro caminho senão viver a opção que se escolheu. Encarnála, diminuindo, assim, a distância entre o que se diz e o que se faz.

Essa visão, certamente, contribui para que se tenha uma maior clareza do que se pode fazer no enfrentamento das questões socioeducativas no conjunto do movimento social. Promover a família nas ações dos projetos pedagógicos significa enfatizar ações em seu favor e lutar para que possa dar vida às leis. Mais do que criar um novo espaço para tratar das questões da família ou da escola, a própria escola deve articular seus recursos institucionais de maneira a assegurar que as reflexões, os debates, os estudos e as propostas de ação possam servir de embasamento para que o desenvolvimento social se concretize, por meio de práticas pedagógicas educativas efetivas.

Segundo Valenine (1995, p. 7):

A cidadania é o espaço para a realização das pessoas. É por meio de seu exercício que a sociedade pode reassumir seus rumos, redefine sua organização e reorganizar suas atitudes e objetivos, para que sejam voltadas para o bem comum e para que se atualizem de acordo com as mudanças que vão ocorrendo. 
Quando os pais não se mostram presentes na educação e depois na vivência dos filhos na escola, isso pode causar transtornos ainda mais graves no desenvolvimento da criança. É muito importante que a família participe de todas as fases da vida do jovem, orientando as suas atitudes e identificando qualquer situação fora do comum.

A participação na vida escolar dos filhos é de suma importância para o desempenho do aluno, pois quando os pais acompanham a criança em todo o seu processo de desenvolvimento Educacional, ela se sente valorizada e importante na vida de seus pais. Tais sentimentos somente contribuem para o seu aprendizado.

Existem muitas maneiras dos pais participarem deste processo, sendo que algumas contribuições tornam-se mais relevantes, como o auxílio nas tarefas escolares, ou incentivo à leitura e o seu envolvimento nos eventos pedagógicos corridos na escola.

Já o papel da escola na educação das crianças é o de ensinar e preparar as próximas fases da vida. O bom desenvolvimento escolar das crianças na educação infantil depende de todos os aprendizados que elas têm na escola, mas dependem principalmente da educação que eles recebem em casa. Portanto, pais e educadores necessitam ser grandes e fiéis companheiros nesta nova caminhada da formação educacional do ser humano.

Desta forma, a família e a escola são parceiros fundamentais no desenvolvimento de ações que favoreçam o sucesso escolar e social das crianças, formando uma equipe. É fundamental que ambas sigam os mesmos princípios e critérios, bem como a mesma direção em relação aos objetivos que desejam atingir.

\section{A IMPORTÂNCIA DA RELAÇÃO FAMÍLIA/ESCOLA}

Cabe a escola formar cidadãos críticos reflexivos e, autônomos, conscientes de seus direitos e deveres, capazes de compreender a realidade em que vivem preparados para participar da vida econômica, social e política do país, apta a contribuir para a construção de uma sociedade mais justa.

De acordo com Parolim (2003, p. 99)

[...] tanto a família quanto a escola desejam a mesma coisa: preparar as crianças para o mundo; no entanto, a família tem suas particularidades que a diferenciam da escola, e e suas necessidades que a aproximam dessa mesma instituição. A escola tem sua 
metodologia e filosofia para educar uma criança, no entanto ela necessita da família para concretizar o seu projeto educativo.

A escola e a família, assim como outras instituições, vêm passando por profundas transformações ao longo da história. Essas mudanças acabam por intervir na estrutura familiar e na dinâmica escolar de forma que a família, em virtude das circunstâncias entre elas o fato de as mães ou responsáveis terem de trabalhar para ajudar no sustento da casa, tem transferido para a escola algumas tarefas educativas que deveriam ser desenvolvidas em casa.

Em vista disso, é que destacamos a necessidade de uma parceria entre a família e a escola, visto que, apesar de cada uma apresentar valores e objetivos próprios no que se refere à educação do aluno, necessita uma da outra e quanto maior for a diferença maior será a necessidade de relacionar-se.

Porém, é importante ressaltar que nem a escola e nem a família precisam modificar a forma de se organizar, basta que estejam abertas à troca de experiências, mediante uma parceria significativa. A escola não funciona isoladamente, faz-se necessário que cada um dentro de sua função e trabalho, busque atingir uma contribuição coletiva, construindo assim, para melhoria do desempenho escolar dos alunos.

É quase impossível separar aluno/filho, por isso, quanto maior for o fortalecimento dessas relações família-escola, melhor será o desempenho escolar desses filhos/alunos. Neste sentido, é importante que a família e escola saibam aproveitar os benefícios deste estreitamento de relações, pois isto irá resultar em princípios facilitadores da aprendizagem e formação social da criança.

Sabemos que esta situação é muito comum no mundo globalizado em que vivemos, por isso, não é pertinente ficar culpando os pais por atribuir à escola tal papel. Naturalmente, depois da família, são nelas que os alunos permanecem mais tempo, desta forma, esses dois sistemas são de fundamental importância no processo cognitivo da criança. Ao abordar isso, Oliveira (1999, p. 196) esclarecem que:

[...] não compete apenas a escola a função de Educar, mas também a família. Esse esta hoje tem a sobrecarga da vida moderna (trabalho da mãe além do pai, falta de cuidado substituto para os filhos) é importante lembrar, entretanto, que não é o tempo que se está junto com os filhos, mas a maneira como se estabelece a relação com eles, o 
que importa. Se os filhos sabem que podem contar com os pais onde eles tiverem quando necessário, seus pais tem uma parte de seu tempo diário e de lazer reservado para dar atenção ou fazer um programa com os filhos [...] pode se esperar menor probabilidade de problemas.

No entanto, ao longo da vida de acompanhamento dos pais e participação da escola, o beneficiado será sempre a criança. É importante ressaltar que a família é o centro e a primeira convivência educacional da criança, sendo dela a responsabilidade de integrá-la na sociedade, estimulando a sua participação e a construção de conceitos de valores morais.

E a escola é, portanto, um ambiente propício para a aprendizagem dos conhecimentos pertinentes para viver em sociedade. Porém, participando deste processo, ela se sentirá apta a conviver no meio social. Mesmo sabendo da importância das duas comunidades, uma não pode superar a outra, mas andam contribuindo mutualmente para o sucesso e a felicidade dos envolvidos, em especial a criança.

Entretanto, para que esta parceria se desenvolva de forma positiva é necessário que a família não atribua somente à escola a responsabilidade pelo processo formativo da criança e que a escola abra espaço para a participação da família, não somente em eventos como em reunião de pais, mas cotidianamente de forma que os pais e responsáveis se conscientizem da importância de sua participação no processo educativo, e participem ativamente na educação escolar dos filhos.

Desta forma, Tiba (2007, p. 187) diz:

\begin{abstract}
A Rigor, a educação escolar é diferente da familiar. Não há como uma substituir a outra, pois ambas são complementares. [...] a escola nunca deve absorver a educação familiar, pois seu objetivo é preparar profissionalmente seus alunos, cuidando, portanto, da convivência grupal e social.
\end{abstract}

O ambiente familiar, bem como suas relações com o aprendizado escolar revelase um campo pouco explorado, porém muito importante para o desenvolvimento e aprendizagem das Crianças. Sendo assim, é indispensável que a família esteja em harmonia com a instituição, uma vez que a relação harmoniosa só pode enriquecer e facilitar o desempenho educacional das Crianças. E como nos diz Prado (1981, p. 12), “a família não é um simples fenômeno natural, mas pelo contrário, é uma instituição 
social que varia no tempo e apresenta formas e finalidades diferentes dependendo do grupo social em que esteja".

Assim, a preparação para a vida, a formação da pessoa, a construção do ser, são responsabilidades da família quando a criança está em seu interior e esta deve preparar os jovens para atuar com liberdade, mas sem perder a responsabilidade sobre seus atos. É papel da família contribuir para uma boa formação de caráter dos seus filhos, repassando os valores éticos e morais, sem eximir da sua responsabilidade o papel de educadora.

Mas são nas escolas que também se trabalha os valores e a ética, por isso, é preciso repensar o papel da escola e a importância da qualidade implica nas características pessoais e profissionais das pessoas envolvidas e comprometidas com a educação. A escola é um ambiente de importante convívio no qual recebem estímulos, espaço para a socialização e tem o objetivo de preparar o aluno profissionalmente.

\section{PAPEL DO PROFESSOR NA EDUCAÇÃO INFANTIL}

A participação do professor neste processo de interação é de fundamental importância para a formação do aluno. Nessa trajetória da sociedade em que vivemos, é de grande valor salientar a importância dos pais e dos professores como construtores de um mundo melhor.

No processo de ensino-aprendizagem, o professor tem a responsabilidade de incentivar seus alunos a refletirem sobre as ações escolares, incluindo as de interação família e escola, da grande aproximação afetiva entre pais e alunos e professores, que resultaram em estratégias de ensino para o desenvolvimento educacional, garantindo sucesso escolar da Criança e Adolescente.

Segundo o próprio Piaget $(2007$, p. 50) [...] "toda pessoa tem direito à educação, é evidente que os pais também possuem o direito de serem se não educados, ao menos, informados no tocante a melhor educação a ser proporcionada aos seus filhos". No entanto, ser professor é ajudar a criança a superar as dificuldades que lhe chegam ao cotidiano. O verdadeiro educador no sentido de sua participação é ajudar a formar cidadãos de bem, conhecendo as necessidades do educando e procurando extrai o que tem de melhor na sua participação, ajudando-o a reformular o que tenha que ser repensado. 
Cury (2008, p. 119) diz que "desejamos ter condições apenas para lapidar a inteligência dos nossos jovens, fazendo-os amar a arte de pensar e aprender a grandeza dos direitos e dos deveres humanos". Deve existir entre o professor e o aluno uma ponte que liga os seus mundos, pois o educador precisa conhecer o seu educando, através de um diálogo em que ele expresse realmente o porquê de comportamentos variados, ficando mais fácil sua intervenção para poder lapidá-lo.

Diante de todo esse processo Cury (2018, p. 119), mais uma vez contribui e nos alerta que, "por trás de cada aluno arredio, de cada jovem agressivo, há uma criança que precisa de afeto". É importante que o professor procure compreender a maneira como seus alunos agem, pois muitas vezes eles demonstram ser aquilo que deles não esperam. A relação professor-aluno deve ser cultivada a cada dia, pois um depende do outro, os dois crescem e caminham juntos. É nesta relação madura que o professor deve ensinar, pois aprendizagem não ocorre somente em sala de aula.

Por isso, é importante lembrar que não existe nada mais prazeroso do que o amor que os educadores têm por seus educandos, esse amor ultrapassa todas as barreiras e preocupações que os pais têm com os filhos, é um dom que somente a divina sabedoria poderá explicar.

Um professor se constrói pelas suas atitudes quando adota uma relação professor-aluno e na sua importância que ele vier até eles, da forma que mostram o mundo, de se relacionar com ele, a maneira de lecionar e estabelecer os papéis que cabem a cada um deles nessa aprendizagem, são reflexos de como somos, de como vivemos e pensamos em um determinado momento de nossa vida. Complementando, Aranha (1989, p. 194) aponta que:

[...] o professor não só quer mudar o comportamento do aluno, pois aí reside o cerne do processo educativo, como também quer Educar para um mundo melhor que está para ser construído. E esta ação não é solitária, mas deve ser o resultado da ação Coletiva dos professores e alunos na luta por melhores condições de vida.

O professor só deve se dar por satisfeito quando ver seus objetivos atingidos. Portanto, a alma de qualquer instituição é o professor. Assumir essa parcela de responsabilidade é o caminho para que a educação seja uma prioridade. O principal valor de um bom professor é sua personalidade, a capacidade de comunicar na própria 
vida, de questioná-la, de se atrever a pensá-la, a inventá-la, porém, para que sirva junto com cada um dos seus alunos, como um espaço de aprendizagem.

Entretanto, Moreira (2012, p. 29), enfatiza que o futuro professor precisa de conhecimentos mais ecléticos para não só apresentar o mundo geográfico e humano ao seu aluno, como também mostrar o mundo interno que se movimenta dentro e fora de si mesmo construindo um ser consciente. Para que isso ocorra o professor deve, em primeiro lugar, gostar e acreditar naquilo que faz, ou seja, através de seus atos e ações ele servirá de modelo para seus alunos; se ele ensina a refletir, se ele ensina a respeitar o próximo, ele deve respeitar seus alunos e assim por diante. Deste modo, ele está sendo uma prova viva daquilo que está ensinando, pois bem à sua frente existem seres humanos que estão sendo moldados por ele.

O verdadeiro educador, no sentido de sua profissão, ajuda a formar cidadãos de bem, conhecendo a intimidade do educando e procurando extrair o que tem de melhor no seu íntimo, ajudando a reformular o que tem que ser repensado. Ser professor é muito mais do que passar teorias e conceitos, é edificar-se pelo próprio exemplo. Antunes (2005, p. 53) destaca que:

Ajudar a criança a construir um bom caráter é a mesma coisa que ajudá-la a desenvolver sua consciência do erro e do acerto. Caráter e consciência expressam a visão que ela possui de si mesma e aproxima-se muito do sentimento de autoestima. É por essa razão que a educação do caráter é importante.

Ter uma boa interação, estabelecer um trabalho conjunto com outros profissionais de modo integrado e relacionar o ato de Educar e ensinar de maneira responsável, reconhecendo a criança como um ser inteiro, são características que o professor deve cultivar de maneira ética, respeitando os demais profissionais, os alunos e as famílias.

É importante também, ser criativo e paciente nas relações, ter disponibilidade para brincar com os alunos, exercitar o olhar e a escuta e reconhecer que a educação, especialmente nesta fase, é um ato de amor, de construção, de exploração de potencialidades, de busca e descoberta.

Devemos sempre incentivar a criança para que os objetivos possam ser sempre alcançados e, acima de tudo, termos um conhecimento claro delas. Se ocorrerem estes 
aspectos, estaremos cada vez mais próximo das crianças, acompanhando-as o ato da aprendizagem e da construção constante do seu conhecimento. Desta maneira se exigirá do educador o conhecimento das reações das crianças, percebendo suas tentativas, limites e possibilidades, planejando a ação pedagógica a partir dessas observações e reflexões.

\section{CONSIDERAÇÕES FINAIS}

Este trabalho é resultado de uma pesquisa bibliográfica, essencialmente. Sobre a importância da família e escola no processo de desenvolvimento da aprendizagem da criança, inúmeros autores abordam essa questão, pretendendo investigar qual o papel da família junto à escola no desempenho das crianças.

Na educação, a escola sempre teve um papel fundamental, e hoje além de ensinar para a cidadania e para o trabalho, tem também a responsabilidade de passar os valores fundamentais para a vida do indivíduo, sendo que esse papel deveria ser uma iniciativa da família, que muitas vezes não estão integrados na aprendizagem e formação de seus filhos. O apoio da família aos trabalhos desenvolvidos com os alunos seria um aliado importante para o bom êxito na construção do saber.

Assim, compreende-se que o diálogo entre a escola e a família seja capaz de possibilitar a troca de ideias entre elas e em nenhuma instância compete a escola julgar como certa ou errada a educação que cada família oferece, pois o objetivo da escola é oportunizar e abrir espaços para que valores sejam adquiridos, bem como trabalhar o respeito e as diferenças expressadas pela família, proporcionando e garantindo a integridade básica do aluno e da família.

O diálogo promove uma maior aproximação e pode ser o começo de uma grande mudança no relacionamento entre a família e a escola. Sendo assim, a sociedade necessita de uma parceria de sucesso entre a família e a escola, pois só assim poderá, realmente, fazer uma educação de qualidade e que possa promover o bem-estar de todos.

Conclui-se então que a relação escola família cria compromissos, de interrelações, reproduz laços éticos dando novos significados e abrindo horizontes para uma formação de prática pedagógica. Só assim se poderá alcançar uma sociedade coerente 
em que seus agentes conheçam e cumpram seus papéis em todos os processos, sobretudo, no processo educacional, sem deixar de lado a família e o social.

\section{REFERÊNCIAS}

ARANHA, Maria Lúcia de Arruda. Filosofia da educação - 1. Ed. São Paulo: moderna, 1989, p. 194.

ARIES, Philipe. História social da Criança e da família. Ltd editora S.A, 1978, p. 25.

ANTUNES, Celso. A linguagem do afeto: como ensinar virtudes e transmitir valores e. Final Campinas, São Paulo. Papirus, 2005, p 53.

BOCK, Ana Mercês Bahia et all. Psicologias: uma Introdução ao Estudo de Psicologia. São Paulo: Saraiva, 1989, p. 143.

CURY, Augusto. Pais brilhantes professores fascinantes. Rio de Janeiro: Sextante, 2008, p. 119.

FREIRE, Paulo. Pedagogia da Autonomia: saberes necessários à prática educativa. 11.1 AD Rio de Janeiro: paz e Terra, 1999, p. 18.

MOREIRA, Antônia Nolay de Lima. Professor construir: repensando a educação. Construir notícias, ano 11, p. 29, Maio/junho 2012, p. 29.

OLIVEIRA, Vera de, e Bossa, Nádia A. (Org.). Avaliação psicopedagógico da criança de 0 a 6 anos. Petrópolis/RJ: vozes, 1999, p.196.

PIAGET, J. Para onde vai a educação. Rio de Janeiro: José Olímpio. 2007, p. 50.

PRADO, Danda. O que é família. São Paulo: Brasiliense, 1981, p. 12.

PARO, Victor Henrique. Administração escolar: introdução crítica. São Paulo: Cortez, 1993, p. 68.

PAROLIN, Isabel. Relação família e escola: revista atividades e experiências. São Paulo: positivo, 2003, p. 99.

REIS, Risolene Pereira. Mundo jovem. $\mathrm{n}^{\circ}$ 373. Fev. 2007. P. 6

SZYMANSKI, Heloisa. A relação família-escola: desafios e perspectivas. Brasília: plano Editora, 2007, p. 6.

TIBA, Içami. Disciplina, limite na medida certa. São Paulo: gente, 2007, p. 187. 
VALENINE, L.D. Qual cidadania? In: Congresso Nacional de Educação, 15. Fortaleza CE 1995. O professor necessário na construção da Cidadania. Fortaleza, AEC, jul. 1995, p. 7.

TORRES, Sueli. Uma função social da escola. 2008. Em

www.fundaçãoromi.org.br/homesite/news.asp?news=775. Acesso em 11/04/2020.

WEIL, Pierre G. A criança, o lar e a escola - guia prático de relações humanas e psicológica para pais e professores. Petrópolis: vozes, 1984, p 47. 


\title{
A IMPORTÂNCIA DA ATUAÇÃO DOS PROFESSORES NA EDUCAÇÃO INFANTIL
}

\author{
FAUSTINO, Weverson Waldones ${ }^{15}$ \\ MELO, Manoel Gilvan de ${ }^{16}$ \\ CAFÉ, Joana Darc de Melo ${ }^{17}$
}

\section{RESUMO:}

O professor de Educação Infantil é alguém crucialmente importante às concepções subjacentes nas inovações das práticas pedagógicas para a criança, como agente do processo de construção e aprendizagem. O presente artigo tem como propósito contribuir com o debate acerca da função do professor no cotidiano das práticas escolares, abordar a importância da sua atuação na educação infantil. O processo metodológico da pesquisa partiu de uma revisão de literatura, a partir da análise da construção do perfil deste profissional à aprendizagem da criança, de forma a evidenciar a identidade desse profissional, bem como sua especificidade e função no contexto escolar. Diante de análises neste intuito, de modo geral, presume-se que as práticas pedagógicas contribuem para aprendizagem infantil nesta abordagem, especificamente, sobre a função e atuação deste profissional nos anos iniciais, ressaltando sua importante contribuição na construção do ensino na Educação Infantil.

PALAVRAS - CHAVES: Educação Infantil. Professor. Função e Atuação.

\section{INTRODUÇÃOO}

A Educação Infantil tem como finalidade o desenvolvimento absoluto das crianças até cinco anos de idade, sendo nesta etapa que as crianças descobrem novos valores, sentimentos, costumes, ocorrendo também o desenvolvimento da autonomia, da identidade e a interação com outras pessoas.

A Educação Infantil é importante, pois cria condições para que as crianças possam conhecer e descobrir novos valores, costumes e sentimentos, através das

\footnotetext{
${ }^{15}$ Mestrando do Curso de Ciências da Educação pela Faculdade do Estado do Maranhão (FACEM). Atualmente é Professor dos anos iniciais da Rede Estadual no município de Ipanguaçu/RN. E-mail: weverson_faustino.90@hotmail.com

${ }^{16}$ Mestrando do curso de Ciências da Educação pelo Centro de Educação Continuada e Aperfeiçoamento Profissional (CECAP). Atualmente é professor efetivo dos Municípios de Itajá/RN e Ipanguaçu/RN. Email: m-gilvanmelo@ hotmail.com

${ }^{17}$ Mestranda do Curso de Ciências da Educação pelo Centro de Educação Continuada e Aperfeiçoamento Profissional (CECAP). Atuou como Professora da Educação Básica no Estado do Rio Grande do Norte e no Estado do Espírito Santo. E-mail: cafe00@gmail.com
} 
interações sociais, e nos processos de socialização, o desenvolvimento da identidade e da autonomia.

Sendo assim, é na Educação Infantil que se inicia a construção da autonomia e do desenvolvimento das estruturas cognitivas, sociais e afetivas dos alunos. Compete, então, ao professor, desenvolver atividades escolares planejadas e executadas com responsabilidade, criatividade em sala, para assim haver uma interação maior entre alunos e educadores.

A Educação Infantil envolve qualquer forma de educação da criança, ou seja, ela na família, comunidade, sociedade e cultura. De acordo com RCNEI (BRASIL, 1998), a instituição de Educação Infantil é um dos espaços de inserção das crianças nas relações éticas e morais que permeiam a sociedade na qual estão inseridas.

É considerada a primeira etapa da educação básica, ajudando no desenvolvimento psicológico, físico e social da criança. Conforme diz a LDB, lei 9394/96, Art. 29:

\begin{abstract}
A Educação Infantil é conceituada como a primeira etapa da Educação Básica e tem como finalidade o desenvolvimento integral da criança até cinco anos de idade, em seus aspectos físico, psicológico, intelectual e social, complementando a ação da família e da comunidade. (BRASIL, 1996).
\end{abstract}

Com a expansão da oferta na Educação Infantil, a demanda por professores qualificados também aumenta. Nas creches, por exemplo, a proporção deve ser para cada 15 alunos dois professores e no máximo 25 alunos por sala. Por isso, o Ministério da Educação tem intensificado as ações de formação de docentes para atuar nesta etapa da Educação Básica.

Pretende-se que, este artigo contribua com a reflexão acerca da função do professor na escola pública e a importância deste profissional para a Educação Infantil. Tendo em vista as várias possibilidades de discussão sobre a temática, optou-se por refletir sobre uma suposta perda de identidade profissional imposta, principalmente, pela falta de profissionais para desempenhar as diversas funções que a demanda educacional pública exige na atualidade.

Hoje, a escola possui um caráter formador, aprimorando valores e atitudes, desenvolvendo, desde a mais tenra idade, o sentido da observação, despertando a 
curiosidade intelectual nas crianças, capacitando-as a buscar informações, onde quer que elas estejam para usá-las no seu cotidiano.

Levando em consideração que se deve refletir sobre as intervenções pedagógicas, é bastante importante o processo de aprendizagem na Educação Infantil, pois, atualmente, as ações dos professores têm sido o centro das atenções no que tange às questões educativas e das problemáticas que às rodeiam.

Dentre uma das questões que ganhou destaque nestes termos, tem sido a formação continuada, porque ela é a base primordial da transformação conceitual da prática docente. Desta forma:

A formação do educador deve ser entendida como um processo dinâmico, contínuo e permanente, tendo como base um conhecimento cada vez melhor da criança, conhecimento psicopedagógicos que o ajudem a compreender melhor as técnicas e destrezas que lhe permitirão uma boa e correta atuação educativa, conhecimentos sociais para adequar melhor a realidade educativa ao contexto socioeducativo (ARRIBAS, 2004, p. 32).

Para que o professor exerça de forma satisfatória suas funções, ele deverá trabalhar de maneira determinada, para que possa identificar a realidade de cada problema, solucionando-o de forma favorável, conseguindo assim resultados que auxiliem de forma eficiente em seu papel na Educação Infantil.

\section{ASPECTOS METODOLÓGICOS}

A metodologia utilizada para a presente pesquisa é classificada em qualitativa exploratória baseada em pesquisas bibliográficas, ressaltando abordagens conceituais sobre a Educação Infantil e o papel do professor, no que tange o processo do desenvolvimento da criança nos seus anos iniciais de aprendizagem, como também toda a estrutura envolvida dentro da educação infantil.

Tendo como princípio que toda pesquisa bibliográfica pressupõe uma base de dados, bem como critérios de seleção do material, procurou-se atentar com muito cuidado para esses tópicos no decorrer do artigo. A pesquisa foi pautada em livros, artigos científicos, legislação federal e documentos oficiais do Ministério da Educação.

Ao decorrer do desenvolvimento do trabalho, a percepção da pesquisa bibliográfica tornava-se nitidamente correlacionadas com a seleção do material que foi 
utilizado, sendo assim, percebeu-se que os dados selecionados tinham um embasamento teórico, o que facilitou o desenvolvimento do trabalho como um todo, podendo afirmar que houve coerência, efetividade e unicidade.

A pesquisa bibliográfica reside no fato de permitir ao investigador a cobertura de uma gama de fenômenos muito mais ampla, sendo uma vantagem particularmente importante quando o problema de pesquisa requer dados muito dispersos pelo espaço. “A pesquisa bibliográfica também é indispensável nos estudos históricos. Em muitas situações não há outra maneira de conhecer os fatos passados senão com base em dados secundários" (GIL, 2011, p. 50).

De acordo com Gil (2011), a pesquisa bibliográfica é constituída, principalmente, de livros e artigos científicos, desenvolvidos a partir de materiais já elaborados. São exigidos em quase todos os estudos, e algumas pesquisas são desenvolvidas exclusivamente a partir de fontes bibliográficas.

Observou-se que a importância da pesquisa bibliográfica estava em perceber a relação da percepção entre realidade e cientificidade, o que embasou o desenvolvimento do presente artigo.

\section{A EDUCAÇÃO INFANTIL NO BRASIL HOJE}

A Educação Infantil é compreendida como a primeira etapa da Educação Básica, oferecida hoje no Brasil a crianças de zero a cinco anos, tanto na rede pública, como na rede privada de ensino. Tem por finalidade contemplar as dimensões do cuidar e educar, visando o desenvolvimento integral do aluno.

De acordo com as Diretrizes Curriculares Nacionais Especificas para a Educação Infantil em seu art. $5^{\circ}$ (Resolução n5/2009, de 17 de dezembro de 2009), nesta etapa, a Educação é oferecida em creches e pré-escolas, às quais se caracterizam como espaços institucionais não domésticos que constituem estabelecimentos educacionais públicos ou privados que educam e cuidam de crianças de 0 a 5 anos de idade no período diurno, em jornada integral ou parcial, regulados e supervisionados por órgão competente do sistema de ensino e submetidos a controle social (BRASIL, 2009, p. 12).

De acordo com as Diretrizes Curriculares Nacionais para a Educação Infantil (BRASIL, 2010, p. 30) devido à transição da Educação Infantil para o Ensino Fundamental, é necessário que a proposta pedagógica propicie formas de garantir a 
continuidade do processo de ensino-aprendizagem e desenvolvimento da criança, sempre respeitando suas singularidades e sua faixa etária, não antecipando os conteúdos a serem trabalhados no ensino fundamental.

Em relação à legislação que ampara a infância no Brasil, Kramer (2005, p. 134) faz os seguintes apontamentos: Em termos legais, podemos afirmar que nunca o Brasil teve uma legislação tão moderna no que se refere à infância: a Constituição de 1988, que garante, entre outras coisas, a Educação Infantil como direito das crianças e suas famílias. Lei de Diretrizes e Bases da Educação Nacional de 1996, que reconhece a Educação Infantil como primeira etapa da Educação Básica; o Plano Nacional de Educação de 2001; o Estatuto da Criança e do Adolescente de 1990 são instrumentos legais que reconhecem a criança como sujeito social de direitos.

A Educação Infantil no Brasil até pouco tempo destinava-se a crianças de zero a seis anos de acordo com a LBD 9394/96: em seu art. 20º qual define o atendimento de crianças de zero a três anos em creches e de 4 a 6 anos em pré-escolas. Com a implementação da Lei 11.274 de 06 de fevereiro de 2006, realiza-se a alteração dos artigos 29, 30, 32 e 87 da LDB n o 9.394, estabelecendo que o ensino fundamental tenha duração de nove anos, onde os alunos a partir dos 6 anos necessitam ser matriculados no ensino fundamental.

Desta forma, a Educação Infantil sofre algumas modificações, conforme é apresentado nas Diretrizes Curriculares Nacionais para a Educação Básica, conforme Resolução CNE/CEB No 05/2009, art. $5^{\circ}$ em seus parágrafos $1^{\circ}$ e $2^{\circ}$ :

$\S 1^{\circ}$ - É obrigatória a matrícula na Educação Infantil de crianças que completam 4 ou 5 anos até o dia 31 de março do ano em que ocorrer a matrícula. $\S 2^{\circ}$ - As crianças que completam 6 anos após o dia 31 de março devem ser matriculadas na Educação Infantil (BRASIL, 2009).

Nas creches, devem conter profissionais especializados em Educação Infantil que disponham realizar os cuidados com as crianças em união com a escolaridade adequada, que valorizem a criatividade da criança e usem materiais, brinquedos, livros em quantidade suficiente, variados e adequados à faixa etária dos alunos.

O ambiente escolar deve conter um espaço dinâmico, onde possam ocorrer brincadeiras, é importante que seja um lugar bastante explorado, de fácil acesso, limpo e seguro e organizado. Nas pré-escolas as atividades como pintura e música, contação de 
histórias, oficinas de desenho, atividades que envolvem os cuidados com o corpo, são atividades indicadas e adequadas nessa etapa da escolarização da primeira infância.

Ter salas adequadas às idades dos alunos, ter recursos pedagógicos variados, funcionários, como professores qualificados que apresentem planos pedagógicos coerentes.

\section{A Trajetória do Professor Pedagogo na Educação Brasileira}

Para discutir o perfil profissional do pedagogo, sua função e atuação no espaço escolar, foi preciso fazer uma breve retomada histórica com o propósito de analisar a caminhada do pedagogo, que devido às mudanças na legislação foi marcada por diversas alterações de atribuições e competências, revelando muitos percalços na construção da identidade deste profissional no espaço escolar.

A função das creches é cuidar das crianças, suprindo a ausência da família, todavia, o atendimento das creches voltado para a Educação precisa trabalhar para o bem estar físico, mental e social das crianças, dando ênfase a um atendimento qualificado e cobrando mais das instituições.

Os projetos pedagógicos se tornam um objetivo a ser introduzido como nova função das creches, mas infelizmente esta situação causa grande desafio a algumas instituições, visto que a falta de planejamento e profissionais qualificados dificulta muito o processo de mudança. Ocorre o fato de que em algumas creches estão despreparadas em relação aos currículos pedagógicos, que foram elaborados com o intuito de apoiá-las em relação ao desenvolvimento da criança.

\section{O PAPEL DO PROFESSOR DA EDUCAÇÃO INFANTIL NO CUIDAR E O EDUCAR - OS DESAFIOS}

O educador, em seu dia a dia contribui no desenvolvimento da criança, ajudando a falar, andar, comer, se vestir e a ser independente, apesar de muitas vezes não ter formação acaba praticando tais ações de uma forma natural sem perceber a ponderação de sua contribuição.

O educador ideal deve possuir algumas características básicas: ser observador, ter olhos, ouvidos, sensibilidade para perceber a necessidade da criança, do grupo. Deve ser pensador, pois a reflexão 
precede e acompanha a atuação propriamente dita. (MACHADO, 2002, p. 48).

Desta maneira, um hábil profissional da Educação e um currículo pedagógico que oportunize base para a formação da criança é indispensável para a Educação Infantil, porquanto é através dele que os outros fatores serão construídos e desenvolvidos.

É evidente que a falta de profissionais qualificados é uma das maiores questões que certas creches encontram ao introduzir o binômio em suas rotinas e projetos pedagógicos. Em muitas situações os formadores estão desabilitados para o cuidado, privando as crianças de uma educação significativa.

\section{O PAPEL DO PROFESSOR DA EDUCAÇÃO INFANTIL COMO GUARDIÃO DO BRINCAR}

A qualidade da educação de um país deve ser uma de suas principais metas de governo. No entanto, no Brasil, nem sempre o profissional da Educação recebe o reconhecimento que merece. Por esse motivo, cabe a ele mesmo se destacar no mercado de trabalho competitivo. A pós-graduação em Educação Infantil é uma das especializações que vem ganhando destaque nos últimos anos.

Afinal, enquanto uma criança brinca, passeia, ouve uma história ou, até mesmo, participa de uma refeição com outras pessoas, suas funções psicológicas são modificadas. A base de seu desenvolvimento será a forma como o indivíduo recebe esses estímulos durante a infância, desta forma, ter amigos, conversar, explorar o mundo ou brincar com alguém.

Devemos destacar que o papel do educador/professor é fundamental para o desenvolvimento infantil. Afinal, existem tarefas que uma criança não é capaz de realizar sozinha, mas se torna capaz se alguém lhe passar instruções, der demonstrações e fornecer pistas.

Esta é a função do professor, que tem o papel de mediador, devendo facilitar a aproximação entre as crianças, além de decidir sobre as práticas que devem ser apropriadas em grupo, aumentando as interações sociais dos indivíduos. Portanto, por que a maior parte das crianças estão fora da Educação Infantil e são obrigadas a esperar durante seus 5, 6 ou 7 anos para receberem sua primeira educação formal e orientada? 
A educação sempre foi e será o bem mais precioso de um indivíduo e, inserindo a criança em um ambiente educacional desde cedo, beneficia o processo de aprendizagens básicas como a locomoção, desenvolvimento gradual da fala, da linguagem, inteligência e suas aptidões.

Ressaltando que cabe aos professores repensar sua atuação pedagógica e, a partir daí, desenvolver sua prática, visando o bem estar do aluno e, ao mesmo tempo, a construção de novos saberes, pois o que se constrói neste período, irá refletir futuramente no dia a dia do aluno.

\section{CONCLUSÃO}

O ensino infantil é uma das fases mais importantes na vida de uma pessoa. Afinal, é nela em que alguns traços de personalidade são construídos, e o ambiente escolar desempenha um papel socializador em que a criança começa a ampliar sua rede de relações, sendo que é através do professor que ela consegue construir conhecimentos expressivos.

Recentes pesquisas, nacionais e internacionais, comprovam que crianças atendidas em creches de qualidade com professores capacitados mostram maior desenvolvimento intelectual e social ao longo do tempo. Por isso, o papel do professor é fundamental no andamento das atividades na Educação Infantil, pois ele é o mediador entre a criança e o conhecimento. Assim sendo, é extremamente necessário que esse profissional esteja em uma constante busca por aprender sobre o desenvolvimento de criançase a forma como elas veem e sentem o mundo.

Já a habilidade deste educador é saber a tênue diferença entre brincar e ensinar, já que é brincando que as crianças amadurecem, exploram o ambiente e refletem sobre as formas culturais onde vivem. Em contrapartida, o professor deve utilizar seus conhecimentos para elaborar comentários, formular perguntas, provocar desafios e a incentivar a verbalização. Portanto, além das rotinas de sala de aula, o professor em educação infantil tem o compromisso em manter um zelo pelas crianças que as acompanham em todos os ambientes, desde os pátios da escola até na convivência em casa com seus pais.

Segundo o MEC, o mercado de trabalho na área da Educação vem sofrendo uma carência por profissionais na Educação Básica, devido à falta de procura. Na Educação 
Especializada, o setor sofre ainda mais pela escassez de profissionais. Por esse motivo, investir em uma pós-graduação pode ser a solução para se tornar referência de habilidades únicas e indispensáveis nas novas áreas do mercado de trabalho.

Profissionais graduados na área da Educação que possuem especializações específicas dificilmente sofrem com desemprego. Além disso, a satisfação profissional de quem se especializa na Educação Infantil é garantia de saber que está fazendo toda a diferença na formação do cidadão e na construção de um mundo melhor.

\section{REFERÊNCIAS}

ARRIBAS, Teresa Lleixà. Educação infantil: desenvolvimento, currículo e organização escolar. $5^{\text {a }}$ edição. Porto Alegre: Artmed, 2004.

BRASIL. Ministério da Educação. Secretaria de Educação Básica. Diretrizes curriculares nacionais para a educação infantil. Secretaria de Educação Básica. Brasília: MEC, SEB, 2010. Acesso em: 03 jul. 2018.

. Ministério Da Educação E Do Desporto. Secretaria De Educação Fundamental. Referencial curricular nacional para a educação infantil: formação pessoal e social. Brasília: MEC/SEF, v.01 e 02.1998. 85p.

Ministério de Educação. Conselho Nacional de Educação. Câmara de Educação Básica. Resolução CNE/CEB n.5, de 17 de dezembro de 2009. Fixa as Diretrizes Curriculares Nacionais a Educação Infantil. Diário Oficial da União, Brasília, DF, 18 dez. 2009, Seção 1, 1728 p. 18. Disponível em:

http://portal.mec.gov.br/index.php?option=com_content\&view=article\&id=12992:diretr izespara-a-educacao-basica\&catid=323:orgaos-vinculados. Acesso em: 15 jul. 2018.

GIL, A. C. Métodos e técnicas de pesquisa social. 6. ed. Reimpr. São Paulo: Atlas, 2011. $200 \mathrm{p}$.

MACHADO, M. L. de A. (Org.). Encontros e desencontros em educação infantil. São Paulo: Cortez, 2002.

KRAMER, Sonia. Profissionais de educação infantil: gestão e formação. São Paulo: Ática. 2005. 
A IMPORTÂNCIA DA PRÁTICA DE CONJUNTO NA ESCOLA ESPECIALIZADA EM MÚSICA

\author{
SILVA, Johnny Jonas do Nascimento ${ }^{18}$
}

\title{
RESUMO:
}

Este artigo trata-se de uma investigação sobre a importância das aulas de prática de conjunto na escola especializada em música Casa Talento/RN, e busca observar e relatar os processos intrínsecos ao discurso sobre caminhos evolutivos nos estudos da música, permitindo o surgimento de novos estímulos aos participantes. Este trabalho tem como objetivo principal, identificar quais avanços significativos no aprendizado musical, a prática de conjunto pode oferecer, com vistas a fomentar o desenvolvimento e a emancipação musical dos alunos pesquisados, tendo como fundamentação teórica e reflexão, autores que tratam das práticas musicais coletivas como: Grossi (2009), Passos e Pinto (2005). A pesquisa foi pautada em uma abordagem qualitativa, sendo usada como coleta de dados a observação participante. Os resultados obtidos foram apresentados baseando-se nas entrevistas e experiências vivenciadas pelos alunos, através de atividades ligadas ao desempenho individual e ao mesmo tempo compartilhadas entre os demais do grupo, mostrando autonomia e domínio de conteúdos teóricos musicais usados na prática. Conclui-se que as atividades musicais relacionadas ao processo empírico construído em conjunto, podem oferecer meios de desenvolvimento musical, proporcionando aos alunos aumento na capacidade criativa.

PALAVRAS-CHAVE: Prática de conjunto. Escola especializada em música. Aprendizado musical em práticas de conjunto.

\section{INTRODUÇÃO}

É de extrema relevância pensar na pesquisa, sobre a importância da prática de conjunto na escola especializada em música, pois esta permite reforçar e apresentar novas perspectivas acerca do desenvolvimento do aluno e uma visão ampliada sobre a competência musical adquirida no domínio das suas atribuições como estudante de música. Esta competência pode estar relacionada diretamente às práticas musicais coletivas, mostrando também a relevância e a necessidade de se trabalhar assuntos com os alunos, partindo se possível desde o seu contexto histórico.

Em momentos do cotidiano é visto frequentemente os diversos rótulos verbais dados à reunião de estudantes de música que tocam em grupo, entretanto sobre o uso

\footnotetext{
${ }^{18}$ Estudante do curso de Especialização do Ensino de Música em Múltiplos Contextos pela Universidade Federal do Rio Grande do Norte (UFRN). Professor de música do Centro Suzuki de Natal/RN. Professor de música pela Prefeitura do município de Guamaré/RN. E-mail: johnnyalfhguitar25@yahoo.com.br
} 
desses rótulos, é possível apresentar uma definição característica e abrangente sobre a prática de conjunto musical, também conhecida como prática coletiva. É uma atividade que visa reunir pessoas de várias famílias de instrumentos ou da mesma família, podendo também ser praticada em gênero instrumental ou vocal, elas devem ser coordenadas por um professor, de modo a propiciar a participação de todos.

Esta organização pode ser em uma única turma ou em várias, dependendo da disposição do espaço destinado e da organização da instituição, como também da quantidade de pessoas dispostas por turma, a escolha dos gêneros musicais que serão trabalhados, podem ser Jazz, MPB, Rock etc.

Este assunto merece ser tratado em pesquisas, pois é visto que alguns assuntos existentes nestas práticas não são discutidos nas aulas individuais de instrumento com seu professor, às vezes o tempo de duração da aula, o roteiro do planejamento que deve ser seguido ou outras situações não permitem o "fazer musical na prática". Em contra partida, a prática de conjunto como novo espaço de ensino musical contribuem para a existência de um conjunto de ações que também propiciam outros aprendizados significativos, e é através destas práticas que o executante pode desenvolver suas habilidades técnicas e compartilhá-las entre os demais, criando assim, uma interação e socialização no grupo.

Santos (2013, p. 36) discorre que: "como vantagens do ensino em grupo [...] tal prática gerava uma competição saudável entre os alunos, oferecia maior motivação e propiciava troca de conhecimentos". A autora Cruvinel (2005), ainda relacionado ao ambiente das práticas e os benefícios que estes proporcionam, corrobora que quando acontece uma maior interação entre o ambiente destas práticas musicais e os outros indivíduos, estimula a independência, liberdade, autocompreensão, senso crítico, desinibição, sociabilidade, e acima de tudo, o desenvolvimento musical em sua totalidade.

Este artigo tem como objetivo relatar através da discussão com os alunos de uma escola especializada em música, os procedimentos usados no ensino e na formação de práticas em conjunto, reafirmam a real necessidade de se apresentar os processos que podem ser desencadeados em um ambiente de práticas musicais em turmas de prática de conjunto. 
De que formas essas práticas também contribuem para um avanço musical significativo? É possível que a competência musical e domínio das habilidades dos conteúdos práticos estudados em sala individualmente, possam ser estimulados sem a existência de uma prática em conjunto?

Não se quer afirmar que apenas a prática de conjunto trará este suporte estimulador para o desenvolvimento da autonomia e habilidade musical, mas é mostrada a oportunidade de oferecer outros ambientes musicais além daquelas vivenciadas no estudo individual, lhes permitindo abrir portas para a criatividade, interação e a exposição prática, mas concentrada, explorativa e participativa. É difícil pensar em como estimular o desenvolvimento musical sem a colaboração dessas práticas, sendo pensadas de forma corporativa quando se engloba as habilidades básicas, e inclusive a socialização.

Complementando, Passos e Pinto (2005, p. 1) inferem que "a atividade de prática de conjunto visa fornecer aos alunos uma experiência de performance musical em grupos". Este contato compartilhado de ideias musicais e com o instrumento através da prática de conjunto oferece um fortalecimento necessário para o crescimento musical autônomo e desenvolvimento nas habilidades técnicas.

Entretanto, a fim de atender a um roteiro de planejamento sobre o propósito deste trabalho é apresentado aqui, objetivos que irão nortear a produção deste artigo.

Os objetivos específicos propostos são:

- Descrever os processos relativos ao convívio entre alunos que contribuem com os resultados;

- Registrar através de observações a autonomia musical adquirida no desenvolvimento individual de cada um dos participantes;

- Enunciar as atividades propostas nas práticas;

- Identificar comportamentos que podem refletir nas ações do cotidiano nas aulas individuais;

- Comparar os tipos de dificuldades encontradas pelos alunos no decorrer das práticas;

- Relatar os resultados obtidos durante as atividades observadas na prática de conjunto a fim de que se possa contribuir com as pesquisas no campo de ensino musical na escola especializada em música; 
O trabalho aqui apresentado surgiu a partir de observações, que aconteceram na escola especializada em música Casa Talento, situada na cidade de Natal/RN, desde o período inicial até a concretização de todo o processo. Pode ser possível demonstrar que a prática de conjunto em seu formato clássico procura atender aos objetivos essenciais no que se refere ao tocar e produzir música juntamente com todas as suas características peculiares e seus anseios. Esta pesquisa foi dividida em quatro fases complementares e distintas:

A primeira fase das observações constituiu-se na abordagem de ensino voltado para o estudo dos elementos musicais básicos que são usados para a composição e arranjo como: harmonia, melodia, ritmo e propriedades do som, e de como esses elementos eram usados para que os alunos posteriormente pudessem identificá-los em músicas que seriam estudadas e executadas nas práticas no decorrer do semestre referente à pesquisa.

Na segunda fase, o professor da turma apresenta uma letra de música autoral, para que os alunos possam identificar elementos musicais, além dos citados anteriormente, e que foram estudados na primeira fase, como: ritmo textual (faz referência ao termo tratado por Roy Bennett no livro aprendendo a compor, na p. 60, para indicar uso do ritmo métrico das palavras procurando as notas acentuadas da música e fazendo coincidir com as sílabas tônicas das palavras), fórmula de compasso, criação da melodia e aplicação dos acordes. O ritmo que seria executado, as partes que poderiam dividir a música como A, B, C, aplicando-o na letra da música composta pelo professor.

$\mathrm{Na}$ terceira fase os alunos criaram uma letra de música com um tema escolhido por eles e aplicaram os elementos musicais estudados nas fases anteriores. A quarta fase se consolidou com a apresentação das duas músicas desenvolvidas nas práticas, a letra de música apresentada pelo professor e a música completa composta pelos alunos, ambas apresentadas no recital ao final do semestre.

\section{METODOLOGIA}


Para a construção deste trabalho, foi utilizada uma abordagem qualitativa, que se caracteriza pela escolha de meios técnicos investigativos que demonstram a habilidade do pesquisador diante de problemas identificados na pesquisa e põe à prova sua proficiência, tratando da qualidade no levantamento de dados e dos resultados obtidos para contribuição da produção de conhecimento. Chizzotti (1995, p. 85) menciona que:

\begin{abstract}
A pesquisa qualitativa [...] é uma criação que mobiliza a acuidade inventiva do pesquisador, sua habilidade artesanal e sua perspicácia para elaborar a metodologia adequada ao campo de pesquisa, aos problemas que ele enfrenta com as pessoas que participam da investigação. $\mathrm{O}$ pesquisador deverá, porém, expor e validar os meios e técnicas adotadas, demonstrando a cientificidade dos dados colhidos e dos conhecimentos produzidos.
\end{abstract}

De acordo com Chizzotti (1995), na pesquisa qualitativa é pressuposto que as pessoas nela envolvidas manifestem o senso comum, partindo de seus próprios conhecimentos práticos adquiridos no cotidiano, servindo como uma concepção de vida, mas que essa experiência vivida não traduz um conhecimento crítico para a pesquisa em sua totalidade, tendo em vista que a pesquisa qualitativa está relacionada a uma profundidade maior dos fatos, não atuando somente em senso comum, mas buscando entender o processo dos fenômenos e seus significados de forma mais específica. Deslandes (1994, p. 21) comenta que:

A pesquisa qualitativa responde a questões muito particulares. Ela se preocupa, nas ciências sociais, com um nível de realidade que não pode ser quantificado. Ou seja, ela trabalha com o universo de significados, motivos, aspirações, crenças, valores e atitudes, o que corresponde a um espaço mais profundo das relações dos processos e dos fenômenos que não podem ser reduzidos a operacionalização de variáveis.

A metodologia utilizada neste trabalho como coleta de dados foi a observação participante, havendo o envolvimento do observador no ambiente junto aos alunos e às atividades propostas. Sobre isto, Marconi e Lakatos (2003, p. 194) relatam que a observação participante "consiste na participação real do pesquisador com a comunidade ou grupo. Ele se incorpora ao grupo, confunde-se com ele. Fica tão próximo quanto um membro do grupo que está estudando e participa das atividades normais deste." 
A escolha dos instrumentos utilizados na pesquisa foi: entrevistas semiestruturadas com cinco alunos do grupo escolhido aleatoriamente, sendo treze alunos ao total, distribuídos nos demais grupos não participantes da pesquisa.

Ainda referente às entrevistas, Guerra (2014) considera que:

O roteiro das entrevistas poderá haver perguntas fechadas, pelo tratamento que se dá acerca apenas da identificação ou classificação, mas a característica principal é possuir perguntas abertas para oferecer ao entrevistado a possibilidade de falar mais livremente sobre o tema proposto. (GUERRA, 2014, p. 20).

Contudo, Deslandes (1994, p. 58), traz uma concepção sobre a flexibilidade da entrevista que em determinadas situações da pesquisa possibilita a junção de duas abordagens: as estruturadas e não estruturadas, demonstrando a liberdade de se trabalhar com ambos os direcionamentos, a estas, deu-se o conceito de entrevista semiestruturada.

A pesquisa bibliográfica para a elaboração deste trabalho traz reflexões da área, com autores das práticas musicais coletivas, tais como: Grossi (2009), Cruvinel (2005), Dantas (2010), Passos e Pinto (2005), complementados por autores que tratam sobre a criatividade musical: Deslandes (1994), Gainza (1988), Rocha (2016), e metodologia das práticas coletivas: Santos (2013), dentre outros. Esse aporte teórico utilizou-se de textos, dissertações, monografias, livros, artigos publicados em periódicos e em anais de congressos da Associação Brasileira de Educação Musical - ABEM.

\section{A prática de conjunto no ciclo de aprendizagem criativa de beineke}

O desenvolvimento das atividades foi baseado nas três fases do ciclo de aprendizagem criativa tratada por Beineke (2009), fazendo-se uma descrição sobre os processos que permearam a realidade vivenciada nas práticas, pois através dela, junto a outros materiais de apoio, pôde-se ampliar a organização e a forma de conceber o desenvolvimento das atividades. Beineke (2009, p. 246), relata que o ciclo de aprendizagem criativa em música, ele não se resume apenas na observação do que os alunos aprendem, mas de "como, quando e por que se ensina e se aprende música". 
Compor (músicas, ideias de músicas, improvisar, elaborar arranjos, registrar, processos criativos, composição em grupo)

Com base neste ciclo, foram desenvolvidas nas aulas de prática de conjunto diferentes abordagens acerca da composição, de como iniciar a construção de uma composição, quais materiais musicais utilizar, como partir do zero na criação de uma música com seu instrumento de estudo, se deveria iniciar pela letra ou instrumentação, isso foram alguns dos questionamentos apresentados nos encontros, indo até aos processos que poderiam ser tomados para uma elaboração bem simplificada da música, partindo do princípio da identificação dos elementos básicos através da audição de músicas do repertório MPB, POP ROCK.

Elas foram usadas nos primeiros encontros em versões gravadas de músicas que tinham pouca instrumentação, para que eles tivessem uma assimilação mais clara de como extrair esses elementos através da apreciação, na medida em que ouviam, iriam respondendo de forma oral de acordo com a apresentação dos elementos musicais, que no caso aqui se refere à harmonia, melodia e ritmo.

As atividades eram feitas com um tocador de áudio e até mesmo alguns momentos com um celular usando um cabo de áudio para ser transmitido com mais volume na sala, ajudando assim, no exercício de percepção. Os exercícios partiram primeiramente do estímulo através da apreciação, incentivando e desafiando os alunos para que se conseguissem aproveitar o máximo cada apreciação e que isso mais tarde desencadearia na criação de uma composição e arranjo em conjunto, em que todo processo analisado e extraído das apreciações pudessem ser vistas e replicadas na música criada.

Apresentar (presencialmente ou não presencialmente, apresentação das composições em sala de aula, recitais em público ou compartilhados em redes sociais)

Acerca das apresentações, aconteceram, segundo o ciclo de Beineke (2009), de duas formas, tanto presencial como a não-presencial. $\mathrm{O}$ objetivo proposto dentro do próprio plano de ensino elaborado para estas práticas era que após a consolidação de uma composição criada por eles, ela seria apresentada em recital que geralmente 
acontece ao final de cada semestre na instituição escolhida para a pesquisa, estas apresentações foram divulgadas também em redes sociais.

Criticar (aspectos musicais, análise do processo criativo, aspectos extra musicais, análises dos aspectos intersubjetivos)

Neste tópico, acerca das críticas, foi percebido que após a retomada do recesso escolar no primeiro encontro, elas surgiram voluntariamente por parte dos alunos, trazendo o levantamento das análises de como se deu a apresentação de um modo geral, os processos para a elaboração dos ensaios, a escolha das músicas trabalhadas durante o semestre anterior a apresentação e organização dos instrumentos no palco, considerando ser este uma crítica de aspecto musical, a ansiedade, o nervosismo, a própria experiência adquirida por eles que julgaram ser importante para futuras apresentações que é visto aqui como elemento intersubjetivo e extramusical.

\section{ANÁLISES}

Para o desenvolvimento das análises foi tomada como base a partir de entrevistas semiestruturadas, tendo como enfoque as contribuições de aprendizado com os processos atendidos nas práticas relacionadas à importância de se ter a prática de conjunto e os benefícios que ela trouxe, para que fosse relatado o que foi vivenciado nas aulas.

Mantendo o anonimato dos alunos foram utilizados os seguintes pseudônimos: (Aluno A, B, C, D e E).

As questões apresentadas aqui, como fonte principal da pesquisa tratam da percepção dos alunos sobre as práticas em conjunto. A primeira pergunta está relacionada às atividades das práticas, se ofereceram estímulos e contribuíram para a aprendizagem musical. Segundo a sua experiência obtida com as práticas, você acredita que elas puderam ajudar a estimular o seu desenvolvimento musical?

$\mathrm{Na}$ perspectiva de alguns entrevistados eles falaram que:

Sim, aprendi a ter mais paciência, entender que cada músico tem seu tempo e enxerga os detalhes e assuntos de um jeito próprio, estamos sempre aprendendo ou ensinando alguma coisa, percebendo coisas novas na música e na vida (ALUNO A). 
[...] acho que uma palavra que sintetiza muito a prática de conjunto é: potencializa o conhecimento que o aluno teve com o professor em sala de aula, acho que ela resume bem... têm outras nuances aí, mas a potencialização do aprendizado acho que seja a mola mestra da prática de conjunto (ALUNOB).

Esta experiência relatada pelos alunos mostra diferentes percepções acerca dos benefícios que as práticas em conjunto proporcionam. Na fala do aluno $\mathbf{A}$, ele apresenta que cada participante nas práticas tem uma visão diferente do processo de aprendizagem, mesmo havendo a concepção de que atividades estão sendo feitas em grupo. Os benefícios adquiridos são ímpares, mas é notável que o estímulo para o aprendizado realmente aconteça de acordo como é apresentado pelo aluno $\mathbf{B}$.

Ainda, é relevante inferir que as experiências obtidas nestas práticas vão além do que se reunir pra tocar músicas, mas também explorar o que é aprendido em sala nas aulas individuais, como declara os alunos $\mathbf{B}$ e $\mathbf{D}$.

É importante que o aluno saia da sala e faça a prática de conjunto até pra ele confirmar aquilo que ele aprendeu na prática com o professor de sala (ALUNO B).

Me deu a experiência de tocar em grupo né é... e... colocar na prática que eu não tinha, o de tocar um instrumento dentro de uma prática de conjunto, pegar uma música e tocar (ALUNO D).

A segunda pergunta está relacionada à parte motivacional dos alunos de se interessarem em participar das práticas. O que lhe motivava a fazer parte das atividades nas práticas em conjunto?

Ver coisas diferentes do que já toco... de pegar o que tem na aula e colocar na prática de conjunto (ALUNO C).

O que me motivou, foi poder botar em prática... poder tocar... duas coisas, primeiro tocar... que eu não toco em igreja, não toco em lugar nenhum, era um espaço que toda semana eu iria sentar pra tocar. E segundo é tocar em grupo, ou seja, essa história de você sincronizar, a tocar só o pedaço de uma música, essas coisas que agente não aprende quando ta estudando o instrumento, a aula em sala com o professor (ALUNO D).

A prática de conjunto ela motiva o aluno a se apresentar, se mostrar e ele acaba perdendo um pouco o medo de errar porque como está na 
prática de conjunto...e... aquilo ali é uma atividade pedagógica então é... é importante que o aluno saia da sala de aula e faça a prática de conjunto (ALUNOB).

A motivação pessoal é um fator crucial para a participação dos alunos em cada encontro e o sucesso na aplicação das atividades, independente do contexto em que ele se insere, pois ele pode ser considerado o combustível que alimenta o desenvolvimento contínuo do aprendizado. Percebemos aqui, que cada aluno traz uma experiência diferente acerca do que movem eles para participarem das práticas, sendo citado como exemplo pelo o aluno $\mathbf{C}$, que vê coisas diferentes do que ele costuma tocar, ou pelo aluno $\mathbf{D}$, que não tem nenhum espaço que ele possa tocar em grupo se não tivesse um espaço de ensaios que pudesse praticar em conjunto.

O que me motiva é aprender com outros alunos e professores, autoconfiança, socialização. O ambiente de ensaio é onde me sinto em casa, música me dá sentido (ALUNO A)

[...] o que me motivava e me motiva é justamente você sair da teoria e da parte individual pra você fazer parte do conjunto que é uma perspectiva diferente, é a mesma coisa de você ter a percepção de um solista e você esta dentro da orquestra, a prática de conjunto te ensina muito! Você saber que um momento tem que ficar mais baixo outra vez estar mais alto, a hora que você tem que aparecer a hora que você tem que ficar no silêncio (ALUNO B).

Os alunos A, B e D descrevem algumas características das práticas que geraram neles o desejo de estarem ali, participando desta vivência das práticas. Eles apresentaram acerca da forma da organização de como era preparado o repertório, a observação no comportamento dos alunos quando estavam em grupo conversando, o desenvolvimento da autoconfiança, as dinâmicas que eram interpretadas nas músicas, mostrando a necessidade do momento em que teria que parar de tocar, de tocar baixo e tocar alto, vivências e características essas, difíceis de presenciar em uma aula individual como contribuição.

Para mim foram duas motivações, uma é porque não tenho até hoje onde tocar pra me desenvolver tocando um repertório, lá a gente preparava um repertório, a gente tocava o repertório e o comportamento em grupo eu não tinha até então, foram essas duas coisas que me motivaram e me motiva até hoje (ALUNO D). 
A terceira pergunta buscou identificar se a prática de composição e arranjo contribuiu junto às atividades de sala com o professor de instrumento. As experiências obtidas nas atividades da prática de conjunto ajudaram a reforçar os conteúdos vistos em sala de aula com seu professor de instrumento?

Com certeza, você percebe como é importante a orientação teórica e prática de alguém com mais experiência no assunto sobre como criar uma composição, sozinho não se enxerga muita coisa, qualquer conhecimento a mais só vem pra agregar, na convivência você percebe como o aprendizado não termina (ALUNO A).

[...] aquela música lá que eu compus, mas acabou que serviu pra Codinome Beija-flor que agente mudou o arranjo, e você acaba tendo uma base daquela música que agente estava criando quando foi criar o arranjo da outra e em outras músicas que deu vontade de colocar alguma coisa (ALUNO C).

Acredita-se que o contato com a prática de composição e arranjo contribui sim, para o desenvolvimento musical, inclusive no sentido de aquisição de experiências relacionadas a esse campo de atividades, que muitas vezes o aluno não consegue associar ao que ele vivenciou anteriormente, encontrando relação com um segundo material que tenha a mesma proposta, mas, a partir de que ele mantém essas atividades em constante prática, o processo passa a se tornar fluente.

O aluno $\mathbf{C}$ relata que devido a constantes contatos com a prática de se produzir uma composição e arranjo, possibilitou a ele o desejo de reproduzir o aprendizado em outras músicas. $\mathrm{O}$ aluno $\mathbf{A}$ discorre que a importância de se ter uma pessoa com mais experiência fazendo parte do processo de composição e arranjo oferece uma condição de maior aprendizado, porque como ele mesmo apresenta "sozinho não se enxerga muita coisa".

A quarta pergunta da entrevista semiestruturada solicita que os alunos façam uma breve descrição do que foi visto e entendido como ações necessárias na prática de conjunto, tendo em vista que algumas dessas ações também possam se manifestar em um ambiente não propício a atividades que visem à coletividade, no caso, as aulas individuais que se propõe ao estudo da composição e arranjo. Faça uma breve descrição de como aconteciam às aulas da prática de conjunto. 
Eram passadas dicas de execução, partes da música, leitura e harmonia. Entrosamento musical entre os alunos (ALUNO A).

a prática de conjunto replica o que vai acontecer na realidade, daí a importância da prática... co-relacionar o conhecimento teórico e identificar na música aquele conhecimento teórico (ALUNO B).

Reuníamo-nos e decidíamos um repertório. $O$ professor eventualmente trazia uma temática pertinente. Analisávamos a música em conjunto (geralmente treinada antes na aula individual) e a executávamos, parando para reflexão e ajustes, ao término de cada execução. Ideias iam sendo propostas e discutidas, geralmente chegávamos a um resultado final num mesmo encontro. (ALUNO E).

A correlação apresentada aqui pelo aluno $\mathbf{B}$, diz respeito à relevância que se tem e que deve ser dada ao conhecimento teórico junto às práticas de conjunto, pois converge com o que o aluno A complementa, que além de proporcionar o entrosamento musical que é uma característica quase que exclusiva das práticas coletivas, também remete a associação equilibrada da teoria com a prática.

Inclusive tratando-se de reflexões e ajustes apresentados pelo aluno $\mathbf{E}$, que também são associadas à teoria e prática, pois no momento da reflexão que é sustentada como base os conceitos teóricos de conteúdos e que vão ser empregados na música, irão gerar os ajustes necessários, envolvendo a leitura musical tanto harmônica quanto melódica, e estes elementos não tem como serem dissociados um do outro dentro dos dois contextos, prático e teórico.

A quinta e última pergunta que permeia o enfoque desta pesquisa está ligada à visão dos alunos acerca de propostas e atividades que no ponto importante da pesquisa, beneficie e contribua no encontro das práticas. O que você acrescentaria como contribuição para o bom desenvolvimento das atividades de prática de conjunto, de acordo com as experiências que você vivenciou no período em que fez parte das atividades?

Estudava muitas músicas, talvez fosse o caso de estudarmos menos músicas e aproveitar mais (ALUNO D).

Eu sugeriria mais tempo de discussão com o professor. Às vezes, a pressão por ter que se apresentar (o que considero, sim, importante), fazia com que ficássemos muito presos ao cumprimento dos repertórios e perdíamos oportunidades de discutir, aprimorar 
conhecimentos e receber as orientações do professor. Esse é um aspecto que poderia melhorar. Sugeriria haver apenas uma apresentação por ano... assim o grupo se fortaleceria, amadureceria mais primeiro e certamente geraria apresentações mais estruturadas. (ALUNOE).

É importante ressaltar que, nesta pesquisa, "estudar muitas músicas” como foi apresentado pelo aluno D pode evidenciar um momento de pôr em prática “o tocar necessário para evoluir", que naquele momento inicial das práticas fazendo referência possivelmente à prática de rotina em que só ensaiava para uma apresentação específica, e reforçando o aluno $\mathbf{E}$, em concordância com o aluno $\mathbf{D}$, refere-se também a este aproveitamento, sugerindo um tempo para maior discussão com o professor e aprimorar os conhecimentos, embora fosse um momento de proporcionar aos alunos maior produção de material para se trabalhar como repertório e que pode ter sido julgado naquele momento pelo orientador como o mais eficaz.

Entretanto, o aporte apresentado aqui tem um alto grau de interesse e aceitação por parte de orientadores que estão diante de atividades que envolvem a participação de um grupo de alunos em práticas coletivas.

Na medida do possivel pudesse ter mais ensaios e incentivo para mais alunos comparecerem [...] percebo que existe uma descrença na música como meio de vida, como arte e propagação de ideias, essa cultura está acabando e não deveria ser assim porque a música é importante pra existência, ela dá sentido, interfere na realidade, faz pensar e buscar soluções (ALUNO A).

As contribuições feitas pelos alunos acerca de melhorias na elaboração das atividades e como elas aconteceram durante o período de ação da pesquisa, podem e devem favorecer a uma possível forma de reestruturação do plano de ensino da prática de conjunto, fazendo com que possa se pensar e agir acerca da programação e planejamento dos encontros, buscando oferecer encontros que promovam a possibilidade no aumento de encontros e da participação de mais alunos como foi evidenciado pelo aluno A.

\section{CONSIDERAÇÕES FINAIS}

Conclui-se que, todas as informações apresentadas nesta pesquisa mostram o quanto é significativo dar cada passo para construir uma formação musical de alunos em 
práticas coletivas, dentro do processo de uma construção bem alicerçada e robusta de vivências, que ensinam como se podem direcionar alunos ao desenvolvimento de uma prática em conjunto, pensando em seu processo de elaboração.

Entretanto, neste trabalho, buscou-se analisar a extensão de atividades relacionadas à prática de conjunto, atingindo aos seus objetivos e relatando os procedimentos usados para demonstrar a importância destes espaços e a partir desses pontos descreverem os resultados que comprovam o desenvolvimento autônomo dos alunos.

As observações ajudam a perceber de um lado externo, mas também participativo, como se dá a relação comportamental dos alunos envolvidos com a criação das ideias musicais, e à necessidade de intervenção quando necessária, para redirecioná-los para o foco do processo, levando em consideração as mudanças emergentes que surgem no momento em que está se produzindo e criando. E perceber, acima de tudo, a responsabilidade e o "poder" de autogoverno que é imposta em mãos a partir de que se assume a condução de uma turma, para que se possa atingir bons resultados e objetivos determinados.

Em conclusão, esta pesquisa poderá estar ajudando ao professor acerca do aperfeiçoamento como educador musical, consolidando uma contribuição na atuação do orientador em turmas de prática de conjunto, trazendo a reflexão de que um professor que tem a responsabilidade de administrar encontros de práticas coletivas deve estar em constante processo de adaptação e reciclagem, estando atento a atingir a objetivos determinados para cada turma.

No decorrer do tempo, essas adaptações e experiências adquiridas irão fazer com que as atividades musicais vivenciadas sejam bem melhor aproveitadas, oferecendo um suporte maior na aprendizagem dos alunos, mas também para que o professor passe a ter mais proficiência na condução da aula e competência para a tomada de decisões em situações diferenciadas no cotidiano.

Por fim, as particularidades destas observações poderão contribuir para pesquisas futuras relacionadas às práticas coletivas, bem como para a formação continuada do pesquisador em função da melhoria do ensino na educação musical, fortalecendo as experiências na docência para que ela possa ser concebida de forma 
articulada na construção da ação pedagógica desenvolvida nas escolas especializadas em música.

\section{REFERÊNCIAS}

BEINEKE, Viviane. Processos intersubjetivos na composição musical de crianças: um estudo sobre aprendizagem criativa. 2009. 289 f. Tese (Doutorado em Música) Instituto de Artes, Universidade Federal do Rio Grande do Sul, Porto Alegre, 2009.

CRUVINEL, F. M. Educação musical e transformação social - uma experiência com ensino coletivo de cordas. Goiânia: Wolnwy Unes. 2005.

CHIZZOTTI, Antonio. Pesquisa em ciências humanas e sociais. 2a Edição Cortez editora.1995. $164 \mathrm{pg}$.

DANTAS, Taís. Aprendizagem do instrumento musical realizada em grupo: fatores motivacionais e interações sociais. Universidade Federal da Bahia - UFBA PPGMUS, 2010.- Doutorado em Educação Musical SIMPOM: Subárea de Educação Musical.

DESLANDES, Suely Ferreira. Pesquisa social, teoria, método e criatividade. Suely Ferreira Deslandes, Otavio Cruz Neto, Romeu Gomes; Maria Cecília de Sousa Minayo (organizadora). - Petrópolis, RJ: Vozes, 1994.

GAINZA, Violeta Hemsy de. Estudos de psicopedagogia musical/ Violeta Hemsy de Gainza; [tradução de Beatriz A. Cannabrava]. -3. Ed.-São Paulo: Summus, 1988.

(Coleção Novas Buscas em Educação; v. 31).

GROSSI, Cristina. Formando Educadores Musicais para a 'Informalidade' na Sala de Aula da Escola. ABEM, Campo Grande UFMS, 2009.

GUERRA, Elaine Linhares de Assis. Manual de pesquisa qualitativa. Edição Grupo Ănima Educação. 2014.

MARCONI, Marina de Andrade; LAKATOS, Eva Maria. Fundamentos de metodologia científica. 5. ed. São Paulo: Atlas, 2003.

PASSOS, Luís Otávio Teixeira; PINTO, Leonardo Bernardes Margutti. Elaboração de Repertório para Prática de Conjunto: relato de experiência. XIV Encontro Anual da ABEM. Belo Horizonte BH, 2005.

ROCHA, José Leandro Silva. Aprendizagem criativa de piano em grupo. São Paulo: Blucher, 2016. 180p. : Il., color.

SANTOS, Rogerio Lourenço dos. O ensino de piano em grupo: uma proposta para elaboração de método destinado ao curso de piano complementar nas universidades 
brasileiras. 2013. 255 f Tese (Doutorado em música)- Escola de Comunicação e Artes, Universidade de São Paulo, São Paulo, 2013. 


\title{
A IMPORTÂNCIA DE CONHECER O NIM
}

\author{
SILVA, Selma Gomes da ${ }^{19}$
}

\section{RESUMO:}

A espécie vegetal Nim (Azadirachta Indica), vem sendo cultivada em grande número no município de Guamaré. Nativa do subcontinente Índico, de grande porte e bastante resistente à seca, fato que facilita sua propagação por se adaptar com facilidade ao clima. Em nosso município o crescimento dessa planta está sem controle, chegando a tomar o espaço das nativas do bioma local, bem como em todo o Nordeste tornando-se uma ameaça para o meio ambiente por causar danos como: intoxicação. Através deste projeto pretendemos fazer com que a população compreenda que apesar desta planta trazer alguns benefícios, ela também traz riscos para alguns seres vivos e a determinadas espécies de vegetais. Essas informações serão levadas aos alunos e comunidade escolar da escola benvinda Nunes Teixeira, através de: palestras, apresentação de slides, distribuição de folders contendo informações detalhadas sobre o assunto, e atividade prática como o plantio de mudas de plantas nativas. Com essas ações esperamos contribuir significativamente para que haja a conscientização da população e que todos evitem o plantio desta árvore a fim de evitar a ação dos polinizadores diminuindo a proliferação desta espécie que não é adequada para arborização ou florestamento e desta forma ampliarmos o conhecimento de todos sobre o assunto.

PALAVRAS-CHAVES: Nim. Conscientização Ambiental. Projeto de extensão.

\section{INTRODUÇÃO}

O cultivo do Nim e sua proliferação estão provocando outras espécies vegetais e até animais. São Objetivos de Desenvolvimento Sustentável informar acerca do elevado aumento no plantio da espécie exótica o que prejudica o bioma caatinga agravando ainda mais o processo de desertificação em nosso estado e em toda região do Semiárido, segundo o Secretário de Agricultura Sebastião Fernandes (2017).

O plantio desta espécie trará grandes prejuízos ao meio ambiente e ao bioma em um futuro próximo, com base em várias justificativas. A espécie Nim se alimenta dos microrganismos da terra, é repelente natural de proporções desastrosas para a fauna e a flora, tem poder extraordinário de reprodução que já está sem controle, ela é árvore invasora, é abortivo natural que já ocasiona danos na região (FERNANDES, 2017).

\footnotetext{
${ }^{19}$ Estudante do Curso de Especialização em Ensino De Ciências pela Faculdade Venda Nova do Imigrante (FAVENI/ES). Professora estagiária da Educação Básica do município de Guamaré/RN. E-mail: selma19gomes@ hotmail.com 
Alertamos ainda, que o Nim não é adequado para arborização e jamais para o reflorestamento, que tem que ser feito com plantas nativas e se não tomarmos providências, em curtíssimo prazo, as espécies do bioma caatinga desaparecerão.

O projeto será desenvolvido em uma escola do município de Guamaré. Além de apresentar os alunos, ainda contribui para melhorar o ambiente local e global, tornando disponível à população, incentivando o seu consumo e fazendo com que as árvores sejam mais respeitadas e valorizadas, tornando possível a preservação das árvores.

Este projeto visa o atendimento da comunidade escolar, oportunizando uma contribuição maior para diminuir os impactos danosos que o homem tem feito em nossa cidade.

Faz parte do projeto também uma abordagem em aula e durante o plantio, sobre os valores atribuídos para a sociedade assim como os problemas ambientais e a importância das plantas para capturar o carbono atmosférico produzido pelas combustões de origem veicular.

Este projeto foi pautado nos problemas ambientais que foram vistos no Município de Guamaré, com isso foi pensando em minimizar esses problemas, gerando conhecimento que por sua vez, será repassado para esses alunos.

\section{FUNDAMENTAÇÃO TEÓRICA}

Cultivado em inúmeras regiões do país, o Nim (Azadirachta indica), trata-se de uma espécie originária da Índia, pertencente à família do Meliceae e bastante utilizada em algumas regiões do mundo como alimento.

Em vários países, incluindo o Brasil, essa árvore tem sido estudada para fornecer produtos alternativos aos agrotóxicos, como extratos de frutas, sementes, ramos e folhas e para controlar pragas em culturas onde o uso de agrotóxicos não é permitido, como no caso dos cultivos orgânicos (CPT, 2006).

\section{Características botânicas}

É uma árvore de crescimento rápido, podendo alcançar de 10 a $20 \mathrm{~m}$ de altura, com tronco semiereto a reto, marrom-avermelhado, duro e resistente, de 30 a $80 \mathrm{~cm}$ de diâmetro, e apresenta um sistema radicular que pode atingir profundidade de até $15 \mathrm{~m}$. 


\section{Ecologia da planta}

A planta cresce durante os cinco primeiros anos de 4 a $7 \mathrm{~m}$. Sua floração normalmente se inicia no segundo ano de idade, e a produção de frutos passa a ser significativa após três anos do plantio, com cerca de $8 \mathrm{~kg}$ de frutos planta.

No Brasil, a produção de frutos se inicia em dezembro nas regiões Central, Norte e Nordeste; na região Sudeste, a produção predomina entre fevereiro a abril, e na região sul, vai de maio até junho (MARTINEZ et al., 1998).

\section{Clima e solo}

O Nim é uma planta de clima tropical, podendo se adaptar ao clima subtropical. Seu máximo potencial de desenvolvimento é obtido com temperaturas entre 20 e $32^{\circ} \mathrm{C}$ (GRUBER, 1992). É mais resistente às altas do que as baixas temperaturas, tolerando temperaturas altas, mas não suportando temperaturas abaixo de $4^{\circ} \mathrm{C}$ por muito tempo. Geadas causam mais danos em mudas pequenas do que em árvores maduras, porém podem reduzir drasticamente a produção de frutos no ano seguinte.

A planta é resistente à seca, podendo se desenvolver com precipitação média anual de $400 \mathrm{~mm}$, porém as condições ideais estão entre 800 e $1800 \mathrm{~mm}$. Pode se desenvolver em qualquer solo, tendo preferência pelos profundos e bem drenados. $\mathrm{O} \mathrm{pH}$ do solo ideal para seu crescimento deve variar de 6,5 e 7,5 (GRUBER, 1992).

\section{Benefícios do Nim}

De acordo com Sodepaz (2006), o Nim tem trazido vários benefícios para a humanidade, pois a árvore é utilizada para arborização de ruas e praças, no campo como quebra vento e como sombra. Sua madeira é resistente a cupins e tem sido utilizada na fabricação de móveis, mourões, estacas, esteios, ripas, caibros e utensílios domésticos.

Os benefícios que o Nim traz ainda, segundo Sodepaz (2006), também vem acontecendo como inseticida, acarcida, fungicida e nematicida. Com os extratos das folhas, sementes e cascas do Nim, são obtidos o óleo, a torta moída e o pó de suas partes trituradas. Esses produtos têm demonstrado ação repelente e de alteração no crescimento e no desenvolvimento de um grande número de espécies de pragas (CPT, 2006). 


\section{Medicamentos e cosméticos}

Apesar de poucos estudos nesta área, sabe-se que o Nim tem sido empregado com algum sucesso na medicina, como antimicrobiano e no combate de problemas dermatológicos. Na indústria de cosméticos, tem-se obtido bons resultados na fabricação de xampus, sabonetes e cremes dentais (CPT, 2006; OSI, 2006).

\section{Uso veterinário}

Em animais, estudos recentes, têm mostrado que o Nim pode ser um grande aliado para controle de carrapato, mosca-do-chifre e no controle de sarna, ainda segundo Sodepaz (2006).

Porém apesar de inúmeros benefícios que a utilização do Nim vem trazendo para a humanidade, estudos comprovam que sua toxicidade também traz grandes malefícios. Pesquisadores apontam alguns males que a planta tem trazido para muitos.

\section{Malefícios do Nim para as abelhas}

Segundo as pesquisas, um dos principais problemas do uso do Nim é a durabilidade da azadiractina. Em condições de campo, a atividade da azadiractina é reduzida rapidamente permanecendo no máximo 8 dias. Essa degradação é causada pela ação da luz ultravioleta, queda no pH e por chuvas (CABONI et al., 2002; SCHMUTTERER, 1990).

Os produtos à base de Nim são conhecidos pela sua eficiência e baixa toxicidade ao homem e ao meio ambiente. Várias formulações foram testadas e não apresentaram efeitos tóxicos em mamíferos (GOVINDACHARI et al., 2000; SCHMUTTERER, 1990). Portanto, a rápida degradação da azadiractina e a baixa toxicidade dos produtos à base de Nim para os mamíferos reduzem consideravelmente a preocupação quanto às possíveis contaminações do mel.

Entretanto, a seguir pode-se verificar que a toxicidade do Nim parece afetar os insetos. Produtos originados a partir do Nim podem perturbar a ecdise dos insetos ou até mesmo impedí-la. Por essa razão, as formas jovens são mais afetadas pelos produtos à base de Nim (UNAL; UKKUZU, 2010). Esses princípios ativos podem ainda causar distúrbios no metabolismo dos insetos promovendo esterilidade em fêmeas e mudanças degenerativas em testículos (KRAUSS et al., 1987 apud KABEH; JALINGO, 2007). 


\section{Danos ambientais}

De acordo com o pesquisador especialista, José Cícero (2013), a planta Nim (nem) extremamente invasora, vem provocando verdadeiro desequilíbrio nos ecossistemas da região. Malgrado à controvérsia, ainda há quem diga que isso é apenas o começo. Com grandes chances de piorar, caso nada venha a ser feito por parte dos órgãos competentes, é preciso que se diga que a mono arborização (de qualquer espécie) corresponde a uma prática altamente contrária e deletéria à Natureza e sua biodiversidade.

São tão graves os efeitos provocados pela utilização desregrada do Nim que já podemos chamar esta prática de "desmatamento ou desertificação verde". Tamanha e preocupante já estão sendo as consequências desta alternativa altamente invasora para a fauna e a flora, assim como para os padrões do frágil bioma da caatinga, afirma o pesquisador especialista José Cícero (2013). O especialista ainda acrescenta que, num curto espaço de tempo, dentre outras coisas, a extinção de espécies nativas e endêmicas da região. Podemos dizer que o Nim é uma planta que tanto pode trazer benefícios como malefícios para a nossa humanidade.

\section{Objetivo Geral}

Apresentar aos alunos e à comunidade escolar os malefícios e os benefícios do Nim indiano, bem como os impactos que ele pode causar ao meio ambiente.

\section{Objetivos específicos}

- Reconhecer árvores nativas da região, informando os alunos sobre a sua importância para sobrevivência das espécies locais.

- Desenvolver o plantio de árvores nativas, tendo em vista, despertar o interesse do público de substituir o Nim por uma espécie nativa.

- Apoiar os alunos interessados no desenvolvimento do viveiro comunitário.

- Através de palestras, fornecer informações sobre as características do Nim. 
- Informar por meio de folders, as vantagens e as desvantagens do Nim para seus fins.

- Distribuir mudas nativas para o uso do plantio urbano e rural.

\section{METODOLOGIA}

Este projeto está sendo realizado por meio de um levantamento de dados e bibliográficos baseado em pesquisas 'online', de artigos atuais de livros, artigos clássicos relacionados aos temas. Os artigos lidos para esta revisão serão pesquisados nas bases de dados do Scielo, e também em ferramentas de busca como o Google Acadêmico (2019).

Os dados necessários para a realização da revisão da literatura serão obtidos através da leitura dos artigos na íntegra e os dados levantados foram agrupados em subitens com o objetivo de sistematizar as informações.

O presente projeto será exposto para a Escola Municipal Benvinda Nunes Teixeira, foram selecionadas três turmas do ensino fundamental e do EJA em média 20 alunos em cada turma, da qual são alunos em anos finais; e uma turma do ensino fundamental, será cedido 90 minutos que dá em duas aulas de um professor, visando melhor aproveitamento do material. Este trabalho será divido em etapas como: escolha do tema, elaboração do trabalho, execução do projeto.

Para que todos as fazes ocorram como planejado será realizado uma reunião com a Secretaria de Meio Ambiente, juntamente com a responsável do Pólo da Universidade Aberta do Brasil - UAB de Guamaré, a senhora Marcia Meyre e os componentes deste grupo;

Para discutimos como podemos realizar esse momento de parceria, aproveitando a oportunidade já será solicitado as mudas para o plantio na escola e para distribuir.

$\mathrm{Na}$ elaboração do projeto serão preparados os slides em conjunto com os membros, em seguida vem a preparação dos folders, ficando designado para um componente do grupo criar e juntamente com os demais será feito a impressão.

Após tudo está acertado com a Escola Municipal Benvinda Nunes Teixeira, junto com o Pólo UAB e a secretaria de Meio Ambiente, será a hora de preparar o local do plantio para poder apresentar a proposta do projeto para a comunidade estudantil, em 
seguida ocorrerá a palestra para turma do ensino fundamental e EJA, juntamente com a distribuição dos folders e logo depois a realização do plantio das mudas e fazer distribuição das mesmas.

Em um primeiro momento será feita uma exposição oral sobre os benefícios e malefícios que o Nim indiano pode causar e ao final deste primeiro momento, será aberto para um pequeno debate.

No segundo momento será distribuído folders para que cada aluno possa levar para casa e ler com calma a respeito do assunto, contendo os benefícios e os malefícios da planta, como podemos mudar a situação da cidade que se encontra repletas destas plantas.

Já no terceiro momento será feita uma pequena horta em um espaço cedido pela escola, para que com isso os alunos possam ver como é simples o plantio e como podemos aos poucos substituir o Nim por outras opções que não causem danos.

E no último momento serão distribuídas algumas mudas para os alunos que tiverem interesse em plantar em suas residências. Essas mudas serão cedidas pela Secretaria de Meio Ambiente do município.

\section{JUSTIFICATIVA}

O cultivo do Nim e sua proliferação estão provocando outras espécies vegetais e até animais. São Objetivos de Desenvolvimento Sustentável informar acerca do elevado aumento no plantio da espécie exótica o que prejudica o bioma caatinga agravando ainda mais o processo de desertificação em nosso estado e em toda região do Semiárido, segundo Secretário de Agricultura Sebastião Fernandes (2017).

O plantio desta espécie trará grandes prejuízos ao meio ambiente e ao bioma em um futuro próximo, com base em várias justificativas. A espécie Nim se alimenta dos microrganismos da terra, é repelente natural de proporções desastrosas para a fauna e a flora, tem poder extraordinário de reprodução que já está sem controle, ela é árvore invasora, é abortivo natural que já ocasiona danos na região (FERNANDES, 2017).

Alertamos ainda que o Nim não é adequado para arborização e jamais para o reflorestamento, que tem que ser feito com plantas nativas e se não tomarmos providências, em curtíssimo prazo, as espécies do bioma caatinga desaparecerão. 
O projeto será desenvolvido em uma escola do município de Guamaré além de apresentar os alunos ainda contribui para melhorar o ambiente local e global, tornando disponível à população, incentivando o seu consumo e fazendo com que as árvores sejam mais respeitadas e valorizadas, tornando possível a preservação das árvores.

Este projeto visa o atendimento da comunidade escolar, oportunizando uma contribuição maior para diminuir os impactos danosos que o homem tem feito em nossa cidade.

Faz parte do projeto também uma abordagem em aula e durante o plantio, sobre os valores atribuídos para a sociedade assim como os problemas ambientais e a importância das plantas para capturar o carbono atmosférico produzido pelas combustões de origem veicular.

Este projeto foi pautado nos problemas ambientais que foram visto no Município de Guamaré, com isso foi pensando em minimizar esses problemas, gerando conhecimento que, por sua vez, será repassado para esses alunos.

\section{RESULTADOS ESPERADOS}

Espera-se, com a realização deste projeto:

- Conscientizar a comunidade sobre os malefícios causados pela plantação do Nim;

- Identificar as plantas que podem substituir o Nim para a melhoria do equilíbrio ecológico.

- $\quad$ Fortalecer o pensamento de que, uma vez que se opta pelo plantio de nim ao invés de uma espécie não inseticida, se altera toda uma comunidade de seres vivos que antes estavam presentes naqueles locais.

- $\quad$ Fazer conhecer os riscos a vida dos seres humanos e animais se houver o contato direto com a planta seja pela Folha, caule ou fruto.

- Mostrar a importância da preservação do ecossistema, fazendo assim o plantio de outras espécies como a castanhola e a amendoeira.

\section{REFERÊNCIAS}


CARBONI, P.; SARAIS, G.; ANGIONI, A.; GARCIA, A. J.; LAI, F.; DEDOLA, F.; CABRAS, P. Residues and persistence of neem formulations os strawberry after field treatment. Journal of Agricultural and Food Chemistry, Davis, v.54, p.10026-10032, 2006.

CÍCERO, José. O Nim indiano e a invasão biológica do bioma da caatinga. 2013. Disponível em: http://blogdaaurorajc.blogspot.com/2013/04/o-nim-indiano-e-invasaobiologica-do.html. Acesso em fev/2020.

\section{CPT - CENTRO DE PRODUÇÕES TÉCNICAS.}

http://www.cpt.com.br/produtos/16_0486.php (17 de fevereiro de 2006).

GOOGLE. Nim. Disponível em: <www.google.com>. Acesso em: 05 abr. 2019.

GRUBER, A. K. Biologia y ecologia del arbol de nim (Azadirachta indica A. Juss.). Extraccion, medicion, toxicidad y potencial de crear resistencia.Ceiba, v.33, p.249-256, 1992.

KRAUS, W.; BOKEL, M.; CRAMER, R.; GUTZEIT, H.; HERR, B.; KAUFMANN, I.; POHNL, H. Natural products as pesticides. In: International Plant Protection Congress, 12. Rio de Janeiro. Resumos. Brasília, MARA, n.p., 1991.

MARTINEZ S.S. (Ed.). O nim- Azadirachta indica: natureza, uso múltiplo, produção. Londrina: Iapar, 2002, 144p.

OSI - Organix South Inc. http://www.theraneem.com/products.html (17 de fevereiro de 2006).

SCHMUTTERER, H. Properties and potential of natural pesticides from the neem tree, Azadirachta indica. Annual Review of Entomology, n. 35, p. 271-297, 1990.

SECRETÁRIO DE AGRICULTURA SEBASTIÃO FERNANDES. Programas gerais da política agropecuária do município. Lei Municipal. Prefeitura Sebastião Fernandes, 2017.

SODEPAZ - Solidaridad Para EI Desarrollo Y La Paz http://www.sodepaz.org/nim/ (17 de fevereiro de 2006).

UNAL, S.; UKKUZU, E. Larvaecidal effects of azadirachtin on the pine processionary moth. African Journal of Biotechnology, Nairobi, v. 8, n. 19, p. 51285131, 2009. Disponível em: . Acesso em: 20 jan. 2010. 


\section{APÊNDICES}

Membros da equipe executora do projeto: Nome e função (coordenador, coordenador adjunto, colaborador, ministrante).

\begin{tabular}{|l|l|}
\hline Nome & Função \\
\hline Selma Gomes da Silva & Coordenadora \\
\hline Danielly Rejane Queiroz Silva Oliveira & Ordenador adjunto \\
\hline Josineide Pereira da Silva, Cristiane & Ministrante \\
Silva Barreto e Artanusia Sousa da & \\
Cruz do Nascimento & \\
\hline $\begin{array}{l}\text { Lucas Félix de Oliveira e Dominique da } \\
\text { Costa silva }\end{array}$ & Colaborador \\
\hline
\end{tabular}

Cronograma de atividades: Definição das etapas do projeto por período de tempo

\begin{tabular}{|l|l|l|l|}
\hline Atividade & Período & $\begin{array}{l}\text { Membro do projeto } \\
\text { que irá executá-la } \\
\text { de realização }\end{array}$ & $\begin{array}{l}\text { Cargahorária } \\
\text { destinada à essa } \\
\text { atividade }\end{array}$ \\
\hline $\begin{array}{l}\text { Apresentação do } \\
\text { projeto a escola } \\
\text { comunidade } \\
\text { estudantil }\end{array}$ & $06 / 05$ a 07/05 & $\begin{array}{l}\text { Dominique da Costa } \\
\text { Silva }\end{array}$ & $5 h$ \\
\hline $\begin{array}{l}\text { Produção de } \\
\text { folders } \\
\text { explicativo } \\
\text { sobre o Nim }\end{array}$ & $07 / 05$ & Selma Gomes da & $5 h$ \\
\hline
\end{tabular}




\begin{tabular}{|c|c|c|c|}
\hline $\begin{array}{l}\text { Palestra para } \\
\text { turma da EJA e } \\
\text { distribuição de } \\
\text { folder }\end{array}$ & 08/05 a 09/05 & $\begin{array}{l}\text { Josineide Pereira da } \\
\text { Silva }\end{array}$ & $5 h$ \\
\hline $\begin{array}{l}\text { Preparaçãodo } \\
\text { local do plantio }\end{array}$ & $10 / 05$ a 13/05 & $\begin{array}{l}\text { Lucas Félix de } \\
\text { Oliveira }\end{array}$ & $10 h$ \\
\hline 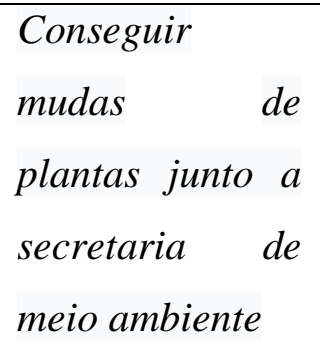 & $14 / 05$ a $15 / 05$ & $\begin{array}{ll}\text { Danielly } & \\
& \text { Rejan } \\
\text { e Queiroz Silva } \\
\text { Oliveira }\end{array}$ & $5 h$ \\
\hline $\begin{array}{l}\text { Palestra para } \\
\text { turma do ensino } \\
\text { fundamental e } \\
\text { distribuição de } \\
\text { folder }\end{array}$ & $16 / 05$ a $17 / 05$ & $\begin{array}{l}\text { Artanusia Souza } \\
\qquad d a \quad \text { Cruz } \\
\text { do Nascimento }\end{array}$ & $5 h$ \\
\hline $\begin{array}{l}\text { Realizar } \quad \text { o } \\
\text { plantio das } \\
\text { mudas e fazer } \\
\text { distribuição de } \\
\text { mudas }\end{array}$ & $20 / 5$ & $\begin{array}{lr}\text { Cristiane } & \text { Silva } \\
\text { Barreto e } & \text { Selma } \\
\text { Gomes da Silva }\end{array}$ & $10 h$ \\
\hline
\end{tabular}


A IMPORTÂNCIA DO AEE PARA UMA EDUCAÇÃO INCLUSIVA

\author{
MELO, Janelene Rita Teixeira de ${ }^{20}$
}

\title{
RESUMO:
}

O Atendimento Educacional Especializado (AEE) é uma política nacional de educação especial na perspectiva da educação inclusiva, publicada pelo Ministério da Educação (MEC) em 2008, e inaugura um novo marco legal, teórico e organizacional da educação pública brasileira. O AEE tem como objetivos: possibilitar a articulação entre atendimento escolar e especializado, em unidades escolares; facilitar acesso e atendimento ao aluno com deficiência e sua família; e possibilitar o desenvolvimento da aprendizagem e da convivência sem discriminação. Este atendimento é ofertado no contraturno em Salas de Recursos Multifuncionais (SRM), que são ambientes dotados de equipamentos, mobiliários e materiais didáticos e pedagógicos para acessibilidade, e são organizados e destinados à implantação de espaços de AEE. Este artigo apresenta o resultado de orientação de Trabalho de Conclusão de Curso (TCC) de Especialização a distância em Atendimento Educacional Especializado (AEE), a partir de pesquisas bibliográficas, observações do aluno no ambiente escolar e familiar, entrevistas com professores regentes, pais e equipe multidisciplinar, foi elaborado um plano individual de AEE que prevê estratégias de inclusão para o desenvolvimento da aprendizagem, conforme as necessidades e possibilidades concretas dos alunos e da escola.

PALAVRAS-CHAVE: Atendimento Educacional Especializado. Aprendizagem. Aluno. Deficiências. Necessidades educacionais especiais.

\section{INTRODUÇÃO}

Este trabalho aborda a importância do Atendimento Educacional Especializado AEE, visando uma educação inclusiva integrada às salas de recursos multifuncionais SEM, com um intuito de promover ao aluno necessidades especiais, uma aprendizagem de forma efetiva, juntos com os demais alunos.

$\mathrm{O}$ argumento principal deste trabalho é ressaltar a importância do AEE para os avanços na aprendizagem do aluno com deficiência, de forma a definir estratégias pedagógicas que favoreçam o acesso do aluno ao currículo.

Logo, coloca-se questões que norteiam este trabalho:

- Como integrar o trabalho do professor de sala regular, ao da sala de recursos multifuncional?

\footnotetext{
${ }^{20}$ Mestranda no curso de Ciências da Educação pela Faculdade do Estado do Maranhão (FACEM). Professora da Educação Básica do município de Guamaré/RN.E-mail: janelenerita@gmail.com
} 
- É preciso ter uma sala de recursos dentro da própria escola?

- Há diferença entre a sala de apoio pedagógico e a sala de recursos?

A integração do professor de sala regular com o de sala multifuncional, necessita-se de tempo e espaço para que eles se encontrem e compartilhem informações. Essa interação é muito importante para o processo de inclusão.

A sala de apoio pedagógico é destinada a qualquer aluno que precise de reforço no ensino. Já a sala de recursos oferece o chamado Atendimento Educacional Especializado - AEE, exclusivamente para quem tem alguma deficiência, algum transtorno global do desenvolvimento ou altas habilidades.

A lei diz que, no turno regular, o aluno com deficiência deve assistir às

aulas na classe comum e, no contra turno, receber o AEE de preferência na mesma escola.

Em 2008 o Ministério da Educação publicou o documento denominado

"Política Nacional de Educação Especial na perspectiva da Educação Inclusiva" (BRASIL, 2008a), tendo como base a Educação para a diversidade e a compreensão de que:

A Educação Especial é uma modalidade de ensino que perpassa todos os níveis, etapas e modalidades, realiza o atendimento educacional especializado, disponibiliza os recursos e orienta quanto a sua utilização no processo de aprendizagem nas turmas comuns de ensino regular (BRASIL, 2008).

O Atendimento Educacional Especializado (AEE), na perspectiva da educação inclusiva, tem um caráter exclusivamente de suporte e apoio à educação regular, através do atendimento à escola, ao professor da classe regular e ao aluno.

O AEE é um serviço da Educação Especial que identifica, elabora e organiza recursos pedagógicos e de acessibilidade que eliminem barreiras para a plena participação dos alunos, considerando suas necessidades específicas. Ele deve ser articulado com a proposta da escola regular, embora suas atividades se diferenciem das realizadas em salas de aula de ensino comum.

Deve ser realizado no período inverso ao da classe frequentada pelo aluno e preferencialmente, na própria escola. Há ainda a possibilidade deste atendimento 
acontecer em uma escola próxima. Nas escolas de ensino regular, o AEE deve acontecer em salas de recursos multifuncionais que é um espaço organizado com materiais didáticos, pedagógicos, equipamentos e profissionais com formação para o atendimento às necessidades educacionais especiais, projetadas para oferecer suporte necessário a estes alunos, favorecendo seu acesso ao conhecimento.

$\mathrm{O}$ atendimento educacional especializado é muito importante para os avanços na aprendizagem do aluno com deficiências na sala de ensino regular. Os professores destas salas devem atuar de forma colaborativa com o professor da classe comum para a definição de estratégias pedagógicas que favoreçam o acesso do aluno ao currículo e a sua interação no grupo, entre outras ações que promovam à educação inclusiva. Quanto mais o AEE acontecer nas escolas regulares, nas que os alunos com deficiências estejam matriculados, mais trará benefícios para eles, o que contribuirá para a inclusão, evitando atos discriminatórios.

O professor para trabalhar no AEE, precisa estar preparado para as diversas situações que irá encontrar e tem que ter consciência que não vai lidar apenas com um modelo de aluno. Precisa refletir sobre sua prática, para que possa buscar novos conhecimentos e aprimorar o ensino que está sendo oferecido para o aluno em sala de aula. Cabe ao professor do AEE:

A partir de observações criteriosas, ajustar suas intervenções pedagógicas ao processo de aprendizagem dos diferentes alunos, de modo que lhes possibilite um ganho significativo do ponto de vista educacional, afetivo e sociocultural (PRADO \& FREIRE, 2001, p.5).

A inclusão educacional, para ser efetivada, necessita ser trabalhada de forma coletiva, ou seja, é necessário a participação de todos os membros da equipe escolar para planejar juntos os melhores caminhos a serem trilhados. $O$ atendimento educacional especializado foi criado para dar um suporte para os alunos com deficiência e para facilitar o acesso ao currículo de acordo com o Decreto $\mathrm{n}^{\circ} 6571$, de 17 de setembro de 2008.

A discussão e reflexão abordado neste artigo aponta para o contexto da educação inclusiva, observando as grandes mudanças que as salas de AEE tem passado e que, tem um princípio de que tem se destacado muito na sociedade ganhando assim, o seu espaço. Com a implantação deste novo recurso, muitas crianças passaram a ter uma 
atenção maior, em que é garantido aos alunos com necessidades especiais uma aprendizagem de forma efetiva juntos com os demais alunos.

As salas de Recursos Multifuncional funcionam no contra turno da unidade integrada ao Atendimento Educacional Especializado (AEE), sendo desenvolvidas funções e atividades que auxiliam no aprendizado do aluno. As ações se integram aos compromissos do Projeto Político Pedagógico da Escola.

O objetivo deste artigo é propiciar condições para que o aluno com deficiência possa construir o seu aprendizado, dentro do quadro de recursos intelectuais que lhe é disponível, tornando-se agente capaz de produzir significado e conhecimento, fazendo-o pensar, imaginar ações em pensamento e de tomar consciência de que são capazes de usar a inteligência de que dispõem.

O Atendimento Educacional Especializado é uma forma de propiciar oportunidades para inclusão, sendo um espaço de transição para aquisição de hábitos e atitudes, facilitando a convivência social numa classe regular de ensino.

Este artigo também visa mensurar a importância do Atendimento Educacional Especializado como apoio à inclusão escolar de alunos com deficiência e como forma de assegurar direitos. O que defendo é a existência do atendimento educacional especializado, pois a inclusão não acontece simplesmente pela presença física do aluno com deficiência nas classes comuns, mas pela interação e aprendizado que eleva os conhecimentos destes alunos.

$\mathrm{O}$ aluno com deficiência requer ações pedagógicas diferenciadas, e para isso, a escola deve organizar seus espaços físicos e pensar na produção de materiais pedagógicos, pensando nas especificidades da criança decorrente de sua necessidade motora e de comunicação. No AEE: “o aluno constrói conhecimento para si mesmo. Aqui ele não depende de uma avaliação externa, mas de novos parâmetros relativos às suas conquistas diante do desafio da construção do conhecimento" (BRASIL, 2006, p. 27).

Neste sentido, a reorganização do sistema educacional, na perspectiva inclusiva, aponta para um novo modelo de escola e, consequentemente, um novo modelo de formação docente pautada na atenção à diversidade, considerando diferentes modos de aprender e ensinar. O trabalho do professor do AEE é, basicamente, propor situações 
para que o aluno possa interagir e ao mesmo tempo sair de uma posição passiva diante da aprendizagem, e passe para uma postura de apropriação do saber.

\section{DESENVOLVIMENTO}

A Educação Especial no formato do AEE se constitui, portanto, na ferramenta, no suporte indispensável que viabiliza a escolarização desses alunos no ambiente escolar comum. Sem recursos, estratégias e materiais adaptados que atendam às necessidades educacionais especiais, seria muito difícil garantir a participação efetiva nas atividades propostas, bem como a interação com os outros alunos e professores.

O Decreto $\mathrm{n}^{\circ}$ 6.571, de 17 de setembro de 2008 (BRASIL, 2008b), que dispõe o AEE destaca, dentre outros objetivos propostos, a elaboração e utilização de recursos que respondam aos ajustes necessários para a efetiva aprendizagem dos alunos com necessidades educacionais especiais.

Conforme o mesmo Decreto, o AEE será efetivado por várias ações definidas como:

[...] espaços da escola onde se realiza o Atendimento Educacional Especializado para os alunos com necessidades educacionais especiais, por meio do desenvolvimento de estratégias de aprendizagem, centradas num novo fazer pedagógico que favoreça a construção de conhecimentos pelos alunos, subsidiando-os para que desenvolvam o currículo e participem da vida escolar.

Neste sentido, é esperado que, o professor que atua no serviço especializado, explore os materiais e recursos existentes nas salas de recursos multifuncionais, bem como elabore materiais de modo a ajustá-los às necessidades educacionais dos alunos acompanhados no AEE.

Inicialmente é feito um diagnóstico de cada aluno junto à equipe multidisciplinar da escola e especialistas da área, sendo feito o levantamento das necessidades educacionais especiais, e a partir deste momento, traçamos atividades para alcançar as potencialidades dos alunos e desenvolvê-las da melhor maneira possível.

São realizadas atividades em grupos e individuais, determinadas pelas necessidades de cada aluno. De acordo com o planejamento, são desenvolvidas atividades iguais ou semelhantes, visando à coordenação motora, percepção visual, ao 
assunto do planejamento, à autonomia, à socialização, à interação no grupo. A prática no AEE é diversificada, de acordo com a clientela.

A autonomia é muito valorizada durante os atendimentos, sendo assim, existe sempre um trabalho direcionado ao diálogo e compreensão dessas fases emocionais do aluno. Há diversos benefícios que podem ser desenvolvidos na SRM de forma paralela e que auxilia o desenvolvimento do ensino na sala de aula comum.

Algumas das vantagens que eram associadas à classe especial podem ser potencializadas na sala de recursos, pois o trabalho com pequenos grupos é estimulado, permitindo melhor acompanhamento do aluno, favorecendo trajetórias de aprendizagem mais individualizadas sob a supervisão de um docente com formação específica. No caso da sala de recursos, a grande vantagem é que esse processo tem condições de alternância contínua com aquele desenvolvido na sala de aula comum.

Dentre as importantes mudanças que a escola e o professor precisam incorporar, destaca-se a utilização das Tecnologias de Informação e Comunicação - TIC, que constituem um diversificado conjunto de recursos tecnológicos. Esses recursos são utilizados no contexto educacional de forma a

favorecer a aprendizagem dos alunos e, em especial, dos alunos com deficiências, conforme Schirmer et al. (2001, p. 31):

Tecnologia Assistiva é uma expressão utilizada para identificar todo o arsenal de recursos que contribuem para proporcionar ou ampliar habilidades funcionais de pessoas com deficiências e, consequentemente, promover vida independente e inclusão.

Diante deste contexto, em que a legislação garante o AEE para os alunos com deficiências, TGD ou altas habilidades (superdotação), são recursos imprescindíveis para facilitar, e até mesmo superar as barreiras que impedem a escolarização desses alunos.

\section{CONCLUSÃO}

Diante deste estudo exibido, constata-se, então, que a proposta de inclusão educacional vai muito além da garantia do direito de todos os alunos frequentarem às salas regulares de ensino, contempla, também, à adequada formação profissional de professores do ensino regular e do AEE. Ainda determina a adequada infraestrutura do 
sistema educacional para que inclua as TIC de modo geral. E os recursos compreendidos como tecnologia assistiva possam subsidiar a aprendizagem dos alunos acompanhados no AEE.

As escolas devem garantir o acesso dos alunos da educação especial às classes comuns, promover articulação entre o ensino regular e a educação especial, contemplar a organização curricular flexível, valorizar o ritmo de cada aluno, avaliar suas habilidades, necessidades e ofertar o atendimento educacional especializado, além de promover a participação da família no processo educacional.

Deste modo, percebe-se que, para a concretização desta proposta, se faz necessária uma parceria entre professor de classe comum, professor do AEE, família do aluno e comunidade escolar. O espaço escolar deve ser pensado, planejado e adaptado para sua acessibilidade e o Projeto Político-Pedagógico articulado com tais necessidades.

Diante de materiais pesquisados, posso dizer que o trabalho do professor na sala de Recursos Multifuncionais é de extrema importância dentro do âmbito escolar, pois este recurso tem a intenção de complementar e/ou suplementar o trabalho do professor de sala regular.

No entanto, durante o período em que me encontro realizando esta função na escola em que trabalho no interior do Rio Grande do Norte, pude compreender as leis que regem a Educação Especial e, especificamente, o Atendimento Educacional Especializado. Por isso, o professor de AEE em um trabalho colaborativo com o professor da sala de aula regular, são responsáveis por tornar este trabalho com alunos com deficiência mais fluente nas salas de aulas comuns.

De acordo com este trabalho, o professor de AEE ainda dispõe de algumas ferramentas úteis às suas atribuições, uma delas é o estudo de caso realizado com os educandos a fim de direcionar as atividades a serem desenvolvidas posteriormente. Também serve como ferramenta para elucidar vários aspectos da vida do educando, como por exemplo, os parceiros na área da saúde que o educando já utiliza, o serviço como complemento ao seu tratamento ou direcionamento deste aluno para esses parceiros.

Uma outra ferramenta utilizada na sala de recursos é o Plano do AEE, que pode ter diversas finalidades de acordo com a deficiência apresentada pelo educando, por este 
motivo, o plano deve ser individualizado e focado para aumentar as potencialidades, suprir as necessidades e diminuir barreiras enfrentadas pelo discente na escola.

Portanto, posso concluir que, ser professor de AEE é promover nas escolas uma verdadeira educação inclusiva, construindo uma escola que aceita e entende os estudantes dentro das suas dificuldades.

\section{REFERÊNCIAS}

BRASIL. Decreto 6.571 de 17 de setembro de 2008. Dispõe sobre o Atendimento Educacional Especializado. Brasília, DF, 2008b.

. Ministério da Educação. Secretaria de Educação Especial. Política

Nacional de Educação Especial na perspectiva da educação inclusiva. Documento elaborado pelo Grupo de Trabalho nomeado pela portaria $\mathrm{n}^{\circ} 555 / 2007$, prorrogada pela portaria n ${ }^{\circ}$ 948/2007, entregue ao Ministro da Educação em 07 de janeiro de 2008.

Brasília, DF, 2008a.

. Ministério da Educação. Plano do Desenvolvimento da Educação: razão, princípios e programas. Brasília.: MEC, 2007. ORGANIZAÇÃO DAS NAÇÕES UNIDAS. Convenção sobre os Direitos das Pessoas com Deficiências, 2006.

PRADO, M. E. B,: FREIRE, F. M. P. A formação em serviço visando a reconstrução da prática educacional. In: FREIRE, F. M. P.: VALENTE. A. (orgs) Aprendendo para a vida: os computadores na sala de aula. São Paulo: Cortez, 2001.

SCHIRMER, C. R. et al. Atendimento Educacional Especializado: deficiência física. Brasília, DF: Cromos, 2007. 


\section{A MONITORIA ACADÊMICA COMO UM INSTRUMENTO DE FORMAÇÃO DOCENTE E PROFISSIONAL NA DISCIPLINA DE METODOLOGIA DO ENSINO DE CIÊNCIAS}

OLIVEIRA NETO, Benjamim Machado de ${ }^{21}$

\section{RESUMO:}

O referido artigo científico tem a proposta de descrever a experiência em contato com as atividades de monitoria na disciplina de Metodologia do Ensino de Ciências, do curso de Licenciatura em Pedagogia, na instituição denominada de Faculdade de Educação, Ciências e Letras do Sertão Central (FECLESC), que fica localizada na cidade de Quixadá, no interior do Estado do Ceará. Os objetivos foram: abordar a vivência do monitor na sala de aula; analisar a importância da formação docente em tal modalidade; apresentar o referencial teórico. O método teve como base a observação, a coleta de informações e a anotação, além da revisão bibliográfica sobre o tema questão, tais como: Alves (2011); Bassi (2011); Barbosa (2006); Campos (2008); Cury (1998); Duarte (2012); Ferreira (2000). A monitoria possibilitou ampliar o conhecimento teórico e prático de uma área específica da graduação, por meio de um conjunto de tarefas e situações vivenciadas em uma turma do $6^{\circ}$ semestre, como uma forma de aprender o exercício da docência e os caminhos para o aperfeiçoamento profissional. Por fim, foi realizado o registro dos encontros, dos exercícios avaliativos, das avaliações e das ações pedagógicas, que resultou em uma oportunidade que privilegia o estudante em diversos aspectos do saber, como a construção de novas experiências, de reaprender de forma significativa e de refletir acerca da capacitação do professor.

PALAVRAS-CHAVE: Monitoria. Formação de professores. Metodologia do Ensino de Ciências.

\section{INTRODUÇÃO}

A pesquisa simboliza um conjunto de tarefas vivenciadas em uma modalidade de ensino e aprendizagem que tem um valor significativo para a formação, que possibilita ampliar o conhecimento teórico e prático, como uma forma de refletir sobre a importância do programa de monitoria para a formação docente e profissional.

Os objetivos da respectiva pesquisa foram: abordar a vivência do monitor na sala de aula; analisar a importância da formação docente em tal modalidade; apresentar o referencial teórico.

\footnotetext{
21 Especialista em Psicopedagogia Clínica e Institucional. Consultor Acadêmico, Pedagógico e
} Psicopedagógico no Estado do Ceará. E-mail: benjamim.neto@aluno.uece.br 
O motivo de fazer parte do processo de seleção para a bolsa de monitoria na disciplina de Metodologia do Ensino de Ciências teve como base a importância da referida área para a formação de professores, tendo em vista que o ensino-aprendizagem não abrange somente a exposição de conteúdo, mas envolve o aperfeiçoamento docente, profissional e acadêmico.

O respectivo programa é oferecido pela Universidade Estadual do Ceará (UECE) no curso de graduação, com objetivo de desenvolver um trabalho em conjunto com o professor, sendo uma atividade de ensino-aprendizagem e de formação docente, que pode ser renumerada ou voluntária no período de um ano.

Assim, o trabalho consiste em um relato de experiência sobre a monitoria da Disciplina de Metodologia do Ensino de Ciências, na turma de $6^{\circ}$ semestre, no período letivo 2018.2, em conjunto com o professor e os estudantes do curso de Pedagogia.

Desse modo, a atividade desenvolvida na disciplina em questão, teve como base as experiências registradas por meio de anotações em contato com as ações em sala de aula, como uma forma de buscar conhecer a função do professor e a importância da formação docente.

A turma de Pedagogia foi assistida pela docente Cecília Rosa Lacerda e pelo monitor Benjamim Machado de Oliveira Neto, que firmou contrato no Programa de Monitoria Acadêmica da PROMAC, em conjunto com a FECLESC.

A monitoria possui um papel essencial na relação entre a formação docente e a disciplina de Metodologia do Ensino de Ciências, na qual o professor não exerce apenas uma função, mas de estar preparado para lidar com as diversas situações que se deparam no cotidiano escolar, devendo buscar o aperfeiçoamento profissional.

\section{METODOLOGIA}

O procedimento metodológico pautou-se na revisão bibliográfica, com base em estudos de autores específicos sobre o assunto em questão, sendo eles: Alves (2011); Bassi (2011); Barbosa (2006); Campos (2008); Cury (1998); Duarte (2012); Ferreira (2000); Grisa (2012); Haje (2017).

Por sua vez, a pesquisa utilizou da observação e da construção de relatório, por meio de registros em contato com as diversas situações e acontecimentos em sala, na 
busca de abordar a vivência do monitor na sala de aula e analisar a importância da formação docente.

A investigação permitiu construir um trabalho com base em referencial teórico e trabalho prático, que possibilitou elaborar os seguintes tópicos: trajetória histórica das políticas nacionais da Educação; importância da formação docente para o processo de ensino-aprendizagem; análise das informações do relatório.

\section{DESENVOLVIMENTO}

Finalizado o resumo, a introdução e a metodologia, que permitiu construir uma parte do conteúdo da pesquisa, tornam-se conveniente começar o próximo tópico do estudo, no caso, a trajetória histórica das políticas nacionais.

Com advento dos direitos e das garantias na educação, os autores começaram a estudar que a infância é uma fase especial da vida, que reforçou a ideia dos alunos terem as necessidades protegidas, que resultou em uma legislação reconhecida pela Constituição Federativa do Brasil de 1988 (OLIVEIRA, 2002).

O teórico Cury (1998, p. 11) apresenta um estudo que cita o movimento social como um fator que contribuiu para a incorporação da Constituição Federal e a construção de direitos que contemplam a educação, devendo o Estado atender as particularidades das crianças e as demandas da população:

(...) a Constituição incorporou a si algo que estava presente no movimento da sociedade e que adivinha do esclarecimento e da importância que já se atribuía à educação infantil. [...] Ela não incorporou esta necessidade sob o signo do amparo ou da assistência, mas sob o signo do Direito, e não mais sob o amparo do cuidado do Estado, mas sob a figura do dever do Estado. Foi o que fez a Constituição de 88: inaugurou um direito, impôs ao Estado um dever, traduzindo algo que a sociedade havia posto. (CURY, 1998, p.11)

Conforme o texto do autor, a Constituição Federal foi essencial para regulamentar o direito e garantias ao acesso à escola, bem como proporcionou a gratuidade do ensino público em todas as modalidades e níveis do sistema escolar, com base em uma concepção pedagógica e de políticas educacionais, que contribuiu para o desenvolvimento cognitivo, social e afetivo dos estudantes. 
Após a construção de um sistema de políticas públicas para assegurar o direito dos educandos, a educação ganha uma legislação chamada de Lei de Diretrizes e Bases da Educação, o dispositivo legal $\mathrm{n}^{\circ}$ 9394/96, que resultou em novas formas de organização e prática educativa voltadas para os níveis escolares.

Para compreender a importância da Lei de Diretrizes e Bases da Educação, o Conselho e o Estatuto das Crianças e dos Adolescentes, como um conjunto de direitos e garantias conquistadas do decorrer da história, analisa-se o pensamento da teórica Maria Clotilde Ferreira (2000, p. 184):

Inseriu as crianças e adolescentes no mundo dos direitos humanos. $\mathrm{O}$ ECA estabeleceu um sistema de elaboração e fiscalização de políticas públicas voltadas para a infância, tentando com isso impedir desmandos, desvios de verbas e violações dos direitos das crianças. Serviu ainda como base para a construção de uma nova forma de olhar a criança: uma criança com direito de ser criança. Direito ao afeto, direito de brincar, direito de querer, direito de não querer, direito de conhecer, direito de sonhar. Isso quer dizer que são atores do próprio desenvolvimento (FERREIRA, 2000, p. 184).

Conforme a teoria do estudioso, a LDB foi uma conquista para a família, a comunidade, a educação e o Estado, no sentido que trouxe um conjunto de políticas públicas e apoio do governo para garantir os direitos das crianças e dos adolescentes, que permitiu combater desvios na administração escolar e a proteger o desenvolvimento dos alunos.

Assim, as instituições começam a assumir uma função mais pedagógica, com base em um conjunto de políticas educacionais e na lei, que possibilitou elaborar documentos e normas que influenciaram o contexto da Educação, tais como: Referencial Curricular para Educação Infantil; Diretrizes Curriculares Nacionais para Educação Infantil; Parâmetros Nacionais de Qualidade para Educação Infantil; Parâmetros Básicos de Infraestrutura para Instituições de Educação Infantil (DUARTE, 2012).

O teórico Alves (2011, p. 31) explica a proposta dos documentos e as políticas nacionais para a Educação Infantil, como um modo de analisar que tais iniciativas englobam um conjunto de princípios e medidas pedagógicas, que buscam aperfeiçoar as prática do educador, a estimular as habilidades e a promover o desenvolvimento das crianças: 
Apresentam caráter mais aberto e democrático, propondo que as propostas pedagógicas devem respeitar princípios éticos (desenvolvimento da autonomia, da responsabilidade, da solidariedade e do respeito ao bem comum), estéticos (formação para o exercício da sensibilidade, da criatividade, da ludicidade e da diversidade de manifestações artísticas e culturais) e políticos (exercício progressivo dos direitos e deveres da cidadania, da criticidade e da democracia) e integrar educação e cuidado (ALVES, 2011, p. 31).

Ao analisar o texto, percebe-se a importância de tais documentos para o avanço da Educação, tornando o modelo antigo que tinha uma proposta assistencialista em um sistema que valorizam as necessidades, as particularidades, a socialização e a autonomia dos estudantes.

Através da ampliação de investimentos e a elaboração de um novo modelo de políticas nacionais, com a influência do Banco Mundial e de instituições bancárias internacionais, deu origem a criação do Fundo de Manutenção e Desenvolvimento do Ensino Fundamental e de Valorização do Magistério (FUNDEF), a partir da ementa constitucional $\mathrm{n}^{\circ}$ 14, no dia 12 de Setembro de 1996 (CAMPOS, 2008).

Com a extinção do FUNDEF, o governo criou uma nova política nacional intitulada de Fundo de Manutenção e Desenvolvimento da Educação Básica e de Valorização dos Profissionais de Educação (FUNDEB), cuja a proposta tinha por finalidade equilibrar a distribuição de recursos e de oferecer um investimento maior para a Educação Infantil, com base na Lei $n^{\circ}$ 11.494, no dia 20 de Julho de 2007 (BASSI, 2011).

Após a implantação de melhorias na educação, como um modo de estimular o investimento e a qualidade do ensino, outro acontecimento marcou o contexto histórico, mais especificamente, a partir ano de 2003 a 2005, em um momento que envolveu a participação do MEC e da SEB (Secretaria de Educação Básica), que deu início a elaboração de um documento intitulado de Política Nacional da Educação Infantil (GRISA, 2012).

Nesse sentido, o PNE é uma política que estabelece um documento referente aos objetivos, metas e diretrizes para a educação, devendo existir um ensino pautado uma ação pedagógica que cuide e eduque, levando em conta o desenvolvimento e as necessidades das crianças, além de assegurar o espaço escolar, materiais, equipamentos, estrutura física e o funcionamento adequado das instituições. 
Com tantas elaborações de documentos no decorrer da história, que resultou em um conjunto de movimentos sociais, políticos e científico em favor dos direitos, a civilização não parou de lutar por um ensino de qualidade, sendo uma mobilização que permitiu a formulação de uma nova política nacional, a Base Nacional Comum Curricular (CAMPOS, 2013).

O processo de formulação do documento da BNCC não foi realizado de uma vez e nem em um período, mas que durante a história teve que passar por três etapas até chegar a aprovação e homologação, que possibilitou criar a primeira versão em Setembro de 2015, a segunda em Maio de 2016 e a terceira em Dezembro de 2017 (HAJE, 2017).

A BNCC é um documento que normaliza a aprendizagem e o desenvolvimento das crianças ao logo da vida escolar, considerado as habilidades, as competências, as necessidades, a igualdade, as individualidades e o contexto histórico dos aluno(a)s, que engloba o processo de escolarização e de socialização, além de discutir e refletir sobre as ações pedagógicas.

Concluído o tópico sobre as políticas nacionais, deve-se iniciar o próximo assunto do artigo, com a proposta de discutir a importância da formação docente para o processo de ensino-aprendizagem, para que seja possível analisar as teorias e os estudos, devendo o professor desenvolver uma forma mediadora capaz de equilibrar o conteúdo, as atividades e a socialização.

Para entender o tópico em questão, a autora Maria Carmem Barbosa (2006, p. 224) apresenta um estudo que explica a importância da formação docente para o processo de aprendizagem, sendo uma relação que deve ser construída e mostra que não é apenas a necessidade de ensinar o conteúdo, mas de conhecer o universo dos alunos e o contexto social:

Dar-se conta do que há de educativo, de cuidados e de socialização nas atividades, nas conversas, nos atos que são realizados com as crianças. O quanto é importante ver e escutar o que há de alegria, de imprevisto, de inusitado, de animação no convívio cotidiano. Enfim, o professor precisa entender que as suas ações, da organização do ambiente à solicitação de atividades, bem como os comportamentos e materiais oferecidos, têm repercussões no ato educativo (BARBOSA, 2006, p. 224). 
Segundo a ideia da estudiosa, analisa-se que o processo de ensino-aprendizagem não é realizado apenas no ato cuidar e educar, mas envolver métodos, planejamento e estratégias, como a socialização dos trabalhos que possibilitam criar um ambiente de diálogo e a organização dos materiais, sendo uma forma que os educadores venham a desenvolver atividades e participarem da rotina escolar.

Por meio de uma formação docente e de um trabalho de socialização, o educador pode construir um conjunto de atividades, métodos e estratégias que favoreçam o aprendizado dos estudantes, devendo gerar oportunidades para viverem novas situações e experiências.

É fundamental que o professor não apresente somente preparo e capacidade, deve mostrar um conjunto de habilidades para lidar com as situações complexas que ocorrem na rotina escolar, devendo identificar as mudanças de humor e as necessidades das crianças, para que seja possível abordar a raiva, o estresse, a ansiedade e os conflitos, que são fatores que prejudicam o desenvolvimento cognitivo, emocional e social dos alunos.

É devido acrescentar na estrutura do relatório o estudo de Nilson José Machado (1996, p. 52) para fundamentar o conteúdo sobre as vivências, aprendizagem e o conhecimento, como uma forma de compreender a importância da formação docente, conforme a explicação do autor:

[...] por um lado, a limitação a atividades "concretas", de manipulação, é insuficiente, mesmo nas séries iniciais do ensino; as atividades operatórias mais fecundas costumam relacionar-se diretamente com a realização de algum projeto, ainda que bastante incipiente, no nível das concepções. Por outro lado, ainda que pareça possível durante certos períodos, é insólito - e muito mais difícil trabalhar-se apenas no nível das concepções, sem relações diretas com objetos materiais, ainda que através de suas representações (MACHADO, 1996, p. 52).

De acordo com o autor, analisa-se que o processo de aprendizagem ocorre no meio que está inserido, sendo uma situação que passa do concreto para o abstrato e da experiência para interação, para que seja possível construir o saber e o desenvolvimento dos alunos.

Por isso, o educador deve buscar aperfeiçoar as habilidades e o conhecimento, para que seja possível construir uma prática que engloba não apenas o conteúdo, mas 
que aborda as diversas possibilidades de trabalhar as atividades e a desenvolver o aprendizado por meio de métodos estratégicos.

Assim, o professor deve observar a prática e o método utilizado em sala de aula, ainda mais quando os alunos são crianças e que é uma fase da vida que exige um cuidado especial, no sentido de perceber o nível de abstração do conteúdo que expõe e se tais informações estão à altura do desenvolvimento das crianças.

O estudo de S. Lima Pimenta (2004, p. 41), traz um conjunto de informações que explica o papel do docente vai além de ministrar a aula e desempenhar uma função, no sentido que o profissional deve ter experiência, habilidade e conhecimento, como uma forma de construir uma prática social em favor do desenvolvimento dos alunos:

De acordo com o conceito de ação docente, a profissão de educador é uma prática social. Como tantas outras, é uma forma de se intervir na realidade social, no caso por meio da educação que ocorre não só, mas essencialmente, nas instituições de ensino. Isso porque a atividade docente é ao mesmo tempo prática e ação (PIMENTA, 2004, p. 41).

Conforme a obra do estudioso, a prática educativa deve ser uma ação social, tanto para construir um ambiente de interação quanto para criar uma relação com o meio, com a finalidade de contribuir não apenas para o processo cognitivo, mas trabalhar a socialização, a conhecer novos métodos e aprender de forma significativa.

Por esta razão, o processo de aprendizagem exige uma prática docente que utilize métodos estratégicos e uma ação social, que possibilita conciliar a rotina escolar e os conteúdos, devendo o professor realizar uma forma mediadora capaz de equilibrar o aprendizado e a socialização.

O tópico seguinte é acerca da exposição das informações do relatório, que teve como base as situações vivenciadas em sala, como uma forma de analisar a ação do professor e a importância da formação docente na disciplina de Metodologia do Ensino de Ciências.

As atividades realizadas no mês de março estavam ligadas a um filme denominado de "Óleo de Lorenzo"; elaboração da síntese dos textos sobre avaliação da aprendizagem no ensino de ciências - subsídios teóricos para a reflexão da prática e a aula de ciências nas séries iniciais do Ensino Fundamental - ações que favorecem a aprendizagem. 
Dentre os diversos conteúdos trabalhados no referido mês, destacaram-se os conhecimentos dos textos citados anteriormente, que subdividiram nos seguintes assuntos: tipos de avaliações (tecnicista, formativa e somativa); a relação de poder do professor; avaliação diagnóstica e participativa.

Em seguida, outra atividade foi realizada, como uma forma de colocar em prática o estudado até o momento, na qual os estudantes tinham que se dividir em grupos e fazer uma encenação, tais como: a primeira equipe interpretou o ensino tradicional, com a atuação de uma educadora que constrangia os alunos que tiravam nota baixa; o outro grupo abordou a avaliação surpresa; e por último, a postura arrogante do professor.

No mês de Abril, as atividades que foram desenvolvidas voltaram-se para as vivências e a exposição das miniaulas, que na primeira situação os estudantes teriam a oportunidade de ter um contato inicial com tal produção, enquanto no segundo momento de colocar em prática tudo que foi estudado.

Os cincos grupos davam início à exposição das miniaulas e das apresentações que representariam uma das avaliações da disciplina. A primeira equipe abordou um conjunto de conteúdos teóricos e práticos sobre o sistema digestório, tais como: a boca, saliva, trituração, bolo alimentar, movimento peristáltico, produção de ácido, suco gástrico, vitaminas, faringe, esôfago, fígado, estômago, vesícula, pâncreas, intestino, e ânus. A dupla utilizou de materiais e objetos para tornarem as informações ainda mais significativas, sendo que em uma situação, os alunos usaram garrafas, copos, meia, leite, vinagre, detergente e água, com a finalidade de realizar uma experiência e simular o sistema digestório.

A segunda equipe ficou responsável pelo assunto acerca do sistema solar e trouxe uma maquete de isopor com os planetas, como forma de explicar o conteúdo, tanto na teoria quanto na prática. O grupo falou de todos os planetas, o sistema solar e o universo, com uma linguagem simples, compreensível e produtiva, criando um momento significante e de interação, que envolveu a turma, a professora e o monitor.

O terceiro grupo apresentou a temática referente à alimentação saudável, em que utilizaram cartazes e de uma metodologia interativa com a turma, como estratégia de conhecer o que os estudantes comem, o que acham que são alimentos adequados e prejudiciais à saúde. Abordou a pirâmide alimentar, as vitaminas, a atividade física, as 
doenças, o tempo e o preço dos alimentos. Posteriormente, a dupla passou uma atividade para que os universitários anotassem o que comem em casa e trouxessem na próxima aula.

A quarta dupla abordou o assunto sobre o sistema respiratório e falou acerca dos seguintes tópicos: nariz; pelos; cavidade nasal; entupimento do nariz; detectores de odores; proteção de doenças; epiglote; faringe; laringe; cordas vocais; oxigênio; difusão; traqueia; brônquios; inspiração de carbono. O grupo trouxe um conjunto de materiais recicláveis e curiosidades como uma atividade, para que os colegas explorassem e tivessem contato com tais objetos, bem como deu um tempo para pesquisar e solicitou que a turma respondessem questões que mencionaram na aula em questão.

A última equipe ficou responsável para falar do conteúdo sobre mudanças climáticas, utilizando cartazes, figuras, mapa conceitual e plantas, além de ter abordado um conjunto de informações e conteúdos sobre: as consequências da globalização, o desmatamento, as queimadas, a poluição atmosférica, a destruição do meio ambiente, a consciência ambiental e a importância de plantar árvores. Após a conclusão da aula, a dupla pediu para a docente que no fim do encontro tivesse um momento para plantar, junto com os colegas, uma semente no estacionamento da faculdade.

As atividades que foram desenvolvidas no mês de maio englobaram aula de campo em um espaço turístico da cidade, com confraternização em meio à natureza, a avaliação da disciplina, entrega dos trabalhos avaliativos, o sorteio de um livro e o encerramento.

Durante a viagem até ao local em questão, os estudantes tiveram a oportunidade de observar a natureza, as paisagens e as belezas naturais, como uma forma de sair um pouco da sala de aula e ter contato com uma atividade prática.

Chegando ao Cedro, os universitários junto com a docente procuraram um lugar e organizaram um espaço adequado, tanto para se reunirem, quanto para realizar a confraternização. Foram realizadas as seguintes ações pedagógicas: avaliação a disciplina, do professor e do monitor; coleta de sugestões para melhoria da disciplina; conversas sobre o contexto atual, a importância da Educação e a Ciências; momento de música e de reflexão; confraternização; apreciação do Cedro, como a parede do açude, a barragem, os galpões, as construções e obras antigas, entre outros; registro por meio de 
fotos; sorteio de um livro de autoria da professora da disciplina; e o encerramento afetivo.

O outro tema abordado na pesquisa, refere-se ao tópico sobre o resultado e discussão, sendo um espaço que possibilitou analisar a vivência na referida bolsa e a refletir a importância da monitoria na formação docente, já que é uma experiência troca de conhecimento teórico e prático em contato com a sala de aula.

As experiências vivenciadas em conjunto com a professora em sala não permitiram apenas desenvolver o conteúdo, mas, principalmente, gerou a oportunidade de ter contato com o ensino-aprendizagem, o planejamento da aula, o conhecimento teórico-prático e a relação professor-estudante, demonstrando o valor da monitoria para o desenvolvimento da formação docente.

Dessa forma, o processo de ensino-aprendizagem não engloba somente o conteúdo das matérias e a formação do indivíduo, mas de tentar construir um ambiente que os alunos experimentem, vivenciem e sintam, para que seja possível desenvolver a criticidade, a participação e a autonomia.

Com base no que foi vivenciado na monitoria, destacou-se a importância que a educação tem de firmar o compromisso com a formação docente e o aperfeiçoamento profissional, tornando-se evidente que cada vez mais os estudantes, os professores e as universidades estão assumindo tal missão.

\section{CONSIDERAÇÕES FINAIS}

A atividade de monitoria teve como base o cotidiano das aulas e as situações vivenciadas em sala, que possibilitou trabalhar as seguintes atribuições: conhecer a função do professor; aprender a ministrar aulas; colaborar nas tarefas; acompanhar o desenvolvimento do programa; aperfeiçoamento profissional e formação docente.

O acompanhamento foi realizado por meio de observação das atividades expostas no cotidiano da sala de aula, com base em um conjunto de metas, ações, práticas e metodologias que foram repensadas sempre que possível, demonstrando que diversos são os fatores que podem influenciar no processo de ensino e aprendizagem.

Por fim, a respectiva experiência na monitoria foi a oportunidade privilegiada de aprendizagem em diversos aspectos do saber, como a construção de novas vivências e 
de reaprender os conteúdos estudados, bem como um espaço de criação de atividades, de estratégias e de organização, além da capacitação docente e profissional.

\section{REFERÊNCIAS}

ALVES, Bruna Molisani Ferreira. Infâncias e educação infantil: aspectos históricos, legais e pedagógicos. Dossiê temático. Revista Aleph: Rio de Janeiro, ano V, n. 16, 2011.

BARBOSA, Maria C. S. A Rotina nas Pedagogias da Educação Infantil: dos binarismos à complexidade, Currículo sem Fronteiras, v.6, n.1, p. 56-69, Jan/Jun 2006.

BASSI, Marcos Edgar. Financiamento da educação infantil em seis capitais brasileiras. Cadernos de Pesquisa, v. 41, n. 142, p. 116-141, jan./abr. 2011.

CAMPOS, R. Educação infantil e os organismos internacionais: quando focalizar não é priorizar. 2008. 15p. Disponível em <www.anped.org.br> Acesso em 10 de Dezembro de 2019.

CAMPOS, Maria Malta. Entre as políticas de qualidade e a qualidade das práticas. Cadernos de Pesquisa, São Paulo, v. 43, n. 148, p. 22-43, jan./abr., 2013.

CURY, C. R. J. Lei de Diretrizes e Bases e perspectivas da educação nacional. In. Revista Brasileira de Educação. São Paulo: ANPED, nº 8, mai/ago 1998, p.72- 85.

DUARTE, Luiza Franco. Desafios e legislações na Educação Infantil. IX ANPED SUL - Seminário de Pesquisa em Educação da Região Sul, 2012.

FERREIRA, Maria Clotilde Rossetti. Os fazeres na Educação Infantil. São Paulo. Cortez, 2000.

GRISA, C. Políticas públicas para a Agricultura Familiar no Brasil: produção e institucionalização das ideias. 2012. 280 p. Tese (Doutorado) - Instituto de Ciências Humanas e Sociais, Universidade Federal Rural do Rio de Janeiro, Rio de Janeiro, 2012.

HAJE, Lara. Fórum Nacional de Educação considera Base Nacional Curricular Comum ilegítima. Câmara dos Deputados: Brasília, 2017. Disponível em: < http:// www2. camara. leg. br/ camaranoticias /noticias /educacao-e-cultura/535651-forumnacional-de-educacao-considera-base-nacional-curricular-comum-ilegitima.html. >Acesso em 15 de Dezembro de 2019.

MACHADO, Nilson José. Epistemologia e Didática: as concepções do conhecimento e inteligência e a prática docente. São Paulo: Cortez, 1996. 
OLIVEIRA, Stela Maris Lagos. A legislação e as políticas nacionais para a educação infantil: avanços, vazios e desvios. In: MACHADO, Maria Lúcia (Org.) Encontros e desencontros em educação infantil. São Paulo: Cortez, 2002.

PIMENTA, Selma Garrido; LIMA, Maria do Socorro Lucena. Estágio e docência. 3 ed. São Paulo: Cortez, 2008. 


\title{
ABORDAGENS DIFERENCIADAS NO ENSINO FUNDAMENTAL: O PAPEL DO PROFESSOR NA RELAÇÃO COM O ALUNO
}

\author{
NEVES, Magda Lúcia ${ }^{22}$ \\ SILVA, Francisco Clécio Araújo ${ }^{23}$ \\ GREGÓRIO, Maria Irani ${ }^{24}$ \\ FREITAS, Dayana Lucia Rodrigues de ${ }^{25}$
}

\section{RESUMO:}

A afetividade é um tema que sempre deve passar por reflexões, visto sua importância no processo formativo; particularmente no que diz respeito à relação da afetividade e à prática educativa de qualidade. Este trabalho tem como objetivo geral refletir sobre a importância da afetividade na relação professor-aluno no ensino fundamental, etapa esta que muitas vezes não utilizada da afetividade em suas práticas. Trata-se de uma pesquisa bibliográfica, em que foram utilizados como autores base: Branden (1999), Galvão (1995), Macedo (2005), Moreno et al. (2003) entre outros. Através deste estudo pode-se concluir que no tempo em que a criança/adolescente está dentro do espaço escolar suas relações de afetividade podem gerar valores para sua formação pessoal. Neste ambiente o aluno vai construindo uma relação afetiva que pode ser importante até mesmo dentro de sua casa. Para os professores, a afetividade é um conjunto de normas, posturas e ações que estes profissionais adotam para levar os alunos a se sentirem como protagonista de sua própria história. De forma geral, podemos afirmar que a afetividade no processo de formação da criança é primordial para que o mesmo tenha procedimentos positivos dentro do processo de aprendizagem em qualquer nível escolar.

PALAVRAS-CHAVE: Afetividade. Ensino-aprendizagem. Professor. Aluno.

\section{INTRODUÇÃO}

A afetividade no processo formativo dos alunos é um tema que sempre deve passar por reflexões, principalmente no que diz respeito à relação da afetividade e a prática educativa de qualidade.

\footnotetext{
${ }^{22}$ Especialista em Alfabetização e Letramento pelo Instituto Superior de Educação Elvira Dayrell/MG. Professora da Educação Básica do município de Guamaré/RN. E-mail: magda_neves@ @otmail.com

${ }^{23}$ Especialista em Educação Infantil pela Faculdades Integradas de Patos/CE (FIP). Professor de Educação Básica do município de Guamaré/RN. E-mail: leciofrancisco@yahoo.com.br

${ }^{24}$ Especialista em Neuropsicopedagogia, Educação Especial e Inclusiva pela Faculdade Venda Nova do Imigrante (FAVENI/ES). Professora da Educação Básica do município de Guamaré/RN. E-mail: iranigregorio13@gmail.com

${ }^{25}$ Mestra em Ciências da Educação pelo Centro de Educação Continuada e Aperfeiçoamento Profissional (CECAP). Professora da Escola Técnica Fanex Rede de Ensino - Macau/RN. Professora da Educação Básica do município de Guamaré/RN. E-mail: dayannaproducoes@gmail.com
} 
A definição da afetividade é ao mesmo tempo limitada e ampla. Limitada, pois, os sentimentos se movem num nível subjetivo em busca de seu encontro e percepção; proporcionando a cada indivíduo a liberdade para sentir e expressá-la, segundo suas próprias necessidades e desejos. Ampla, pois justifica as atitudes e comportamentos humanos (DAVIS, 2005).

Dentre outras vertentes, as relações sociais são permeadas por aspectos afetivos que caracterizam a formação da personalidade humana. A abordagem do papel da afetividade num contexto de desenvolvimento integral da criança pretende de modo geral, identificar a relação dos vínculos afetivos socialmente construídos no contexto escolar e o sucesso de uma aprendizagem mediada pelo adulto. Nota se que,

O processo educacional não é um processo isolado; é constituído, conjuntamente por professores e educandos na interação e com vínculo na afetividade, na participação, na cooperação de ambos, construindo-se e acomodando-se, assim, a aprendizagem. (GIANCATERINO, 2007, p. 74).

A separação entre cognitivo e afetividade justifica, ainda hoje, algumas práticas docentes que deixam transparecer a inconsciência dos professores sobre a necessidade de interação das crianças com o meio e com as pessoas com quem convivem. Desta forma, procurou-se observar de que modo acontece a afetividade entre o professor e aluno. Conforme diz Giancaterino (2007, p. 77): “a relação professor/aluno torna-se assim, o núcleo concreto das práticas educativas e do contrato pedagógico, o que estrutura os sentidos cruciais entre professor escolar".

A temática da afetividade entre aluno e professor é altamente relevante, especialmente por se tratar de Educação Infantil e Ensino Fundamental. Todavia, continuará sendo importante em qualquer nível de ensino e nas relações interpessoais, e em uma visão comunitária, na educação para a Saúde e na educação Social. Dentro dessa perspectiva, Moreno et al. (2003, p. 10) ressalta que:

Uma das crenças fortemente enraizadas em nossa cultura têm sido durante muitos séculos, constituidoras de aspectos claramente distintos do ser humano: "aparentemente pensamos com o cérebro e amamos com o coração". Por outro lado, é como encontrar a crença de que a razão tem sido considerada como aquilo que nos conduz a porto seguro da verdade, ou, ao menos, nos aproxima dele, enquanto que o 
universo das emoções se supõe impregnado de armadilhas que nos induzem facilmente ao erro.

Há muito tempo existem estudos da psicologia que apresentam questões afetivas da criança, que começa dentro de sua casa e perpassa pelos ambientes onde ela se insere. Dentro da escola, a afetividade na relação do professor facilita a aprendizagem do aluno, pois a afetividade está enraizada no processo de ensinoaprendizagem e na transformação da mentalidade da criança/adolescente no ambiente escolar.

Contudo, percebemos que a maioria dos alunos utiliza a violência como forma de comportamento rotineiro na escola, tanto na fala como na agressão física, para assim tentar mostrar um pouco da carência que tem. Poderíamos levantar essa questão como algo que acontece no cotidiano da criança talvez. Por que muitos alunos agridem uns aos outros, mesmo sabendo que isso é proibido? E até onde essas atitudes influenciam a escola a agir de forma diferente? Talvez seja preciso a escola realizar procedimentos em muitas situações que não competem ao seu dever para incentivar que aconteçam sempre atos de respeito, justiça, diálogo etc.

\section{OS ESTUDOS E PESQUISAS RELACIONADOS AO PROCESSO AFETIVO NA FORMAÇÃO EDUCACIONAL}

Os vínculos afetivos socialmente despertam condutas e emoções únicas e específicas, caracterizando o processo contínuo de formação da identidade subjetiva e social dos indivíduos. A afetividade pode ser entendida como o domínio das emoções, das experiências sensíveis e principalmente, da capacidade de entrar em contato com sensações que se referem às vivências dos indivíduos e as formas de expressão essencialmente humanas.

As contribuições de estudiosos como Vygotsky acentuam a importância da infância e das etapas de evolução da criança, bem com as relações com o meio cultural e a construção da linguagem, para o processo de desenvolvimento cognitivo. A linguagem e o pensamento humano têm origem social. A cultura faz parte do desenvolvimento e deve ser integrada ao estudo e a explicação das funções superiores. (BOCK; FURTADO; TEIXEIRA, 1999, p. 87). 
Ao analisar a teoria Walloniana sobre o desenvolvimento da criança, Galvão (1995) afirma que no contexto do desenvolvimento infantil podem-se identificar a existência das etapas diferentes, porém, integradas gradualmente, se caracterizando pela apresentação de necessidades e interesses específicos, seguindo uma ordem, que segundo Wallon:

[...] estas revoluções de idade para idade não são improvisadas por cada indivíduo. São a própria razão da infância, que tende para a edificação do adulto como exemplar da espécie. Estão inscritas, no momento oportuno, no desenvolvimento que conduz a esse objetivo (apud MAHONEY; ALMEIDA, 2006, p. 59).

Ainda, Mahoney e Almeida (2006) afirmam que, segundo a proposta Walloniana, tais etapas ou estágios podem ser assim definidos como: Impulsivoemocional, que compreende o período de 0 a 1 ano; sensório-motor e Projetivo que se observa nas crianças de 1 a 3 anos; Personalismo que se identifica em crianças de 3 a 6 anos; Categorial, observando em crianças de 6 a 11 anos; Puberdade e Adolescência que se estende dos 11 anos em diante.

Assim, existem estágios em que a afetividade está direcionada para a busca do entendimento de si mesmo, de forma que "o conjunto afetivo está mais evidenciado nos estágios impulsivo-emocional, personalismo, puberdade e adolescência" (MAHONEY; ALMEIDA, 2006, p. 60).

Enriquecendo esse olhar sobre a afetividade, Galvão (1995, p. 39), destaca que "conforme a idade, a criança interage mais fortemente com um ou outro aspecto de seu contexto, retirando dele os recursos para o seu desenvolvimento". Há momentos e períodos em que a criança volta sua atenção para a exploração do mundo através de suas ações ora para a formação de vínculos e ainda á reflexão mental dessas experiências num nível abstrato e cognitivo.

A afetividade é parte integrada da subjetividade, sendo as expressões melhores compreendidas se considerar os afetos que as acompanham. Logo, o afeto determina o comportamento humano e constitui um aspecto de fundamental importância na vida psíquica, pois, expressam-se nos desejos, sonhos, expectativas, palavras e gestos que cada ser humano nutre ao longo da vida. Para Piaget (apud PULASKI, 1986, p. 139), “todo ato de inteligência é acompanhado por sentimentos (de interesse, de prazer, de 
esforço etc.), e que esses sentimentos fornecem a motivação, a energia que ativa o crescimento intelectual".

Os vínculos afetivos, enquanto acolhimentos, se tornam condição essencial para o crescimento e desenvolvimento global da criança/adolescente. A afetividade é a dinâmica mais profunda e complexa de que o ser humano pode participar. O ser humano tem suas necessidades físicas e emocionais que, ao serem atendidas, formam um forte laço emocional construído com base na interação com os outros indivíduos. É possível compreender que o contato social configura-se como o suporte afetivo do desenvolvimento dos sentimentos dos indivíduos em relação ao mundo, pois possibilita a construção de esquemas de ações e comportamentos, frente aos objetos, situações e pessoas (BRANDEN, 1998).

Diante do exposto, tanto o ato emocional quanto a inteligência são de suma importância na formação intelectual e na formação educacional do aluno, precisando ainda, o educador reconhecer os sentimentos no processo educacional para tentar trabalhar, no sentido de melhorar, o crescimento educacional do aluno.

Dentro da escola, a relação entre professor e o grupo de alunos ou em particular com cada um, é preciso que aconteça a todo tempo, tanto na sala de aula como nos momentos externos. Isso mostra uma relação mais próxima da afetividade entre aluno e professor.

Desta forma, o docente precisa, acima de tudo, saber lidar com situações extremas, em que o aluno agride e usa palavras de baixo calão. A ação do professor de não agredir na mesma proporção já é um ato de desarme diante do aluno.

\section{O EDUCADOR COMO UM INTERMEDIADOR NO PROCESSO AFETIVO COM O ALUNO}

O trabalho docente é carregado de uma função social, pois, quando realizado competentemente, através de uma ação mediadora, oportuniza ao aluno relacionar os acontecimentos e situações à sua volta e buscar ações e atitudes que possam transformar o meio em que vivem.

As relações emocionais provocadas pela afetividade envolvida nas relações sociais influenciam as formas de comportamento em todos os momentos do processo de educação. Segundo Piletti (1998, p. 24) “no decorrer de sua vida diária, o aluno sofre 
uma série de influências que vão ter repercussões negativas e positivas em seu trabalho escolar".

$\mathrm{Na}$ medida em que se realizam essas experiências de aprendizagem, a criança se desenvolve, as necessidades afetivas se deslocam do plano fisiológico para o plano cognitivo. Assim, conforme coloca Tassoni (2000, p. 14), “mesmo mantendo-se o contato corporal como forma de carinho, falar da capacidade do aluno, elogiar o seu trabalho, reconhecer seu esforço, constitui-se formas cognitivas de vinculação afetiva".

As relações afetivas permeadas por cargas afetivas positivas marcam o processo de aquisição do objeto do conhecimento, contribuindo também, a construção da autonomia à medida que possibilita a confiança dos alunos no professor em relação capacidades e decisões (BRANDEN, 1998).

Sobre o mesmo ponto de vista, Vayer (1989) afirma que, a relação intrínseca entre os objetivos socioafetivos e cognitivos da educação, requer um contexto de relação adulto-criança permeada pelo respeito recíproco, pela afeição e pela confiança, garantindo à criança um ambiente favorável ao seu desenvolvimento intelectual e moral.

A integração da afetividade e inteligência permite aos indivíduos atingir níveis de evolução cada vez mais complexos. Essa integração entre afeto e cognição é o que fundamenta o entendimento de um desenvolvimento integral do ser humano, no trabalho educativo cotidiano não existe separação entre o pensar e o agir, pois os sujeitos ali envolvidos não se desapropriam de aspectos afetivos que compõem sua personalidade ao entrar na sala de aula (BORBA; SPAZZIANIL 2007). Além das necessidades cognitivas trazidas pelos alunos, existem também as necessidades afetivas muitas vezes não satisfeitas e compreendidas no ambiente familiar.

O papel do educador é compreender essas necessidades individuais e afetivas para a vida de sentimentos humanos. A ternura, o amor, o respeito, o desejo, são aspectos relevantes a essas necessidades (BRANDEN, 1998). A estrutura familiar influencia o desenvolvimento em vários aspectos e um deles é na vida escolar.

Uma aprendizagem significativa inicia-se com as relações sociais, que são aspectos importantes do desenvolvimento humano, quando se trata de atividades escolares, podemos elencar que para a criança, algo se torna significativo quando há reflexão sobre a relação com seu cotidiano, contudo, o professor terá que ter plena consciência da influência que exerce sobre a criança ao desenvolver hábitos, 
estimulando a ter sua própria independência. Nessa perspectiva, a criança adquire segurança, tendo o professor como modelo ou suporte na compreensão de suas atitudes.

Segundo Macedo (2005), a curiosidade pode ser entendida como uma das características naturais da criança e é manifestada em níveis crescentes a cada fase de seu desenvolvimento. Apresentar para a criança a complexidade da vida atual permite o processamento desta novidade que está sendo apresentada como um estímulo para novas descobertas ou curiosidades, tornando-a capaz de crescer individualmente e socialmente. A prática docente está, desta forma, permeada por responsabilidades, compromisso, senso crítico e autoconsciência, além disso, o educador deve ter, subjetivamente, vocação e prazer por ensinar. Sua prática educativa deve, antes de tudo, ser uma extensão de seus princípios e valores éticos.

Pode se concluir que, a ampliação do ambiente social configurada pela escola e o surgimento de novas situações e outras realidades, faz que a criança viva em constante estado de curiosidade exigindo do professor o suprimento dessas necessidades.

Quando se refere à inteligência ou à capacidade cognitiva do ser humano, quase sempre surge a indagação sobre a capacidade de aprendizagem do indivíduo diante de um determinado objeto do conhecimento. Esta capacidade de aprender é, em parte, determinada pelo modo como são apresentados os conhecimentos e pelo significado afetivo. A Interrelação entre pensamento e ação caracteriza todas as realizações humanas, assim, como diz Pulaski (1986, p. 27), "as operações mentais, emergem de ações motoras e experiências sensoriais que são interiorizadas" pelas crianças.

Desta forma, num processo educativo deve-se buscar uma ação ou uma práxis reflexiva, possibilitando, não a repetição e memorização, mas uma mudança de atitudes que implica em considerar as trocas afetivas na interação cotidiana.

A individualidade da criança deve ser observada e respeitada, uma vez que existem diferenças nos ritmos e mecanismos de aprendizagens por elas criados. Ao expressar um sentimento de amor pelos alunos e, consequentemente, pelo trabalho educativo, o professor deve guiar seu comportamento dando provas de um senso de humor oportuno e necessário. Deve manifestar um amor individual e coletivo pelos alunos, renunciando muitas vezes, suas vontades e desejos para ir à busca da realização das necessidades infantis. 


\section{CONCLUSÕES}

Conclui-se que, é no período da infância que se constrói a base da identidade adotada na vida adulta e que, os adultos que convivem com a criança tornam-se referência comportamental e moral, servindo como modelos a serem seguidos.

As experiências humanas e, particularmente, as infantis, são mais bem compreendidas e vivenciadas em sua plenitude quando são carregadas de significado prático e afetivo. Prático, quando se tornam úteis às situações cotidianas e afetivo, quando geram sentimentos e emoções perceptíveis nas relações que se estabelecem socialmente.

A afetividade, enquanto relação com cargas afetivas positivas, garante a segurança e o apoio emocional para as descobertas e, que, as crianças se lançam em busca do conhecimento do mundo e de si mesmas. O interesse, a curiosidade, as dúvidas e os medos encontram no campo afetivo, espaço para se expressarem. Ao possibilitar essa expressão, a criança sente-se segura e autônoma para a construção de seu próprio conhecimento, considerando a importância do meio social para a formação integral do ser humano.

Foi possível constatar que os professores compreendem que o papel do adulto é o de servir como mediador entre a criança e o mundo. As relações sociais, alémfamiliares, ampliam essa mediação ao oferecer à criança uma diversidade de situações na qual tenha que elaborar novos mecanismos de compreensão de fatos, conceitos e atitudes.

Pode-se concluir que é no período escolar que a ampliação dessas relações ganha maior significado, por ser um período em que a criança constrói para si a concepção social do mundo enquanto relações humanas além-familiares. Conforme apontaram os professores, a afetividade é para eles, um conjunto de postura, comportamento, atitudes e ações adotadas pelo professor, que possam levar o aluno a sentir-se valorizado, benquisto e respeitado perante os outros.

No momento em que a criança experimenta uma realidade de confiança, de tratamento de carinho, este pode construir uma sensação maior de autoestima, de sentirse amado, ter autocontrole, saber controlar seus sentimentos e emoções. Claro que 
estamos falando de uma criança, mas é a partir dessa perspectiva que começa um crescimento neste sentido.

A escola é um espaço privilegiado de interação social, onde o trabalho com o conhecimento sistematiza-se, promovendo o contato com a cultura e suas ferramentas, possibilitando a apropriação de uma diversidade de recursos de aprendizagem. Portanto, a escola é um espaço de aprendizagem do mundo, dos conteúdos, de si e do outro, onde são germinadas as boas ações, mas em muitas situações não se aprende o que vive dentro da escola.

O docente precisa a todo tempo estar atento nas falas, gestos e necessidades dos alunos. O espaço educacional é o lugar onde as interações acontecem e são das mais variadas formas, por isso a intervenção, no sentido do auxílio por parte do professor, assegura a alta afirmação do discente. Ao professor, em algumas ocasiões é preciso esquecer os conteúdos e trabalhar realmente aquilo que pode ser essencial na vida daquele aluno: a autoafirmação para que ele possa conseguir lidar com seus próprios problemas.

Como pensamos trabalhar a afetividade dentro do convívio escolar, não significa apenas dar carinho, afeto ou deixar passar alguns comportamentos inadequados, mas esses sentimentos são demonstrados pelo professor, a partir do momento que se constrói uma relação em que o aluno crie autoconfiança, regulando suas ações e permitindo que, pelo exercício desse falar de si, possam tornar-se futuramente, adultos equilibrados e sensíveis às necessidades do outro.

Por fim, no tempo em que a criança está dentro do espaço escolar, suas relações de afetividade podem ganhar mais valores. Dependendo se for recíproco, é um momento em que a criança vai construindo uma relação afetiva que pode ser importante, até mesmo dentro de sua casa. Para os professores, a afetividade é um conjunto de normas, posturas e ações que estes profissionais adotam para levar o aluno a se sentir protagonista de sua própria história.

\section{REFERÊNCIAS}

BOCK, A. M. B.; FURTADO, O.; TEIXEIRA, M. L. T. Psicologias: Uma Introdução ao Estudo de Psicologias. São Paulo: Saraiva, 1999. 
BORBA, V. R. S.; SPAZZIANI, M, L. Afetividade no Contexto da Educação

Infantil. Ribeirão Preto, 2007. Disponível em: http://www.anped.org.br/ reuniões/30ra/trabalhos. Acesso em: 23 08-18.

BRANDEN, N. Autoestima e os seus seis pilares. São Paulo: Saraiva, 1998.

DAVIS, C. Piaget ou Vygotsky. Uma Falsa Questão. Viver mente \& cérebro. Rio de Janeiro: Ediouro; São Paulo: Segmento-Duetto, V. 2, n. 2, p. 38-49, 2005.

GALVÃO, I.; Henri Wallon: Uma Concepção do Desenvolvimento Infantil. Petrópolis: Vozes, 1995.

GIANCATERINO, R. Escola, Professor, Aluno: Os Participantes do Processo Educacional. São Paulo: Madras, 2007.

MACEDO, L. de. O ancestral do humano e o futuro da humanidade. Viver mente \& cérebro. São Paulo: Segmento-Duetto, V. 1, n. 1, p. 06-23, 2005.

MAHONEY, A. A; ALMEIDA, L. R. Viver mente \& cérebro. São Paulo: SegmentoDuetto, v.6, n.6, p.56-65, 2006.

MORENO, M.; SASTRE G.; LEAL, A.; BUSQUETS, M. D. Falemos de Sentimentos: A afetividade como um tema transversal. São Paulo: Moderna, 2003.

PILETTI, N. Psicologia Educacional. São Paulo: Ática, 1988.

PULASKI, M. A. S. Compreendendo Piaget: uma Introdução ao Desenvolvimento Cognitivo da Criança. Rio de Janeiro: LTC, 1986.

TASSONI, E. C. M.; Afetividade e aprendizagem: A relação professor-aluno. Campinas, 2000. Disponível em: 〈http://www.anped.org.br/reunioes/23/textos/2019t>. Acesso em: 02/09/2018.

VAYER, P. O Diálogo Corporal. A ação educativa para a criança de 2 a anos. Brasil: Manole, 1989. 
ACESSIBILIDADE E INCLUSÃO DE CRIANÇAS COM DEFICIÊNCIA FÍSICA NAS ESCOLAS: COMO ACONTECE?

BRÁS, Regina Maria ${ }^{26}$

\section{RESUMO:}

O presente trabalho constitui-se numa intervenção socioescolar e traz como cerne de suas discussões e pesquisas, a educação inclusiva. O início deste percurso rumo à inclusão social acontece na escola, pois através dos alunos poderemos gerar uma consciência inclusiva que atenda toda a sociedade. Ao integrar o espaço, esses sujeitos desenvolvem suas habilidades, interagem e se relacionam uns com os outros, ampliando os seus conhecimentos. A inclusão se manifesta pela capacidade da escola oferecer respostas desejadas à diferença de aprendizagem das crianças. Ela busca que a escola se transforme em espaço de permuta o qual favoreça o modo de ensinar e aprender. Transformar o ambiente significa gerar condições para que todos participem do processo de renovação do conhecimento. A escola que inclui valoriza o desempenho do aluno, percebendo que este processo transforma a vida escolar e a relação com os demais, modificando inclusive seu modo de formação pessoal e profissional. Para a realização deste trabalho, foi utilizada como estratégia metodológica a pesquisa-ação, fundamentada nos estudos de Tripp (2005) e que proporciona ao professor assumir também a função de pesquisador, aproximando-se do seu objeto de estudo e, acima de tudo, agindo de forma coerente e direcionada sobre o mesmo. A prática da pesquisa fundamenta-se, também, numa revisão bibliográfica consistente, apoiada em diferentes teóricos e estudiosos da área da Educação, dentre os quais destacamos: Mantoan (2007), Schirmer et al. (2007) e Machado (2007) que muito contribuíram no processo de construção do conhecimento. A realização deste trabalho trouxe contribuições ímpares para a nossa formação profissional, pessoal e acadêmica.

PALAVRAS-CHAVES: Inclusão. Acessibilidade. Educação.

\section{INTRODUÇÃO}

Nesta intervenção socioescolar abordaremos sobre a inclusão de alunos com deficiência na escola, além das discussões por elas geradas, foi o motivador para este trabalho. Na busca de uma educação inclusiva, optamos pelo respeito às pessoas com deficiência no âmbito escolar. Precisamos mudar essa realidade de exclusão, colaborando com todos para que essas pessoas não se isolem da sociedade.

A educação inclusiva proporciona às pessoas com necessidades especiais 0 acesso ao conhecimento e ao ambiente escolar, com isto os alunos diferentes aprendem

\footnotetext{
${ }^{26}$ Mestranda do Curso de Ciências da Educação pela Faculdade do Estado do Maranhão (FACEM). Professora da Educação Básica dos municípios de Macau/RN e Guamaré/RN. E-mail: reginamariabras@ hotmail.com
} 
a interagir com os demais. $\mathrm{Na}$ escola inclusiva todos desenvolvem ações que possibilitam o seu desempenho escolar, assim, todos evitam a exclusão e aprendem a conviver com a diversidade humana. Incluir significa garantir uma educação para todos na busca do respeito e desigualdade, portanto, o ambiente escolar é um espaço onde compartilhamos o conhecimento e a troca de experiência com o diferente. Para garantir a inclusão, se faz necessário oferecer uma educação de qualidade, havendo o respeito às diferenças, valorizando a diversidade humana por meio do conhecimento da igualdade, na busca de combater o preconceito e a discriminação.

Esta pesquisa tem por finalidade combater o preconceito e a desigualdade, que geram indivíduos sem comprometimento com as relações sociais, visando respeitar os desafios para a construção de uma proposta inclusiva, que garanta a todos os alunos uma educação de qualidade, combatendo à discriminação, estimulando o respeito às diferenças e valorizando as pessoas com deficiência pelo sentimento de solidariedade. Este trabalho foi desenvolvido na visão de que a sociedade perceba que o ambiente escolar é o espaço que oferece a participação de todos e traz muitos benefícios para as pessoas, desenvolvendo a sua interação social, portanto, desta forma, a sociedade passa a perceber que as pessoas com deficiência precisam ser amados e respeitados, conforme as suas possibilidades.

O objetivo principal da nossa pesquisa é mostrar como acontece a inclusão do aluno com deficiência física na escola, mesmo diante da falta da acessibilidade. Também buscamos, com a realização desta intervenção socioescolar, valorizar a diversidade humana, pela sua importância para o enriquecimento de todas as pessoas; reconhecer as necessidades e competência dos colegas; conscientizar a sociedade que a deficiência não é um sinônimo de inferioridade e incapacidade. A metodologia escolhida para referenciar a construção deste trabalho científico foi a pesquisa-ação, que segundo Tripp (2005), caracteriza-se como uma estratégia que permite a aproximação do professor com o pesquisador, através da vivência, do contato direto com o objeto de estudo.

A opção desta metodologia de pesquisa evidenciou-se na busca de soluções para os problemas existentes nas escolas, visando o respeito na tentativa de quebrar as barreiras que impedem o acesso de pessoas com deficiência no ambiente escolar. Na construção deste estudo nos respaldamos em Mantoan (2007), afirmando que a inclusão 
é uma ação que provoca a melhoria da qualidade de vida e da educação básica e superior, para que o alunado com e sem deficiência tenha possibilidade de desempenhar à educação em sua plenitude, sendo indispensável que o ambiente escolar acompanhe suas práticas, a fim de atender às diferenças.

Este acompanhamento é necessário para que as crianças passem por várias experiências educacionais, sem retirar dela o proveito desejável e valioso. A maioria das escolas, ainda está distante de se tornar inclusiva, pois não acreditam nas utilidades que esses alunos poderão adquirir ao longo das novas situações.

Diferentes práticas de ensino proporcionam que os alunos possam acompanhar os mais elevados níveis de ensino de acordo com o desenvolvimento de cada um, como nos garante a constituição. Segundo Schirmer et al. (2007), os alunos com deficiência física possuem a indicação de recursos que supram suas necessidades, ou seja, soluções simples que darão assistência e conforto a todos, deixando-os relaxados, na busca de garantir um aprendizado de qualidade sem exclusão escolar.

Oferecer o acesso às pessoas com deficiência é garantir a todos condições para que tenham uma melhoria de qualidade de vida. De acordo com Machado (2007), os profissionais da engenharia e da arquitetura, podem executar projetos arquitetônicos na escola de forma que seus espaços escolares sejam realmente inclusivos, sendo assim, os ambientes acessíveis promovem às pessoas com deficiência o bem-estar de todos, contribuindo para a sua aprendizagem. Uma escola adaptada atende às necessidades de alunos com diferentes tipos de deficiência, lembrando que a acessibilidade é um direito garantido por lei, para que todos possam ter acesso a todos os espaços escolares e que seja possível interagir com as atividades com segurança e independência conforme suas limitações.

\section{A INCLUSÃO DO ALUNO COM NECESSIDADES EDUCACIONAIS ESPECIAIS NA ESCOLA: BREVES REFLEXÕES}

Nesta pesquisa, vamos abordar um pouco sobre a história e as leis que permitem a inclusão de pessoas com deficiência no âmbito escolar. Desta forma, é imprescindível conhecer o que nos move nesta ação, buscando o direito de todos a uma escola de todos, sem exclusões, discriminação e preconceitos. Para garantir o direito de todos é 
necessário conhecer os fundamentos e como eles estão expressos em nossos documentos legais.

Vamos debater a situação educacional vivenciada pelas pessoas com deficiência, nos dias atuais, não esquecendo de que é providência de todo um processo de evolução do atendimento às mesmas na sociedade. Abordamos também a questão da deficiência/diferença, numa visão histórica até a busca pela sua plena inclusão escolar e social. Sendo através dessas ações desenvolvidas é que podemos construir uma sociedade aberta a todos, que respeite a diversidade humana e que atenda aos interesses de todos os cidadãos.

\section{ACESSIBILIDADE ARQUITETÔNICA: O QUE DIZEM OS ESPECIALISTAS?}

Com fundamentos nos princípios do Desenho Universal e da Lei ${ }^{\circ} 10.098 / 00$, toda escola deve favorecer ambiente de fácil acesso, para as pessoas com deficiência na busca de eliminar barreiras arquitetônicas, adaptando os espaços que atendam à toda diversidade humana. Contamos com a ação fiscalizadora dos Ministérios Públicos Estaduais para garantir o direito de acessibilidade espacial para as pessoas com deficiência. Se a nossa meta é alcançar a participação permanente de alunos com deficiência nas atividades escolares, é preciso oferecer um ambiente adequado para garantir essa interação.

A acessibilidade arquitetônica é feita devido um processo de análise das circunstâncias do ambiente, numa parceria permanente entre profissionais da educação e profissionais da arquitetura e engenharia, visando uma perspectiva ampla de inclusão. Se faz necessário verificar as necessidades específicas provenientes de cada tipo de dificuldade: motora, sensorial, de comunicação, cognitiva ou múltipla. (MACHADO, 2007).

Nos espaços das instituições escolares, os projetos de acessibilidade arquitetônica devem ser desenvolvidos por intermédio de parceria estabelecida entre profissionais da Educação e profissionais da arquitetura e engenharia. Torna-se obrigatório pôr em destaque que, para a aprovação da licenciatura de certificado de conclusão de projeto arquitetônico, deverão ser observados os princípios do desenho universal e atestado o atendimento às normas de acessibilidade previstas pela Associação Brasileira de Normas Técnicas (ABNT). 
A acessibilidade procede das condições adequadas de acesso à informação, das possibilidades de se locomover, permitindo às pessoas com deficiência participar da sociedade e constituir relações com as demais pessoas. Recorrendo a Dischinger et al (2004), os projetos arquitetônicos acessíveis podem se valer dos cinco princípios do Desenho Universal que muito colaboram para a inclusão escolar.

Segundo Machado (2007), são eles: $1^{\circ}$ Direito à equidade, participação: todos os ambientes devem ser delineados de forma a não isolar ou excluir pessoas, oferecendo a socialização e a interação entre indivíduos. Desta maneira, os ambientes e equipamentos acessíveis não devem ser isolados dos demais espaços, pois facilita o uso independente das pessoas com habilidades e restrições diferentes.

$2^{\circ}$ Direito à independência: todos os espaços físicos, a exemplo de pátio caminhos, salas dentre outros e seus componentes como brinquedos, pisos, rampas e carteiras, devem permitir o desempenho de atividades de forma independente por todos os usuários.

$3^{\circ}$ Direito à tecnologia assistiva: todos os alunos com deficiência têm direito à utilização de equipamentos, instrumentos, recursos e material pedagógico acessível de uso individual ou coletivo necessários para o desempenho das atividades escolares.

$4^{\circ}$ Direito ao conforto e segurança: todos os ambientes e equipamentos podem facilitar o desenvolvimento das atividades, dando-lhe conforto e segurança de acordo com as necessidades específicas de cada um.

$5^{\circ}$ Direito à Informação Espacial: entende-se que a possibilidade de acesso à informação espacial é necessária para a compreensão, orientação e acesso dos espaços para todos os indivíduos.

A partir da Convenção sobre os Direitos das Pessoas com Deficiência (ONU, 2006, p. 2), comprovada no Brasil como modificação constitucional, conceitua-se pessoa com deficiência como, "aquelas que têm impedimentos de natureza física, intelectual ou sensorial, em interação com diversas barreiras, podem impedir sua participação completa e efetiva na sociedade com as demais pessoas". Esta ideia define um importante processo de transformação no ponto de vista das pessoa com deficiência, passando do modelo clínico, que destaca a limitação do sujeito para o modelo social, que determina a acessibilidade como base essencial para a participação plena das pessoas com deficiência no contexto social. Nesta proporção, “a remoção de barreiras 
promove a independência, a autonomia e a dignidade de forma que atenda a todos os cidadãos" (BOARETTO, 2006, p. 13).

De acordo com os especialistas, a acessibilidade busca uma sociedade mais inclusiva, a fim de garantir o direito e o acesso dos alunos com necessidades especiais no espaço escolar. Segundo Lovato e Zych (2008, p. 5), as escolas no Brasil já deveriam estar adaptadas às necessidades de todos os alunos, pois a realidade a qual enfrentamos é outra. As mesmas necessitam de modificações e adaptações em vários ambientes, na tentativa de oferecer condições para que não ocorra a exclusão. As escolas devem proporcionar a socialização, favorecendo condições mínimas de acessibilidade na perspectiva de minimizar e oferecer acesso sem barreiras, que pode vir a dificultar a estabilidade das pessoas com deficiência.

De acordo com Machado (2007), os ambientes acessíveis não proporcionam apenas o bem-estar para as pessoas com deficiência, mas também estimulam e aproximam toda a gama de diferenças humanas. Podemos observar que a nossa sociedade apresenta barreiras que dificultam a inclusão das pessoas com deficiência em vários setores. Barreiras estas que limitam a inserção social de pessoas vistam como “diferentes", partindo de atitudes preconceituosas fundadas nos padrões de normalidade, e do ponto de vista físico. É preciso modificar a nossa sociedade para que o atendimento às pessoas com deficiência garantam-lhes mais interação, proporcionando uma melhoria na qualidade de vida (LOVATO; ZYCH, 2008).

A adequação dos sistemas sociais vem sendo enfatizada, principalmente, a partir da década de 90, através de documentos internacionais, como a Declaração de Salamanca (1994), da UNESCO, que aborda extensamente o conceito de inclusão, procurando o desenvolvimento de programas que atendam a diversidade dos educandos que frequentam nossas escolas. Faz-se necessário adequar os espaços das escolas já existentes e orientar os novos projetos escolares com fundamentos em desenhos acessíveis.

Há uma grande necessidade de promover a formação continuada para os profissionais de engenharia e da arquitetura, no sentido de buscar o conhecimento do desenho universal e à conscientização de que escolas acessíveis são um direito que é garantido por lei (MACHADO, 2007). Dar-se a entender que a acessibilidade significa 
oferecer condições de vida, possibilitando a todos, segurança, autonomia e garantias, para que todos possam viver com dignidade.

Precisamos do respeito e o conhecimento dos direitos humanos para garantir ambientes acessíveis para todos (LOVATO; ZYCH, 2008). Visando uma educação inclusiva, a acessibilidade é elemento necessário para promover uma educação de qualidade, sendo indispensável para garantir o direito ao acesso dos alunos com deficiência no contexto da escolar. Porém, a organização de condições que promovam o acesso no âmbito escolar aos alunos com deficiência deve estar ligada aos processos pedagógicos, a fim de subsidiar a aprendizagem dos alunos com necessidades educacionais especiais.

A acessibilidade promove condições de vida, possibilitando a todos um espaço seguro e confortável, fazendo com que as pessoas possam viver de forma independente, superando as reais barreiras de acesso e aprendizagem, a fim de proporcionar a participação de todos, livres de obstáculos que impeçam ou dificultem a sua acessibilidade. Portanto a eliminação de barreiras arquitetônicas permite acesso aos espaços de uso coletivo, favorecendo às pessoas com deficiência, a sua liberdade.

Necessitamos de novos projetos arquitetônicos, visando mudanças para ampliar o aprendizado dessas pessoas e o convívio social. A acessibilidade, no âmbito escolar, constrói ações que promovam a interação de todos os alunos nos processos de aprendizagem, sendo assim, as necessidades especiais de algumas pessoas, passarão a ser vistas de forma normal, a partir do momento que todos estejam conscientizados desta diversidade humana, buscando uma sociedade mais inclusiva. Segundo Lovato e Zych (2008), a acessibilidade compõe um fator de grande importância para o exercício da cidadania das pessoas com necessidades especiais, contribuindo para sua participação dentro da sociedade. Sendo assim, se faz necessário criar condições para que as pessoas com deficiência possam construir seu espaço e viver com autonomia.

\section{AS DIFICULDADES NO PROCESSO DE INCLUSÃO DE CRIANÇAS ESPECIAIS}

De acordo com Dischinger (2004), a incapacidade de desenvolver alguma atividade não é unicamente o resultado da restrição da função corporal, mas também o da interação das ações corporais e as causas, costumes, práticas e organização do meio em que está inserido. $\mathrm{O}$ aluno pode ter uma deficiência sem sentir-se uma pessoa com 
deficiência, quando o poder público fornece em suas escolas, meios de acesso que garantam a todos o direito de ir e vir na busca de superação, que são alcançados pelos recursos disponíveis, tanto materiais quanto humano. Algumas vezes os alunos estarão vedados de acompanhar as aulas com a regularidade necessária, por motivo de cuidados de saúde que deverão ser priorizados.

Embora conheçamos os limites das terminologias, elas podem nos auxiliar na busca de serviços e recursos que garantam a pessoa com necessidade especial a sua participação na sociedade (MANTOAN, 2004). De acordo com a limitação física de cada um, faz-se necessário utilizar recursos e equipamentos especiais para o seu desenvolvimento educativo, buscando a participação do aluno nas condições práticas vivenciadas no cotidiano escolar, sendo assim, todos transformam o ambiente em busca de uma verdadeira qualidade de vida (BRASIL, 2010).

Para suprir as dificuldades dos portadores de necessidades especiais no âmbito escolar é necessário que os professores especializados, os responsáveis pelo Atendimento Educacional Especializado, abasteçam recursos para acesso ao conhecimento e ambiente escolar, proporcionando ao educando independência na realização de suas tarefas e na reprodução do seu espaço de comunicação e habilidades de seu aprendizado (SCHIRMER et al., 2007).

O Decreto $\mathrm{n}^{\mathrm{o}} 3.298$ de dezembro de 1999 cita os recursos garantidos às pessoas com deficiência e entre eles encontram-se: equipamentos e material pedagógico especial para educação, capacitação e recreação da pessoa com deficiência e outras que ofereçam $\mathrm{o}$ acesso e a melhoria funcional e a autonomia pessoal. $\mathrm{O}$ ensino inclusivo desafia o sistema educacional, a comunidade escolar e toda uma rede de pessoas, que se inserem na mudança de fazer uma educação que assume o tempo presente como uma oportunidade de combater o preconceito em reconhecimento e respeito às diferenças.

A falta de recursos no ambiente escolar implica no processo de desenvolvimento e na construção de conhecimentos das pessoas com necessidades especiais, assim não há subsídio para que desenvolvam o currículo e participem da vida escolar (BRASIL, 2010). Um aluno com deficiência física sente dificuldade de produzir muitas tarefas rotineiras no ambiente escolar, e por isso necessita de ajuda e cuidados de todos que estejam em sua volta, afirmam Schirmer et al. (2007). A inserção de recursos nas escolas implicará no desenvolvimento do processo de descoberta e aquisição de 
conhecimento, pois necessitamos de apoio para que no espaço do atendimento especializado sejam desenvolvidos os recursos e as estratégias favoráveis, no sentido de respeitar a participação do aluno, promovendo o acesso ao conhecimento escolar.

É preciso fazer uso da legislação, para que de fato, nossos ambientes escolares se transformem em ambientes acolhedores e que supram as necessidades das pessoas com deficiência. De acordo com Dischinger et. al. (2004), os ambientes e equipamentos adaptados, possibilitam o uso independente, na medida do possível, por pessoas com habilidades e limitações diferentes. Ao entrar na escola, o aluno com deficiência sente o impacto do desenvolvimento de projetos e estudos que resultam em tratar das incapacidades específicas, servindo para compensar as dificuldades que nos cerca. Segundo Schirmer et. al. (2007) é indispensável um encontro da Tecnologia com a Educação, sendo duas áreas que oferecem a construção do conhecimento, buscando complemento uma na outra.

$\mathrm{Na}$ busca de uma escola inclusiva, podemos introduzir recursos que favoreçam o desempenho dos alunos, sendo o material como fonte inspiradora para tantos outros recursos e alternativas que ainda surgirão (SCHIRMER et. al., 2007). Uma escola inclusiva deve garantir condições, para que as crianças possam ter acesso a todos os ambientes, assim eles terão condições de frequentar a totalidade das aulas. Todos têm direito aos recursos materiais e pedagógicos, desta forma facilita e garante $o$ aprendizado dos conteúdos do currículo escolar. O material escolar e pedagógico adaptado deve despertar no professor e no professor especializado a reflexão e a criatividade, para resolução de possíveis barreiras que interrompem o acesso ao aprendizado

O desenvolvimento de recursos para a aprendizagem dos alunos com deficiência tem como objetivo, estimular as aulas tornando-a mais atraente, significativa e todos se beneficiam. Essas ações promovem atividades para desenvolver o potencial de todos os alunos, sendo assim, as pessoas com necessidades especiais se tornarão protagonistas de sua própria história (SCHIRMER et al., 2007). Devemos conhecer o aluno, sua história, suas dificuldades e desejos e observar quais são as suas necessidades encontradas, que lhe impedem o acesso aos espaços da escola e ao conhecimento.

\section{A ESCOLA COMO ESPAÇO DE PROMOÇÃO NO PROCESSO DE INCLUSÃO}


De acordo com Mello (1978), sabemos que o ambiente escolar influencia o aluno de forma significativa e dá a oportunidade de construir possibilidades, em que todos se sintam reconhecidos, valorizados e respeitados. Sendo a escola um espaço privilegiado pelo compartilhamento do conhecimento, fazendo-se necessário considerar que a aprendizagem é a parte de um processo maior construído na vida cotidiana. A escola possui um papel fundamental no processo de desenvolvimento da vida da criança e do jovem.

Ao entrar no ambiente escolar, todas têm a oportunidade de conviver e de se relacionar com diferentes pessoas, percebendo que todas tem características próprias. Ao ingressar na escola da educação infantil é de fundamental importância, por todos os aspectos físicos, sociais, emocionais e psicológicos, etapa do desenvolvimento, que lhe auxiliará como base para toda a sua vida futura. Em uma escola inclusiva, as crianças aprendem umas com as outras. Crianças sem deficiência aprendem a reconhecer e valorizar as diferenças, sendo assim, essa convivência vai trazer muitas vantagens para seu futuro (STAINBACK; STAINBACK, 1999). É importante que as crianças sintam que podem contribuir para uma mudança e que todas percebam a inclusão nas salas de aula, trabalhando para capacitar todas, na perspectiva de melhorar suas próprias condições de vida.

A escola tem como objetivo ensinar os alunos a entender as desigualdades sociais e capacitá-los para trabalhar ativamente na mudança da sociedade. A escola tem por finalidade respeitar cada criança, com seu jeito próprio de aprender, respeitando, desta forma, seus interesses. Ao desenvolver os planos de ação que fazem parte do Projeto Pedagógico, as escolas se encarregam de assumir o compromisso de oferecer educação de qualidade para todas as crianças, na busca de atender às necessidades específicas dos alunos.

Garantir o processo de ensino às necessidades dos alunos é uma importante ferramenta para o sucesso da aprendizagem. No espaço escolar, o professor especializado vai desenvolver com os alunos as questões relativas às necessidades específicas de aprendizagem, para que todos possam interagir e ter acesso a todos os conteúdos realizados na classe comum. 
Nas escolas inclusivas, os professores são os verdadeiros responsáveis pelo processo de aprendizagem de todos os alunos, sendo a coisa mais do seu filho, na busca de ajudar a superar as dificuldades e aplaudir os progressos. As escolas oferecem diversas oportunidades para a participação dos pais, previstas no Projeto Pedagógico, gratificante que os professores podem fazer é explorar seus próprios conhecimentos e valores sobre a diversidade humana. Pois os pais devem estar presentes e acompanhar o desenvolvimento como Conselho de Escola, Associação de Pais e Mestres e outras.

$\mathrm{Na}$ escola, todas as crianças aprendem a se relacionar e enfrentar desafios do dia a dia, formando seu círculo de amizade. Portanto, todas têm a oportunidade de conversar, trocar ideias, mostrar seus limites e possibilidades, expor seus pontos de vista e expressar seus desejos. Segundo Mantoan (2007), a inclusão é um desafio enfrentado pela escola comum que oferece a melhoria da qualidade da educação, dando oportunidade de empreender alguma coisa nova e imprevista para nós, preparando-as para a tarefa de renovar um mundo melhor.

Assim sendo, a educação especial na escola deve ser encarada como um processo contínuo que terá a inclusão como consequência. A ação pedagógica favorece a todos os alunos o desenvolvimento de conceitos em práticas escolares compatíveis com esse grande desafio, assegurando e dando condições para que todos possam aprender de acordo com o seu ritmo de aprendizagem. Visando um ensino de qualidade e, consequentemente, inclusivo, a escola incentiva e valoriza o professor que é o responsável pela tarefa fundamental da aprendizagem dos alunos.

No espaço escolar, lidar com as diferenças é um desafio constante à fixação das identidades, sendo também, um meio de construir a própria identidade (SCOTT, 1988). Afinal, as escolas existem para formar e gerar novos cidadãos, na busca de mudanças no ensino comum para que possa atender às exigências de uma educação para todos. É nos bancos escolares que aprendemos a conviver com as diferenças, dividindo as responsabilidades e repartindo as tarefas.

O exercício dessas ações gera a cooperação, o sentido de produzir em grupo, o hábito de compartilhar o saber e o reconhecimento da diversidade humana. É necessário enfrentar os desafios da inclusão escolar, sem fugir da nossa realidade, pois é o ensino que coloca o aluno como foco de toda ação educativa, dando-lhe o direito a novas descobertas (MANTOAN, 2007). Uma escola inclusiva garante a igualdade entre alunos 
diferentes, onde todos possam participar e sejam aceitos como membros valiosos delas. Trata-se de uma prática educativa que visa melhorar a aprendizagem de todos em um mesmo ambiente educativo. A educação inclusiva é um processo inacabado que provoca, procurando eliminar as barreiras que impedem uma educação para todos.

Como afirma Mantoan (2007), a escola recomenda um ensino em que aprender é um ato contínuo, resultante de uma rede de relações que vai sendo preparada pelos aprendizes, em ambientes escolares que não discriminam e oferecem oportunidades extraordinárias de sucesso para todos, dentro das capacidades, interesses e possibilidades de cada um. Ainda segundo Mantoan (2007), o ambiente escolar é um espaço que oferece a interação de uns com os outros e que nos motiva a estabelecer comunicação e a perceber a necessidade de se locomover, entre outras aptidões que nos fazem pertencer à espécie humana.

O aprendizado ganha mais sentido quando a criança está inserida em um ambiente compartilhado, que permite o convívio e a interação. Educar significa proporcionar situações de aprendizagens, possibilitando o desenvolvimento máximo de suas ações e que reabilita a importância de criarmos oportunidades de convivências e desafios para o desenvolvimento, na perspectiva de construirmos uma educação inclusiva.

\section{CONSIDERAÇÕES FINAIS}

Neste texto, podemos assimilar que as pessoas com necessidades especiais, em decorrência de diferenças, foram compreendidas e educadas de maneiras diferentes das demais de acordo com os padrões sociais de cada sociedade. Com muito esforço e polêmica, essas pessoas foram conquistando o seu espaço na sociedade e defendendo os seus direitos como cidadãos. Uma dessas conquistas diz respeito ao atendimento escolar em classe comum, sem afastar-se do seu convívio social.

Aprendemos também que a educação inclusiva, busca atingir o ideal de uma escola para todos e é representada como um modelo, desenvolvendo os valores humanos e educacionais. Podemos observar que a escola inclusiva não pode atuar de maneira isolada, sem amparo, sem compartilhar suas dúvidas, suas aflições, seus achados e suas decisões. Pois, a educação inclusiva é responsabilidade da escola como um todo. Temos conhecimento que a escola tem obrigação de respeitar às diferenças, 
desenvolvendo ações formativas que ofereçam a reprodução de conhecimentos teóricopráticos, que venham a contribuir para ajudar os que dela fazem parte.

A escola deve receber profissionais que sejam capazes de lançar decisões, compartilhar hábitos de vida, determinar ações, executar adaptações curriculares, criar estratégias com vistas a dividir a construção do conhecimento pelos educandos em geral, realizando reuniões com as famílias e com a comunidade em geral. É o professor que pode tornar as qualidades possíveis de aprendizagens do aluno, a partir de diferentes ofertas didáticas as quais ele pode estabelecer na produção das práticas pedagógicas.

É importante retratar sobre os desafios do cotidiano escolar, precisamos de um novo olhar para as pessoas com deficiência, pois esta será uma nova forma de exercer as possibilidades de cada um. Promover a inclusão, sugere a mudança de atitudes e de olhar acerca da deficiência na busca de romper as barreiras que impedem a conquista de uma educação de qualidade, a qual facilita o atendimento adaptado e que a permanência seja garantido a todos os alunos, oferecendo sua liberdade, independentemente de suas diferenças e necessidades.

Educando todos os alunos juntos, as pessoas com deficiência tem conveniência de preparar-se para vida na comunidade, tomando decisões conscientes que venham a contribuir para a melhoria da paz social. Sabemos que para construir uma escola inclusiva, faz-se necessário garantir as condições de acesso e permanência no espaço escolar, buscando a eliminação de barreiras que impedem os avanços que possam ser percorridos pelos diferentes caminhos que a vida nos proporciona. A escola inclusiva combate o preconceito e a discriminação, visando construir uma sociedade integradora e uma educação de qualidade e satisfatória para todos.

\section{REFERÊNCIAS}

BOARETO, R. Implementação de políticas municipais de acessibilidade. In: Brasil acessível: programa brasileiro de acessibilidade urbana. Brasília: Secretaria Nacional de Transporte e da Mobilidade Urbana/Ministério das Cidades, 2006.

Mello, S. L. (1978). Psicologia e profissão em São Paulo. São Paulo, Ática.

BRASIL. Constituição Federal. Constituição da República Federativa do Brasil. Brasília: Ministérios das Comunicações, 1988. 
Estatuto da Criança e do Adolescente - ECA. Lei Federal no .8 .069 , de 13 de julho de 1990. Goiânia-Goiás, 2010.

Lei 9394, de 20 de dezembro de 1996. Lei de Diretrizes e Bases da Educação Nacional (LDB), Brasília, DF, 1996.

DISCHINGER, Marta (et al.). Desenho universal nas escolas: acessibilidade na rede municipal de ensino de Florianópolis. SME, Florianópolis: Prelo, 2004.

LOVATO, Jessana e ZYCH, Anísia C. A questão da acessibilidade do educando com deficiência física na escola. In: Revista eletrônica Lato sensu - ano $3^{\circ}, \mathrm{n}^{\circ} 01$, março de 2008.

\section{MANTOAN, M. T. E., FÁVERO E. A. G., PANTOJA L.M.P., Atendimento}

Educacional Especializado: aspectos legais e orientação pedagógica. São Paulo: MEC/SEESP, 2007.

SCHIRMER, Carolina R., BROWNING, Nádia, BERSCH, Rita de C., MACHADO, Rosângela. Deficiência física. São Paulo: MEC/SEESP, 2007.

STAINBACK, S. STAINBACK, W. Inclusão: Um guia para educadores. Trad. Magda França Lopes. Porto Alegre: Artes médicas Sul, 1999.

SCOTT, Joan Wallach: Gender and politics of history. Columbia University Press, N.Y.,1988. O livro é uma coletânea dos ensaios aqui referidos. Tradução de Mariza Corrêa, IFCH/Unicamp. Cadernos Pagu (3) 1994: pp. 11-27.

TRIPP, David. Pesquisa-ação: uma introdução metodológica. Trad.: de Lólio Lourenço de Oliveira.Revista Educação e Pesquisa, São Paulo, v. 31, n. 3, p. 443 - 446, set./dez., 2005. Disponível em: < www.scielo.br >. Acesso em julho de 2012. 


\title{
AS CONSEQUÊNCIAS DA AGRESSIVIDADE FAMILIAR NA EDUCAÇÃO ESCOLAR DOS FILHOS NOS ANOS INICIAIS
}

\author{
MELO, Janelene Rita Teixeira de ${ }^{27}$
}

\section{RESUMO:}

Uma família é um sistema em constante procura de equilíbrio, de uma relação com homeostasia. Mesmo nas famílias em que há situações frequentes de violência, esta adapta a sua estrutura e organização à essa mesma violência. O presente artigo trata de uma pesquisa de campo, com o objetivo de identificar as principais consequências sofridas por alunos em seu processo de ensino-aprendizagem, que possuem histórico de violência familiar. Como referência, utilizamos as obras de autores como: Parke, Cassidy, Burks, Carson e Boyum (1992); Sisto (2005); Azevedo e Guerra (1995); Cecconello e Koller (2000), dentre outros. Analisando os registros do desenvolvimento da criança e suas relações parentais, foram observadas problemáticas relacionadas à desestruturação familiar, a falta ou fragilidade de limites estabelecidos à criança e a própria ansiedade pertinente a determinado contexto vivenciado, tanto na família como na escola, que propicia comportamentos agitados e muitas vezes agressivos. Desta forma, a queixa que aparece no comportamento do aprendente é diagnosticada como sintoma de rebeldia e falta de limites, levando ao problema de comportamento como agressividade.

PALAVRAS-CHAVE: Violência familiar. Anos iniciais. Educação dos filhos.

\section{INTRODUÇÃOO}

Uma família é um sistema em constante procura de equilíbrio, de uma relação com homeostasia. Mesmo nas famílias em que há situações frequentes de violência, esta adapta a sua estrutura e organização à essa mesma violência.

Os papéis que desempenhamos no nosso sistema familiar são fulcrais para o equilíbrio familiar, independentemente da funcionalidade ou bem-estar desta. A comunicação, a afetividade, os papéis de poder e de submissão influenciam a dinâmica familiar e as suas interações.

Isto verifica-se nas famílias com episódios de agressão, tanto física, como verbal. Esta violência, muitas vezes escamoteada, resulta de padrões de comunicação pobre, ligados à submissão, à uma afetividade negativa e à ambientes de intimidação e isolamento. Pode também resultar de crenças culturais que, por exemplo, atribuem aos

\footnotetext{
${ }^{27}$ Mestranda no curso de Ciências da Educação pela Faculdade do Estado do Maranhão (FACEM). Professora da Educação Básica do município de Guamaré/RN. E-mail: janelenerita@gmail.com
} 
pais, direitos e deveres de disciplina que nem sempre eles conseguem fazer cumprir ou conhecem outra forma de o fazer.

Algumas teorias defendem que a violência tem um papel estruturante na família e sem esta violência a família deixa de saber como lidar com os problemas. É contra essa estrutura "disfuncional" que a família tem que lutar e esforçar-se para sair, para modificar, se assim o desejar. Como tal, a família tem que se reestruturar e procurar um novo equilíbrio, com um novo foco, uma nova comunicação, fora da narrativa da agressão.

Há que aproveitar todos os recursos que a família já dispõe, da mesma forma que podemos aproveitar todos aqueles que a família desconhece, de tão enraizada que está a sua identidade agressiva ou submissa. A falta de controle de impulsos, o baixo autoconceito, resultante de uma fraca valorização pessoal, são exemplos de fatores que podem influenciar a dinâmica em famílias em que a agressividade pontua.

Em relação à família, autores como Parke, Cassidy, Burks, Carson e Boyum (1992), encontraram evidências de que crianças adotaram muitos padrões de interação social vividos no contexto da família. Como relatou Sisto (2005), as crianças expostas às interações agressivas com suas mães e entre seus pais tenderam a ser agressivas. Para Azevedo e Guerra (1995), as punições sofridas na infância, aumentaram a probabilidade das vítimas se tornarem futuros agressores de seus familiares. Entretanto, Cecconello e Koller (2000), discutiram que o estilo de punição, ou mesmo de relação familiar, não pôde ser considerado determinístico, pois crianças de famílias problemáticas aprenderam a compensar as circunstâncias familiares adversas.

Com relação ao aspecto da transferência do comportamento, verifica-se variação de acordo com o contexto, já que nem todos que agridem em casa fazem o mesmo na escola, e vice-versa. É possível, porém, generalizar de um contexto para outro, sendo mais provável de casa para a escola do que o inverso (LOEBER \& HAY, 1997).

\section{MÉTODOS}

O método utilizado foi o Estudo de Caso, baseados em sessões psicopedagógicas. Estas sessões foram realizadas durante o Estágio Clínico do Curso de psicopedagogia da UVA, sob a orientação do professor Nery Adamy Neto. O estágio foi realizado na E. M. P. A. T., zona rural-Guamaré, sendo realizadas sessões semanais com 
a criança, com a durabilidade de aproximadamente 50 minutos. As sessões e intervenções realizadas foram redigidas para posterior supervisão.

Para melhor compreensão da criança, a intervenção escolar psicopedagógica analisa os problemas de aprendizagem, mais precisamente, o não aprender pode ter causas diversas, o qual aprisiona a criança impedindo-a de aprender plenamente. $\mathrm{O}$ processo de avaliação psicopedagógica é composto de várias etapas que se distinguem pelo objetivo da investigação fundamentada na reflexão de resultados práticos e de pesquisa.

Para este estudo foi necessário a realização do diagnóstico, que implica no uso de provas e testes, além e outras medidas de técnicas de avaliação, investigação, análise e síntese de dados coletados do caso.

\section{ENTREVISTA FAMILIAR}

Logo, a família foi convocada pela direção a comparecer à instituição para uma entrevista com o psicopedagogo em função de repetidas reclamações feita pela professora da criança, de agressividade em sala de aula, fazendo ameaças à professora e aos colegas (de matar com uma faca).

Os pais relataram que, ao tomar conhecimento das ameaças feitas pela criança ficaram chocados. A mãe disse que não apoiava as atitudes do filho e confessou que castigava a criança com agressões físicas por não admitir esse tipo de comportamento, mas não surtia efeito, pois as reclamações continuavam e não sabia mais o que fazer.

O pai falou que estava muito triste e constrangido com a situação, inclusive naquele momento, por se tratar de uma situação muito grave para uma criança de 8 anos de idade, já não sabia mais como e o que fazer. "Em casa, o comportamento dele não é muito diferente", disse o pai. Ele não obedece a ninguém. Chora, grita e esperneia quando não deixa fazer o que ele quer. A mãe disse que as vezes acaba cedendo por não ter mais força de lutar contra ele. A criança em nenhum momento se pronunciou, estava sempre de cabeça baixa e disse que não queria falar nada.

\section{Entrevista de anamnese}

Entrevista com pais ou responsáveis com objetivo de coletar dados importantes do cliente/paciente que possa me conduzir com clareza na investigação. 
Esse encontro foi realizado somente com a mãe da criança. O pai não veio, porque, segundo a mãe, estava trabalhando.

Tivemos uma conversa simpática, rimos e ela mostrou-se muito descontraída e assim quebramos o gelo. Após a descontração, me apresentei como estudante de psicopedagogia clínica, com o intuito de investigar a queixa referida ao filho J. F.C, feita pela professora S. M. M, e não se mostrou surpresa, me confirmando.

A gravidez não foi planejada pelo casal, pois já tinha uma filha ainda pequena e só iria planejar outra gravidez mais tarde. Quando descobriu a gravidez já ia pro segundo mês e ficou muito apreensiva, nervosa, com medo de contar para o marido. Após duas semanas ela decidiu dar a notícia ao pai da criança e a reação não foi diferente do que ela imaginava. A notícia não foi de bom grado. Mas com o passar dos dias eles acabaram aceitando e contaram para os familiares que receberam a notícia com alegria, mas em nenhum momento pensaram em aborto.

Ela teve muitos enjoos durante toda a gestação, pressão alta e não se alimentava direito, mesmo fazendo acompanhamento médico. Ela passou por algumas internações, uma por dengue e outras por pressão alta.

Seu parto foi natural, porém, prematuro, pois a criança nasceu de sete meses e alguns dias e ficou na incubadora por dois meses. Ela disse que chorou muito com medo de perder o filho, mas o médico achou melhor assim para lhe poupar a vida. Ela relatou que sua maior alegria foi quando o bebê saiu do hospital e o amamentou. A sensação foi indescritível, parecia que era mãe pela primeira vez.

Aos seis meses de idade a criança sofreu uma convulsão por causa de uma febre muito alta, mas não deixou sequelas. Por causa desse incidente, ela confessa que ficou com medo de deixá-lo dormir sozinho e colocava na cama do casal.

Contou que foi muito difícil a separação de quarto aos quatro anos de idade. Ao acordar no meio da noite, chorava muito até que voltava para a cama dos pais e assim perdurou por mais de um ano. Já superado aos seis anos de idade, ao contrário da chupeta e da mamadeira, que até o presente momento não conseguiu largar. E mamou até três anos, logo que foi para a pré-escola.

Também não foi fácil a sua adaptação à escola e a falta do mamar. Todos os dias a professora fazia o relato do choro e da resistência dele ao entrar na sala de aula. Batia 
nos armários, jogava objetos, mordia a professora e não participava das brincadeiras, só aos poucos ele começou a interagir com os colegas meio tímido e ressabiado.

Segundo o depoimento da mãe, a criança tem sono tranquilo e dorme no quarto com a irmã mais velha. No seu desenvolvimento psicomotor, a criança engatinhou aos seis meses com a barriga no chão e começou a dar os primeiros passinhos aos onze meses.

Quanto ao comportamento, ela me relata que J. F. C não gosta de obedecer a regras, dizendo que ele faz sempre o que quer e na hora que quer. Se ela se opõe, ele chora, grita, chuta e bate nela. Não tem rotina e quando coloca ele de castigo, não fica. O pai trabalha o dia todo e quase não participa do cotidiano da criança. Não costumam brincar com o filho e dificilmente saem para passear com ele.

\section{Visita escolar}

Ao visitar a Escola M. P. A. T, o psicopedagogo apresentou a proposta de investigar dificuldades de aprendizagem no ambiente escolar. Sendo assim, a direção fez relatos de problemáticas variáveis, sendo a agressividade, a que mais prejudica a aprendizagem das crianças na sala de aula.

Ao observar salas de $1^{\circ}$ ao $3^{\circ}$ ano dos anos iniciais no turno matutino, é notório que crianças de 6 a 9 anos de idade apresentam pouco interesse na aprendizagem, dando lugar às conversas paralelas, gritos, palavrões, xingamentos e até mesmo à agressividade. Muitas vezes a professora interrompe a aula, por não ter condição de conduzi-la pelas variáveis causas, começando com o bullyng gerando a agressividade.

O intervalo também não é diferente. As crianças se apropriam das mesmas práticas irregulares praticadas em sala de aula. Apresentam resistência em obedecer às regras e os limites impostos pelas coordenadoras de turno.

\section{Entrevista operativa centrada na aprendizagem (E.O.C.A)}

$\mathrm{Na}$ primeira sessão, foi elaborada para a criança, uma entrevista centrada na aprendizagem, para descobrir o vínculo que ela teria com a aprendizagem. Arrumei sobre a mesa uma caixa com, tampa contendo os seguintes materiais: papel sulfite (branco e colorido), folha pautada, lápis de cor (fechado), tesoura, canetas hidrocor, 
lápis (sem ponta), apontador, borracha, gibi, revista de vídeo game, alfabeto móvel e um dominó (de figuras e palavras).

Enquanto conversávamos, a criança não apresentou curiosidade, não expressou nenhuma reação diante do objeto exposto em sua frente. Foi necessário que lhe instigasse a abrir a caixa e mesmo assim ele resistiu a princípio, demonstrando total desinteresse em abri-la. Insisti mais um pouco e assim ele tirou a tampa, mas nem olhou para o material. Disse para ele que aquele material era para ele usar e mostrar o que ele sabia fazer, o que lhe tinham ensinado e o que tinha aprendido na escola, mas não arriscou fazer algo. Com muito insistência, ele pegou nos materiais, mas nada além disso.

\section{Sessões lúdicas centradas na aprendizagem (para crianças)}

Ao experimentar o lúdico nas sessões, pude observar que a criança demonstrou um potencial significativo do que vinha apresentando anteriormente.

No jogo pega varetas, pude observar além da motricidade fina, vários aspectos lógico-matemático. Vi como lidava com o sucesso e o fracasso, com o cumprimento de regras e mais uma vez, a rejeição em escrever o placar do jogo.

Experimentando a "Hora do Jogo", de diferentes formas, com facilidade eu obtinha dados sobre aspectos afetivos gerais da aprendizagem da criança. Assim, observei que a criança ficava mais espontânea e se revelava com mais facilidade, e pude perceber a total rejeição aos objetos de aprendizagem escolar. .A partir dessas experiências, passei a adotar, sistematicamente, o uso desta forma de sessão, obtendo sempre resultado satisfatório.

É notável a disponibilidade da criança para o jogo e o brincar. Mostrei para ela um livro, contendo histórias e quebra-cabeças com os personagens da história. Após ler o texto em voz alta para a criança, que me ouviu atentamente, coloquei o jogo na mesa e ela demonstrou felicidade e prazer ao montar com sucesso o quebra-cabeça, verificando a relação que a criança faz com semelhança e diferença do objeto manipulado.

\section{Provas e testes}


Neste estudo, foram aplicadas as técnicas projetivas para descobrir o vínculo que a criança estabelecia com a escola, a família e consigo mesmo, e as provas operatórias para conhecer o funcionamento e o desenvolvimento das funções lógicas da criança.

$\mathrm{Na}$ aplicação das técnicas projetivas que estabelece os vínculos escolares, a criança manifestou uma rejeição muito significativa à sala de aula, ao desenhar a sua sala sem incluí-lo na mesma. Ao ser questionado, ele mencionou que neste dia não estava presente, somente seus colegas e a professora, pois não estava presente todos os dias na escola por não gostar dela. Com os aspectos, consigo mesmo, ela relaciona lutas às brincadeiras, uma conduta social duvidosa que não expressa afeto ao outro.

Nos vínculos familiares, a criança expressa uma jornada sem rotina de cunho estabelecida pela família. Nos desenhos, a criança expressa muita liberdade por si mesmo, sem qualquer orientação dos pais, ou seja, sem uma rotina a seguir. Nestes vínculos é notável a desestruturação na elaboração com a aprendizagem da criança.

Nas provas operacionais de conservação, a criança está avaliada no nível 2 por apresentar oscilação nas respostas, pois ora conserva, ora não conserva.

Ainda foi aplicado o teste de instrumento de avaliação do repertório básico para a alfabetização (I. A. R), instrumento de auxílio envolvendo habilidades e conceitos considerados fundamentais para a alfabetização. Dentre essas, atividades envolvendo conceitos matemáticos de lateralidade. Além disso, a criança não expressa conceitos básicos, processo este, que deveria estar consolidado.

De acordo com Condemarin et al. (1989, p. 72), “a lateralidade na criança se tornar mais evidente pela diferenciação de lado esquerdo e direito, a partir dos 6 a 8 anos de idade".

\section{Síntese diagnóstica}

De posse das informações, através da anamnese feita com a mãe do aprendente e com a professora, a partir deste ponto estabeleci um diagnóstico de intervenção psicopedagógica com o aprendente, fazendo assim, uso das hipóteses que me conduziram à identificação das causas das dificuldades de aprendizagem apresentadas pelo o aprendente em estudo. 
Pois, a história do aprendente estará sempre relacionada com a da família, mais especificamente, com as representações e significações presentes nas suas interações familiares.

Após os dados colhidos, percebe-se que o aprendente demonstra sentimento de tristeza, conflito interno, que resulta na dificuldade de concentração como no relacionamento ensinante e aprendente. Sua idade cronológica é coerente com sua idade mental. Percebe-se um forte abalo emocional por parte do aprendente.

Em relação a si: Insegurança, medo, autoestima baixo, desequilíbrio emocional, desajuste de afetividade, conflito interno e insatisfação. Em relação à família: Insatisfação e sentimento de inadequação no contexto familiar. Em relação à Escola: Imaturidade cognitiva, medo do novo, autoestima baixa. Em relação ao social: às vezes apresenta oscilação de humor.

Diante disso tudo, a hipótese levantada durante as sessões psicopedagógicas com o aprendente é que a criança se encontra bloqueada por problemas emocionais, carregada de vínculos negativo que, consequentemente, estão interferindo negativamente na sua atenção para aprendizagem, desautorizando-a de ser mais criativa e de construir sua autoria de pensamento.

O aprendente não apresenta nenhum problema de inteligência, é motivado pela professora para aprender a ler, mas, no momento, passa por problemas emocionais, o que sugere tratar-se de um problema de aprendizagem-sintoma, uma vez que existem causas ligadas à sua estrutura individual e familiar, comprometendo a dinâmica de articulação entre a inteligência, o desejo, o organismo e o corpo.

\section{Entrevista de devolução}

O embasamento para a realização desta devolutiva à escola foram às observações e as anotações realizadas durante o período destinado às sessões de atendimento psicopedagógico. Concluí que, o aprendente sofre de questões de cunho afetivo e social, pois em todas as atividades propostas se referiu à família com pouco apreço e que está compatível com o nível de desenvolvimento para sua faixa etária préoperatória (7 anos). Em relação à leitura e à escrita, encontra-se no nível pré-silábico. Nas atividades realizadas, ele fez registros diferentes entre palavras, modificando a 
quantidade e a posição e fazendo variação nos caracteres, podendo conhecer ou não os sons de algumas letras ou de todas elas.

Para a reconstrução de suas hipóteses, quanto escrita e leitura, recomendo a exploração dos conhecimentos já atingidos, com elogios, parabenizá-lo por suas realizações e incentivá-lo a tentar fazer de formas diferentes. O emprego do lúdico nesta etapa da vida é de grande utilidade, pois as crianças nessa faixa etária fazem associações entre o imaginário e o real, então, jogo de adivinhações, alfabeto móvel, recorte, música, dramatizações, fantoches, entre outras atividades, farão com que se divertindo, ele possa aprender e que tal aprendizagem seja de fato significativa, para que desta maneira, ele próprio construa o seu conhecimento.

Sugiro à professora, atividades pedagógicas em que as crianças utilizem o imaginário e o lúdico para o desenvolvimento cognitivo (jogos, alfabeto móvel, recortes, música, dramatizações, fantoches). Um espaço onde o lúdico predomine e que de forma diferenciada, ele possa realizar atividades que venham a desenvolver os seus conhecimentos, fazer como ele possa adquirir outras, participando efetivamente desta construção.

Para o desenvolvimento físico, sugiro o trabalho multidisciplinar na realização das atividades físicas: natação, dança e música, a fim de melhorar a concentração e tranquilidade disciplinar para sua eficaz realização. Em centros públicos, como Polo Esportivo, existe atendimento gratuito para a população.

\section{APRESENTAÇÃO DO SUJEITO}

O aprendente J. F. C. é do sexo masculino, de 7 anos de idade, filho mais novo de três irmãos, nascido em 12/04/2007, filho de M. A. C., com profissão doméstica e de J. L. S. C., com profissão de porteiro. A criança estuda na rede municipal, zona rural de Guamaré/RN, cursando o $2^{\circ}$ ano dos anos iniciais.

Deu início ao tratamento terapêutico no dia 19 de novembro de 2013 com término no dia 26 de março de 2014, acompanhado pela responsável (mãe).

Indicado pela instituição, com problemas de aprendizagem e por apresentar sinais de agressividade. A queixa apresentada ao psicopedagogo partiu da instituição do aprendente, com problemas acentuada na aprendizagem. Essa solicitação foi feita com a 
finalidade de obter dados relevantes que possam levar à identificação da origem da dificuldade que o aluno está apresentando.

Segundo a professora, o aluno não apresenta desejo de aprender, desempenhando um papel escolar inadequado aos conhecimentos adquiridos de acordo com a sua idade e sua interação social, seguindo uma postura expressiva de agressividade, comprometendo assim, sua aprendizagem.

\section{CONCLUSÃO}

A pesquisa realizada demonstrou que a escola procura atendimento clínico devido à queixa de comportamentos inadequados dos aprendentes em diferentes ambientes, ou seja, em casa, na escola e na comunidade.

$\mathrm{O}$ aluno com 7 anos e nove meses de idade, cursando o $2^{\circ}$ ano dos anos iniciais, após se sentir acolhido e estimulado pelo psicopedagogo, apresentou-se nos diversos momentos da avaliação com tranquilidade, humor estável e uma postura afetivo triste. Interagiu bem, com naturalidade, através do contato de olhos inconstante, e em alguns momentos de seus relatos da vida diária, um pouco de tensão e ansiedade.

Durante as atividades, o aprendente manteve uma atividade motora, com poucos movimentos físicos, pouca gesticulação, expressão facial triste, pouca alteração na expressividade. $\mathrm{O}$ aluno apresentou uma sensação de inacessibilidade à realidade de seus posicionamentos e sentimentos em relação à família, evidenciando sentir-se "estigmatizado", pela mesma, associando esta evidência ao relato da mãe.

O aluno evidencia estar bem fisicamente, estatura normal para sua idade, apresentou-se com os cabelos bem cortados à moda atual dos garotos da sua idade, uniforme limpo, demonstrando cultivar bons hábitos e cuidados com a higiene.

A queixa investigada no caso evidencia dificuldades no contexto da aprendizagem e de condutas antissociais, como sendo decorrentes de um contexto inadequado. Verificou-se assim, que a queixa da instituição, que a princípio poderia representar um transtorno, tinha a causalidade relacionada a outros fatores do ambiente familiar.

Analisando os registros do desenvolvimento da criança e suas relações parentais, foram observadas problemáticas relacionadas à desestruturação familiar, à falta ou fragilidade de limites estabelecidos à criança e a própria ansiedade pertinente a 
determinado contexto vivenciado, tanto na família como na escola, que propicia comportamentos agitados e muitas vezes agressivos. Desta forma, a queixa que aparece no comportamento do aprendente é diagnosticada como sintoma de rebeldia, falta de limites, levando ao problema de comportamento como agressividade.

A pesquisa realizada busca à eficácia de procedimentos interventivos, educacionais e psicológicos, para a criança e família, e recursos mais precisos de diagnóstico. Os resultados obtidos na análise sobre a queixa da criança, encaminhada pela instituição como agressiva, atestaram o grau elevado de informações imprecisas e contraditórias sobre o aprendente, tanto do professor que tem o aluno em sala de aula diariamente, quanto dos pais da criança com o comportamento tão diferenciado.

É importante que pais, professores, psicólogos e demais profissionais da Saúde e Educação, busquem maior compreensão dos aspectos do desenvolvimento afetivo e cognitivo da criança, para contribuir na melhoria da qualidade de vida da criança. Para isso, há necessidade de formação de profissionais, voltados às informações básicas de identificação dos transtornos comportamentais, suficientes para possibilitar o entendimento da condição e minimizar os efeitos negativos de um diagnóstico equivocado na aprendizagem.

\section{REFERÊNCIAS}

AZEVEDO, M. A.; Guerra, V. Violência doméstica na infância e na adolescência. São Paulo: Robe, 1995.

CECCONELlO, A. M.; KOLLER, S. H. Competência social e empatia: um estudo sobre resiliência com crianças em situação de pobreza. Estudos de Psicologia, 2000.

CONDEMARIN, M. et al. Maturidade Escolar: manual de avaliação e desenvolvimento das funções básicas para a aprendizagem escolar. Porto Alegre: Artemed, 1989.

LOEBER, R.; HAY, D. F. Development of aggression. Annual Review of Psychology, 1997.

PARKE, R. D., et. al. Familial contribution to peer competence among young children: The role of interactive and affective processes. Em R.D. Parke \& G. W. Ladd (Orgs.), Family-peer relationships: Modes of linkages (pp.86-95). Hillsdale, NJ: Erlbaum, 1992. 
SISTO, F. F. Aceitação-rejeição para estudar a agressividade nas escolas. Psicologia e Estudos, 2005, 10(1), 117-125. 


\title{
AS INTERVENÇÕES PSICOPEDAGÓGICAS PARA A SUPERAÇÃO DAS DIFICULDADES DE APRENDIZAGEM NAS SÉRIES INICIAIS
}

\author{
VALE, Francisca Antonia de Souza ${ }^{28}$
}

\section{RESUMO:}

Atualmente, os alunos constituem cerca de metade da população estudantil com necessidades educativas especiais. $\mathrm{O}$ educador deve utilizar os materiais adequados, para que o aluno não encontre dificuldades de aprendizagem na leitura, afinal, a leitura é a base da realização do objetivo do educando. Trata-se aqui não de uma análise sobre os "déficits", mas de uma reflexão textual das dificuldades de aprendizagem apresentadas pelos alunos, que necessariamente não se encontram definidas como sendo aqueles que possuem necessidades educacionais especiais, mas que precisam vivenciar a inclusão escolar e social. A pesquisa buscou identificar por que uns alunos aprendem com tamanha facilidade sobre determinado assunto, enquanto outros não compreendem, ou avançam lentamente. $O$ presente artigo aborda esta temática, percebendo a aprendizagem enquanto processo e produto inacabado e diferentemente desenvolvido. Discorre sobre os estudos conceituais da aprendizagem e as principais dificuldades que os alunos têm apresentado na efetivação de sua construção do saber escolar. Teve como objetivo, descrever como o processo de aprendizagem se efetiva; e identificar as principais dificuldades de aprendizagem apresentadas nas escolas brasileiras entre os alunos das séries iniciais do Ensino Fundamental, tendo em vista relacioná-las às sugestões de práticas favoráveis às superações cognitivas, segundo estudos da Psicopedagogia e da Pedagogia aplicada.

PALAVRAS-CHAVE: Dificuldades de aprendizagem. Anos iniciais. Ensinoaprendizagem.

\section{INTRODUÇÃO}

Desde que surgiu o ensino até hoje, sabe-se que grande parte dos alunos apresenta dificuldades na aprendizagem e estas começam desde a pré-escola e se arrastam pelas séries iniciais. É na primeira infância que se assentam as bases para o desenvolvimento da inteligência da criança. Estas dificuldades podem estar relacionadas à uma série de fatores. Um deles é o método de ensino utilizado pelas escolas ou pelo professor, outro fator é a falta de motivação dos alunos em sala de aprendizagem por parte dos professores.

\footnotetext{
${ }^{28}$ Especialista em Psicopedagogia Clínica e Institucional pelo Instituto de Educação de Pesqueira/PE. Professora Auxiliar de Educação Especial no município de Guamaré/RN. E-mail: antonniavalle@hotmail.com
} 
Vários autores, como Sara Pain (1992), Alicia Fernandez (2001) e Maria Lucia Weiss (2004), chamaram atenção para o fato de que o maior percentual de fracasso na produção escolar, de crianças encaminhadas a consultório e clínicas, encontra-se no âmbito do problema de aprendizagem reativos, produzido e incrementado pelo próprio ambiente escolar (WEISS; CRUZ, 1999, p. 46).

Segundo Piaget (1974), a aprendizagem é um processo de desenvolvimento intelectual, que se dá por meio das estruturas de pensamento e está estritamente relacionada à ação do sujeito sobre o meio, partindo do princípio de interação de Vygotsky, e acontece em etapas: assimilação, acomodação e equilibração.

As Dificuldades de Aprendizagem - DA, são desordens neurológicas que interferem com a recepção, integração ou expressão de informação, caracterizando-se em geral, por uma discrepância acentuada entre o potencial estimado do aluno e a sua realização escolar. Numa perspectiva educacional, as DA refletem uma incapacidade ou impedimento para a aprendizagem da leitura, da escrita, ou do cálculo ou para a aquisição de aptidões sociais.

Isto quer dizer que os alunos com DA podem apresentar problemas na resolução de algumas tarefas escolares e serem "brilhantes" na resolução de outras. Quer dizer ainda que, em termo de inteligência, estes alunos geralmente estão na média ou acima da média.

O termo Dificuldades de Aprendizagem apareceu-nos em 1962 com o fim de situar esta problemática num contexto educacional, tentando assim, retirar-lhe o “estigma clínico" que o caracterizava. Surge, então, uma definição proposta por Kirk (1962), em que era bem evidente a ênfase dada ao componente educacional e o distanciamento, em termos biológicos e de outras problemáticas, tal como deficiência mental, privação sensorial, privação cultural, entre outras.

Uma entre outra definição de nota foi a proposta por Barbosa Bateman (1965), que veio a constituir-se num marco histórico, dado que englobava três fatores importantes que a caracterizavam: discrepância (criança com DA é considerada como possuindo um potencial intelectual acima da sua realização escolar); irrelevância da disfunção do sistema nervoso central (para a determinação dos problemas educacionais da criança, não era essencial evidenciar uma possível lesão cerebral); e exclusão (as DA 
das crianças não eram devidas, visual ou auditiva ou a privação educacional ou cultural).

Estas duas definições viriam a constituir a base fundamental para as definições atuais de DA, das quais vamos destacar duas pelas importâncias que, hoje em dia, lhes são atribuídas. A primeira, é aquela que parece ser a mais aceita internacionalmente, é a que figura na Public Law 94-142, hoje denominada Individuals with Disabilities Education Act (IDEA - Lei de Educação para pessoas com Deficiência).

Num ou mais dos processos básicos envolvidos na compreensão ou utilização da linguagem falada ou escrita, que pode manifestar-se por uma aptidão imperfeita de escutar, pensar, ler, escrever, soletrar, ou fazer cálculos Matemáticos. O termo inclui condições como problemas perceptivos, lesões Cerebral, disfunção cerebral mínima, dislexia e afasia de desenvolvimento. O Termo não engloba as crianças que têm problemas de aprendizagem resultantes principalmente de deficiência visuais, auditivas ou motoras, de deficiência Mental, de perturbação emocional ou de desvantagens ambientais, culturais ou econômicas. (CORREIA, 1991 apud FEDERAL REGISTER, 1977, p. 65083).

Diversos autores, a partir de suas pesquisas, procuram esclarecer os pontos divergentes na literatura em relação às alterações na aprendizagem escolar e, por conta dos seus enfoques (pedagógicos ou clínicos), têm-se as variações na conceituação e caracterização deles no processo de ensino-aprendizagem.

Para Fonseca (1995), a criança com dificuldades de aprendizagem não deve ser "classificada" como deficiente. Trata-se de uma criança normal, que aprende de uma forma diferente, a qual apresenta uma discrepância entre o potencial atual e o potencial esperado. Não pertence a nenhuma categoria de deficiência, não sendo sequer uma deficiência mental, pois possui um potencial cognitivo que não é realizado em turmas de aproveitamento educacional.

O risco está em não se detectar esses casos, não se proporcionando no momento propício às intervenções pedagógicas preventivas, nos períodos de maturação mais plásticos. Se não se detectarem esses casos, a escola com seu critério seletivo de rendimento pode influenciar e reforçar a inadaptação, culminando muitas vezes, mais no atraso mental, na delinquência ou em sociopatias.

No livro "Diagnóstico e Tratamento dos Problemas de Aprendizagem” (lançado no Brasil pela Artmed, em 1985), Pain oferece importantes contribuições aos 
psicopedagogos e professores. Ao conceituar o problema como um sintoma que não se configura em um quadro permanente, a autora enumera quatro grupos de fatores que precisam ser levados em consideração no diagnóstico: orgânico, ligados ao desenvolvimento geral da criança e sua qualidade de vida; específicos, relacionados aos transtornos na área da adequação perceptivo-motora; psicogênese, que se constitui como inibição e defesa; e ambientais, vinculados ao acesso do sujeito ao saber elaborado (científico) em seu meio.

Segundo Chalita (2001, p. 27) "a alfabetização tem de ser acompanhada pela família. os primeiros escritos, o incentivo á leitura, os brinquedos pedagógicos". Tudo isso precisa ter significado para a criança. Assim, o papel dos pais é de estimular e propiciar momentos de cumplicidade, de amor e carinho para a formação da criança.

Em 1989, Sara Pain escreveu que o professor precisa estimular o aluno à participação e ter tolerância em períodos necessários de ensaio e confusão, e aceitar comportamentos transtornos, alfabetização, para ela, deve ser um momento de alegria e, em grande parte, cabe ao professor propiciar esse ambiente na sala de aula.

Para Strick e Smith (2001), as dificuldades de aprendizagem referem-se não a um único distúrbio, mas a uma ampla gama de problemas que podem afetar qualquer área do desempenho acadêmico. As dificuldades são definidas como problemas que interferem no domínio de habilidades escolares básicas, e elas só podem ser formalmente identificada até que uma criança comece a ter problemas na escola.

As crianças com dificuldades de aprendizagem são crianças suficientemente inteligentes, mas enfrentam muitos obstáculos na escola. São curiosos e querem aprender, mas sua inquietação e incapacidade de prestar atenção tornam difícil explicar qualquer coisa a eles. Essas crianças têm boas intenções, no que se refere aos deveres e tarefa de casa, mas no meio do trabalho esquecem as instruções ou os objetivos. As dificuldades de aprendizagem devem ser diagnosticadas de forma diferente em relação a outros transtornos próximos, ainda que, frente à presença em uma pessoa de uma dificuldade de aprendizagem e de outros, seja necessário classificar ambos os transtornos, sabendo que se trata de dois transtornos diferentes.

Ramozzi-Chiarottino (1994, p. 83), que realiza pesquisas nesse enfoque, explica:

Depois de vários anos de observação do comportamento da criança em situação natural, chegamos à conclusão de que os distúrbios de aprendizagem são determinados 
por deficiências no aspecto endógeno do processo da cognição e de que a natureza de tais deficiências depende do meio no qual a criança vive e de suas possibilidades de ação neste meio, ou seja, depende das trocas do organismo com o meio, num período crítico de zero a sete anos.

Para Fonseca (1995), as dificuldades de aprendizagem aumentam na presença de escolas superlotadas e mal equipadas, carentes de materiais didáticos inovadores, além de frequentemente contarem com muitos professores "derrotados" e "desmotivados". A escola não pode continuar a ser uma fábrica de insucessos. Na escola, a criança deve ser amada, pois só assim, se poderá considerar útil.

Portanto, só porque uma determinada criança tem problemas para assimilar um determinado conteúdo, isso não significa que ela tenha um QI baixo, ou que não venha a aprender outros conteúdos. O que nós professores precisamos é descobrir meios para poder estar ajudando a essas crianças superarem seus anseios e suas dificuldades com novos métodos para que a aprendizagem ocorra num contexto significativo.

\section{COMO SUPERAR?}

A aprendizagem é um processo amplo que envolve diversos fatores relacionados ao sujeito e às relações deste com o meio. O não aprender deve ser analisado de forma ampla, buscando compreender o contexto em que o sujeito está inserido, bem como a situação em que se explicitou a dificuldade de aprendizagem.

O principal desafio que tem os pais, professores e profissionais que trabalham com crianças que apresentam dificuldades é ajudá-las a adquirir confiança em si mesmas, a acreditar nas suas capacidades. Eles devem saber que as pessoas aprendem de diferentes modos e que sua energia pode ser encaminhada para encontrar estratégias adequadas para a aprendizagem, ao invés de procurar maneiras de esconder suas dificuldades.

Conforme Castaño (2003), o termo Dificuldade de Aprendizagem pode ser caracterizado por alterações no processo de aprendizagem da leitura, escrita e raciocínio logico-matemático, podendo estar associadas ou não a comprometimentos da linguagem oral.

Já para França (1996), a distinção feita entre os termos dificuldades e distúrbios de aprendizagem está baseada na concepção de que o termo "dificuldade" está 
relacionado a problemas de ordem pedagógica e/ou sócio-culturais, logo, o problema não esta centrado apenas no aluno, sendo que essa visão é mais frequente utilizada em uma perspectiva. Por outro lado, o termo "distúrbio" está vinculado ao aluno que sugere a existência de comprometimento neurológico em funções corticais específicas, sendo mais utilizado pela perspectiva clínica ou remediativa.

Zorzi (2003) relata que, crianças que não tenham apresentados quaisquer dificuldades no desenvolvimento da linguagem oral, podem vir a apresentar dificuldades específicas de alfabetização, manifestando-se em termos de alterações de leituras, assim como, de escrita, são características nesse caso.

Conforme a International Dislexia Association - AID (1994), a dislexia é um distúrbio de linguagem, de origem constitucional, caracterizado pela dificuldade em decodificar palavras simples. Mostra uma insuficiência no processo fonológico, sendo que essas dificuldades em decodificar palavras simples não são esperadas para a idade. Apesar da instrução convencional, adequada, inteligência, oportunidade sócio-cultural e ausência de distúrbios cognitivos e sensoriais, a criança falha no processo de aquisição dos problemas da linguagem com frequência, incluídos os problemas de leitura, aquisição e capacidade de soletrar. Aprendizagem da leitura apesar de ter um desenvolvimento intelectual adequado para esse processo (AID, 2002).

A criança com dislexia tem por si só uma autoestima baixa, portanto, ela necessita de ajuda de profissionais capacitados para ajudá-la a se superar os poucos ou logo haverá evasão escolar. Sendo assim, cabe à escola e ao professor mediar esse conhecimento; ciente que a dislexia tem vários níveis e grupos cada um tendo sua especificidade deverá receber o devido tratamento sugerido por um especialista, como por exemplo, psicólogo ou fonoaudiólogo.

A Escola torna um ambiente aversivo e gerador de ansiedade, pois é nesse local que a criança se depara frente a frente com seus problemas e com as exigências de ter uma boa produção para poder passar de ano (MORAES, 1992, p. 88).

Martins (1975) classifica-as como dislexia com alteração primária da linguagem, dislexia com transtorno articulatório grafo motor e dislexia com transtorno viso perceptivo. 
Derdyk (1989, p.73) observa que a ação criadora que envolve o jogo possibilita uma série de relação que por vezes não conseguimos aglutinar em outras atividades convencionais da sala de aula. O mesmo ainda afirma que o lúdico é um mecanismo estratégico de desenvolvimento da aprendizagem, pois propicia o envolvimento do sujeito apresentada e possibilita a apropriação significativa do conhecimento.

O desafio principal que os pais, professores e profissionais que trabalham com crianças com dificuldades tem é ajudá-las a aumentar a confiança em si mesmas, a acreditar nas suas capacidades. Devem saber que as pessoas aprendem de maneiras diferentes e que sua energia pode ser encaminhada para encontrar estratégias adequadas para sua aprendizagem, ao invés de buscar formas de esconder suas dificuldades.

Por isso, os pais, professores e profissionais que trabalham com essas crianças têm uma grande responsabilidade. Suas habilidades de observação, detecção de problemas, saber como dar um feedback e definir como e quando intervir são de suma importância. Estas crianças precisam de um ambiente seguro, estimulante, onde os erros sejam permitidos e assumir riscos sejam incentivados. Quando sente que aprender é uma experiência excitante, podendo sentir prazer, então isso se transformará em algo que nunca termina, durará a vida toda.

Cabe salientar que, de acordo com Rotta, Ohlwller e Riesgo (2006, p. 27), “os transtornos de aprendizagem compreendem uma inabilidade específica, como de leitura, escrita ou matemática, em indivíduos que apresentam resultados significativamente abaixo do esperado para seu nível de desenvolvimento, escolaridade e capacidade intelectual"'.

O termo "transtorno" é usado por toda a classificação, de forma a evitar problemas ainda maiores inerentes ao uso de termos tais como "doença" ou "enfermidade". "Transtorno" não é um termo exato, porém é usado para indicar a existência de um conjunto de sintomas ou comportamentos clinicamente reconhecível associado, na maioria dos casos, a sofrimento e interferência com funções pessoais (BRASIL, 1996, p. 5).

O futuro destas criança está nas mãos das pessoas que estão ao seu lado na aprendizagem. A confiança em si mesmas, a capacidade de tomar decisões, a habilidade para resolver problemas, a motivação para atingir objetivos dependerá da forma como elas forem apoiadas. Não existe uma receita única. Cada criança é um ser humano único 
e importante. Respeitar a individualidade, aceitar diferentes formas de pensar, de sentir, de agir e de aprender é um ponto básico na educação destas crianças.

Partindo desse pressuposto, cabe pensar o modo que estão estabelecidos os ambientes de aprendizagem. Estão vinculados aos interesses dos alunos e propiciam interação entre sujeito aprendente e objeto de aprendizagem? A aprendizagem parte das experiências reais e possibilita a apropriação do conhecimento? Talvez a resposta a essas indagações não esteja conseguindo estabelecer uma metodologia que atenda a diversidade existente no mundo atual.

Embora as dificuldades de aprendizagem tenham se tornado o foco de pesquisas mais intensas nos últimos anos, elas ainda são pouco entendidas pelo público em geral. As informações abundantes até mesmo entre professores e outros profissionais da Educação. Não é difícil entender a confusão. Para começo de conversa, o termo dificuldades de aprendizagem refere-se não a um único distúrbio, mas a uma ampla gama de problemas que podem afetar qualquer área do desempenho acadêmico.

Fernandez (2001) fala de um enfoque clínico, que significa preocupa-se com os processos inconscientes e não somente com a patologia. É fazer uma escuta particular do sujeito, que possibilita não só encontrar as causas do não aprendizado, mas também organizar metodologias para facilitar o aprendizado e o desempenho escolar. É importante que o ensinamento introduza o conhecimento ao aprendiz de forma prazerosa através do lúdico e de forma inconsciente o brincar vai criando vínculo como conhecimento.

Na hipótese apresentada por Pinheiro (2004, p. 143), a superação é atrelada às possibilidades de que o processo de Ensino-aprendizagem esteja "voltado para a singularidade dos processos de aprendizagem do aluno". Campos (2005), ao apresentar as considerações finais de seu trabalho, levanta questionamentos:

Por que alguns alunos conseguem superar, enquanto outros não? Por que alguns que passam pela mesma experiência de vida, ou seja, são oriundos de famílias desestruturadas, alcoólatras, pobres, são submetidos á mesma falta de estruturas físicas e operacional da escola, como como também submetidos aos cuidados de professores mal preparados, conseguem superar seus fracassos acadêmicos, enquanto, outros não? E, às vezes, isto acontece em uma mesma turma. Por que? Como resposta vale pensar que os sentidos produzidos ao longo da história de vida promovem distintas configurações personológicas única e individualizadas. (CAMPOS, 2005, p. 104) 
Diante do que vimos, podemos chegar a um pensamento que a escola tem uma tarefa relevante no resgate da autoestima distorcida da criança, por ter uma concepção socialmente transmissora de educação e de cultura, que transcende as habilidades educacionais familiares, além das responsabilidades e competências em desvendar para a criança o significado e o sentido do aprender. A escola precisa encontrar caminhos junto à família e à sociedade, contando com a atuação, também de profissionais especiais.

\section{COMO A PSICOPEDAgOGIA PODE INTERVIR NA SUPERAÇÃO DAS DIFICULDADES?}

Para o psicopedagogo, a experiência de intervenção junto ao professor, num processo de parceria, possibilita uma aprendizagem muito importante e enriquecedora, principalmente se os professores forem especialistas nas suas disciplinas. Não só a sua intervenção junto ao professor é positiva, também a sua participação em reuniões de pais, esclarecendo o desenvolvimento dos filhos, em conselhos de classe, avaliando o processo metodológico na escola como um todo, acompanhando a relação professor e aluno, aluno e aluno, aluno que vem de outra escola, sugerindo atividades, buscando estratégias e apoio.

Segundo Bossa, (2011, p. 23).

[...] cabe ao psicopedagogo perceber eventuais perturbações no processo aprendizagem, participar da dinâmica da comunidade educativa, favorecendo a integração, promovendo orientações metodológicas de acordo com as características e particularidades dos indivíduos do grupo, realizando processos de orientação. Já que no caráter assistencial, o psicopedagogo participa de equipes responsáveis pela elaboração de planos e projetos no contexto teórico/prático das políticas educacionais, fazendo com que os professores, diretores e coordenadores possam repensar o papel da escola frente a sua docência $\mathrm{e}$ as necessidades individuais de aprendizagem da criança ou, da própria 'ensinarem. O conhecimento e o aprendizado não são adquiridos somente na escola, mas também são construídos pela criança em contato com o social, dentro da família e no mundo que a cerca. A família é o primeiro vínculo da criança e responsável por grande parte da sua educação e da sua aprendizagem.

E por meio dessa aprendizagem que a criança é inserida no mundo cultural, simbólica e começa a construir seus conhecimentos e seus saberes. Contudo, na 
realidade, o que temos observado é que as famílias estão perdidas, não estão sabendo lidar com situações novas: pais trabalhando fora o dia inteiro, pais desempregados, brigas, drogas, pais analfabetos, pais separados e mães solteiras.

Essas famílias acabam transferindo suas responsabilidades para a escola, sendo que, em decorrência disso, presenciamos gerações cada vez mais dependentes e a escola tendo que desviar de suas funções para suprir essas necessidades. O papel do psicopedagogo nestes casos é de extrema importância para que este aluno se desenvolva nos estudos, pois ele é um dos profissionais capacitados na prevenção e no tratamento destes problemas de aprendizagem.

O professor, por sua vez, não está preparado para enfrentar casos como este. Os cursos de formação de professores deveriam ocupar-se, de uma forma abrangente, esses distúrbios, para o professor ao menos saber do que se trata, também, porque às vezes, ele é o único que mais convive com a criança, e que pode notar algum problema e encaminhá-lo para o profissional adequado.

A intervenção psicopedagógico, antes de ser aplicada deve ser planejada, assim como todo trabalho. Faz parte da intervenção psicopedagógica, estratégias e metodologias próprias para cada caso e para cada pessoa. No caso dos disléxicos não é diferente, o psicopedagogo deve planejar meios pelo qual ele irá promover a aprendizagem do aluno, e segundo Capretz (2012), a melhor maneira de se trabalhar com um disléxico é explorando a aprendizagem multissensorial com o lúdico, ou seja, utilizando outros canais que não sejam a visão, como por exemplo, caminhar com a criança sobre uma letra, deixá-la interagir com a caixa tátil, fazer gelatina na forma das letras, fazer uma sopa de letras, vendar a criança para ela tentar descobrir com o dedo a forma de alguma letra ou palavra, colar barbante ou feijão em cima da letra etc.

Todas essas sugestões são formas lúdicas, pois o trabalho do psicopedagogo é e deve ser lúdico para que a criança se desenvolva com outros meios sensoriais. Obviamente, não é possível, também, fazer apenas estas opções apresentadas. O ideal é mesclar sempre, para que aos poucos a criança seja introduzida no mundo das letras sem notar.

Segundo Alicia Fernandez (1990, p. 177), “[...] a intervenção psicopedagógica não de se dirige sintoma, mas o poder por mobilizar a modalidade na aprendizagem em um determinado momento, e é a partir daí que vai transformando o processo de ensino- 
aprendizagem". A intervenção do psicopedagogo pode ser de forma preventiva, a qual detecta as dificuldades e promove sugestões metodológicas, orientação vocacional, educacional, e ocupacional ou de forma terapêutica.

A intervenção psicopedagógico focaliza o sujeito na relação com aprendizagem. A meta do psicopedagogo é ajudar aquele que, por diferentes razões, não consegue aprender formal ou informalmente, para que consiga não apenas interessar-se Por aprender, mas adquirir ou desenvolver habilidades necessárias para tanto [...]. (RUBINESTEIN, 2001, p. 25).

BOSSA (2011, p. 23) complementa, dizendo que:

Cabe ao psicopedagogo perceber eventuais perturbações no processo e aprendizagem, participam da dinâmica da comunidade educativa, favorecendo a integração, promovendo orientações metodológica de acordo das características e particularidades dos indivíduos do grupo, realizando processos de orientações.

Fermino (1996) relaciona algumas possibilidades de diagnóstico e intervenções:

1. Estratégias que visam à recuperação por parte das crianças, de conteúdos escolares avaliados como deficitários;

2. Procedimentos de orientação de estudos (organização, disciplina etc);

3. Atividades, como brincadeiras, jogos de regras e dramatizações realizadas na escola e fora dela, com objetivo de promover a plena expressão dos afetos e o desenvolvimento da personalidade de crianças com e sem dificuldades de aprendizagem;

4. Atendimentos em consultório de crianças com dificuldades de aprendizagem na escola (encaminhamentos feitos pela própria escola);

5. Pesquisa de instrumentos que podem ser utilizados para auxiliar o processo de aprendizagem de crianças, bem como o seu desenvolvimento no que se refere à inteligência e afetividade.

Neste contexto, foram apontados as modalidades mais frequentes de atendimentos, com o objetivo de desvendar a natureza e as características próprias, para que o profissional possa refletir sobre o alcance da mediação a que ele se propõe quando planeja e inicia uma intervenção, para que tenha noção de seus limites e dificuldades.

O trabalho de Macedo (1992), baseado na epistemologia construtivista de Piaget (1974), sugere intervenções por meio de jogos de regras. Por suas características 
próprias, os jogos de regras oferecem a possibilidade de se analisar os erros e as estratégias do trabalho psicopedagógico. Para Macedo (1992), seria criar condições para que o aluno possa e deseje relacionar-se com o mundo em um nível formal do desenvolvimento cognitivo.

Souza (2001) apresenta também algumas modalidades de intervenções ou atividades psicopedagógico praticadas pelos profissionais da área. Em geral, os psicopedagogos elaboram atividades, que objetivam a recuperação de conteúdos escolares, avaliados como, estando ainda incompletos para o aluno; e estratégias de orientação de estudos;

Planejamento de atividades que propiciam a expressão dos afetos e o desenvolvimento da personalidade da criança com ou sem dificuldades de aprendizagem; atendimento clínico de alunos com dificuldades de aprendizagem; e pesquisas de instrumentos e recursos que auxiliem a aprendizagem e o desenvolvimento das crianças, considerando seus aspectos cognitivos e afetivos.

Para tanto, a escola precisa recorrer aos psicopedagogos para juntos estruturarem ações, estratégias e intervenções psicopedagógicas, que contribuam como soluções para diminuir os problemas de aprendizagem, pois o aluno é sujeito de transformação e de aquisição de aprendizagem.

\section{CONSIDERAÇÕES FINAIS}

Os problemas de aprendizagem constituem uma situação real dentro das instituições, portanto, faz-se necessário que todos os envolvidos no processo de ensino e aprendizagem sejam leitores e pesquisadores de problemas de aprendizagem para que possa possibilitá-los a entender melhor como se dá a influência de fatores intra e extras escolares, e como podem ser trabalhados de forma a minimizar problemas de aprendizagens no dia a dia da escola.

Muitas dificuldades de aprendizagem são decorrentes de metodologias inadequadas, professores desmotivados e cansados, brigas e discussões entre colegas, entre outras. A escola deve ser a segunda casa do indivíduo, um lugar onde ele possa se sentir bem e entre amigos, contar com a professora sempre que precisar ou sempre que tiver um problema familiar. (outra causa de dificuldades de aprendizagem) e manter contato com os outros membros da equipe escolar, como coordenação pedagógica. 
A escola não pode continuar a ser uma fábrica de insucessos. Na escola, a criança deve ser amada, pois só assim se poderá considerar útil. Os métodos de ensino inadequados, falta de percepção por parte da escola, do nível de maturidade da criança, professores que não dominam determinados assuntos, superlotação das classes, dificultando a atenção do professor para todos os alunos.

\section{REFERÊNCIAS}

AID (International Dislexia Association, 1994) apud IANHEZ, M. E.; NICO, M. A. Nem Sempre é o Que Parece: como enfrentar a dislexia e os fracassos escolares. Rio de Janeiro: Elsevier, 2002

BATEMAN, B. (1965). An education's view of a diagnostic approach to rearning desordens. In J. Hellmuth (ed), Learning desordens, Vol, I, seattle: special Child publications.

BOSSA, Nádia, A. A psicopedagogia no Brasil: Contribuições a partir da prática-4 $4^{a}$ ed. Rio de Janeiro: Wak, 2011.

BRASIL, (1996). Conselho Nacional de Saúde. Resolução nº 196, de 10 de outubro de 1996. Aprova as Diretrizes e Normas regulamentadoras de pesquisas envolvendo seres humanos.

CAMPOS, G.B. A. A constituição subjetiva do aluno em situação de fracasso escolar. 2005. Dissertação de Mestrado. Faculdade de Educação Universidade. 2005.

CAPRETZ, Nançy, Problemas e distúrbios da aprendizagem. Departamento de pósgraduação e Extensão. Valinhos, SP. Anhanguera educacional, 2012. Disponível em: Acesso 13 de dezembro 2012.

CASTAÑO. M. G. O. Cidadania e inclusão. 2003 (Apresentação de Trabalho conferencia ou palestra).

CHALITA, Gabriel. Educação: a solução está no afeto. São Paulo: Gente, 2001

CORREIA, Luiz de Miranda. Problematização das dificuldades de aprendizagem nas necessidades educativas especiais. Porto: APRORT, 1991.

DERDYK, Edith. Formas de pensar o desenho: Desenvolvimento do grafismo infantil. São Paulo: Editora Scipione, 1989.

FERMINO, Fernandes Sisto...(ET AL). Atuação psicopedagogica e aprendizagem escolar, Petrópoles, RJ:nvozes, 1996.

FERNANDEZ, Alicia. O saber em jogo: a psicopedagogia propiciando autorias de pensamentos. Porto Alegre: Artes Medicas; 2001. 
FONSECA, V. Introdução às dificuldades de aprendizagem. Porto Alegre: Artes Médias, 1995. p.16

FRANÇA, C. Um novato na psicopedagogia. In: SISTO, F. F. atuação psicopedagógico e aprendizagem escolar. Petrópolis: Vozes, 1996.

KIRK, S. A. (1962). Educating Excepcional Children. Boston: Houghton Mifflin.

MACEDO, Lino de. "Prefácio" a scoz et. Alii, pcopedagogia-contextualização, Formação e Atuação profissional. Porto Alegre: Artes Médica, 1992.

MARTINS, A. P. L. Dificuldades de Aprendizagem especificas: questões sobre estratégias de aprendizagem. Sonhar, Vll (2002).

MORAES, A. M. P. Distúrbio de Aprendizagem uma abordagem psicopedagógico. São Paulo: Edicon, 1992.

PAIN, Sara. Diagnostico e tratamentos dos problemas de aprendizagem. $4^{\mathrm{a}}$ ed. Porto Alegre: Artes Médicas, 1992.

PIAGET J. Grécco. Aprendizagem e conhecimento. Rio de Janeiro. Livraria Freitas Bastos; 1974.

PINHEIRO, P. M. A. Sucesso escolar: uma possibilidade na relação professor $\mathbf{X}$ aluno. 2004. Dissertação de Mestrado. Faculdade de Educação. Universidade de Brasília. 2004.

RAMOZZI-CHIAROTTINO, Z. Em busca do sentido da obra de Jean Piaget. $2^{a}$ ed. São Paulo: Ática, 1994. 118p.

ROTTA, NEWRA TELLECHEA, OHLWLLER, LYGIA RIESDGO, Rudimar dos Santos. Transtorno de Aprendizagem: abordagem neurobiológica e multidisciplinar. SP, Artimeden (2002).

RUBISNSTEIN, E. A psicopedagogia e a Associação Estadual de Psicopedagogos de São Paulo. In: SCOZ, B, RUBINSTEIN, E.., ROSSA, E.., BARONE, L. psicopedagogia, o caráter interdisciplinar na formação e Atuação profissional. Porto Alegre: Arte Médica, 1987.

SOUZA, Evanira Maria de. Problemas de Aprendizagem: crianças de 8 a 11 anos. Bauru, EDUSC, 1996. Completo para pais e educadores. Porto Alegre: Artmed, 2001.

STRICK, C. e SMITH, L. Dificuldades de aprendizagem de A a Z - Um guia completo para pais e educadores. Porto Alegre: ARTMED, 2001.

WEISS, Maria Lúcia L. Psicopedagoga Clinica: uma revisão diagnóstica dos problemas de aprendizagem escolar. 10ª ed. Rio de Janeiro: DP\&A, 2004. 
WEISS, Alba Maria Lemme, CRUZ, Maria Lúcia R. A Informática e os Problemas Escolares de Aprendizagem. Rio de Janeiro: DP\&A, 1999.

Zorzi, J. L. (1998). Aprender a escrever: A apropriação do sistema ortográfico. Porto Alegre: Artes Médicas. 
AUTISMO, MEDIAÇÃO ESCOLAR, FORMAÇÃO DOCENTE E FAMÍLIA PARTICIPATIVA: UM OLHAR VOLTADO PARA AS POLÍTICAS PÚBLICAS QUANTO À INCLUSÃO NA EDUCAÇÃO INFANTIL

NASCIMENTO, Kamila Alkmim ${ }^{29}$

\section{RESUMO:}

O presente trabalho norteará questões acerca da Educação Especial e Inclusão no Contexto Amazônico. Assim, em um primeiro momento, tem por objetivo analisar a inclusão dos alunos autistas matriculados na Pré-Escola Creche Infante Tiradentes da Polícia Militar do Estado do Amazonas - PECIT; da cidade de Manaus, e por consequência, investigar a necessidade de formação dos docentes da instituição de ensino objeto de estudo, no que tange à Educação especial, especificamente no que se refere ao tratamento e educação com as crianças que possuem Transtorno de Espectro Autista (TEA). Abordará ainda, a importância desta capacitação e o quanto ela pode auxiliar no desenvolvimento expressivo quanto ao aprendizado das crianças. $\mathrm{O}$ trabalho enfatizará também, que a parceria da família é imprescindível no processo ensino/aprendizagem, devendo fazer escolhas viáveis juntamente com a escola, buscando somar à formação do aluno, além de ser essencial ao auxílio em sala de aula com o docente. Tão importante quanto a questão da inclusão, é pesquisar como ela ocorre para a realização da matrícula de crianças portadoras de TEA no âmbito da Educação Infantil. Se existem parâmetros e se a legislação brasileira é verdadeiramente aplicada ao matricular tais alunos; e ainda se a escola recebe o fomento necessário das políticas públicas previstas, no tocante ao amparo destas crianças. Em suma, o trabalho dará ênfase à capacitação e formação do professor, além do apoio do mediador a fim de cooperar para o progresso do processo de inclusão quando o profissional tiver que lidar com crianças com autismo.

PALAVRAS-CHAVE: Autismo. Formação. Inclusão. Educação Infantil.

\section{INTRODUÇÃO}

Dentre várias carências, o tema autismo foi escolhido pelo fato da pesquisadora além de possuir formação pedagógica, ter exercido uma função na instituição em questão; onde atuou como subcomandante/vice-diretora no período que compreende o ano de 2015 a 2018; a qual se transforma aqui em objeto de estudo. A pesquisa de campo foi realizada, utilizando-se, através de entrevistas e formulários com alguns profissionais que lidam diariamente com os alunos autistas neste universo educacional.

\footnotetext{
${ }^{29}$ Especialista em Direito Público Material pela Universidade Gama Filho/RJ. Bacharel em Direito pelas Faculdades Integradas Pitágoras/MG. Bacharel em Ciências Militares e Segurança Pública pela Universidade Estadual do Amazonas - UEA. Atualmente é Oficial da Polícia Militar do Estado do Amazonas. E-mail: kamilalkmim@gmail.com
} 
No âmbito escolar, a pesquisa foi realizada através da observação das crianças com autismo, em especial, sobretudo, durante as aulas e no convívio com os demais colegas. Desta forma, através dos levantamentos, permite-se discutir os pontos positivos e negativos relacionados à inclusão de crianças autistas na educação infantil.

A educação inclusiva consiste na busca pelo acesso e permanência de alunos com deficiência, transtorno global do desenvolvimento, altas habilidades (crianças superdotadas) e transtorno de espectro autista no espaço escolar; esta vem sendo amplamente divulgada e praticada como forma de garantir o direito e acesso a uma educação igualitária.

Esse novo modelo educacional surge, então, como uma proposta de assegurar aos alunos com necessidades especiais os mesmos direitos nas escolas regulares, promovendo a interação entre alunos. Porém, a sua prática ainda é difícil para a escola e para o aluno, por diversos fatores, entre eles, as dificuldades enfrentadas por professores da Educação Infantil da Pré-Escola Creche Infante Tiradentes, que se veem diante de uma situação para a qual, por muitas vezes, não foram preparados, sendo este um dos objetos essenciais a ser abordado no trabalho de pesquisa.

Concomitantemente, deve-se considerar de extrema relevância, saber quais as principais necessidades do professor, além de auxiliar a escola a elaborar métodos para suprir tais dificuldades, qualificando o trabalho dos professores e daqueles que podem um dia, receber em sua turma um aluno com autismo, pois, em um momento em que a educação inclusiva vem sendo amplamente divulgada, não há como se pensar nesta temática, sem considerar a prática do professor, e as garantias das políticas públicas voltadas para essa questão.

E é pensando nessa prática pedagógica, que a pesquisa tem como tema a inclusão de alunos com autismo e a importância da mediação escolar no desenvolvimento da criança com transtorno de espectro autista. A pesquisa contém as seguintes questões norteadoras: 1) Qual o papel dos mediadores escolares na inclusão de alunos com TEA na Pré-Escola e Creche Infante Tiradentes localizada no município de Manaus: políticas públicas, dificuldades enfrentadas e desafios futuros. 2) Qual o conhecimento dos professores em relação ao conceito de autismo e de como lidar em sala de aula? 3) Como reconhecer as necessidades e dificuldades da criança com autismo em sala de aula? 4) Qual a participação das políticas públicas no que tange o 
amparo das crianças autistas e quanto a formação dos professores? 5) Como é aceitação e compreensão dos pais no que se refere ao autismo?

O trabalho pautou-se em observar a capacitação dos profissionais, famílias e interessados na compreensão dos desafios atuais de Inclusão Escolar, estimulando o pensamento crítico sobre a atuação do Mediador Escolar na Educação Infantil; de modo a analisar como o professor realiza o atendimento a alunos com autismo, enfatizando seus conhecimentos prévios, habilidades, necessidades e dificuldades.

Quanto aos objetivos específicos, buscou-se identificar iniciativas que demonstram a compreensão da educação inclusiva na Pré-Escola Creche Infante Tiradentes da Polícia Militar do Estado do Amazonas - PECIT, isto é, se o professor recebe alguma formação para atuar em classes com alunos com autismo; os métodos e/ou atividades que o professor utiliza nos dias atuais, levantar dados acerca das principais dificuldades enfrentadas no cotidiano escolar, e se possuem mediadores disponíveis pelo Estado ou Município, para atuarem diretamente com tais alunos, facilitando o desempenho em sala de aula, entre o mediador e o professor no que se refere ao desenvolvimento psicossocial da criança.

Diante do exposto, a pesquisa apresenta fundamentação teórica com base em dados bibliográficos de cunho qualitativo, o qual apresenta o conceito de autismo, aborda ainda questões acerca da educação inclusiva, apresenta as leis e diretrizes que surgiram para apoiar o direito de todos ao acesso a uma educação de qualidade, além de dissertar sobre o papel do professor e mediadores, além dos métodos que possam ser utilizados em sala de aula.

\section{METODOLOGIA}

A presente pesquisa tem como referenciais teóricos as proposições norteadas pelos grandes pensadores Piaget (1982), Montessori (1995), Skinner (1989) e Vygotski (2000). Um exemplo são as abordagens nas questões de Vygotski, que prevê como essencial o conhecimento do ambiente cujas crianças se interagem, pois tal compreensão ajudará a assimilar sua sistematização psicossocial, abordando a questão do desempenho psíquico, como crucial para o discernimento e conhecimento do grau em que a criança se encontra no que se refere ao autismo, caso seja necessário intervir pedagogicamente. Já os demais pensadores supracitados, seguem a linha do 
condicionamento em que as crianças são influenciadas pelo meio as quais estão inseridas.

A metodologia da pesquisa ocorrerá por meio da pesquisa bibliográfica com abordagem qualitativa; verificando como ocorre o processo de inclusão escolar, pesquisa esta que será feita através da pesquisa de campo, a ser realizada por meio de trabalhos de análises interpretativas, isto é, entrevistas e questionários a serem aplicados especificamente aos profissionais que lidam diariamente com alunos autistas na PECIT.

\section{DESENVOLVIMENTO}

\section{Conhcendo o transtorno do espectro autista com ênfase na inclusão social.}

O Autismo é considerado uma síndrome comportamental, sendo um distúrbio de desenvolvimento permanente e incapacitante, com sintomas que surgem por volta dos três anos de idade. Há um amplo e persistente prejuízo na interação social, na imaginação e comunicação verbal ou não verbal, como por exemplo, contato visual direto, expressão facial, posturas e gestos corporais (APA, 2002; ORRÚ, 2009).

O autismo é classificado como Transtornos Invasivos (Globais) do Desenvolvimento, representada no DSM - IV por danos graves e agressivos nas áreas do desenvolvimento. O início do transtorno autista ocorre por volta três anos de idade. Em alguns casos, os pais relatam a falta de interação social da criança desde o nascimento desta ou logo após.

Considerando que a educação especial esta é voltada a atender exclusivamente a alunos com necessidades especiais, se organizou como sendo substitutivo ao ensino comum, o que levou a criação de instituições especializadas, escolas e classes especiais. Esses alunos, segundo o Ministério da Educação são: “educandos que apresentam dificuldades acentuadas de aprendizagem ou limitação no processo de desenvolvimento que dificultem o acompanhamento das atividades curriculares" (BRASIL, 2001, p. 43).

Movimentos em busca dos direitos humanos das pessoas com deficiências são importantes para o destaque da educação especial no Brasil, e é uma das áreas que mais se desenvolve para melhor atender esta parcela da população, pois busca a quebra de barreiras que impeçam o exercício da cidadania desses alunos, cujas necessidades específicas demandam recursos, equipamentos e níveis de especialização definidos de 
acordo com a condição física, sensorial ou mental (CAMPBELL, 2009; CUNHA, 2010).

Os alunos que frequentam as escolas especiais possuem o mesmo direito constitucional de acesso à educação regular, assim garantido pela Constituição Federal de 1988, art. 208, que prevê "atendimento educacional especializado aos portadores de deficiência, preferencialmente na rede regular de ensino." A Constituição Federal, garante que toda escola deve atender aos princípios constitucionais, não podendo excluir nenhuma pessoa em razão de sua origem, raça, sexo, cor, idade ou deficiência, ou seja, garante a educação para todos.

No artigo 58 da Lei de Diretrizes e Bases da Educação (LDB), nº 9.394/96, “entende-se por educação especial, para os efeitos desta Lei, a modalidade de educação escolar, oferecida preferencialmente na rede regular de ensino, para educandos portadores de necessidades especiais." Porém, se não for possível inserir o aluno com necessidades especiais nas classes comuns, o atendimento educacional deverá ser feito em escolas especializadas. A intenção praticada era que apenas aqueles que conseguissem se adaptar às atividades da escola pudesse ser inserido a ela.

A inclusão, principalmente de pessoas com necessidades especiais tem sido muito discutida e comentada entre educadores, entidades, políticos etc. Surgiu como parte dos processos recentes de democratização e pode ser entendida como a ação de proporcionar para populações social e economicamente excluídas, oportunidades e condições de serem incorporadas à parcela da sociedade que, assim como estabelecer condições para que todos possam viver com adequada qualidade de vida e como cidadãos plenos (BRASIL, 2008).

A Declaração de Salamanca (1994) e o Tratado de Guatemala (1999) declaram que a escola deverá adaptar-se para melhor atender às necessidades desses alunos, para que sejam inseridos nas classes regulares. A educação inclusiva assume então, papel fundamental acerca da função da escola em superar a lógica da exclusão. Na Convenção de Guatemala é alegado que "toda diferenciação ou exclusão que possa impedir ou anular o exercício dos direitos humanos e de suas liberdades fundamentais é definido como discriminação", essa declaração permitiu uma nova interpretação sobre a atuação da educação especial. (CAMPBELL, 2009). 
Segundo Vygotsky (apud MEC, 2008), “a aprendizagem é construída primeiramente, a partir da interação social, para depois passar ao plano individual, ou seja, está entre o que o aluno é capaz de fazer com a ajuda de outros e o que pode fazer por si mesmo".

E em grupo é a melhor forma de beneficiar a todos, compartilhar a aprendizagem com outros pode tornar-se algo estimulante e enriquecedor. A escola é um espaço de todos, no qual os alunos constroem o conhecimento segundo suas capacidades e se desenvolvem como cidadãos, nas suas diferenças. (ROPOLI, 2010; CAMPBELL, 2009).

É reconhecido pela Convenção sobre os Direitos das Pessoas com Deficiência, que as pessoas com deficiência têm direito à educação e a sua efetivação, feita com os estados que fazem parte da Convenção, assegurando um sistema educacional inclusivo em todos os níveis, e um aprendizado que visa o desenvolvimento das potencialidades e a participação em uma sociedade livre (ONU, 2006).

A escola torna-se inclusiva quando reconhece as diferenças dos alunos diante do processo educativo, ou seja, precisa adaptar-se à diversidade de características de seus alunos, para suprir às necessidades educacionais.

Os sistemas de ensino devem prover soluções, estratégias para as necessidades especiais do educando, buscar alternativas para que este aluno possa ser incluído, no que for possível, nas atividades escolares. Surge com essa política, o Atendimento Educacional Especializado - AEE, um serviço da educação especial que "[...] identifica, elabora e organiza recursos pedagógicos e de acessibilidade, que eliminem as barreiras para a plena participação dos alunos, considerando suas necessidades específicas" (BRASIL, 2008, p.10).

$\mathrm{Na}$ questão de se ter um aluno incluso em uma escola regular é obrigatório a oferta pelos sistemas de ensino de um espaço que busca complementar ou suplementar a formação do aluno, visando sua autonomia, denominados de Sala de Recursos Multifuncionais, onde o aluno é inserido, pois suas "necessidades educacionais específicas podem ser atendidas e discutidas no dia a dia escolar e com todos os que atuam no ensino regular" (ROPOLLI, 2010, p. 18).

Para manter a Sala de Recursos Multifuncionais e garantir o atendimento especializado, é destinado recursos do Fundo Nacional de Desenvolvimento da 
Educação Básica - FUNDEB, segundo o decreto №. 6.571, de 17 de setembro de 2008. Exige-se que os alunos estejam matriculados na classe comum e na sala de recursos multifuncional da mesma escola, ou quando esta não possui uma sala de recursos, deve ser oferecido ao aluno o atendimento em outra escola ou em um centro de atendimento especializado público ou sem fins lucrativos.

A relação professor/aluno/autismo é um processo da construção de sua autonomia na escola, porém este trabalho não será fácil, se a família não participar na educação do aluno. A descoberta do autismo traz preocupações, angústias e incertezas à família. A escola e a família são responsáveis pelo desenvolvimento do aluno, por isso, é necessário que "trabalhem da mesma forma, estabelecendo os mesmos princípios que permitirão uma articulação harmoniosa na educação" (CUNHA, 2010, p. 93).

Diante disso, foi em 1930 que, Skinner iniciou o estudo do comportamento a partir dos estudos já realizados acerca do comportamento respondente, ou seja, a pedagogia do condicionamento, onde o desenvolvimento de seu trabalho o levou a teorizar sobre outro tipo de relação do indivíduo com seu ambiente, a qual viria a ser nova unidade de análise de sua ciência: o comportamento operante (SKINNER, 1989).

Já Reis (2002) evidencia que o behaviorismo compreende a corrente da Psicologia que procura explicar o comportamento humano como resultado das influências dos estímulos do meio. Conforme ele, a visão de homem para Skinner equivale à visão empirista de Locke, ou seja, para ele o homem é produto das forças do meio no qual vive, haja vista que, as crianças, desde o nascimento, sofrem uma influência mútua com os adultos, que procuram introduzi-las em suas relações e cultura. Portanto, é por meio da mediação dos adultos que os processos psicológicos mais complexos tomam forma, de acordo acontece o crescimento das crianças, os processos acabam por serem realizados por si próprias. (REIS, 2002, p. 92).

Concernente à educação de autistas, esta é direcionada para que os alunos possam aprender conceitos básicos para melhor conviverem dentro da sociedade, e a forma de como a criança atingirá o objetivo esperado varia conforme o método que será adotado, os estilos de aprendizagem são importantes e não devem restringir as habilidades.

É necessário antes, organizar e simplificar o ambiente, apresentando menos estímulos sensoriais, facilitando à criança a focar a atenção nos detalhes relevantes. 
Uma informação dada visualmente tem como objetivo amenizar as dificuldades de comunicação existentes. O professor é o responsável em proporcionar tais atividades ao educando, buscando nestes, uma forma prazerosa de aprender, contudo, para que isso aconteça, faz-se imperioso que o educador seja estimulado desde sua formação, de modo que compreenda a criança como capaz de construir socialmente seu próprio conhecimento.

Neste sentido, as atividades lúdicas são sempre cruciais ao aluno, assim como cabe ao professor conhecer as fases que este aluno se encontra para assim não atropelar as fases de seu desenvolvimento e aprendizado. Neste mesmo aspecto, Montessori (1995) e Piaget (1982) afirmam que cada fase deve ser vivenciada pela criança e unicamente ela, espontaneamente, deve saber quando seguir para a próxima fase.

\title{
HISTÓRICO DA UNIDADE DE ENSINO:
}

A Pré-Escola Creche Infante Tiradentes - PECIT, situada à Rua Dr. Aristides Rocha s/n, Bairro Petrópolis, sendo esta sua sede, e o anexo na Avenida Professor Nilton Lins, bairro Parque das Laranjeiras, na cidade de Manaus-AM, foi inaugurada em 1986 tendo por finalidade precípua atender aos filhos de policiais militares que emanavam do interior, consubstanciando a política social da Instituição. Segundo o Projeto Político Pedagógico da Instituição,

\begin{abstract}
A PECIT constitui-se como um dos programas assistenciais de maior valia da Polícia Militar do Amazonas a cargo da sua Diretoria de Promoção Social (Lei Delegada n. 53/2005), tornando-se uma referência no que tange à educação infantil. Além de promover à assistência ao policial militar, a PECIT, consciente da sua atribuição social, abriu às portas a comunidade amazonense. Para melhor atender a população, a Polícia Militar do Amazonas firmou convênio de cooperação técnica com a Secretaria Municipal de Educação SEMED. Urge esclarecer, que a Pré-Escola Creche Infante Tiradentes, ante sua origem militar, possui uma estrutura diferente, seguindo procedimentos de acordo com as diretrizes da Policias Militar do Amazonas, sem com isto, modificar o Programa Disciplinar estabelecido pela Secretaria Municipal de Educação. Em razão disso, pauta suas ações em duas premissas fundamentais: a Educação e a Disciplina, características fundamentais para o trabalho pedagógico desenvolvido na Escola. (PPP-PECIT, 2017, p. 16)
\end{abstract}

O valor categórico da instituição está em envolver os alunos de modo a moldálos em sua fase inicial no tocante à personalidade, como crianças aptas a reivindicarem 
seus direitos e capazes cumprir os seus deveres. A Pré-escola Creche Infante Tiradentes volta-se para o bem estar físico e psicossocial de cada aluno, no intuito de que se sintam seguras e felizes no ambiente escolar, este objetivo se estende a toda equipe pedagógica orientada para realizar um distinto trabalho conforme os anseios de todos os seguimentos da creche.

A Pré-escola Creche Infante Tiradentes, instituição conveniada à Secretaria Municipal de Educação (SEMED), preza pela Educação Infantil inclusiva como sendo aquela que acolhe e valoriza toda diversidade presente nos espaços de Educação Infantil fase Pré escola e creche. Deste modo, as práticas pedagógicas desenvolvidas na PECIT devem contemplar elementos da cultura dos povos afro-descentes e demais culturas que compõem a diversidade apresentada, contemplando "a pluralidade cultural, isto é, a diversidade de etnias, crenças, costumes, valores etc. que caracterizam a população brasileira" (BRASIL, 1996).

Neste contexto há que salientar ainda, que a presença da família e a parceria direta com a escola, são cruciais para que seja congregada a atitude de acolhimento e aceitação por parte das crianças em relação ao outro quanto às diferenças e peculiaridades existentes na instituição.

\section{RESULTADOS E DISCUSSÃO}

A educação inclusiva supõe que o professor tenha a coragem de assumir o preconceito, a dificuldade, o medo, a impotência diante da diversidade, porque só assim terá condições de aprender ou rever estratégias pedagógicas, para tanto, como forma de alcançar os resultados referentes às dificuldades e desafios enfrentados pela PECIT, quanto à educação inclusiva, foi aplicado o questionário abaixo aos profissionais e professores da Instituição em comento:

\section{Indicadores para a inclusão de crianças com Transtorno de Espectro Autista na Pré-Escola Creche Infante Tiradentes da Polícia Militar do Amazonas.}

(O presente questionário tem por objetivo desenvolver um estudo sobre a inclusão de crianças com TEA ou outros Transtornos na Educação Infantil. As informações obtidas são de caráter anônimo e confidencial). 
Escola:

Formação Acadêmica:

Ano:

Formação Especializada:

Ano:

Idade:

Sexo: $F \_M \_N^{o}$ de alunos da sala de aula:

$\mathrm{N}^{\mathrm{o}}$ de alunos da sala de aula com Transtorno do Espectro Autista:

Por favor, coloque um X na caixa que indica a sua opinião:

\begin{tabular}{|c|c|c|c|c|c|}
\hline & & $\begin{array}{c}\text { CONCORDO } \\
\text { PLENAMENT } \\
\text { E }\end{array}$ & $\begin{array}{c}\text { CONCORD } \\
\text { O } \\
\text { PARCIALM } \\
\text { ENTE }\end{array}$ & DISCORDO & $\begin{array}{l}\text { NECESSIDADE DE } \\
\text { MAIS } \\
\text { INFORMAÇÕES }\end{array}$ \\
\hline 01. & $\begin{array}{l}\text { Tudo é feito } \\
\text { para que todos } \\
\text { se sintam bem. }\end{array}$ & & & & \\
\hline 02. & $\begin{array}{l}\text { Os alunos } \\
\text { ajudam-se uns } \\
\text { aos outros. }\end{array}$ & & & & \\
\hline 03. & $\begin{array}{c}\text { Os } \\
\text { profissionais } \\
\text { colaboram uns } \\
\text { com os outros. }\end{array}$ & & & & \\
\hline 04. & $\begin{array}{l}\text { Professores e } \\
\text { alunos tratam- } \\
\text { se com } \\
\text { respeito. }\end{array}$ & & & & \\
\hline 05. & $\begin{array}{c}\text { Escola e } \\
\text { família } \\
\text { trabalham em } \\
\text { parceria. }\end{array}$ & & & & \\
\hline 06. & $\begin{array}{c}\text { Observa-se } \\
\text { muita } \\
\text { expectativa } \\
\text { relativamente a } \\
\text { todas as } \\
\text { crianças. }\end{array}$ & & & & \\
\hline 07. & $\begin{array}{l}\text { Professores, } \\
\text { pais e alunos, } \\
\text { compreendem } \\
\text { bem a } \\
\text { finalidade da } \\
\text { inclusão. }\end{array}$ & & & & \\
\hline 08. & $\begin{array}{c}\text { Todas as } \\
\text { crianças são } \\
\text { igualmente } \\
\text { valorizadas. }\end{array}$ & & & & \\
\hline 09. & $\begin{array}{c}\text { A escola } \\
\text { trabalha em } \\
\text { prol da }\end{array}$ & & & & \\
\hline
\end{tabular}




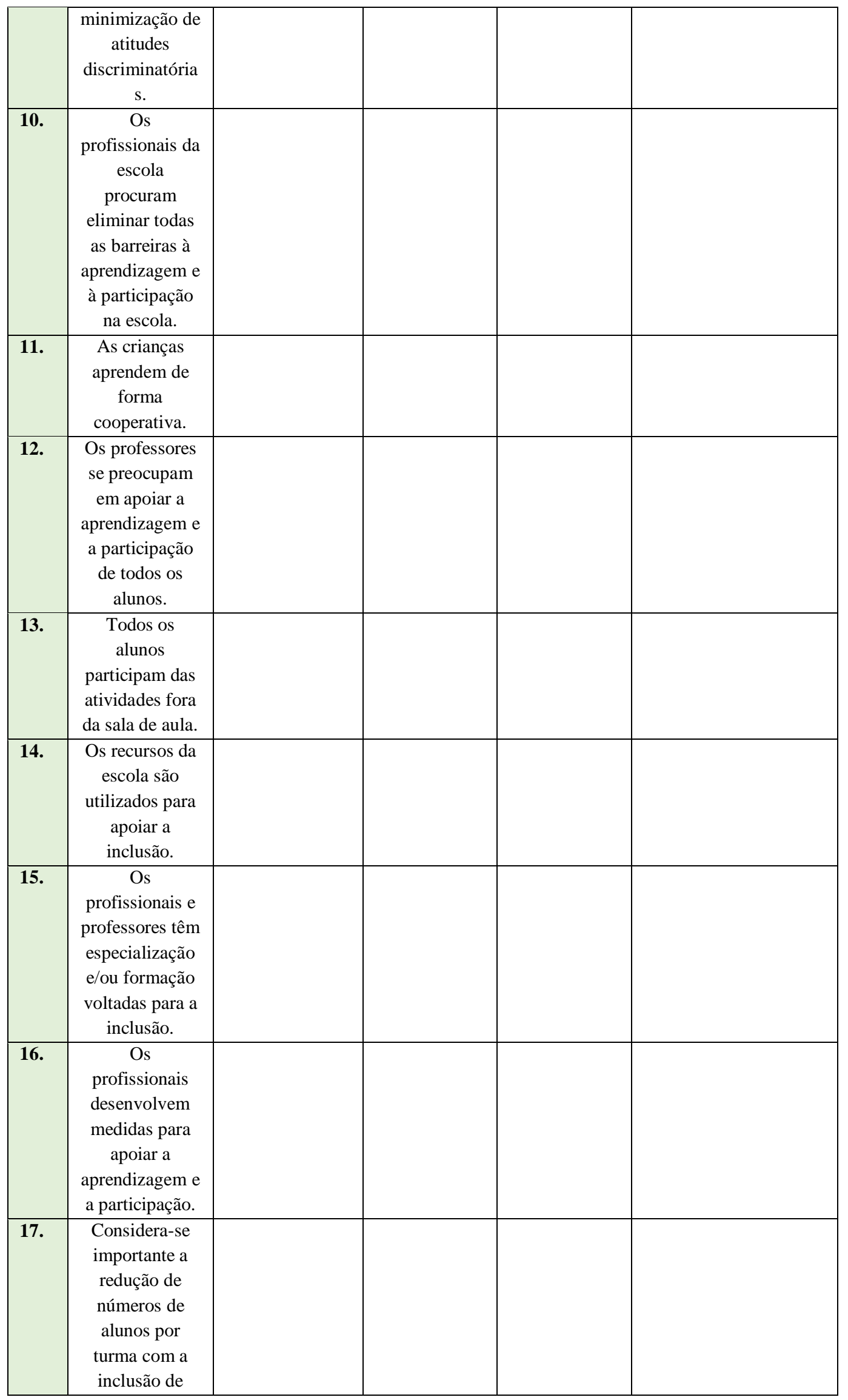

E-BOOK AMPLAMENTE: EDUCAÇÃO NA CONTEMPORANEIDADE. $1^{\mathrm{a} E d . ~ V o l .01 ~}$ D.O.I: $10.29327 / 513932$ ISBN: 978-65-860-9027-7 


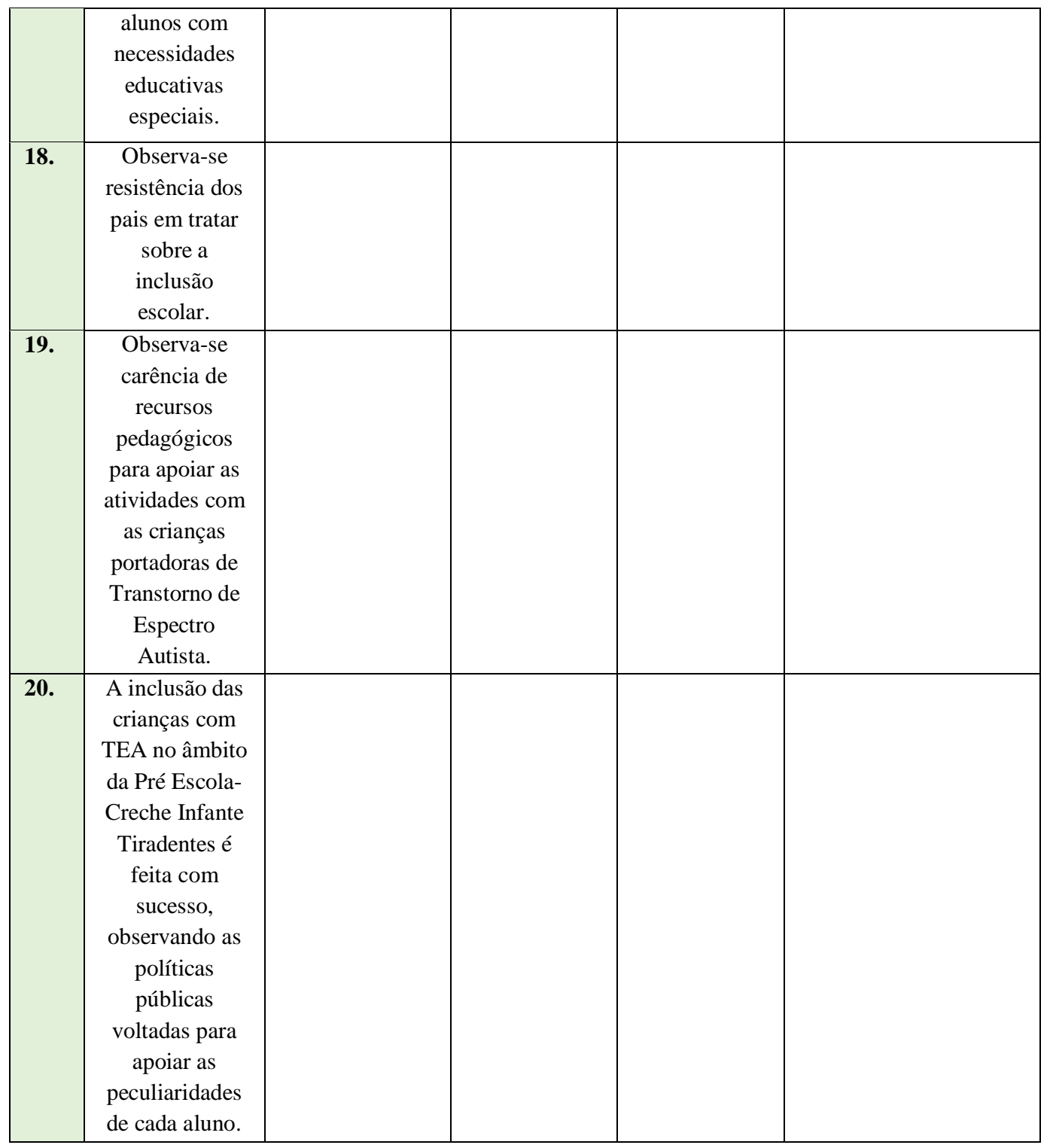

Resultados obtidos através dos questionários aplicados: 


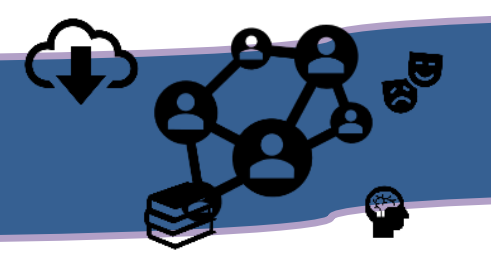

\section{Indicadores referente à inclusão social no âmbito da Pré-escola Creche Infante Tiradentes da Polícia Militar do Amazonas}

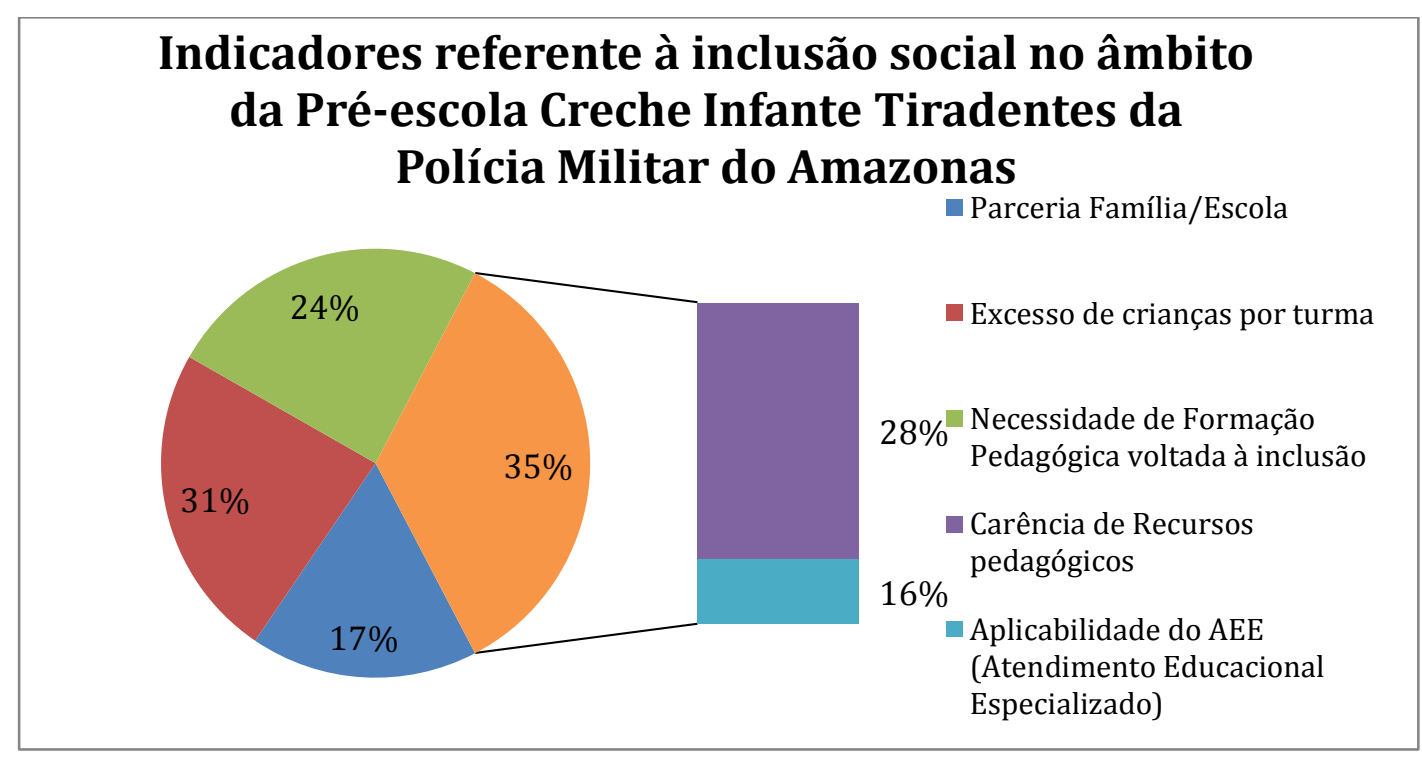

Através dos resultados alcançados, nota-se que alguns dos principais desafios enfrentados pela Pré-Escola Creche Infante Tiradentes, estão no excesso de alunos matriculados por turmas, em detrimento da carente formação pedagógica dos professores e profissionais da educação no que tange à inclusão na Educação Infantil e na carência de recursos pedagógicos oferecidos pelo Estado e/ou Município à PECIT, considerando, desta forma, um defasado aproveitamento das Políticas Públicas que deveriam ser empregadas em prol do bem-estar dos alunos com autismo e/ou que tenham outras necessidades específicas.

Deste modo, seria crucial a parceria da Escola com Órgãos e Instituições que possam apoiar em vários aspectos (psicopedagógicos, recursos multifuncionais, palestras com os profissionais da educação, cursos, dentre outros) como forma de viabilizar a aplicabilidade do Atendimento Educacional Especializado, destinado às crianças que necessitam de cuidados especiais.

No tocante ao amparo às crianças com TEA e outros transtornos, a Polícia Militar do Amazonas, disponibiliza efetivo de policiais militares femininas para auxiliarem tanto em sala de aula, como na rotina integral e execução de atividades peculiares à faixa etária, que exigem das professoras e auxiliares maior grau de atenção em virtude da segurança dos alunos, contudo, embora exista o apoio e suporte do comandante geral da PM-AM quanto à disponibilidade de efetivo, este não é suficiente, uma vez que, o número de crianças com autismo, hiperatividade ou transtornos globais do desenvolvimento é bastante amplo. Isso gera um cuidado específico para com este 
aluno, ou seja, uma formação/atenção especializada e individualizada, que compete privativamente ao Estado e/ou Município prover tal insuficiência, disponibilizando mediadores e/ou professores com formação e experiência em inclusão.

Assim, consequentemente, o efetivo de policiais militares existentes na PECIT, supririam àquelas turmas cujo número de crianças com TEA fossem menores, já que a formação policial é distinta; contudo, podem de forma exímia, auxiliar nas demais atividades escolares e lúdico-pedagógicas atinentes à rotina da criança.

Evidencia-se, desta forma, a premente necessidade através dos órgãos competentes, em conceder professores que exerçam a mediação pedagógica, facilitando, incentivando e motivando a aprendizagem, que ativamente coopera para que a criança alcance seus objetivos e que atenda especificamente aqueles alunos que carecem desta atenção especializada na PECIT, atuando ainda como intermediário nas questões sociais e de comportamento de modo a favorecer o processo educativo, estimulando a comunicação e linguagem, os quais são objetos da sua formação.

\section{CONSIDERAÇÕES FINAIS}

Diante dos resultados apresentados na pesquisa, observa-se que a integração entre escola comum e a educação especial, traz a concepção de que uma não irá substituir a outra, sem descaracterizar o que é próprio da cada uma. Para atuar no AEE, os professores devem ter formação específica para este exercício, que atenda aos objetivos da educação especial na perspectiva da Educação inclusiva.

Todavia, não há como pensar na inclusão escolar sem considerar o docente, pois este, mesmo possuindo uma formação fantástica não será possível dar conta de tanta diferença, dentro da sala de aula, se não contar com um apoio, que é um dos nossos objetos de estudo como dito anteriormente: o Mediador. A articulação com os profissionais do AEE é importante para a criação de estratégias para lidar com o aluno. Os educadores, a escola como um todo deve buscar maneiras inovadoras, facilitadoras, diferenciadas e produtivas para a construção de uma melhor qualidade de vida para a criança com autismo.

Neste contexto, a inclusão exige mudanças na estrutura e no funcionamento das escolas, estimulando a participação e o progresso de todos, adotando novas práticas pedagógicas, mudanças na formação dos professores e nas relações entre família e 
escola, assim como, romper valores, repensar categorias e promover novos paradigmas, para educar tais alunos com sucesso, conhecendo os principais obstáculos e suas justificativas. E o desafio da realização torna-se responsabilidade de todos na escola, pois situações isoladas não são suficientes para prover a inclusão.

O sucesso da aprendizagem está em explorar talentos, atualizar possibilidades, desenvolver as potencialidades naturais de cada aluno. As dificuldades e limitações são reconhecidas, mas não conduzem o ensino, como acontece atualmente. $\mathrm{O}$ argumento mais frequente dos professores, quando resistem à inclusão é o fato de não estarem/não terem sido preparados para esse trabalho. Eles devem ser estimulados a um crescimento profissional contínuo.

\section{REFERÊNCIAS}

AMA - ASSOCIAÇÃO AMIGOS DO AUTISTA - BRASIL 2005. Disponível em: < http://www.ama.org.br/site/index.php >. Acesso em novembro de 2016

\section{AMERICAN PSYCHIATRY ASSOCIATION (APA). Manual diagnóstico e} estatístico de transtornos mentais-DSM-IV-TR. Porto Alegre: Artmed, 2002.

BRASIL, Constituição da República Federativa do Brasil de 1988. Capítulo III. Da Educação, da Cultura e do Desporto. Seção I Da Educação. Artigo 205. Brasília: Senado Federal, 1988.

Lei de Diretrizes e Bases da Educação Nacional, LDB 9.394, de 20 de dezembro de 1996. Ministério da Educação: Brasília. Disponível em: <http://portal.mec.gov.br/arquivos/pdf/ldb.pdf>. Acessado em novembro de 2016.

\section{Política Nacional de Educação Especial na Perspectiva da Educação}

Inclusiva. Ministério da Educação. Secretaria de Educação Especial. Brasília: MEC/SEESP, 2008.

Projeto Político pedagógico da Pré Escola Creche Infante Tiradentes. Secretaria Municipal de Educação. Manaus, 2017.

CAMPBELL, Selma Inês. Múltiplas Faces da Inclusão. Rio de Janeiro: Wak Editora, 2009

CUNHA, Eugênio. Autismo e inclusão: psicopedagogia práticas educativas na escola e na família. 2.ed. - Rio de Janeiro: Wak Editora, 2010.

DECLARAÇÃO DE GUATEMALA. Convenção Interamericana para a eliminação de todas as formas de discriminação contra as pessoas portadoras de deficiência. Guatemala, 1999. 
DEClaraÇÃo DE SALAMANCA. Sobre Princípios, Políticas e Práticas na Área das Necessidades Educativas Especiais. 1994. Disponível em:

$<$ http://portal.mec.gov.br/seesp/arquivos/pdf/salamanca.pdf >. Acessado em novembro de 2016.

MONTESSORI, Maria. Mente absorvente. Rio de Janeiro, Portugália Editora (Brasil). 1995.

ORGANIZAÇÃO DAS NAÇÕES UNIDAS - ONU. Convenção sobre os Direitos das Pessoas com Deficiência. 2006.

ORRÚ, Silvia Ester. Autismo: O que os pais devem saber? Rio de Janeiro: Wak Editora: 2009.

PIAGET, J, O Nascimento da Inteligência na Criança, 4.ed. Rio de Janeiro: Zahar, 1982.

REIS, Risolene Pereira. In: Mundo Jovem. São Paulo. Fev. 2002.

ROPOLI, Edilene Aparecida. A Educação Especial na Perspectiva da Inclusão

Escolar: a escola comum inclusiva - Brasília : Ministério da Educação, Secretaria de Educação Especial ; [Fortaleza] : Universidade Federal do Ceará, 2010. v. 1. (Coleção A Educação Especial na Perspectiva da Inclusão Escolar)

SKINNER, B. F. Behaviorism and Logical Positivism de Laurence Smith. In Questões Recentes na Análise Comportamental. Campinas, SP: Papirus, (1989)

VYGOTSKI, L.S. A Formação Social da Mente: O Desenvolvimento dos Processos Psicológicos Superiores. 4 ed. São Paulo: Martins Fontes, 2000. 


\section{CARTA PEDAGÓGICA: ESCRITA DE UM COLETIVO DE EDUCADORES(AS)}

SILVA, Ida Letícia Gautério da ${ }^{30}$ SATT, Jorge Antônio de Oliveira ${ }^{31}$ SILVA, Daiane Leal $\mathrm{da}^{32}$ VIEIRA, Menetem Ferreira ${ }^{33}$

Esta é uma escrita emergente de um sonho coletivo. Nosso escrever é coletivizado e tem como princípio o reconhecimento do trabalho docente dentro da Educação Básica. Assim, esta carta é uma produção de um grupo de professores (as) que se permitiu repensar a sua prática e, com esperança, promover um espaço de interações e diálogos na/para/sobre seu fazer na escola. Sendo assim, esta carta também é um manifesto por uma Educação Pública de qualidade e de valorização dos seus educadores e educadoras. Queremos expressar de que maneira, nós docentes, estamos pensando o processo de formação, portando, iremos narrar nosso movimento de resistência, de desacomodar, visando problematizar nossa prática à luz do pensamento freiriano dentro da nossa realidade, ou seja, em nossa escola.

Nesta perspectiva, iniciamos nosso relato embalados por palavras como amorosidade, esperança, práxis, rigor, diretividade, possibilidade, resistência. $\mathrm{O}$ estudo dessas compreensões foi iniciado durante o Pré-Fórum de Estudos: Leituras de Paulo Freire, realizado no mês de março. Nessa ocasião, os educadores (as) da Escola Municipal de Ensino Fundamental Professor João de Oliveira Martins da cidade do Rio Grande viajaram até nossa capital, Porto Alegre, para participar das ações do Pré Fórum, atividade a qual integrou o calendário de formação continuada da escola.

\footnotetext{
${ }^{30}$ Mestra em Educação Ambiental pela Universidade Federal do Rio Grande (FURG/RS). Docente da EMEF. Prof. João de Oliveira Martins/RS. E-mail: jorginhosatt@yahoo.com.br

${ }^{31}$ Mestre em Educação Ambiental pelo Programa de Pós Graduação em Educação Ambiental da Universidade Federal do Rio Grande (UFRN). Docente da EMEF. Prof. João de Oliveira Martins/RS. Email: idaquimica@gmail.com

${ }^{32}$ Especialista em Educação Infantil e Anos Iniciais pelo Centro Universitário Leonardo da Vinci/SC. Docente da EMEF. Prof. João de Oliveira Martins/RS. E-mail: daiane_kssino@ hotmail.com

${ }^{33}$ Especialista em Educação de Jovens e Adultos pela Universidade do Paraná (UNOPAR). Coordenadora Docente da EMEF. Prof. João de Oliveira Martins/RS. E-mail: menetem@ hotmail.com
} 
Essa experiência foi frutuosa e mobilizadora, uma vez que motivados (as) pelos diálogos feitos nesse encontro os professores (as) fizeram uma provocação à direção para que fosse organizado um Pré Fórum de Leituras de Paulo Freire. Retornamos a Rio Grande, provocados (as) a desacomodar-nos e irmos de encontro à corrente da formação continuada, onde por vezes os eventos nos são enviados prontos e sem relevância para a realidade específica de cada escola. Diante disso, nos questionamos: enquanto escola, podemos promover uma formação que coloque em relevo os nossos saberes escolares e da experiência educativa?

Partindo dessa indagação, reunimo-nos e formamos um coletivo para organizar o evento na nossa escola. Trata-se de um movimento de boniteza que, conforme afirma Freire (1997), quando despertos deste sentimento encontramos possibilidades de modificar o mundo e os nossos contextos de ação. Éramos e somos empolgação pura! Dialogávamos pessoalmente uma vez por semana e virtualmente quase que diariamente. Estudamos o Dicionário Paulo Freire (STRECK; REDIN; ZITKOSKI, 2008) e elencamos verbetes suleadores do nosso evento. Formamos nossas duplas e mergulhamos em nossos verbetes. Nesse movimento de estudo, nos propomos não somente a ler os verbetes, mas com rigorosidade constatar esses conceitos na vivência escolar e a partir disso repensar nossa prática. Pesquisamos, refletimos, problematizamos, discordamos e principalmente nos acolhemos em nossas diferenças. Criamos camisetas e nos assumimos coletivo, coletivo capaz de viver na prática o que Freire denomina "inédito viável".

Apresentamos a proposta ao grande grupo da escola, queríamos envolver todos os setores dela. As turmas leram a poesia "A Escola" e dela lindos desenhos surgiram. Destes desenhos, confeccionamos cadernos que teriam a grande tarefa de tentar registrar tudo que iríamos vivenciar no nosso grande dia. O grupo de artesanato formado pela comunidade do bairro se aproxima de Freire através da imagem do livro "À sombra desta mangueira" e daí surgem várias "mangueiras" de EVA que lindamente compuseram nosso evento. Afinal, "Escola é, sobretudo gente".

Pensamos então, será que podemos ampliar ainda mais a nossa roda de conversa? Foi daí então que convidamos algumas escolas "vizinhas" para se juntar a nossa proposta. E para nossa alegria, duas aceitam o desafio e se juntam ao nosso coletivo. Foi iniciado com isso o fortalecimento da rede de escolas. 
Se houveram momentos difíceis? Sim, houve. Quando levamos a proposta para todos os nossos docentes, tiveram aqueles que resistiram e, por vezes, não participaram. Mas sabemos que a resistência faz parte de todo processo educativo e seguimos tentando mobilizar o maior número de colegas.

No sábado do dia quatorze de abril, foi realizado o Pré Fórum de Estudos de Paulo Freire da E.M.E.F. Prof. João de Oliveira Martins, um marco importante no processo de formação permanente, fazendo história enquanto escola pública da periferia que se faz protagonista de sua práxis. Empoderando e dando voz aqueles que vivem diariamente os processos de ensino aprendizagem.

Foi um momento de grande ansiedade e nervosismo para a equipe organizadora, mas também de imensa alegria e boniteza. Foi uma reunião de ideias e ideais, de crença de que é possível a transformação da escola a partir dela mesma.

Em um primeiro momento houve a fala de dois professores da Universidade Federal do Rio Grande - FURG. Neste andamento, questões como a formação de professores e a importância do legado de Freire emergiram da conversa. Foi possibilitado pensar o entrelaçamento entre o ensino básico e o ensino superior. Em um segundo momento, aconteceu as rodas de conversa por sala. E quanta riqueza de experiências (com) partilhadas, a teoria e a prática entremeadas. Foi a práxis freiriana sendo vivenciada naquele momento, pois assim como Freire (1997, p. 41), entendemos que a prática não pode ser dissociada da teoria e vice e versa. Assim, NOSSO Pré Fórum foi um momento de leitura pedagógica e de transformação em que podemos "ler a escola" em conjunto e através disso modificar nossos rumos.

Durante as rodas de conversa, trocamos relatos, experiências e desabafos sobre questões da escola e dificuldades encontradas no cotidiano. Os (as) colegas relataram a identificação com os verbetes, que ora se deu por curiosidade, ora por necessidade/afinidade, podendo com isso externar suas ideias, dúvidas e compreensões acerca das leituras realizadas. Esse foi o momento em que todos (as) "puderam dizer a palavra", para posteriormente realizarmos a síntese de tudo o que foi exposto.

Ao retornamos para o grande grupo, a apresentação das sínteses foi um momento de emoção e destaque, pois os grupos foram imensamente criativos na elaboração das suas sínteses apresentando-as na forma de acróstico, carta-pedagógica, palavras geradoras, esquemas e pequenos parágrafos. Sentimos emoção neste momento, porque 
pudemos expressar as ideias de cada grupo e ao mesmo tempo compartilhar nossos desejos, esperanças e possibilidades.

No último momento, se deu a fala da Professora da UNISINOS, trazendo sua contribuição freiriana, compartilhando suas experiências e sintetizando os principais acontecimentos do evento. Ao final, o sentimento que fica é que a experiência não está findada, dela fica a certeza de que precisamos dar continuidade ao processo de formação permanente que iniciamos com a organização do evento. Então, podemos dizer que esta carta não é uma carta de adeus, mas sim uma carta de até breve.

Rio Grande, abril de 2018. Coletivos de educadores (as) da EMEF. Prof. João de Oliveira Martins.

\section{Referências}

FREIRE, Paulo. Pedagogia da autonomia: saberes necessários à prática educativa. $6^{\mathrm{a}}$ ed. São Paulo: Paz e Terra, 1997.

STRECK. Danilo R.; REDIN, Euclides, ZITKOSKI, Jaime. Dicionário Paulo Freire. Belo Horizonte: Autêntica Editora, 2008. 


\section{CAUSAS E IMPLICAÇÕES DA INDISCIPLINA ESCOLAR EM UMA TURMA DE $6^{\circ}$ ANO DE UMA ESCOLA DE ENSINO FUNDAMENTAL EM ESTREITO - MA}

SILVA, João Carlos Marinho da ${ }^{34}$

\section{RESUMO:}

O respectivo artigo é fruto de uma investigação acadêmica acerca do fenômeno da indisciplina escolar, realizada com educadores e educandos em uma turma de $6^{\circ}$ ano, do Ensino Fundamental da Unidade Integrada Virgílio Franco em Estreito - MA. A pesquisa iniciou com um levantamento bibliográfico e, posteriormente foi realizado um estudo de campo, com o objetivo de coletar dados por meio de entrevistas, questionários e observações indiretas. A indisciplina é uma temática instigante e se constitui como um objeto de pesquisa relevante. É um atributo genuinamente humano e é caracterizado pelo comportamento inadequado do indivíduo em sociedade. A origem da indisciplina é diversa, no entanto, no âmbito educacional, está associada à ausência de afetividade no ambiente familiar; a desestruturação familiar e, sobretudo, a ausência de regras e limites instituídos pela família e pela própria escola. As consequências da indisciplina escolar são devastadoras e podem incorrer em evasão escolar, desistência e até mesmo em reprovação do educando.

PALAVRAS-CHAVE: Afetividade. Desestruturação. Escola. Família. Indisciplina.

\section{INTRODUÇÃO}

A indisciplina escolar é um tema instigante e carece de uma compreensão mais ampla acerca das causas e dos efeitos nocivos que esta disfunção social provoca no ambiente escolar. Posto que, a indisciplina é um fenômeno psicossocial caracterizado pelo distúrbio do comportamento humano e, como tal, pode incidir diretamente no baixo rendimento do educando em sala de aula.

Assim, foi realizado um levantamento de recursos bibliográficos e documentos escolares (PPP, 2014; REGIMENTO ESCOLAR, 2014), visando desta forma, compreender as causas, os efeitos e as consequências do fenômeno da indisciplina no ambiente escolar. E, sobretudo, o papel da escola no que tange à resolução do problema da indisciplina e a sua participação na construção de uma sociedade que prima por uma educação de qualidade e sem violência.

\footnotetext{
${ }^{34}$ Mestrando em Ciências da Educação pelo Programa de Mestrado Internacional da University Grendal (EUA). Psicanalista Clínico - SBPMA. E-mail: jemarinho77@ hotmail.com
} 
Em seguida foi desenvolvido um estudo de campo em uma turma do $6^{\circ}$ ano na Unidade Integrada Virgílio Franco, com o intuito de manter um contato mais direto com a realidade da escola investigada (PPP, 2014).

A escola está situada na Rua 11, s/n, no bairro Alto Bonito em Estreito - MA. Neste sentido, a coleta de dados deu-se mediante a elaboração de questionários, relatos e entrevistas semiestruturadas com educadores e, por meio de análises e observações indiretas do comportamento dos educandos em sala de aula.

A pesquisa constatou que a gênese da indisciplina escolar está na instituição familiar, já que a família representa a primeira instituição social constituída e, como tal, é a principal entidade responsável pela formação social e moral do indivíduo em sociedade. Desta forma, cabe à prole desenvolver as primeiras orientações educativas, por meio de princípios que contemplem a dignidade do indivíduo em sociedade.

Entretanto, os especialistas comungam da concepção de que em um lar desajustado e desassistido de afeto e harmonia, o índice de indisciplina e agressividade é bastante elevado. Além disso, a exposição constante à discórdia conjugal e desentendimento familiar pode desencadear nas crianças e adolescentes, ansiedade, depressão e demais distúrbios do comportamento (SHAFFER, 2005).

$\mathrm{O}$ estudo revelou que os efeitos e as consequências da indisciplina no ambiente escolar são devastadores e nocivos para a formação moral e intelectual do educando. Pois, é fato corrente que o aluno indisciplinado na maioria das vezes é interpretado como desordeiro, antissocial e, sobretudo, indesejado pelos colegas e professores em sala de aula. Fato este, que incorre em suspensão, expulsão, evasão, desistência e até mesmo reprovação no término do ano letivo. (REGIMENTO ESCOLAR, 2014).

A inexistência de uma política familiar eficiente que prima pelo estabelecimento de regras e limites dos filhos no lar, é um fator também assinalado pelo estudo de campo. Pois, estudos revelam que pais permissivos contribuem diretamente para a formação de um comportamento inadequado do indivíduo em sociedade, sobretudo no que tange ao seu respectivo ambiente escolar. (AZEVEDO, 2011).

Além disso, foi percebido que a escola como instituição formal da educação por excelência tem um papel fundamental na formação integral do indivíduo. A função da escola não se esgota somente no ato de ler e escrever, é, antes de tudo, uma missão 
humanitária. Desta forma, é pertinente ressaltar a necessidade de se estabelecer uma relação salutar entre escola, educandos e comunidade.

\section{COMPREENDENDO A INDISCIPLINA ESCOLAR}

A indisciplina é uma característica genuinamente humana e como tal, remonta ao surgimento da própria humanidade. Este fenômeno é caracterizado pelo comportamento inadequado do indivíduo em sociedade e, sobretudo, pelo descumprimento de regras, desrespeito ao próximo, inadequação moral e desobediência à ordem social estabelecida no meio no qual ele está inserido.

Desta forma, entende-se por indisciplina todo e qualquer comportamento humano que é caracterizado e interpretado pelas pessoas como uma conduta nociva, que delibera rebeldia e instabilidade emocional em um determinado ambiente social. Tratase, portanto, de ações inadequadas desenvolvidas pelo próprio homem e que não contemplam os anseios da sociedade, uma vez que as mesmas vão de encontro aos valores que regem a ordem e o bem estar social das pessoas que residem em um dado espaço geográfico.

[...] Costuma-se compreender a indisciplina, manifesta por um indivíduo ou um grupo, como um comportamento inadequado, um sinal de rebeldia, intransigência, desacato, traduzida na "falta de educação ou de respeito pelas autoridades", na bagunça ou agitação motora. Como uma espécie de incapacidade do aluno (ou de um grupo) em se ajustar às normas e padrões de comportamento esperados. [...]. (AQUINO, 1994, p. 85).

A indisciplina é concebida ainda como uma postura antiética perante os membros de um grupo social, pois, a sua prática banaliza os valores instituídos pela sociedade. Não obstante, essa inadequação moral interfere de forma negativa, não somente na esfera familiar, como se imagina. Mas é antes de tudo, um problema estrutural que incorre de forma incisiva na organização do espaço escolar e das demais instituições sociais que primam por um modelo de comportamento amistoso.

Embora, esse fenômeno não seja caracterizado em um primeiro momento como um ato de violência, isso não significa dizer que o mesmo não será considerado como tal em um futuro próximo. Haja vista, que a indisciplina representa para a sociedade o estágio embrionário de um distúrbio do comportamento humano e, caso não haja uma 
intervenção adequada nesse processo, o mesmo poderá incorrer na cultura do ódio, da agressividade e, sobretudo, na manifestação de uma violência generalizada entre as pessoas. Nesta perspectiva, Aranha e Martins (2005, p. 284), informam:

[...] há violência quando, mesmo sem usar o chicote ou a palmatória, o pai ou professor conseguem o comportamento desejado doutrinando as crianças, impondo valores e dobrando-as para a obediência cega e a aceitação passiva da autoridade. Procedimento semelhante ocorre no mundo adulto, pela manipulação ideológica que obriga á adesão sem críticas das consciências e das vontades, de modo que o indivíduo acredite estar pensando e agindo por sua própria intenção.

Em uma perspectiva educacional, o fenômeno da indisciplina é visto pela comunidade acadêmica como um comportamento irregular e prejudicial no que tange ao desenvolvimento psicossocial do indivíduo, pois o mesmo interfere de forma negativa no processo de ensino e aprendizagem do educando. Além do mais, o desencadeamento deste desequilíbrio emocional o impede de desenvolver de forma plena as suas competências e habilidades em seu respectivo ambiente escolar.

O fenômeno da indisciplina escolar é um tema relevante e está bastante em voga nas discussões acadêmicas na atualidade. Haja vista, que as suas causas são diversas e variam de acordo com a cultura e a região onde esse problema ocorre. Sabe-se, portanto, que vários fatores contribuem para a cultura deste comportamento em nosso cotidiano, podendo ser associado à desestruturação familiar; a ausência de afetividade e de bons exemplos no lar e, sobretudo, pela ineficiência de uma política que prima pelo estabelecimento de regras e limites no ambiente familiar. Segundo Rodrigues, Assmar e Jablonski (2007, p. 215):

[...] Quando as crianças, por exemplo, observam atos agressivos de alguém, elas aprendem ou adquirem uma resposta agressiva; quando, subsequentemente, interagem com outros, elas podem desempenhar uma resposta adquirida; nesse caso, a resposta selecionada é que é dependente de reforço. Estudos com adultos parecem comprovar isso: apesar de a maioria dos adultos saber como ser agressiva, a sua predisposição ou prontidão para ser agressivo depende da presença de um modelo agressivo [...].

É pertinente salientar que a prática da indisciplina, da agressividade e, sobretudo, da violência generalizada não é um fenômeno emergente como se imagina. Muito pelo contrário, trata-se de algo corriqueiro no ambiente familiar e, 
consequentemente, é reproduzida de forma discriminada e em grande escala na esfera pública.

\section{PRINCIPAIS CAUSAS DA INDISCIPLINA ESCOLAR}

\section{Ausência de Afetividade e de Bons Exemplos no Lar}

A presença da indisciplina no ambiente escolar tornou-se comum na atualidade. Vários são os fatores que concorrem para a efetivação desse comportamento inadequado no cotidiano do educando em sala de aula. Dentre eles, figura-se a ausência de afetividade e de bons exemplos no ambiente familiar.

Sabe-se, portanto, que o homem é um ser gregário e como tal, necessita de um ambiente social ajustado, que lhe permita desenvolver suas relações interpessoais de forma salutar. Para tanto, faz-se necessário que o meio no qual ele está inserido possua um estado de espírito favorável à sua formação moral e cognitiva, principalmente, no que tange a construção de um comportamento relacional, que prima pelo desenvolvimento da cultura da afetividade em sala de aula.

A vida em sociedade é necessária e essencial. O ser humano não consegue se desenvolver sem o outro. As relações são diferentes, complicadas, mas ninguém duvida de que não há como viver sem elas. Não há saída, é preciso enfrentar a diversidade e conseguir costurar relacionamentos, que se dão em vários níveis: há os familiares, os escolares, os profissionais, os eventuais, os duradouros, os sexuais, os afetivos, os políticos e outros, de modo que não existe momento de nossa vida em que não estejamos nos relacionando com alguém. (CHALITA, 2001, p. 210).

A afetividade é concebida como um sentimento genuinamente humano, sem o qual o homem não se constitui como um ser social. Trata-se de um atributo enobrecedor, que permite ao indivíduo compreender a pessoa do outro e criar laços de amizade e de respeito ao próximo. Neste sentido, notou-se durante a realização da pesquisa de campo na escola, que a ausência de uma relação afetiva no ambiente familiar não somente desencadeia distúrbios do comportamento, mas, sobretudo, afeta diretamente o processo de ensino e aprendizagem do educando em sala de aula.

Desta forma, torna-se necessário notar a grande relevância do papel da afetividade e do diálogo na construção de uma educação que preza pela qualidade. 
Ademais, sem essa prerrogativa, não se constitui de bom grado uma formação moral, profissional e comportamental do educando, uma vez que em todo empreendimento educacional é inadmissível que os agentes da educação não desenvolvam uma boa relação entre si, pautada na afetividade e no respeito mútuo em seus respectivos estabelecimentos. Nesta perspectiva, Leontiev (et al, 2005, p. 44) explica:

O desenvolvimento psicointelectual da criança realiza-se no processo de interação com o ambiente natural e social. Conduzir o desenvolvimento através da educação significa organizar esta interação, dirigir a atividade da criança para o conhecimento da realidade e para o domínio - por meio da palavra - do saber e da cultura da humanidade, desenvolver concepções sociais, convicções e normas de comportamento moral. O problema mais importante a este respeito é o da relação recíproca entre aprendizagem, educação e desenvolvimento psicointelectual.

Verificou-se durante a realização desta investigação, que a ausência de bons exemplos no ambiente escolar é um fator relevante para a compreensão do fenômeno da indisciplina escolar. Já que, o mesmo incide de forma significativa na formação da personalidade do indivíduo. A rigor, a ausência de boas referências dos pais no núcleo familiar, desencadeia nos filhos não somente um comportamento agressivo, mas, sobretudo, um desvio de conduta.

Nesta perspectiva, a atividade educacional fundamenta-se em experiências e modelos de comportamento que primam pela adequação moral do indivíduo em sociedade e, que poderão servir como bons exemplos às futuras gerações. No entanto, a ausência deste suporte familiar impossibilita que o educando desenvolva um comportamento relacional no ambiente escolar, uma vez que que este não teve uma orientação adequada em sua prole, e em detrimento da falta dessas referências indispensáveis à formação moral e social, ele está fadado ao fracasso da indisciplina. Diante disso, Nolte e Harris (2009, p. 22-3) relatam:

Um padrão de agressividade na família pode acabar ensinando às crianças que brigar é uma necessidade, uma espécie de solução. Elas podem crescer esperando que a vida seja uma batalha, que só serão tratadas com justiça se brigarem por isso. Não é o que desejamos para nossos filhos. A maneira como nós, os pais, resolvemos nossas diferenças e lidamos com as crises familiares prepara o ambiente para nossos filhos aprenderem a lidar com conflitos - seja com hostilidade e briga ou com diálogo construtivo e empenho por uma solução. 
Percebe-se, que o papel da família é de grande relevância na formação da conduta dos filhos, uma vez que essa instituição representa o primeiro grupo social que o indivíduo tem contato ao nascer e como tal, a sua função é imprescindível na formação moral e social do homem.

\section{Desestruturação Familiar}

A família é a primeira instituição social constituída que se tem notícia e o seu papel é imprescindível na formação do homem em sociedade. Entretanto, na atualidade, esta entidade tem dado sinais de falência, pois a mesma perdeu a unidade, sua principal característica. Todavia, esse desarranjo familiar reflete diretamente na indisciplina do educando em sala de aula, pois o mesmo reproduz de forma fiel os conflitos vivenciados em seu respectivo ambiente familiar.

Nesta perspectiva, a família é o primeiro grupo social no qual o indivíduo ao nascer realiza o seu primeiro contato interpessoal. Desta forma, a participação da família na formação moral e cultural do educando é indiscutível, sobretudo, no que tange ao estabelecimento de valores e princípios que nortearão o agir do indivíduo em sociedade. Pois, segundo Tiba (2005, p. 123), “a educação familiar e a escolar são básicas para a sociedade". Seguindo esta mesma linha de raciocínio, Oliveira (2002, p. 163), argumenta:

De forte influência na formação do indivíduo, a família é o primeiro grupo social a que pertencemos. Embora as normas sociais institucionalizadas determinem as regras de funcionamento da instituição familiar, cada família tem ainda suas próprias regras de comportamento e controle. Em cada grupo familiar os membros se reconhecem biológica e culturalmente, pois cada família possui uma cultura particular.

A desestruturação da família é um dos fatores de destaque na compreensão do fenômeno do distúrbio do comportamento humano e incide na formação da cultura da indisciplina, principalmente da indisciplina escolar, objeto de estudo da respectiva pesquisa realizada. Nesta perspectiva, faz-se necessário perceber que educadores e estudiosos da Educação são unânimes em apontar eventos familiares, como: separação dos pais, conflitos no lar e uso de drogas como fatores desagregadores da instituição familiar. 
Além disso, a falta de harmonia entre os membros que compõe uma dada família reflete não somente no mau comportamento do educando, mas sobretudo, em seu rendimento intelectual em sala de aula. Haja vista, que é comum entre os educadores, a concepção de que a criança que é vítima de um lar desajustado e desassistido de atenção pela família, apresenta indisposição e inaptidão para desenvolver as atividades em seu respectivo ambiente escolar. Neste sentido, Chalita (2001, p. 20) comenta:

\begin{abstract}
A família tem a responsabilidade de formar o caráter, de educar para os desafios da vida, de perpetuar valores éticos e morais. Os filhos se espelhando nos pais e os pais desenvolvendo a cumplicidade com os filhos. Não é exemplo de família aquele em que o filho assiste à mãe pegar na feira 14 laranjas e não 12, e pagar uma dúzia. Não é exemplo de família aquele em que o filho é testemunha involuntária dos desentendimentos entre os pais; ou aquele em que os pais, frustrados com a própria infância e adolescência, projetam na prole toda a energia negativa, agressiva e cruel [...].
\end{abstract}

A pesquisa revelou que a falta de apoio e de acompanhamento da família aos filhos no ambiente escolar, tornou-se uma prática corriqueira no dia a dia dos profissionais da educação, no atual contexto social. Pois, sabe-se que o educador tem assumido em sala de aula não somente o posto de orientador educacional como se imagina. Na maioria das vezes, este personagem tem acumulado de forma magistral as funções de conselheiro e, sobretudo, de terapeuta familiar, ao se deparar com crianças desoladas e desassistidas de apoio nas dependências da escola.

Desta forma, a desagregação do ambiente familiar no qual a criança está inserida, somada à ausência de um suporte moral dos pais, propicia aos filhos um terreno fértil para a reprodução da cultura da violência em seu respectivo espaço escolar. Haja vista, que esse educando advindo de um lar vulnerável e desajustado é impossibilitado de desenvolver um comportamento adequado, que lhe permita socializar-se com os seus colegas o mesmo espaço geográfico, sem deliberar um ato de indisciplina. De acordo com esta ótica, Nolte e Harris (2009, p. 15) explicam:

As crianças são como esponjas. Absorvem tudo o que fazemos tudo o que dizemos. Aprendem conosco o tempo todo, mesmo quando não damos conta de que estamos ensinando. Assim, quando adotamos um comportamento crítico - reclamando delas, dos outros e do mundo em torno de nós -, estamos lhes mostrando como condenar e criticar os outros. Estamos ensinando a ver o que está errado no mundo, e não o que estar certo. 
A criança é um ser em potencial e como tal, está sempre aberta à aprendizagem e, esta predisposição à curiosidade e à investigação faz dela um armazenador natural de informações. No entanto, é salutar perceber que esta característica pode ser prejudicada pelo ambiente familiar, uma vez que este nem sempre predispõe de uma estrutura social e psicológica adequada para o convívio de uma criança.

\section{Ausência de Regras e Limites no Ambiente Familiar}

A origem das regras é incerta, mas estima-se que a sua presença no meio social é correlata ao surgimento da própria humanidade. Entretanto, o que se sabe, é que as regras são inevitáveis e imprescindíveis à manutenção da ordem social. Já que na maioria das vezes, estas funcionam como um regulador do comportamento humano, que contemporiza conflitos e fiscaliza as atitudes inadequadas do homem em sociedade.

O estabelecimento de regras e limites é necessário ao convívio do ser humano em sociedade. Ademais, as regras são mecanismos sociais que primam pela organização moral e comportamental do indivíduo no meio no qual ele está inserido. Esse recurso humano tem a prerrogativa de manter e zelar pela ordem do ambiente, por meio de acordos e diálogos estabelecidos entre as pessoas que compõe um mesmo grupo familiar. Desta forma, Nolte e Harris (2009, p. 89) orientam que:

Toda casa funcionam com base em um conjunto de vários acordos específicos e gerais que facilitam o ritmo da vida diária em família. Desde o protocolo do jantar ao grau de limpeza exigido nas áreas comuns e até os rituais da hora de dormir, pais e filhos seguem inúmeros pressupostos tácitos que tornam mais fácil a coexistência. Esses acordos são a cola que mantém as coisas unidas em uma família, ajustando pais e filhos a satisfazem as expectativas uns dos outros.

Em uma sociedade capitalista em que as relações sociais são mediadas por uma plataforma mercadológica, manter a família sobre regras no sentido pleno da palavra, talvez seja o grande desafio do século XXI. No entanto, é necessário que se estabeleça regras e limites no ambiente familiar, sob pena dos filhos não desenvolverem um comportamento sociável no ambiente escolar. Neste sentido, a professora, codinominada de P1 ao ser entrevistada sobre a origem da indisciplina escolar, 
declarou: "a origem da indisciplina escolar está na falta de diálogo, de regras e limites impostos pelos pais aos seus filhos no ambiente familiar".

Ao contrário do que muitas pessoas imaginam, a boa relação entre pais e filhos não se constitui somente de atitudes permissivas, em que os pais para serem "aceitos" ou "aprovados" pelos filhos, devem fazer vista grossa diante do mau comportamento deles. Contudo, ao contrário do que se pensa a respeito deste fenômeno, especialistas em comportamento familiar apontam que uma boa relação entre pais e filhos pressupõe diálogo, regras e, sobretudo, a imposição de limites aos filhos.

A autoridade dos pais e o respeito por parte de seus filhos não são incompatíveis com a mais singela amizade. Por um lado, você não deve ser permissivo nem um joguete nas mãos dos seus filhos, por outro, você deve procurar ser um grande amigo deles. [...] A verdadeira autoridade e o sólido respeito nascem através do diálogo. $\mathrm{O}$ diálogo é uma pérola oculta no coração. Ela é tão cara e tão acessível. Cara, porque ouro e prata não a compram; acessível, porque o mais miserável dos homens pode encontrá-la [...]. (CURY, 2003, p. 46).

Os efeitos e as consequências da indisciplina são prejudiciais para a vida em sociedade. Haja vista, que o mau comportamento gera restrições sociais e na maioria das vezes, chega até mesmo provocar o isolamento e a rejeição do indivíduo em espaços públicos. Sabe-se ainda, que o fenômeno da indisciplina seja um comportamento antissocial e desencadeador de conflitos entre as pessoas. No entanto, é no ambiente escolar que os seus efeitos são devastadores, sobretudo, no que tange ao desenvolvimento intelectual do educando. Nessa perspectiva, Melo informa (2010, p. 29) que

\begin{abstract}
A existência na classe de um agressor em potencial ou vários deles, seu comportamento agressivo influenciará nas atividades dos demais, induzindo um comportamento agressivo. $\mathrm{O}$ agressor tem a tendência de usar da violência em situações de conflito. Ele se impõe pela força física subjugando os demais. $\mathrm{O}$ agressor identifica na sala a vítima pelas características psicológicas de ansiedade, insegurança, passividade, timidez e de aparente fragilidade [...].
\end{abstract}

Contudo, é conveniente salientar que o fenômeno da indisciplina interfere de forma negativa no processo de ensino e aprendizagem da criança. Pois, o aluno indisciplinado não consegue se concentrar em sala de aula em decorrência do seu comportamento agressivo e intimidador. Fato este, que incorre em vários 
desdobramentos, como evasão escolar, desistência e em último dos casos, a reprovação do educando ao término do ano letivo.

\section{RESULTADOS E DISCUSSÃO}

Os respectivos resultados apresentados foram extraídos de relatos, observações e questionários, realizados por meio de entrevistas semiestruturadas com os educadores e educandos do $6^{\circ}$ ano do Ensino Fundamental, da Unidade Integrada Virgílio Franco em Estreito - MA, entre os meses de Março e Junho de 2019.

Contudo, para a efetivação da pesquisa foram entrevistados 10 educadores e analisados informalmente 40 educandos da respectiva unidade de ensino. Neste sentido, a pesquisa revelou a existência de vários fatores que contribuem de forma incisiva para a instalação de uma cultura da indisciplina na sociedade, sobretudo, no que tange a indisciplina no ambiente escolar, conforme podem ser demonstrados abaixo por meio de gráficos.

Figura 1- Gráfico referente às principais causas da indisciplina escolar

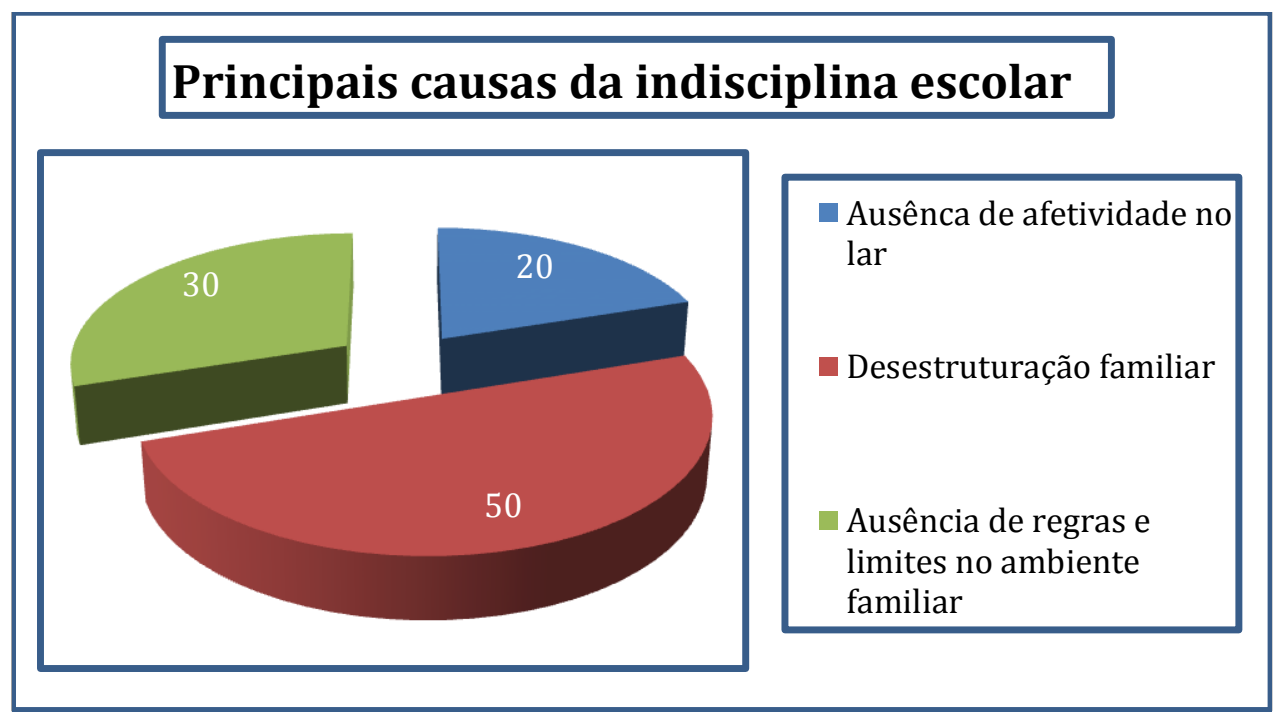

Fonte: Dados da pesquisa (elaborado pelo próprio autor)

A enquete realizada com os educadores sobre as principais causas da indisciplina no ambiente escolar revelou que, cerca de $20 \%$ dos entrevistados responderam que a origem da indisciplina escolar está na ausência de afetividade e de bons exemplos no lar. Já para a maioria dos professores, que corresponde a uma totalidade de $50 \%$ dos 
entrevistados, a causa principal da indisciplina escolar está na desestruturação da família. A "família é essencial para que a criança ganhe confiança, para que se sinta valorizada, para que se sinta assistida" [...], afirma Chalita (2001, p. 26).

No entanto, para o restante dos entrevistados, aproximadamente $30 \%$ dos professores entrevistados, declaram que a gênese do fenômeno da indisciplina escolar está na falta de regras e limites no ambiente familiar. Neste sentido, o professor, cuja identificação será pelo codinome $\mathrm{P} 2$, ao ser questionado acerca da origem da indisciplina escolar, afirma: "a origem da indisciplina escolar está na falta de acompanhamento dos pais, ausência de conversa entre pais e filhos". Neste sentido, Azevedo (2011, p. 75) informa: “[...] Os limites são uma forma de disciplina muito útil e importante para estabelecer regras com crianças e adolescentes".

Figura 2 - Gráfico referente à interferência da indisciplina na aprendizagem do educando.

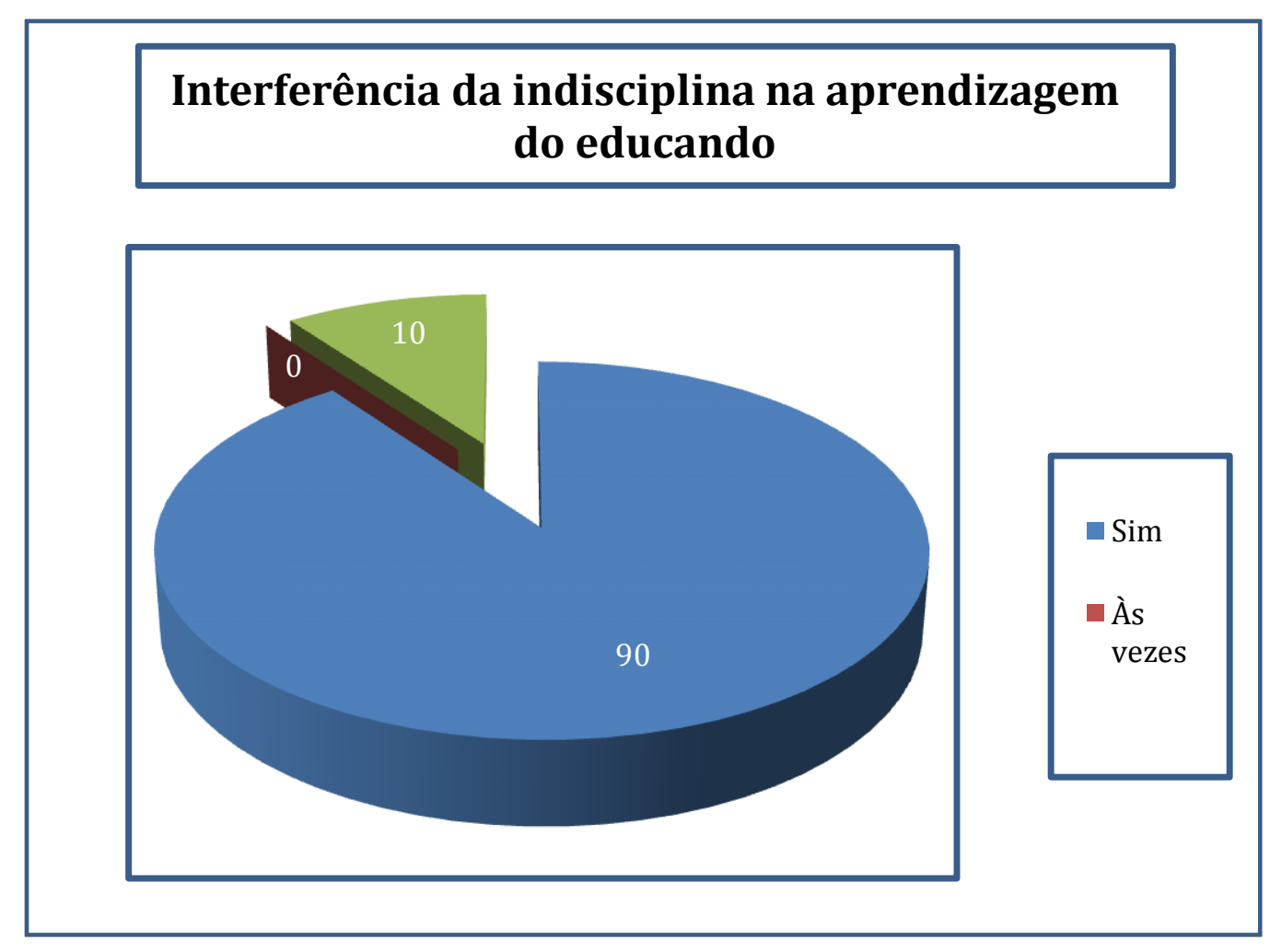

Fonte: Dados da pesquisa (elaborado pelo próprio autor) 
Quando questionados se a indisciplina interfere no processo de ensino e aprendizagem do educando, cerca de $90 \%$ dos educadores, ou seja, a grande maioria dos entrevistados disse que sim, a indisciplina é realmente um dos principais fatores responsáveis pelo déficit de aprendizagem do educando na atualidade.

Constatou-se também, que nenhum dos educadores entrevistados aderiu à opção não, por entender que o fenômeno da indisciplina é prejudicial à atividade intelectual e representa uma ameaça para o desenvolvimento do educando em sala de aula. $\mathrm{O}$ " [...] aluno disciplinado é aquele que se encaixa no molde de uma criança ideal, o indisciplinado é, ao contrário, aquele cuja imagem aparece institucionalmente fora de foco", diz Aquino (1994, p. 31). Entretanto, a pesquisa revelou que apenas $10 \%$ dos educadores submetidos à enquete optaram pela opção às vezes, por acreditarem que a indisciplina nem sempre interfere de forma radical no rendimento escolar do educando.

Figura 3 - Gráfico referente à indisciplina como promotora da violência em sala de aula.

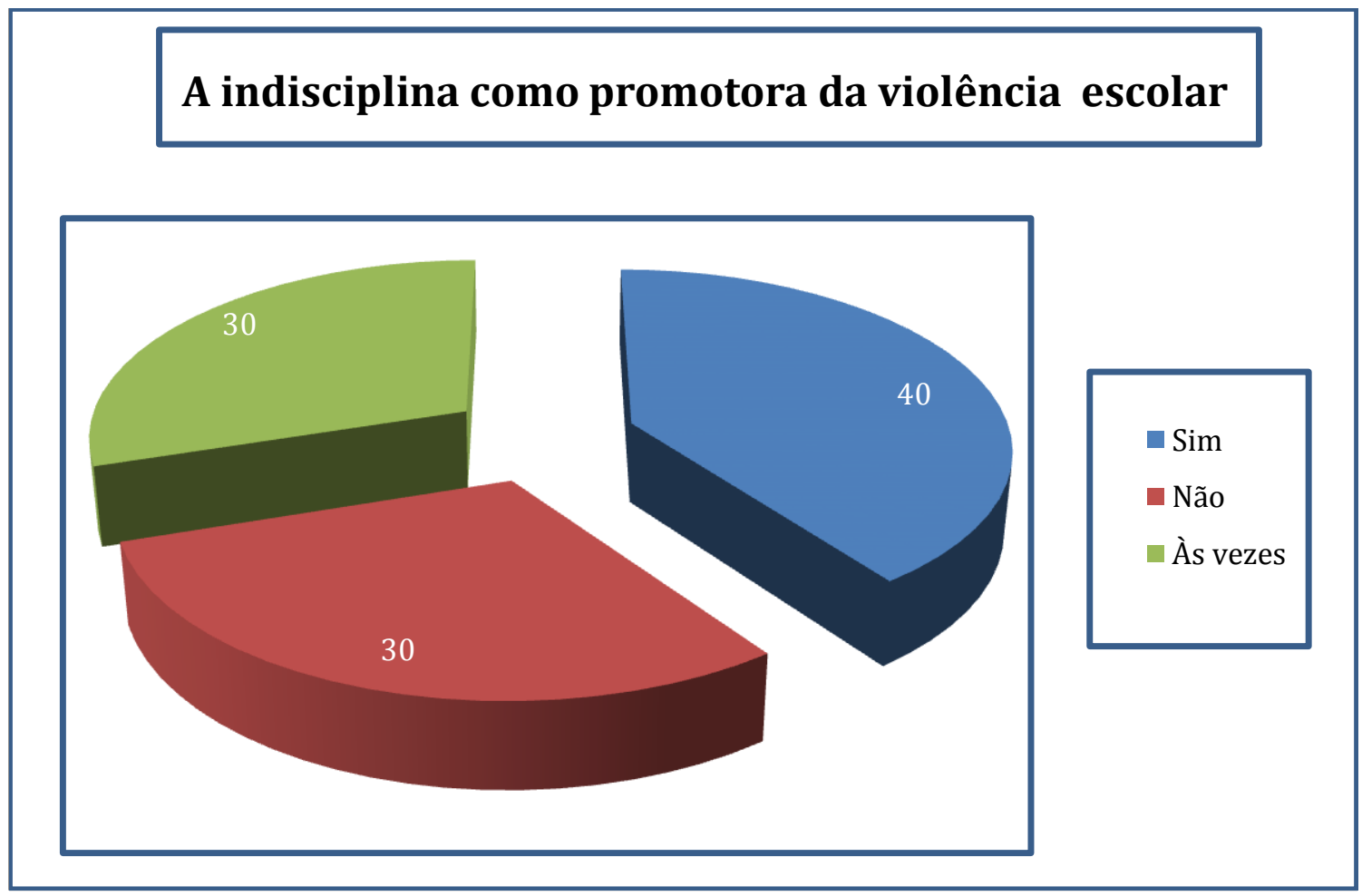

Fonte: Dados da pesquisa (elaborado pelo próprio autor) 
Ainda perguntado se a indisciplina promove a violência em sala de aula, a maioria dos educadores, cerca de $40 \%$ respondeu que sim, pois eles acreditam que a indisciplina desencadeia não somente uma atitude inadequada, mas, sobretudo, um comportamento agressivo do educando no ambiente escolar. "[...] Encontramos exemplos desses casos em qualquer pátio de recreio de escola de ensino fundamental", relatam Nolte e Harris (2009, p. 22).

Entretanto, de todos os educadores entrevistados, uma totalidade de $30 \%$ respondeu a opção às vezes, pois afirmam que apesar da indisciplina ser um comportamento inadequado, nem sempre é a causa da violência. Em contrapartida, a pesquisa revelou que os demais educadores, cerca de $30 \%$ dos entrevistados optaram pela opção não, entendendo, desta forma, que a indisciplina não promove a cultura da violência no ambiente escolar.

\section{CONSIDERAÇÕES FINAIS}

A pesquisa foi realizada de acordo com o planejado, pois, o objeto de estudo indisciplina escolar, despertou de fato o interesse e a curiosidade dos agentes envolvidos no processo de investigação. Nesta perspectiva, a pesquisa em questão procurou descobrir as causas e as consequências da indisciplina no ambiente escolar.

A familiaridade com o tema deveu-se ao fato desse mau comportamento do indivíduo, incidir de forma significativa no processo de ensino e aprendizagem do educando em sala de aula. Haja vista, que esta temática é de grande relevância não só para a compreensão do fenômeno da indisciplina escolar como se imagina, mas, sobretudo, de como o ser humano deve agir em sociedade.

Foi constatado durante o estudo, que a questão da indisciplina escolar é de grande relevância para se compreender o risco iminente que esse problema representa para a formação intelectual do educando, sobretudo, no que tange à garantia de um ensino de qualidade. Ademais, o aluno que apresenta este distúrbio do comportamento não consegue se concentrar para desenvolver as suas atividades em sala de aula.

A pesquisa revelou também, que as causas da indisciplina escolar são diversas. No entanto, a ausência de afetividade e bons exemplos no ambiente familiar; a falta de regramento e limites na prole; e, sobretudo, a desestruturação da família assinala para a gênese desse distúrbio do comportamento. 
Diante da necessidade da abordagem do assunto em questão, fez-se necessário recorrer ao auxílio de pesquisas bibliográficas e de campo com o intuito de conhecer o assunto de forma mais específica. Por isso, o estudo contou com aplicação de questionários e entrevistas com educadores, além de análises e observações indiretas com os alunos em sala de aula.

Todavia, a temática indisciplina escolar não é estanque, muito pelo contrário, é um assunto atual e requer um trato especial a seu respeito. Todavia, trazer à tona esse problema em sala de aula é bastante salutar para a compreensão deste fenômeno tão presente no cotidiano escolar. Ademais, é pertinente estabelecer uma aliança entre escola e comunidade, com o objetivo de promover mecanismos que possam dirimir as dificuldades provocadas pela indisciplina escolar na atualidade.

\section{REFERÊNCIAS}

AZEVEDO, Ivan Lima de. Limites na medida certa. Bragança Paulista: Editora Literária, 2011.

AQUINO, Julio Groppa. Indisciplina na escola: alternativas teóricas e práticas. São Paulo: Summus editorial, 1994.

ARANHA, Maria Lúcia de Arruda; MARTINS, Maria Helena Pires. Temas de filosofia. - 3. ed. rev. - São Paulo: Moderna, 2005.

CHALITA, Gabriel. Educação: a solução está no afeto. - 1. ed. - São Paulo: Editora gente, 2001.

CURY, Augusto Jorge. Pais brilhantes, professores fascinantes. Rio de Janeiro: Sextante, 2003.

LEONTIEV, Alexis... [et al]. Psicologia e pedagogia: bases psicológicas da aprendizagem e do desenvolvimento. São Paulo: Centauro, 2005.

MELO, Josevaldo de Araújo de. Bullying na escola: como identificá-lo, como prevenilo, como combatê-lo. Recife: EDUPE, 2010.

NOLTE, Dorothy Law; HARRIS, Rachel. As crianças aprendem o que vivenciam. Rio de Janeiro: Sextante, 2009.

OLIVEIRA, Pérsio Santos de. Introdução à sociologia. - 24. ed. - São Paulo: Ática, 2002. 
PPP, Projeto Político Pedagógico. Unidade Integrada Virgílio Franco. Estreito-MA, 2014.

Regimento Escolar. Unidade Integrada Virgílio Franco. Estreito, 2014.

RODRIGUES, Aroldo; ASSMAR, Eveline Maria Leal; JABLONSKI, Bernardo.

Psicologia Social. - 25. ed. - Petrópolis, RJ: Vozes, 2007.

SHAFFER, David R. Psicologia do Desenvolvimento: infância e adolescência. São Paulo: Pioneira Thomson, 2005.

TIBA, Içami. Adolescentes: quem ama educa. São Paulo: Integrare Editora, 2005. 


\section{CONSTRUÇÃO E ACIONAMENTO DO IMAGINÁRIO SOCIODISCURSIVO EM LIVROS ILUSTRADOS}

CORREIA, Júlia Vieira ${ }^{35}$

\section{RESUMO:}

A pesquisa, filiada à Teoria Semiolinguística de Análise do Discurso e desenvolvida na UFF como projeto de Iniciação Científica (2016/2017), propõe uma análise acerca da construção do imaginário sociodiscursivo em livros ilustrados. Trabalha-se, através da semiolinguística, com obras do escritor e ilustrador Ziraldo: Flicts ([1969]2012), Meninas (2016) e O planeta lilás ([1979]1986). Objetiva-se, logo, entender a importância do livro ilustrado como formador. Neste sentido, analisa-se a composição do gênero: duas parcelas indissociáveis - uma verbal e outra visual. Isto é, palavras e figuras plásticas compõem uma única narrativa, como um produto literário artístico, rico e criativo - além de capaz de contribuir para a criatividade de seu leitor. A partir disso, apura-se como o imaginário sociodiscursivo é acionado nesse processo. Ademais, considerando o público-alvo infantojuvenil das obras, investigam-se as lacunas existentes no engendramento entre o verbal e o imagético e a estreita relação delas com o acionamento desse imaginário. Neste âmbito, a pesquisa se direciona para a mediação de leitura, fundamental para a interpretação produtiva desses textos, cujo foco é a criança em formação. Contempla-se, então, o livro ilustrado como uma ferramenta de processos formativos, que, entretanto, não é explorada na educação formal pelos currículos. Como metodologia, sob orientação da professora Dr ${ }^{a}$. Beatriz Feres (UFF), houve o estudo teórico com: Nikolajeva e Scott (2011), Barthes (1990) e, principalmente, Charaudeau (2018). Houve também uma verificação de reconhecimento de signos e de acionamento do imaginário sociodiscursivo em base escolar, com Flicts (ZIRALDO, 2012). Como resultado, pode-se dizer que o imaginário explorado nesta literatura é extremamente rico e fundamental para a formação do aluno, sendo acionado tanto pela parcela verbal, quanto pela visual.

PALAVRAS-CHAVE: Semiolinguística. Imaginário sociodiscursivo. Livro ilustrado. Educação.

\section{INTRODUÇÃO}

A pesquisa propõe uma análise de livros ilustrados de Ziraldo com o objetivo de verificar a atuação do imaginário sociodiscursivo (CHARAUDEAU, 2018) na construção do sentido. Após definição e exemplificação do conceito de "livro ilustrado" como objeto semiótico, será analisada a evocação do imaginário sociodiscursivo na interpretação do conjunto verbo-visual observado na configuração de Flicts

\footnotetext{
${ }^{35}$ Mestranda do Curso de Estudos de Linguagem (UFF). Professora da rede privada de Niterói/RJ. E-mail: vieirajulia@id.uff.br
} 
([1979]2012), Meninas (2016) e O planeta lilás ([1979]1986). Busca-se investigar como as duas parcelas significativas desses textos se confrontam e interagem entre si. Pensa-se, também, em como é essa relação, se é expandida ou se limita às interpretações e em como o imaginário sociodiscursivo é acionado na interação entre as duas partes.

Este trabalho se torna importante não só por contribuir para o campo da linguística ao aplicar as teorias do texto em livros ilustrados, como também por contribuir, de certa forma, para o ensino. Difundir a literatura destinada para crianças é uma necessidade, visto que o hábito da leitura deve ser criado nesta fase para que, assim, haja um adulto leitor posteriormente.

Além disso, com esta análise, percebe-se que o livro destinado ao público infantil traz palavras, expressões, figuras, desenhos e outros signos linguísticos repletos de sentidos que contribuem para uma formação completa, de caráter cultural e discursivo. Ler e interpretar as histórias contidas nesses livros configura-se como um exercício de desenvolvimento e crescimento interpretativo dos bens simbólicos e da visão de mundo. Assim, o estímulo à leitura e à interação com essas obras é fundamental para as crianças, já que hoje há diversas outras formas de entretenimento, mas com outras finalidades.

É importante ressaltar, também, que os livros ilustrados, embora muitas vezes classificados como literatura infantil, podem ser trabalhados com crianças maiores, adolescentes e adultos. Após ler Flicts (2012) com uma abordagem mais social para as turmas de ensino fundamental II de um colégio estadual de Niterói, os alunos criaram um projeto de leitura do mesmo livro para idosos da comunidade onde se encontra a escola. A agente de leitura da escola, intrigada, achou que não seria adequado, pois se tratava de um livro infantil. Então, os alunos disseram: “depende da abordagem". Assim, já é possível constatar como o imaginário sociodiscursivo se mostra presente nessa leitura, de forma rica - por permitir tantas abordagens -, e o quão prazeroso é trabalhar com esse gênero.

\section{O LIVRO ILUSTRADO}

O livro ilustrado, objeto desta pesquisa, é uma obra verbo-visual estática formada por duas parcelas: uma verbal e uma não verbal. Essa última seria visual, isto é, composta a partir de imagens - no caso, ilustrações. A relação verbo-visual se 
consolida, no caso desta pesquisa, inerente à construção da narrativa e quase sempre amplia o sentido da parcela verbal. Os ilustradores, tratando-se de livros ilustrados, podem ser considerados coautores, nesse gênero textual, visto que as imagens produzidas são tão importantes quanto a parte verbal para a construção de sentido.

Os livros selecionados para análise são, na verdade, escritos e ilustrados pela mesma pessoa, Ziraldo Alves Pinto, o que pode explicar seu sentido ser tão integrado. As duas parcelas, além de se complementarem, têm real e igualitária importância. Para completar, nas palavras de Nikolajeva e Scott (2011, p. 13), “o caráter ímpar dos livros ilustrados como forma de arte baseia-se em combinar dois níveis de comunicação, o visual e o verbal".

É importante ressaltar, ainda, que livro ilustrado não deve ser considerado sinônimo de livro com ilustração. O processo de construção deste se dá de forma diferente do daquele. Nos livros com ilustração, o ilustrador dá uma conformação visual ao conteúdo da parte verbal, muitas vezes, limitando-a a uma interpretação pessoal. Além disso, estes livros podem apresentar inúmeros ilustradores, em diversas edições, e quase sempre criam seu texto imagético de forma redundante em relação ao texto verbal. Desta forma, a ilustração não altera a construção do sentido da parcela verbal.

Neste sentido, Nikolajeva e Scott (2011, p. 21) propõem a seguinte afirmativa: "Kristin Hallberg distingue o livro com ilustração e o livro ilustrado, sendo o último baseado na noção de iconotexto, uma entidade indissociável de palavra e imagem, que cooperam para transmitir uma mensagem". As autoras ratificam, desse modo, a ideia de livro ilustrado contendo apenas um único texto.

Deve-se destacar que a parte visual dos livros não se limita apenas aos desenhos. As cores, os tamanhos e o design têm influência sobre aquilo que é decodificado e absorvido na leitura. Além disso, tudo faz parte do livro, isto é, o título e a capa já fazem parte da história e do material utilizado para construí-la. Analisa-se, desta forma, um conjunto e não apenas elementos isolados ou específicos.

Além disso, é importante perceber que as mensagens podem estar presentes em vários elementos. Pensando em um mundo globalizado, vê-se que as mídias apresentam mensagens carregadas de informações através de diversos suportes. Barthes (1990, p. 32) ressalta, para completar, 
Hoje, ao nível das comunicações de massa, quer-nos parecer que a mensagem linguística está presente em todas as imagens: como título, legenda, como matéria jornalística, como legendas de filme, como fumetto; como se vê, questiona-se hoje o que se chamou uma civilização da imagem: somos ainda, e mais do que nunca, uma civilização da escrita, porque a escrita e a palavra são termos carregados de estrutura informacional.

A parcela imagética, que engloba todos esses fatores, nos livros ilustrados, não se apresenta apenas com a finalidade de facilitar a leitura. Em alguns casos, a imagem apenas ilustra o que foi dito no verbal, criando um processo redundante. Meninas, de Ziraldo (2016), nas páginas 15 e 17, apresenta ilustrações de meninas, corroborando o enunciado verbal das páginas 14 e 16 (Cf: imagem 4), que contêm a descrição de duas meninas. O planeta lilás, também de Ziraldo (1986), apresenta, na capa (Cf: imagem 1), abaixo do título, apenas um planeta lilás. A obra trabalha, ainda, da página 8 à 15 , somente com as cores descritas no âmbito verbal.

\section{Imagem 1}

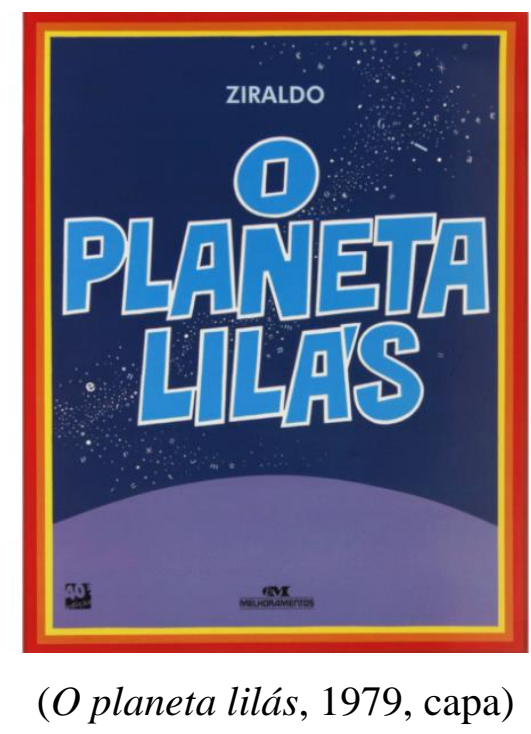

Ademais, Flicts, do mesmo autor (2012), traz, na página 5 (Cf: imagem 2), em que a história começa, o fragmento verbal "Era uma vez uma cor / muito rara e muito triste / que se chamava Flicts" ao final da página, com fundo branco, e nos outros $75 \%$ da página a cor chamada de Flicts. Nas páginas seguintes (Cf: imagem 2), há orações sobrepostas às páginas vermelha e amarela que, nestes exemplos, apenas ratificam o verbal. 


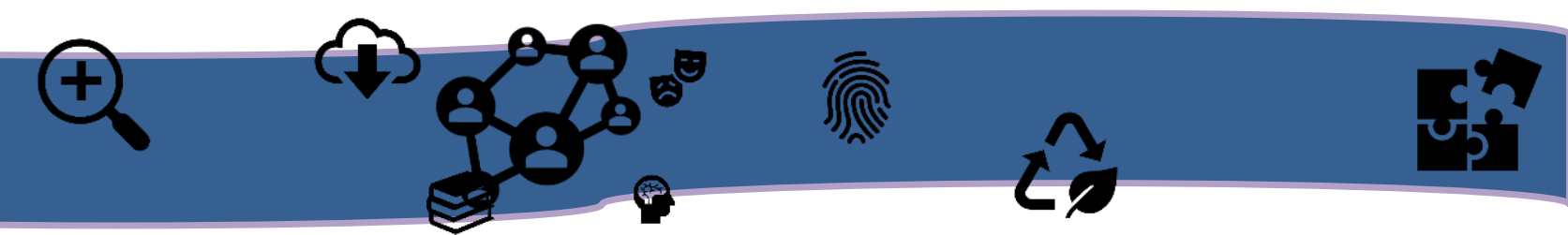

\section{Imagem 2}

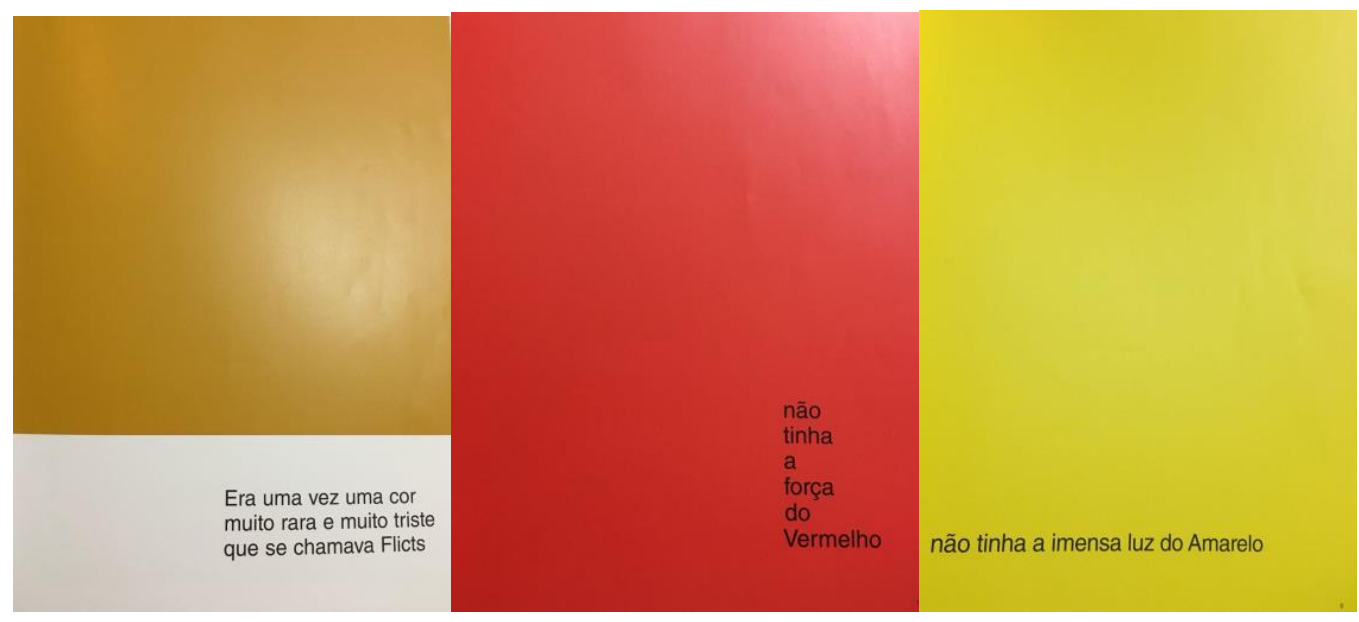

(Flicts, 2012, p. 5, 7, 9)

Em Meninas, contudo, nas páginas 34 e 35, há um enunciado verbal narrando o crescimento da menina, que estava maior que a cama e continuava a crescer “desmesuradamente”. No visual, há a ilustração atravessada das pernas da menina, cujas imagens anteriormente a projetavam em tamanho menor, cabendo inteiramente na página. Ela mostra, também, a significação do verbal, mas não a limita. É, de certa forma, redundante, mas não na mesma escala que os exemplos anteriores.

\section{Imagem 3}

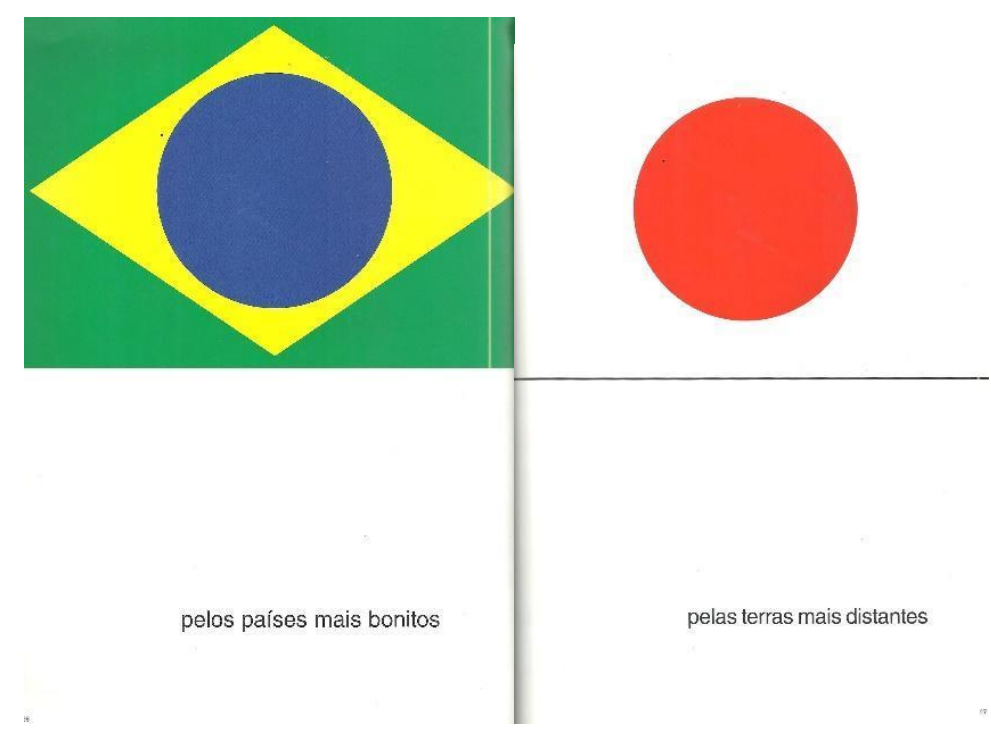




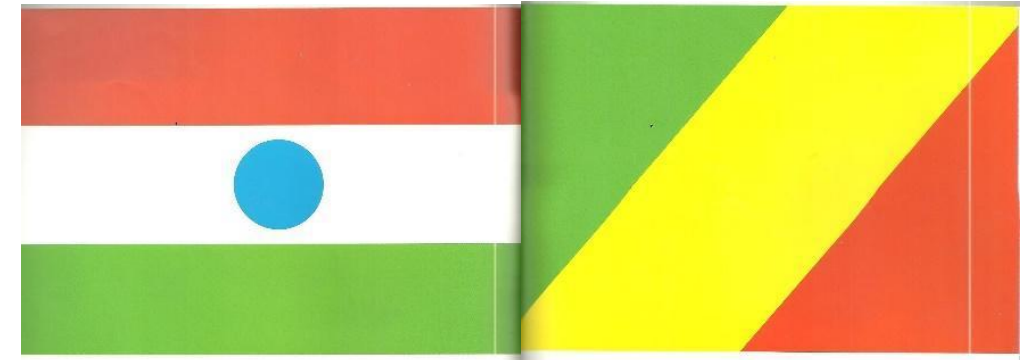

(Flicts, 2012, p. 26-29)

Em outros casos, o verbal, sozinho, não é eficiente na produção de sentidos. Isto é, a parcela verbal se ancora na visual. Ainda em Flicts, é dito que o protagonista Flicts - que seria uma cor - correu o mundo. Há, então, quatro páginas (Cf: imagem 3) com bandeiras de países e trechos verbais. Estes, sem a parcela imagética, não atingiriam o sentido que atingem com as ilustrações. As bandeiras do Brasil, do Japão, da Índia e do Congo, respectivamente, trazem a significação que faltava às frases. Isso ocorre de modo tão eficaz, porque a ilustração e a parte verbal foram construídas de forma integrada e, no caso das obras de Ziraldo, pela mesma pessoa.

Percebe-se, portanto, que as ilustrações não se dividem em "facilitadores para a parte verbal" e "sentidos necessários para o entendimento a parte verbal". Existem níveis diferentes na construção dos livros ilustrados. Algumas imagens carregam mais significados, ao passo que outras, nem tanto. Por isso, Nikolajeva e Scott (2011, p. 14) dizem que "a tensão entre as duas funções gera possibilidades ilimitadas de interação entre palavra e imagem em um livro ilustrado".

Faz-se necessária, logo, a interpretação de ambos os signos encontrados nas obras, de forma que se atinja a análise hermenêutica, que, segundo as autoras (2011, p. 14), "parte do todo, depois observa os detalhes, retorna ao todo com um entendimento melhor, e assim sucessivamente, em um círculo eterno conhecido como círculo hermenêutico." Esse procedimento é realizado por qualquer leitor e acontece de forma intuitiva. 

Serafini (2010, p. 86) explica a relação da sociedade atual com a imagem da seguinte forma:

Nicholas Mirzeoff (1998) sugere que a sociedade contemporânea é ocularocêntrica, não porque as imagens visuais são mais comuns, mas porque nossas experiências são mais bem entendidas como experiências visuais totalmente construídas. (em tradução livre)

Levando em consideração, ainda, que o público-alvo dos livros ilustrados é infantil, a experiência e o entendimento da leitura podem ser muito mais bem construídos a partir da composição verbo-visual. Por fim, cita-se Kress (apud SERAFINI, 2010, p. 96) novamente, que diz: "recursos semióticos, por exemplo, cor, fotografia e pintura, não significam apenas coisas diferentes, eles significam coisas de forma diferente" (em tradução livre).

\section{IMAGINÁRIO SOCIODISCURSIVO}

A leitura de um livro ilustrado, isto é, da obra verbo-visual estática que contém seu sentido construído a partir da integração entre as duas parcelas textuais, depende não só da interpretação dessas, mas também de um terceiro fator: do sentido discursivo que se atribui aos signos. Os signos que compõem as duas parcelas carregam significados, no entanto, cada ser interpretante traz sua bagagem cultural e a projeta nos signos de forma diferente. Barthes (1990, p. 32) diz, ainda, que "toda imagem é polissêmica e pressupõe, subjacente a seus significantes, uma 'cadeia flutuante' de significados, podendo o leitor escolher alguns e ignorar outros". As leituras, logo, divergem, como um processo natural e esperado.

Além disso, outro fator fundamental que exerce notória influência nesse processo é a linguagem - ou as linguagens, muitas vezes. No exemplo dos livros ilustrados, há a presença de duas linguagens: a verbal e a não verbal, sendo esta visual, criada a partir de ilustrações. Charaudeau (2018, p. 24) explica:

A finalidade do ato de linguagem (tanto para o sujeito enunciador quanto para o sujeito interpretante) não deve ser buscada apenas em sua configuração verbal, mas, no jogo que um dado sujeito vai estabelecer entre esta e seu sentido implícito. Tal jogo depende da relação dos protagonistas entre si e da relação dos mesmos com as circunstâncias de discurso que os reúnem. 
Essas relações, embora pareçam simples, não são. Em alguns casos, os textos limitam e condicionam a interpretação a apenas uma. Em outros, há mais possibilidades de entendimento. Como disse Charaudeau (2016, p. 51), considerando EUc como produtor de fala e TUi como sujeito interpretante, "de uma maneira geral, todo ato de linguagem envolve $n$ estratégias para o EUc e muitas possibilidades interpretativas para o TUi". Ou seja, esse processo se mostra muito mais amplo do que se imagina no momento da leitura.

Por isso, chega-se ao imaginário sociodiscursivo, objeto de investigação desta pesquisa, que não só é acionado no momento da leitura de livros ilustrados, mas também muitas vezes é criado e modificado a partir dela. Contudo, esse imaginário não é inventado, irreal ou fictício. Segundo Charaudeau (2018, p. 203),

\begin{abstract}
O imaginário é efetivamente uma imagem da realidade, mas imagem que interpreta a realidade, que a faz entrar em um universo de significações. Ao descrever o mecanismo das representações sociais, aventamos com outros a hipótese de que a realidade não pode ser aprendida enquanto tal, por ela própria: a realidade nela mesma existe, mas não significa. A significação da realidade procede de uma dupla relação: a relação que o homem mantém com a realidade por meio de sua experiência, e a que estabelece com outros para alcançar o consenso de significação. A realidade tem, portanto, necessidade de ser percebida pelo homem para significar, e é essa atividade de percepção significante que produz os imaginários, os quais em contrapartida dão sentido a essa realidade.
\end{abstract}

O imaginário sociodiscursivo, de real interesse para esta pesquisa, foi proposto com o fim de integrar a noção estabelecida acima ao quadro teórico de uma análise do discurso. Charaudeau (2018, p. 207) afirma, então, como se dá sua parte discursiva:

Os imaginários sociodiscursivos circulam, portanto, em um espaço de interdiscursividade. Eles dão testemunho das identidades coletivas, da percepção que os indivíduos e os grupos têm dos acontecimentos, dos julgamentos que fazem de suas atividades sociais.

E Rosane Santos Mauro Monnerat (2013, p. 309), tendo como base a teoria de Charaudeau, explica:

Os imaginários sociodiscursivos veiculam imagens mentais pelo discurso, configurando-se explicitamente (palavras ou expressões) ou implicitamente (alusões). Dessa forma, esses imaginários - imersos no inconsciente coletivo tecido pela história - podem contribuir para o 
estabelecimento de crenças numa determinada sociedade, orientar as condutas aceitas numa dada época e desempenhar o papel de responsáveis pela constituição do sujeito com fins de adaptação ao meio ambiente e de comunicação com o outro.

Isso significa, pois, que os imaginários preenchem as lacunas interpretativas. Em somatória, Nikolajeva e Scott (2011, p. 15) afirmam:

O texto verbal tem suas lacunas e o mesmo acontece com o visual. Palavras e imagens podem preencher as lacunas umas das outras, total ou parcialmente. Mas podem também deixá-las para o leitor/espectador completar: tanto palavras como imagens podem ser evocativas a seu modo e independentes entre si.

Essas lacunas, em maior ou menor escala, podem ser completadas a partir do imaginário sociodiscursivo. Em Flicts (Cf: imagem 3), como foi dito anteriormente, há a representação das bandeiras de quatro países: Brasil, Japão, Índia e Congo. Abaixo delas, os escritos "pelos países mais bonitos", "pelas terras mais distantes", "pelas terras mais antigas" e "pelos países mais jovens", que acionam o imaginário sociodiscursivo para que se chegue a uma interpretação completa. É preciso relacionar a beleza do Brasil com a natureza do país, com a riqueza da fauna e da flora, com as praias paradisíacas etc. É necessário, também, ter conhecimento acerca da posição em que o Japão se encontra em relação ao Brasil para então entender que aquele seria o país mais distante. E, por fim, é importante saber que a Índia é um país "antigo", conhecido desde a época da expansão marítima, e que o Congo obteve sua descoberta e sua independência tardiamente, sendo a última próxima à publicação da obra.

Durante a leitura de livros ilustrados, para que se alcance uma ou mais interpretações - já que o texto permite isso - o imaginário sociodiscursivo é utilizado. Cada leitor projeta suas vivências no texto, como disse Serafini (2010, p. 89): “imagens e textos significam coisas porque os leitores trazem experiências e entendimentos das imagens, da linguagem e do mundo para eles quando estão lendo" (em tradução livre).

Posteriormente, Serafini (2010, p. 98) dá a seguinte explicação sobre como ocorrem as percepções ao se deparar com um texto verbo-visual:

Entender as imagens e os elementos do design apresentados nos textos multimodais exige que os leitores considerem aspectos de produção e recepção, além dos aspectos da imagem e do próprio texto. A capacidade das imagens de nos afetar como espectadores depende dos 
significados culturais mais amplos que elas evocam e dos contextos políticos, sociais e culturais em que são vistas. (em tradução livre).

O imaginário sociodiscursivo se consagra como uma ferramenta produtiva para a interpretação plena dos textos, junto à decodificação das palavras e das imagens. Interpretar livros ilustrados é, então, uma tarefa que demanda três fases: leitura da parcela verbal, leitura da parcela visual interrelacionada à verbal e acionamento do imaginário sociodiscursivo - não necessariamente nessa ordem.

Meninas, de Ziraldo, traz, na página 12, com grande destaque, o texto majoritariamente verbal, mas que já possui traços imagéticos, como cor e tamanho diferentes "Era uma vez...". Inicialmente, essa expressão está enraizada no imaginário sociodiscursivo como algo que remete a inícios de contos de fadas e histórias com finais felizes. Portanto, os clássicos que se iniciam por essa sentença são evocados. Em seguida, há uma explicação: "É assim que começam / as histórias / com final feliz". Nesse momento, Ziraldo completa, mostrando que se trata de mais uma dessas histórias, seguindo o estereótipo pré-determinado.

\section{Imagem 5}

Um marinheiro que sabe diminuir e somar, imaginar jogos raros, desenredar seus problemas e que, estando no lago, sonha que está no mar. Ele segue, bem tranquilo, no comando de sua nave, com a calma de quem conhece o mar que navega. Também é um professor, que, matemagicamente, sabe todas as sentenças, proposições, locuçôes que existem no que ele fala. E, também, escreve livros. Leva na proa do barco, cantando uma canção, com sua voz pequenina, a menina.

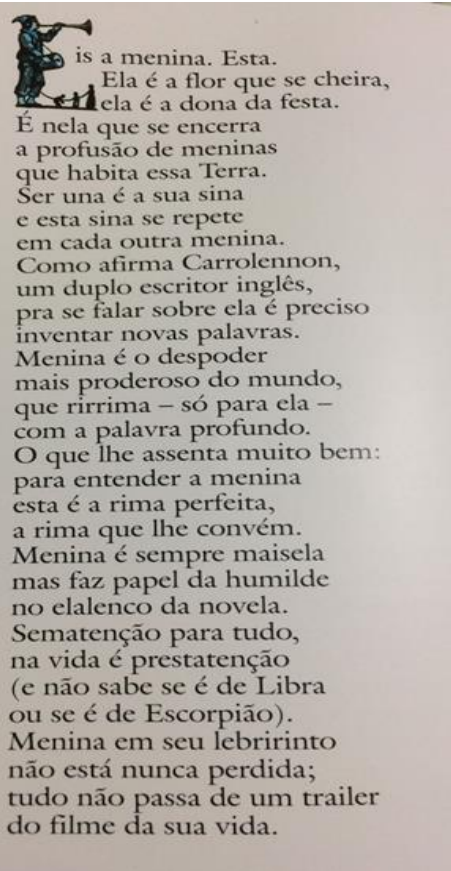

(Meninas, 2016, p. 13 e 14)

Na página 13 (Cf: imagem 5), encontram-se neologismos, que são palavras inventadas a partir dos recursos disponíveis na língua. Em “matemagicamente”, cria-se 
um advérbio para caracterizar de que forma o professor sabe tudo. Unem-se as palavras matemática e mágica no nível morfológico e, no nível semântico, reafirma-se a ideia já existente no imaginário sociodiscursivo de que a matemática é muito difícil de ser compreendida e, nesse caso, só seria possível compreendê-la junto à mágica.

Em seguida, na página 14 (Cf: imagem 5), a menina é caracterizada como "flor que se cheira". De acordo com o imaginário sociodiscursivo, sabe-se que isso seria algo positivo. No entanto, usa-se, na realidade, a expressão na forma negativa, quando alguém não presta, como "não é flor que se cheira". Depois, ainda elogiando a menina, diz-se que ela é a dona da festa. Essa construção também é encontrada no imaginário sociodiscursivo dos leitores como algo positivo.

Mais adiante, as ilustrações e o verbal introduzem uma intertextualidade (Cf: imagem 4) com a obra Alice no país das maravilhas, de Lewis Carroll. Num tom de paródia, Ziraldo constrói um texto com "país do Lugar Nenhum”, “terra do Gato-queRi", "País dos Cavalinhos", entre outros, como menções a coelhos, gatos e cavalos. Essas expressões são carregadas de sentidos - algumas mais, outras menos - que estabelecem essa intertextualidade que só se concretiza por meio do imaginário sociodiscursivo. Por essa ótica, a obra mais recente do autor é muito rica.

\section{Imagem 6}

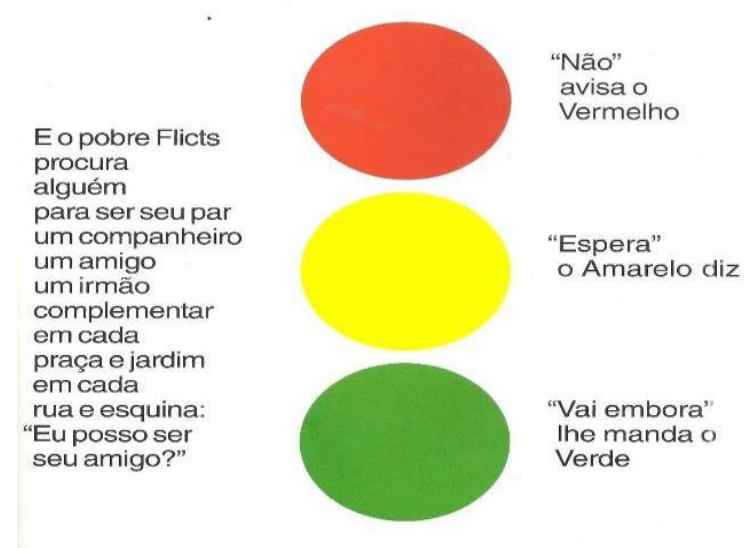

e mais uma vez sozinho o pobre Flicts se vai

(Flicts, 2012, p. 35)

Na obra de 2012, a significação das cores se mostra bastante presente também. O personagem Flicts (Cf: imagem 6) está procurando, em cada praça, jardim, rua e 
esquina, alguém para ser seu par, companheiro, amigo ou irmão. Então, há uma construção verbo-visual que apresenta as cores vermelha, amarela e verde, como em um sinal de trânsito, com os dizeres ao lado "Não", "Espera" e "Vai embora". Nesse momento, ao se analisar somente a parcela imagética, pode-se relacioná-la ao semáforo e, ao se analisar as duas parcelas, percebe-se como são complementares e aciona-se o imaginário sociodiscursivo. Verifica-se que a luz vermelha é a que diz "pare" ou "não continue" - uma negativa -, a luz amarela é a que diz "atenção, o sinal irá fechar" ou "espere" - um aviso - e a luz verde diz "vá em frente" ou "siga" - que, nesse caso, não seria em direção ao possível amigo, mas sim para Flicts seguir seu próprio caminho.

O planeta lilás, citado anteriormente, tem seu sentido construído de forma diferente. Os desenhos não são tão predominantes nas páginas. A parte visual se ancora no imaginário sociodiscursivo para criar significados. Ziraldo espera que seus leitores acreditem em seu discurso e imaginem, literalmente, que onde está indicado por setas exista aquilo que é dito no verbal.

O autor e ilustrador aproveita-se, ainda, da ideia real e bastante difundida de que não é possível enxergar coisas muito pequenas sem lente de aumento ou microscópio e muito distantes sem um telescópio ou aparelhos do gênero, como no caso do espaço, e não desenha o personagem principal nem sua espaçonave.

\section{Imagem 7}

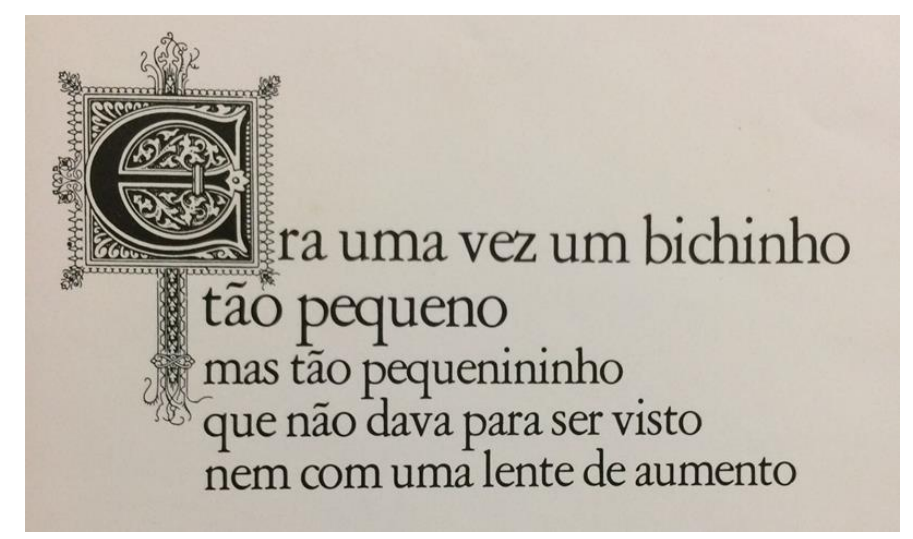

(O planeta lilás, 1979, p. 3)

Como, na parte verbal (Cf: imagem 7), é dito "Era uma vez um bichinho / tão pequeno / mas tão pequenininho / que não dava para ser visto / nem com uma lente de aumento" e em seguida "Ele era muito pequeno", justifica-se a ausência de sua imagem. 
Ademais, utiliza-se como recurso de ênfase a diminuição do tamanho da letra, de forma que a ideia expressa do verbal seja corroborada.

\section{Imagem 8}

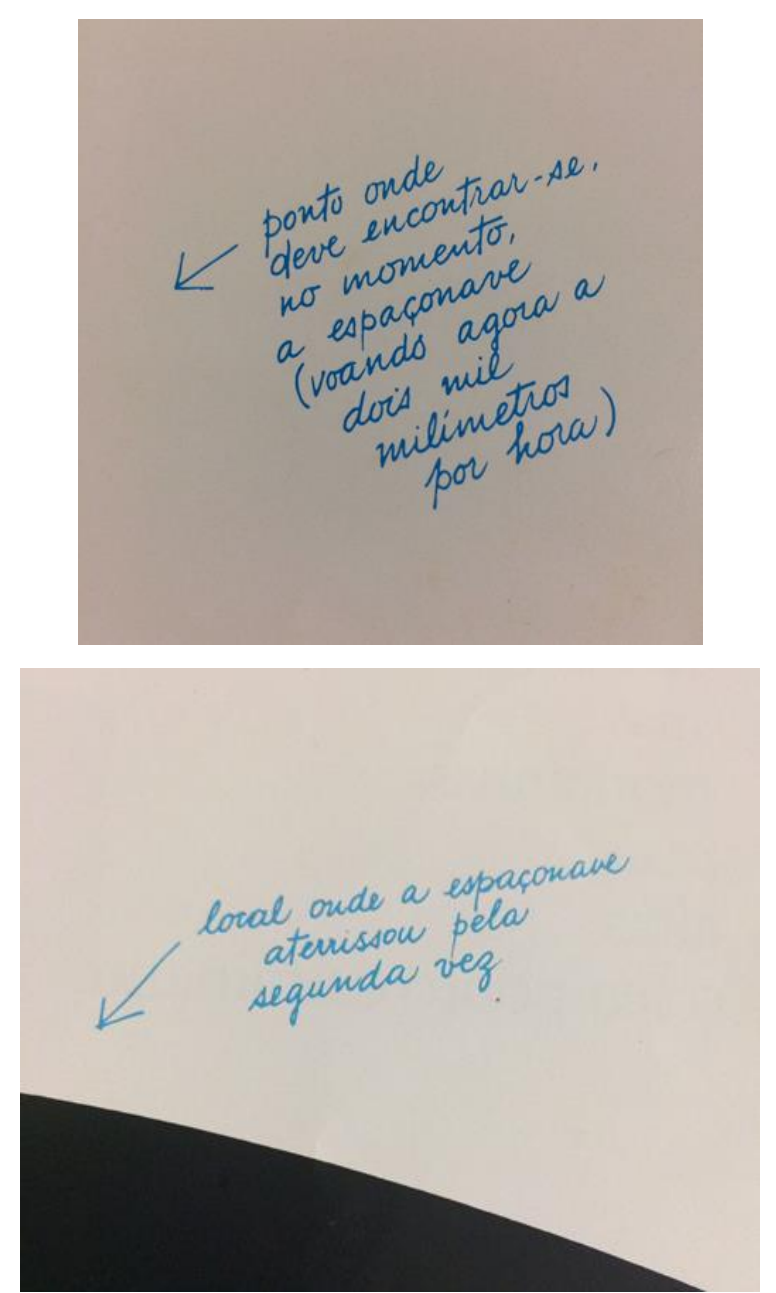

(O planeta lilás, 1979, p. 9 e 19)

Ziraldo trabalha, então, com setas e, junto de algumas, as estruturas verbais (Cf: imagem 8) "provável local / de onde a / espaçonave / foi lançada", "ponto onde / deve encontrar-se, / no momento, / a espaçonave / (voando agora a / dois mil / milímetros / por hora)", "ponto final / onde pousou / a astronave", "local onde a espaçonave / aterrissou pela / segunda vez", entre outros que ratificam a verossimilhança dentro dessa história.

Isto é, Ziraldo consegue criar uma história composta de palavras e imagens, mas sem o desenho do personagem principal e seu meio de locomoção no espaço, convencendo os leitores de que aquilo realmente é possível, dentro do campo verossímil dos livros ilustrados infantis. 


\section{EXPERIÊNCIA NA BASE ESCOLAR}

No ano de 2017, foi realizada, após este estudo teórico, uma atividade do Programa Mais Educação no Colégio Estadual Maria Pereira das Neves, localizado na comunidade do Preventório, em Charitas, Niterói. A experiência foi com o livro Flicts, levado pela professora, e foi realizada com as turmas de $6^{\circ}$ a $9^{\circ}$ ano do Ensino Fundamental.

O livro selecionado foi lido em roda de leitura, tendo a professora como mediadora de leitura nesse momento. Os alunos tiveram total liberdade para interromper a leitura, apontar questionamentos e fazer observações. Quando a participação deles não correspondia à esperada, perguntas eram feitas pela professora-mediadora a fim de acionar o imaginário sociodiscursivo.

Numa mediação de leitura imparcial, os alunos levaram o debate durante e após a leitura para questões como bullying, inclusão, preconceito e racismo. Verificou-se, portanto, o acionamento do imaginário sociodiscursivo mais concreto e também a relação do livro com a realidade exterior aos muros da escola, como prega Freire (2005).

Por fim, alguns alunos, muito envolvidos com leitura, de modo geral, e com o livro, resolveram lê-lo para os idosos da comunidade, num programa criado por eles, visando ao bem-estar dos mais velhos. Nesse sentido, pode-se entender que os alunos perceberam nos idosos dificuldades de entrosamento, como ocorre com Flicts, visto que a população mais idosa atualmente é bastante desvalorizada.

Eles foram, então, à biblioteca buscar o livro e se depararam com a versão destinada às escolas públicas, em que as cores são mais fracas. Flicts, por exemplo, é quase um laranja, e as páginas que trazem uma diversidade de cores, nesta versão, apresentam cores limitadas e praticamente iguais. Por isso, fica claro que os elementos para textuais, como material, cores, tamanho e outros fazem-se relevantes.

\section{CONCLUSÕES}

Compreendeu-se, portanto, como o imaginário sociodiscursivo se constrói dentro das narrativas e como o resultado desse engendramento - o livro ilustrado - pode ser uma ferramenta formativa. Foi visto que, em alguns casos, o verbal aciona mais o 
imaginário sociodiscursivo, como o livro Meninas (2016), que traz uma parcela verbal mais densa, repleta de neologismos carregados de sentidos. Em outros casos, o visual faz mais essa relação, como em Flicts (2012), em que as cores, muitas vezes organizadas de forma que compõem imagens significativas, trazem muitos sentidos e fazem o leitor acionar seu imaginário sociodiscursivo.

Observou-se que majoritariamente o verbal se destaca. Há uma passagem analisada, porém, que evidencia o oposto. As bandeiras, em Flicts (2012), carregam um sentido e uma explicação que a parte verbal não é capaz de trazer. Percebe-se claramente um grau de necessidade daquelas imagens mais elevado em relação a outras passagens dos livros ilustrados destacados.

Constatou-se, também, a necessidade da mediação de leitura quando o públicoalvo é infantil. Também se vê que o livro ilustrado pode ser abordado, com criatividade, em outros segmentos, ainda que os currículos assim não o façam. $\mathrm{O}$ acionamento do imaginário sociodiscursivo, portanto, mostrou-se rico e indispensável na formação dos alunos, despertando também o interesse pela leitura.

\section{REFERÊNCIAS}

BARTHES, Roland. O óbvio e o obtuso: ensaios críticos III. Editora Nova Fronteira: Rio de Janeiro, 1990.

CHARAUDEAU, Patrick. Discurso político. Editora Contexto: São Paulo, 2018.

CHARAUDEAU. Linguagem e discurso: modos de organização. Editora Contexto: São Paulo, 2016.

FREIRE, Paulo. Pedagogia da autonomia: saberes necessários à prática educativa. 52. ed. Rio de Janeiro: Paz e Terra, 2015.

KRESS, Gunther. Literacy in the New Media Age. London: Routledge. 2003.

MONNERAT, Rosane Santos Mauro. As herdeiras de uma evolução: imaginários sociodiscursivos e estereótipos. Cadernos do CNLF, Vol. XVI, nº 04, t.1 - Anais do XVI CNLF (p.306-316).

NIKOLAJEVA, Maria e SCOTT, Carole. Livro ilustrado: palavras e imagens. Editora Cosac Naify: São Paulo, 2011. 
SERAFINI, Frank. Reading Multimodal Texts: Perceptual, Structural and Ideological Perspectives. In: Children's Literature in Education (2010) 41:85-104.

ZIRALDO, Alves Pinto. Flicts. 2. ed. Editora Melhoramentos: São Paulo, 2012.

ZIRALDO. Meninas. Editora Melhoramentos: São Paulo, 2016.

ZIRALDO. O planeta lilás. Editora Melhoramentos: São Paulo, 1983. 


\title{
CONTRIBUIÇÕES DO PROGRAMA RESIDÊNCIA PEDAGÓGICA PARA A FORMAÇÃO DE DOCENTES: CONCEPÇÃO DOS PRECEPTORES
}

\author{
SOUSA, Jefferson Martins de ${ }^{36}$ \\ DANTAS, Ana Lívia Moura de Paiva ${ }^{37}$ \\ NASCIMENTO, Lidja Caroline do ${ }^{38}$ \\ CARLOS, Camila Ursulla Batista ${ }^{39}$ \\ OLIVEIRA, Glycia Melo de $e^{40}$
}

\begin{abstract}
RESUMO:
O presente estudo investigou a concepção dos preceptores do subprojeto de Educação Física da UERN, em Mossoró-RN, a respeito da contribuição do programa Residência Pedagógica para a formação dos futuros docentes. Para coleta dos dados, utilizou-se a entrevista semiestruturada com os três preceptores do subprojeto. Desta forma, estabeleceu-se três categorias de análise, a saber: Educação física escolar; Formação inicial e estágio; RESPED. Portanto, o Programa Residência Pedagógica se apresenta como um meio de formação diferenciada e mais completa, contribuindo significativamente com o estreitamento das relações entre Universidade, escola e comunidade, concebendo assim, maior propriedade aos residentes em suas atuações nas escolas, proporcionando benefícios também para os preceptores.
\end{abstract}

PALAVRAS-CHAVE: Educação Física Escolar. Programas. Docência. Preceptores.

\section{INTRODUÇÃOO}

Segundo Rangel-Betti e Betti (1996) desde a década de 1980 - com a chamada crise de identidade da Educação Física, a formação profissional é vista como questão crucial para esta área, tendo sido motivo de inúmeras produções e debates. A formação

\footnotetext{
${ }^{36}$ Licenciado em Educação Física pela Universidade do Estado do Rio Grande do Norte (UFRN). Docente Efetivo da Rede Municipal de Ensino da cidade de Patos/PB e, também, da Rede Estadual de Ensino do Governo do Estado da Paraíba com lotação no município de Sousa/PB. E-mail: jeffersonmsfla@gmail.com

${ }^{37}$ Graduada em Licenciatura em Educação Física pela Universidade do Estado do Rio Grande do Norte (UERN). Egressa do Programa de Residência Pedagógica-RESPED. Monitoria no Laboratório de Alfabetização Motora (LAM). E-mail: falarcomanna21@outlook.com

${ }^{38}$ Licenciada em Educação Física pela Universidade do Estado do Rio Grande do Norte (UFRN). Atualmente trabalha com projetos na área de Educação e gênero, além de assistência terapêutica no Método Denver de Intervenção Precoce no RN. E-mail: lidja_caroline@outlook.com

${ }^{39}$ Mestre em Educação pelo Programa de Pós-Graduação da Universidade Federal do Rio Grande do Norte. Docente da Universidade do Estado do Rio Grande do Norte. E-mail: lidja_caroline@outlook.com ${ }^{40}$ Mestre em Educação Física pelo Programa Associado de Pós-Graduação em Educação Física da Universidade de Pernambuco e Universidade Federal da Paraíba. Docente da Universidade do Estado do Rio Grande do Norte. E-mail: glyciamelo@uern.br
} 
profissional apresenta-se como principal meio para garantir aos futuros docentes acesso à produção do conhecimento, oferecendo sustentação teórica e prática aos mesmos. Desta forma, evidencia-se a necessidade de uma formação de qualidade com vistas a democratizar o conhecimento e garantir a autonomia na busca e produção do mesmo (BARBOSA-RINALDI, 2008).

Figueiredo (2004) afirma que a Educação Física ocupa, em nossa sociedade, a posição de principal promotora da saúde e, por vezes, na visão popular, está associada somente ao aspecto biológico, seja em escolas, academias, clubes ou outros locais orientados à prática de exercício. Embora que muitos discentes ao ingressarem em um curso de Educação Física tenham esta ideia supracitada, hoje já se entende que esta área ultrapassa unicamente a questão da saúde, compreendendo produções culturais que envolvem também aspectos lúdicos e estéticos (FIGUEIREDO, 2004).

Tardif (2002), no texto "Saberes Profissionais dos Professores e Conhecimentos Universitários: elementos para uma epistemologia da prática profissional dos professores e suas consequências em relação à formação para o magistério", argumenta que as experiências sociais do aluno (ginásticas, esportes, lutas, danças, jogos, etc) funcionam como um filtro através do qual ele aceita/rejeita os conhecimentos dos cursos de formação. Logo, um dos grandes desafios da formação inicial em Educação Física é conseguir abalar noções errôneas, pequenas e/ou limitadoras desta área, abrindo novos horizontes aos ingressantes.

Por sua vez, a segmentação do conhecimento, a fragmentação entre teoria e prática, e a abreviação do universo de conhecimento também está presente no ensino superior, junto com a prevalência de conteúdos técnicos e científicos e com disposição das disciplinas, fracionando o conhecimento e não permitindo que os futuros professores pensem, reflitam e nem os relacionem com sua prática profissional (BARBOSA-RINALDI, 2008).

Para Pimenta (2010), o conhecimento, a teoria como cultura objetivada, além de seu papel formativo, permitirá que os futuros professores tenham uma ação contextualizada a partir do momento em que os saberes teóricos se articulam com os saberes da prática, "[...] ao mesmo tempo ressignificando-os e sendo por eles ressignificados". Deste modo, o papel da teoria é oferecer "[...] perspectivas de análise para compreenderem os contextos históricos, sociais, culturais, organizacionais e de si 
mesmos como profissionais, nos quais se dá sua atividade docente, para neles intervir, transformando-os" (BARBOSA-RINALDI, 2008).

Ora, se as Diretrizes Curriculares para Formação de Professores apontam como campo de atuação a docência na Educação Básica, nada mais coerente que os cursos de formação de professores de Educação Física levem os futuros professores a uma compreensão sobre a instituição escolar, em especial, à respeito de seu funcionamento e cotidiano, além de pensar sobre o lugar da escola na formação dos professores de Educação Física, partindo do princípio de que sem conhecê-la, não há como entender suas reais necessidades (DUDECK; MOREIRA; MELO, 2017).

Fica claro que a elaboração do conhecimento do futuro docente encontra-se estreitamente dependente da possibilidade de o ir testando em contexto real. Assim sendo, um aspecto estratégico da formação está na integração entre conhecimento profissional e conhecimento acadêmico, realizada a partir da aproximação das experiências de formação ao contexto da realidade profissional - escola (ONOFRE, 2002). Para isso acontecer, efetivamente, o futuro docente de Educação Física deve ser preparado para enfrentar e refletir, criticamente, sobre os fenômenos e as situações conflituosas existentes na educação física escolar. Visto isso, é necessário que os cursos estabeleçam com a escola uma relação extremamente próxima para que se concretize com a prática docente uma formação mais adequada (BARBOSA-RINALDI, 2008).

Com efeito, as novas orientações para os cursos de licenciatura estabelecem também que as práticas pedagógicas devem estar presentes desde os primeiros anos da formação inicial e o estágio supervisionado na segunda metade. Isto posto, colabora-se para que a formação do professor possa ser pautada por uma prática crítica e reflexiva desde o início do curso. Neste contexto entram as Práticas como Componentes Curriculares, os Estágios supervisionados e alguns Programas formativos que dizem respeito à política nacional de formação de professores, dentre eles o Programa Institucional de Bolsas de Iniciação à Docência - PIBID e o Residência Pedagógica RESPED. Programas estes que têm contribuído significativamente para a inserção dos licenciandos nas escolas, tendo estas oportunidades de vivenciar o universo escolar já nos primeiros momentos do curso e isto, sem dúvidas, vai contribuir na compreensão que ele deve ter sobre a escola (BARBOSA-RINALDI, 2008). 
Cumpre frisar que neste trabalho a ênfase recairá sobre o Programa de Residência Pedagógica, lançado em 2018, e que visa promover a imersão do licenciando em escola de educação básica e o consequente aperfeiçoamento da formação prática. Essa imersão deve contemplar, entre outras atividades, regência de sala de aula e intervenção pedagógica, acompanhadas por um preceptor - professor da escola, com experiência na área de ensino do licenciando e orientada por um docente da sua Instituição Formadora (CARVALHO; FERREIRA, 2018).

O Residência Pedagógica, articulado aos demais programas da Capes que compõem a Política Nacional de Formação de Professores tem como premissas básicas o entendimento de que, os egressos, ao final de seus cursos, devem ter habilidades e competências que lhes permitam realizar um ensino de qualidade nas escolas de educação básica (CARVALHO; FERREIRA, 2018). A rigor, também se entende o programa como um processo de valorização do trabalho desenvolvido e consequentemente, da formação de professores. Financeiramente, ressalta-se o investimento por meio de bolsas para vinte e quatro discentes - residentes; três docentes da educação básica - preceptores; e docentes supervisores da universidade. Tudo isto referente ao subprojeto de Educação Física, cabe ressaltar.

Finalmente, evidencia-se um objetivo de estabelecer uma relação dialógica da universidade (residentes, docentes orientadores e coordenação) inserida no cotidiano da cultura escolar (alunos e alunas, professores e professoras, coordenação pedagógica, direção, funcionários dos serviços gerais e pais e responsáveis), mediante a imersão do residente no cotidiano escolar num sentido ampliado e, que deve considerar a importância do trabalho coletivo e da tarefa de aprofundamento da reflexão sobre a prática, bem como o desenvolvimento de competências que permitam um pensamento crítico à respeito da realidade (CARVALHO; FERREIRA, 2018).

Dito isso, o presente trabalho visa investigar a concepção dos preceptores do subprojeto de Educação Física da UERN, Campus Central, a respeito da contribuição do programa Residência Pedagógica para a formação dos futuros docentes.

\section{METODOLOGIA}

O presente estudo é uma pesquisa descritiva com delineamento transversal. Participaram do estudo os três preceptores (dois do sexo masculino e uma do sexo 
feminino) do subprojeto de Educação Física do Programa de Residência Pedagógica, que também são professores de escolas situadas no município de Mossoró-RN.

Para verificar e extrair o ponto de vista dos preceptores utilizou-se uma entrevista semiestruturada composta por perguntas de identificação, além de oito perguntas abordando temas acerca da Educação Física Escolar, Formação Inicial, estágio remunerado e obrigatório, experiência docente dos preceptores e, claro, acerca do Residência Pedagógica, mais especificamente sobre o subprojeto de Educação Física. O tratamento das respostas obtidas foi feito através da Análise de Conteúdo de Bardin (2009). Garantindo o anonimato dos preceptores, estes serão referidos como 'Preceptor A, Preceptor B, e Preceptor C.'

\section{RESULTADOS E DISCUSSÃO}

A partir das respostas obtidas, obteve-se três categorias, a saber: Educação Física Escolar, Formação Inicial e Estágio e Residência Pedagógica - RESPED. Um dado importante e comum é que os três preceptores foram graduados em Licenciatura Plena pela Universidade do Estado do Rio Grande do Norte, e possuem título de especialistas. Divergem apenas quanto ao tempo de atuação profissional na área, exercendo a profissão há 14, 11 e 19 anos, respectivamente para os Preceptores A, B e C.

Salienta-se ainda que estes docentes preceptores já supervisionaram inúmeros estagiários em diferentes épocas, então, logram de vasta gama de experiências e contribuições para compartilharem. Isto posto, busca-se uma opinião alheia às IES sobre concepção e entendimento destes preceptores a respeito da formação profissional em Educação Física. No Quadro 01 estão elencadas as três categorias de análise com suas respectivas ideias mais relevantes e citadas pelos docentes:

\begin{tabular}{|c|l|}
\hline CATEGORIAS DE ANÁLISE & \multicolumn{1}{|c|}{ IDEIAS RELEVANTES } \\
\hline \multirow{3}{*}{ Educação Física Escolar } & - Fundamental importância na Formação \\
& do cidadão; \\
& -Desenvolvimento integral e Socialização \\
& do aluno; \\
& - Ultrapassa a questão física e a prática \\
& esportiva. \\
\hline & - Didática; \\
& - Aulas práticas; \\
& - Estágios obrigatórios e remunerados; \\
\hline
\end{tabular}




\begin{tabular}{|c|c|}
\hline Formação Inicial e Estágio & $\begin{array}{l}\text { - Experiências da graduação; } \\
\text { - Estágio abrangente, porém solto } \\
\text { (ausência dos supervisores na escola); } \\
\text { - Estágio mostra habilidades e facilidades } \\
\text { dos estagiários - direcionamento; } \\
\text { - Praticar o ensinar; } \\
\text { - Troca de experiências de ambas as } \\
\text { partes. }\end{array}$ \\
\hline Residência Pedagógica - RESPED & $\begin{array}{l}\text { - Formação mais completa; } \\
\text { - Exige-se mais dos discentes; } \\
\text { - Maior inserção e vínculo com a escola } \\
\text { por parte dos discentes; } \\
\text { - Leva-se mais a sério que o estágio; } \\
\text { - Aprende-se mais a como ser professor } \\
\text { (administrar aula); } \\
\text { - Retira os preceptores da acomodação; } \\
\text { - Influências positivas nas aulas de EF; } \\
\text { - Pouca influência a nível de toda } \\
\text { instituição escolar. }\end{array}$ \\
\hline
\end{tabular}

Quadro 1: Concepções e ideias mais relevantes.

Evidencia-se que, no que diz respeito à Educação Física Escolar, esta é situada pelos preceptores como de fundamental importância na formação cidadã do aluno, transcendendo a questão física e à prática esportiva, acarretando o desenvolvimento integral e a socialização do aluno. Nesse sentido, Dudeck, Moreira e Melo (2017) afirmam que a formação cidadã para intervir na vida pública é um dos pilares da socialização dos alunos na escola. Destaca assim que, se deve manter a dinâmica, o equilíbrio e as normas de convivência nas instituições sociais.

Por sua vez, Neira (2009) ressalta que os objetivos da Educação Física escolar são idênticos aos da escola, cabendo, não somente a ela, mas a todos os componentes curriculares estudar e aprofundar uma parcela determinada da cultura, no caso específico da Educação Física, o patrimônio corporal. Tal fato deve ser feito examinando como grupos sociais se apropriam e criam movimentos, esportes, brincadeiras ou outros. Em função disso que se ressalta a necessidade e importância de uma ação pedagógica conjunta, atribuindo ao professor de Educação Física responsabilidade idêntica aos demais, atentando também para os temas transversais.

Como foi visto, a Educação Física tem como objeto de estudo a cultura corporal, sendo estas representações de um campo vasto que engloba a produção de práticas expressivas e comunicativas que, se apresentam a partir da expressão corporal. 
Conforme Carvalho e Ferreira (2018), é importante abarcar mais que a questão física, o processo de ação-reflexão-ação sobre a prática deve estar presente. Logo, em suas dinâmicas torna-se necessário estimular a reflexão, isto firma uma educação voltada à transformação social.

No que se refere a integração social, Rocha (2017) afirma que a Educação Física possibilita, as crianças, lograrem habilidades, conhecimentos e atitudes, isto permite-as confrontar ideias, escolher e tomar decisões. Diz ainda que, a atividade física é também um saber que deve ser compartilhado com todos - possibilitando uma consciência cívica - e devem possibilitar e orientar a escolha de valores futuros nas vidas dos discentes.

Com relação à importância da Educação Física, Pereira (2009) afirma que um dos contributos está na melhoria da saúde do indivíduo. Outra razão invocada para justificar este pensamento é o fato desta disciplina estabelecer, de maneira mais notável, relações sociais entre os estudantes.

Convém ressaltar que, quanto a Formação Inicial e Estágio, houve diversidade de ideias, sendo muito positivo para todos, porém com algumas ressalvas. Para a Formação Inicial destacaram-se a Didática e as aulas práticas como elementos importantes para o exercício docente. Os estágios - obrigatório e/ou remunerados agregaram a estes docentes vivências valiosas para suas carreiras, evidenciando assim, segundo seus relatos, habilidades e facilidades destes em determinados campos de atuação.

O meu primeiro estágio foi com o fundamental menor e, foi a partir dai que outras pessoas começaram a ver que eu tinha facilidade ou habilidade, não sei como vamos dizer, para trabalhar com crianças. Então eles começaram a me puxar e me mostrar que eu tenho essa habilidade de trabalhar com crianças (Preceptor B).

Corroborando com essa ideia Pimenta (2010) traz uma ideia de que o "estágio é suporte essencial do desenvolvimento da competência técnica necessária ao futuro professor”. Assim, também como Colombo e Ballão (2014) que afirmam que a função do estágio é reforçar o aprendizado profissional do educando através da experiência prática.

Como foi dito anteriormente, algumas ponderações foram feitas no que concerne ao Estágio Curricular. O Preceptor A, por exemplo, advertiu acerca da ausência dos 
orientadores, classificando o estágio como solto. Seguindo essa ideia, Pimenta e Lima (2006) criticam essa versão do estágio, em que ele se reduz à observação dos professores e à mera imitação desses modelos, sem nenhuma contextualização com a realidade social no qual está inserida e sem qualquer fundamentação teórica. Deve-se ainda atentar para essa questão, visto que um componente que busca aproximar a Universidade da instituição escolar apresenta uma lacuna comunicativa entre supervisores de campo e acadêmicos.

Com relação a influência do Estágio na formação dos discentes, os preceptores acreditam que este atua direcionando a prática e o ensinar, podendo servir como espelho daquilo que deve ou não ser feito, inspirando ou não estes futuros profissionais. Anacleto et al. (2017) cita que o estágio supervisionado colabora no processo formativo do futuro professor de Educação Física, servindo como momento/etapa da formação inicial que fomenta as competências necessárias para superar os dilemas e obstáculos que são inerentes ao ambiente da escola. A troca de experiências entre discente e supervisor também é citado pelos preceptores como momentos de ganhos mútuos. Guerra (1999, p. 04) colabora com esse pensamento, quando afirma que o "estágio é uma via de mão dupla, onde o estagiário precisa da escola, mas ao mesmo tempo o estagiário tem que se perguntar qual é a contribuição dele para a escola”.

No que se refere ao Residência Pedagógica - RESPED, este programa é situado, pelos preceptores, como parte de uma formação mais completa em que se exige mais dos discentes, ao passo que estes também atribuem maior conceito a este programa do que ao Estágio Curricular, embora sejam parecidos. O Residência denota uma maior inserção na escola o que, possibilita, criação de vínculos e laços entre instituição escolar e residentes, segundo Preceptor B.

O Residência apresenta-se como algo a mais na formação. Os meninos aqui estão vivenciando todos os momentos, estão tendo um planejamento maior, conhecendo mais profundamente funcionários $e$ alunos, porque tem mais tempo. O residente consegue criar um vínculo com a escola (Preceptor B).

Assim, Tardif (2005) concorda que somente o contexto do trabalho interativo cotidiano permite compreender as características cognitivas particulares da docência, e não o inverso. Este maior contato que programas de iniciação à docência como o 
RESPED proporciona, além de facilitar as experiências nas relações pessoais e profissionais, geram maior visibilidade e autonomia ao residente. Sem contar as discussões orientadas, reuniões e diálogos que contribuem de forma mais aprofundada na formação inicial. Complementando a discussão, Marcelo (2009) alerta que:

\begin{abstract}
Estar centrado na prática não necessariamente implica envolver-se em situações de sala de aula em tempo real. É dizer que para aprender, os professores necessitam utilizar exemplos práticos, casos e materiais escritos, casos de multimídia, observações de ensino, diários de professores e exemplos de trabalhos dos alunos. Estes materiais permitem que os professores obtenham informações para saber sobre a prática e discutir ensino (MARCELLO, 2009, p. 49).
\end{abstract}

Quanto aos preceptores, estes se percebem como responsáveis em relação à demonstrar aos acadêmicos/residentes a importância que estes têm e terão futuramente para com seus futuros alunos, no campo profissional. Vêem ainda o Residência como uma ferramenta para melhoria do próprio trabalho deles, pois retiram-nos de possíveis acomodações e relaxamentos, buscando assim dar exemplo para os residentes e, futuros profissionais.

O Preceptor C, ao ser questionado como se percebe na condição de preceptor, afirmou que se sente privilegiado. Complementou assegurando que esses momentos em que ocorrem trocas de experiências são muito bons porque, com o passar dos anos, há um relaxamento natural e, com a chegada dos residentes - motivados, acaba por motiválos também, fazendo com que procurem e evoluir seus conhecimentos e metodologias.

Estar disposto a fazer reflexões sobre a prática e buscar a ampliação dos conhecimentos independente da experiência, é um ponto chave na carreira docente. Neste contexto, Pimenta e Lima (2012, p. 35) afirmam que, "o modo de aprender a profissão, conforme a perspectiva da imitação será a partir da observação, imitação, reprodução e, às vezes, reelaboração dos modelos existentes na prática consagrados como bons".

\title{
CONCLUSÃO
}

Com efeito, depreende-se que a vivência do exercício docente no contexto escolar para os estudantes representa situações de aprendizado profissional, pois aproxima-os da realidade educativa deste local de trabalho. Sob esta ótica, deve 
proporcionar ao futuro docente uma interação adequada com a escola, com os alunos e com os professores da instituição, acarretando a aquisição de conhecimentos acerca do sistema educacional e a cultura profissional, bem como a obtenção da identidade profissional destes futuros docentes.

Pode-se concluir que o Residência Pedagógica, no ponto de vista dos preceptores, constitui-se um importante modo de inserção de futuros profissionais na escola, agregando influências positivas para as aulas de Educação Física e, ao mesmo tempo, acarreta ganhos e maior experiência no fazer pedagógico pelos discentes residentes, porém ainda com uma influência tímida a nível escolar.

\section{REFERÊNCIAS}

ANACLETO, F.N.A. et al. O estágio supervisionado na formação do professor de educação física: refletindo sobre o diálogo entre teoria e prática. Arquivos em Movimento, Rio de Janeiro, v. 13, n. 1, p.78-88, jun. 2017

BARBOSA-RINALDI, I.P. Formação inicial em Educação Física: uma nova epistemologia da prática docente. Movimento, Porto Alegre, v. 14, n. 03, p. 185-207, setembro/dezembro de 2008.

BARDIN, Laurence. Análise de conteúdo, Edições 70, Lisboa. Portugal, LDA, 288p, 2009.

CARVALHO, A.C.D.; FERREIRA, A.C.P. A educação física na residência pedagógica: o desafio da pesquisa-ação. ESEFFEGO, Grupo de Trabalho (GT 01: Educação Física e Contexto Escolar), 2018.

COLOMBO, I.M.; BALLÃO, C.M. Histórico e aplicação da legislação de estágio no Brasil. Educar em Revista, Curitiba, v. 1, n. 53, p.171-186, julho/2014.

DUDECK, T.S.; MOREIRA, E.C.; MELO, J.P. Reflexões sobre o lugar da escola na formação de professores de Educação Física. Motrivivência, Florianópolis/SC, v. 29, n. 51, p. 234-250, julho/2017.

FIGUEIREDO, Z.C.C. Formação docente em Educação Física: experiências sociais e relação com o saber. Movimento, Porto Alegre, v. 10, n. 1, p. 89-111, janeiro/abril de 2004.

GUERRA, Mirian Darlete Seade. Reflexões sobre um processo vivido em estágio supervisionado: Dos limites às possibilidades. 1999.22 fls. 1999. Tese de Doutorado. Dissertação (Mestrado em Educação) - Universidade Federal de Mato Grosso do Sul, Mato Grosso do Sul. 
LIMA, M. S.; PIMENTA, S. (2006). Estágio e docência: diferentes concepções. Poíesis Pedagógica, 3(3 e 4), 5-24.

MARCELO GARCIA, C. La evaluacion deldesarrolo profesional docente: de lacantidad a lacalidad. Revista Brasileira de Formação de Professores - RBFP, v.1, n. 1, p. 4370, maio/2009.

NEIRA, M.G. Em vez de formar atletas, analisar a cultura corporal. Nova Escola, 2009; n. 224, p. 38-42, ago. 2009.

ONOFRE, M.T.A.S. Das características do conhecimento prático dos professores de educação física às práticas da sua formação inicial. Sociedade portuguesa de educação física, 2002.

PEREIRA, P.; COSTA, F.C.; DINIZ, J.A. as atitudes dos alunos face à disciplina de educação física: um estudo plurimetodológico. Boletim SPEF n. ${ }^{\text {34 }}$, pp. 83-94, 2009.

PIMENTA, S.G. O estágio na formação de professores: unidade teoria e prática-9 ed. São Paulo: Cortez, 2010.

PIMENTA, S. G.; LIMA, M. S. L. Estágio e Docência. 7ª ed. São Paulo: Cortez, 2012.

RANGEL-BETTI, I.C.; BETTI, M. Novas perspectivas na formação profissional em educação física. Motriz - Volume 2, Número 1, junho/1996.

ROCHA, L. Não Educação sem Educação Física: Educação Física e Educação Cívica. Sociedade Portuguesa de Educação Física, 2017.

TARDIF, M. Saberes profissionais dos professores e conhecimentos universitários: Elementos para uma epistemologia da prática profissional dos professores e suas consequências em relação à formação para o magistério. Revista Brasileira de Educação, Jan/Fev/Mar/Abr 2002.

TARDIF, M.; CLAUDE, L. O trabalho docente: elementos para uma teoria da docência como profissão de interações humanas. Petrópolis, RJ. Editora Vozes: 2005. p. 32-33. 


\section{DO CÁRCERE À CASA DE CULTURA: UMA NOVA PERSPECTIVA}

SILVA, Josevane Francisco da ${ }^{41}$

\section{RESUMO:}

O texto procura discutir às ações do processo que culminou na desocupação da Antiga Casa de Detenção do Recife, para a implantação no mesmo espaço de uma Casa da Cultura como um projeto amplo político e sociocultural para Estado de Pernambuco. Refletir sobre a ressignificação do espaço carcerário que funcionou durante 118 anos no centro da cidade do Recife e o término de suas atividades penitenciárias levado ao cabo entre 1971 - 1973. O período de sua reestruturação e recebimento de novos equipamentos para o exercício de sua nova atividade e a reinauguração do antigo prédio centenário em 1976, como Casa da Cultura do Estado de Pernambuco - denominada Casa da Cultura Luiz Gonzaga.

PALAVRAS-CHAVE: Cultura. Patrimônio. Identidade.

\section{INTRODUÇÃO}

A pedra fundamental para a construção da antiga Casa da Detenção do Recife foi colocada no solo às 04:00h do dia 08 de dezembro de 1850 (DP,09/12/1850, p.1), sito à Rua Floriano Peixoto por detrás da Rua da Concórdia, sobre a margem do Rio Capibaribe, que corta o centro da cidade do Recife e deságua no Oceano Atlântico. A casa de Detenção funcionou por 118 anos e foi desocupada em 1973 - em pleno regime militar - e os presos foram transferidos para outras unidades prisionais construídas na região metropolitana do Recife e no interior do Estado (DP, 16/03/1973, p. 1).

Depois de uma reforma ininterrupta que durou três anos conduzida pela Fundação do Patrimônio Histórico e Artístico de Pernambuco - FUNDARPE, a antiga Casa foi inaugurada como Casa da Cultura do Estado de Pernambuco em 11 de abril de 1976 (JC, 11/04/1976, p.13), onde funciona até os dias atuais. A Casa da Cultura foi tombada como patrimônio cultural do Estado em 16 de maio de 1980 (DP, 21/05/1980, p. 5).

\footnotetext{
${ }^{41}$ Mestrando pelo Programa de Pós-graduação em História da Universidade Católica de Pernambuco (PPGH-UNICAP). E-mail: josevanepaz@yahoo.com.br 
Imagem n ${ }^{\circ}$ 1: Antiga Casa de Detenção do Recife.

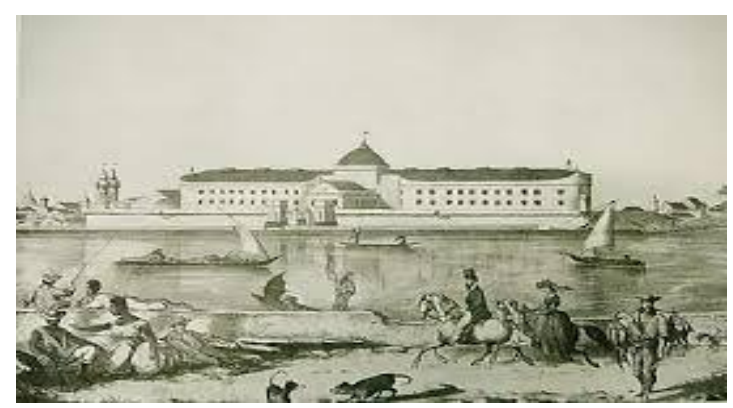

Fonte: Acervo FUNDARPE.

Neste artigo, falaremos sobre o processo de transição da antiga Casa de Detenção do Recife, para à Casa da Cultura de Pernambuco e de sua importância para o desenvolvimento das ações culturais para o Estado, bem como do seu alcance para às demais regiões nordestinas.

Imagem $\mathbf{n}^{\circ}$ 2: Casa da Cultura de Pernambuco

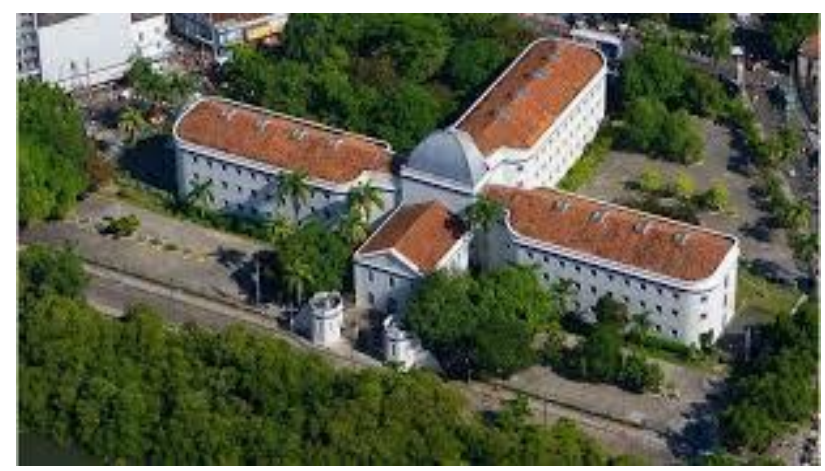

Fonte: Acervo FUNDARPE.

Falar sobre cultura, entretanto, iniciaremos com a reflexão da escritora Silva (2010):

O significado mais simples desse termo afirma que a cultura abrange todas as realizações materiais e os aspectos espirituais de um povo. $\mathrm{Ou}$ seja, em outras palavras, cultura é tudo aquilo produzido pela humanidade, seja no plano concreto ou no plano imaterial, desde artefatos e objetos até ideias e crenças. Cultuar é todo complexo de conhecimento e toda habilidade humana empregada socialmente. Além disso, é também todo comportamento aprendido, de modo independente da questão biológica. 
Essa definição foi criada por Edward Tylor no século XX e, apesar de sua atualidade, gerações e gerações de antropólogos procuraram aprofundá-la para melhor compreender o comportamento social. Entre esses pensadores, um dos mais influentes foi Franz Boas, que no começo do século $\mathrm{XX}$, iniciou uma crítica sistemática às teorias até então vigentes que defendiam a existência de uma hierarquia entre culturas. Tais teorias chamadas evolucionistas pela influência de obras de Charles Darwin, defendia que todas as culturas passavam pelas mesmas etapas, ou estágios, durante sua existência, evoluindo, progredindo das mais primitivas para as mais avançadas ao longo do tempo, sendo que o estágio mais avançado da humanidade era o atingido pelo Ocidente, visão que dava ao etnocentrismo status de ciência (SILVA, 2010, p. 85).

Para Calabre (2009):

Na década de 1950, foi marcada por movimentos de polarização das artes e de renovação estética, como a bossa nova, o cinema novo, a poesia concreta ou os grupos de teatro Arena e Oficina. Para Renato Ortiz (1991:164), na década de 1950 até meados de 1960, "relação entre política e cultura se expressava como complementaridade" e "os grupos culturais podiam, dessa forma, associar o fazer cultura ao fazer política (CALABRE, 2009, p. 56).

Segundo Silva (2001), antes de desfechar-se o golpe civil militar de 1964, o Brasil vivia uma efervescência cultural. Destacavam-se neste período diversas manifestações culturais, da música à literatura, do teatro à explosão do cinema.

\begin{abstract}
A década de 60 será sempre lembrada como a época dos grandes festivais de música popular brasileira, do Cinema Novo, dos Teatros Oficina e Arena, do Centro Popular de Cultura (...) da jovem guarda e o Tropicalismo. Nesta época, marcada pela experimentação, pela revolta contra o estabelecido, pela busca de um a linguagem artística posta a serviço da revolução, vários artistas e intelectuais militantes em suas áreas de criação buscavam fórmulas para promover a conscientização do povo brasileiro de forma a levá-lo a assumir seu lugar na revolução que se aproxima. A percepção da cultura como "elemento de transformação socioeconômica" [...], produzida na década de 50, durante o governo de Juscelino Kubitschek, e mantida até a sua extinção após o golpe militar de 1964 (SILVA, 2001, p. 27).
\end{abstract}

Na visão de Calabre (2009), o início da década de 60 havia sentimentos de mudanças profundas e de significados tanto no campo da política, como nas manifestações artísticas e culturais. Por um lado, havia um direcionamento da cultura de massa notadamente através do rádio e da televisão que adentravam nos lares e 
influenciavam o cotidiano das pessoas. Nesse caso, as produções hollywoodianas, a chegada do estilo rock and roll, a bossa nova dentre outros estilos musicais (CALABRE, 2009, p. 57).

\section{COMO SURGIU A IDEIA DA CASA DA CULTURA}

Neste momento de contestação e efervescência, chegou ao Brasil o conhecimento acerca das políticas culturais que já vinham sendo experimentadas em alguns países da Europa, mas precisamente, na Espanha e na França. O que deu maior visibilidade com a execução e os resultados do projeto foi o francês. Fruto das ações promovidas pelo Ministro da Cultura do governo de Charles de Gaulle, André Malraux, em 1961, divulgou-se a criação de Casas da Cultura por todo território galo, como parte do primeiro plano quinquenal relativo às atividades culturais (CALABRE, 2009, p. 72).

O sucesso desta política cultural desenvolvida na francesa não demorou para ultrapassar às suas fronteiras e influenciar propostas similares em países tão distantes como o Brasil. Alguns Estados, dentre os quais Pernambuco, tentaram levar à prática algumas pautas da agenda francesa, porém, buscando traduzi-las e adaptá-las às especificidades de cada região. Não é por demais lembrar que em 1963, o então Governador Miguel Arraes expressasse desejos de transformar a antiga Casa de Detenção do Recife, em uma Casa da Cultura do Estado de Pernambuco (DP, 08/01/64, p. 5).

Para auxiliar e pensar a viabilidade do empreendimento, foi convidado para assumir a chefia da Casa Civil do Estado o já reconhecido artista plástico Francisco Brennand, pois através de seus contatos e ações se facilitariam a um só tempo, tanto as negociações com as autoridades políticas, como com os grupos empresariais, além de angariar o apoio do meio artístico e intelectual (LEAL, 1983, p. 1). Em matéria publicada no Diário de Pernambuco, em 06 de outubro de 1963, destaca-se justamente esse papel de articulador em nível nacional, esforçando-se por demonstrar a importância político-econômica e cultural para o Estado (DP, 06/10/1963, p. 3).

Foi neste momento que Brennand se aproximou da embaixada da França com intuito de fazer um intercâmbio, para obter mais detalhes a respeito de como foram implantadas as Casas da Cultura daquele país, sob o auspício do Ministro da Cultura da 
França, André Malraux. Interessa então, segundo Leal, tentar construir uma relação harmoniosa, realizando intercâmbio envolvendo os dois países.

Neste sentido, deve-se acrescentar que a ideia da criação de uma Casa da Cultura para o Estado de Pernambuco, na mesma edificação que até então funcionava um estabelecimento penal, teve como incentivo, além da valorização patrimonial de um edifício emblemático encravado num dos locais mais privilegiados da cidade, a influência de um dos mais célebres movimentos culturais já produzidos em Recife e no Brasil, notadamente, conhecido por Movimento de Cultura Popular (MCP). Posto em atividade em 1960, o CMP,

[...] foi instituído para promover e incentivar com ajuda de particulares e dos poderes públicos a educação de crianças e adultos e proporcionar a elevação do nível cultural do povo. Era um departamento autônomo da prefeitura do Recife, cuja sede era situada nas históricas terras do Arraial do Bom Jesus. O MCP foi envolvido pelo simbolismo da "Recife da insurreição pernambucana. Do nativismo. Da abolição. Das revoluções libertárias”. Um grupo de intelectuais artistas e educadores como apoio da prefeitura da cidade do Recife, propõe-se a tarefa de "organizar" as massas urbanas, em um processo cujo objetivo era livrar a sociedade recifense da opressão exercida pelo atraso econômico e social que imperava naquela capital em meados do século XX (SOUZA, 2014, p. 11).

Para Soares (1982, p. 22) se experimentava na década de 1960, um profundo sentimento de insatisfação com o desenvolvimento econômico desigual da região, sobretudo em relação a outros estados do sul do Brasil, intensificando ainda mais a geração de uma pobreza profunda.

Foi, portanto, nesse contexto, que Brennand, enquanto na dianteira em viabilizar o projeto, deu os primeiros passos para o processo de desocupação e reestruturação da antiga Casa de Detenção do Recife, a fim de transformar a nova Casa, agora da Cultura do Estado de Pernambuco (DP, 06/10/1963, p. 3).

O secretário do interior e da Justiça e o Deputado Souto Dourado, juntamente como o artista plástico buscavam após algumas visitas prévias ao estabelecimento e várias gestões, transferir os presos existentes na já centenária Casa de Detenção para outras unidades prisionais pernambucanas. Uma dessas visitas foi realizada na companhia de Lina Bo Bardi, arquiteta modernista ítalo-brasileira, bastante conhecida por ter projetado o Museu de Artes de São Paulo (BRENNAND, 2019). 
Em entrevista concedida no dia 17 de abril de 2019, em seu ateliê, Brennand afirmou que a visita visou a realização de um levantamento das condições do imóvel e quais seriam as primeiras medidas efetivas a se fazer após o seu esvaziamento. Conforme o projeto original, o prédio havia de passar por uma reforma profunda a fim de melhorar a sua infraestrutura bastante comprometida depois de mais de um século de uso contínuo.

Com o golpe civil-militar de 31 de março de 1964, e, com a prisão e exílio do Governador Miguel Arraes, na sede do Poder Executivo no Palácio do Campo das Princesas, o projeto que ainda não havia sido executado, ficou para trás deixado literalmente todo sua organização em cima da mesa, como relatou em entrevista o exchefe da Casa civil, Francisco Brennand:

[...] Nós chegamos a fazer escultura, leituras, comparações etc., mas tudo isso ficou em cima de minha mesa [...] que dizer era um projeto ambiciosíssimo e calharia muitíssimo bem com aquilo que Arraes pretendia na época, que Arraes era um revisor, ele queria modificar, ele tinha suas ambições nacionais que não puderam se concretizar mas no fundo do se coração eu acredito que ele queria ser presidente da República, não era para menos" (BRENNAND, 2019).

O projeto pernambucano de criar uma Casa da Cultura para o Estado não ter tido tempo de nascer sob o governo Arraes, a ideia da Casa de Cultura não pareceu estar em desalinho e nem foi abandonada pelos governos posteriores. Depois de alguns anos paradas, ações para a sua concretização parecem ter ressurgido com toda força a partir dos anos de 1970. É oportuno frisar que discutida e agradado alguns setores do governo à época, construção da primeira Casa da Cultura saiu do papel em finais de 1970, no Estado baiano, na cidade de Lençóis, Nos anos subsequentes já contava dezessete casas, distribuídas pelo Brasil:, Amazonas, Acre, Pará, Bahia, Rio de Janeiro, Minas Gerais, Mato Grosso, Rio Grande do Norte, Rio Grande do Sul e São Paulo (CALABRE, 2009, p. 73).

Como frisamos neste artigo, em Pernambuco, o projeto caiu no esquecimento. Mesmo que pensado por políticos e intelectuais há vários anos, somente no ano de 1973, já sob o governo de Eraldo Gueiros Leite, que resolveu-se retomá-la através da secretaria da pasta da Justiça e do Interior do Estado, presidida por José Paz de Andrade. Enquanto responsável pelo sistema prisional, coube a ele as ações para 
encerrar o funcionamento da Casa de Detenção, e a transferência dos presos remanescentes para outros estabelecimentos, como a Penitenciária Agrícola e Colônia Penal da Macaxeira (DP, 16/03/1973, p. 1).

Com a retomada da criação da Casa da Cultura inseria-se, tal como algumas de suas homônimas, num valioso projeto nacional estabelecido pelos militares, conhecido como Programa Integrado de Reconstrução das Cidades Históricas do Nordeste, como o claro interesse de fomentar o turismo de dentro e fora do país, buscando assim incrementar a renda de uma parcela menos favorecida da população e, por fim, o desenvolvimento da economia local. O referido programa fazia parte da política desenvolvimentista levado a cabo pela Superintendência do Desenvolvimento do Nordeste SUDENE ${ }^{42}$ conforme parecer da Fundação do Patrimônio Histórico e Artístico de Pernambuco - FUNDARPE e assinado pelo Secretário do Planejamento do Governo Federal em $1974^{43}$.

O projeto foi recepcionado e celebrado com o termo de cooperação técnica entre o Governo Estadual e Federal, pois, como atendia aos requisitos recebeu parecer favorável do IPHAN, ${ }^{44}$ que estava dentro da filosofia do Programa Cidades Históricas do Nordeste (PCHN) do Governo Federal, para construção da Casa da Cultura de Pernambuco.

\footnotetext{
${ }^{42}$ Ata da $162^{a}$. Reunião Ordinária do Conselho Deliberativo da Superintendência do Desenvolvimento do Nordeste (SUDENE), realizada no dia 19 de dezembro de 1973, sob a presidência do Exmº Sr. Dr. João Paulo dos Reis Veloso, Ministro do Planejamento e Coordenação Geral, no auditório Marechal Humberto de Alencar Castelo Branco, situado no $19^{\circ}$ andar do edifício INPS, à Avenida Dantas Barreto n 315 , na cidade do Recife, Capital do Estado de Pernambuco. Disponível em: http://procondel.sudene.gov.br/ acesso dia 13 de julho 2019.

Instituto do Patrimônio Histórico e Artístico Nacional é uma autarquia federal do Governo do Brasil, criada em 1937, vinculada ao Ministério da Cidadania, responsável pela preservação e divulgação do patrimônio material e imaterial do país.

${ }^{43}$ - Projeto-PE - 004 - (Antiga Casa de Detenção do Recife) - Parecer da Secretaria Executiva do Programa Integrado de Reconstrução das Cidades Históricas do Nordeste, com sua utilização para fins turísticos, sobre o projeto de agenciamento e equipamento complementar da Casa da Cultura de Pernambuco (Arquivo Geral do IPHAN - Cx $-32-\mathrm{PCH}$, p.1/ Doc. Olinda/Recife. Ata da 162 $2^{\mathrm{a}}$. Reunião Ordinária do Conselho Deliberativo da Superintendência do Desenvolvimento do Nordeste (SUDENE), realizada no dia 19 de dezembro de 1973, sob a presidência do Exmº Sr. Dr. João Paulo dos Reis Veloso, Ministro do Planejamento e Coordenação Geral, no auditório Marechal Humberto de Alencar Castelo Branco, situado no $19^{\circ}$ andar do edifício INPS, à Avenida Dantas Barreto $n^{\circ} 315$, na cidade do Recife, Capital do Estado de Pernambuco. Disponível em: http://procondel.sudene.gov.br/ - acesso dia 13 de julho 2019.

${ }^{44}$ Instituto do Patrimônio Histórico e Artístico Nacional é uma autarquia federal do Governo do Brasil, criada em 1937, vinculada ao Ministério da Cidadania, responsável pela preservação e divulgação do patrimônio material e imaterial do país.
} 
A assessoria técnica do PCHN opinou favoravelmente no sentido de que a Casa de Detenção do Recife fosse restaurada conforme o organograma de execução entre o Governo de Pernambuco e o Governo Federal. Desta forma, ficou acordado por parte do Governo de Pernambuco a contrapartida de $20 \%$ (vinte por cento) do total das inversões fixas, correspondente a Cr\$390.000,00 (TREZENTOS E NOVENTA MIL CRUZEIROS). Por outro lado, o projeto fosse merecedor do aporte financeiro no valor de Cr\$ 1.560.000,00 (HUM MILHÃO, QUINHENTOS E SESSENTA MIL CRUZEIROS), por parte do Governo Federal, perfazendo um total de $80 \%$ (oitenta por cento) das inversões. ${ }^{45}$

A liberação desses recursos estava condicionada ao cronograma de desembolso, constante do parecer, ficando, portanto, à responsabilidade da Fundação do Patrimônio Histórico e Artístico de Pernambuco - FUNDARPE, fazer constar por meio de depósito bancário explicitamente no Banco do Brasil S/A, na Cidade de Recife-PE. Assim sendo, coube a FUNDARPE, solicitar à Secretaria de Planejamento da Presidência da República - SEPLAN/PR, o agenciamento e equipamento complementar para o monumento histórico da Antiga Casa de Detenção do Recife, para a devida adaptação para a nova casa da Cultura de Pernambuco dentro dos princípios do ( $\mathrm{PCHN}$ ), com utilização para fins turísticos ${ }^{46}$.

Para atingir seus objetivos, o projeto previa pavimentação de passeios; pátios de estacionamento de veículos; acesso aos blocos do monumento; restauração das antigas guaritas e dos torreões da guarda do antigo acesso ao velho presídio; execução de pequenos bancos para lazer do público; preparação dos locais internos para apresentação folclóricas ao ar livres; iluminação das áreas agenciadas em torno da antiga Casa de Detenção para valorização do prédio ${ }^{47}$.

\footnotetext{
45 - Projeto-PE - 004 - (Antiga Casa de Detenção do Recife) - Parecer da Secretaria Executiva do Programa Integrado de Reconstrução das Cidades Históricas do Nordeste, com sua utilização para fins turísticos, sobre o projeto de agenciamento e equipamento complementar da Casa da Cultura de Pernambuco (Arquivo Geral do IPHAN - Cx - 32 - PCH, p.1/ Doc. Olinda/Recife.

46 Projeto-PE - 004 - (Antiga Casa de Detenção do Recife) - Parecer da Secretaria Executiva do Programa Integrado de Reconstrução das Cidades Históricas do Nordeste, com sua utilização para fins turísticos, sobre o projeto de agenciamento e equipamento complementar da Casa da Cultura de Pernambuco (Arquivo Geral do IPHAN - Cx - $32-$ PCH, p. 2/ Doc. Olinda/Recife.

${ }^{47}$ Idem, p. 4
} 
A ideia era oxigenar o local onde estava encravada a antiga Casa de Detenção do Recife, transformando-o em um local socialmente aceito; com novos incrementos de atividades culturais e com novas possibilidades de ressignificar um local que historicamente abrigou centenas de vidas que pela sua condição social foram segregadas e muitas delas ceifadas.

\section{FIM DA CASA DE DETENÇÃO DO RECIFE}

A Casa de Detenção do Recife foi extinta oficialmente pelo Decreto 2793, de $1^{\circ}$ de março de 1973, sendo todos os detentos levados para dois novos presídios, construídos em tempo recorde, um na Ilha de Itamaracá, para os presos de melhor comportamento, outro em Dois Unidos, destinado para aqueles considerados mais perigosos (DP, 16/03/1973, p. 1). A transferência, conforme declaração de José Paz de Andrade, vinha sendo reivindicada pela sociedade há pelo menos 30 anos (DP, 16/03/73, p. 1). Mas o certo é que se desconhece qualquer tipo de consulta ou pressão realizada por parte da população, a não ser por parte das classes abastadas, letradas e governantes.

Com a retirada dos últimos presos, já no dia 16 de abril de 1973, às 9h da manhã, deu-se início à solenidade de descerramento da placa de inauguração das obras da futura Casa da Cultura do Estado de Pernambuco. Na ocasião, conforme matéria publicada no Diário de Pernambuco (DP, 16/03/73, p. 1), acompanhavam o Governador Eraldo Gueiros Leite, o Secretário Assistente Fausto Freitas, o professor Otávio Lyra, substituto da pasta da Educação e Cultura, e o prefeito da cidade do Recife, Augusto Lucena, juntamente com o secretário da Educação Municipal Alfredo de Oliveira, e seu Assistente Reginaldo Guimarães. Integrava ainda a comitiva: os desembargadores Augusto Duque, Pedro Martiniano, Agamenon Duarte, Feliciano Porto, Cláudio Vasconcelos e o historiador Flávio Guerra.

Pelo que se ver no convite expedido pelo Secretário da Justiça (DP, 13/03/ 1973, p. 4), o evento foi um ato restrito à poucas pessoas apenas, e restrito à algumas autoridades, porém, carregado de gestos e ações extremamente simbólica. Para começar, participou no ato, além dos convidados ilustres, os presos que haviam desenvolvido bom comportamento, os quais começaram a derrubar os muros da antiga Casa de Detenção, inaugurando com isso, uma nova etapa na história da edificação que, por 
mais de um século recebeu e deteve o povo, mas não de maneira espontânea e voluntária (DP, 16/03/1973, p. 1).

A Casa da Cultura devia nascer, portanto, com uma nova perspectiva, continuava sendo chamada de "casa", mas com outro sentido. Embora, saibamos que o cotidiano prisional fosse muito mais vivo e cheio de vozes, bem como a ideologia da velha instituição era a da ordem de calar, segregar e permanecer inerte. Agora, seria um lugar de idas e vindas, sem grades, de portas abertas, de liberdade para criar e com perspectiva de ressignificar o local prisional e sua memória infame.

Trabalhamos com o conceito de "memória infame" a partir do entendimento de que, ao derrubar os muros e realizar outros gestos simbólicos durante o início das obras, os presos, autoridades do executivo e intelectuais comungavam de uma memória coletiva pejorativa e infame, acerca da história da antiga na instituição, do local e do próprio edifício que, agora, desejavam transformar em santuário da cultura do povo pernambucano.

Para Michael Pollak (1992, p. 201):

A priori, a memória parece ser um fenômeno individual, algo relativamente íntimo, próprio da pessoa. Mas Maurice Halbwachs, nos anos 20-30, já havia sublinhado que a memória deve ser entendida também, ou sobretudo, como um fenômeno coletivo e social, ou seja, como um fenômeno construído coletivamente e submetido a flutuações, transformações, mudanças constantes.

Essa memória desagradável, impossível de ser borrada de um todo com a preservação do edifício, devia ao menos ser ressignificada. Havia-se de se tentar apagar das suas paredes a "escuridão" e a violência" (FOUCAULT, 2008, p. 95), que por anos entrava e a associava rapidamente à privação de liberdade.

Encravada em pleno centro da cidade do Recife, às margens do rio Capibaribe, o imponente prédio guardava milhares de histórias, uma vez que milhares de presos comuns e políticos - passaram ou morreram em seu interior, sendo ademais as grossas e frias paredes testemunhas de um Recife que se movia e se transformava sob os olhares dos presos às suas janelas.

Apenas por curiosidade, entre os presos famosos, destacam-se João Dantas (assassino de João Pessoa), morto no estabelecimento, e Gregório Bezerra. Após o golpe civil-militar de 1964, não sem um toque de ironia, também esteve nele recluído o 
ex-governador Miguel Arraes, e o Deputado Federal por Pernambuco Francisco Julião. $^{48}$

Realizada as cerimônias de início das obras para a viabilização do recebimento da verba necessária para a reforma do antigo complexo prisional, adaptando-o para a nova finalidade, foi necessário fundar uma autarquia. Daí nasceu a Fundação do Patrimônio histórico e Artístico de Pernambuco - FUNDARPE, em 1973, com a missão de reestruturar organizar e fazer funcionar a nova Casa da Cultura de Pernambuco, adequando-a para o uso em atividades de caráter artístico-cultural ${ }^{49}$.

As palavras "adaptar" e "adequar" não são meramente explicativas sobre como fora idealizado o projeto. Houve por parte de importantes intelectuais a preocupação para que a edificação não perdesse com a revitalização do espaço suas características originais. Isso era, de fato, uma preocupação do Conselho de Cultura, sob a presidência de Gilberto Freyre, conforme pode-se comprovar documentalmente através da felicitação enviada ao governador por ter preservado os traços arquitetônicos do prédio $^{50}$. Tais notícias deviam ser certamente um bálsamo para esses homens sensíveis aos destinos das construções com forte importância histórica, ainda mais quando corria a informação de que o prédio seria derrubado. (JC,11/03/1973, p. 13).

\section{“REINAUGURAÇÃO” DO ANTIGO ESPAÇO CARCERÁRIO - AGORA, CASA CULTURA DE PERNAMBUCO.}

Embora o projeto seja mais antigo, pode-se afirmar que a criação da Casa da Cultura de Pernambuco se viu beneficiada, entre 1974 e 1978, com a implantação da Política Nacional da Cultura, que passou a atribuir funções do tipo ao Ministério da Educação e Cultura - MEC. Paradoxalmente, foi a primeira vez na história republicana que o Brasil teve condições de formular um conjunto de diretrizes que tinham por objetivo desenvolver uma política cultural nacional, envolvendo, portanto, os órgãos federais interligados com outros ministérios, notadamente envolvendo secretarias

\footnotetext{
${ }^{48}$ Casa da Cultura de Pernambuco - Tecnologia na Promoção da Cultura- Arquivo FUNDARPEA. P.3/SD.

49 Jornal Projeto do Commercio - de 11 de abril de 1973, p. 13

${ }^{50}$ Concelho Estadual de Cultura-PE, Livro de Ata no 4, Ata da $10^{\text {a }}$ Sessão Plenária do Conselho Estadual de Cultura de Pernambuco, 27/02/1973, p. 165. Nessa ata, Gilberto Freyre, na condição de presidente, felicita o Gobernador Eraldo Gueiros por ter preservado a antiga Casa de Detenção, autorizando apenas a derrubada dos muros laterais.
} 
estaduais e municipais de cultura, bem como outras instituições privadas. (SILVA, 2001, p. 63).

De fato, sem os recursos federais, o apoio da prefeitura do Recife, e do incentivo e colaboração de intelectuais vinculados à academia e às letras, certamente a Casa da Cultura não teria saído do papel. Depois de três anos ininterruptos de obras e reparos da ex-casa de Detenção do Recife, uma reportagem do segundo caderno do Jornal do Commercio, de 11 de abril de 1976, narrava vibrantemente a inauguração da nova instituição:

A casa da Cultura de Pernambuco cuja história começa no dia 14/04/1976, e que vai ser contada com artesanato nordestino, com cantadores, seus violeiros, seus ceramistas, seu teatro. Onde antes havia a residência do Diretor e funcionava a parte da administrativa, agora é o auditório para conferências e audições musicais. Onde viviam em condições subumanas mais de mil homens, agora estarão museu, exposições rotativas, restaurantes típicos, centro de informação turística, livrarias, discotecas regionais, pequenas oficinas artesanais. (JC, 11/04/1976, p. 4).

Com a inauguração da Casa da Cultura de Pernambuco, criou-se uma expectativa para alavancar as atividades culturais no nosso Estado e especialmente da Capital Pernambucana. Na fala do Ministro da Educação Ney Braga, durante a inauguração, reconhecia a importância do investimento no setor, como vetor importante para o desenvolvimento do Estado de Pernambuco e Região, dentro do Plano Nacional de Cultura do Governo Federal, por interlocução da FUNDARPE ${ }^{51}$.

A antiga Casa de Detenção, agora Casa da Cultura de Pernambuco, foi dotada de equipamento necessário ao conforto exigido para a nova função. Para não descaracterizar o desenho arquitetônico, e manter a similaridade da construção dos meados do século XIX, e dar acessibilidade aos novos frequentadores da Casa, foi colocado elevadores logo de início dos blocos de acessos aos antigos "raios" que davam acesso às celas.

Agora, o novo espaço teria outra função no centro da cidade de Recife, compondo uma nova sinfonia: lojas de artesanatos; bares e restaurantes; museus de arte popular; museu do carnaval; cinema de arte; teatro de arena; centro de pesquisa e arte popular e folclore. Dentre outras manifestações culturais, sob a "regência" de artistas,

51 Jornal do Commercio de 11 de abril de 1976, p.13 
artesãos e comerciantes interessados em desenvolver as atividades culturais na Casa da Cultura de Pernambuco ${ }^{52}$.

O que se esperava a partir daquele momento, era que os espaços de uma antiga penitenciária se oferecessem para outras atividades culturais, isto posto, inspirava acreditar que a cultura é a mais ampla expressão possível do nosso espírito criador em literatura e artesanato.

A Fundação do Patrimônio Histórico e Artístico de Pernambuco, na qualidade de responsável pela Casa da Cultura de Pernambuco e de empreender as suas atividades culturais no Estado e Região, começou a povoar o mais "novo" empreendimento cultural do Estado, com as mais variadas atividades culturais, conforme matéria veiculada na imprensa local ${ }^{53}$.

Conforme pode-se observar através da programação de eventos da FUNDARPE, do ano de 1976, no período compreendido entre 14 de abril a 30 de junho do mesmo ano $^{54}$, foram empreendidos grandes esforços no sentido de dar visibilidade à nova casa recém-inaugurada, com várias atividades culturais e tantas outras manifestações de características próprias do nosso povo.

Conforme as atividades programadas com o calendário, a programação versavam desde a inauguração da Casa da Cultura de Pernambuco, bem como todas as expertises para aquele momento próprio e de celebração, fazendo constar, portanto, o início do que deveria ser o espírito a partir daquele espaço, com apresentação de maracatu e caboclinhos; demonstração de ciranda com a participação efetiva do público presente; da apresentação da Orquestra popular Brasileira; concerto Oficial da Orquestra Sinfônica do Recife e do quinteto de Sopro da Sinfônica, até os festejo de São Pedro, com apresentação da quadrilha matuta, zabumba, coco de roda, conjuntos regionais e comidas típicas da época.

Na continuidade das atividades calendário, houve a necessidade de se fazer uma integração com outras culturas, como por exemplos o Consulado da Alemanha, que na

\footnotetext{
52 Jornal do Commercio de 14 de abril de 1976, p.04

53 Jornal do Commercio de 15 de abril de 1976, p.14.

54 Casa da Cultura - Relatório de Atividades Culturais, desde o dia da inauguração da Casa da Cultura, até outras atividades subsequentes, para o cumprimento de um calendário festivo e de aclamação de todo sociedade pernambucana para ressignificar o "novo" local da mais alta expressão da cultura popular do Estado: Marcelo Carvalho dos Santos- Secretário Executivo da FUNDARPE (1976, p. 1-3) Programa Cidades Históricas do Nordeste-Caixa 32 IPHAN - Arquivo- Recife.
} 
ocasião fez uma exposição de atividades culturais daquele país, organizada pelo Museu Estadual de Arte de Munique e os Institutos Goethe Brasil, semelhantemente, foi realizada também uma exposição de Arte e Cultura sob a ótica dos Pintores Franceses contemporâneos, pelo Consulado da própria França ${ }^{55}$, como forma de apresentar e fazer interagir com o novo espaço cultural do Estado, considerando que a sua inspiração partiu dos ideais franceses.

As celas que receberam uma reforma profunda depois de mais de um século de atividades degradantes, ocupadas por homens, passam, portanto, a receber novos ocupantes, estes, com outros significados, pois, a ideia era ressignificar o local com as atividades mais significativas e mais próxima da população. Os poucos comerciantes e artesãos que iniciaram as atividades na Casa, estavam por ansiosos por aquele momento histórico, conforme registra matéria do Diário de Pernambuco de 11 de janeiro de 1976 (DP, 11/01/1976, p. 5).

Os produtos foram chegando as mais diversas regiões do Estado de Pernambuco, como também de outros Estados da Região Nordeste, dos mais diversos gêneros possíveis de criação. Na linha de algodão renda de bilro renascença palas; na argila cerâmica decorativa (jarros, cinzeiros, adereços) vasos, figuras, cortinas, cerâmica utilitária, canecos e jogos de refeição para feijoada; com o couro do boi bolsas sandálias tamancos cintos casacos e tapetes; na confecção vestidos, saia, blusas, artigo para crianças e peças masculinas; com chifre bengalas botões pulseiras e objetos decorativos; perfumaria artesanal à base de ervas, folhas e raízes; pedras semipreciosas; santos e outras peças a base de estopa; tapeçaria; de sisal bolsas sacolas tapetes cestos e estandarte; da palha bolsas esteiras sacolas e chapéus; sobre a madeira entalhes, baú, esculturas, carrancas adereços e peças decorativas; com tela, tecido e linha de bordados 56 .

É de se notar, a grande quantidade de produtos vendidos e comercializados na Casa da Cultura de Pernambuco, permitindo ao público que lá visitavam, uma gama de diversidades em termos de apresentação de produtos, o que vem a denotar, a versatilidade dos produtores de artesanato. Outro fator importante era grande margem

\footnotetext{
55 Idem.

${ }^{56}$ Comissão Sindicante da Casa da Cultura Relatório Final - informativo adicional ao relatório final das atividades a situação do comercio de artesanato na casa da cultura de Pernambuco, junho de (1982, p, 46) -Arquivo FUNDARPE.
} 
para opção, segundo o gosto dos visitantes que era muito positivo, além de demonstrar que já havia uma perspectiva por parte dos idealizadores da Casa da Cultura e dos comerciantes que ali se instalaram, de apresentar tais produtos para um público eclético e exigente, tanto do ponto de vista do consumidor interno como também dos estrangeiros ${ }^{57}$.

É nesse contexto, que a Casa da Cultura se mostra à sociedade Pernambucana, buscando sobretudo, ratificar a importância da cultura popular como um dos elementos de resistência contra a dominação de classe.

Para Arantes (2012):

Desse ponto de vista a "cultura popular" surge como "outra" cultura que, por contraste ao saber culto dominante, apresenta-se como "totalidade" embora sendo, na verdade, construída através da justaposição de elementos residuais e fragmentários considerados resistente a um processo "natural" de deterioração (ARANTES, 2012, p. 18).

Para o mesmo autor:

Como que num exorcismo, esses fragmentos que teimam em emergir aqui e ali, em momentos cruciais de nossa vida são deslocados para o passado e para outros lugares. O que é identificado e escolhido como elemento constitutivo das tradições nacionais é recriado segundo os moldes ditados pelas elites cultas e, com nova roupagem, desenvolvido, digerido e devolvido a todos os cidadãos. (ARANTES, 2012, p. 18).

É oportuno salientar que a preocupação com a cultura a partir dos anos 60 e 70, não foi apenas um movimento da sociedade brasileira e muito menos focada em seus monumentos antigos, dentre os quais igrejas, prédios públicos, casarões ou obras de extremas excepcionalidade e de valor estético, e do simbolismo. Outrossim, visava também buscar a valorização do ser humano naquilo que ele mais se expressa de forma individual e coletiva.

Segundo Barbosa e Couceiro (2018, p. 12),

57 Comissão Sindicante da Casa da Cultura Relatório Final - informativo adicional ao relatório final das atividades a situação do comercio de artesanato na casa da cultura de Pernambuco, junho de (1982, p, 46) -Arquivo FUNDARPE. 
[...] na metade do século $X X$, no afã de reconstrução pós-guerra, novos questionamentos se evidenciaram no cenário mundial. Instituições como a ONU - Organização das Nações Unidas -, e a UNISCO - Organizações das Nações Unidas para Educação, a Ciência e a cultura -, criadas nesse momento, deram visibilidade a diferentes demandas que sugiram por parte dos chamados países do Terceiro Mundo, das colônias e dos movimentos sociais que começavam a organizar em prol dos direitos civis.

Para os mesmos autores:

Nessa nova conjunto político-econômica, a compreensão da noção de bem cultural começa a ser revista. Primeiramente pelo teor eurocêntrico das atribuições do patrimônio, ou seja, pela supervalorização da monumentalidade dos bens. Essa atribuição soava artificial quando se pensava nos países cuja tradição e identidade se expressavam de modo mais intenso a partir de manifestações orais, de artes e modos de fazer, danças, folguedos e ritos. Outro aspecto importante refere-se à noção de preservação. Não eram apenas bens de "pedra e cal" que corriam risco de se extinguirem. (2018, p. 12).

Apesar dos esforços por parte do governo do Estado na época, em ocupar todos os espaços da antiga Casa de Detenção do Recife, nem tudo funcionou como deveria, mesmo considerando as dificuldades que surgiram naturalmente. Faltava, portanto, uma articulação por parte da gestão da FUNDARPE, no sentido de catalogar melhor os produtos artesanais regionais na busca de convergi-los para o novo centro da cultura pernambucana e de não preterir os produtos oriundos das demais regiões nordestinas ${ }^{58}$.

Para um dos seus idealizadores:

[...] A Casa da Cultura não foi projetada para ser um depósito de materiais de artífices, foi planejada para ser um centro pulsantes de atividades culturais para o desenvolvimento de todo Estado de Pernambuco da Região Nordeste e do Brasil. Onde as pessoas pudessem utilizar aquele espaço gigantesco da melhor maneira possível. (BRENNAND, 2019).

De acordo com o senhor Celi Cadena Cavalcanti, um dos primeiros comerciantes de artesanatos durante uma entrevista realizada em seu estabelecimento, narrou o seguinte:

\footnotetext{
${ }^{58}$ Comissão Sindicante da Casa da Cultura Relatório Final - informativo adicional ao relatório final das atividades a situação do comercio de artesanato na casa da cultura de Pernambuco, junho de (1982, p, 46) -Arquivo FUNDARPE.
} 
Assim que a casa foi inaugurada ela bateu o seu objetivo, com poucos meses ela já estava praticamente toda preenchida no térreo e no primeiro andar estava começando a movimentar o espaço. Foi criado um convênio em parceria com a Rede Globo através da secretaria de cultura e educação do Estado de Pernambuco para buscar o financiamento para os eventos da casa[...] A casa da cultura passou a ser o point de encontro do centro da cidade do Recife. Como ainda não havia shopping center as pessoas frequentavam a casa durante a semana e nos domingos eles se encontravam também (CELI, 2019).

Olha, quando inaugurou a casa da cultura realmente era boa, olha vou te explicar era uma beleza. Todo dia havia programação, bumba meu boi, ciranda, maracatu, reisado um negócio muito bacana. A casa funcionava da terça-feira aos domingos na segunda era fechada para realizar a limpeza. ${ }^{59}$

Na fala dos comerciantes fica evidenciado a ação de pertencimento daquele novo espaço, notadamente, para os produtores de artes, pois, para isso ele foi designado e ao mesmo tempo, da importância da ocupação pelas pessoas, no sentido de se inteirar do significado do lugar na produção das artes populares e compreender, sobretudo naquele espaço - o pertencer de cada cidadão.

Segundo Arantes (2012):

Quem é o povo de quem se fala? A expressão cultura popular implica em visões valorativas (negativas) dessa categoria social. Ela se refere, por um lado, a "povo massa" (em contraposição a "elite", pensando neste caso como suporte de um não saber. Por outro, como constituindo o espaço social onde se preservam (deturpam) as tradições nacionais. Por outro lado, essas maneiras de pensar a cultura pressupõem ou que ela seja passível de cristalização, permanecendo imutável no tempo, a despeito das mudanças que ocorrem na sociedade, ou, quando muito, que ela esteja em eterno "desaparecimento". Como sugerem os nossos exemplos, cultura é um processo dinâmico; transformações (positivas) ocorrem, mesmo quando intencionalmente se visa congelar o tradicional para impedir a sua "deterioração". É possível preservar os objetos, os gestos, as palavras, os movimentos, as características plásticas exteriores, mas não se consegue evitar a mudança de significado que ocorre no momento em que se altera o contexto em que os eventos culturais são produzidos (ARANTES, 2012, p. 20-21).

59 Florisvaldo Regis Loureiro- artista plástico um dos primeiros comerciantes que ocupou a casa da cultura de Pernambuco, em entrevista realizada no dia 16 de janeiro de 2019 em seu ateliê no bairro de San Marin Recife. 
A Casa da Cultura de Pernambuco, depois de inaugurada e ocupada com atividades culturais renasceria para contar "novas" histórias diferentes daquelas que foram produzidas em suas dependências desde o momento de sua construção em meados do século XIX (DP, 09/12/1850, p. 1), até o seu fechamento com mais mil detentos conforme noticiou o Diário de Pernambuco de 16 de março de 1973 (DP, 16/03/1973, p. 1). Ou seja, ainda estava longe de ser aclamada como um local de apagamento de uma memória infame.

Para Camdau (2018):

A memória, ao mesmo tempo em que nos modela, é também por nós modelada. Isso resume perfeitamente a dialética da memória e da identidade que se conjugam, se nutrem mutuamente, se apoiam uma na outra para produzir uma trajetória de vida, uma história, um mito, uma narrativa. Ao final, resta apenas o esquecimento. (CAMDAU, 2018, p. 16).

$\mathrm{Na}$ visão de Nora (1993) "Na falta da intenção da memória, os lugares de memórias serão lugares de histórias" (NORA, 1993, p. 22).

\section{CONSIDERAÇÕES FINAIS}

O presente artigo busca analisar a criação da Casa da Cultura de Pernambuco a partir de dois momentos significativos: primeiro, vendo-a como objeto de um projeto político sociocultural mais amplo para o Estado de Pernambuco; segundo, lançando reflexos sobre o processo de restauração do espaço a partir dos novos usos dados ao local escolhido, levado a cabo entre 1971 e 1973, tendo em vista que o mesmo abrigara por mais de um século a Casa de Detenção do Recife.

Em se tratando do primeiro ponto é preciso situar o projeto da Casa da Cultura dentro de um movimento de incentivo ao desenvolvimento regional por meio do Programa Cidades Históricas do Nordeste desenvolvido pelos militares. A ideia consistia em patrocinar a implementação de espaços de produção e divulgação da cultura local, de forma a estimular o turismo e reforçar a identidade regional.

O segundo, se refere à escolha do edifício da centenária Casa de Detenção do Recife para abrigar a CCPE. Associado a um local de memória, o edifício foi alvo de várias iniciativas no sentido de tentar manchar o seu antigo uso, para poder dar lugar aos novos fins. 
Embora se tenha preservado uma cela mais, além do edifício como um todo, a memória infame da CDR não possui lugar de destaque na produção de uma nova representação sobre o espaço. Se não houve um êxito em apagá-la da recordação dos vivos, por outro lado ninguém pode dizer que não houve uma tentativa por negá-la. Até porque o processo de ressignificação só tem sentido quando o lugar ocupado passa a potencializar novas possibilidades de construir novas histórias, associada à memória coletiva, portanto, indissociável da organização social (POLLAK, 1992, p. 214).

Imagem $\mathbf{n}^{\circ}$ 3: Cela original da antiga casa de Detenção do Recife,

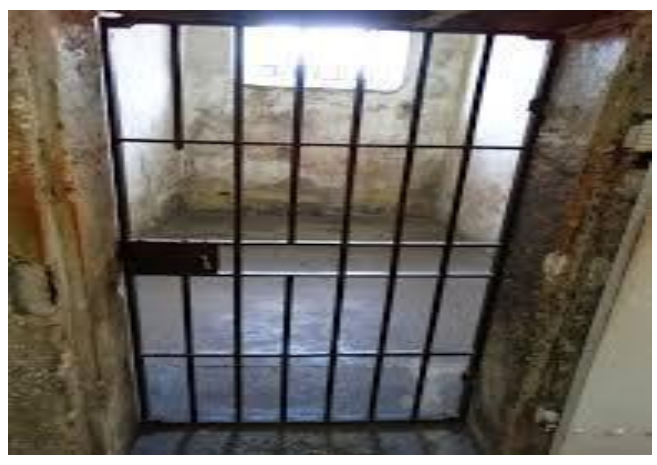

Fonte: Acervo FUNDARPE

\section{REFERÊNCIAS}

ARANTES, Antônio Augusto. O que é cultura popular. São Paulo: Brasiliense (Coleção primeiros passos, 36). 2012.

BARBOSA, Cibele; COUCEIRO, Sylvia: Cultura imaterial e memória cultural em Pernambuco. In: GUILLEN, Isabel Cristina Martins (Org). Tradições e Traduções: a cultura imaterial em Pernambuco. Recife, Ed. Universitária da UFPE, 2018. p.12

CALABRE, Lia. Práticas Culturais no Brasil: dos anos 1930 ao século XXI. Rio de Janeiro: Editora FGV, 2009.

CAMDAU, Joël. Memória e Identidade. São Paulo, Editora Contexto, 2018.

FOUCAULT, Michel. Vigiar e Punir: nascimento da prisão. Rio de Janeiro, Ed. Petrópolis, 2008. p.95.

LEAL, César Barros. A Delinquência Juvenil: Seus Fatores Exógenos e Prevenção. Editora: Aide, Rio de Janeiro, 1983.

NORA, Pierre. Entre memória e história: a problemática dos lugares. Projeto História. São Paulo: PUC-SP, n. 10, 1993. p. 22 
POLLAK, Michael: Memória e Identidade Social- Estudos Histórico: 1992.

SILVA, Kalina Vanderlei; SILVA, Maciel Henrique - Dicionário de Conceitos históricos- $3^{\text {a }}$ edição- São Paulo: Contexto, 2010, p. 85.

SILVA, Vanderli Maria da. A construção da política cultural do regime militar: concepções, diretrizes e programas (1974- 1978). São Paulo, Dissertação (Mestrado), Faculdade de Filosofia, Letras e Ciências Humanas da universidade de São Paulo. 2001.

SOARES, José Arlindo. A frente do Recife e o Governo de Arraes: nacionalismo em crise 1955 - 1964. Rio de Janeiro: Paz e Terra, 1982. p. 22.

SOUZA, Fábio Silva de. O Movimento de Cultura Popular do Recife (1959-1964). São Paulo, Dissertação (Mestrado), Faculdade de Filosofia, Letras e Ciências Humanas da Universidade de São Paulo. 2014. p.11.

\section{ENTREVISTAS}

BRENNAND, Francisco (2019). Francisco Brennand: depoimento em 17 de abril de 2019. Entrevistador: Josevane Francisco da Silva. Transcrição: Valeska Maria Ferreira da Silva. Recife.

CAVAlCANTI, Celi Cadena (2019). Celi Cadena Cavalcanti: depoimento em 17 de janeiro de 2019. Entrevistador: Josevane Francisco da Silva. Transcrição: Valeska Maria Ferreira da Silva. Recife.

LOUREIRO, Florisvaldo Regis (2019). Florisvaldo Regis Loureiro: depoimento em 16 de janeiro de 2019. Entrevistador: Josevane Francisco da Silva. Transcrição: Valeska Maria Ferreira da Silva. Recife.

\section{FONTES IMPRESSAS E MANUSCRITAS}

Diário de Pernambuco, 09/12/1850,p.1 - Disponível em:

http://bndigital.bn.gov.br/hemeroteca-digital/. acesso em 20 de dezembro 2019.

Diário de Pernambuco, 16/03/1973,p.1 - Disponível em:

http://bndigital.bn.gov.br/hemeroteca-digital/. acesso em 10 de junho 2019.

Jornal do Commercio, 11/04/1976, p.13 - APEJA- Arquivo Público Estadual Jordão Emerenciano.

Diário de Pernambuco, 21/05/1980, p.1 - Arquivo FUNDARPE.

Diário de Pernambuco, 08/01/1964,p.5 - Disponível em:

http://bndigital.bn.gov.br/hemeroteca-digital/. acesso em 27 de novembro 2019. 
Diário de Pernambuco, 06/10/1963,p.3 - Disponível em:

http://bndigital.bn.gov.br/hemeroteca-digital/. acesso em 10 de junho 2019.

Diário de Pernambuco, 06/10/1963,p.3 - Disponível em:

http://bndigital.bn.gov.br/hemeroteca-digital/. acesso em 10 de junho 2019.

Diário de Pernambuco, 16/01/1973,p.1 - Disponível em:

http://bndigital.bn.gov.br/hemeroteca-digital/. acesso em 10 de junho 2019.

Diário de Pernambuco, 13/03/1973,p.4 - Disponível em:

http://bndigital.bn.gov.br/hemeroteca-digital/. acesso em 10 de junho 2019.

Diário de Pernambuco, 16/03/1973,p.1 - Disponível em:

http://bndigital.bn.gov.br/hemeroteca-digital/. acesso em 10 de junho 2019.

Jornal do Commercio, 11/04/1976, p.13 - APEJA- Arquivo Público Estadual Jordão Emerenciano.

Jornal do Commercio, 11/04/1976, p.04 - APEJA- Arquivo Público Estadual Jordão Emerenciano.

Jornal do Commercio, 11/04/1976, p.13 - APEJA- Arquivo Público Estadual Jordão Emerenciano.

Jornal do Commercio, 11/04/1976, p.04 - APEJA- Arquivo Público Estadual Jordão Emerenciano.

Diário de Pernambuco, 11/01/1976,p.5 - Disponível em:

http://bndigital.bn.gov.br/hemeroteca-digital/. Acesso em 10 de junho 2019.

Diário de Pernambuco, 16/03/1976,p.1 - Disponível em:

http://bndigital.bn.gov.br/hemeroteca-digital/. Acesso em 10 de junho 2019.

Diário de Pernambuco, 16/03/1976,p.1 - Disponível em:

http://bndigital.bn.gov.br/hemeroteca-digital/. Acesso em 10 de junho 2019.

\section{SIGLAS}

CDR: Casa de Detenção do Recife

PCHN: Programa Cidades Históricas do Nordeste

SEPLAN/PR: Secretaria de Planejamento da Presidência da República

FUNDARPE: Fundação do Patrimônio Histórico e Artístico de Pernambuco 


\section{HISTÓRIA CULTURAL E MEMÓRIA}

SILVA, Josevane Francisco da ${ }^{60}$

\section{RESUMO:}

O texto procura refletir sobre cultura, história e memória, numa perspectiva de atendimento às pessoas. $O$ texto reflete ainda sobre a discussão da conceituação da palavra cultura nas mais diversas formas de sociedade e da sua aplicabilidade em épocas diferentes. Busca também, refletir acerca da memória como uma reflexão da construção do processo da nossa identidade que é o nosso maior patrimônio.

PALAVRAS-CHAVE: Cultura. Memória. Identidade.

\section{INTRODUÇÃO}

Quando falamos em cultura, precisamos compreendê-la de que não se resume apenas a uma prática social e, seu nome não expressa a definição absoluta da palavra. $\mathrm{O}$ termo cultura acompanha a própria evolução da humanidade, notadamente, naquilo em que o ser humano necessita para o seu desenvolvimento, acompanhada de valores individuais, coletivos, memórias, anseios, dentre outros, como vetores impulsionadores, onde a cultura terá terreno para o seu desenvolvimento.

Desta forma, compreender o processo cultural nunca foi uma tarefa fácil, por ela se dividir em tantas outras possibilidades de manifestações, como por exemplo a "cultura popular", como uma das vertentes da "cultura", que se manifesta dentro de uma territorialidade majoritariamente coletiva. Isto posto, também possibilita o desenvolvimento de outras formas, pelas quais a cultura se apresenta, construindo um campo de possibilidade a ponto de favorecer às pessoas "menos favorecidas" ou "socialmente desfavorecidas", no intuito de que elas se sintam representadas por aquelas manifestações oriundas de sentimentos coletivos, sem, contudo, perder a representação da individualidade (ARANTES, 2012, p. 7).

\footnotetext{
${ }^{60}$ Mestrando pelo Programa de Pós-graduação em História da Universidade Católica de Pernambuco (PPGH-UNICAP). E-mail: josevanepaz@yahoo.com.br
} 


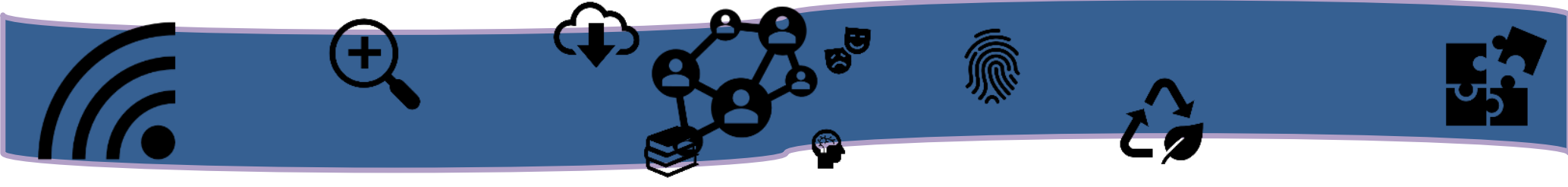

\section{CULTURA}

O Conceito de cultura tem sido discutido e analisado desde os meados do século XIX, pelas ciências humanas, buscando a compreensão desse significado para a compreensão do valor cultural na vida das pessoas. Por outro lado, não teria sentido tal discussão, sobre compreender o papel da cultura na relação humana, faz sentido entendermos o real valor da cultura, dentro dos relacionamentos sociais.

Para tanto, na visão de Kalina Vasconcelos Silva (2010) e Maciel Henrique Silva (2010), o conceito de cultura:

O conceito de cultura é um dos principais nas ciências humanas, a ponto de a Antropologia se constituir como ciência quase somente em torno desse conceito. Na verdade, os antropólogos, desde o século XIX procuram definir os limites de sua ciência por meio da definição de cultura. $\mathrm{O}$ resultado é que os conceitos de cultura são múltiplos e, às vezes, contraditórios. O significado mais simples desse termo afirma que cultura abrange todas as realizações materiais e os aspectos espirituais de um povo. Ou seja, em outras palavras cultura é tudo aquilo produzido pela humanidade, seja no plano concreto ou no plano imaterial, desde artefatos e objetos até ideias e crenças. Cultura é todo complexo de conhecimentos e toda habilidade humana empregada socialmente. Além disso, é também todo comportamento apreendido, de modo independente da questão biológica. Essa definição foi criada por Edward Tylor no século XX e, apesar de sua atualidade, gerações e gerações de antropólogos procuravam aprofundá-la para melhor compreender o comportamento social. Entre esses pensadores, um dos mais influentes foi Franz Boas, que no começo do século XX iniciou uma crítica sistemática às teorias até então vigentes que defendiam a existência de uma hierarquia entre culturas. (SILVA; SILVA, 2010, p. 85).

Considerando que para Geertz (2012, p. 22), Wagner (2012, p. 34) e Arantes (2012, p. 9), o conceito de cultura é muito mais abrangente e questionaram sobre o seu papel e significado da mesma nas sociedades, levando em consideração às suas próprias características.

De acordo com Williams (1992):

Tanto o problema quanto o interesse da sociologia da cultura podem ser percebidos de imediato na dificuldade do termo que obviamente a define: "cultura". A história e o uso desse termo excepcionalmente completo podem ser estudados em Kroeber e Kluckhohn (1952) e Williams (1958 e 1976). Começando com o nome de um processo cultura (cultivo) de vegetais ou (criação e reprodução) de animais e, por extensão, cultura (cultivo ativo) da mente humana - ele se tornou, 
em fins do século XVIII, particularmente no alemão e no inglês, um nome para configuração ou generalização do "espírito" que informava o "medo de vida global" de determinado povo. Herder (1784-91) foi o primeiro a empregar o significado plural, "culturas", para intencionalmente diferenciá-lo de qualquer sentido singular ou, como diríamos hoje, unilinear de "civilização". Esse termo pluralista amplo foi, pois, de especial importância para a evolução da antropologia comparada no século XIX, onde continuou designando um modo de vida global e característico (WILLIAMS, 1992, p. 10 e 11).

Assim, de acordo com o mesmo autor, o processo de absorção da compreensão cultural é complexo, e, partindo da premissa que esse processo evolutivo é de competência dos seres humanos, onde eles constroem as suas narrativas de vidas dentro de suas próprias realidades e de como a cultura é compreendida na qualidade de um componente de vital importância para a permanência de suas celebrações, entendendo que a cultura lhes pertence. Vejamos:

Enquanto isso, no uso mais geral houve grande desenvolvimento do sentido de "cultura" como cultivo ativo da mente. Podemos distinguir uma gama de significados desde um estado natural desenvolvido como em "pessoas de cultura", "pessoa culta", passado por os processos desse desenvolvimento - como em "interesse culturais", "atividade culturais" até os meios desses processos - como em cultura considerada como "as artes" e "o trabalho intelectual do homem". Em nossa época, é o sentido geral mais comum, embora todos eles sejam usuais. Ele coexiste, muitas vezes desconfortavelmente, com o uso antropológico e o amplo uso sociológico para indicar "modo de vida global" de determinado povo ou de algum outro grupo social. (WILLIAMS, 1992, p. 11).

É pertinente frisar o quanto a cultura abrange uma diversificação de atividades, sejam elas em qualquer área do relacionamento humano. Não podemos limitá-la, simplesmente por questões de ambientes e ou de trabalhos. Entretanto, os espaços não podem influenciar a ponto de comprometer os resultados das ações culturais. As questões raciais também não devem serem tomadas como empecilhos para o desenvolvimento da cultura.

Segundo Silva e Silva (2010):

A mesma premissa serve na afirmação de que o meio geográfico também não determina comportamentos culturais. Assim, quaisquer tipos de discriminações sociais feitas com base em sexo ou raça, como aqueles discursos proferidos em nossa sociedade que afirmam que determinados trabalhos não podem ser feitos por mulheres, ou que 
algumas atividades consideradas inferiores são exclusivamente "trabalho de negro", não possuem base biológica. Mas são discursos criados para justificar a posição dominante de determinados grupos sociais. O estudioso brasileiro Alfredo Bosi, por exemplo, em Dialética da Colonização, define cultura a partir da linguística e da etimologia da palavra: cultura, assim como culto e colonização, viria do verbo latino colo, que significa eu ocupo a terra. Cultura, dessa forma, seria o futuro de tal verbo, significando o que se vai trabalhar, o que se quer cultivar, e não apenas em termos de agricultura, mas também de transmissão de valores e conhecimento para as próximas gerações. (SILVA; SILVA, 2010, p. 86).

Apesar de toda essa construção sistemática para compreensão do significado da cultura, ainda há divergências do seu significado e de sua aplicabilidade, como já salientamos neste trabalho, conforme a visão de vários autores, dentre eles: Geertz (2012), Arantes (2012) e Wagner (2012).

Dentro dessa perspectiva, a palavra cultura ainda apresenta ambiguidade de compreensão. Para Wagner (2012), a palavra cultura (culture) que nasce de uma situação em desalinho do particípio do verbo passado latino colere "cultivar", aflora alguns dos seus mais céleres significados, como por exemplo: a manutenção do cultivo, se referindo ao solo propriamente dito.

Assim, a partir dos séculos XII- XV, na França e Inglaterra medievais, surgiu o termo cultura, que usamos nos dias atuais e que versa sobre à denominação de "um campo arado" (WAGNER, 2012, p. 49), senão vejamos:

Em tempos posteriores "cultura" adquiriu um sentido mais específico, indicando um processo de procriação e refinamento progressivo na domesticação de um determinado cultivo, ou mesmo o resultado ou incremento de tal processo. Assim é que falamos de agricultura, apicultura, da "cultura da vinha" ou de uma cultura bacteriana. O sentido contemporâneo do termo - um sentido "sala de ópera" emerge de uma metáfora elaborada, que se alimenta da terminologia da procriação e aperfeiçoamento agrícola para criar uma imagem de controle, refinamento e "domesticação" do homem por ele mesmo (WAGNER, 2012, p. 49-50).

Desta forma, a manutenção da criatividade das nossas ações culturais é definida graças as extensões das técnicas e das descobertas. Entretanto, qualquer tipo de trabalho, seja ele inovador ou apenas uma repetição do que já foi feito em relação a essa soma de cultura, já constitui um contexto de significado (WAGNER, 2012, p. 51-52). 


\section{CULTURA POPULAR}

Quando falamos em cultura, não podemos deixar de mencionar a cultura popular. A expressão também não é nova, sua aparição no cenário popular brasileiro versa desde o início da década de 1960, pois, a palavra cultura popular já existia há muito tempo, entretanto, não foi uma invenção brasileira, muito menos é nossa a originalidade da palavra.

Assim, em vários países do mundo já se falava em cultura popular. Contudo, foi na Europa, especificamente na França, quando se discutia a elitização da cultura e ao mesmo tempo, como o povo teria acesso aos bens culturais. Entretanto, nos países socialistas, da China até Cuba, a revolução cultural era uma palavra de ordem (FÁVERO, 1983, p. 7).

Todavia, a ideia de que o homem constrói e desconstrói suas próprias realizações não é uma coisa recente. Tal assertiva, pode ser encontrada em filosofias tão diversificadas quanto o Mu'tazila do islã e nos ensinamentos do budismo, assim como, em outros sistemas de pensamentos, talvez menos criteriosos. A busca por esses encontros, diz respeito porque as culturas tendem a controlar as suas realidades, notadamente entre os dominantes e dominados (WAGNER, 2012, p. 9).

Ainda não ultrapassamos a compreensão da palavra cultura, pois, como já citamos neste trabalho, a terminologia da palavra é tão complexa como a sua aplicabilidade. Dentro deste universo gigantesco, a "cultura" foi se modificando e encontrando espaços para a sua compreensão e materialidade, inevitavelmente, as suas divisões foram se popularizando e, como em uma época cada vez mais voltada para um pensamento antropológico, o mundo moderno passou a oferecer aos homens a possibilidade real de um “certo” domínio na natureza. Para o escritor Fávero (1983):

Em circunstância tão sérias, a cultura, orientada pelos grupos privilegiados, funciona como freio e fator de conformismo. As manifestações culturais são, portanto, nas duas condições, fortemente marcadas por características ideológicas que justificam o "statu qou". Diante desse quadro, é cabível a apresentação da sociedade brasileira como composta por grupos culturalmente dominados e grupos culturalmente dominantes, que impõem uma cultura de reflexo e não reflexão. [...] Mas, por sua própria feição antropológica, a época moderna é também uma idade ideológica, fazendo com que através das obras culturais (pelas quais o homem se realiza) o homem procure justificar-se a si mesmo e na existência história em que se encontra, 
impondo, de certa forma, aos homens esse modo de existir, através dos atos pelos quais diretamente os homens se comunicam: os valores, ideias, as tendências de um determinada época etc. (FÁVERO, 1983, p. 22).

Assim, para compreender melhor esse assunto, usaremos aqui o conceito de cultura popular usado pelo próprio autor, onde ele reconhece que essa divisão da cultura, perpassa essa compreensão limitada e, estabelece uma relação de comunicação, no sentido de que o homem reconheça o seu lugar de sujeito na sua própria criação cultural, que segundo Fávero (1983) conceitua:

Expressão "cultura popular" surge como uma denúncia dos conceitos culturais em voga que buscam esconder o seu caráter de classe. Quando se fala em cultura popular acentua-se a necessidade de pôr a cultura a serviço do povo, isto é, dos interesses efetivos do país. Em suma deixa-se clara a separação entre uma cultura desligada do povo, não popular, e outra que se volta para ele e, com isso, coloca-se o problema da responsabilidade social do intelectual, o que obriga a uma opção. Não se trata de teorizar sobre a cultura em geral, mas de agir sobre a cultura presente, procurando transformá-la, entendê-la, aprofundá-la. (FÁVERO,1983, p. 49-50).

Todavia, dentro dessa perspectiva, assim como a definição de cultura não é uma unanimidade nas ciências humanas, devido a sua força de atuação e dos seus resultados; do mesmo modo, se enquadra a "cultura popular" com suas expressividades e características próprias, que segundo Arantes (2012), conceitua:

"Cultura popular" está longe de ser um conceito bem definido pelas ciências humanas e especialmente pela Antropologia Social, disciplina que tem dedicado particular atenção ao estudo da "cultura". São muitos os seus significados e bastante heterogêneos e variáveis os eventos que essa expressão recobre. Ele remete, na verdade, a um amplo espectro de concepções e pontos de vista que vão desde a negação (implícita ou explícita) de que os fatos por ela identificados contenham alguma forma de "saber", até o extremo de atribuir-lhes o papel de resistência contra a dominação de classe (ARANTES, 2012, p.7-8).

Assim, para o mesmo autor a terminologia da palavra cultura popular, apesar de ser um assunto que já vem sendo trabalhado na sociedade brasileira deste a década de 
1960, ainda causa mal-estar que, de modo geral, ainda não é bem aceito pela classe dominante e por muitos intelectuais ${ }^{61}$.

Seguindo o pensamento de Arantes (2012), em relação à cultura popular, ela não está dissociada da própria "cultura" como se fosse uma expressão mais forte da palavra cultura, ou só teria sentido a sua aplicabilidade quando houvesse um rompimento entre a classe dominante e a classe dominada. Pois, a cultura ou a "cultura popular" tem um alcance muito mais abrangente.

Registra A. Buarque de Holanda, em seu conhecidíssimo Pequeno Dicionário Brasileiro da Língua Portuguesa, que a palavra "cultura", em seu uso corrente, significa "saber, estudo, elegância, esmero"; ela evoca os domínios da filosofia, das ciências e das belas-artes. Nas sociedades estratificadas em classes, essas esferas da "cultura" são, na verdade, atividades especializadas que têm como objetivo a produção de um conhecimento e de um gosto que, partindo das universidades e das academias, são difundidos entre as diversas camadas sociais como os mais belos, os mais corretos, os mais adequados, os mais plausíveis, etc. Nesse sentido, "ser culto" é uma condição que engloba vários atributos: ter razão, ter bom gosto ou, numa palavra, como diz o nosso dicionário, "saber, ter conhecimento, estar informado" (ARANTES, 2012, p. 9-10).

Desta Forma, se observarmos ao nosso redor, damos conta de que são tantas variáveis e valores culturais que compõem a sociedade brasileira, que será difícil compreendê-la devido às suas complexidades e diferenças. Brasil, país gigante formado por pessoas de outras nacionalidades, cheios de contrastes sociais, não poderia se firmar se não levasse a sério a composição da sua formação cultural (ORTIZ, 1984, p. 7).

Não obstante, no Brasil, não é de se estranhar que, quando se fala de cultura popular, dependendo do lugar de fala ou da situação do lugar de fala e se for proferida por autoridade do mundo capitalista, o que se observa como atividade "popular", pode ser considerado como uma produção desprovida do "conhecimento". Por outro lado, a cultura popular que já vem sendo estudada no Brasil há bastante tempo, por diversos autores, onde eles a classificam por denominação de "folclore", dentro de uma

\footnotetext{
${ }^{61}$ Muita gente torce o nariz, levanta as sobrancelhas ou movimentar-se com impaciência quando ouve o enunciado "cultura popular". Em primeiro lugar, ao fato dessa noção ter servido a interesses políticos populistas e paternalistas, tanto de direita quanto de esquerda; em segundo, ao fato de que nada de claramente discernível e demarcável no concreto parece corresponder aos múltiplos significados que ela tem assumido até agora. Já é tempo e nos indagarmos sobre o sentido mais profundo dessa expressão e sore a convivência de a continuarmos usando como rótulo identificar de não se sabe muito por quê (ARANTES, 2012, p. 8-9).
} 
perspectiva de objetos práticos, sobretudo religiosas e dentro de uma concepção "tradicionalista". (ARANTES, 2012, p. 14 e 16). Ainda, na visão do mesmo autor:

Pensar a "cultura popular" como sinônimo de "tradição" é reafirmar constantemente a ideia de que a sua Idade de Ouro deu-se no passado. Em consequência disso, as sucessivas modificações por que necessariamente passaram esses objetos, concepções e práticas não podem ser compreendidas, senão como deturpadoras ou empobrecedoras. Aquilo que se considera como tendo tido vigência plena no passado só pode ser interpretado, no presente, como curiosidade (ARANTES,2012, p. 17).

Assim, para Fávero (1983), o que define a expressão cultura popular, como está sendo apreciada aqui, é ter a sensibilização para compreender que a cultura pode ser um instrumento de conscientização e de transformação social (FÁVERO, 1983, p. 50).

\section{MOVIMENTO DA CULTURA POPULAR - MCP}

Para compreendermos melhor os valores que a cultura é capaz de desenvolver nas pessoas e nas comunidades, pretende-se partir deste ponto e narrar de forma sucinta o que foi o MCP; assim, para compreendermos o significado da cultura popular, quando ela é desenvolvida em benefício da população, obedecendo a critérios objetivos, traçados e metodologias adequadas, dentro de uma perspectiva do processo ensino aprendizagem.

O MCP surgiu a partir da década de 1960, quando Miguel Arraes ${ }^{62}$, atuou como prefeito da cidade de Recife, conforme explica Barbosa (2010):

O MCP, foi um movimento social instituído, no início da década de 1960, por um grupo de intelectuais que pensou junto com o povo e elaborou as ideias filosóficas a partir da arte, fundamentando-se nas raízes da cultura popular. Ele trouxe mudanças significativas nas condições de vida da população pernambucana e transformações relevantes na cultura popular, visto que aqueles intelectuais buscavam construir uma política cultural que possibilitasse, por meio da educação, melhor qualidade de vida. Como enfatizou a educação popular no Brasil, podemos considerá-lo um movimento social de ampliação da educação, o qual lutava pela transformação estrutural da

62 Miguel Arraes (1916-2005), político brasileiro. Prefeito da cidade de Recife. Governador de Pernambuco durante o golpe militar de 1964, foi deposto, preso e exilado na Argélia, onde permaneceu durante 14 anos. 
sociedade, ao mesmo tempo em que funcionava como instrumento de mudança social, embora por si só não podemos transformar a sociedade. (BARBOSA, 2010, p. 64)

É importante deixar claro que o objetivo do MCP, versava em desenvolver e transmitir para a sociedade a arte, a música, o teatro e a dança, que o povo queria aprender e trazia as lembranças expressivas dos traços da cultura local (BARBOSA, 2010, p. 65). Além do mais, o movimento em tela, buscava sobretudo o desenvolvimento cultural do povo de Pernambuco, que na época, uma boa parte da sua população era analfabeta e não tinha uma participação efetiva na vida política e o mais grave, eles não tinham o direito de votar (SOUZA, 2014, p. 11).

Assim, a visão do MCP procurava desenvolver nas pessoas o espírito de "libertação" por meio da cultura popular e da educação de base. Desta forma, o movimento conseguiu unir intelectuais, estudantes e principalmente o povo (populares), que, em função dessa empreitada, usava desses mecanismos como uma alavanca, capaz de modificar o pensamento de uma sociedade.

Sendo assim, o MCP foi tão significativo para a compreensão do processo educacional brasileiro, que Letícia Rameh Barbosa, relata na sua obra, Movimento de Cultura Popular: impactos na sociedade pernambucana (2010), um relato crítico e reflexivo emitido pelo conceituado Frei Beto, sobre esse movimento à época, vejamos:

[...] neste momento, surge neste País uma nova postura epistemológica, quer dizer, uma nova maneira de pensar o Brasil, de encarar o Brasil. E, sobretudo, uma tentativa de aproximação cultural do universo popular. E essa tentativa de refletir em todo processo de criação artística. Todo esse pessoal do Cinema Novo, da Bossa Nova surge aí. Assim como o tem o Movimento da Cultura Popular no Recife, havia os Centros de Cultura Popular da União Nacional dos Estudantes do Brasil inteiro, que suscitava manifestações de arte com um conteúdo pró-causas populares. Hoje a gente tem uma visão mais crítica, sabe que ainda não era o próprio povo manifestando sua criação artística, ainda éramos nós, universitários, intelectuais, falando em nome do povo. Por exemplo, a obra de Oduvaldo Vianna Filho, as primeiras peças do Guarnieri, refletem bem isso. Nós interpretávamos a realidade, a partir dos interesses da classe popular (FREIRE; FREI BETTO, 186, p. 27-28; Apud BARBOSA, 2010, p. 65).

O MCP foi um dos movimentos de vanguarda na cidade de Recife que buscava, sobretudo, atender uma parcela da população que vivia marginalizada, sem cultura, sem 


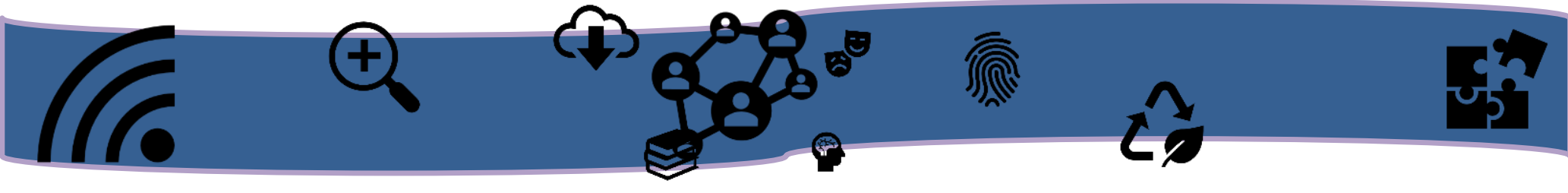

educação, sem perspectivas de dias melhores, de uma condição humana socialmente desfavorecida, notadamente, de uma parcela significativa da população, que viviam fora das salas de aula, especialmente as crianças e adultos recifenses, deixados de ser assistidos pelo poder público constituído.

Tal fato, chamou à atenção do recém-eleito prefeito da cidade de Recife à época, Miguel Arraes. Pois, o prefeito em questão, pretendia buscar soluções práticas, que o caso requeria. Desta forma, buscava também, envolver outros atores sociais para implementar de forma conjunta, medidas sociais para atender aquela massa carente. É o oportuno frisar, que segundo o Prefeito, a prefeitura da cidade de Recife não dispunha de recursos suficientes em seu orçamento para atendê-los, muito menos, de profissionais qualificados no quadro da educação municipal, para enfrentar tamanho desafio.

Assim, na fala de um dos idealizadores do MCP, fica evidenciado a importância da criação desse movimento, no sentido de construir nas pessoas o processo contínuo na busca pela cidadania, condição sine qua non, para o fortalecimento do cidadão, no sentido de que ele possa reivindicar melhorias sociais e condição de vida, para uma população historicamente marginalizada:

Foi a beira do Rio Capibaribe. No antigo prédio da Prefeitura, na Rua da Aurora. Lembra, logo o poeta Manuel Bandeira, na Evocação do Recife. "Como eram lindos os nomes das ruas da minha infância: rua do Sol, rua da Saudade, rua da Aurora". Foi lá, na Aurora onde tudo começou. Miguel Arraes, recém eleito prefeito do Recife, convocou o encontro. Queria ouvir professores, intelectuais, artistas e operários. E, abriu a reunião dizendo: "O Recife tem milhares de crianças sem escola. E a prefeitura não tem, no orçamento, recursos para a educação. Nem na sua estrutura administrativa, pessoal para o ensino, nem órgão específico educacional. E, no entanto, quero começar este ano, atendendo as crianças do Recife. Mobilizando alunos. Iniciando aulas. Abrindo escolas. Quero trabalhar com as classes populares; com elas e para elas. Este é o problema, que vamos discutir agora". Na discussão fui interpelado pelo prefeito, quanto ao que havia feito da Europa. [...]mencionei o Curso de Doutorado, na Faculdade de Direito da Universidade de Paris. Àquele ano, o professor Jean Lhomme aprofundou conosco a análise da "Política Social da Inglaterra Contemporânea". E, logo em seguida, publicou uma obra sobre o tema. Georges Lasserre, oficial do exército francês, durante a guerra de 1939 a 1945, caiu prisioneiro dos alemães, e num campo de concentração escreveu "Socializar com Liberdade - a Vocação do Europa" [...] Lembrei, ainda, da reunião com o prefeito, que Norma Porto Carreiro, minha esposa, ali sentada ao meu lado, havia feito o Curso de Pedagogia, na Sorbonne. Fora aluno de Jean Piaget e de Roger Cousinet. Fizera estágio em "La Source", escola experimental 
da Universidade. E, nos Alpes Marítimos, no sistema Freinet. Findou o encontro, com a minha indicação pelo próprio prefeito, a fim de apresentar uma proposta de solução para o problema do Recife. A prefeitura sem recursos. Sem estrutura educacional. E, as crianças, sem escolas. (COELHO, 2012, p. 1-2).

De acordo com Coelho (2012), o Movimento de Cultura Popular surgiu:

O primeiro "Peuple et Culture", denominava-se também, oficialmente, "Mouvement de Culture Populaire". [...] (nome que vingou na França), [...]. Dele, herdamos o nome. E quase diria: o sobrenome (Mouvement de Culture Populaire), menos usado na França. E, em grande parte, absorvemos o espírito. (COELHO, 2012, p. 7).

O MCP proporcionou ao Recife, outra visibilidade para que a cidade encarasse às questões sociais e produzissem soluções concretas com a participação efetiva da população e denunciasse outras desigualdades sociais, por meio das manifestações culturais. Com a chegada de Miguel Arraes, como Governador, no Palácio dos Campos das Princesas, sede do Poder Executivo do Estado em 1962 (COELHO, 2012, p. 108), o MCP, revigorou-se com a posse do seu primeiro presidente Germano Coelho, agora, Secretário de Educação e Cultura do Estado (COELHO, 2012, p. 122).

Assim, Barbosa (2010), relata as preocupações com os menos assistidos:

Aqui no Estado, os intelectuais de várias facções, unidos por uma causa em comum- a preocupação com os menos assistidos-, faziam, mediante diversas linguagens, suas denúncias dentro de sua área, embora cada área fosse interligada. Dentre esses intelectuais que se destacaram em Pernambuco, salientamos: Josué de Castro, com A geografia da fome, em que denunciou que a fome se estendia por todo mundo, era não só uma questão social como também política; na educação Paulo Freire, com a alfabetização de adultos, buscou a conscientização política juntamente com o povo; na música, Geral Menucci e Francisco Julião com o Hino do camponês; no teatro, Hermilo Borba Filho e Ariano Suassuna, este, filhos dos setores de classe dominantes, fez a opção pelas classes populares e, juntos com toda sua equipe, denunciava as questões políticas e sociais por meio das peças teatrais.[..].(BARBOSA,2010,p. 73-74).

Assim, o Movimento de Cultura Popular - MCP, ainda teve fôlego para percorrer o Brasil, num pequeno espaço de tempo, com objetivo precípuo de desenvolver um projeto de educação popular, sobre os olhares da cultura local 
(BARBOSA, 2010, p. 232). Mas, com o golpe civil militar de 31 de março de 1964, o MCP teve as suas atividades encerradas ${ }^{63}$.

Germano Coelho, na sua entrevista (2003), mostrou-se ainda muito indignado com a ocorrência do golpe militar:

Vi indignado, como fundador e primeiro presidente do MCP, em sede do Sítio da Trindade -dois tanques de guerra, agressivamente estacionados sobre o gramado. Que era então o MCP para se constituir, assim, em alvo da repressão? Que perigo trazia para a sociedade a cultura popular. Os documentos do tempo, mais do que os depoimentos posteriores, revelam a força e o espírito verdadeiro da instituição. Um deles, o Hino do Movimento da Cultura Popular... (COELHO, 1986, p. 09; Apud. BARBOSA, 2010, p. 234).

Desta forma, observou-se que o golpe militar, foi sem dúvida nenhuma, um alvo de repressão ao $\mathrm{MCP}$, pois não se via perigo nenhum que esse movimento trouxesse a sociedade pernambucana, tendo inclusive, documentos queimados, obras de artes destruídos e profissionais envolvidos perseguidos e destituídos de seus cargos.

\section{MEMÓRIA}

Tal como se compreende o processo expansivo da cultura, os conceitos de memória e identidade são de fundamental importância para aqueles que tenham interesses e queiram se debruçar no campo das ciências humanas na mesma perspectiva de estudar a cultura e suas correntes (CANDAU, 2018, p. 9).

Assim, a partir da década de 1980, o escritor Pierre Nora, enfatizou os locais de memória como um espaço de conjugação entre memória e história. Apesar que as duas abordagens são completamente distintas, e ainda dentro do mesmo raciocínio do autor:

Os lugares de memória são, antes de tudo, retos. A forma extrema onde subsiste uma consciência comemorativa numa história que chama, porque ela a ignora. É a desritualização de nosso mundo que faz aparecer a nação. O que secreta, veste, estabelece, decreta, mantém pelo artifício e pela vontade uma coletividade fundamentalmente envolvida em sua transformação e sua renovação. Valorizando por natureza o mais novo do que o antigo, o mais jovem do que o velho,

\footnotetext{
${ }^{63}$ Mas detalhes sobre o assunto, consultar as obras de: COELHO Germano- MCP: Movimento de Cultura Popular- Recife: 2012; BARBOSA, Letícia Rameh. Movimento de Cultura Popular: impactos na sociedade pernambucana. Recife Liceu, 2010; DE SOUZA, Fábio Silva: Movimento de Cultura Popular (1959-1964). Dissertação apresentada à Faculdade de Filosofia e Ciências Humanas da Universidade de São Paulo para a obtenção do título de Mestre em História. 2014.
} 
mais o futuro do que o passado. Museus, arquivos, cemitérios e coleções, festas de aniversários, tratados, processos verbais, monumentos, santuários, associações, são marcos testemunhais de uma outra era, das ilusões de eternidade. Daí o aspecto nostálgico desses empreendimentos de piedade, patéticos e glaciais. São os rituais de uma sociedade sem ritual; sacralizações passageiras numa sociedade que dessacraliza; fidelidades particulares de uma sociedade que aplaina os particularismos; diferenciações efetivas numa sociedade que nivela por princípio; sinais de reconhecimento e pertencimento de um grupo numa sociedade que só tende a reconhecer indivíduos iguais e idênticos. Os lugares de memória nascem e vivem do sentimento de que não há memória espontânea, que é preciso criar arquivos, que é preciso montar aniversários, organizar celebrações, pronunciar elogios fúnebre, notariar atas, porque essas operações não são naturais (NORA, 1993, p. 12).

Desta forma, as atividades humanas estão relacionadas a um sentimento de memória e as suas atividades estão voltadas para as questões pessoais ou coletiva. $\mathrm{O}$ escritor consagrado por suas observações, voltadas para o pensamento da sociologia de Durkheim, Halbwachs (2003), destaca-se analisando a memória no âmbito da coletividade, isto é, a nossa memória não é desenvolvida no campo da individualidade.

Todavia, a percepção de busca pelo passado não está desconectada de uma coletividade. Contudo, as nossas lembranças individuais afloram como um espelho das experiências passadas, das quais, nós vivíamos ou pertencemos aos grupos dos quais fazíamos partes (HALBWACHS, 2003, p. 30), conforme o mesmo autor:

Nossas lembranças permanecem coletivas e nos sãos lembrados por outros, ainda que se trate de eventos em que somente nós estivemos envolvidos e objetos que somente nós vimos. Isto acontece porque jamais estamos sós. Não é preciso que outros estejam presentes, materialmente distintos de nós, porque sempre levamos conosco e em nós certa quantidade de pessoas que não se confundem. (HALBWACHS, 2003, p. 30).

Assim sendo, a convicção da memória de cada ser humano, está vinculada à lembrança da coletividade. Sendo assim, as atividades culturais, neste caso específico, as ações desenvolvidas pelo Movimento de Cultura Popular-MCP, criado na década de 1960, pela prefeitura da cidade de Recife, era uma expressividade da nossa memória individual, produzida na coletividade. Uma vez que, tanto a cultura quanto a memória fazem parte da nossa identidade, e por conseguinte, transmitida de geração para geração. 
Entretanto, na concepção de Le Goff (2003), a memória como um sentimento de preservar algumas informações importantes, pode fazer com que o homem busque à sua atualização ou modifiquem certas impressões ou informações, que a mesma a considerem como passadas (LE GOFF, 2003, p. 419). Ou seja, as lembranças escondidas por várias décadas só serão revividas no presente se elas foram contadas como fatos históricos relevante (CANDAU, 2018, p. 16), que segundo o mesmo autor:

\begin{abstract}
A memória, ao mesmo tempo em que nos modela, é também por nós modelada. Isso resume perfeitamente a dialética da memória e da identidade que se conjugam, se nutrem mutuamente, se apoiam uma na outra para produzir uma trajetória de vida, uma história, um mito, uma narrativa. Ao final, resta apenas o esquecimento. (CANDAU, 2018, p. 16).
\end{abstract}

Assim, ao longo deste artigo, buscou-se refletir acerca da importância das ações culturais na vida de uma sociedade, sua forma de agir, sua compreensão naquilo que é importante para a construção de valores culturais, presentes na própria comunidade. Apesar que essa relação de poder sempre marcaram a construção social entre a classe dos dominantes e classe dos dominados na busca da identidade para cada tipo de construção.

Para Castells (1999, p. 24), as identidades são assim definidas: identidade legitimadora, identidade de resistência e identidade de projetos, conforme observamos:

- Identidade legitimadora, introduz mecanismo para a construção de uma sociedade civil composta de instituições organizadas, contudo, não despreza à contribuição de atores sociais, dentre outros envolvidos na busca da reprodução de uma identidade de dominação.

- Identidade de Resistência esta é considerada como uma das mais importantes, pois, cria mecanismo de resistência em desfavor da lógica dominante. E por conseguinte,

- Identidade de Projetos, é quando os atores sociais se utilizando de materiais culturais já existentes ao seu dispor passa construir uma nova formatação de identidade que possibilite definir a posição de cada um em sociedade (CASTELLS, 1999, p. 24-26).

Já, Candau (2018), relata cinco ideias que ele a consideram importantes para a compreensão dos estudos da memória. Vejamos: 
1.Tal como a noção de cultura, os conceitos de memória e identidade são fundamentais para qualquer um que tenha algum interesse no campo das ciências Humanas e Sociais. 2.Contra as concepções "objetivistas", "reificadoras", "primordialistas", "substancialistas", "essencialistas", "originárias", "fixistas" etc. de identidade, observa-se um relativo consenso entre os pesquisadores em admitir que essa seja uma construção social, de certa maneira sempre acontecendo no quadro de uma relação dialógica com outro. 3.O consenso existe igualmente em reconhecer que a memória é, acima de tudo, uma reconstrução continuamente atualizada do passado, mais do que uma reconstituição fiel do mesmo: "a memória é de fato mais um enquadramento do que um conteúdo, um objetivo sempre alcançável, um conjunto de estratégias, um "estar aqui" que vale menos pelo que é do que pelo que fazemos dele". A ideia segundo a qual as experiências passadas seriam memorizadas, conservadas e recuperadas em toda sua integridade parece insustentável. 4.0 mnemotropismo ${ }^{64}$ de numerosas sociedades modernas encontra sua origem na "crise do presentismo, $\mathrm{o}$ desaparecimento de referência e a diluição de identidades. A busca memorial é então considerada como uma resposta às identidades sofredoras e frágeis que permitiria "apoiar um futuro incerto em um passado reconhecível. Variante à primeira vista, tende talvez ao contraditório: as paixões considerando-se também as tensões identitárias contemporâneas, são a consequência de uma perda de memória. 5. Enfim, admite-se geralmente que a memória e identidade estão indissoluvelmente ligadas (CANDAU, 2018, p. 9-10).

\section{CONSIDERAÇÕES FINAIS}

Este artigo tem por objetivo refletir sobre a nossa cultura, entendendo que ela é o maior patrimônio que nós temos. Tal premissa, parte da miscigenação para a formação do povo brasileiro. Nossa cultura é rica em todos os aspectos e, este patrimônio precisa ser preservado, respeitando e observando as características de cada região brasileira e comunidades afins.

Defender a cultura é um dever de todos brasileiros, pois, a sua conservação ratifica que este patrimônio é nosso e faz parte da nossa memória. Em décadas recentes, quando a nossa cultura começou a ser trabalhada nas comunidades menos favorecidas, como por exemplo: na cidade de Recife - com a instauração do MCP -, cujo movimento tinha como objetivo colocar o cidadão como sujeito das ações culturais dentro de uma

\footnotetext{
${ }^{64}$ 1. Conceito utilizado por Joel Candau em "Memória e Identidade". 2. Junção dos conceitos abstratos de Mnemosyne $=$ deusa da memória e Tropismo $=$ aproximação. 3. Significa literalmente a aproximação da memória.
} 
perspectiva de patrimônio "libertador", foi interrompido. O quanto é importante ter a cultura como patrimônio e ao mesmo tempo como identidade do povo.

Logo, as palavras memória, patrimônio e identidade dentro de uma conjuntura cultural essas, podem ser aglutinadas em apenas duas, se for entendido que o patrimônio faz parte também das extensões da memória, pois, a memória tende a fortalecer a identidade. (CANDAU, 2018, p. 16).

Na citação a seguir conforme relata a autora, a noção de patrimônio em processo se inseriu, portanto, no projeto mais amplo de construção de uma identidade nacional, e passou a servir ao processo de consolidação dos Estados-nações modernos, neste sentido, vinha cumprir inúmeras funções simbólicas:

1. Reforçar a noção de cidadania, na medida em que são identificados, no espaço público, bens que não são de posse privada, mas propriedade de todos os cidadãos, a serem utilizados em nome do interesse público. Nesse caso, o Estado atua como guardião e gestor desses bens; 2. ao partir da identificação, nos limites do Estado Nacional, de bens representativos da nação - demarcando-a assim no tempo e no espaço - a noção de patrimônio contribui para objetivar, tornar visível e real, essa entidade ideal que é a nação, simbolizada também por obras criadas expressamente com essa finalidade (bandeiras, hinos, calendário, alegorias e mesmo obras de artistas plásticos, como David). A necessidade de proteger esse patrimônio comum reforça a coesão nacional; 3. os bens patrimoniais, caracterizados desde o início por sua heterogeneidade, funcionam como documentos, como "provas materiais" das versões oficiais da história nacional, que constrói o mito de origem da nação e uma versão da ocupação do território, visando a legitimar o poder atual; 4. a conservação desses bens - onerosa, complexa e frequentemente contrária a outros interesses, públicos e privados - é justificada por seu alcance pedagógico, a serviço da instrução dos cidadãos. (FONSECA, 1997, p. 59-60).

\section{REFERÊNCIAS}

ARANTES, Antônio Augusto. O Que é Cultura Popular. São Paulo: Brasiliense, 2012, p. 7-10, 14-15 e 17.

BARBOSA, Letícia Rameh. Movimento de Cultura Popular: Impactos da Sociedade Pernambucana. Recife: Liceu, 2010, p. 65, 73-74, 232 e 234.

CANDAU, Joel. Memória e Identidade. São Paulo: Contexto, 2018, p. 9-10 e 16. 
CASTELLS, Manuel. O Poder da Identidade. São Paulo: Paz e Terra 1999, p. 24-26.

COELHO Germano. Movimento de Cultura Popular, Recife: Ed. do Autor, 2012, p. 1-2 e 108 .

FÁVERO, Osmar. Cultura e Educação Popular: Memória dos Anos 60, Rio de Janeiro, Edições Graal, 1983, p.7, 27, 50.

FONSECA, Maria Cecília Londres. O Patrimônio em Processo. Rio de Janeiro; UFRJ, 1997 , p. $59-60$

FRAZAO. Dilva. Resumo da Biografia de Miguel Arraes. Bacharela em Biblioteconomia pela UFPE. Redação de conteúdos educativos para WEB, site ebiografia. Disponível em: https://www.ebiografia.com/miguel_arraes/. Acesso em 30 Mar. 2020.

GASPAR, Lúcia. Movimento de Cultura Popular. Pesquisa Escolar Online. Fundação Joaquim Nabuco, Recife. Disponível em:

<http://basilio.fundaj.gov.br/pesquisaescolar/>. Acesso em: 30 Mar 2020.

GEERTZ, Clifford. A Interpretação das Culturas. Rio de Janeiro: LTC, 2012, p. 22.

HALBWACHS, Maurice. A memória Coletiva. $2^{\text {a }}$ Edição São Paulo Centauro, 2003, p. 30.

LE GOFF, Jacques. História e Memória. $5^{\text {a }}$ Ed. Campinas, SP: Editora da UNICAMP, 2003, p. 419.

NORA, Pierre. Entre Memória e História: A Problemática dos Lugares. In: Projeto História. São Paulo: PUC-SP. nº 10, 1993, p. 12.

ORTIZ, Renato. Cultura brasileira e identidade nacional. Edição, 3. Editora, Brasiliense, 1984.

SILVA, Kaline Wanderlei; SILVA, Maciel Henrique. Dicionário de Conceitos Históricos. 3.ed. São Paulo: Contexto, 2010, p. 85.

SOUZA, Fábio Silva de: Movimento de Cultura Popular (1959-1964). Dissertação apresentada à Faculdade de Filosofia e Ciências Humanas da Universidade de São Paulo para a obtenção do título de Mestre em História. 2014

WILliAMS, Raymond. Cultura, Paz e Terra. Rio de Janeiro, 1992, p. 10-11.

WAGNER, Roy. A Invenção da Cultura. São Paulo: 2017, p. 9, 34, 49-50, 51-52. 
NAWEÜ I TACÜMAGÜ: UMA EXPERIÊNCIA VIVENCIADA NO CURSO DE FORMAÇÃO DE PROFESSORES INDÍGENAS EM BENJAMIN CONSTANTAM

LIMA, Jorge Luís de Freitas ${ }^{65}$

\section{RESUMO:}

Este trabalho apresenta um relato de experiência de realização do evento sobre expressão cultural resultante das atividades desenvolvidas na disciplina Expressão Cultural I, componente curricular do Curso de Formação de Professores Indígenas, turma Alto Solimões, promovido pela Faculdade de Educação da Universidade Federal do Amazonas por meio do Departamento de Educação Escolar Indígena no Instituto de Natureza e Cultura em Benjamin Constant-AM. Os docentes-cursistas pertencem à duas etnias: tikuna e kokama. O objetivo da disciplina foi compreender a potência sinestésica da expressão cultural, bem como sua percepção e expressão por diferentes linguagens em nível individual e em grupo, como subsídio para o reconhecimento da relação entre saberes, cultura, identidade e desenvolvimento do pensamento crítico. Aa atividades desenvolveram-se numa abordagem interacionista, introduzidas a partir de discussões a respeito dos conceitos de cultura e da apresentação do conceito de performances culturais. Com ênfase no "renascimento das culturas indígenas" na história recente, afunilou-se a discussão para a temática da globalização cultural "Contra-Hegemônica" e o impacto desta "nova onda" no cotidiano das populações indígenas. Ao final de cada discussão, os participantes apresentavam seus posicionamentos sob a forma de apresentação de seminários. Foram abordadas, também, questões referentes ao potencial criativo humano e sua relação com as diferentes formas de expressão cultural. Ao final da disciplina, os participantes produziram em diferentes linguagens, formas de representação e expressão de suas culturas, uma exposição. A metodologia adotada para a organização do evento foi a separação do que seria exposto em categorias assim distribuídas: pinturas corporais, máscaras, artesanato, dança, canto e trajes tradicionais. Todo o registro da escrita pelos discentes foi feito primeiro na língua materna deles e depois em português. Utilizou-se como suporte teórico Bachelard (1982), Rojas Niño (1997), Canedo (2007) e Pinto (2010). O evento contou com a presença de docentes e discentes dos cursos de graduação do Instituto de Natureza e Cultura.

PALAVRAS-CHAVE: Cultura. Expressão. Seminário. Exposição.

\section{INTRODUÇÃO}

Em outubro de 2018 vivenciamos uma experiência durante a ministração da disciplina Expressão Cultural, integrante do currículo do Curso de Formação de

\footnotetext{
${ }^{65}$ Doutor e Mestre em Sociedade e Cultura na Amazônia pela Universidade Federal do Amazonas (UFAM). Docente da Universidade Federal do Amazonas/UFAM. E-mail: jorgefreitas@ufam.edu.br
} 
Professores Indígenas - FPI, promovido pelo Departamento de Educação Escolar Indígena - DEEI da Faculdade de Educação - FACED da Universidade Federal do Amazonas-UFAM, realizada no Instituto de Natureza e Cultura-INC/UFAM no município de Benjamin Constant-AM.

Durante o período de realização da disciplina, seis dias em período integral, foram desenvolvidas atividades que permitiram a reflexão junto aos 60 (sessenta) professores indígenas das etnias tikuna e kokama sobre a potência sinestésica da expressão cultural e como se dá a sua percepção e expressão por diferentes linguagens em nível individual e grupal, como subsídio para a compreensão de sua cultura e a contribuição disso para o desenvolvimento do pensamento crítico. A disciplina aconteceu de forma modular e, como professor convidado, pude conhecer um pouco mais sobre a proposta de formação de professores indígenas previamente à realização da disciplina.

O trabalho com os professores-discentes e as atividades desenvolvidas alicerçouse em pressupostos de discussão teórica atualmente aceitos relacionados aos estudos culturais no que se refere às diferentes formas de expressão da cultura, os diversos conceitos, o conceito de performances culturais, considerando-se também o potencial criativo humano e, a partir disso evidenciar as diferentes formas de se fazer com que se percebessem culturalmente no meio em que vivem.

As aulas fora ministradas numa abordagem interacionista, levando-se em consideração o conhecimento prévio dos professores-discentes e, a partir dele, promover a reflexão a respeito da cultura e suas formas de expressão com vistas à construção do conhecimento a respeito da potência sinestésica da expressão cultural. Tais fundamentos subsidiaram as discussões e posicionamentos críticos dos professores-discentes sobre as políticas públicas de promoção e valorização da cultura nacional, com ênfase nos povos indígenas.

O encerramento da disciplina culminou com a exposição "Expressão Cultural" que possibilitou aos professores socializarem com a comunidade acadêmica e externa as diferentes formas de expressão da cultura deles.

\section{AS ATIVIDADES DESENVOLVIDAS}


O pontapé inicial da realização da disciplina foi a apresentação da proposta de desenvolvimento das atividades e dos procedimentos de avaliação. Após a concordância com os procedimentos, fez-se uma espécie de dinâmica de grupo com o intuito de se "quebrar o gelo" e estabelecer um clima de proximidade e conhecimento entre os envolvidos no processo ensino-aprendizagem.

A partir da leitura do texto "Cultura é o quê??" - reflexões sobre o conceito de cultura e a atuação dos poderes públicos, estabeleceu-se um momento de discussão a respeito da diversidade de conceitos que podem ser encontrados sobre cultura. Procurou relacionar os diferentes conceitos e como as diferentes áreas de conhecimento vislumbram a cultura e, posteriormente, como os professores-discentes se identificavam ou não com cada um deles.

Ao final do processo, sugeriu-se uma atividade em grupo (ver figura 1) com o objetivo de, a partir da compreensão deles, elaborassem um conceito de cultura. Foi decidido com o grupo que o registro escrito seria feito na língua materna deles (tikuna e kokama) e em língua portuguesa. Importante destacar a dificuldade levantada pelos kokama em relação à escrita na língua deles, dada a dificuldade de registro, em decorrência da falta de uso pelos mais jovens, ressaltando, inclusive, a necessidade de empreender esforços no sentido de garantir a preservação da língua kokama, haja vista os poucos que a dominam serem anciões com idade bastante avançada e serem muito incipientes os estudos e registros nesta língua.

Não obstante, consideramos importante relatar o entusiasmo e comprometimento de todos os grupos nas discussões e na produção do material exposto, bem como a satisfação deles em ver seus trabalhos produzidos na sua língua materna e expostos para serem vistos pela comunidade do INC. A oportunidade de se posicionar, de se fazer ouvir, mas também ouvir, de questionar e responder a questionamentos foi um momento de muito aprendizado, principalmente pelas trocas de experiências das formas de compreensão da cultura de diferentes formas, partindo sempre das experiências vivenciadas pelos professores-discentes e eu, enquanto mediador. 


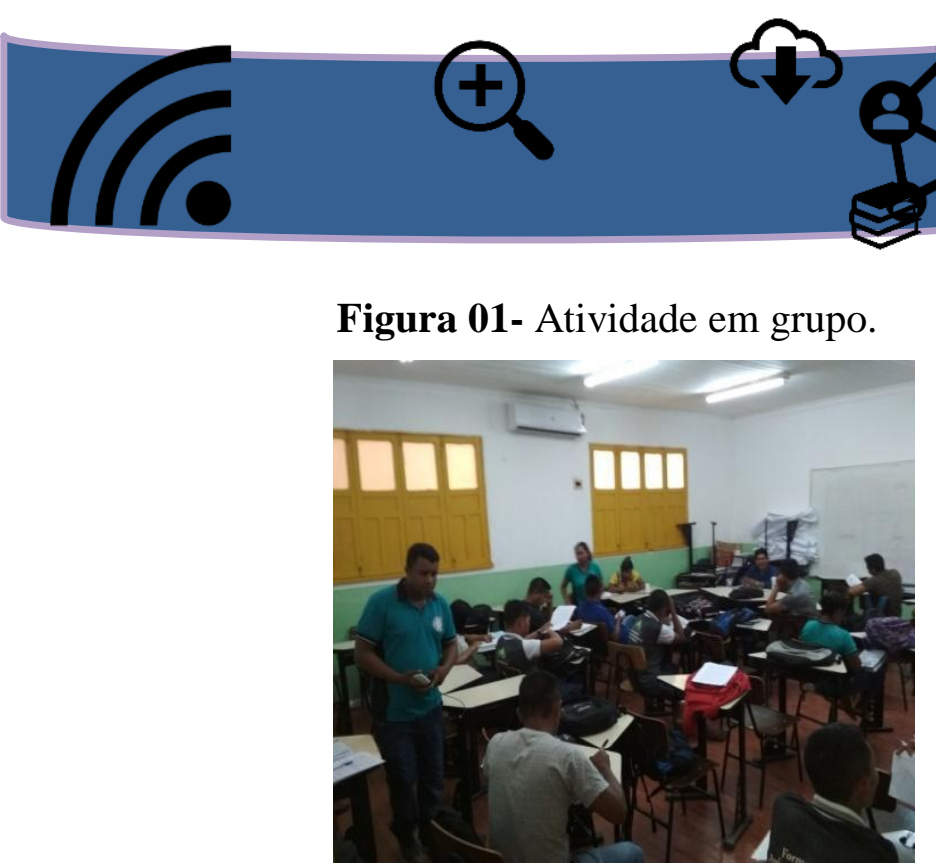

Fonte: Jorge L. F. Lima, 2018.

Figura 03 - Conceitos de cultura G2.

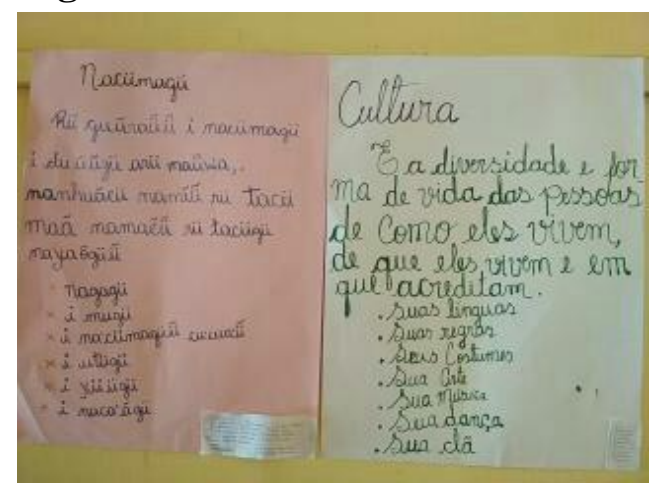

Fonte: Jorge L. F. Lima, 2018.
Figura 02- Conceitos de cultura G1.

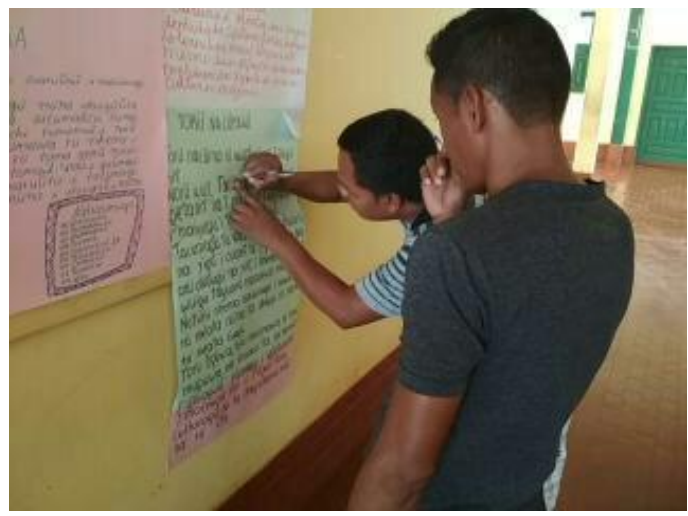

Fonte: Jorge L. F. Lima, 2018.

Figura 04 - Conceitos de cultura G3.

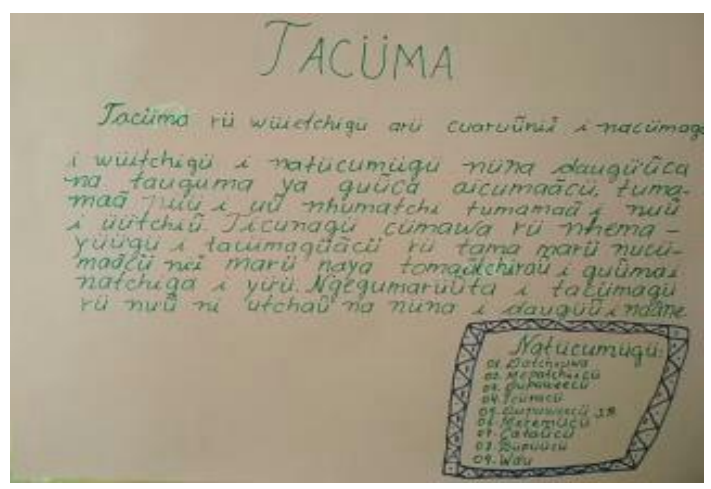

Fonte: Jorge L. F. Lima, 2018.

Figura 05 - Conceitos de cultura G4.

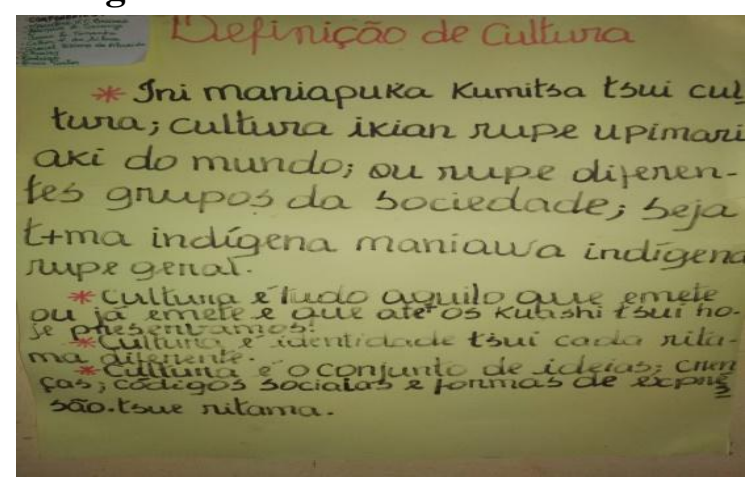

Fonte: Jorge L. F. Lima, 2018.

Por se considerar importante tornar visível o que estava sendo discutido e produzido na disciplina, resolveu-se expor os cartazes com os conceitos sobre cultura elaborados, resultantes do trabalho dos grupos, conforme se vê nas figuras 2 a 5 . 
Uma vez ambientados e esclarecidos sobre de que cultura estávamos falando, enveredamos rumo a mais algumas descobertas, desta vez alicerçados pela leitura do texto Performances culturais: um conceito interdisciplinar e uma metodologia de análise, segundo o qual:

Performances Culturais é um conceito que, primeiramente, está inserido numa proposta metodológica interdisciplinar e que pretende o estudo comparativo das civilizações em suas múltiplas determinações concretas; visa também o estabelecimento do processo de desenvolvimento destas e de suas possíveis contaminações; assim como do entendimento das culturas através de seus produtos "culturais" em sua profusa diversidade, ou seja, como o homem as elabora, as experimenta, as percebe e se percebe, sua gênese, sua estrutura, suas contradições e seu vir-a-ser (CAMARGO, s/d, p. 1).

O propósito da leitura e discussão do texto foi oportunizar aos participantes a percepção de si, a partir do outro, mas considerando-se também o meio social em que se vive. Refletir acerca de como, por meio da convivência e do passar do tempo, as mudanças decorrentes da modernização, e das diferentes formas de contato podem interferir na "avaliação" do modo de vida fundamentado pela tradição. E, também, compreender que pela comparação é possível se evidenciar as singularidades de cada sociedade, e por isso mesmo não pensá-las, em termos de cultura, de forma hierarquizada, pois é exatamente esse olhar hierarquizante que culmina com o estabelecimento da dicotomia expressa pelos termos civilizado x não-civilizado, a partir da convicção equivocada de que existem culturas superiores a outras. Obviamente, tal posicionamento se fundamenta na consideração de "formas totalizantes estabelecidas pelo "senso comum" nas definições de civilização.

Sob essa perspectiva, Barth (1998, p. 152) assevera que:

[...] a pertença étnica não pode ser determinada senão em relação a uma linha de demarcação entre membros e não-membros de um determinado grupo social. Trata-se, portanto, de uma característica de reconhecimento pelos outros, que define o pertencimento de alguém a determinado grupo étnico, e não o fato de manifestar certas crenças e traços culturais. Foi, então, a partir da Constituição de 1988 que a Funai passou a investir, também, na capacitação de índios, para que estes viessem a assumir as funções educativas nas comunidades em que estavam inseridos. 
Para mim enquanto professor foi muito gratificante ver o modo como os docentes-cursistas iam se demonstrando motivados e entusiasmados com as temáticas apresentadas, principalmente quando se posicionavam a respeito da oportunidade de terem o direito de falar de seus anseios e enfrentamentos enquanto professores indígenas, ressaltando a importância do diálogo, principalmente pela proposta da disciplina em valorizar a língua deles e sua cultura, que geralmente é discriminada e marginalizada.

Não pude deixar de registrar, também, as diferentes falas a respeito da escola em que estão inseridos, geralmente caracterizadas pela falta de estrutura e condições de trabalho. Principalmente no que se refere à política de contratação de professores e de formação continuada deficitária que é ofertada pelo poder público. Segundo os docentes-cursistas, "cobram muito, mas não oferecem muito para garantir bons resultados".

Foram discutidos também temas relacionados ao modo como funciona a educação indígena em Benjamin Constant-AM, como é planejado o calendário acadêmico, material didático e valorização da cultura, ressaltando-se de forma recorrente nos posicionamentos, a necessidade de se rever grande parte dos itens citados no que se refere ao modo como são "propostos". Incluíram-se também nas discussões, não só a relevância do curso de formação, mas também as dificuldades enfrentadas para participar dele.

Aproveitando os ânimos e entusiasmo das reflexões, propusemos a leitura do texto A Globalização Cultural "Contra-Hegemônica” no Ciberespaço: o caso dos povos indígenas (PINTO, 2010). A ideia foi trazer para a discussão a influência que a internet teve sobre a redefinição das fronteiras mundiais a partir do surgimento do que se chamou "processo de globalização cultural" e os impactos da "revolução tecnológica" e das mídias nas minorias étnicas.

Os resultados foram muito proveitosos, pois os docentes-cursistas manifestaram seu posicionamento a respeito da importância que a internet e as diferentes mídias sociais têm no sentido de oportunizar a maior visibilidade das questões indígenas. Destacaram também a facilidade que as redes sociais propiciam no que se refere à divulgação do que acontece em suas comunidades, por mais longínquas que seja sua localização. Destacaram também que as redes sociais são mecanismo importantes para 
serem usados como forma de defesa e proteção, pois possibilitam que sejam feitas denúncias com maior abrangência na divulgação.

$\mathrm{Na}$ oportunidade, aproveitou-se para se fazer utilização da tecnologia, e sugeriuse e orientou-se que se elaborasse a apresentação em power point dos resultados das leituras e das discussões para que fossem expostas pelos docentes-cursistas com o uso do projetor de mídias. Os trabalhos foram uma oportunidade de minimizar as dificuldades que alguns apresentavam para falar em público. O mais interessante é que a maioria deles solicitou para fazer a apresentação na língua deles. Para mim foi uma experiência única, pois conseguia acompanhar a apresentação escrita em língua portuguesa, com tradução simultânea para a língua tikuna e a kokama. Atividade muito produtiva.

A atividade seguinte teve como mote, além da relação com as anteriores, a leitura e discussão dos textos A Busca das Categorias da Criatividade do Homem Comum (ROJAS NIÑO, 1997) e A Criatividade como Condição do Ser Humano (HOLANDA; VERAS, 2009), com o propósito de subsidiar a realização da exposição sobre as diferentes formas de expressão da cultura tikuna e da cultura kokama. Assim, procurou-se mediar junto aos docentes-cursistas, a integração de tudo o que foi discutido até ali e, a partir da compreensão da criatividade humana e seus "fatores influentes", e da utilização de seu potencial criador, socializar com a comunidade acadêmica do Instituto de Natureza e Cultura e comunidade local que se fizesse presente, as diferentes formas de expressão cultural das etnias deles.

Neste sentido, deixou-se inteiramente a critério dos docentes-cursistas a escolha do modo como seria organizada a exposição que, de comum acordo, denominou-se NAWEÜ I TACÜMAGÜ (Expressão Cultural). Eles decidiram que a exposição se organizaria em torno de cinco eixos temáticos (figuras 10 a 13) que abrangeriam as expressões culturais das duas etnias tikuna e kokama, assim definidos:

a) Pinturas corporais

b) Máscaras

c) Música e dança

d) Artesanatos

Todo o material da exposição foi produzido pelos docentes-cursistas e foram expostos por eles no espaço de convivência do Instituto de Natureza e Cultura. Na 


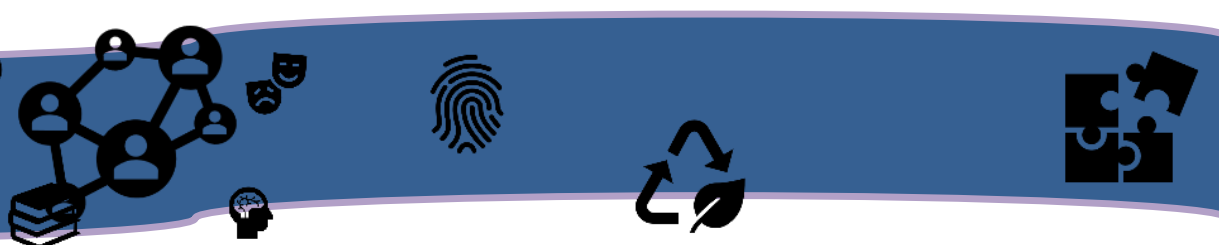

oportunidade, foram convidados os discentes dos cursos de Administração, Antropologia, Ciências: Biologia e Química, Letras, Antropologia, Ciências Agrárias e do Ambiente e Pedagogia para prestigiarem o evento. As danças foram apresentadas concomitantes à exposição, no espaço de convivência do INC.

Figura 08 - Identificação da exposição.

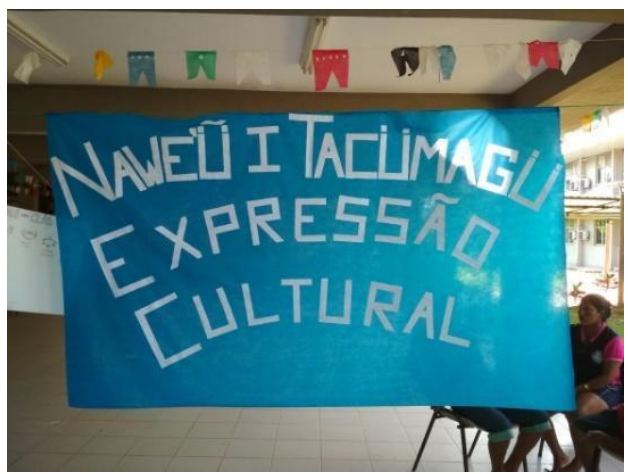

Fonte: Jorge L. F. Lima, 2018.
Figura 09 - Exposição na área de conivência.

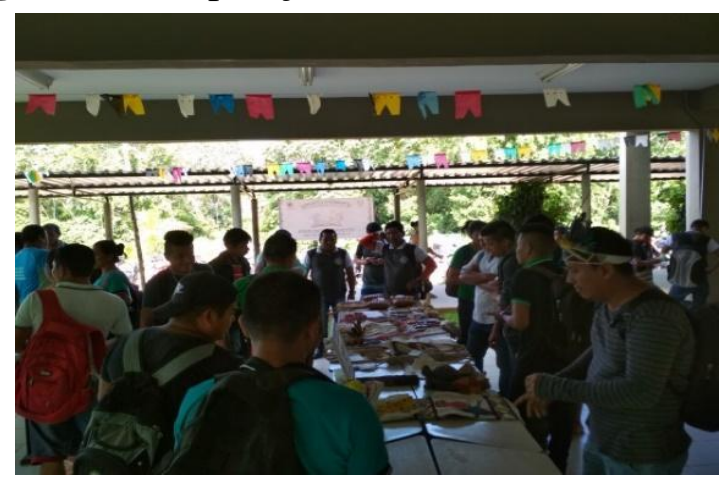

Fonte: Jorge L. F. Lima, 2018.

Foram momentos muito significativos de aprendizado e de troca de experiências. Um fato que chamou a atenção foi o desconhecimento que alguns alunos das etnias que estavam expondo demonstraram sobre alguns elementos das tradições deles, a exemplo da identificação dos diferentes clãs, bem como das pinturas corporais que os identificava.

A curiosidade e o interesse demonstrado pelo público quanto aos itens expostos demonstraram a importância do evento como forma de socializar as diferentes formas de expressão cultural dos tikuna e dos kokama, com destaque para os discentes pertencentes a essas etnias.

Figura 10 - Grafismos corporais.

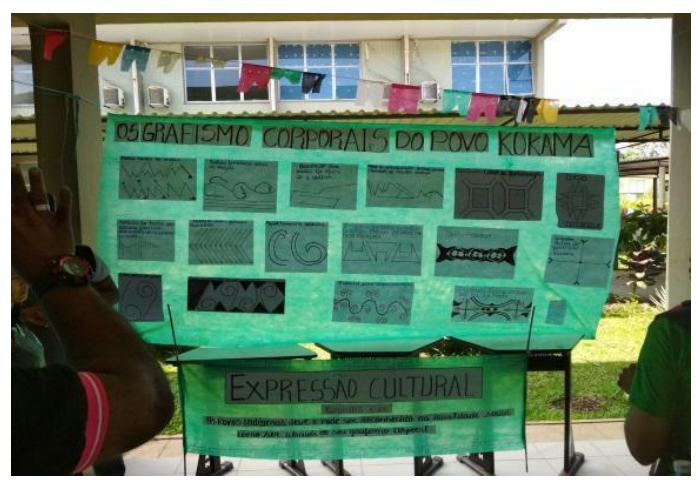

Fonte: Jorge L. F. Lima, 2018.
Figura 11 - Artesanato.

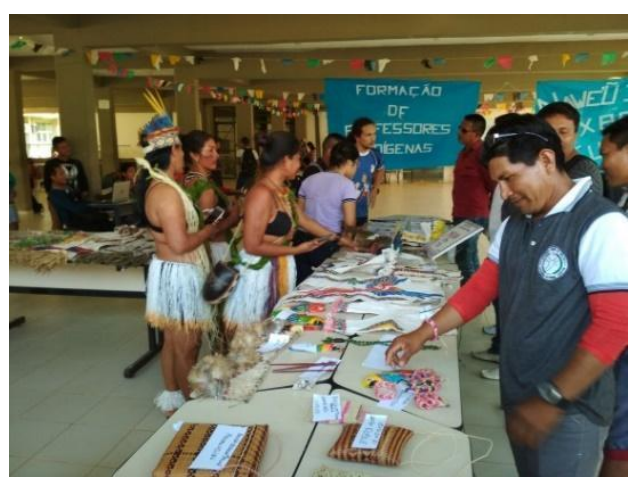

Fonte: Jorge L. F. Lima, 2018. 
Figura 12 - Música e dança.

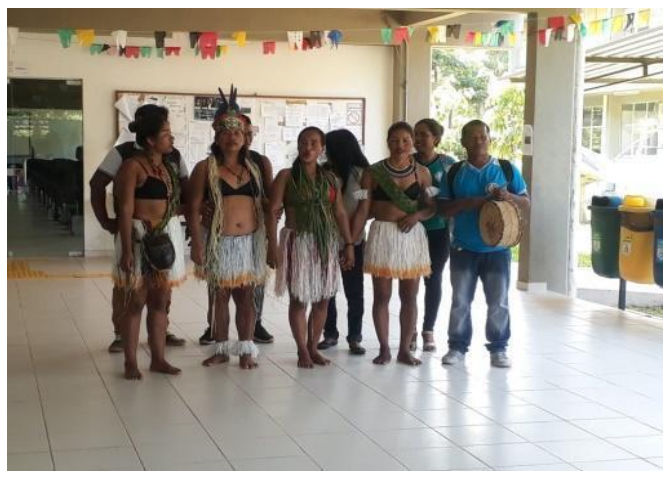

Fonte: Edilani R. de Oliveira, 2018.
Figura 13 - Máscaras.

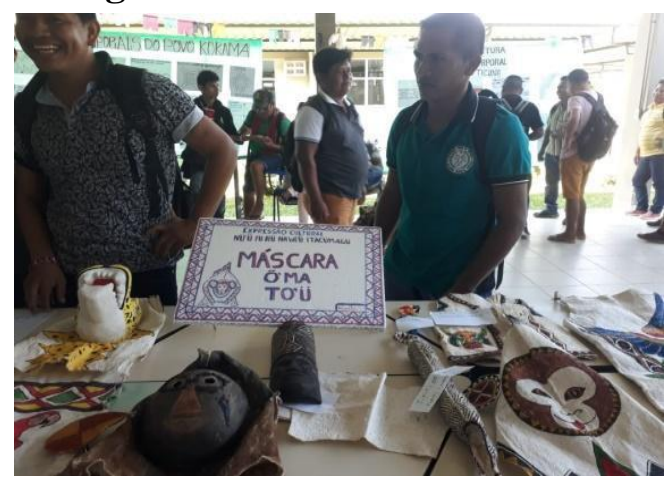

Fonte: Edilani R. de Oliveira

\section{CONSIDERAÇÕES FINAIS}

Não há dúvidas de que a realização do evento foi uma experiência memorável (para mim, Jorge Luís, especialmente, pois tive honra de receber de algumas docentescursistas tikuna e a denominação WE'ÊCÜ cujo significado é onça nadadora) e extremamente significativa para o processo de formação dos professores indígenas, principalmente, porque a partir do que foi vivenciado, pode-se perceber a importância de se redimensionar o papel do professor em sala de aula, afastando a ideia de vê-lo como mero transmissor de conhecimentos, aplicador de provas e exercícios, com a atribuição inerente à função de indicar a aprovação ou reprovação do aluno.

Neste sentido, a exposição também tornou possível evidenciar para os docentescursistas e expectadores o quanto é importante a participação do professor como mediador da construção do conhecimento de uma forma criativa, dinâmica e estimuladora.

Atividades, como as desenvolvidas, permitiram perceber que é possível fazer diferente, com ações que colocam o discente no centro do processo ensinoaprendizagem e, acima de tudo, contribuem para os alunos perceberem o quanto é relevante se fazer visto por meio do que podem realizar e, assim, despertar no "outro" a valorização e o respeito pela sua cultura, no caso específico, a cultura indígena. 
Permitiu também compreender que, mesmo aqueles que pertencem a determinada etnia podem desconhecer performances culturais que lhes são próprias e, a partir de momentos como esses, possam ter acesso à informações, visualizar e até vivenciar (no caso da dança, por exemplo) momentos de interação e reconhecimento de suas tradições e assim promover a valorização de sua cultura.

Os objetivos foram alcançados, os resultados, um sucesso!

Tenho plena convicção, portanto, de que a realização das atividades nesta disciplina contribuiu para a percepção do quanto as atividades de ensino se tornam produtivas quando o centro do processo é o aluno. Mas também é preciso ter a convicção de que os universos e realidades de ensino-aprendizagem são diferentes e sempre acontecem em ambientes marcados pela heterogeneidade de agentes e por diferentes condicionadores, o que pode contribuir significativamente para o sucesso ou não dos resultados das atividades desenvolvidas.

O caminho para lidar com essas nuances de diversidade, passa necessariamente pela busca constante de atualização. Mas para isso, precisamos estar convictos de que nunca estaremos prontos, mas em constante construção e estar atentos às mudanças e transformações que se apresentem durante a nossa trajetória docente.

\section{REFERÊNCIAS}

BACHELARD, Gaston: El Aire y lós Sueños. Fondo de Cultura Económica, Bogotá, 1982.

BARTH, Fredrik. Os grupos étnicos e suas fronteiras. In.: POUTIGNAT, Philippe.

Teorias da etnicidade. São Paulo: Unesp, 1998.

CANEDO, 'Cultura é o quê? - Reflexões sobre o conceito de Cultura e a Atuação dos Poderes Públicos. In.: ANAIS. V Encontro de Estudos Multidisciplinares em CulturaENECULT, Salvador-BA, maio de 2007.

CAMARGO, Robson Corrêa de. Performances Culturais: um conceito interdisciplinar e uma metodologia de análise. Disponível em:

https://performancesculturais.emac.ufg.br/up/378/o/Performances_Culturais_Um_conc eito_interdisciplinar_e_uma_metodologia_de_an\%C3\%A1lise-Robson_Camargo.pdf. Acesso em 08/10/2018.

HOLANDA, Julia de; VERAS, Ingrid Almeida. A Criatividade Como Condição de Ser Humano. In.: Revista Filosofia Capital. Vol. 4. Edição 8, 2009. 
PINTO, Alejandra Aguilar. A Globalização Cultural "Contra-Hegemônica" no

Ciberespaço: o caso dos Povos Indígenas. 2010.

ROJAS NIÑO, Carlos G. Criatividade do Homem comum, estética, educação, cotidiano". Tese UNICAMP: Filosofia e História da Educação, 1997, N/E. 


\title{
NEOLIBERALISMO E O PAPEL DO ESTADO NA CONSTRUÇÃO DA NOVA POLÍTICA EDUCACIONAL PARA O ENSINO MÉDIO: CAMINHOS PARA UM PROJETO HEGEMÔNICO DE FORMAÇÃO DA JUVENTUDE EM PERNAMBUCO
}

\author{
NOGUEIRA, Josefa Uérica De Araujo ${ }^{66}$ \\ ARAÚJO, Micilane Pereira De ${ }^{67}$ \\ SILVA, Jamerson Antônio De Almeida Da ${ }^{68}$
}

\section{RESUMO:}

Este trabalho tem como objetivo analisar a nova política educacional para o ensino médio, expressa pela Lei 13.415/2017, e suas implicações para a formação da juventude em Pernambuco. Entendemos que a nova política educacional faz parte de um conjunto de iniciativas hegemônicas para concretizar um novo modelo de formação para a juventude. Tomamos como marco teórico o Materialismo-Histórico-Dialético. Neste caminho, foi realizada uma análise documental e uma entrevista semiestruturada com a gerente da Gerência de Políticas de Ensino Médio da Secretaria de Educação de Pernambuco. Acreditamos que esta nova Política Educacional objetiva desenvolver a lógica de flexibilização da pauta empresarial, distanciando-se dos fundamentos de uma formação crítica e humana, situação que poderá implicar no aprofundamento das desigualdades educacionais.

PALAVRAS-CHAVE: Política Educacional. Reforma do Ensino Médio. Ensino Médio.

\section{INTRODUÇÃO}

O presente trabalho situa-se no campo de estudo sobre Políticas Públicas em Educação, mais especificamente sobre a Reforma do Ensino Médio, regulamentada pela Lei 13.415/2017. O estudo faz parte de uma pesquisa de Mestrado ainda em andamento que está sendo desenvolvida no programa de Pós-Graduação em Educação da Universidade Federal de Pernambuco, articulando-se, ainda, aos estudos realizados pelo

\footnotetext{
${ }^{66}$ Mestranda do Programa de Pós-graduação em Educação da Universidade Federal de Pernambuco (UFPE), na linha de pesquisa: Política Educacional, Planejamento e Gestão da Educação. Professora da Rede Estadual de Educação de Pernambuco. E-mail: uericaaraujo@ hotmail.com

${ }^{67}$ Mestranda do curso de Educação na linha de pesquisa: Política Educacional, Planejamento e Gestão da Educação pela Universidade Federal de Pernambuco (UFPE). Professora do quadro efetivo da Rede Estadual de Educação de Pernambuco. E-mail: lanepereira.a@gmail.com

${ }^{68}$ Pós-Doutor pela Universidade do Estado do Rio de Janeiro (UERJ). Doutor em Educação pela Universidade Federal da Bahia (UFBA). Professor Associado 2 do Curso de Pedagogia da UFPE/CAA/NFD. E-mail: jamersonufpe @ gmail.com
} 
Grupo de pesquisa “GESTOR - Pesquisa em Gestão da Educação e Políticas do Tempo Livre".

A complexidade do contexto político e econômico do nosso país tem refletido nas inúmeras contradições que envolvem a construção de políticas educacionais para o ensino médio, que sofreram alterações importantes no curso das mudanças provocadas pelo modelo de Estado neoliberal, a partir dos anos 90. Mais recentemente, por ocasião das intensas disputas políticas e ideológicas que culminou no impeachment de Dilma Rousseff e a posse definitiva de Michel Temer como o novo presidente da República, foi encaminhado para o Congresso Nacional um novo Projeto de Lei para o Ensino Médio, cujo processo de legitimação ignorou a construção de debates mais profundos pelo conjunto da sociedade.

No decorrer desse processo, o que mais vimos de maneira exaustiva foram propagandas e comerciais acerca da Reforma do Ensino Médio. Slogans como "novo ensino médio, quem conhece, aprova" acabaram por transmitir uma visão romântica sobre o tema, ao tempo em que reforçaram, a partir do apelo midiático, uma ideologia que tentou legitimar tal política junto à população e estabelecer um consenso em torno do tema.

Nessa conjuntura, a Reforma do Ensino Médio foi efetivada através da Lei 13.415/2017, trazendo para o centro do debate uma forte retórica em torno do direito de escolha por partes dos escolares sobre sua formação, induzindo-os à ideia de que podem escolher uma área do conhecimento ou ainda, uma formação técnica e profissional de sua preferência (KUENZER, 2017).

Entretanto, o cenário apresenta questionamentos envolvendo por um lado, o discurso político e midiático em torno das iniciativas da Reforma e, por outro, as reais necessidades da juventude brasileira. Para responder a este questionamento temos como objetivo analisar as determinações da nova política educacional para o ensino médio, efetivada a partir da Lei 13.415/2017 e suas implicações para a formação da juventude em Pernambuco.

Para isso, tomamos como marco teórico o Materialismo-Histórico-Dialético, acreditando que este referencial crítico é o que melhor nos possibilita uma leitura para além da aparência do fenômeno estudado. Sob esse ponto de vista, foi realizada uma análise documental da Lei 13.415/17. Realizamos também, uma entrevista semiestrutura 
com a gerente da Gerência de Políticas de Ensino Médio da Secretaria de Educação de Pernambuco, responsável pela implementação do Novo Ensino Médio no estado. A entrevista teve duração de 40 minutos e foi realizada no dia 19 de outubro de 2018 no prédio da SEE. A análise dos dados foi conduzida através da Análise de Conteúdo Bardin (2016).

\section{A NOVA ORDEM NEOLIBERAL E SEUS IMPACTOS PARA AS POLÍTICAS EDUCACIONAIS NO BRASIL}

O que chamamos hoje de neoliberalismo surgiu na Europa e na América do Norte, após a II Guerra Mundial. De acordo com Perry (1995) o neoliberalismo: “Foi uma reação teórica e prática veemente contra o Estado intervencionista e de bemestar" (PERRY, 1995, p. 9).

No final dos anos 40, o estado de bem-estar social se consolidava na Inglaterra e em outros países da Europa, como resposta à crise herdada pela Guerra. O capitalismo entrava em sua fase de maior lucratividade, a chamada "era de ouro do capitalismo", o que dificultou por algum tempo a ascensão do neoliberalismo de base econômica, política e ideológica.

Entretanto, já nos últimos anos da década de 1960 e início da década de 1970, o sistema capitalista começou a dar indícios de exaustividade, culminando em uma longa e intensa recessão. Dentro desta nova conjuntura, a economia apresentou baixas taxas de crescimento com grande aumento da inflação, desencadeando uma serie de transformações no centro do sistema capitalista (PERRY, 1995).

A crise instaurada no capitalismo, segundo os defensores do neoliberalismo, decorreu dos gastos excessivos do Estado com a provisão social, resultado da luta travada pelos movimentos sindicais e operários, que segundo Perry (1995):

Havia corroído as bases de acumulação capitalista com suas pressões reivindicativas sobre os salários e com sua pressão parasitária para que o Estado aumentasse cada vez mais os gastos sociais. Esses dois processos destruíram os níveis necessários de lucro das empresas e desencadearam processos inflamatórios que não podiam deixar de terminar numa crise generalizada das economias de mercado (PERRY, 1995, p. 10).

Neste cenário de crise, procurava-se uma nova forma de reorganizar o sistema capitalista e garantir seu desenvolvimento. Assim, o modo de produção fordista 
taylorista foi substituído pelo toyotismo. Este novo modelo pressupõe diversas inovações organizacionais, tecnológicas e sociometabólicas, trazendo no cerne desse processo os princípios da flexibilização e empreendedorismo pautados no neoliberalismo (ALVES, 2007).

Assim, as mudanças decorrentes do processo de reestruturação produtiva - que buscava consolidar novas formas de acumulação do capital, intensificando a atuação do mercado - tornou-se ponto de partida para consolidar o projeto neoliberal, em pleno vigor atualmente. Dessa forma, o papel do Estado ganha novo direcionamento ao promover novas formas de manutenção do capital a partir desta lógica.

Para Perry (1995) a solução estava clara:

Manter um Estado forte, sim, em capacidade de romper o poder dos sindicatos e no controle do dinheiro, mas parco em todos os gatos sociais e nas intervenções econômicas. A estabilidade monetária deveria ser a meta suprema de qualquer governo. Para isso seria necessária uma disciplina orçamentária, com contenção de dos gastos com o bem-estar, e a restauração da taxa "natural" de desemprego, ou seja, a criação de um exército de reserva de trabalhadores para quebrar os sindicatos (PERRY, 1995, p. 11).

Neste percurso, o neoliberalismo se estabeleceu no cenário mundial a partir da vitória de Margaret Thatcher na Inglaterra, o primeiro governo de um país de capitalismo avançado comprometido com a implantação de uma agenda de base neoliberal. Fato este que não ficou restrito a apenas à Inglaterra; outros países seguiram a mesma cartilha neoliberal estabelecendo uma dinâmica para além da superação da crise econômica, mas, sobretudo, de cunho político e ideológico que determina todas as instâncias da sociedade (PERRY, 1995).

Nos Estados Unidos, a gestão Ronald Reagan deu início à implantação do neoliberalismo na América do Norte. Com fortes vieses mercadológicos, esta agenda é de fundamental importância para entendermos as determinações históricas que culminaram na cartilha neoliberal do Consenso de Washington ${ }^{69} \mathrm{e}$, por conseguinte, nas pautas políticas da América Latina.

\footnotetext{
69 O Consenso de Washington é uma agenda política de caráter neoliberal que reúne um conjunto de medidas a fim de promover ajustes nas políticas da América Latina, sob o comando de Organismos Multilaterais, como o Banco Mundial e o Fundo Monetário Internacional.
} 
Alheias às particularidades regionais do continente latino-americano, essas políticas se traduziram por aplicar receituários técnico-ideológicos aos diferentes países da região. Conforme Soares (2009), o ajuste estrutural de base neoliberal na América Latina tem como foco principal a implementação de políticas privatizante e de mercado.

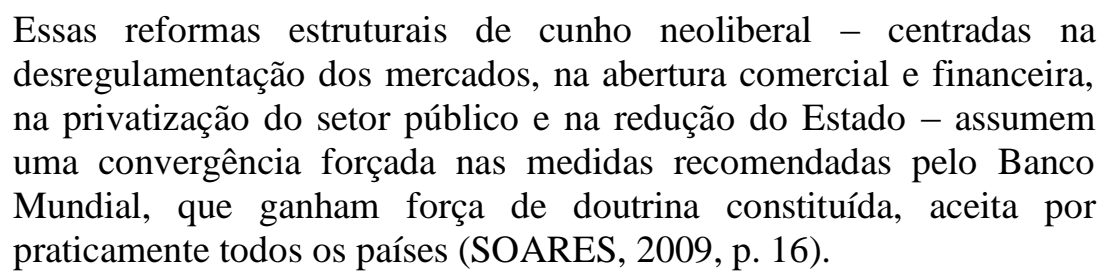

Aqui no Brasil, as determinações promovidas pelas cartilhas internacionais encontram um fértil terreno nas políticas privatizantes e reformistas dos governos Collor de Mello e Fernando Henrique Cardoso. Tais determinações, preconizadas, especialmente, pelo Banco Mundial, incluem um conjunto de medidas na área físcal, tributária, financeira, que se traduziram em privatização das empresas públicas, reforma do aparelho estatal e dinâmica sem restrições do capital estrangeiro.

Apesar dos governos Lula da Silva e Dilma Rousseff, que organizaram seus discursos mais à esquerda da ideologia capitalista, o neoliberalismo vem se mantendo como base econômica e política no Brasil, desde as suas primeiras investidas na década de 1990. Entretanto, nestes governos foram adotadas medidas que buscavam minimizar os grandes problemas sociais causados por seus antecessores, Collor e FHC. (MORAIS, 2014).

Face ao exposto, podemos observar que desde a década de 1990, quando o neoliberalismo acena para sua consolidação no país, iniciou-se o processo para redimensionar as políticas educacionais com o objetivo de responder às pressões internacionais. Segundo Saviani, (2007):

Essas políticas que inicialmente tiveram de ser, de algum modo, impostas pelas agências internacionais de financiamento mediante as chamadas condicionalidades, em seguida perdem o caráter de imposição, pois são assumidas pelas próprias elites econômicas e políticas dos países latinoamericanos (SAVIANI, 2007, p. 428).

Esta nova ordem de determinação mercadológica se materializa na vida dos indivíduos através de um sistema de significados que produz indivíduos trabalhadores 
polivalentes, empreendedores e flexíveis, determinados por uma moral individualista e competitiva, própria do mundo dos negócios.

A educação, neste contexto, passa a ser vista não mais como um bem público, mas como parte integrante do capital. E os princípios da flexibilização, controle da performance e qualidade total consiste na premissa-base das reformas no campo educacional, partindo de uma forte retórica empreendedorista, fruto de um intenso trabalho de promoção do projeto hegemônico.

Com isso, as palavras de ordem que passam a nortear a educação pública, nos termos de Freitas (2012) são: responsabilização, meritocracia e privatização. Esses princípios, segundo o autor, estão intimamente ligados ao processo de precarização e mercadorização do sistema público de educação.

Sendo assim, a criação do Novo Ensino Médio faz parte de um conjunto mais amplo de iniciativas reformistas, de onde subjaz um caráter neoliberal muito mais agressivo, que encontrou espaços para se desenvolver no meio social e político com o impeachment de Dilma Rousseff e a posse de Michel Temer como presidente da República. Neste percurso, o alvo principal das reformas para garantir o desenvolvimento do capitalismo são os cortes bruscos na provisão estatal, realizados através de um conjunto de medidas, a saber: a Reforma da Previdência, a PEC n. 95/16, que estabelece um congelamento dos gastos na Educação e na Saúde por 20 anos, a Reforma das Leis do Trabalho (CLT) e, ainda, a aprovação do Projeto de Lei que regulamenta a terceirização.

Diante dessa conjuntura econômica e social desencadeada, por um lado, pelo neoliberalismo e, por outro, pela ação conjunta do Estado com o segmento empresarial, se faz necessário compreendermos as determinações que envolvem a formação da juventude a partir da Reforma do Ensino Médio (Lei 13.415/2017).

\section{A CONSTITUIÇÃO DA NOVA POLÍTICA EDUCACIONAL (LEI 13.415/2017)}

Recentemente, as reflexões acerca do ensino médio se intensificaram. Os debates sobre essa importante fase da educação básica ganharam novos direcionamentos, visto que, sob o comando da lógica do setor empresarial, o cerne da questão concentrou-se na flexibilização do percurso formativo, reafirmando cada vez mais a disputa do Ensino Médio pela atividade produtiva. Com o apoio do Ministério da 
Educação (MEC) e dos Conselhos de Secretários de Educação (CONSED), os segmentos empresariais vêm ganhado espaço nas discussões e definições das políticas educacionais, defendendo uma concepção de educação que se distancia dos interesses das classes trabalhadoras, ao desarticular um currículo pautado na organicidade entre as dimensões da ciência, da tecnologia, da cultura e do trabalho (KUENZER, 2017).

Assim, durante todo processo histórico de implementação da Reforma do Ensino Médio vieram à tona inúmeras contradições e disputas envolvendo o Ensino Médio brasileiro na atualidade. Neste sentindo, nos propomos, na presente seção, apontar as principais contradições que a reforma apresenta e como ela está diretamente ligada à lógica do mercado pautada na flexibilização do trabalho, traduzida na reforma e na flexibilização do ensino.

Para firmar sua ideologia, a atual reforma contou, segundo Ramos (2016), com uma forte carga ideológica para formar o consenso a partir de grandes propagandas televisivas, pois durante o curto período de debate, que antecedeu a implementação da Reforma, o que mais vimos foram propagandas e comerciais sobre o tema.

Nos termos de Apple (2006), a ideologia pode ser compreendida com:

\begin{abstract}
Algum tipo de "sistema" de ideias, crenças, compromissos fundamentais, ou valores sobre a realidade social. [...] A ideologia foi avaliada historicamente como uma forma de falsa consciência que distorce o quadro que temos da realidade social e serve aos interesses da classe dominante de uma sociedade (APPLE, 2006, p. 53/54).
\end{abstract}

Neste sentindo, o discurso de fácil entendimento utilizado nos vários Slogans como: "novo ensino médio, quem conhece, aprova" acabaram por transmitir uma visão romântica acerca do tema, ao mesmo tempo em que reforçaram uma ideologia que tentou legitimar tal política junto à população.

Ainda conforme Ramos (2016):

A linguagem simples, veiculada por jovens sorridentes, demonstrando satisfação por um ensino médio em que eles poderiam "escolher o que gostam", "estudar o que interessam" entra pelos lares dos brasileiros com suas televisões ligadas, prometendo a solução para esse "grande problema" que é o ensino médio. Seriam os jovens da propaganda televisiva do governo federal reais representantes da juventude brasileira? (RAMOS, 2016, p. 37). 
Antes de apontarmos as mudanças oriundas da Lei 13.415/2017, é necessário discorrer, mesmo que brevemente, sobre a forma autoritária com que este instrumento legal foi implantado, pois embora tenham existido fortes embates dos setores progressistas, em especial por parte do Movimento Nacional em Defesa do Ensino Médio, e do Movimento dos Estudantes Secundaristas, a proposta do governo foi aprovada incondicionalmente (KUENZER, 2017).

Este processo pode ser evidenciado a partir do pouco espaço destinado ao debate, assim com o tempo reduzido entre a construção da Comissão Especial (março de 2012) para realizar os estudos que subsidiariam o PL n 6840 (2013, versão inicial, e dezembro de 2014, versão substitutiva); as edições da Medida Provisória (setembro de 2016); e da nova Lei (fevereiro de 2017) (KUENZER, 2017).

Julgamos necessário apresentar o conteúdo da reforma em tela de forma mais técnica e objetiva. Assim sendo, nos apoiaremos em Kuenzer (2017), que organiza as mudanças previstas na Lei em duas linhas: carga horária e organização curricular.

No que se refere a carga horária a Lei ${ }^{\circ} 13.415 / 201$ :

$\S 1^{\circ}$ A carga horária mínima anual de que trata o inciso I do caput deverá ser ampliada de forma progressiva, no ensino médio, para mil e quatrocentas horas, devendo os sistemas de ensino oferecer, no prazo máximo de cinco anos, pelo menos mil horas anuais de carga horária, a partir de 2 de março de 2017 (BRASIL, 2017).

Com isso, em cinco anos, respeitando os 200 dias letivos, a carga horária diária deverá ser de 5 horas, até alcançar gradativamente 7 horas diárias, ou seja, período integral da jornada escolar (KUENZER, 2017).

A esse respeito, Ramos (2016) questiona se as escolas apresentam condições objetivas para a ampliação da jornada escolar, pois mesmo garantidos os subsídios financeiros às escolas que ofertarem o ensino integral de acordo com os critérios exigidos pelo MEC, o repasse para as instituições dependerá da disponibilidade orçamentária do Ministério (RAMOS, 2016; KUENZER, 2017).

Em relação à organização curricular, a mesma obedece ao princípio da flexibilização, como já discutido anteriormente neste trabalho. A necessidade de garantir uma formação flexível em resposta ao rigor do antigo Ensino Médio e a sua quantidade excessiva de disciplinas serviu de argumento para justificar a reforma. 
Sob a justificativa da flexibilização das trajetórias curriculares para atender aos projetos de vida dos jovens, a organização curricular passa a admitir diferentes percursos. Assim, da carga horária total, no máximo 1.800 horas serão comuns, atendendo à Base Nacional Comum Curricular (BNCC) e incluindo a parte diversificada prevista no art. 26 da Lei $n^{\circ}$ 9394/1996; o art. 35 da Lei ${ }^{\circ}$ 13.415/2017, em seu quinto parágrafo, contudo, estabelece apenas a duração máxima do conteúdo curricular comum, "de acordo com a definição dos sistemas de ensino" (KUENZER, 2017, p. 334).

Ainda com a autora:

A carga horária de componentes curriculares comuns corresponde a dois terços de um percurso de 3 anos com 800 horas por ano e a $60 \%$ de um percurso de 3 anos com 1.000 horas por ano; caso o percurso seja integral, com 1.400 horas por ano em 3 anos, o conteúdo comum corresponderá a $38 \%$ do total do curso, ou seja, pouco mais que um terço (KUENZER, 2017, p. 334).

Sendo assim, o tempo restante será distribuído entre itinerários formativos, segundo a escolha do aluno, a saber: Linguagens e suas Tecnologias; Matemáticas e suas Tecnologias; Ciências da Natureza e suas Tecnologias; Ciências Humanas e Sociais Aplicadas; e formação técnica e profissional (RAMOS, 2016; KUENZER, 2017).

Esta nova organização curricular não é tão inovadora de fato, visto que ela pode ser facilmente reconhecida na Reforma Capanema do Governo Vargas e também se assemelha bastante ao ocorrido na Ditadura Militar. Culminando em gerações inteiras divididas entre os que tiveram acesso apenas a uma área de formação. Já a formação técnica e profissional ficou destinada para as camadas populares, aumentando ainda mais as desigualdades sociais.

(...) a regressão à lógica da Reforma Capanema da Era Vargas, pela qual os estudantes escolheriam suas áreas de "vocação": os ramos científico e clássico no ciclo ginasial. Isto resultou gerações divididas em dois grupos, a saber: os que nunca haviam estudado química e física, por exemplo; e os que nunca estudaram sociologia e filosofia, dentre outros conhecimentos das ciências humanas. A formação técnica e profissional, por sua vez era a opção para os pobres, regulamentada pelas demais leis orgânicas (dos ensinos comercial, industrial e normal). Gerações divididas conforme a dinâmica econômica e sujeitos partidos em suas capacidades e realizações (RAMOS, 2016, p. 39). 
Os itinerários que cada escola irá oferecer ficam sob a responsabilidade do sistema de ensino e de acordo com a realidade local. Esses diferentes arranjos de itinerário poderão dificultar a escolha dos alunos, pois a escola poderá optar por apenas uma única área do conhecimento. Apenas duas disciplinas são obrigatórias ao longo de todo Ensino Médio: Língua Portuguesa e Matemática.

As disciplinas de Artes, Educação Física, Sociologia e Filosofia obedecem aos mesmos critérios descritos acima, fato que pode significar uma menor duração destas disciplinas, em relação às demais. No que concerne às Línguas Estrangeiras, a Língua Inglesa recebeu uma ênfase maior, tendo em vista que sua oferta é obrigatória. As demais línguas poderão ser ofertadas em caráter optativo (RAMOS, 2016; KUENZER, 2017).

Neste sentindo, é importante refletirmos sobre as condições objetivas dessa reforma educacional, pois quando olhamos para a realidade dos nossos estados e municípios, percebemos que grande parte das cidades, principalmente as do interior, contam apenas com uma única escola de Ensino Médio, como é o caso de Pernambuco.

É possível também que os gestores escolares optem por ofertar itinerários que dispõe de uma maior quantidade de professores na escola. Este fato pode levar a outra grave consequência: a redução drástica de concursos em áreas especificas, podendo acarretar a extinção de algumas carreiras docentes (RAMOS, 2016).

A formação técnica e profissional, nos termos da reforma, é subtraída da formação básica comum, passando a ser um itinerário, onde poderá ser realizada por um profissional com notório saber. Sendo assim, não é mais preciso ter uma formação especializada para cada área. Existe ainda a possibilidade do sistema de ensino estabelecer convênios com instituições de ensino que ofertem formação técnica e profissional de modo presencial e a distância (KUENZER, 2017).

Após, apresentarmos as principais mudanças contidas na Reforma do Ensino Médio, entendemos que fica evidente uma ação articulada entre os setores empresarias e o Estado para garantir essa etapa da educação dos jovens aos ditames do capital, formulada sob uma lógica discursiva de que a juventude tem o "direito" de escolher seu próprio caminho formativo. O cenário sinaliza, no entanto, para mais um ataque neoliberal aos direitos sociais, conquistados a duras penas pela classe trabalhadora. 


\section{O PROCESSO DE IMPLANTAÇÃo dA NOVA POLÍTICA EDUCACIONAL EM PERNAMBUCO: PRIMEIRAS REFLEXÕES}

Nos últimos anos, Pernambuco vem protagonizando um papel importante na implementação das novas reformas educacionais para o ensino médio. Um exemplo desse feito consiste na inserção do sistema de educação integral como uma política educacional, no qual foi implantado em 2008 o Programa de Educação Integral (PEI), que criou as Escolas de Referência em Ensino Médio (EREMs), através da Lei Complementar $\mathrm{n}^{\circ} 125$ de 10 de julho de 2008. Um dos objetivos desse programa é a reestruturação do currículo do ensino médio a partir da educação em tempo integral no estado.

Todavia, esse processo vem apresentado diversas contradições tanto no plano estrutural, quanto na própria concepção de educação integral e de juventude defendida pelo projeto.

De acordo com Silva e Silva (2017):

Há um processo, em curso, de implementação de políticas de ampliação da jornada escolar e/ou de realização de uma educação integral/integrada, centrado em uma lógica neoliberal que intensifica e torna precário o trabalho docente, ao trazer para o cenário escolar novas atribuições: proteção e guarda de adolescentes e jovens; expectativas em torno da garantia da empregabilidade em um cenário de desemprego estrutural; melhoria dos indicadores sociais do país através de resultados em avaliações standards e da melhoria do fluxo escolar e da certificação (SILVA e SILVA, 2017).

Traçar uma análise sobre o ensino médio integral não é o objetivo desse estudo. Entretanto, julgamos importante apresentar um panorama do sistema educacional de Pernambuco, sobretudo do ensino médio, pois a conjuntura atual do estado poderá nos oferecer subsídios para entender os desdobramentos da nova reforma.

Assim, atualmente o estado conta 09 tipos de Escolas, conforme aponta a tabela abaixo:

Tabela 1 - Quantidade de Escolas Estaduais em Pernambuco Conforme os Tipos de Escolas

Tipos de Escolas em Pernambuco Quantidade de Escolas 


\begin{tabular}{|c|c|}
\hline \multicolumn{2}{|c|}{ Escolas Regulares } \\
\hline Escolas de Ensino Básico & 507 \\
\hline Centros Especiais & 6 \\
\hline Escolas Prisionais & 15 \\
\hline Escolas Conveniadas & 7 \\
\hline Escolas Quilombolas & 1 \\
\hline \multicolumn{2}{|c|}{ Escolas de Referência } \\
\hline Integral & 165 \\
\hline Semi-Integral & 170 \\
\hline \multicolumn{2}{|c|}{ Escolas Técnicas } \\
\hline & 41 \\
\hline \multicolumn{2}{|c|}{ Escolas Indígenas } \\
\hline & 146 \\
\hline Total de Escolas & 1.058 \\
\hline
\end{tabular}

Fonte: Autoria própria, dados obtidos através da Secretaria de Educação de Pernambuco via e-mail (2018).

No geral Pernambuco dispõe de 1.058 escolas de ensino médio divididas em 09 tipos de escolas, quais sejam: escolas de ensino básico, centros especializados, escolas prisionais, escolas conveniadas, escolas quilombolas, escolas integrais, escolas semiintegrais, escolas técnicas e escolas indígenas, distribuídas em 16 Gerências Regionais.

\section{Gráfico 1 - Quantidade de Escolas da Rede Estadual de Ensino de Pernambuco}




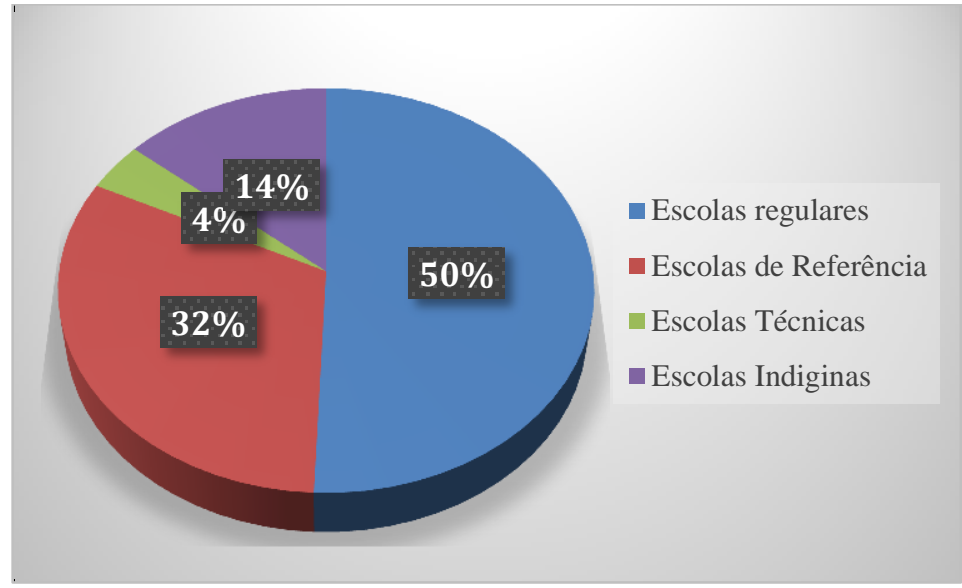

Fonte: Autoria própria, dados obtidos através da Secretaria de Educação de Pernambuco via e-mail (2018).

Como pode ser evidenciado no gráfico acima, Pernambuco apesar de ser pioneiro na implementação das escolas de referência, grande parte das instituições educacionais não são EREMs, posto que 50\% das escolas são regulares (escolas de ensino básico, centros especializados, escolas prisionais, escolas conveniadas, escolas quilombolas), $14 \%$ são escolas indígenas, $4 \%$ são técnicas e apenas $32 \%$ são escolas de referência (integral e semi-integral).

Neste sentido, mais de 50\% das escolas precisarão se adequar à ampliação da carga horária estabelecida pela Lei 13.415/2017. Este fato apresenta uma grande contradição, porque mesmo a lei prevendo um incentivo financeiro para as escolas que adotarem a nova reforma, temos que lembrar que está em vigência a PEC n. 95/16, que estabelece um congelamento dos gatos na Educação e na Saúde por 20 anos, o que dificultará a distribuição dos incentivos financeiros.

Para entendermos melhor o panorama de Pernambuco com relação à implementação da Lei 13.415/2017 realizamos uma entrevista semiestruturada com a gerente da Gerência de Políticas do Ensino Médio, onde foram abordados os principais pontos da lei suscitada, apresentando como unidades temáticas: processo de construção e implantação da lei, ampliação da carga horária; flexibilização do percurso formativo e formação técnica/profissional.

Sobre o processo de construção e implementação da Lei 13.415/2017 em Pernambuco a gestora nos relatou que: 
Desde 2015 nós participamos desse processo, participamos de vários colegiados onde a gente fazia estudos, fazia proposições, e aí com o primeiro golpe que nós tivemos com a saída de Dilma, eles mudaram todas as nossas propostas e lançaram essa lei. Para vocês terem conhecimento porque eles podem jogar e dizer que foi construído por nós, pelos gestores do Ensino Médio, foi, mas não foi essa (GERENTE).

Havia um projeto em discussão para a construção do novo ensino médio que vinha sendo amplamente discutido pelos gerentes das Gerências de cada estado brasileiro junto ao Ministério da Educação, entretanto o projeto foi substituído pelo atual governo de forma autoritária e sem a aprovação de parte considerável da população.

Assim, após a aprovação da nova lei ficou decidido que a implementação da mesma em Pernambuco se daria, segundo a gerente, por meio de um projeto piloto.

Para a aplicabilidade da legislação nós começamos esse ano com 20 escolas regulares, com um projeto piloto aqui na região metropolitana nas 4 regionais: Recife Norte, Recife Sul, Metro Norte, Metro Sul, as 4 na capital, e com 5 escolas em cada regional por ser um projeto piloto e ter vários entraves na nossa análise (GERENTE).

No que se refere à ampliação da carga horária, o Projeto Piloto em desenvolvimento no estado estabeleceu nas 20 escolas a ampliação de 01 aula na grande de horário, onde os alunos:

[...] agora tem 6 aulas de $50 \mathrm{~min}, 5$ horas de aula, que aí, ao termino do ano os alunos irão ter 1.000hrs já como a lei preconiza. Os critérios foram: ter professor da casa, disponibilidade, uma escola acessivel, acessível que eu digo, é o professor aceitar, porque tem muita escola que é muito arredia, resistente, então escolas que os professores abraçassem o projeto. E feito isso, os gestores regionais escolheram as escolas (GERENTE).

A flexibilização do percurso formativo no projeto que está sendo implementado nas 20 escolas se dá mediante as seguintes estratégias:

Aí nós temos o quê? Uma nova matriz curricular para essas 20 escolas, nessa matriz a gente entrou com duas novidades que a lei rege. Nós entramos com projeto de vida e empreendedorismo, e disciplinas de componentes curriculares eletivas. A própria escola era quem escolhia de acordo com a demanda, onde era feita uma escuta 
com os alunos e com a comunidade. Você oferece o que você tem capacidade. Primeiro você mapeia o que pode oferecer, eu posso oferecer uma eletiva de robótica, uma eletiva de complementação de matemática, de língua portuguesa, vamos pensar assim, estou dando apenas sugestões, e aí foi para plenária e os estudantes escolheram (GERENTE).

Ainda com a Gerente:

Então nós nesse bloco de 20 escolas, temos um bloco de mais de 60 eletivas, e aí nós fizemos o seguinte: as eletivas elas têm duração só de 1 semestre, então o aluno durante o ano pode cursar duas eletivas. Então a gente tornou, eu diria, bem atrativo para o estudante, porque ele sai daquela matriz fechada, rígida, engessada e aí eles vêm para uma que eles próprios escolheram, uma matriz democrática, uma que eles vão cursar o que escolheram. Então é por esse caminho aí que nós estamos fazendo a nossa implantação da lei (GERENTE).

Sobre a flexibilização do percurso formativo, Kuenzer (2017) afirma que os critérios que regem a Lei estão pautados em princípios mais amplos, pois situa-se no campo da aprendizagem flexível a qual é fruto do resultado de uma metodologia inovadora. Esta metodologia, por sua vez, promove uma articulação sutil entre o desenvolvimento tecnológico, a diversidade de modelos dinamizadores da aprendizagem e as mídias interativas, elementos justificados pela urgência de desenvolver o ensino para atender às demandas de uma sociedade pautada pela competitividade.

Quando foi perguntada sobre as diferentes composições de cada GRE, e como a Secretaria de Educação pretende se movimentar para atender as diferenças do sistema, principalmente nas cidades que contam apenas com 01 única escola estadual de Ensino Médio, a entrevistada foi enfática em suas colocações afirmando que:

Isso é o grande gargalo nosso. Estamos aguardando porque vários conselheiros estão contra justamente por isso. Porque $54 \%$ das cidades do Brasil, só tem uma escola. E para surpresa da gente e para surpresa de vocês, quem tem mais cidades com uma escola só, é São Paulo. Em Pernambuco nós temos 30 cidades com apenas uma escola. É aí, a grande preocupação nossa (GERENTE).

Neste sentido, a implantação da nova reforma do ensino médio em Pernambuco evidencia inúmeras contradições que vão desde o plano estrutural até a concepção de formação da juventude no Estado. A Lei 13.415/2017 previa, como já levantado 
anteriormente, que o novo ensino médio deveria ser implantado a partir de 2 de março de 2017. No entanto, após um ano de sua implantação o que temos em Pernambuco é apenas um projeto piloto que contempla menos de $4 \%$ do total das escolas regulares como pode ser evidenciado no gráfico abaixo.

\section{Gráfico 2 - Porcentagem do número de escolas que adotaram o projeto} piloto do novo ensino médio em Pernambuco

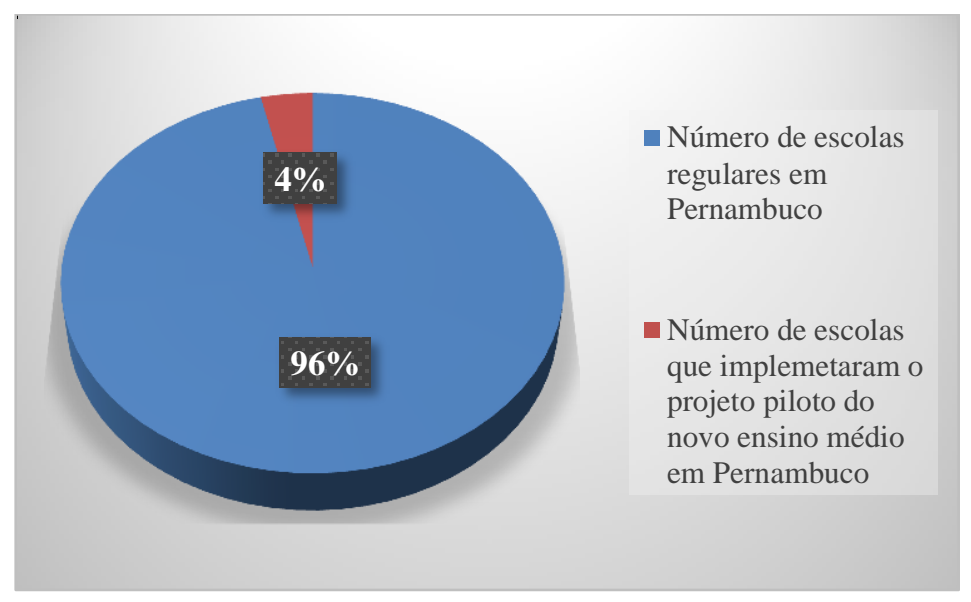

Fonte: Autoria própria, dados obtidos através da Entrevista com a gerente da Gerência de Política Educacionais do Ensino Médio da Secretaria de Educação de Pernambuco (2018).

Sendo assim, a proposta que Pernambuco pretende desenvolver para atender as demandas das diferentes regiões do estado e superar a quantidade de escolas por município, nas palavras da Gerente é a seguinte:

A minha proposta é a seguinte, a minha atual: educação profissional a gente já tem, o $5^{\circ}$ itinerário a gente vai deixar dentro das escolas técnicas, os outros 4 itinerários a gente vai pensar, a nossa proposta é: oferecer pelo menos dois itinerários a cidade que só tenha uma escola o aluno não pode ser prejudicado, se existe 4 itinerários formativos, o estado tem obrigação de oferecer os 4, então como seria, a gente poderia abrir espaços, 4 espaços, 4 salas de aulas ou 4 ambientes pedagógicos, porque esses 4 itinerários, eles serão trabalhados de forma interdisciplinar. $O$ aluno do $1^{\circ} \mathrm{A}$ ele pode tá unido com o do $1^{\circ} \mathrm{B}$, nos itinerários, então vai ser uma reorganização dentro da escola, onde a gente poderia não deixar nenhum itinerário sem oferecer (GERENTE). 
A preocupação da Gerência para implementar as mudanças em Pernambuco previstas pela Lei 13.415/2017 foi evidente na fala da entrevistada, pois as contradições que as medidas vêm apresentando apontam para um novo projeto de adaptação da juventude à nova ordem social, assim como estabelece uma escola para elite e outra para as camadas populares, culminando no aumento das desigualdades sociais e no próprio sistema de ensino do estado.

É evidente que existem outros pontos importantes que a Lei estabelece, mas no momento nossas primeiras reflexões sinalizam para um processo de exclusão de grande parte da sociedade que pode passar a não ter acesso a essa etapa da educação. Pensamos assim, pois vivemos em uma sociedade extremamente desigual onde milhares de jovens ainda têm que escolher entre estudar ou trabalhar, e quando estão inseridos pela educação, nem todos têm acesso à educação de qualidade.

Por fim, gostaríamos de fechar esta sessão com a última fala da entrevistada, onde foi aberto um espaço para as suas considerações sobre a nova Lei:

Na minha opinião, pessoal mesmo, eu avalio como negativa. Eu avalio que ela vem trazer prejuízos para os estudantes. A gente tinha uma proposta muito boa. A gente tinha uma proposta de reforma do Ensino Médio onde a gente pretendia que o estudante saísse com mais aprendizado e dessa forma como está, eu não vejo avanços (GERENTE).

\section{CONSIDERAÇÕES FINAIS}

Ao refletir sobre a Reforma do Ensino Médio (Lei 13.415/2017), percebemos que ao contrário do discurso que foi fortemente difundido em toda mídia nacional, esta nova Política Educacional objetiva desenvolver no âmbito educacional uma lógica de flexibilização pautada em princípios empresariais. Tais implicações desdobram-se em uma formação desarticulada e fora dos fundamentos de uma formação crítica e humana, fato este que, conforme foi explicitado, acarretará em diversos problemas na formação da juventude, aumentando cada vez mais as desigualdades sociais.

Nessa perspectiva, significa dizer que se faz extremamente necessário compreender a agenda de reestruturação do ensino médio, dentro de uma conjuntura mais ampla, o que exige um movimento que parte da compreensão da sociedade em que esta dinâmica se realiza, ou seja, dentro do modelo hegemônico neoliberal. Assim, 
entenderemos que as expectativas que são postas à juventude se limitam apenas à sua adequação ao modelo vigente, que se volta unicamente à garantia do aumento das taxas de crescimento econômico.

Neste cenário, a crítica a essa nova política educacional ganha especial importância, pois a ampliação do tempo, a hierarquização das disciplinas, a imposição da escolha precoce aos jovens ainda em fase de descobertas são questões que merecem toda atenção dos educadores e dos formuladores de políticas educacionais.

Soma-se a isso, a derrota das lutas travadas historicamente por uma formação integral, considerando que a oferta dos itinerários ficou a cargo das escolas, na maioria das vezes fragilizadas estruturalmente. Por fim, as condições materiais da maioria dos jovens inviabilizam o seu ingresso nesta modalidade de ensino porque são pressionados a entrarem no mercado de trabalho muito cedo.

Assim, a Reforma evidencia ir na contramão para equacionar o problema entre a oferta e as diferentes demandas sociais. Na verdade, nos mostra que irá cada vez mais ampliar as desigualdades educacionais e sociais, revigorando, por outro lado o desenvolvimento da classe economicamente hegemônica (KUENZER, 2017).

Defendemos neste estudo, então, um ensino médio que considere as diferentes experiências de vida do jovem estudante: se são pobres ou ricos, urbanos ou do campo, se pretendem seguir uma carreira técnica ou acadêmica. Enfim, um ensino médio que supere a dualidade histórica que sustenta a educação brasileira e tenha como objetivo a construção de uma sociedade justa, igualitária e democrática, comprometida com a emancipação da classe trabalhadora

\section{REFERÊNCIAS}

ANDERSON, Perry. Balanço do neoliberalismo. In: Pós-neoliberalismo: As políticas Sociais e o Estado Democrático. Rio de Janeiro: Paz e Terra: 1995.

\section{ALVES, G. Dimensões da Reestruturação Produtiva: ensaios de sociologia do} trabalho. $2^{\text {a }}$ edição - Londrina: Praxis; Bauru: Canal 6, 2007.

APPLE, Micchael. Ideologia e Currículo. $3^{\circ}$ edição - Porto Alegre, 2006.

BARDIN, L. Análise de conteúdo [1977]. Lisboa: Edições 70, 2016. 
BRASIL. Congresso Nacional. Lei 13.415 de 16 de fevereiro de 2017. Disponível em: legis.senado.leg.br/legislacao/ListaTextoSigen.action?norma $=602639 \& \mathrm{id}=14374947 \& \mathrm{i}$ $\mathrm{dBinario}=15657824 \&$ mime $=$ application $/ \mathrm{rtf}>$

FREITAS. Os reformadores empresariais da educação: da desmoralização do magistério à destruição do sistema público de educação. Rev. Educação e Sociedade, Campinas, v. 33, n. 119, p. 379-404, abr./jun. 2012. Disponível em: 〈http://www.scielo.br/pdf/es/v33n119/a04v33n119.pdf>

KUENZER, Acácia. Trabalho e escola: a flexibilização do ensino médio no contexto do regime de acumulação flexível. Educação \& Sociedade, Campinas, v. 38, n. 139, p. 331-354, abr./jun. 2017.

MORAIS, Edima. Utilizações das escolas de referência em ensino médio pelo governo do estado de Pernambuco: uma análise do programa de educação integral. Dissertação - Universidade Federal de Pernambuco, Centro Acadêmico do Agreste, Programa de pós-graduação em educação contemporânea - PPGEDUC, 2014.

RAMOS, M. N.; FRIGOTTO, G. Medida Provisória 746/2016: A contra-Reforma do Ensino Médio do Golpe de Estado de 31 de agosto de 2016. Revista HISTEDBR Online, [S.1.], v. 16, n. 70, p. 30-48, maio 2017. ISSN 1676-2584. Disponível em: <https://periodicos.sbu.unicamp.br/ojs/index.php/histedbr/article/view/8649207/15754>

SAVIANI, Dermeval. História das ideias pedagógicas no Brasil. Campinas: Autores Associados, 2007.

SILVA, Katharine; SILVA Jamerson. Trabalho docente e educação integrada nas escolas técnicas estaduais de Pernambuco. Educar em Revista, Curitiba, Brasil, n. 65, p. 237-247, jul/set. 2017.

SOARES, Laura. Os custos sociais do ajuste neoliberal na América Latina. São Paulo, Cortez, 3. Ed. 2009. 


\title{
NOVAS TECNOLOGIAS E PRÁTICAS PEDAGÓGICAS: RECURSOS PARA A
} ALFABETIZAÇÃO NA EDUCAÇÃO DO BRASIL

\author{
SOUSA, Josélia Isidio Rodrigues $\mathrm{De}^{70}$ \\ SANTOS, Maria Da Conceição Dos ${ }^{71}$
}

\section{RESUMO:}

A história da humanidade mostra que o homem se supera a cada nova época, e notamos que tem acelerado nos últimos anos. As novas tecnologias invadiram os espaços de convivência humana, estão no trabalho, em casa, na escola, nas praças, em todos os ambientes, fazem parte do meio, deixaram de ser um fator de comunicação para se tornarem parte das "relações interpessoais", e assim dominar as formas de acesso à informação. Pensando nesse aspecto, da influência da tecnologia como forma de conquistas do conhecimento, traçamos uma linha de pesquisa que parte do uso das redes sociais e da internet, como um recurso para a alfabetização e o letramento, na utilização desses meios como ferramenta de incentivo à leitura, à escrita e à criação. Não deixando de utilizar os livros, mas com o propósito de agregar as novidades que invadem cada vez mais o cotidiano das pessoas, de fatos que acontecem no dia a dia, o que é comum, vermos crianças utilizando celulares, tablets e outros instrumentos de acesso às redes de comunicação virtual. $\mathrm{Na}$ atual realidade, as escolas públicas têm utilizado a tecnologia digital e fornece aos alunos acesso direto, através das redes móveis WI-FI, e o uso de aparelhos pessoais e da escola, como Data show, laboratório de informática ou salas de Multimídias.

PALAVRAS-CHAVES: Educação. Tecnologia. Alfabetização. Interação.

\section{INTRODUÇÃO}

A internet foi o grande passo da humanidade para a interação entre as pessoas do mundo inteiro no novo milênio. O que de princípio era para ser usado como comunicação passou a ser também um recurso infinito de informação e conhecimento, além de gerar nossas formas de relacionamento interpessoais, politização e propagação de ideias.

$\mathrm{O}$ que antes era distante da realidade das pessoas, fazia parte do mundo da fantasia, do cinema, dos filmes de ficção se tornou real e indispensável ao convívio social. Hoje por onde andamos vemos pessoas interagindo e criando formas de

\footnotetext{
${ }^{70}$ Especialista em Alfabetização e Letramento pelo Instituto Faculdade Venda Nova do Imigrante (FAVENI/ES). Professora Polivalente dos municípios de Guamaré/RN e Macau/RN. E-mail: joseliaisidio@bol.com.br

${ }^{71}$ Especialista em Estudo da Língua Portuguesa pela Faculdade Venda Nova do Imigrante (FAVENI/ES). Professora nos municípios de Guamaré/RN e Galinhos/RN. E-mail: ceycysantos@ hotmail.com
} 
relacionamento e tudo isso através da leitura. Mas como devemos aproveitar esse recurso como ferramenta para incentivar à leitura, à escrita e à criatividade dos alunos das escolas públicas brasileiras na fase de alfabetização?

Pensando nessa problemática, traçamos uma pesquisa baseada na influência da internet e das redes sociais no cotidiano das pessoas e das transformações que esses fatores têm provocado na educação do nosso país, pois as inovações tecnológicas estão presentes não apenas nos lares, trabalho e espaços de lazer, mas também nas escolas e instituições de ensino, além de serem utilizados por pessoas de todas as faixas etárias. Por ser um meio onde é necessário utilizar a leitura e a escrita para conseguir o acesso à informação, buscamos dentro da pesquisa bibliográfica teórica qualitativa conhecer como esses meios podem ser utilizados para promover a alfabetização e incentivar a leitura das crianças de $1^{\circ}$ ao $5^{\circ}$ ano do ensino fundamental - anos iniciais da educação brasileira.

$\mathrm{O}$ referente artigo tem como objetivos conhecer os conceitos que envolvem tecnologia e comunicação, saber como se deu a influência nos meios sociais e mostrar como essas ferramentas podem ser utilizadas nas escolas, por professores e alunos. Com base na realidade que hoje permeia os espaços educacionais, pesquisamos estudiosos, teóricos da Educação e experiências vivenciadas por profissionais da Educação, através de artigos publicados em revistas virtuais (periódicos online), que apresentam o contexto do que acontece dentro desses espaços. Não podemos ignorar que a tecnologia digital se tornou um meio fundamental para a comunicação, informação e conhecimento, por isso torná-la uma ferramenta de direcionamento para o letramento.

\section{A TECNOLOGIA E SUAS INOVAÇÕES NA REALIDADE HUMANA.}

Geralmente, confundimos tecnologia com ciência, o que se faz necessário abordarmos sobre esses conceitos é comentar de modo breve sobre o contexto histórico que se desenvolveu no decorrer das transformações humanas. Pensamos que é impossível separar os dois, pois não conseguimos imaginar que uma não teria surgido sem a outra.

Voltando aos remotos momentos da conhecida pré-história, assim definida pelos autores dos livros didáticos, nos deparamos com as técnicas que foram utilizadas para conseguir fogo, compor escritas, produzir tintas para deixar a sua presença registrada 
nas paredes das cavernas e paredões de vários cantos do nosso planeta. A palavra tecnologia, segundo Veraszto (2004, p. 61) vem do grego techné que consistia muito mais em se alterar "o mundo de forma prática do que compreendê-lo". Na técnica, ainda afirma o autor a questão principal é do como transformar, modificar, produzir, construir, fabricar, tem sua significação na junção de duas palavras techné, que é saber fazer, e logia do grego Logus, razão, portanto tecnologia significa "a razão do saber fazer" (RODRIGUES, 2001).

Mas, não é tão simples assim, o conceito de tecnologia tem várias definições, também porque representa tempos, épocas diferentes em que é utilizado. Sabemos que a humanidade tem passado por várias transformações e desde as técnicas usadas para a construção das pirâmides no Egito, a tecnologia tem demonstrado ao longo de seu desenvolvimento à atuação em todas as áreas da sociedade. Como disse Gama (1987, p. 54) não se pode simplesmente ter uma definição exata desse termo, já que se têm diferentes interpretações.

Porém no decorrer da história podemos ver notadamente que as técnicas de produção do trabalho e o desenvolvimento da produção humana política e econômica tem uma junção direta com a tecnologia, então percebemos como nos mostra Rodrigues (2001), que existe um marco divisório entre a técnica e a tecnologia.

O conhecimento histórico do desenvolvimento das técnicas e das tecnologias produzidas pelo homem desde o começo dos tempos contribui de maneira significativa para que possamos entender o processo criador da humanidade e, essencialmente, compreendermos melhor a tecnologia como uma fonte de conhecimentos próprios, em contínua transmutação e com novos saberes sendo agregados a cada dia, de forma cada vez mais veloz e dinâmica (VERASZTO, 2004, p. 66).

Todas as técnicas empregadas pela humanidade para se obter a evolução, desde o simples fato de se tornar sedentário, moldar o ferro e se constituir em sociedade, fez o homem despertar para o que realmente se propunha a fazer dentro desse aspecto, criar.

Criar, passou a ser uma questão de necessidade, de adequação, a cada nova possibilidade de progresso de tornar a vida mais prática, talvez fosse realmente o pensamento da década de 1950, quando a tecnologia das naves espaciais tomava os desejos de um novo milênio fora do nosso planeta. Não foi assim que aconteceu, as 
pesquisas de avanço da informação e da comunicação podem até ter nascido das remanescentes investidas das guerras ideológicas econômicas, mas trouxe ao mundo possibilidades de poder realmente dar ao homem o que é seu, a tecnologia é de autoria do ser humano e a ele pertence, por infinitos objetivos, essa capacidade faz com que a mesma se torne fundamental para o desenvolvimento do modo de vida em sociedade.

Dentro do nosso contexto histórico, a ciência e a tecnologia sempre foram decisivas. Neste mundo, onde as transformações estão acontecendo rapidamente, nos deparamos com o seu caráter excludente, determinante de quem está no controle. Milton Santos (2000, p. 89) atento para essas transformações como indício de um mundo que está voltado para o "desenvolvimento econômico, mas distante de um equilíbrio social", pois essas mudanças não atingem a todos de igual maneira.

As diferenças sociais não sofreram modificações devido aos avanços tecnológicos, ainda está insistente, permeável, não foi absorvida pelas inovações e o chamado "acesso a todos". O caminho para as verdadeiras transformações está em atingir quem dela faz uso. Portanto, a "Educação é esse caminho - e a escola como espaço de sua operacionalização" (SANTOMÉ, 1998, p. 102), basta procurar saber como tais soluções serão desenvolvidas. Ainda segundo o autor, a educação se revela como campo privilegiado de "produção/difusão de novas práticas/tecnologias", as quais possibilitam a promoção de "compatibilidade" entre os homens e as mudanças que se operam no seu meio social, sobretudo dentro de suas competências técnicas, individuais e personalizadas (SANTOMÉ, 1998).

Todo este reflexo dos avanços aos quais as gerações atuais têm vivenciado, foi provocado por cada passo dado no passado, mas nos países em desenvolvimento, a maioria dos indivíduos encontra-se fora da competitividade do mercado, que também é um fator herdado das condições sociais do contexto histórico ao qual estamos inseridos, no caso do Brasil.

A Educação e as tecnologias de informação têm, nas últimas décadas, demonstrado que estão integradas. $\mathrm{Na}$ verdade, para que ocorra a inclusão social que tanto se discute, é fundamental que as escolas busquem inovar no uso de seus recursos.

No Brasil a educação tem se revelado como uma estratégia para romper o atraso tecnológico e promover a inserção de seu público no mercado competitivo do trabalho. Esse é o resultado da industrialização como influência no processo educativo, que se 
fez, principalmente, nas últimas décadas do século XX, dentro de uma perspectiva técnico-profissional, buscando qualificar a mão-de-obra para atuar dentro desse setor.

\begin{abstract}
A Educação, mais uma vez, passa a ser utilizada como instrumento de conformação social, sendo subordinada a necessidade de novas formas de inserção social postas exclusivamente pelo capital e que se pautam nas premissas do fim da sociedade do trabalho e emergência da sociedade da informação, pautada em um novo científico-tecnológico. A Educação como prática social que se defini nos múltiplos espaços da sociedade, na articulação com os interesses políticos, econômicos, sociais e culturais dos grupos em constante interação no universo social, é constituída das relações sociais e se apresenta historicamente como um campo de disputa hegemônica. (FRIGOTTO, 1999, p. 25 e 56).
\end{abstract}

Tecnologia e Educação no Brasil ainda é um tema que pede muita reflexão, diante dos problemas sociais que a nossa sociedade vem arrastando desde sua formação, como relatamos anteriormente. Muitos autores nos dão essa ideia de que a relação da educação brasileira com os novos meios de comunicação e informação não está organizada, precisa ser algo a ser mais bem empregado pelas escolas. Oliveira et al. (1984, p. 87) diz que o nosso papel histórico cultural promoveu a abertura de estratégias de trabalhos educativos que garantem a inserção de vários métodos para a construção do saber, já que "o brasileiro é aberto às novidades, o que realmente não se tem é o norte para ser definido, no caso a melhoria social e a valorização cidadã".

\title{
A IMPORTÂNCIA DA TECNOLOGIA PARA A ALFABETIZAÇÃo NO BRASIL
}

A sala de aula é o espaço dos descobrimentos da informação, por mais que a internet esteja cheia de sites que conduzam ao que se quer, é dentro do espaço de comunicação entre pessoas de modo presencial, onde ainda ocorre a maior compreensão dos contextos da humanidade e dos seus valores. Saber usar recursos tecnológicos para ampliar o entendimento da vida humana através da educação, com certeza é o melhor caminho para garantir o sucesso desses meios na sociedade, para que a humanidade possa realmente ter pontos positivos de suas criações, evitando a distorção para o mau uso e construindo espaços de melhores convivências no futuro. Hoje o professor tem além do computador e da internet, recursos audiovisuais importantes na realização das 
aulas, tudo isso para estar de acordo com o que pede a realidade, imagens, atualidade e velocidade na informação.

Dentre os novos meios tecnológicos que nos são apresentados, a Internet é, sem dúvida, o mais revolucionário deles. Sua utilização nos permite, por exemplo, "organizar, transformar e processar as informações em velocidade" e capacidade cada vez maiores e com custos cada vez mais reduzidos. Uma rede de recuperação e distribuição que pode beneficiar tanto aqueles que produzem tais informações, quanto aqueles que se utilizam dela.

O índice de difusão da Internet em 1999 era tão grande no mundo inteiro que estava claro que o acesso generalizado seria a norma nos países avançados no início do século XXI. Por exemplo, nos EUA, em 1997-8, a diferença racial no acesso à Internet cresceu, mas o acesso à Internet aumentou $48 \%$ em um ano nos lares de hispânicos, e $52 \%$ nos lares de negros, em comparação com 52,8\% nos lares de brancos. De fato, entre universitários, a diferença de raça e sexo no uso da Internet estava desaparecendo em fins do século. E em 2000, 95\% das escolas públicas dos EUA tinha acesso à Internet. (CASTELLS, 2003, p. 439).

Castells (2003) nos mostra com a sua pesquisa que a internet pode ser uma ferramenta de acesso de todos, porém, na prática, vários desafios devem ser vencidos: a segregação e o desrespeito racial é um deles, mencionado na citação do autor. A Educação é, sem dúvidas, esse ponto de partida. A história nos revela que o próprio ato de ensinar foi um processo evolutivo que exigiu transpor barreiras sociais, não mais entender que o rico deveria saber, mas que todos pudessem obter conhecimento. A forma como a sociedade utiliza as redes sociais tem realmente integrado o mundo, de forma que propõe sua utilização de forma positiva e negativa. Assim, definir esses pontos acaba sendo, também, um papel da Educação e das escolas.

Mas como utilizar o recurso da internet e das redes sociais como ferramenta para a alfabetização e letramento de crianças do $1^{\circ}$ ao $5^{\circ}$ ano? Na verdade, pensamos em: como incentivá-las? É necessário fazer uma reflexão desta didática através de uma proposta que justifique sua utilização, assim como com qualquer outro recurso. As tecnologias ampliam as possibilidades do trabalho do professor, como por exemplo os recursos de audiovisual que podemos acessar na internet em páginas virtuais que disponibilizam esse recurso. Através de vídeos e músicas apresentamos uma nova maneira da criança criar e construir seus saberes. 
De acordo com alguns relatos que obtivemos de fontes online, as professoras de uma escola do interior do Brasil, mostram que o uso de tais recursos, há aproximadamente 10 anos atrás, não era cogitado. Porém, foi preciso adaptar-se às novas propostas de uso. Informatizar a escola foi algo que transformou o cotidiano e dinamizou suas técnicas para incentivar a leitura e a escrita.

Ao passo que a criança reconhece os nomes dos sites, vídeos, anúncios, desenhos animados e o mundo o qual ela tem acesso, essas informações vão se tornado comum e fazendo parte do seu dia a dia. Nessa decodificação estão presentes, letras e números, os símbolos que usamos para compor a escrita e a leitura, assim como afirma Libâneo (2007, p. 309) que: “o grande objetivo das escolas é a aprendizagem dos alunos, e a organização escolar necessária é a que leva a melhorar a qualidade dessa aprendizagem".

Portanto, é preciso ter cuidado na elaboração de um plano para assistir aos alunos com uso da tecnologia da informação, por meio da internet e das redes virtuais, é fundamental saber como aplicar. Em um dos relatos que lemos, uma professora do $2^{\circ}$ ano fala sobre a experiência que realizou em sua sala de aula, a construção de um livro escrito pelos próprios alunos, utilizando a sala de multimídia da escola: "os alunos foram distribuídos em duplas e trios, porque não havia computadores para todos, um auxiliava o outro no que queriam colocar no livro, completavam as histórias, baseadas em relatos da vida de cada um, como uma partida de futebol no campinho do bairro, passeio de bicicleta, ou até mesmo um desejo de algo que queriam realizar”.

Ensinar com as novas mídias será uma revolução se mudarmos simultaneamente os paradigmas convencionais do ensino, que mantêm distantes professores e alunos. Caso contrário, conseguiremos dar um verniz de modernidade, sem mexer no essencial. (MORAN, 2000, p. 63).

É um desafio, na verdade, é preciso que os profissionais das escolas estejam preparados para usar esses recursos, não pode se obter resultados de forma aleatória, principalmente quando se fala de leitura e escrita, dentro do processo de alfabetização, uma responsabilidade que requer cuidados. Conduzir o aluno a usar essas ferramentas precisa de orientação. 
Constatamos através do que nos mostrou a professora do $2^{\circ}$ ano, o qual citamos anteriormente, que, primeiro foi apresentado como era organizado um livro e como os mesmos são importantes. O livro é uma ferramenta essencial, não é obsoleta, o que precisamos é agregar novas ferramentas, sem descartar nenhum recurso, para podermos ter uma variedade de meios para trabalhar as possibilidades de construção do saber.

No caso da fase de alfabetização, que se inicia antes mesmo da criança ingressar na escola, segundo Lazzari (2010, p. 11), pois ao chegar na escola presenciamos um sujeito falante, que demonstra capacidade de produzir e entender "estruturas linguísticas" complexas, devido às interações sociais. Então, cabe a escola fornecer possibilidades para que esses sujeitos organizem suas ideias e possam expressar oralmente e por escrito, "fazendo com que o aluno avance como um ser falante, leitor e escritor", sendo fundamental uma proposta pedagógica que possibilite esse avanço, como afirma Cagliari (2009, p. 6):

O processo de alfabetização inclui muitos fatores, e, quanto mais ciente estiver o professor de como se dá o processo de aquisição de conhecimento, de como a criança se situa em termos de desenvolvimento emocional, de como vem evoluindo o seu processo de interação social da natureza da realidade linguística envolvida no momento em que está acontecendo a alfabetização, mais condições terá o professor de caminhar de forma agradável e produtiva o processo de aprendizagem, sem os sofrimentos habituais. O processo de alfabetização inclui muitos fatores, e, quanto mais ciente estiver o professor de como se dá o processo de aquisição de conhecimento, de como a criança se situa em termos de desenvolvimento emocional, de como vem evoluindo o seu processo de interação social da natureza da realidade linguística envolvida no momento em que está acontecendo a alfabetização, mais condições terá o professor de caminhar de forma agradável e produtiva $\mathrm{o}$ processo de aprendizagem, sem os sofrimentos habituais.

É um processo que requer a interação do aluno com o professor, e utilizar meios, ferramentas de avanços da alfabetização no ambiente escolar é um recurso didático que faz parte da realidade da criança atual. Ela tem contato com aparelhos digitais e com a internet. Não é difícil encontrarmos nos mais variados espaços, crianças "acessando" as páginas virtuais e se comunicando, jogando, assistindo vídeos e filmes. Fazer com que esses acessos tenham resultados positivos no processo de escrita e leitura promove a evolução da criança por ela própria, mas através da orientação, e de como esse meio não substitui os demais já utilizados pela educação, tudo tem o seu lugar, tem sua 
importância, não podemos considerar obsoleto o uso dos demais recursos que dispusemos anteriormente.

\section{CONSIDERAÇÕES FINAIS}

A escolha do tema para a elaboração deste artigo, vai de encontro à nossa realidade, que hoje está cercada das atividades virtuais, do mundo da cibercultura, que se tornou tão cotidiano e comum, como apontam os estudiosos, as pesquisas e os dados sobre seu uso no dia a dia. Para tudo, praticamente, usamos aparelhos digitais, a internet, as redes de conexão, para pedir comida, pagar conta, interagir com outras pessoas, trocar ideias, anunciar, publicar vídeos, trabalhos, fotos, e até mesmo manter relações interpessoais. É um fato que não podemos desprezar, portanto, o principal objetivo deste trabalho foi de mostrar como esses recursos podem possibilitar um meio para influenciar no avanço da alfabetização.

Diante desta nova condição da humanidade de se comunicar e informar, as escolas buscam, cada vez mais, seguir às inovações. Na verdade, a própria realidade força esse acontecimento, é uma constante que não se pode ignorar. Então, cabe aos educadores utilizá-la da melhor forma possível para ampliar a leitura e a escrita. Existem alguns fatos que, de modo pessoal, vemos como negativos, por exemplo o individualismo e a troca das relações pessoais por virtuais. Para que tais fatores como interação, aprendizado, inovação e cooperação, se tornem reais é preciso orientação para se fazer um bom uso desses meios.

Assim, também é com os processos de leitura e escrita. De acordo com os Parâmetros Curriculares Nacionais - PCN's (BRASIL, 1997), a criança deverá ser capaz de "expandir o uso da língua portuguesa para produzir textos", constituir seu universo como tem noção do que é, da realidade a qual faz parte. Os aspectos culturais que estão presentes no seu dia a dia dizem muito mais do que os fatores externos, que distantes do que conhecem não oferecem segurança.

As tecnologias de informação podem servir de pontes entre o mundo real e a construção da linguagem para a alfabetização. Frisamos que é essencial que o professor conheça as razões dessa utilização, saiba promover a interação dos mundos como fator de atuação na educação. 


\section{REFERÊNCIAS}

BARBOSA, R. L. L. . IV Congresso Internacional sobre Pesquisa (Auto) Biográfica. 2010. (Congresso).

BRASIL. Parâmetros Curriculares Nacionais / Ministério da Educação. Secretaria de Educação Básica. Diretoria de Currículos e Educação Integral. 1997.

CAGLIARI, Luiz Carlos. Alfabetização e linguística / Luiz Carlos Cagliari - São Paulo: Sipione,2009. (Coleção pensamento e ação na sala de aula).

CASTELLS, M. A sociedade em rede. São Paulo: Editora Paz e terra S/A, 2003.

FRIGOTTO, G. Educação e crise do capitalismo real. 3. ed. São Paulo: Cortez, 1999.

GAMA, R. A Tecnologia e o Trabalho na História. São Paulo: Nobel Edusp (Livraria Nobel S.A. e Edusp). 1987.

LIBÂNEO, José Carlos. Educação escolar: políticas, estrutura e organização. 5.ed. São Paulo: Cortez, 2007.

LORENZATO, S. Porque não ensinar geometria? Educação Matemática em Revista. Sociedade brasileira em Educação Matemática - SBEM. Ano III. 1º semestre 1995.

MORAN, José Manuel et al. Novas tecnologias e mediação pedagógica. 6. ed. Campinas: Papirus, 2000.

OLIVEIRA, J.A.; OLIVEIRA, João Batista Araújo; GUIMARÃES, Sonia Dantas Pinto; BOMÉRY, Helena Maria Bousquet. A política do livro didático. São Paulo:

Summs/Campinas: Universidade Estadual de Campinas, 1984.

RODRIGUES, A. M. M. Por uma filosofia da tecnologia. In: Grinspun, M.P.S.Z.(org.). Educação Tecnológica - Desafios e Pespectivas. São Paulo: Cortez, 2001: 75-129.

SANTOMÉ, Jurjo Torres. Globalização e interdisciplinaridade: o currículo integrado. Porto Alegre: Artmed, 1998.

SANTOS, Milton. Por uma outra globalização: Do Pensamento Único à consciência Universal. São Paulo: Record, 2000.

VERASZTO, E. V. Projeto Teckids: Educação Tecnológica no Ensino Fundamental. Dissertação de Mestrado. Campinas. Faculdade de Educação. UNICAMP. 2004. 


\title{
O PAPEL DO PROFESSOR NOS PROCESSOS ADAPTATIVOS DOS ALUNOS
}

\author{
NEVES, Magda Lúcia $^{72}$ \\ SILVA, Francisco Clécio Araújo ${ }^{73}$ \\ FERNANDES, Ylka de carvalho ${ }^{74}$ \\ FREITAS, Dayana Lucia Rodrigues de ${ }^{75}$
}

\section{RESUMO:}

Este trabalho tem por objetivo analisar o processo de adaptação à escola, vivenciado por crianças de 4 e 5 anos de idade, no início da vida escolar. Pretende-se investigar o que pensam os pais e os professores sobre esse processo, observando sentimentos, reações e estratégias que estão envolvidas. Parte-se da concepção de adaptação como um processo contínuo que na escola envolve crianças, familiares e professores. Este trabalho trata-se de uma pesquisa bibliográfica fundamentado nos pressupostos teóricos de Balaban (1988), Maldonato (1985), Davini (1999) entre outros. Concluímos que, neste contexto, foi possível perceber que o processo de adaptação infantil é permanente e não tem período definido para acontecer, ele faz parte da dinâmica da vida coletiva. Cabe à escola, considerá-lo como aspecto de seu trabalho e encaminhá-lo, respeitando às necessidades e as características dos envolvidos.

PALAVRAS-CHAVE: Adaptação. Educação. Sentimentos e reações.

\section{INTRODUÇÃO}

O processo de adaptação é um organizador fundamental no início da vida escolar da criança, porque se constitui em um balizador para os outros organizadores, pelo papel que desempenha para a criança na faixa etária dos dois aos seis anos de idade. Entretanto, o início da vida escolar, historicamente, tem sido encarado pelos profissionais como sendo o período em que a criança chora ao chegar à escola e não como um processo gradativo envolvendo muitos sentimentos, tanto por parte dos adultos com por parte das crianças. Entrar na escola, para muitas crianças, significa

\footnotetext{
${ }^{72}$ Especialista em Alfabetização e Letramento pelo Instituto Superior de Educação Elvira Dayrell/MG. Professora da Educação Básica do município de Guamaré/RN. E-mail: magda neves@ @otmail.com

${ }^{73}$ Especialista em Educação Infantil pela Faculdades Integradas de Patos/CE (FIP). Professor de Educação Básica do município de Guamaré/RN. E-mail: cleciofrancisco@ yahoo.com.br

${ }^{74}$ Especialista em Educação Inclusiva pela Faculdade Kennedy/RN. Professora da Educação Básica do RN. E-mail: magda_neves@hotmail.com

${ }^{75}$ Mestra em Ciências da Educação pelo Centro de Educação Continuada e Aperfeiçoamento Profissional (CECAP). Professora da Escola Técnica Fanex Rede de Ensino - Macau/RN. Professora da Educação Básica do município de Guamaré/RN. E-mail: dayannaproducoes@gmail.com
} 
entrar num mundo novo, grande e desconhecido, diferente do pequeno mundo familiar, ao qual estão habituados e, de início, essa pode ser uma situação temida (MALDONATO, 1985, p. 26).

Geralmente, esta é a primeira grande separação da criança que, provavelmente, influenciará a atitude futura dela em relação à escola e a outras separações, que com certeza vivenciará. Considerando os primeiros contatos da criança na Educação Infantil, no que diz respeito à ambiência, é sempre um desafio tanto para o professor, como para os pais. As emoções de ambos afloram quando a criança começa a apresentar sinais de apego aos pais, e rejeição à sala de aula. Quando se trata de entrar na escola infantil, fala-se de momentos delicados e marcantes na vida do aluno, pois envolve sentimentos e expectativas de pessoas que esperam algo melhor para um futuro próximo.

É a ampliação deste espaço fora do lar, que marcará um longo caminho na vida escolar da criança, necessitando assim, ser bem administrado, pois toda criança, seja qual for sua história e sua idade, terá que enfrentar o primeiro dia de aula e esta experiência acarreta ansiedade e insegurança.

Este período é desenvolvido sem "prazos" para acabar e iniciar aprendizagens mais "sistemáticas", pois as atitudes espontâneas das crianças vão encadeando-se e integrando-se as propostas de professor, num trabalho também sistemático que versa sobre conteúdos inerentes e necessidades deste seu momento de evolução (HENRIQUES, 1987, p. 191).

Este processo, denominado adaptação, implica em novas conquistas para a criança, para seus pais e exige dos educadores, um atento e constante trabalho pedagógico, pois eles fazem parte da construção da rotina, a apropriação de espaço e principalmente o estabelecimento de vínculos entre as crianças, os pais e os professores educadores. Para a criança, todos são estranhos e os pais serão o suporte, o apoio. Porém, os pais não devem interferir na rotina da sala de aula ou nas atividades propostas pela professora. Reid (1999, p. 99) ressalta que:

Essa é geralmente a primeira grande separação. Na maioria das vezes é a mãe que tem a incumbência de levar o filho pela primeira vez a escola maternal [...] Isso faz a mãe reviver separações pelas quais passou, e mesmo que estas tenham sido resolvidas com êxito, não há como fugir ao fato de que estamos lidando com experiência emocional [...] O fluxo de emoções sentido pela maioria das mães não reflete 
apenas sentimentos relacionado à criança, mas também suas próprias lembranças de separação.

Ao longo da história da Educação Infantil, o processo de adaptação, foi por muitas vezes, encarado pelos profissionais como sendo um período de tempo e espaço determinado pela própria escola e tinha como objetivo, fazer as crianças pararem de chorar, sem pensar que esse processo não é expressado pelas crianças apenas com o choro, mas com dores, vômitos e doenças.

\begin{abstract}
Imaginar que o sucesso de um processo de adaptação se resume a ter ausência de choro e banalizar uma situação que não termina em si mesma os sintomas que a criança apresenta como doenças, regressões, alterações de comportamentos, etc. está ai para comprovar que elas não falam que as coisas não vão bem somente chorando (BORGES, 2002, p. 32).
\end{abstract}

As novas experiências terão repercussões para as crianças, pais, familiares mais próximos e até mesmo para aquelas pessoas que acolhem, ou seja, os professores e demais profissionais da instituição escolar. Durante este tempo em sua vida, o discente depara-se com duas conquistas fundamentais: a independência e a autonomia. É como afirma Balaban (1988, p. 25): “a separação é uma experiência que ocorre em todas as fases da vida humana".

A família é o primeiro grupo social em que aprende conhecimentos sobre a língua que se fala, os hábitos de higiene e de alimentação, a forma de morar, a música e as normas de comportamento. Através do grupo familiar, ela entra em contato com os usos e costumes da comunidade em que vive. Família e comunidade são as primeiras fontes de informação sobre o mundo.

A criança defronta-se com novas questões de sociabilidades e terá que se relacionar com seus semelhantes - as outras crianças da classe e da escola - e com eles dividir seus brinquedos e materiais; podendo, assim, envolve-se com o novo (educador/colegas), experimentando novas formas de ser e sentir, sem que para isso, o já conhecido (pais/familiares) perca espaço em seus afetos.

O professor educador é aquele que faz a ponte entre a criança e o desconhecido, trazendo objetivos de conhecimento para perto, tornando-o observáveis, palpáveis e familiares. Se o professor for uma pessoa atenciosa, a criança será capaz de transferir 
seus sentimentos "básicos" de confiança, da sua casa para escola. Enfim, o professor é o principal mediador e tem que atender às expectativas dos pais, ganhar a confiança das crianças e de seus familiares e ainda, conduzir o processo de adaptação das crianças, além de trabalhar seus próprios sentimentos.

Considerando as necessidades da criança e para essa nova fase que inicia em sua vida escolar, ou seja, sua adaptação ao novo ambiente, Davini (1999, p. 56-57) faz o seguinte comentário:

Trabalhar com crianças pequenas, contrariamente ao que é dito no senso comum, demanda adultos experientes, sensíveis e amorosas [...] Formar uma pessoa para ter todo preparo [...] bem como para disporse a suportar todo esse processo, fazendo boas intervenções e superando o mal-estar, é um trabalho delicado, demorado e de grande investimento, portanto devemos escolher com cuidado a pessoa que irá assumir esta respeitosa função de educar crianças pequenas. Função que necessita de preparo psicológico e formação pedagógica.

Enfim, adaptações bem trabalhadas favorecem o aprofundamento do desejo de aprender e de construir conhecimento.

\section{SENTIMENTOS E REAÇÕES INFANTIS AO ENTRAR NO AMBIENTE ESCOLAR.}

O início da vida escolar é um período muito difícil, que envolve muitos sentimentos e de todos os envolvidos. É importante lembrar que, nesse contexto, não é só a criança que está chegando à instituição escolar, chegam também os pais, que se encontram com os professores, que se preparam para tal acontecimento.

[...] é a primeira separação da criança de seus pais e também primeira de muitas que ela vai vivenciar em sua vida, sendo uma situação dolorosa tanto para os pais quanto para as crianças. É nesse período que podem vir à tona os sentimentos e experiências vividas, anteriormente, em todos os envolvidos pais, professores e crianças (BORGES, 2002. p. 39).

Os sentimentos e reações são diferentes para cada um e às vezes pode ser um processo difícil e demarcado, seja para o bebê, para a maior da Educação Infantil e para aquele que já está iniciando o Ensino Fundamental. Trata-se de um processo de renovação e mudança na vida de todos que estão envolvidos (pais, professores e 
discentes). A criança pode apresentar reações de tristeza e insegurança, levando em conta que toda separação é difícil, provocando, na maioria das vezes, sentimentos como: medo, desconforto e ansiedade. De acordo com Balaban (1988, p. 13), "a separação dos pais ou daquela pessoa que é a principal fonte de atenção torna as crianças pequenas, frequentemente muito infelizes. Elas muitas vezes se sentem deixadas de lado e abandonadas".

Algumas crianças não choram quando se despedem dos pais, mas depois de um determinado período (uma semana, um mês), não querem mais ir à escola. A reação atrasada pode vir a qualquer hora, pois muitas vezes elas estão envolvidas com as novidades e quando essas acabam, vem à realidade da separação. Muitas crianças choram logo no primeiro dia e o choro se prolonga por semanas, perguntando sempre por seus pais e se eles vão voltar logo. Todas essas reações apresentam um sentimento de tristeza e perda por parte das crianças, “[...] pois elas com frequência acham que a perda não vai ter fim, que não vão parar de se sentir tristes, que não vão nunca parar de chorar" (BALABAN, 1988, p. 37).

Algumas crianças apresentam comportamentos regressivos, como chupar o dedo, comer muito ou não comer nada, urinar na roupa, dormir muito ou recusa-se a fazê-lo. Também querer vestir-se sozinho, sentir dores de barriga, procurar ficar mais perto dos pais, querer estar no colo, ser sombra dos adultos, tanto na escola como em casa.

Esses são comportamentos próprios da vida escolar. Eles são para a maioria passageiro e provavelmente vão desaparecer quando as crianças se tranquilizarem, acreditando que seus pais os mandam para a escola ou para creche para que tenham bons e felizes momentos e que os professores podem cuidar delas. Uma confiança desse tipo demora para se desenvolver (BALABAN, 1988, p. 45).

O reaparecimento de atitudes que relembram a época de bebês é comum nesse processo de adaptação, porque a criança precisa adquirir autoconfiança, fazendo uso da imagem da mãe. Speers citado por Balaban (1988, p. 37) acredita que "essa repetição é importante para que adaptação da criança à escola tenha êxito".

Balaban (1988, p. 39), comenta que: "quando a criança é capaz de dominar seus sentimentos na escola, está dando um passo gigante no seu crescimento”. Entretanto, sabe-se que, para a criança, esse processo envolve sofrimento, mas, ao mesmo tempo, é 
necessário para que o sujeito possa, através desta nova experiência, construir um caminho sólido para sua independência e autonomia.

Consciente de todos os fatores que estão envolvidos no processo de adaptação, é preciso pensar e planejar uma inserção gradativa da criança no ambiente escolar, com o objetivo de tornar esse processo de adaptação o mais tranquilo possível para todos, criando um ambiente em que tanto a criança quanto sua família sintam-se confiantes, respeitados e acolhidos. A escola deve se organizar para receber pais e crianças, transmitindo seus objetivos e suas propostas de forma clara e honesta. As estratégias nesse período, devem ser, então, bem pensadas e planejadas pela equipe da escola, levando em consideração sua realidade e sua disponibilidade.

[...] orientam que antes do início das aulas, devem ser organizadas reuniões coletivas e entrevistas individuais com os pais para a escola expor aos responsáveis, a sua proposta pedagógica, os seus objetivos, explicando-lhes como se dá esse processo de adaptação, enfatizando que esse momento merece uma atenção especial (DAVINI; FREIRE, 1999, p. 31).

Rêgo (1995) propõe uma ação pedagógica para esse período, tais como: realizar uma reunião coletiva com os pais antes do início das aulas, na qual se discutirá o processo de adaptação e o trabalho pedagógico; receber as crianças na sala de aula, por ser um lugar menor e aconchegante; a professora deve cuidar pessoalmente de todas as questões que se referem às crianças; estabelecer uma rotina de trabalho, mesmo que seja flexível, mas com momentos bem definidos; iniciar o trabalho pedagógico com um tema de pesquisa, que auxilie as crianças a estarem discutindo as questões a cerca do novo momento de suas vidas; o trabalho pedagógico deverá ser encaminhado por uma professora e a outra estaria mais disponível para se envolver com problemas individuais (choro, vômito, xixi...); manter um contato diário com os pais; propor atividades que propiciem a capacidade de representar.

Os educadores, juntamente com a equipe pedagógica da escola, devem acrescentar às suas estratégias de acolhimento aos pais, um trabalho de dinâmicas, envolvendo atividades com o corpo e a mente. O projeto de trabalho, vivências e sentimentos dos pais; a entrada, na escola, consiste em outra estratégia adotada, no sentido de promover um encontro entre pais de crianças novatas, pais de alunos que já frequentavam a escola e equipe de professores. 
De acordo com Balaban (1988), a escola pode proporcionar uma visita das crianças com seus pais ao local. É importante destacar que, neste período, se faz necessário a presença de um adulto ligado à criança, seja pai ou mãe e até mesmo outro responsável, pois se sabe que essa presença é fundamental para a verdadeira inserção da criança na escola, pois a força para as crianças, enquanto sua ausência leva à fraqueza.

\begin{abstract}
Isso transmite as crianças um pouco da alegria que esta por vir e lhes serve como um ponto de referencia familiar quanto chegam para o primeiro dia de aula. Isso permite que os pais falem com seus filhos sobre a escola como se antecipassem o primeiro dia. Os pais também gostam de se familiarizar com uma situação na qual estão para entrar. [...] A ideia é que a partir do mais concreto, ou seja, a mãe presente no próprio espaço da criança (extraclasse), o processo de separação evolua gradualmente, até que a mãe se ausente da escola e volte na hora combinada para então saber se já é ou não para levar seu filho. Se ele estiver bem, a professora escolhe o melhor momento para o dia seguinte levando-o pessoalmente para sua mãe, conquistando a confiança e a cumplicidade da criança (CAMPOS, 1999, p. 22).
\end{abstract}

O professor pode incluir na rotina, passeios pela escola, para que o grupo tenha a oportunidade de conhecer o espaço físico, visitas (previamente combinadas) às outras salas, também às crianças e professoras da escola, assim como, atividades em conjunto no espaço externo. É importante não permitir ou aceitar que os pais saiam às escondidas, pois a criança que está no ambiente se sente protegida pela presença deles. Balaban (1988, p. 119) reforça essa afirmação quando aborda que "esse tipo de comportamento gera na criança insegurança, medo, abandono. Esses sentimentos raramente são uma base firma sobre a qual se começar uma experiência nova".

Nesta perspectiva, o planejamento é imprescindível para que as crianças e os pais se sintam bem acolhidos, no sentido de fazê-los desenvolver a confiança nos profissionais e na instituição. Conforme os estudos de Balaban (1988, p. 30) "quando a transição de casa para a escola é favorável, o processo traz consequências positivas e importantes para o desenvolvimento da criança como para o bem-estar da família”.

\title{
O PAPEL DO PROFESSOR NA ADAPTAÇÃO
}

Sabe-se, nesta fase, que os professores também passam por momentos de muita expectativa/ansiedades/excitações, com a perspectiva de encontrar um novo grupo de crianças e pais. Muitas das vezes, sentem-se pressionados, tanto pelas famílias, quanto 
pelas outras pessoas da escola, para que façam as crianças pararem de chorar, no menor tempo possível. Os professores, com frequência, se sentem pressionados pelas necessidades contraditória das crianças, pelas exigências dos pais e por suas inclinações pessoais (BALABAN, 1988, p. 24).

Percebe-se que, nesse período, faz surgir nos professores muitos sentimentos: tais como anseio, quanto ao tempo que vai durar o choro; aflição, tendo tantos pais por perto durante alguns dias; a sensação de raiva, com as atitudes de alguns pais. É possível que, neste momento, os professores lembrem ou revivam outras situações semelhantes, vivenciadas por eles anteriormente.

Talvez, um dos sentimentos mais forte gerado no professor durante o período de adaptação, seja o sentimento de impotência, diante do choro da criança. Muitas vezes os professores sentem insegurança, pois nada que faz, parece dar certo para consolar a criança. Outra situação comum durante a adaptação, refere-se à rejeição e o constrangimento diante de tantos pais dentro da sala. Alguns professores não conseguem suportar a presença dos pais, sem se sentirem vigiadas e analisados em sua competência profissional.

Não há nada de estranho em os professores sentirem as mesmas situações diversas e contraditórias que as crianças e os pais. No entanto, tem que compreender esses sentimentos para lidar com eles. Com muita maturidade profissional, a melhor forma de superar e lidar com esses sentimentos é conversando sobre eles. Nenhum professor está sozinho nessa situação, este é um fato que acontece com frequência no meio pedagógico. Os professores não devem ter "auto culpa", se sentindo incapazes.

O professor deve encaminhar esse processo e, como profissional, deverá demonstrar segurança e firmeza em determinadas situações, ainda que inesperadas e imprevisíveis. Neste caso, os pais, às vezes, sentem-se no direito de tomar iniciativas na sala como: brincar com o filho, não levando em conta que ali está um grupo; tomar a frente em discussões de alunos. E os professores precisam estar preparados para intervir como um profissional, retirando a mãe de sala com delicadeza, mas firme e explicando qual é o papel dela naquele momento.

Enfim, entende-se que o professor seja o principal mediador, pois este tem que atender às expectativas dos pais, ganhar a confiança das crianças e de seus familiares e ainda, conduzir esse processo, além de trabalhar seus próprios sentimentos. Estão a todo 
tempo sendo colocados à prova e é necessário sempre, ampliar e capacitar os seus conhecimentos.

\section{CONSIDERAÇÕES FINAIS}

A elaboração deste trabalho, demonstra que a adaptação é um processo continuo, sem tempo e hora determinados para acontecer, é um processo que cria expectativas e gera sentimentos em todos aqueles que estão envolvidos, as próprias crianças, seus pais e os professores, tornando-se supremos e ao mesmo tempo, complexo e único. Quando a criança inicia sua vida escolar, encontra um mundo todo novo, com pessoas que ainda não conhece sentimentos diversos, surpresas, enfim, um misto de alegrias, crescimentos, aprendizagens e medos.

Este passo na vida da criança será o primeiro de muitos que ela vai dar por toda a sua vida. Se esse momento for tranquilo e bem conduzido pela família e pela escola, contribuiremos de forma a garantir maior segurança e autonomia, para que a criança enfrente seus obstáculos de modo positivo e confiante. É importante dizer que, não existe nenhuma conduta padronizada que seja ideal para lidar com essa situação, pois as crianças manifestam necessidades diferentes.

A atitude da família e da escola durante este período é essencial. Para ajudar a criança a sentir-se mais segura, o pai e a mãe devem estabelecer limites, demonstrar autoridade e segurança, estimular a convivência com professores e colegas, e ir aumentando, aos poucos, a permanência da criança na escola. Não se deve prometer recompensas que não tenham relação com o fato (eu te dou isso ou eu te levo para passear se você ficar bem) ou mentir para a criança dizendo que vai ao banheiro e sair escondido.

É certo que, ao enfrentar este momento junto com seu filho, a família estará contribuindo para a conquista de sua independência e autonomia, além de prepará-lo para conviver em sociedade, fazer amigos, aprender a dividir, compartilhar, respeitar a si mesmo e ao outro. Cada situação merece um cuidado especial, inclusive com as situações em que a criança já frequentou outras escolas ou que já esteve na escola em anos anteriores, precisando de um período para se adaptar aos horários, à rotina e à professora. 
O mais importante disso tudo é que pais e professores estejam dispostos a conversar e a colaborar, tendo clareza de que propiciarão às crianças, oportunidades para se estruturarem emocionalmente e assim, conviverem em sociedade, aprendendo a compartilhar e a ter limites.

\section{REFERÊNCIAS}

BALABAN, Nancy. O início da vida escolar: da separação à independência. Porto Alegre: Artes Médicas, 1988.

BORGES, M. F. S. T. e SOUZA, R. C. de (org.) A práxis na formação de educadores de Educação Infantil. Rio de Janeiro: DP \& A, 2002.

CAMPOS, M. M. A formação de professores para crianças de 0 a 10 anos: Modelos em debate. Revista Educação \& Sociedade, ano XX, n. 68, dez. 1999.

DAVINI, Juliana; FREIRE, Madalena (Org.). Adaptação: pais, educadores e crianças enfrentando mudanças. São Paulo: Espaço Pedagógico, 1999. (Série Cadernos de Reflexão).

HENRIQUES, L. A. O período de adaptação na pré-escola em um enfoque psicopedagógico. In: SCOZ, B. J. L. (et. al.). Psicopedagogia - o caráter interdisciplinar na formação e atuação profissional. Porto Alegre: Artes Médicas, 1987.

MALDONATO, M. T. Comunicação entre pais e filhos. A linguagem do sentir. Petrópolis: Vozes, 1985.

REGO. Teresa Cristina. Vygotsky: uma perspectiva histórica - cultural da Educação, 4 Ed, Petrópolis, RJ: Vozes 1995.

REID, Susan. Compreendendo seu filho de 2 anos. Trad. Cláudia Gerpe Duarte. Rio de Janeiro: Imago, 1999. 


\section{O PROFESSOR E A EDUCAÇÃO INCLUSIVA: UM NOVO OLHAR NO}

\section{ÂMBITO ESCOLAR}

FONSECA, Silvinha de Melo ${ }^{76}$

JULIÃO, Márcia Aparecida da Silva Oliveira ${ }^{77}$

FIGUEIRÊDO, Nilza Tavares de ${ }^{78}$

ARAÚJO, Layze Rose de Melo Fonseca ${ }^{79}$

\section{RESUMO:}

O sistema educacional tem funcionado de forma expulsiva, produzindo fracasso, deficiências e necessidades que poderiam não existir, comprometendo diretamente essas demandas à Educação Especial e deste modo, a inclusão deixa de acontecer. A educação inclusiva precisa marcar um lugar de diferença, onde o encaminhamento de crianças ou jovens para escolas ou salas especiais possam constituir exceções a ser recomendadas. Este trabalho tem como objetivo geral refletir sobre a atuação do professor com os alunos com deficiência. Apresenta como objetivos específicos: analisar a opinião dos alunos sobre o desempenho dos professores; descrever o papel do professor com relação à inclusão; e ressaltar a importância do atendimento educacional especializado para aluno com deficiência. Como metodologia foi realizada, foi feita uma abordagem qualitativa com uso de entrevista com dois alunos com deficiência que estudam em uma escola na cidade de Macau/RN. A escola em questão foi escolhida por ser tida como referência no âmbito da inclusão. Além disso, entrevistamos alguns professores para saber suas dificuldades e sobre o apoio da sala de AEE. Os resultados estão apresentados de forma descritiva qualitativa. Através da aplicação dos questionários foi possível conhecer a realidade das turmas, os procedimentos metodológicos das professoras regentes, assim como identificar até que ponto a escola realmente está comprometida com a inclusão de pessoas com necessidades educacionais especiais. A escola em questão apresentou diversos pontos positivos no tocante à inclusão, já que realiza a inclusão e socialização dos alunos com deficiência de forma ampla e transformadora. Os professores que atuam nesta escola se sentem preparados para receber esses alunos. Além disso, tanto os alunos como os docentes se sentem apoiados pelos profissionais do AEE. Podemos afirmar que há muito para ser feito, mas, a bandeira da educação inclusiva já foi levantada. Muito foi conseguido, o que faz a luta

\footnotetext{
${ }^{76}$ Mestranda do curso de Ciências da Educação pelo Centro de Educação Continuada e Aperfeiçoamento Profissional (CECAP). Professora da Educação Básica dos municípios de Macau/RN e Guamaré/RN. Email: silvinhademelo@yahoo.com.br

${ }^{77}$ Especialista em Educação Infantil pela Faculdade de Tecnologia Módulo Paulista/SP. Professora da Educação Básica dos municípios de Macau/RN e Guamaré/RN. E-mail: marcia2005_pedagoga@ hotmail.com

${ }^{78}$ Especialista em Educação Infantil pela Universidade Federal do Rio Grande do Norte (UFRN). Professora da Educação Básica dos municípios de Macau/RN e Guamaré/RN. E-mail: antoniograbrielf19@gmail.com

${ }^{79}$ Estudante do Curso de Especialização em Educação Ambiental e Desenvolvimento Sustentável pela Faculdade de Venda Nova do Imigrante (FAVENI/ES). Licenciada em Ciências Biológicas pela Universidade do Estado do Rio Grande do Norte (UFRN). Professora da Educação Básica do município de Macau/RN. E-mail: layzerose.biologia2009@yahoo.com.br
} 
valer a pena. Com estas ações, ganham a sociedade, a escola, a família e as pessoas com necessidades educativas especiais. Por fim, podemos afirmar o quanto é importante que as pessoas com necessidades educacionais especiais estejam inseridas no ambiente regular de ensino, visto que a interação entre estes, a sala de aula, o professor, comunidade escolar e colaboradores traz benefícios a todos.

PALAVRAS-CHAVE: Educação Inclusiva. Docência. Inclusão.

\section{INTRODUÇÃO}

O sistema educacional tem funcionado de forma expulsiva, produzindo fracasso, deficiências e necessidades que poderiam não existir, comprometendo diretamente essas demandas à Educação Especial e deste modo à Educação inclusiva deixa de acontecer. A Educação Inclusiva precisa marcar um lugar de diferença, onde o encaminhamento de crianças ou jovens para escolas ou salas especiais possam constituir exceções a ser recomendadas.

Neste contexto, o professor necessita assumir um papel importantíssimo de compromissos e responsabilidades com essas pessoas. No âmbito da escola não há ninguém com maior competência para assumir essa missão de grande necessidade, que o próprio docente.

Este trabalho foi investigado alguns aspectos sobre inclusão em uma escola de Macau/RN. A escola em questão foi escolhida por ser tida como referência no âmbito da inclusão. Não foram observadas as demais escolas por se tratar de escolas "comuns", que não eram tidas como referência.

Como perguntas norteadoras surges as seguintes indagações: Como o AEE pode ajudar um professor de sala de aula com aluno com deficiência? Como os alunos com deficiência se sentem na escola? Será que realmente existe inclusão na escola?

Este trabalho tem como objetivo geral refletir sobre a atuação do professor com alunos com deficiência. Apresenta como objetivos específicos: analisar a opinião dos alunos sobre o desempenho dos professores; descrever o papal do professor com relação à inclusão; e ressaltar a importância do atendimento educacional especializado para aluno com deficiência.

Como metodologia foi realizada uma abordagem qualitativa com uso de entrevista com dois alunos com deficiência que estudam em uma escola na cidade de Macau/RN. Além disso, entrevistamos alguns professores para saber suas dificuldades e 
sobre o apoio da sala de AEE. Os resultados estão apresentados de forma descritiva qualitativa.

Consideramos a abordagem deste tema de suma importância para a sociedade, visto que precisamos ter uma sociedade verdadeiramente inclusiva e uma escola que possa receber pessoas com deficiência de forma justa e com equidade.

\section{O PAPEL DA ESCOLA E DO PROFESSOR NA INCLUSÃO}

A escola, para se tornar inclusiva, com as suas práticas educacionais, faz-se necessário um clima pleno, que possibilite melhorar a situação do aluno com deficiência, pautada no compromisso e nas atitudes de todos os envolvidos na escola, para que haja uma aprendizagem e aperfeiçoamentos de ambos, como o professor mediador do conhecimento, favorecendo ao aluno que irá ampliar suas competências e habilidades a partir das experiências no cotidiano escolar.

Neste sentido, a deficiência não deve ser vista isoladamente e como um obstáculo, que impede e impossibilita uma pessoa de aprender e desenvolver-se potencialmente. A escola comum tem o dever de ofertar uma proposta de trabalho que inclua integralmente todos num contexto único de formação de pessoas, sem diferenciação de direitos. Como afirma: (BATISTA, 2006, p. 08):

Diante da inclusão, o desafio das escolas comum e especial, é o de tornar claro o papel de cada um, pois uma educação para todos, não nega nenhuma delas. Se os compromissos educacionais dessas não são sobre postas, nem substituíveis, cabe a escola especial complementar a escola comum, atuando sobre o saber particular que invariavelmente vai determinar e possibilitar a construção do saber universal.

Por outra vertente, a escola para educação especial, necessita de equipamentos, materiais e professores especializados. Enquanto o sistema regular de ensino necessita urgentemente ser adaptado e pedagogicamente transformado para atender de forma inclusiva e eficaz. Sabe-se que a educação é crucial no crescimento da pessoa. Portanto, a educação da criança com deficiência seja ela qual for é uma condição imprescindível para o seu desenvolvimento emocional e social como pessoa.

Assim, compreende-se que a educação inclusiva é um processo em que se amplia a participação de todos os discentes nos estabelecimentos de ensino regular. 
Trata-se de uma reestruturação da cultura, da prática pedagógica, e das políticas públicas, vivenciadas nas escolas para que estas possam atender a diversidade de seus alunos, como cita Soares e Carvalho (2012, p. 318):

A constituição de 1988, no inciso III de seu artigo 59, definiu que o direito a educação de alunos com deficiência deveria ser cumprido preferencialmente por seu acesso a rede regular de ensino. Essa ênfase dado a inclusão de alunos com deficiência na rede regular de ensino obrigou o legislador a prever a formação não só do professor especializado, mais também a preparação dos professores do ensino regular para estarem aptos a receber esses alunos.

Entretanto, apesar dessas determinações como também de outros que foram orientados, sabe-se que, na prática, o ensino não funciona de forma eficaz. Nos dias atuais, ainda precisam ser feitas várias mudanças nas instituições escolares, para que esses direitos sejam garantidos e efetivados de forma conveniente, atendendo, deste modo, às demandas decorrentes das necessidades especificas dessas pessoas que apresentam algum tipo de deficiência.

\section{O AEE - ATENDIMENTO EDUCACIONAL ESPECIALIZADO E O PROFESSOR DA SALA DE AULA COMUM}

O AEE é um serviço de educação especial que identifica, elabora e organiza recursos pedagógicos e de acessibilidade que eliminem barreiras para a plena participação dos alunos, considerando suas necessidades especiais específicas. Ele deve ser articulado com a proposta da escola, embora suas atividades se diferenciem das realizadas em salas de aulas de ensino comum (BRASIL, 2009). Deve ser realizado no período inverso ao da classe frequentada pelo aluno e, preferencialmente, na própria escola.

Nas escolas de ensino regular, o AEE deve acontecer em salas de recursos multifuncionais, que é um espaço organizado com materiais didáticos pedagógicos, equipamentos e profissionais com a formação para o atendimento às necessidades educacionais especiais, projetadas para oferecer suporte necessário a estes alunos, favorecendo seu acesso ao conhecimento (BRASIL, 2007). 
$\mathrm{O}$ atendimento educacional especializado é de fundamental importância para os avanços na aprendizagem desses alunos com deficiência na sala de ensino regular. Os professores destas salas devem estar em consonância, como professor da sala de aula comum para adaptar estratégias pedagógicas na sua prática educacional, como suporte e apoio à educação regular, através do atendimento a escola, ao professor da classe regular e ao aluno.

O objetivo do AEE é importante na formação do aluno com atendimento direcionado, através dos recursos e de estratégias que possibilitem sua socialização e o desenvolvimento na aprendizagem. O papel do professor é intervir nas atividades que ele não tem autonomia para desenvolver sozinho, fazendo uma ponte para que esse aluno consiga realizá-las de forma eficaz no seu processo de evolução. "A educação deverá visar que cada aluno chegue a essa autonomia” (MIZUKAMI, 1996, p. 71).

Sendo assim, os métodos, as técnicas e estratégias, dependerão da observação, na dificuldade do aluno, na organização e no planejamento para atender os alunos e orientar as atividades durante o processo. Considerando que o AEE não cabe o ensino de conteúdos escolares, não pode ser confundidos com as aulas de reforço. O AEE serve para ajudar e direcionar o aluno a adquirir habilidades essenciais para um bom desempenho nas aulas regulares. Vale ainda ressaltar a importância do trabalho de interação entre o professor da sala regular, onde há o diálogo de um com o outro sobre os avanços ou retrocessos do aluno no processo de aprendizagem.

Desta forma, as diretrizes confirmam quando diz que: a função do AEE está voltada para: "Identificar, elaborar e organizar recursos pedagógicos e de acessibilidade que eliminem as barreiras para plena participação dos alunos, considerando suas necessidades específicas" (BRASIL, 2009).

$\mathrm{O}$ aluno com deficiência que está matriculado na escola regular, tem à sua disposição, o atendimento educacional especializado para qualquer necessidade específica que a escola regular não consiga suprir durante sua jornada escolar. A inclusão deve garantir a todas as pessoas o direito à escola e à aprendizagem através das possibilidades que são oferecidas a elas.

[...] Igualdade de oportunidades, respeito às necessidades individuais, qualidade no processo de ensino- aprendizagem, melhoria das condições de trabalho dos educadores, mais participação das famílias 
e da sociedade em geral, remoção das barreiras para aprendizagem e participação. (CARVALHO, 2004, p. 79).

Neste sentido, o aluno com deficiência tem o direito à educação e cada avanço é uma conquista que tem que ser partilhada, cada um no seu ritmo, respeitando suas limitações, mas cada etapa vencida é primordial no que se refere a interação, o aprendizado e o aspecto social. A família tem um papel importante em parceria com a escola, apoiando, dialogando e contribuindo no desenvolvimento do educando.

\section{RESULTADOS E DISCUSSÕES}

Como já mencionado anteriormente, para obtenção dos dados, foram realizadas duas entrevistas com dois alunos do ensino fundamental I de uma escola pública situada no município de Macau/RN. Esses alunos entrevistados necessitam de atendimento educacional especial, sendo um aluno com autismo e outro cadeirante.

Os referidos alunos apresentam laudo comprobatório dessas deficiências e características bem marcantes como: dificuldade de relacionamento socioafetivo, linguagem imatura e grande sensibilidade a sons. Os alunos ainda apresentavam certa dependência na realização de tarefas simples do dia a dia. Entre elas se destacam: auxílio para carregar sua mochila escolar e para decidir o que comer na hora do lanche.

Compreendemos ainda que os procedimentos metodológicos das professoras regentes, muitas vezes são prejudicados pela falta de material adequado ao ensino dessas pessoas e ainda de formação continuada na área de inclusão.

Durante a entrevista, que ocorreu de forma individualizada, ambos os alunos descreveram suas rotinas na escola, como seus professores os tratam, qual a interação da turma com eles, se eles sofrem preconceito dentro da escola e como a direção da escola trabalha o tema inclusão.

Foi percebido que os dois alunos estão totalmente satisfeitos com a atuação dos professores, demostraram gostar muito da sala de aula e de como os professores tratam eles. Um dos alunos citou: "dá pra sentir que a tia me ama muito”. Em outro momento, durante a entrevista, o outro aluno citou: "amo minha tia" (referindo-se à professora titular).

Em nenhum momento os alunos relataram sobre preconceito ou maus tratos; pelo contrário, afirmaram o quanto gostam do ambiente escolar e de como seus 
"coleguinhas" são legais. Eles citaram: "gosta da Brenda" (uma aluna da sala); "todos me tratam bem, nem parece que sou diferente". Ambos os alunos alegaram haver sempre ações voltadas a inclusão, tanto em suas salas de aulas como na escola em geral.

Quanto à sala de AEE, os alunos afirmaram gostar muito, pois conseguem tirar dúvidas e aprender mais. Eles falaram: "tenho uma tia só pra mim, fica melhor de aprender"; "faço coisas diferentes da sala de aula".

Em outro momento entrevistamos as professoras titulares, responsáveis pelas turmas onde esses alunos estudam. Na entrevista, foram abordadas questões sobre a formação continuada, o preparo das aulas, a adaptação dos alunos entre outras perguntas. Conseguimos identificar que ambas as professoras já haviam lecionado para alunos com deficiência. Como já falado anteriormente, esta escola é referência na cidade de Macau/RN quanto aos aspectos de inclusão. Identificamos também que, as duas professoras possuem cursos de inclusão e outros temas correlacionados. Esses cursos, segundo as entrevistadas, tanto foram ofertados pela própria escola, como elas também realizam cursos particulares.

Nenhuma das professoras relatou casos de discriminação. Segundo elas, os alunos já possuem uma consciência voltada para a inclusão, além disso, o tema é trabalhado e realizado efetivamente na escola, o que gera uma mudança positiva na compreensão de mundo e socialização de todos na escola.

No caso da sala de aula onde o aluno com autismo estudava, foi notória a preocupação que a referida educadora tinha com sua formação. Segundo relato da professora, procurava levar atividades voltadas para o envolvimento do aluno como: desenhos, pinturas e exercícios para relacionar. No entanto, achava insuficiente para atender as reais necessidades do educando.

Essa mesma professora afirmou sempre contar com a ajuda do AEE para dar suporte e auxilio nas escolhas de algumas atividades realizadas em sala de aula, com interação de todos os alunos. Também falou que é dedicado um horário exclusivo para que este aluno tenha atendimento individualizado, para suprir suas necessidades.

Já em relação aos pontos observados e detectados na entrevista com a professora da sala de aula, onde havia um aluno cadeirante, foi possível constatar que ela também tem um cuidado especial no preparo das aulas, principalmente na adaptação do espaço e na realização de brincadeiras que possam ser aproveitadas por todos. No 
caso desta professora, ela não precisa de adaptação de conteúdos, pois o aluno em questão não apresenta deficiências intelectuais.

A professora também alegou pedir auxílio à professora da sala de AEE para dar sugestões e materiais diferenciados. Também alegou que o aluno tem momentos na sala de AEE para atendimento individualizado. Quanto a sala de AEE, existem profissionais especializados para atendimento aos alunos e apoio aos professores durante o turno matutino e vespertino. A escola não funciona a noite. A sala está totalmente adaptada e apresenta materiais e suporte necessário para um bom desempenho dos atendimentos individualizados.

Por fim, com relação a gestão da escola, todos se empenham em realizar ações que trabalhem a inclusão e socialização dos alunos. Além disso, sempre buscam ofertar cursos para os professores, visando a qualificação e melhoria do serviço prestado.

\section{CONSIDERAÇÕES FINAIS}

Através da aplicação dos questionários, foi possível conhecer a realidade das turmas, os procedimentos metodológicos das professoras regentes, assim, como identificar até que ponto a escola realmente está comprometida com a inclusão de pessoas com necessidades educacionais especiais.

A escola em questão apresentou diversos pontos positivos no tocante à inclusão, já que realiza a inclusão e socialização dos alunos com deficiência de forma ampla e transformadora. Os professores que atuam nesta escola se sentem preparados para receber esses alunos. Além disso, tanto os alunos como os docentes se sentem apoiados pelos profissionais do AEE.

Como ponto negativo, constatamos que a escola não possui estrutura para acolher um quantitativo grande de alunos com deficiência, devido suas limitações físicas estruturais.

Em virtude dos fatos mencionados, percebe-se que a Educação para atingir um nível de inclusão de cunho satisfatório ainda contém muitas barreiras que necessitam ser ultrapassadas. No entanto, não se pode negar que muitas já foram as conquistas pelas pessoas com deficiência, mesmo entendendo-se que, na prática, ainda existem muitos equívocos e aspectos a serem melhorados quando se trata de inclusão. 
Entende-se, partindo deste ponto de vista, que há uma grande necessidade, de apontar instrumentos pedagógicos que mobilizem de forma efetiva o processo de ensino e aprendizagem das pessoas que se encontram, impossibilitados por alguma deficiência, para evoluir cognitivamente, dentro de sala de aula regular.

A educação para classe regular necessita ser mais eficiente e ter a capacidade de suprir essas demandas com eficácia. Deste modo, é fundamental ressaltar a relevância e o verdadeira função das salas de AEE, dentro das escolas como ponte de intermediação entre o aluno com necessidades especiais e o professor de sistema comum.

As salas de aulas precisam ter profissionais capacitados para receber esses alunos, bem como todos. É neste sentido que, se consiste em uma escola para todos, onde busca-se de soluções para ser trabalhadas da melhor forma, que possibilite atender o direito de todos ao saber, sem fazer alusões ao perfil de diferenças existentes entre todos da sociedade.

Uma sociedade justa e igualitária que respeita e valoriza as potencialidades de cada um, independente de seu estado físico, emocional, intelectual ou social, assim, se faz o ensino que abrange a diversidade e a singularidade dos indivíduos que o compõem, levando-os por caminhos pedagógicos coerentes e condizentes com as condições intelectuais de cada um, conduzindo-os para o mundo do conhecimento, necessário para o avanço do discente.

A escola é um espaço ao qual todos têm direito ao acesso, porém é de suma importância que aqueles que nela ingressam, tenham todas as suas necessidades verdadeiramente atendidas. É importante ressaltar que a criança incluída, necessita de adaptações e, neste sentido, um atendimento especializado é importante e necessário.

Portanto, o que falta é que mais escolas estejam preparadas para realizar a inclusão em sua totalidade. Incluir verdadeiramente nela e em sua concepção de ensino o aluno especial, e que possam ofertar a estes a atenção e a qualidade de ensino a que eles têm o direito e merecem ter.

Podemos afirmar que há muito para ser feito, mas, a bandeira da educação inclusiva já foi levantada. Muito foi conseguido, o que faz a luta valer a pena. Com estas ações ganham a sociedade, a escola, a família e as pessoas com necessidades educativas especiais. Por fim, podemos afirmar o quanto é importante que às pessoas com necessidades especiais estejam inseridas no ambiente regular de ensino, visto que a 
interação entre estes, a sala de aula, o professor, comunidade escolar e colaboradores, traz benefícios a todos.

\section{REFERÊNCIAS}

BATISTA, Cristina Abranches Mota. Educação Inclusiva: Atendimento educacional especializado para a deficiência mental. [2. ed]/ Cristina Abranches Mota Batista, Maria Tereza Egler Mantoan. _ Brasília: MEC, SEESP, 2006.

BRASIL. Diretrizes operacionais do Atendimento, Educacional especializado na educação básica, modalidade Educação Especial. Brasília, 2009.

. Resolução n ${ }^{\circ}$. 4, de 02 de Outubro de 2009. Institui Diretrizes operacionais para o atendimento Educacional Especializado. Diário oficial da união. Brasília: CNE/CP, 2009.

Portal de ajudas técnicas: recursos pedagógicos adaptados/. Brasília: MEC/SEESP, 2007.

CARVALHO, R.E. Educação inclusiva com os pingos nos is. Porto Alegre: Mediação, 2004.

MANTOAN, Maria Tereza Eglér (organizadora). O desafio das diferenças nas escolas. $15^{\text {a }}$ ed. - Petropólis, RJ. VOZES, 2013.

MIZUKAMIM, G.N. Ensino: As abordagens do Processo. São Paulo: EPU, 1996.

SOARES, Maria Aparecida Leite; CARVALHO, Maria de Fátima. O professor e o aluno com deficiência. São Paulo: Cortez, 2012. (coleção educação e saúde; vs). https // institutoitard.com.br/artigos.de -educação especial acesso em 19.01.2019. 


\title{
O TRABALHO LÚDICO NA PRÁTICA DA EDUCAÇÃO INFANTIL
}

\author{
SILVA, Anailde Varela $\mathrm{Da}^{80}$
}

\section{RESUMO:}

Uma breve reflexão sobre o trabalho lúdico na educação infantil será realizada através deste artigo, que destaca o aprendizado com qualidade às crianças, baseando nas práticas lúdicas que os professores promovem e fortalecem ainda mais as habilidades nesta fase de aprendizagem. Nesta perspectiva, o artigo tem a proposta de apresentar, como o desenvolvimento das crianças e das atividades lúdicas na fase escolar da educação infantil, contribuem em seu desenvolvimento por inteiro. Em função disso, esta pesquisa foi realizada a partir de uma estrutura bibliográfica, que relacionou conteúdos favoráveis ao entendimento do tema abordado. Foram abordados assuntos sobre o trabalho lúdico na prática da educação infantil e a importância do brincar. Baseado nessas concepções, verificou-se que as brincadeiras com finalidades pedagógicas favorecem o desenvolvimento cognitivo, emocional e social, tornando as crianças conscientes de seu papel na sociedade. Sendo assim, concluiu-se que através das brincadeiras, a criança compreende melhor o mundo onde está incluída, também aprende a respeitar o outro, a obedecer a regras, a construir relações sociais e sistematizar conhecimentos, desenvolvendo-se plenamente.

PALAVRAS-CHAVE: Lúdico. Educação Infantil. Desenvolvimento. Aprendizagem.

\section{INTRODUÇÃO}

É importante, o professor compreender como a prática pedagógica através do brincar é extremamente significativa na educação infantil, assim, através de brincadeiras e jogos a criança desenvolve as habilidades para a aprendizagem processar em seu desenvolvimento cognitivo.

O lúdico tem sido uma das estratégias mais positivas para estimulação do desenvolvimento cognitivo e de aprendizagem na educação infantil. Através de brincadeiras, as crianças desenvolvem as competências de atenção, de memória, de percepção, de sensação e de todos os aspectos básicos referentes à aprendizagem.

Mas para que isso aconteça é necessário que a escola e o professor trabalhem com o desejo de proporcionar os momentos de brincar, com objetivo de destacar como

\footnotetext{
${ }^{80}$ Especialista em Educação Ludopedagógica pela Faculdade do Vale Elivira Dayrell/MG. Professora Aposentada da Educação Básica do município de Macau/RN; Professora da Educação Básica do município de Guamaré/RN. E-mail: anaildevarela@ hotmail.com
} 
um aspecto pedagógico estimula a socialização entre as crianças e que favorece o desenvolvimento de habilidades cognitivas, que contribuem para seu sucesso na escola.

Para que o professor tenha uma prática pedagógica no contexto escolar é fundamental que ele adquira conhecimentos através de formação continuada, que tenha habilidades com educação infantil e a atenção de cada criança, assim como saber preparar atividades que devem estar adequadas aos níveis de compreensão para a turma a qual trabalha.

Para o sucesso no desenvolvimento e na aprendizagem da criança, nesta fase escolar, é necessário que as atividades lúdicas sejam bem planejadas e sistematizadas para propiciar a socialização delas, e o gosto ao brincar coletivamente, demonstrando habilidades sendo construídas. Para o professor, o ato de brincar não pode ser trabalhado como uma simples distração sem objetivos pedagógicos.

Nesta faixa etária, a criança necessita de brincar, a escola não pode romper essa atitude natural, em que elas buscam no imaginário, no faz de conta e nos jogos, uma relação de proximidade com a vida real e a partir desta busca, constroem suas aprendizagens. São nas brincadeiras também, que as crianças da educação infantil aprendem definir e organizar sentimentos, aprendem distinguir situações complexas de situações de conflitos, ampliando cada vez mais seu convívio social.

Este desenvolvimento acontece, gradativamente, à medida que a prática pedagógica do professor contemple atividades e objetivos que possibilitem a criança participar ativamente, criando e recriando conceitos, e elaborando diversas possibilidades, as quais futuramente serão usadas para solucionar situações que surgem no ato do brincar.

\section{DESENVOLVIMENTO}

Toda criança aprende reproduzir uma linguagem e um comportamento de sua convivência no momento do brincar, e aos poucos vai elaborando seus conceitos e construindo seus conhecimentos. Nesta perspectiva, Vygotsky (1984) afirma que, a brincadeira está presente em diferentes tempos e lugares na vida das crianças, porém, cada brincadeira tem um significado no meio social que ela convive de acordo com a cultura do lugar. 
As brincadeiras infantis fazem parte do desenvolvimento das crianças nas mais diversas maneiras, isso não pode ser negado a elas na escola, caso contrário, poderão surgir algumas dificuldades em seu desenvolvimento. Nesta perspectiva, as brincadeiras são aperfeiçoadas com a recriação e imaginação de cada criança de acordo com a idade. Conforme Kiskimoto (2000, p. 32), "para Piaget ao manifestar a conduta lúdica, a criança demonstra o nível de seus estágios cognitivos e constrói conhecimentos”.

Trabalhar através de brincadeiras, jogos, atividades de socialização na educação infantil tem favorecido o desempenho da criança na escola. Assim, a criança começa a desenvolver sua capacidade de imaginação, abstração e aplicar ações relacionadas ao mundo real e ao imaginário. Para Velasco (1996), durante o contato diário da criança com o brinquedo elas serão estimuladas a desenvolver muitas habilidades na sua formação geral e isso ocorre espontaneamente, sem compromisso e obrigatoriedade, mas com alegria e prazer.

Toda criança precisa de receber estímulos para sentir autora de suas aprendizagens, seguindo as propostas de atividades lúdicas oferecidas pelo professor. Outros autores trazem também concepções sobre o ato de brincar como instrumento indispensável no desenvolvimento das crianças. Segundo cita, o autor Redin (2000, p. 46):

O lúdico é a mediação universal para o desenvolvimento e a construção de todas as habilidades humanas. De todos os elementos do brincar, este é o mais importante: o que a criança faz e com quem determina a importância ou não do brincar.

Para esses autores, a brincadeira vai desde a prática livre, espontânea, até como uma atividade dirigida pelo professor, com normas e regras estabelecidas que tem explícito o objetivo de alcançar o sucesso na aprendizagem das crianças, através da construção de conceitos. Assim, os jogos também podem desenvolver o raciocínio lógico, bem como o desenvolvimento físico, motor, social e cognitivo das mesmas.

São muitas as razões para brincar, para que a criança brinque, vai desde o prazer que o lúdico proporciona, até o desenvolvimento cognitivo, motor, afetivo e social dela. São nos momentos de brincadeira que a criança demonstra suas vontades, seus desejos, seus medos e seu nível de conhecimento, o qual é um bom ponto de partida para o professor planejar sua prática pedagógica nesta etapa escolar. 
Nas turmas de educação infantil, a animação que as brincadeiras favorecem estimulam ideias para criação, abstração, fantasia, cognição, bem como os aspectos emocionais e sociais na criança. As crianças pequenas precisam de brincadeiras que estimulam os movimentos, trabalhando para um desenvolvimento motor e cognitivo ao mesmo tempo.

E com o passar do tempo, o ato de brincar vai proporcionar condições favoráveis para a criança enfrentar situações novas e inesperadas, e aprender agir de maneira independente e conseguir enxergar, compreendendo o mundo fora do seu cotidiano habitual. Segundo Carneiro e Dodge (2007, p. 91):

A prática da brincadeira deverá se tornar uma realidade na escola, é preciso mudar a visão dos estabelecimentos a respeito dessa ação e a maneira como entendem o currículo. Isso demanda uma transformação que necessita de um corpo docente capacitado e adequadamente instruído para refletir e alterar suas práticas. Envolve, para tanto, uma mudança de postura e disposição para muito trabalho.

Para um bom desenvolvimento da criança é importante existir uma colaboração entre escola, a família e criança, com objetivo de garantir as habilidades necessárias às crianças da educação infantil, já que as brincadeiras além de proporcionar às crianças momentos alegres, deverá possibilitar também o desenvolvimento dessas habilidades como: físicas, motoras, cognitivas e emocionais. Mas elas só ocorrem quando as crianças têm uma estimulação na escola e no contexto familiar. Para um melhor entendimento, Carneiro e Dodge (2007, p. 201), que afirmam que:

Ao estimular as crianças durante a brincadeira, os pais tornam-se mediadores do processo de construção do conhecimento, fazendo com que elas passem de um estágio de desenvolvimento para outro. Também, ao brincar com os pais, as crianças podem se beneficiar de uma sensação de maior segurança e liberdade para exploração, além de se sentirem mais próximas e mais bem compreendidas, o que pode contribuem para o melhor desenvolvimento de sua auto-estima e independência.

Ainda existem escolas que preparam suas crianças para convivência em um mundo diferente do que vivemos, alguns professores continuam com práticas pedagógicas convencionais, no entanto, devem reelaborar suas práticas de ensino para ações que orientem à aprendizagem da criança e seu próprio conhecimento, afinal, a 
criança e professor devem estar comprometidos no processo de construção da aprendizagem. Caso contrário, não haverá desenvolvimento de habilidades possíveis que são importantes nesta etapa.

A criança deve ser estimulada a aprender, a participar, a ganhar e a perder, mediante os momentos de brincar de forma individual e coletivamente. Se considerarmos a aprendizagem como uma construção mental, é importante ter ideia que brincar um ato de exploração de objetos, de espaços, de companheirismo, de descoberta, e não de um momento de informações e regras sem significados.

Para a criança obter um bom desenvolvimento, ela precisa adquirir a habilidade de pensar sobre vários assuntos, sem a memorização técnica de fatos e informações de assuntos diversos. O professor deve observar a criança e escolher o melhor momento e lugar que poderá utilizar as energias delas em prol do brincar para construir seus aprendizados. É neste momento que a escola deve também educar de forma individual, coletiva, inteligente e divertida.

Então, o professor deve trabalhar na perspectiva de educar e ensinar ludicamente, não apenas deixar as crianças brincarem livremente sem uma coordenação pedagógica cercada de objetivos voltados para construção da aprendizagem. Ao educar, a criança e o professor utilizam do ato consciente e planejado, tornando a criança ativa, afetiva, perceptiva, engajada e feliz no ambiente escolar e familiar, construindo, passo a passo, seu conhecimento. E assim, a escola vai se tornando um local de alegria, de prazer, de satisfação e de desenvolvimento afetivo e intelectual.

Porém, para que um professor para alcance seus objetivos é necessário que repense os tópicos trabalhados e sua prática pedagógica, trocando a rotina monótona da escola, por alegria, por entusiasmo de aprender, pelo jeito da criança ver o mundo, aprendendo a pensar, a compreender e a reconstruir suas aprendizagens.

Almeida (1995) ressalta em seu estudo, que a educação lúdica contribui e influencia na formação da criança, a qual terá um desenvolvimento sadio, aprendendo a partir das ações lúdicas, enriquecendo seus conhecimentos. A prática pedagógica lúdica oferecida à criança exige uma participação ativa, criativa, livre, crítica, promovendo a interação social e tendo em vista o forte compromisso de transformação e modificação do meio. 
Partindo do pressuposto que através do lúdico a criança constrói seu desenvolvimento de maneira segura, feliz, espontânea e harmoniosa, brincando, ela mantém boa autoestima e adquire sua independência, assim como estimula a capacidade visual e auditiva. A criança que não brinca pode ficar apática e desanimada, triste e com pouca aquisição de conhecimentos. O brinquedo existe para a criança, e a criança precisa de brincar. O ato de brincar dá a ela mais oportunidade de ser feliz.

\section{CONSIDERAÇÕES FINAIS}

Considera-se que esta pesquisa será vista como princípio para refletir sobre o trabalho lúdico na prática da educação infantil e no processo de imaginação, criatividade, desenvolvimento motor, socialização e no aprendizado de regras.

Desta maneira, compreende-se que a vivência lúdica para criança no contexto escolar viabiliza diversos caminhos para a integração de aspectos necessários ao ser humano. Aspectos emocionais, corporais, cognitivos que permitem a criança e o professor serem participativos, aprendendo relacionar melhor com o mundo a sua volta, isto implica em um tipo de enfrentamento frente às suas dificuldades. Assim, é fundamental que a família, a escola formem um elo que sustente essa etapa essencial na vida da criança.

Nesta concepção, brincando a criança aprende, pois através do brincar e jogar elas são estimuladas a pensar, avançar no raciocínio, estabelecer vínculos afetivos e sociais, compreender como ocorrem o convívio social e familiar, satisfazer seus desejos, desenvolver várias habilidades e crescer em aprendizagem e criatividade. A partir da prática do brincar, aos poucos, a criança supera o egocentrismo, desenvolve a solidariedade e a empatia, compartilhar jogos e brinquedos, desenvolve novos sentidos para a sua vida escolar e familiar.

Brincando elas terão habilidades sociais importantes à vida, como: cooperação, comunicação, competição e redução da agressividade. Enfim, as crianças apresentam grandes desenvolvimentos a partir de atividades lúdicas, em que o uso de brinquedos e brincadeiras na educação infantil, ajudam no desenvolvimento da expressão corporal, de gestos e da postura, estabelecendo entre o corpo e a mente da criança, seu desenvolvimento. 


\section{REFERÊNCIAS}

ALMEIDA, Paulo Nunes de. Educação lúdica: técnicas e jogos pedagógicos. São Paulo: Loyola, 1995.

CARNEIRO, Maria Ângela Barbato; DODGE, Janine J. A descoberta do brincar. São Paulo: Editora Melhoramentos, 2007.

KISHIMOTO, T. M. (Org.) Jogo, brinquedo, brincadeira e a educação. $4^{\circ}$ ed. São Paulo: Cortez, 2000, p.183.

REDIN, Euclides. O espaço e o tempo da criança: se der tempo a gente brinca. Porto Alegre: Mediação, 2000.

VELASCO, Cacilda Gonçalves. Brincar: o despertar psicomotor. Rio de Janeiro: Sprint Editora, 1996.

VIGOTSKY, L. S. A formação social da mente. São Paulo: Martins Fontes, 1984. 


\section{OS PAÍSES MENOS AVANÇADOS E O PAPEL DA POLÍTICA DE COMÉRCIO EXTERNO NO SEU DESENVOLVIMENTO}

NEVES, Maria Branquinho da Costa ${ }^{81}$

\section{RESUMO:}

$\mathrm{O}$ artigo procura escrutinar a situação dos Países Menos Avançados numa perspectiva jurídico-económica, relacionando-a com o maior ou menor nível de Desenvolvimento Económico. Procura-se analisar as especiais dificuldades que enfrentam estes países, bem como apresentar uma hipótese de superação das mesmas com recurso à aplicação de uma Política de Comércio Externo dirigida e adequada. Para elaboração do presente trabalho, recorreu-se à pesquisa bibliográfica, análise de Doutrina e Jurisprudência.

PALAVRAS-CHAVE: Países menos avançados. Política de comércio externo. Armadilha do desenvolvimento. Desenvolvimento económico.

\section{INTRODUÇÃO}

Surge o presente estudo - Os Países Menos Avançados e o papel da Política de Comércio Externo no seu Desenvolvimento - no âmbito da unidade curricular de "Direito Económico Internacional e Europeu”, justificando-se a opção pelo supradito tema, devido à sua pertinência e especificidade no âmbito da OMC, objeto de estudo na disciplina, bem como ao interesse pessoal da aluna pelo mesmo.

No âmbito dos conteúdos a abordar, e de modo a proporcionar um roteiro para elucidar o leitor face ao iter que irá percorrer, começaremos o desenvolvimento do tema por oferecer uma noção relativa aos conceitos de desenvolvimento e crescimento económicos, passando, de seguida, a fazer o mesmo relativamente ao conceito de Países Menos Avançados. Num capítulo seguinte, abordaremos, de forma breve, algumas “Armadilhas" às quais estes países se encontram presos, passando de seguida a analisálos no quadro da Globalização. Será após este caminho que os enquadraremos no âmbito da OMC (Organização Mundial do Comércio).

\footnotetext{
${ }^{81}$ Mestra em Direito com especialização em Direito Internacional e Europeu pela Universidade Católica do Porto (Portugal). Jurista. E-mail: micostaneves@gmail.com
} 
Após o exame destes conteúdos, procederemos à analise concreta do tema de estudo, com enfoque nas dificuldades a nível de políticas de comércio externo e hipótese de solução das mesmas, para consecução de um efetivo crescimento dos PMA e integração dos mesmos no desenvolvimento global.

Considerando que não é novo o debate, a relevância do desenvolvimento do tema surge pela possibilidade de problematizar o assunto, esperando contribuir com uma compreensão geral do assunto, bem como com uma apreensão de certas posições especializadas sobre o mesmo, nomeadamente do economista Paul Collier.

\section{DESENVOLVIMENTO E O CRESCIMENTO ECONÓMICO}

Quando se fala, nos dias de hoje, na redução da pobreza e de outros Objetivos de Desenvolvimento do Milénio, persiste uma certa relutância em destacar, no âmbito deste debate, o crescimento económico. Existe maior conforto na afirmação de objetivos, como a garantia de um nível de escolaridade adequado bem como do acesso ao mesmo, do que na discussão do crescimento económico.

Este facto é constatado por Paul Collier que, apesar de partilhar do entusiasmo na realização de tais objetivos, admite não partilhar do desconforto relativo crescimento, que considera ser, em regra, benéfico ao cidadão comum, e, até, indispensável para a concretização sólida dos ditos objetivos. (COLLIER, 2010, p. 28-30)

$\mathrm{Na}$ perspetiva de Joseph Schumpeter (2012) deverão ser entendidas, por desenvolvimento, apenas as mudanças na vida económica que não são impostas de fora, mas que surgem por iniciativa própria, de dentro para fora. Paul Collier, ainda que considerando, neste sentido, que a "mudança terá de provir de dentro das sociedades dos últimos mil milhões" aponta para a importância dos esforços dos países ditos desenvolvidos para que tal desenvolvimento tenha, efetivamente, sucesso recurso ao desenvolvimento comercial no âmbito internacional surge como um instrumento crucial para que o crescimento económico seja alcançado no foro de um Estado. (COLLIER, 2010)

O desenvolvimento económico, que atende a aspetos de caráter social, difere do crescimento económico, que atende tão só a questões quantitativas, no entanto, o primeiro passa, quase necessariamente, pelo segundo: 
O processo de crescimento económico moderno pode caracterizar-se, de modo geral, por quatro aspetos de base: uma subida comparativamente rápida e geralmente sustentada do nível de vida médio; uma modificação da estrutura da economia ainda bastante significativa respeitante ao modo de utilização do produto e relativamente menos pronunciada no que respeita à repartição funcional e pessoal dos resultados da atividade económica; uma alteração profunda dos espaços económicos relevantes; uma modificação radical do modo de organização da economia. (NUNES; VALÉRIO, 2004, p. 21)

Este processo, continua a alastrar-se, hoje, para as regiões do globo menos profundamente por ele tocadas no passado. Existem obstáculos e, logicamente, forças impulsionadoras deste alastramento que visa proporcionar à generalidade dos seres humanos a subida do nível de vida, o que constitui tanto a caraterística como a vantagem primordial do crescimento económico moderno (Ibidem). Isto reflete uma espécie de correlação simbiótica entre os dois aspetos - o crescimento económico e o desenvolvimento económico.

\section{OS PAÍSES MENOS AVANÇADOS}

No que diz respeito aos Países Menos Avançados uma categoria dos países considerados em desenvolvimento, a taxa de crescimento destes países tem sido negativa em termos absolutos e estado, em termos relativos, extraordinariamente abaixo do resto do mundo em desenvolvimento. A falta de crescimento é considerada como o problema central dos mesmos e como principal preocupação em termos do seu desenvolvimento. A forma como o crescimento se dá não é, de todo, indiferente, contudo, o problema destes países não é experimentarem uma forma errada de crescimento, mas sim o facto de não experienciarem qualquer crescimento. A suspeição relativa ao crescimento tem vindo a prejudicar um pensamento estratégico para o desenvolvimento dos países dos últimos mil milhões (referimo-nos assim aos PMA, seguindo a lógica de Paul Collier, que compreendem mais de 880 milhões de pessoascerca de $12 \%$ da população mundial- mas representam menos de $2 \%$ do PIB mundial e cerca de $1 \%$ do comércio internacional) (COLLIER, 2010).

Quando nos referimos a PMA, queremos dizer os países que, hoje, são os mais pobres, que não conseguiram crescer e acompanhar o caminho do desenvolvimento trilhado pela maior parte das outras nações do globo. Estes países encontram-se à deriva 
e, muitos deles, estão a desagregar-se. A Assembleia Geral da ONU designa oficialmente a lista dos países menos avançados, que são atualmente 47.

Estes países enfrentam dificuldades muito diferentes e específicas relativamente aquelas que têm vindo a ser abordadas nas ultimas décadas no que denominamos por "países em desenvolvimento", designação que abrange também os PMA, excluindo-se deste conceito somente os países mais desenvolvidos, que compreendem cerca de $16,6 \%$ da população e representam $41,9 \%$ do PIB mundial. Daqui se retira que nem todos os países em desenvolvimento são iguais, sendo que estes onde o desenvolvimento tem falhado, também designados mundanamente por Países de Terceiro Mundo, enfrentam problemas bem mais complexos - estão presos em "armadilhas" - o que exige, naturalmente, respostas igualmente complexas. Tratam-se de nações que, embora coexistam com o século XXI, a sua realidade é a do século XIV: guerra civil, doenças, ignorância. No entanto, esta minoria desafortunada representa um importante problema, não somente para si mesmos, mas para o mundo do século XXI, que se tornará cada vez mais vulnerável a este gueto de miséria e descontentamento que diverge do resto da economia mundial (COLLIER, 2010). Neste sentido, Joseph Stiglitz destaca que, prestar atenção ao interesse individual de todos - em outras palavras, ao bem-estar comum - é uma pré-condição para o bem-estar final de cada um, tomando como facto que, olhar para o próximo não é bom apenas para a alma; é bom para o negócio (STIGLITZ, 2013)

\section{As "Armadilhas"}

Associado ao trabalho do economista Jeffrey Sachs (2018), temos o conceito, há muito existente, de armadilha do desenvolvimento. Este conceito assenta na influência da malária e outros problemas de saúde na manutenção de uma situação de pobreza nacional (COLLIER, 2010). Ora, neste capítulo abordaremos de forma breve quatro armadilhas que têm recebido menos atenção e que têm vindo a ser estudadas pelo economista Paul Collier. São elas: a armadilha do conflito, a dos recursos naturais, a da interioridade com maus vizinhos e a da má governação num país pequeno. Segundo o autor, aquilo que distingue os países objeto do tema em análise, é, não o facto de serem pobres, mas sim o de estarem presos em pelo menos uma das referidas armadilhas. No entanto, refere, é possível escapar-lhes. A questão é que os países que agora se libertem 
das armadilhas, enfrentam problemas mais sérios do que os que o fizeram na década de 80, já que o mercado global é agora bastante mais hostil.

Relativamente à armadilha do conflito, encontramos neste conceito duas formas de conflito político, guerra civil e golpe de Estado, a que alguns dos PMA se encontram presos na forma de padrão. Paul Collier aponta que o baixo rendimento, o crescimento lento e a dependência relativamente à exportação de produtos primários, são três caraterísticas que, globalmente, tornam um país propenso ao conflito, nomeadamente à guerra civil. E que, por si só, o facto de um país ter passado por uma guerra civil, duplica, aproximadamente, o risco de outro conflito, não se confundindo as causalidades, ainda que o conflito influencie diretamente as três características acima apontadas. Conclui que o crescimento ajuda de forma direta a reduzir o risco e que, além disso, aumenta o nível de rendimento, o que também reduz o risco e, por sua vez, este efeito contribui para a diversificação de exportações do país, diminuindo a concentração em exportações de produtos primários, o que reduz ainda mais o risco (Ibidem).

A importância do comércio internacional, e de uma inserção adequada no mesmo, é aqui evidenciada como instrumento para o desenvolvimento. E o mesmo se pode dizer relativamente à armadilha dos recursos naturais. Esta segunda definição constitui uma armadilha muito mais paradoxal, já que o superavit de exportação de recursos naturais reduz significativamente o crescimento, podendo até, nalguns casos, contribuir para a armadilha dos conflitos. A “maldição dos recursos naturais" é já há algum tempo conhecida e prende-se com a subida do valor da moeda que leva à falta de competitividade de outras exportações que seriam melhores veículos de progresso tecnológico. Além disso, nalguns casos a riqueza dos recursos naturais contribui para a armadilha do conflito (Ibidem). E mais, na existência das designadas rendas provenientes de recursos naturais, tanto as regras respeitantes ao modo como o poder é alcançado, como as respeitantes à forma como ele é utilizado, no âmbito de uma política democrática, são afetados, havendo a possibilidade de ser introduzida uma politica de clientelismo, induzindo-se a autocracia (Ibidem).

Relativamente à interioridade, caraterística que não condena à partida um país, o trabalho de Jeffrey Sachs (2018) sugere que o facto de um país ser interior retira cerca de meio ponto percentual à taxa de crescimento. A interioridade, enquanto armadilha, só 
releva nos casos de países que não são abundantes em recursos naturais, e juntamente com o facto de esse país ter vizinhos que não dispõem ou não aproveitam de oportunidades de desenvolvimento da sua economia. Esta situação praticamente condena um país a um crescimento lento, e ocorre quase exclusivamente em nações Africanas (Ibidem).

Já em relação à má governação, Paul Collier elucida a assimetria entre uma situação em que a governação e as politicas económicas são bem desenhadas e as consequências resultantes da situação contrária. Isto porque o processo de crescimento está invariavelmente limitado a taxas de cerca de $10 \%$ e, em contraste, uma governação e políticas terríveis podem destruir uma economia a velocidade alarmante (Ibidem).

Todos os PMA têm estado presos em mais do que uma armadilha, seja simultânea ou sequencialmente. O autor realça o sentido figurativo destes conceitos, reforçando a ideia de que "não é impossível escapar delas, apenas difícil”. (Ibidem)

\section{A Globalização}

Um aspeto das chamadas "forças de mercado", tem vindo a ser centro de atenções há já mais de uma década - o fenómeno da globalização, ou a integração mais aproximada das economias do mundo (STIGLITZ, 2013). A Globalização pode ser dividida em três processos distintos, o comércio de bens, onde nos iremos focar, os fluxos de capital, e a migração de pessoas (COLLIER, 2010). É em relação ao primeiro que podemos afirmar que têm sido alcançados níveis de globalização sem precedentes. Não se concebendo a reversão deste processo como algo desejável, deverão ser, contudo, analisadas as consequências da globalização para os PMA.

Desde a década de 80 que se tem observado uma transformação dramática no volume e na composição do comércio internacional. Os países em desenvolvimento têm vindo a penetrar nos mercados globais de serviços e bens, o que gera, tendo como comparação a comercialização de produtos primários, muito melhores perspetivas de um desenvolvimento rápido e equitativo para estes países, por vários motivos. Até então, as elevadas restrições ao comércio e as economias de escala, instaladas no "mundo rico", levaram a que a manufatura global fosse dominada por esses países desenvolvidos. Por força do diferencial salarial ampliado em certas regiões em desenvolvimento, deu-se uma relocalização de grandes empresas nas mesmas, 
beneficiando-as de infinitas possibilidades. Nos anos 90, a aglomeração de empresas altamente competitivas na Ásia, na sequência deste processo, já não possibilitava competição por parte dos países desenvolvidos, nem dos PMA. Podemos dizer que, nessa altura, os PMA "perderam o barco". Os processos automáticos da economia global que promoveram o desenvolvimento na Ásia vieram dificultar o caminho do desenvolvimento dos países dos últimos mil milhões. Desta forma, muitos destes países viram-se duplamente presos à armadilha da exportação de recursos naturais, seja pelos efeitos de limiar das exportadoras asiáticas, seja pela necessidade desesperada de recursos que esse continente manifesta (Ibidem). Para que um país da categoria dos PMA tenha hipótese de participar no jogo da economia global, terá, antes de mais, de se livrar das armadilhas - tarefa que não se afigura como fácil:

\begin{abstract}
O mercado global está ainda a 'retirar' a estes países, os indivíduos com maior nível de educação que poderiam ser uteis no processo do seu desenvolvimento, além dos grandes obstáculos à tentativa de penetração em mercados de exportação diversificados, pelo que, mesmo que se livrem das armadilhas, estes países tendem a ficar numa espécie de limbo. Isto porque, ainda que apresentem taxas de crescimento sustentadas, o ritmo será muito mais lento do que o ritmo de crescimento dos países em desenvolvimento, continuando assim a divergir de forma acelerada. Serão necessárias décadas para alcançar aquilo que consideramos atualmente ser o limiar do rendimento médio e, nessa altura, já o resto do mundo estará acima. E ainda, a situação de estarem suscetíveis a cair em novas armadilhas, enquanto tiverem rendimentos baixos e crescimento lento (COLLIER, 2010, p. 112).
\end{abstract}

As forças de mercado, que atuam ao longo do processo de globalização, assumiram um papel na criação dos atuais níveis de desigualdade. No entanto, estas forças são, em ultima analise, moldadas pela política, pelo que poderão ser redefinidas de forma a promoverem mais igualdade. É possível fazer com que os mercados funcionem ou que, pelo menos, funcionem melhor. (STIGLITZ, 2013)

\title{
OS PAÍSES MENOS AVANÇADOS NO ÂMBITO DA OMC
}

Os PMA são confrontados com direitos aduaneiros impostos pelos países desenvolvidos, no valor de $3.1 \%$, em média - valores que deixam de fora os produtos agrícolas e incluem as taxas preferenciais. Em confronto, aos países em desenvolvimento são impostos direitos no valor de $3.9 \%$, e sobre as importações 
originárias de outros países desenvolvidos, o valor é de 2.1\%. (CÓRDOBA; LAIRD; VANZETTI, 2004).

O GATT de 1947 não distinguia, ao contrário da OMC, os Países Menos Avançados dos países em desenvolvimento (DAS, 1998). O primeiro documento a fazer-lhes referência expressa terá sido a Declaração Ministerial de Abertura do Ciclo de Tóquio. (MOTA, 2005)

Ainda no GATT de 1947 se reconhecia, embora de forma pouco vincada, a necessidade de se estabelecerem "facilidades adicionais", no que se referia a medidas de proteção, numa única disposição especial a favor dos países em desenvolvimento, o art. XVIII, $\mathrm{n}^{\mathrm{o}} 1$, com a epígrafe "Auxílio do Estado em favor do Desenvolvimento Económico". Com as alterações ao GATT, de 1955, este artigo passou a permitir que os países em desenvolvimento empregassem "medidas de proteção ou de outra espécie que afetem as importações”, em nome do desenvolvimento. Além disto, introduziu-se o artigo XVIIIbis, $\mathrm{n}^{\circ} 3$, alínea b), que passava a considerar a especial necessidade dos países menos desenvolvidos (Ibidem). Com a alteração, o artigo XVIII passou a refletir a estratégia de cariz protecionista, preferivelmente adotada pela maioria dos países pobres para o desenvolvimento económico.

Foi também no mesmo ano que se realizou a Conferência de Bandung, que se concentrou no problema dos países subdesenvolvidos, colocando-se aqui em causa o princípio da não discriminação e chegando-se à conclusão que era necessário associar à ajuda ao desenvolvimento a abertura comercial relativa a produtos manufaturados e agrícolas produzidos por estes. Através da CNUCED (Conferência das Nações Unidas para o Comércio e Desenvolvimento) deu-se, em 1965, o aditamento da Parte IV ao Acordo Geral, que reconhece um estatuto jurídico diferente aos países em desenvolvimento e institui um regime de dualidade de normas nas relações comerciais internacionais. Assim, do art. XXXVI, no8 resulta o princípio da não reciprocidade, uma espécie de cláusula do país em desenvolvimento (MOTA, 2005).

Como primeira realização do princípio, adotou-se, em 1968, o Sistema Generalizado de Preferências que, por definição, viola a cláusula da nação mais favorecida, que passa a ter base jurídica permanente somente em 1979, na sequência da decisão “Tratamento Diferenciado e Mais Favorável, Reciprocidade e Participação Mais Completa dos Países em Desenvolvimento" adotada no Ciclo de Tóquio. O nº1 da 
Decisão ficou comumente conhecido por “Cláusula de Habilitação" e, no n², alínea d), houve uma expressa referência aos PMA enquanto beneficiários da cláusula.

Como contrapartida lógica desta cláusula foi introduzida, sob pressão dos EUA, a 'Cláusula Evolutiva' que determina que um país deixa de beneficiar do regime preferencial com 'o desenvolvimento progressivo das suas economias e a melhoria da sua situação comercial'. Os critérios para aplicação desta cláusula são fixados, no entanto, pelos próprios doadores, razão que leva a refletir do perigo de influência de interesses políticos, estranhas ao desenvolvimento, na retirada do estatuto de país beneficiário. Esta retirada pode resultar, de igual forma, da aplicação dos arts. XX e XXI do GATT, da adesão de um país beneficiário a organizações de integração económica, ou de motivos políticos (como é o caso da adoção de sanções contra um destes países). (MOTA, 2005, p. 473).

Muitos dos atuais acordos comerciais multilaterais que concedem um tratamento especial aos países pobres, estabelecem um regime especial para os PMA. É o que sucede, por exemplo, com o Acordo sobre os Obstáculos Técnicos ao Comércio (art. $12^{\circ}$ ), sobre as Medidas de Investimento Relacionadas com o Comércio (art. $4^{\circ}$ ), sobre a Aplicação do Artigo VI e VII do GATT 1994 (art. 15 e 20, respectivamente). Com o Ciclo de Uruguai (que se iniciou em 1986 e terminou em dezembro de 1994), estabeleceu-se a Decisão relativa às Medidas em favor dos Países Menos Desenvolvidos, que veio constituir uma cláusula geral suscetível de permitir uma aplicação flexibilizada e mais favorável de todas as disposições dos acordos comerciais multilaterais a favor dos PMA, desde que aceite pelos conselhos e comitês competentes. Com isto, passou-se para um regime de pluralidade de normas nas relações comerciais internacionais. (MOTA, 2005)

Com fundamento jurídico na "Cláusula de Habilitação" encontramos o programa da Comunidade Europeia "Tudo Menos Armas e Munições", que entrou em vigor em 2001 e concede, a todos os produtos oriundos dos PMA, exceto armas e munições, uma isenção de direitos aduaneiros sem limites quantitativos no acesso ao mercado comunitário, com derrogações transitórias inicialmente para três produtos agrícolas: bananas, arroz e açúcar, que se mantêm agora para os dois últimos. Prevê-se, contudo, a possibilidade de adoção de medidas de salvaguarda no caso de perturbações graves nos mercados comunitários e nos seus mecanismos reguladores. 
Sendo parte integrante do sistema generalizado de preferências, encontram-se os benefícios concedidos pela iniciativa sujeitos a todas as suas limitações, como o seu caráter unilateral, a sua não consolidação, a possibilidade de retirada temporária das preferências comerciais e as suas regras de origem (MOTA, 2005). Em paralelo a esta iniciativa, encontramos a iniciativa AGOA dos EUA que concede isenções aos produtos oriundos de África (COLLIER, 2010).

\section{Políticas de Comércio Externo como instrumento para o desenvolvimento}

Um dos aspetos que afeta as economias debilitadas e que, ainda que atenuado no Ciclo de Uruguai, não se encontra resolvido, é o da progressividade dos direitos aduaneiros. Este problema constitui um obstáculo à industrialização destes países e consiste no facto de os direitos aduaneiros impostos sobre os produtos finais serem superiores dos que os aplicáveis aos produtos intermediários e estes mais elevados que os aplicáveis às matérias primas correspondentes (MOTA, 2005, p. 516). Além disto, encontram problemas burocráticos, problemas relativos à falta de liberalização dos serviços, e ainda o facto do Acordo TRIPS ignorar por completo o conhecimento tradicional. Por isto se diz que "os países ricos pregam aos países pobres o evangelho do comércio livre, mas depois não o praticam”. (Ibidem)

Assim, e a nível internacional, podemos dizer que os principais problemas que os PMA enfrentam são a dependência em relação a um número reduzido de produtos de base que são afetados por uma deterioração dos termos de troca, a grande volatilidade dos preços mundiais, a forte concorrência entre produtores e fraca concorrência entre compradores, obstáculos, relativamente elevados, ao comércio a nível mundial, especialmente relativos a produtos agrícolas e de mão de obra intensiva, entre outros. (Ibidem)

Para que se proceda a uma resolução do problema dos PMA, que corre o risco de se tornar irresolúvel se não formos além dos atuais esforços - ainda que se assista a uma melhoria dos indicadores sobre pobreza mundial -, terão que ser enfrentadas uma série de questões fundamentais, nomeadamente de coordenação e de enfoque. Por ser necessária uma coordenação de distintos ramos governamentais, o único nível de governo que poderá ser eficaz na afirmação de um comércio externo como instrumento para resolução dos problemas de desenvolvimento destes países, que são na verdade de 
todo o mundo, será provavelmente o topo, assumindo especial relevo o dos países desenvolvidos. Um chefe de governo, deveria impor a coordenação política entre as várias componentes de governo, sendo o único com competência para tal.

Outro problema de coordenação é intergovernamental, terá de haver um trabalho conjunto entre os "principais" governos do mundo para lidar com a questão. Atualmente o fórum onde poderá ocorrer esta coordenação é o G8, sublinhando que não é com a multiplicação da ajuda externa que se resolverá o problema, terá que se desenvolver aqui o instrumento do comércio internacional, a par da de estratégias de segurança e alterações nas leis e novas cartas de direito internacional. Será ainda necessário circunscrever o problema do desenvolvimento a estes países que estão atolados.

Para uma resolução deste problema terão de ser ultrapassadas idealizações bem como ideologias políticas, entre outros factos, a direita deverá reconhecer que a atividade privada dos mercados globais pode gerar nos países mais pobres problemas que necessitam de resolução de âmbito público, a esquerda tem de simpatizar mais com a ideia do crescimento econômico, direcionando a ajuda externa neste sentido. Em suma, como agenda do G8, será necessário restringir o objetivo e alargar os instrumentos (COLLIER, 2010).

\begin{abstract}
A ajuda externa, atribuída em moeda estrangeira, poderá, tal como sucede com a armadilha dos recursos naturais aumentar a pobreza, isto porque gera uma apreciação na taxa de câmbio, fazendo com que cada dólar ganho pelos exportadores se torne menos valioso em termos de moeda local. Como resultado disto, os exportadores sofrem reduções nas suas taxas de lucro podendo entrar em falência. Trata-se, também aqui como sucede na armadilha dos recursos, do problema da doença holandesa. Um dos seus remédios é precisamente a liberalização do comércio para que se desenvolva um aumento na procura correspondente ao aumento na oferta das importações que a ajuda externa proporciona. A campanha à ajuda externa deverá ser acompanhada de campanha a favor da liberalização, que será mais ou menos necessária tendo em conta a sua utilização social (COLLIER, 2010, p. 204).
\end{abstract}

Um dos aspetos que mais poderá sofrer críticas, no âmbito do papel dos países ricos no problema dos PMA, a par da questão da progressividade das tarifas enquanto dificuldade para diversificação das exportações nestes países, será a da proteção à agricultura, setor que assume um regime especial no âmbito da OMC. Estamos perante exemplos de "incoerência entre políticas", já que não é inteligente proporcionar ajuda 
externa para o desenvolvimento e adotar em simultâneo políticas de comércio que dificultam a consecução desse objetivo. Os PMA acabam por não ter uma função, pela fraqueza dos seus mercados, na OMC, que se trata de organização concebida para a negociação e assente numa ideia de reciprocidade. Os próprios governos dos PMA têm vindo a adotar políticas protecionistas, que circunscrevem o nível do seu mercado ao doméstico, fomentadoras de indústrias parasitas, dependentes de atividades de lóbi e não de eficiência produtiva, por não estarem sujeitas a concorrência. A solução não será somente a pura e brusca liberalização destes mercados, que culmina na morte das indústrias nacionais, mas sim um processo gradual que envolva um vasto leque de políticas. (Ibidem)

A integração regional não será a resposta, já que, como descobriu Tony Venables, a integração regional entre países pobres gera divergência, ao invés de convergência. Terá de passar por uma diversificação das exportações, passando para produtos manufaturados e serviços intensos em trabalho. Para penetrarem nestes mercados os PMA necessitam de proteção temporária relativamente à Ásia, situação que já sucede com os programas EBA (Everything But Arms "Tudo Menos Armas e Munições") e AGOA (African Growth and Opportunity Act "Lei sobre crescimento e oportunidade para África"). O que se passa é que estes programas foram concebidos para apaziguar lóbis, não trazendo um resultado positivo por falhas na determinação dos seus pormenores.

Um pormenor que clama por afinamento para tornar o acesso preferencial eficaz, são as Regras de Origem, demasiado restritivas no âmbito do EBA, problema que foi ultrapassado no AGOA. Outro pormenor é o horizonte temporal demasiado curto, no caso do AGOA, já que no EBA não se verifica este problema mas antes uma questão de dificuldades de acesso burocráticas, sendo este último programa mais limitados no que toca aos países beneficiários. Propõe-se um programa simplificado que valha em toda a OCDE (Organização para a Cooperação e Desenvolvimento Económico), com regras de origem mais generosas, cobertura pan-africana, pormenores suficientemente flexíveis para a permitir a entradas dos PMA (especialmente concentrados no continente africano) em novos mercados de exportações (COLLIER, 2010).

Relativamente à $\mathrm{OMC}$, esta organização não dispõe de lucros para distribuir, nem de propósito específico, trata-se de um mercado determinado pela negociação, 
contudo, os mercados dos PMA são tão reduzidos que não dispõem de poder negocial. Enquanto a OMC for apenas uma plataforma de negociação, os PMA não têm lugar nela, pelo que se propõe, abraçando a sugestão de Paul Collier, a adição, por parte da organização, de uma função de transferência ao seu papel de negociação. Com transferência dizemos uma redução, sem reciprocidade, das barreiras ao comércio face aos PMA na forma de doação, não de troca, que coubesse ao secretariado da OMC negociar.

Quantificando-se as concessões de comércio internacional oferecidas por cada país rico numa unidade comum (como aumento esperado das exportações), estas poderiam ser comparadas, iniciando-se uma pressão assente na imagem que cada país pretenda ter relativamente aos outros contribuintes. Esta ronda iniciar-se-ia com uma proposta de comércio sem reciprocidade do secretariado, só se iniciando a negociação após a ronda de transferências, o que pressionaria os países ricos a fazerem propostas aceitáveis. A ronda de transferências só entraria em vigor quando a ronda de negociação estivesse concluída, o que levaria os PMA a facilitar o processo de negociação, ao qual teriam que recorrer se pretendessem obter melhores ofertas finda a ronda de transferências, não se confundindo as duas culturas- transferências e trocas- situação que se verifica atualmente (COLLIER, 2010).

\section{CONCLUSÃO}

Após exploração do tema, cresce em nós a confiança na eficácia das políticas de comércio externo na consecução do desenvolvimento dos PMA, que depende e fortalece-se com uma adequada abordagem política, tanto a nível interno, nestes países e nos países desenvolvidos, como a nível intergovernamental .

Consideramos o assunto debatido como problema de uma enorme complexidade e urgência, gritando, por isso, por soluções igualmente complexas e urgentes. Reconhecemos os esforços apresentados, para contribuição com uma solução efetiva às questões levantadas, como arrojados e impulsionadores de uma abordagem adequada e forte aos problemas dos PMA. Reconhece-se ainda a indispensabilidade da necessidade de debate e focalização da questão no quadro internacional.

Procurámos, com a elaboração deste trabalho, traçar um quadro geral sobre a os dilemas enfrentados pelos PMA, bem como debruçarmo-nos em aspectos especialmente 
carenciados de atenção, para os quais a política de comércio externo poderá servir como um instrumento de superação. Esperamos humildemente ter alcançado esse desiderato.

\section{REFERÊNCIAS}

COLLIER, Paul. OS MILHÕES DA POBREZA, Trad. Paulo Tiago Bento, Alfragide: Casa das Letras, 2010.

CÓRDOBA, Santiago; LAIRD, Sam e VANZETTI, David. BLEND IT LIKE BECKHAM - TRYING TO READ THE BALL IN THE WTO NEGOCIATIONS ON INDUSTRIAL TARIFFS. Geneva. UNCTAD, 2004.

DAS, Bhagirath L., THE WTO AGREEMENTS: DEFICIENCIES, IMBALANCES AND REQUIRED CHANGES. Londres-Nova Iorque: Zed Books, 1998.

GALLUP, John Luke; SACHS., Jeffrey D. THE INTOLERABLE BURDEN OF MALARIA: A NEW LOOK AT THE NUMBERS: SUPPLEMENT TO VOLUME 64 (1) OF THE AMERICAN JOURNAL OF TROPICAL MEDICINE AND HYGIENE. Disponível em: <https://www.ncbi.nlm.nih.gov/books/NBK2624/>. Acesso em: 07 jul. 2018.

MOTA, Pedro Infante. O SISTEMA GATT/OMC: INTRODUÇÃO HISTÓRICA E PRINCÍPIOS FUNDAMENTAIS. Coimbra: Edições Almedina, 2005.

NUNES, Ana Bela; VALÉRIO, Nuno. O CRESCIMENTO ECONÓMICO MODERNO INTRODUÇÃO A UMA HISTÓRIA DA ECONOMIA MUNDIAL CONTEMPORÂNEA. Lisboa: Editorial Presença, 2004.

SCHUMPETER, Joseph Alois. THE THEORY OF ECONOMIC DEVELOPMENT. EUA: Transaction Publishers, 2012.

STIGLITZ, Joseph E. THE PRICE OF INEQUALITY. Londres: Penguin Group, 2013.

UNIDAS, Centro Regional de Informações das Nações. OBJECTIVOS DE DESENVOLVIMENTO DO MILÉNIO (ODM). Disponível em:

<https://www.unric.org/pt/objectivos-de-desenvolvimento-do-milenio-actualidade>. Acesso em: 01 jun. 2018. 


\title{
TRANSIÇÃO E FELICIDADE: PENSANDO ESCOLA E FAMÍLIA COMO INSTITUIÇÕES DE ASSISTÊNCIA, APOIO E INSTRUÇÃO
}

\author{
OLIVEIRA, Vanessa Maria Araújo de ${ }^{82}$ \\ SILVA, Francisco Mário Carneiro da ${ }^{83}$
}

\section{RESUMO:}

O presente estudo se propõe a discutir a dificuldade do jovem no processo de transição da infância para a vida adulta. Ressaltamos alguns fatores que são determinantes para a evasão escolar do aluno que é pouco assistido num estágio do desenvolvimento tão complexo como a adolescência. Ressaltamos, ademais, a necessidade de uma família que está em consonância com a escola e que, juntas, procurem meios de assistir, apoiar e instruir o adolescente nesse processo de transição. Compreendemos que algumas famílias não estão preparadas para dar assistência ao jovem durante este processo de (re)descobrimento e afirmação, por isso ressaltamos a importância da escola, num trabalho conjunto e corresponsável com a família para assistir, apoiar e instruir o adolescente. Para tanto, apoiamo-nos em uma Pesquisa Bibliográfica de modo a compreender melhor o assunto à luz de pesquisas anteriormente elaboradas sobre a temática. $\mathrm{O}$ estudo é de abordagem qualitativa, pois, trabalha com o humano, com concepções e com a subjetividade. Consideramos a pesquisa essencial para discernir melhor sobre a adolescência e o papel da escola e da família neste processo de desenvolvimento.

PALAVRAS-CHAVE: Adolescência. Família. Escola.

\section{INTRODUÇÃO}

Desde a mais tenra infância a criança enfrenta adversidades que a impossibilitam de ter acesso à escola, e, posteriormente milita contra situações que tentam impedi-la de permanecer neste espaço. Nesta produção, busca-se explicitar fatores que se tornam determinantes para a evasão escolar de sujeitos que estão na fase de transição da infância para a vida adulta, bem como apontar estratégias de cooperação entre família e escola para assegurar ao adolescente a assistência, o apoio e a instrução ao longo desse período de transitoriedade em sua vida.

A adolescência caracteriza-se por ser um período da vida, situado entre a infância e a vida adulta, que possui características específicas. Para Sousa et al. (2018)

\footnotetext{
${ }^{82}$ Graduada em Licenciatura em Pedagogia pela Universidade Estadual do Ceará - Fortaleza, Ceará. Professora da Educação Básica/CE. E-mail: vanessaaraj@gail.com

${ }^{83}$ Graduado em Licenciatura em Pedagogia pela Universidade Estadual do Ceará - Fortaleza, Ceará. Email: mariocarter1294@gmail.com
} 
este período entre 10 a 19 anos, conhecido por Adolescência, pode ser caracterizado

[...] pela transição da infância para a fase adulta e assinalada por intensas transformações físicas, por conflitos relacionados às incertezas, pela formação da identidade e da autoestima, pelas instabilidades familiares e sociais e pelo conhecimento da imagem corporal. (SOUSA et al, 2018)

Nesta fase, o adolescente encontra-se frente a uma série de situações que podem afetar seu desenvolvimento, como, por exemplo, a separação progressiva dos pais, a construção da sua identidade, a perda do corpo infantil, a busca de novos horizontes para além da família, entre outras situações. Nesse cenário podem surgir dificuldades tanto para o adolescente quanto para seus pais e pessoas de seus contextos de desenvolvimento próximo (BERTHOUD, 1995; KNOBEL, 1981).

Neste sentido, a fase do ciclo vital suscita, geralmente, readaptações na dinâmica familiar, uma vez que as antigas crenças e práticas não fazem o mesmo efeito sobre este sistema. As novas demandas do filho adolescente e os riscos aos quais o mesmo pode estar submetido trazem preocupações e dificuldades para os pais, principalmente na resolução de conflitos e na orientação em assuntos pouco falados pela própria família associado a alguns comportamentos de risco na adolescência, por exemplo, exercício desprotegido da sexualidade.

Os pais, numa tentativa de atenuar os conflitos, tendem a continuar a empregar estratégias que costumavam funcionar na infância do filho, tentando "puxar as rédeas" do adolescente ou retraindo-se emocionalmente para evitar novos conflitos (PRETO, 1995). Assim, observa-se que os pais podem sentir diversas dificuldades em como lidar com os filhos e em como orientá-lós nesta nova fase do desenvolvimento.

De fato, a adolescência é um momento de transformações não só para o adolescente, mas também para a família que deverá passar por mudanças para adaptarse a esse novo momento do ciclo vital de seus membros. Para Silva e Costa (2019, p. 247): “As famílias são os primeiros núcleos formativos dos sujeitos, portanto, possuem um papel fundamental no processo de ensino-aprendizagem das crianças”.

Para Scheffer (2005), a família possui o papel de ser fonte de segurança, afeto, proteção e bem-estar, funções as quais nem sempre consegue cumprir com todas as crianças, em todas as situações. De fato, destaca-se que ela também pode se constituir 
em um fator de risco para o desenvolvimento de crianças e adolescentes (SCHENKER; MINAYO, 2005). Quando a família não cumpre o seu papel de proteção, cuidando dos seus filhos, dando carinho e limites, ela pode servir como um fator de risco para o desenvolvimento dos mesmos (WEBER, 2007).

Deste modo, entra-se em cena a escola como a segunda mais importante instituição formadora do adolescente. A escola, com sua proposta de formar cidadãos críticos, conscientes, responsáveis e aptos ao trabalho e a cidadania, deve estar sempre preocupada com o bem-estar dos estudantes, sobretudo numa fase tão delicada quanto a adolescência. Souza $(2009$, p. 16) elenca que, “[...] a família é fundamental na formação de qualquer indivíduo, culturalmente, socialmente, como cidadão e como ser humano $[\ldots]^{\prime}$.

Família e escola são as duas intuições mais próximas do adolescente, portanto, devem pensar uma relação de corresponsabilidade que busque equiparar o adolescente neste processo de desenvolvimento cheio de tensões e conflitos. Esse apoio favorece o estudante para que ele não se evada da escola, e esta instituição cumpra seu papel, que é formar esse jovem como um cidadão que terá plena efetivação na sociedade. Complementa Benato e Soares (2014, p. 8): "Escola e família se constituem, assim, como agências socializadoras e educativas, com características comuns e diferenciadas. Ambas preparam os indivíduos, desenvolvendo habilidades que contribuem para sua participação na sociedade".

Para tanto, a fim de compreender alguns dos fatores que compõem o quadro de dificuldades suscitadas pela adolescência, bem como apontar família e escola como instituições importantes para assistência durante este processo de transição, buscamos estruturar um quadro conceitual através da Pesquisa Bibliográfica, de modo a refletir tecer críticas acerca desta problemática.

Esta produção se classifica como uma Pesquisa Bibliográfica, pois, buscamos apresentar e discutir sobre o tema em questão com base em referências teóricas publicadas em livros, periódicos, revistas. Além disso, busca-se “[...] conhecer e analisar as contribuições cientificas quando realizadas independentemente - análise teórica - como parte da investigação empírica (MARTINS; PINTO, 2001, p. 41).

Com base nos nossos objetivos referentes a este estudo, optou-se por uma pesquisa de abordagem qualitativa, pois, como ressalta Chizzotti (1995, p. 79), 
A abordagem qualitativa parte do fundamento de que há uma relação dinâmica entre o mundo real e o sujeito, uma interdependência viva entre o sujeito e o objeto, um vínculo indissociável entre o mundo objetivo e a subjetividade do sujeito. O conhecimento não se reduz a um rol de dados isolados, conectados por uma teoria explicativa; o sujeito-observador é parte integrante do processo de conhecimento e interpreta os fenômenos, atribuindo-lhes um significado. $\mathrm{O}$ objeto não é um dado inerte e neutro, está possuído de significados e relações que sujeitos concretos criam em suas ações.

Através dessa abordagem teremos uma leitura mais apurada da realidade, da subjetividade e dos muitos aspectos humanos que estão envoltos no processo de transição da infância para a vida adulta.

\section{RESULTADOS E DISCUSSÕES}

Como fora mencionado anteriormente, as crianças e os adolescentes militam contra diversas dificuldades para permanecer na escola, a evasão escolar acontece em todas as etapas da Educação Básica, no entanto, este problema se torna mais acentuado no Ensino Médio, dada às diversas situações que acometem o estudante na adolescência (DINIZ, 2015).

Vale ressaltar que para a Organização Mundial de Saúde (OMS) os limites cronológicos da adolescência são de 10 a 19 anos de idade, mas no artigo segundo do Estatuto da Criança e do Adolescente (ECA), considera criança o sujeito que tem até 12 anos completos e adolescente aquele com a faixa etária de 12 a 18 anos de Idade.

Quer sejam nos limites cronológicos da OMS ou do ECA, nessa faixa etária o adolescente tem como direito estabelecido por lei a educação gratuita e de qualidade, portanto, nestes limites a criança e/ou adolescente devem estar inseridos em uma educação escolar regular.

Portanto, é de responsabilidade da escola assistir esse adolescente no processo de transição da infância à vida adulta, bem como garantir situações formativas e de qualidade que o instruam e direcione para a tomada de escolhas conscientes e responsáveis. Para Freitas (2011):

[...] a cada momento fazer o aluno pensar, refletir, analisar, sintetizar, criticar, criar, classificar, tirar conclusões, estabelecer relações, argumentar, avaliar, justificar, etc. Para isto é preciso que os professores trabalhem com metodologias participativas, desafiadoras, 
problematizando os conteúdos e estimulando o aluno a pensar, a formular hipóteses, a descobrir, a falar, a questionar, a colocar suas opiniões, suas divergências e dúvidas, a trocar informações com o grupo de colegas, defendendo e argumentando seu ponto de vista. (FREITAS, 2011, p. 5).

Gostaríamos de ressaltar alguns elementos determinantes para a evasão escolar dos adolescentes, referindo-se aos estudos anteriores a este sobre a temática em questão. Percebemos que existe um fator essencial para evasão principalmente no público feminino: gravidez na adolescência. Por isso, daremos mais ênfase nesse elemento, mas sem deixar de abordar todos os outros que surgem por consequência deste, tais como: quebra dos laços familiares, desamparo, falta de instrução e apoio por parte dos familiares, dentre outros.

A proposta da produção é fazer um paralelo entre a realidade do adolescente que está inserida em uma família que não lhe dá instrução e assistência neste processo de transição e a realidade de um jovem que tem efetiva participação familiar neste processo. Com relação ao primeiro tópico, trataremos da importância da escola como instituição formativa neste processo, ressaltando a relevância da mesma no que diz respeito a orientações e instruções tanto a família, quanto ao adolescente.

\section{ELEMENTOS DETERMINANTES PARA A EVASÃO ESCOLAR NA ADOLESCÊNCIA}

Existem determinados elementos que podem ser compreendidos como marcadores que apresentam algumas das causas que fazem o aluno se evadir da escola.

No processo de gestação da adolescência o jovem estar suscetível a ter crises no relacionamento familiar, a repetir histórias de insucesso de algum de seus familiares, a gravidez prematura advinda da falta ou inadequação da orientação sexual por conta da ausência de um apoio familiar efetivo. Esses são alguns dos fatores determinantes de frustração do adolescente que os leva a largar a escola por não ter perspectivas de mudança da sua atual condição.

Neste processo de transição da infância para a vida adulta, os pais podem sofrer dificuldades com os filhos, principalmente por não saber como lidar com a necessidade de o jovem ser autônomo e, ao mesmo tempo, ser supervisionado e dependente do contexto familiar. De modo geral, os familiares não conhecem, não respeitam e/ou não 
possuem condições satisfatórias para prover as necessidades apresentadas pelos adolescentes (HOGA; BORGES; REBERTE, 2010), sendo observados conflitos entre pais e filhos, principalmente no que se refere à sexualidade (SOARES; AMARAL; SILVA; SILVA, 2008).

Os genitores podem demonstrar ambiguidades em suas práticas, ao exercer o controle e/ou dar autonomia ao jovem, sendo que estas dificuldades acarretariam limitações nos diálogos estabelecidos entre pais e filhos, durante a adolescência. Os extremos de flexibilidade e de rigidez dos pais com os filhos são apontados como um dos possíveis fatores causais associados à situação de gravidez adolescente (HOGA et al., 2010).

A gravidez na adolescência, sobretudo nas famílias mais abastadas, produz um resultado de desconforto e infelicidade para o adolescente, quer seja homem ou mulher. Geralmente, dada a sociedade machista e patriarcal que fazemos parte, a mulher é ainda mais rechaçada por engravidar na adolescência.

A quebra dos laços afetivos com a família, a evasão da escola, o afastamento da vida social e/ou do mercado e trabalho são alguns dos fatores advindos desta circunstância, como salienta Sousa et al. (2008):

[...] a gravidez na adolescência permanece como uma questão preocupante para a saúde pública, uma vez que pode interromper importantes estágios de maturação psicossexual e provocar desorganização familiar, abandono escolar, afastamento social e do mercado de trabalho, aumento dos índices de pobreza e, dessa forma, gerar vários desafios para a equipe de saúde, educadores, governos e sociedade em geral. (SOUSA et al, 2018, p. 2)

A gravidez na adolescência pode derivar da falta de orientação sobre sexualidade e métodos contraceptivos que é precária durante a adolescência.

Observa-se que a família não é uma fonte frequentemente citada, no que se refere à questão da orientação sobre sexualidade. Muitas vezes, os próprios pais não obtiveram dos seus pais nenhuma orientação a respeito da sexualidade e contracepção, portanto, possuem dificuldades de orientar seus filhos sobre o tema. Inclusive, algumas famílias não chegam a abordar esse tema com os filhos (HOGA; BORGES; ALVAREZ, 2009). 
A orientação sexual a adolescente é complexa e possui uma variedade de motivações psicológicas, sociais e afetivas que concorrem para o desenvolvimento e efetivação ou não dessa orientação. Estudos demonstram que as conversas nesse âmbito não são efetivas, pois, repetidamente são permeadas de "reticências, advertências e repreensões".

Com relação ao público feminino, as orientações dos pais buscam frequentemente moldar o comportamento das filhas segundo uma lógica de preservação da moral, não as preparando efetivamente para o exercício de uma vida sexual segura (ARCANJO; DE OLIVEIRA; BEZERRA, 2007; DIAS; GOMES, 2000).

$\mathrm{O}$ despreparo dos pais para lidar com assuntos e situações referentes à sexualidade é explicado também pelo fato dos mesmos não possuírem um modelo internalizado para efetuar essas conversar com os filhos, uma vez que os mesmos provavelmente não vivenciaram essa experiência com seus próprios pais (SOARES; AMARAL; SILVA; SILVA, 2008).

Alguns estudiosos têm apontado para fato de que muitas adolescentes podem ter deixado a escola que fazia parte antes mesmo de engravidar, apontando, assim, a evasão escolar como um indicativo da gravidez precoce (ALMEIDA, 2008; YAZLLE, 2002).

Assim sendo, nos deparamos com duas situações: ou o jovem, inquieto com suas dúvidas, questionamentos e a necessidade de compreender mais de si e do mundo de distância da escola, tem um resultado inesperado ou por estar perdido e sem instrução acaba por abandonar a escola e se desvincular dela por completo.

Entretanto, a escola, quando disposta a efetivar o dever de oferecer uma educação de qualidade e para todos, recebe, acolhe e assiste a cada estudante. Algumas das disciplinas abordadas nos anos finais do Ensino Fundamental proporcionam esse conhecimento do corpo o que pode ser configurado como uma ponte para se trabalhar assuntos que estão diretamente relacionados com a sexualidade.

A sexualidade deve ser trabalhada na escola, tanto com os alunos, quanto com seus pais, às vezes, pela falta de instrução os pais acabam reagindo de forma negativa, assustando ou reprimindo o filho, o que pode acarretar numa frustração que ocasionará possíveis decisões errôneas.

A gravidez na adolescência geralmente envolve renúncias, inclusive da perda de proteção e confiabilidade da família. De fato, algumas famílias não aceitam a situação 
da gravidez na adolescência. As famílias que não aceitam a gravidez, geralmente, são aquelas de camadas médias, que possuem outros projetos para seus filhos, relacionados à maior escolarização e profisssionalização.

Nesses contextos, a reação inicial dos pais é frequentemente de desgosto, rejeição e tristeza, contudo, a atitude tende a mudar com o nascimento do bebê. A reação negativa da família também pode ser sentida através da falta de apoio dos pais, expulsão ou agressão física. Essas reações podem fazer com que a adolescente considere o aborto, adoção e, até mesmo o suicídio como alternativas para dar fim a essa situação difícil (MOREIRA et al., 2008).

As próprias adolescentes tratam à gestação como um problema só delas. Isso provavelmente se encontra associado as questões de gênero, que ainda apontam para a mulher como a principal à responsabilidade pela reprodução e criação dos filhos.

É considerado que a adolescente vive uma relação de normalidade e de afeto com sua família até o momento em que revela sua gravidez, a partir disso instaura-se o conflito e as cobranças realizadas pelos familiares. As cobranças referem-se, principalmente, ao descuido ou não uso de métodos contraceptivos pela adolescente, pois, a maioria das jovens revela que suas mães as haviam alertado sobre a possibilidade de gestação (MONTEIRO et al. 2007).

O que se configura como um grande paradoxo, pois, o pai não orienta e instrui o filho acerca da sua sexualidade, e, ao mesmo tempo, não está disponível a receber um filho com questões problemáticas referente a esta questão. O que acontece em muitas famílias é que o "alerta" é dado de forma autoritária, o que não facilita o desenvolvimento de uma comunicação eficiente que poderia auxiliar na adoção de um comportamento contraceptivo adequado (SILVA; TONETE, 2006).

Deste modo, reafirmamos a importância da escola como entidade formativa que contribui efetivamente na sociedade, sobretudo na formação cidadã. Visto que a escola é espaço democrático e formativo. Quando a escola solicita a presença dos pais e apresenta as dificuldades vivenciadas pelos adolescentes, mostra-se como ente orientador.

\section{PARTICIPAÇÃO FAMILIAR: FATORES PARA UM BOM DESENVOLVIMENTO DA ADOLESCÊNCIA}


Em contrapartida, aos comportamentos repressivos, autoritários e pouco reflexivos acerca das instruções que devem ser dadas por parte da família aos adolescentes, existem aspectos relativos à proteção no contexto familiar, tanto no que diz respeito a fatores de proteção anteriores a gestação/maternidade, como durante a e após a gestação.

O principal fator de proteção para o desenvolvimento saudável da adolescente, é possuir um bom relacionamento com a mãe. Esse tipo de relacionamento pode abrir as portas para uma comunicação honesta entre mãe e filha sobre sexualidade e contracepção. Durante a gestação, e mesmo em momentos posteriores, um bom relacionamento com a mãe pode servir de apoio e proteção para eventuais dificuldades que possam imergir no período (PERSONA et al, 2004).

A reação positiva à gestação associa-se, recorrentemente, ao fornecimento de amparo financeiro e apoio emocional familiar para a jovem gestante ou mãe (PERSONA et al, 2004). Este apoio, por sua vez, correlaciona-se a uma maior adesão às consultas pré-natais e as orientações dos profissionais de saúde (SABROZA et al, 2004).

Percebe-se que a intensidade e a forma como o apoio da família é fornecido variam de acordo com cada caso. Em alguns casos há toda uma mobilização dos membros da família para oferecer uma verdadeira rede de ajuda, sendo observados revezamentos entre os membros femininos da família (mãe, sogra, irmãs e adolescente) para o cuidado com a criança; às vezes, irmãos da jovem podem começar a trabalhar para ajudar no sustento do bebê.

Esse apoio familiar correlaciona-se à adoção de novos modelos de comportamento por parte da adolescente, que assume, definitivamente, as responsabilidades presentes no mundo adulto, associadas à situação de maternidade. Ela mesma, após alguns meses do nascimento do bebê, procura fornecer o sustento e cuidado à criança, restringindo suas saídas noturnas. Além disso, a adolescente pode demonstrar o desejo de terminar os estudos para oferecer um futuro melhor ao filho (HOGA et al., 2009).

O mesmo pode ocorrer com o companheiro da adolescente, que também é percebido como uma importante fonte de apoio no contexto familiar, uma vez que 
oferece tanto ajuda financeira como amor e afeto a adolescente e ao bebê (GODINHO et al., 2000).

De fato, nas situações que a gravidez ocorre em um contexto de organização familiar sólida, as trajetórias das adolescentes, após o nascimento da criança, são marcadas por alianças e por suporte da rede social, que fornecem tanto apoio material como afetivo. Os vínculos afetivos e relacionais se reforçam entre os membros da família e as adolescentes, sendo ofertado tanto a adolescente como a criança um ambiente adequado ao desenvolvimento de ambas (HOGA et al., 2009).

Uma maior união da família pode ser observada como resultado de uma gestação desejada, uma vez que os membros conjugam esforços para auxiliar a adolescente. A família preocupa-se tanto com o bem-estar físico como emocional da adolescente, que lhe oferece cuidados durante a gravidez.

Ela também auxilia na organização da jovem, especialmente quando elabora conjuntamente com ela os planos para o futuro, após o nascimento da criança. Além disso, alguns estudos indicam que a adolescente se torna mais responsável após a gravidez, abandonando alguns comportamentos inadequados e desenvolvendo outros mais adequados, como preocupação com o trabalho e com o estudo (HOGA et al, 2010; MACHADO; SAITO; SZARFARC, 2007; SILVA; TONETE, 2006).

Observa-se que a gravidez e o nascimento da criança provocam forte impacto no cotidiano familiar, pois, exigem mudanças no cotidiano, de espaço físico, hábitos de consumo entre outras. Esses fenômenos geram modificações tanto na vida da adolescente como na vida familiar, cujos planos necessitaram ser adaptados a essa nova condição do membro da família (GUIMARÃES; WITTER, 2007).

\section{CONSIDERAÇÕES FINAIS}

Diante do exposto, concluímos que quando se há necessidade de intervenção por parte da escola, é de suma importância que esta instituição esteja ativa e preparada para auxiliar o adolescente e sua família nesse processo tão delicado que é a adolescência.

Como mencionamos anteriormente, essa fase de transição entre a infância e a vida adulta suscita diversas questões problemáticas, crises existenciais, crise de personalidade, pois, é um processo de (te)descobrimento e afirmação. 
Deste modo, é essencial a presença da família, acompanhando, dando apoio e instrução a este jovem que está fazendo parte deste processo. Mas, quando a família por si só não sabe resolver, a escola entra em ativa e acompanha a família, instruindo e orientando tanto o adolescente, quanto a família - com orientações sobre vida sexual, aconselhamentos e apoio.

Entretanto, compreendemos as limitações que as escolas enfrentam, inclusive com a falta de assistência profissional de um psicólogo que seria extremamente útil nesta instituição. Mas, com o pouco que se tem, família e escola devem pensar estratégias de cooperação e união para acompanhar, instruir e assistir os jovens que estão ao longo desta etapa do desenvolvimento.

\section{REFERÊNCIAS}

ALMEIDA, M. C. C. Gravidez na adolescência e escolaridade: um estudo em três capitais brasileiras [tese] Bahia: Universidade Federal da Bahia. Instituto de Saúde Coletiva; 2008.

ARCANJO, C. M.; DE OLIVEIRA, M. I. V.; BEZERRA, M. G. A. Gravidez em adolescentes de uma unidade municipal de saúde em Fortaleza - Ceará. Escola Anna Nery Revista de Enfermagem, Rio de Janeiro, 2007.

BENATO, Dulcemara Terezinha. SOARES, Solange Toldo. Família e Escola: uma relação de desafios. In: PARANÁ. Secretaria de Estado da Educação. Superintendência de Educação. Os desafios da escola Paranaense na perspectiva do professor PDE, 2014. (Cadernos PDE).Curitiba: SEED/PR., 2014. V.1.

BERTHOUD, C. M. Visitando a fase adolescente. In: CERVENY, C.; BERTHOUD, C. Visitando a família ao longo do ciclo vital. São Paulo: Casa do Psicólogo, 2002.

CHIZZOTTI, Antônio. Pesquisa em ciências humanas e sociais. $2^{a}$ ed. São Paulo, editora Cortez, 1995.

DIAS, A. C. G; GOMES. Conversas, em família, sobre sexualidade e gravidez na adolescência: a percepção de jovens gestantes. Psicologia: Reflexão e Crítica, Porto Alegre, 2000.

DINIZ, Maria Helena. Código Civil Anotado. São Paulo: Saraiva, 2015.

GODINHO, R. A; SHELP, J. R. B; PARADA, C. M. G. L; BERTONCELLO, N. M. F. Adolescentes e grávidas: onde buscam apoio? Revista Latino-americana de Enfermagem, Ribeirão Preto, 2000. 
GUIMARÃES, E. A; WITTER, G. P. Gravidez na adolescência: conhecimentos e prevenção entre jovens. Boletim da Academia Paulista de Psicologia, São Paulo, 2007.

HOGA L. A. K; BORGES, A; ALVAREZ R. Gravidez na adolescência: valores e reações dos membros da família. Acta Paulista de Enfermagem, São Paulo, 2009.

HOGA, L. A. K. Maternidade na adolescência em uma comunidade de baixa renda: experiências reveladas pela história oral. Revista Latino-Americana de Enfermagem, Ribeirão Preto, 2008.

HOGA, L. A. K., BORGES, A. L. V; REBERTE, L. M. Razões e reflexos da gravidez na adolescência: narrativas dos membros da família. Escola AnnaNery Revista de Enfermagem, Rio de Janeiro, 2010.

KNOBEL, M. Síndrome da adolescência normal. In: ABERASTURY, A.; KNOBEL, M. Adolescência normal: um enfoque psicanalítico. Porto Alegre, RS: Artes Medicas, 1981.

MACHADO N. O; SAITO M. I; SZARFARC S. C. Características sócio-demográficas e reprodutivas de adolescentes atendidas no pós-parto no Instituto da Criança da Universidade de São Paulo. Revista Brasileira de Crescimento e Desenvolvimento Humano, São Paulo, 2007.

MONTEIRO, C, COSTAN, N. P; AGUIAR Y. (2007). A violência intrafamiliar contra adolescentes grávidas. Revista Brasileira de Enfermagem, Brasília, 2007.

MOREIRA, T; VIANA, D; QUEIROZ, M; JORGE, M. Conflitos vivenciados pelas adolescentes com a descoberta da gravidez. Revista Escola de Enfermagem USP, São Paulo, 2008.

MARTINS, G. A.; PINTO, R. L. Manual para elaboração de trabalhos acadêmicos. São Paulo: Atlas, 2001.

PERSONA, L; SHIMO A. K. K; TARALLO, M.C. Perfil de adolescentes com repetição da gravidez atendidas num ambulatório de pré-natal. Revista LatinoAmericana de Enfermagem, Ribeirão Preto, v. 12, n. 5, p.745-50, 2004.

PRETO, N. Transformações do sistema familiar na adolescência. In: B. CARTER \& M. MCGOLDRICK. As Mudanças no Ciclo de Vida Familiar: Uma estrutura para a terapia familiar. Porto Alegre: Artmed, 1995, 223-247.

SABROZA, A. R., Leal, M. C., Souza Jr., P. R., \& Gama, S. G. N. (2004b). Algumas repercussões emocionais negativas da gravidez precoce em adolescentes do município do Rio de Janeiro (1999 - 2001). Cadernos de Saúde Pública, 20 (1), S130137. 
SCHENKER, M; MINAYO, M. C. S. Fatores de risco e de proteção para o uso de drogas na adolescência. Ciências e Saúde Coletiva, Rio de Janeiro, 2005.

SILVA, F. M. C.; COSTA, M. A. A. Parceria entre Escola e Família na Formação Integral da Criança. In: VI SEMINÁRIO DE PRÁTICAS EDUCATIVAS, MEMÓRIAS E ORALIDADES, 2019, Fortaleza. História da Educação: memórias e narrativas. Fortaleza: EDUECE, 2019. v. 1. p. 242-251.

SHAFFER, D. R. Psicologia do desenvolvimento: infância e adolescência. Cíntia Regina Pemberton Cancissu (Trad.) São Paulo: Pioneira, 2005

SILVA, L; TONETE, V. A gravidez na adolescência sob a perspectiva dos familiares: compartilhando projetos de vida e cuidado. Revista Latino-americana de Enfermagem, Ribeirão Preto, 2006.

SOARES, S. M.; AMARAL, M. A.; SILVA, L. B; SILVA, P. A. B. Oficinas sobre sexualidade na adolescência: revelando vozes, desvelando olhares de estudantes do ensino médio. Escola Anna Nery Revista de enfermagem, 2008.

SOUSA, Carolina et al. Fatores preditores da evasão escolar entre adolescentes com experiência de gravidez. Cad. saúde colet. [online]. 2018, vol.26, n.2.

SOUZA, Maria Ester do Prado. Família/Escola: a importância dessa relação no desempenho escolar. Santo Antônio da Platina, 2009.

WEBER, L. (2007). Eduque com carinho: equilíbrio entre amor e limites. 2a Edição. Curitiba: Juruá, 2007.

YAZLLE, M. E. H; MENDES, M. C, PATTA, MC, Rocha JSY, Azevedo GD, Marcolin AC. A adolescente grávida: alguns indicadores sociais. Rev Bras Ginecol Obstet. 2002;24(9):609-14. 


\section{TRANSTORNO DO ESPECTRO AUTISTA E EDUCAÇÃO: DESAFIOS E POSSIBILIDADES PEDAGÓGICAS}

SOUZA, Idayane Carla de ${ }^{84}$

\section{RESUMO:}

As discussões em torno da educação especial vêm ganhando espaço no cenário brasileiro mostrando-nos que é possível termos uma educação de qualidade através de recursos e formação continuada dos profissionais da educação. $\mathrm{O}$ presente trabalho tem por objetivo principal refletir sobre a Educação especial, principalmente, as discussões relacionadas ao Transtorno do Espectro autista, possibilitando o conhecimento de algumas teorias significativas para o desenvolvimento integral das crianças com TEA na sala regular. As pesquisas demonstram que a Educação vem se tornando um pilar para o tratamento de várias patologias, pois, por meio dela é possível alcançarmos uma melhoria na interação social, comunicação e comportamental, principalmente, as do espectro autista, haja vista que as relações permeadas pela pluralidade metodológica, bem direcionada, possibilitam estímulos e melhorias em diversos campos comprometidos pela patologia. Nesta perspectiva, entendemos a necessidade de discutir algumas propostas pedagógicas que vêm contribuindo para a inclusão e êxito na construção do conhecimento e da autonomia das pessoas com TEA. Desta forma, realizamos uma discussão teórica e reflexiva a partir de autores como Leon (2002), Ferreira (2017), Tarcitano (2008), Ribeiro (2016), Camargo e Rispoli (2013) entre outros. Percebemos que o trabalho com o TEA se faz de maneira contínua e em uma parceria de todos os envolvidos - escola, família e especialistas-, para que possamos garantir um espaço de qualidade e uma aprendizagem significativa.

PALAVRAS-CHAVE: Transtorno do Espectro autista. Intervenções pedagógicas. Educação inclusiva.

\section{INTRODUÇÃO}

A Educação vem demonstrando seu papel essencial na sociedade, principalmente, no que tange aos aspectos de inclusão social, por isso, a vemos como norteadora para alcançarmos uma sociedade mais justa e igualitária. Sabemos que para alcançarmos tal sociedade por meio da educação precisamos da efetivação das leis referentes à Educação especial, possibilitando que nossas escolas ultrapassem o conceito integrativo da década de 1980, e efetivamente alcance o paradigma da

\footnotetext{
84 Mestranda em Ciências da Educação pelo Centro de Educação Continuada e Aperfeiçoamento Profissional (CECAP). Professora de Educação Especial no município de Guamaré/RN e Professora de Atendimento Educacional Especializado no município do Alto do Rodrigues/RN. E-mail: idayanecarla@gmail.com
} 
educação inclusiva através dos recursos materiais e especiais adequados e profissionais capacitados.

Por isso, é essencial considerarmos as necessidades de cada sujeito e traçarmos estratégias para que efetivamente as nossas crianças com necessidades educacionais especiais construam o conhecimento de forma significativa. Para isso, traçamos o presente trabalho com o objetivo de refletir sobre a educação especial, principalmente, as discussões relacionadas ao Transtorno do Espectro autista, possibilitando o conhecimento de teorias significativas para o desenvolvimento integral das crianças com TEA na sala regular.

O autismo é considerado por alguns estudiosos a exemplo de Petters (1998), Givokate e Mousinho (2004) como “desordem aguda do desenvolvimento”, assim, “[...] a educação é a primeira prioridade para o tratamento, somente em circunstâncias excepcionais, o tratamento psiquiátrico é necessário" (PETTERS apud FERREIRA, 2017, p. 41). Por isso, ressaltamos a importância da educação para a melhoria da interação social, comunicação e comportamento das crianças do espectro autista, haja vista que as relações permeadas pela pluralidade, regras e metodologias bem direcionadas poderá desembocar na melhoria de uma dessas áreas e consequentemente, no aprimoramento das demais áreas (FERREIRA, 2017).

O percurso metodológico deste trabalho qualitativo se baseou em um olhar para abordagens teóricas e metodológicas de pesquisadores da área, que apresentam algumas teorias de trabalho com as crianças do espectro autista, buscando desenvolver os diversos campos comprometidos pela patologia. Assim, acredita-se que ao receber estímulos é possível transitar de um grau severo para um leve, possibilitando assim, mais interação e autonomia das crianças, adolescentes e adultos com TEA. Assim, nos pautamos em uma reflexão e discussão teórica a partir de autores como Leon (2002); Ferreira (2017); Tarcitano (2008), Miranda (s.d) entre outros.

Desta forma, para a construção da presente narrativa dividimos o presente trabalho em dois momentos. No primeiro momento, Os quatro estágios no desenvolvimento do atendimento às pessoas com deficiências e necessidades especiais: rememorando a História da Educação especial no Brasil, buscamos compreender o porquê de muitas instituições ainda viverem nas "franjas da história" entre a integração e a inclusão, pois, sabemos que os tempos históricos não mudam de 
uma hora para outra, por mais que busquemos uma ruptura com o passado ele permanece vivido por um tempo no novo período histórico, talvez por isso, ainda vemos tão forte a presença da integração em nossas instituições.

No segundo momento, Transtorno do Espectro Autista: conceito, garantias legais e intervenções comportamentais e educacionais, visamos discutir desde os aportes legais até as práticas interventivas que mostraram grande relevância para a educação dos TEA, principalmente, aqueles que estão nas salas regulares de ensino.

Assim, precisamos refletir para mudar a realidade e efetivamente garantir a inclusão de nossas crianças, adolescentes, adultos e idosos que estão nas instituições escolares, buscando sempre a autonomia dos mesmos para além dos muros escolares.

\section{OS QUATRO ESTÁGIOS NO DESENVOLVIMENTO DO ATENDIMENTO ÀS PESSOAS COM DEFICIÊNCIAS E NECESSIDADES ESPECIAIS: REMEMORANDO A HISTÓRIA DA EDUCAÇÃO ESPECIAL NO BRASIL}

À luz dos estudos realizados por Miranda (s.d) refletiremos os quatro estágios no desenvolvimento do atendimento às pessoas especiais: negligência, institucionalização, desenvolvimento de escolas e/ou classes especiais em escolas públicas e a integração. Para Mendes e Dechichi (apud MIRANDA, s.d, p. 3) "[...] os quatro estágios identificados em tais países não parecem estar estampados na realidade brasileira”.

Infelizmente, o estágio da negligência perdurou em nosso país por um vasto período, a História apresenta que em outros países no início do século XVIII já não se vivia o período da negligência, em que as pessoas com deficiência eram abandonadas e negligenciadas. Na literatura brasileira, Miranda (s.d.) apresenta que apenas no século XIX algumas instituições foram fundadas no país e mesmo assim atendiam um pequeno número de pessoas com deficiência. “[...] A educação especial se caracterizou por ações isoladas e o atendimento se referiu mais às deficiências visuais, auditivas e, em menor quantidade, às deficiências físicas. Podemos dizer que em relação à deficiência mental houve um silêncio quase absoluto" (MIRANDA, s.d., p. 3).

A década de 1950 fora marcada pela expansão educacional especial em âmbito mundial através de inúmeros debates sobre os objetivos e qualidade em no nosso país. Segundo a autora supracitada, houve um aumento do atendimento de pessoas especiais na rede pública de ensino. Vale ressaltar que neste período há uma maior expansão e 
criação de núcleos especializados, a exemplo da Sociedade Pestalozzi e da criação das APAES. Nesse período também se destacam as campanhas organizadas pelo governo federal, assumindo a responsabilidade em relação ao atendimento educacional das pessoas com deficiência.

Foi na década de 1960 que aumentou o número de escolas de ensino especial. Miranda (s.d) apresenta o quantitativo de 800 escolas para o atendimento de deficientes mentais $^{85}$, em 1969. Nesta empreitada por conquistas institucionais no país, vale ressaltar que foi na década de 1970 que a educação especial se institucionalizou no país em relação ao planejamento das políticas públicas a partir da criação do Centro Nacional de Educação Especial, CENESP, em 1973. Já na década de 1980 com o período de redemocratização do país e o cenário social clamando pela volta da liberdade política e social através de inúmeras manifestações foi possível conquistar algumas garantias no âmbito da educação especial, podemos destacar na CF/88, art.208, a integração das pessoas com deficiência no ensino regular e a garantia do direito de todos à Educação.

Infelizmente, mesmo com algumas políticas públicas garantindo o direito dos cidadãos, muitos ainda não se encontravam na rede regular de ensino. Assim, buscando a efetivação desses direitos a Lei de Diretrizes e Bases da Educação Nacional, em 1996, veio novamente atentar para a necessidade do atendimento educacional especializado sob responsabilidade do poder público, visando melhorar os serviços educacionais dos alunos com necessidades especiais e apontando a necessidade de qualificação dos professores para proporcionar um ensino de qualidade. Miranda (s.d., p. 6) identifica em sua pesquisa que há “[...] carência de recursos pedagógicos e a fragilidade da formação dos professores para lidar com essa clientela".

Desta forma, via-se uma luta pela integração das pessoas com necessidades especiais no âmbito escolar e também pela efetivação da inclusão escolar, que "surge como uma reação contrária ao processo de integração, e sua efetivação prática tem gerado muitas controvérsias e discussões" (MIRANDA, s.d, p. 6). Essa reação contrária surge porque os teóricos da Educação Especial acreditam que incluir não é apenas

\footnotetext{
${ }^{85}$ Vale ressaltar que a pesquisa inicial de Miranda (s.d) foi para o doutoramento em que pesquisou $A$ prática pedagógica do professor de alunos com deficiência mental, assim, é possível perceber que em inúmeros momentos Miranda (s.d) faz referência à Educação dos deficientes mentais.
} 
manter a matrícula do aluno com necessidades especiais sendo necessário a efetivação das leis para que haja escola preparada para garantir uma educação efetiva e de qualidade para todos. Pois, “[...] a inclusão só se efetivará se ocorrerem transformações estruturais no sistema educacional” (MIRANDA, s.d, p. 7).

\section{TRANSTORNO DO ESPECTRO AUTISTA: CONCEITO, GARANTIAS LEGAIS E INTERVENÇÕES COMPORTAMENTAIS E EDUCACIONAIS}

Esta patologia foi estudada inicialmente pelo psiquiatra austríaco, Leo Kanner, na década de 1940, que a denominou "distúrbios autísticos do contato afetivo" (KANNER apud LEON, 2002, p. 12), após observar o comportamento de algumas crianças que este acompanhava, diferindo das patologias já existentes e estudadas naquele período. O termo autístico foi substituído pelo substantivo autismo pelo próprio Kanner.

A denominação de "autismo" tem sua origem nas palavras gregas autos que significa "em si mesmo" e ismo que significa "voltado para", resultando em uma terminologia que indica uma atitude centrada em si mesma, um extremo isolamento (LEON, 2002, p. 12).

Assim como Kanner, outros pesquisadores também estudavam concomitantemente as alterações comportamentais, linguísticas e psíquicas das crianças em seus determinados lugares sociais, em Viena. O psiquiatra Hans Asperger publicou um trabalho doutoral sobre os transtornos do contato visual em crianças, denominado por ele de "psicopatia autística" (FRITH apud LEON, 2002, p. 14). No passado, alguns estudiosos chegaram a confundir a patologia com esquizofrenia e psicose, mas após estudos mais aprofundados descartaram tal possibilidade.

Atualmente, o manual estatístico de doenças mentais (DSM-IV, APA, 1994) compreende o autismo como transtorno invasivo de desenvolvimento e alguns estudiosos a exemplo de Wing e Gould (apud LEON, 2002, p. 15) apresentam que o mesmo compromete as relações sociais, a comunicação, a compreensão social e a imaginação.

Em busca da compreensão do autismo, inúmeros estudos estão sendo voltados para a área cognitiva, para a teoria da mente entre outras áreas que possam contribuir 
para a compreensão dos transtornos de desenvolvimento e de teorias que possam contribuir para a diminuição dos comportamentos estereotipados.

Estudiosos como Frith (apud LEON, 2002, p. 17) e Rutter (apud LEON, 2002, p. 17) apontam que os comportamentos atípicos das crianças com autismo podem estar ligados a déficits cognitivos apresentados em diferentes níveis, desde os mais leves aos mais graves.

[...] naqueles indivíduos acometidos pelo autismo considerado grave, pode-se observar condutas como tentativas extremas de controle do ambiente, seguida da presença de crises de agressividade e uma extrema incapacidade para se adaptar e compreender mudanças, bem como a ausência ou um importante comprometimento das capacidades de simbolização. Já naqueles indivíduos com grau leve de acometimento, observa-se uma tendência ao pensamento literal, pobre capacidade imaginativa, foco limitado de interesse, além de apresentarem, concomitantemente a esses comprometimentos, determinadas habilidades visuais- como memória de rota, por exemplo- notadamente preservadas (LEON, 2002, p. 17).

O diagnóstico precoce das crianças com algum Transtorno do espectro autista (TEA) se faz essencial pelo fato de que a equipe especializada proporcionará atividades voltadas para tais dificuldades e possibilitarão a estas crianças uma certa autonomia e compreensão do mundo em que vivem, minimizando tais dificuldades e muitas vezes transitando de um grau grave para um grau leve.

[...] intervenções precoces poderiam abrandar dificuldades futuras nessas crianças e que normalmente essas manifestações são sutis e difíceis de serem percebidas pelos pais e pediatras, no início do desenvolvimento da criança, antes dos dois anos.[...] algumas manifestações poderiam ser observadas nessa fase do desenvolvimento, pelo fato dessas crianças apresentarem pouco interesse por objetos e por pessoas, terem dificuldade em seguir objetos e olhar para o rosto humano, falta de brincadeiras imitativas, posturas e medos inusitados, problemas alimentares, terem necessidades de rotinas e rituais, apresentarem pobre contato visual, apresentarem movimentos e comportamentos estereotipados e dificuldade com contato físico, além de regressão ou atraso na linguagem verbal ou a deficiência na gestão de apontar (GRILO e SILVA apud RIBEIRO, 2016, p. 5).

Sabemos que o diagnóstico não é dado em pouco tempo, por isso, quanto mais cedo identificar tais características e iniciar o acompanhamento com os profissionais qualificados (neurologista, psicólogo, psiquiatra, terapeuta ocupacional e 
fonoaudiólogo), tendo em vista, intervenções eficazes e diminuição das dificuldades enfrentadas pelos diferentes graus de comprometimento.

Outra característica que observamos nas crianças, adolescentes e adultos com autismo é a dificuldade em compreender emoções/ expressões/ sentimentos dos outros, por isso, os estudiosos buscaram na teoria da mente uma possível explicação para o comprometimento e alterações desta área. Segundo Baron et. al (apud LEON, 2002, p. 18) "a atribuição de crenças e de ideias ao comportamento observado em outra pessoa torna-se impossibilitado em razão de uma forma literal de pensar, da ordem do concreto, e com pensamento predominantemente egocentrado". Assim, ainda segundo a autora "[...] a clássica dificuldade em manter contato visual manifestada por crianças com autismo, também pode estar relacionada com essa dificuldade de colocar-se no lugar do outro" (LEON, 2002, p. 18).

Desta forma, a equipe multiprofissional tem o dever de estimular nossas crianças, por meio de materiais diversos, a sair deste lugar do eu e encontrar meios para compreender o lugar do outro, por mais difícil que seja. Assim, a escola é um importante instrumento para que as crianças compreendam o eu no mundo e o outro a sua volta, haja vista a possibilidade de convivência com outras crianças através da mediação de um educador.

Assim, buscando contribuir com estímulos externos, algumas teorias foram adotadas para facilitar o desenvolvimento das pessoas com o TEA na vida social, educacional e pessoal. Algumas políticas para a garantia de direitos foram adotadas, assim como intervenções comportamentais e educacionais, visando uma inclusão significativa.

\section{Política Nacional de Proteção aos Direitos da Pessoa com Transtorno do Espectro} Autista: discutindo a lei 12.764, de 27 de dezembro de 2012 e seus desdobramentos para a educação especial.

A partir das leituras realizadas sobre a Educação Especial no Brasil, percebemos a constante luta dos familiares e profissionais para a garantia dos direitos das pessoas com deficiências. Com a CF/88 algumas garantias foram consolidadas no âmbito legal, recentemente, em 2012, os direitos da Pessoa com Transtorno do espectro autista foram legalmente promulgados, decorrente de projeto da Comissão de Direitos Humanos e 
Legislação participativa através de proposta apresentada pela Associação em defesa do Autista. Sabemos que a luta não finda com a promulgação da lei, ela é apenas um passo diante da infinidade de pilares que devem ser empilhados para a efetivação e garantia das conquistas. a lei é abrangente para várias síndromes (Asperger, Kanner, Heller e Transtorno invasivo do desenvolvimento sem outra especificação), pois, considera pessoa com transtorno do espectro autista toda aquela que possuir:

\section{$\S 1^{\circ}$}

I- deficiência persistente e clinicamente significativa da comunicação e da interação sociais, manifestada por deficiência marcada de comunicação verbal e não verbal usada para interação social; ausência de reciprocidade social; falência em desenvolver e manter relações apropriadas ao seu nível de desenvolvimento;

II - padrões restritivos e repetitivos de comportamentos, interesses e atividades, manifestados por comportamentos motores ou verbais estereotipados ou por comportamentos sensoriais incomuns; excessiva aderência a rotinas e padrões de comportamento ritualizados; interesses restritos e fixos (BRASIL, 2012).

Esta lei vem ampliar outras já existentes e que garante direitos às pessoas com deficiências, a exemplo da LDB/1996, do estatuto da pessoa com deficiência, da lei $8.112 / 90$, entre outras, pois, ao considerar pessoa com deficiência toda aquela que estiver comprovadamente no espectro autista, a União garantir-lhes-á o direito a previdência e assistência social, à moradia, ao mercado de trabalho, aos serviços de saúde adequados, atendimento multiprofissional, acompanhamento especializado na rede regular de ensino e ao ensino profissionalizante entre outros.

Haja vista que o presente trabalho perpassa pelo âmbito educacional, precisamos ressaltar que a pessoa com transtorno do espectro autista tem o direito a um apoio especializado, caso comprove a necessidade, tendo início a educação especial na Educação Infantil e perpassando ao longo da vida escolar. Assim como, professores com especialização na área para promover um ensino significativo, que garanta o alcance máximo no desenvolvimento de suas habilidades. $\mathrm{O}$ art. 7 da lei versa sobre a garantia da matrícula às crianças do espectro autista em toda rede de ensino regular, punindo na forma da lei àqueles gestores que se recusarem a realizar.

É importante mencionar que qualquer proposta de educação inclusiva para crianças com autismo deverá ser feita dentro de escolas regulares, 
com objetivo de cessar os preconceitos e o isolamento social do autista, possibilitando a aquisição de novas habilidades, uma vez que um dos principais marcadores desse transtorno é o déficit na interação social (CAPOBIANGO, 2017, p. 12).

Esta lei vem ser um marco importante para o direito das pessoas com TEA e a Educação novamente aparece como primordial para tal garantia, então, o acesso à escola regular amparada por lei "[...] reforça a responsabilidade da escola em planejar esse acesso para que ele ocorra de modo inclusivo" (FERREIRA, 2017, p. 42), através da elaboração de práticas pedagógicas que atendam às necessidades individuais dos estudantes para que eles tenham vivências significativas, "[...] uma vez que o aluno com TEA necessita de diferentes metodologias para assegurar seu êxito na construção do conhecimento" (SANCHES apud FERREIRA, 2017, p. 43).

Tarcitano (2008) apresenta que o período de aprendizagem da criança autista pode variar, mas o essencial é sempre acreditar no potencial e estimular nossas crianças ao conhecimento através de um plano direcionado e prático. Precisamos compreender que a criança autista "[...] enxerga o mundo de uma forma diferente, mas vive no nosso próprio mundo" (p. 35), assim, a escola, a família e os especialistas são essenciais para que as crianças autistas construam relações sociais e aprendizagem significativa.

\section{Propostas educacionais significativas: discutindo intervenções pedagógicas para as crianças com TEA na rede regular de ensino}

Quando voltamos nossos olhares para a educação especial na rede regular de ensino, logo, pensamos na garantia dos direitos educacionais de todas as crianças, adolescentes e adultos, no entanto, muitos desafios são enfrentados pelas crianças, pais e profissionais da Educação.

Por um lado, vemos a luta da família em inserir suas crianças em uma escola que contribua significativamente para a autonomia, principalmente, das crianças com necessidades especiais. Não basta integrar nossas crianças, se faz necessário uma educação verdadeiramente inclusiva. Por outro lado, há as angústias de alguns professores em não conseguirem alcançar os objetivos esperados com a multiplicidade de dificuldades presentes na sala de aula. Por isso, é essencial a efetivação da capacitação pedagógica, voltada para as múltiplas deficiências, ofertada pelos 
municípios aos profissionais que já estão atuando, vivências práticas, recursos materiais e estrutura física e pedagógica nas redes regulares.

Tendo em vista que este trabalho tem seus olhares voltados para a educação de crianças com TEA na rede regular de ensino, buscamos conhecer algumas teorias pedagógicas que pudessem contribuir com o trabalho docente, por isso, discutiremos teoricamente algumas propostas metodológicas para o trabalho com crianças autistas,

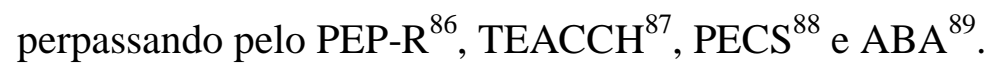

\section{Planejamento educacional: PEP-R e TEACCH}

Em busca de teorias que contribuíssem significativamente para o trabalho educacional com autistas, e demais patologias que se enquadram no espectro, tivemos o contato, inicialmente, com as discussões de Tarcitano (2008) que apresenta experiências práticas educacionais relacionadas às crianças autistas e nos traz o conhecimento do teste PEP-R, que possibilita ao educador um conhecimento proximal da idade global de desenvolvimento da criança, por vezes diferente da idade cronológica. Assim, o educador poderá planejar suas aulas a partir da idade global, buscando garantir uma aprendizagem significativa por meio de estratégias educativas, vejamos quais as áreas que esse teste aborda:

O PEP-R possui uma escala de comportamento que avalia: relacionamento, material, sensorial e linguagem. Uma escala de desenvolvimento que avalia: imitação, percepção, coordenação motora fina e grossa, integração olho mão, desempenho cognitivo e desempenho cognitivo verbal (TARCITANO, 2008, p. 25).

Este teste geralmente avalia crianças entre 1 e 12 anos de idade por compreender que nesta faixa etária elas conseguiriam responder "[...] corretamente a determinado número de itens do teste" (LEON, 2002, p. 24), buscando identificar padrões irregulares e idiossincráticos da aprendizagem.

Uma versão traduzida para o Português vinha sendo utilizada no Brasil desde 1992, para fins clínicos, mas uma versão adaptada e atualizada foi realizada por Leon et.

\footnotetext{
${ }^{86}$ Perfil Psicoeducacional Revisado

${ }^{87}$ Treatment and Education of Autistic and Comunication Handicapped Children (Tratamento e educação de crianças autistas e com desvantagens na comunicação).

88 The Picture Exchange Communication System (Sistema de comunicação por troca de figuras).

${ }^{89}$ Applied Behavior Analysis ( Análise Comportamental Aplicada).
} 
al (2004) no início dos anos 2000 com autorização do autor do instrumento, o médico Eric Schopler. Na versão brasileira foram adaptadas algumas imagens e a substituição de algumas letras, a autora supracitada expõe que “[...] o material do teste é padronizado e envolve materiais, como por exemplo, encaixe de madeiras coloridos, livro de imagens, fantoches, objetos com suas respectivas fotografias, instrumentos musicais e massinha de modelar" (LEON, et al. 2004, p. 44).

Desta forma, os resultados do teste vêm contribuir para que a equipe multidisciplinar possa delinear estratégias para o trabalho com os autistas através dos resultados obtidos, vendo o que a criança já consegue realizar sozinha, quais atividades precisam de auxílio e as que ainda não alcançaram a maturidade para a realização de determinadas atividades. Quando o teste começou a ser desenvolvido na Universidade da Carolina do Norte (EUA), pelo Dr. Eric Schopler, na década de 1960, estava atrelado ao modelo TEACCH, que parte de uma orientação comportamental e cognitiva, utilizando reforçadores que aumentam os comportamentos desejáveis e recursos de imagem para gerar a comunicação.

[...] ao fazer uso de cartões com fotos, desenhos, símbolos ou objetos concretos, preveem-se as ações a serem desenvolvidas e a estrutura física em função da dificuldade da criança autista compreender os espaços (o que vai fazer e onde). No decorrer do tempo, com o desenvolvimento da habilidade em executar uma determinada atividade, esta passará a fazer parte da rotina da criança de forma sistemática (RIBEIRO, 2016, p. 7).

A principal função do método é criar crianças, jovens e adultos autistas autônomos, por isso, um ambiente bem estruturado que proporcione meios para a independência na execução das atividades, proporcionará esta autonomia. Leon (2002, p. 25) mostra que a abordagem desenvolvimentista adotada pelo PEP-R compreende que as crianças “[...] crescem e mudam suas habilidades com a idade", por isso, os estímulos corretos proporcionam melhorias significativas para estas.

Morais (apud CRUZ, 2018, p. 4) aponta algumas características necessárias para o desenvolvimento desta metodologia:

- O fornecimento de informação clara e objetiva das rotinas;

- Um ambiente calmo e previsível;

- O atendimento à sensibilidade do aluno aos estímulos sensoriais;

- Sugestão de tarefas diárias que a criança é capaz de realizar; 
- Promoção da autonomia;

- Adequa-se às necessidades de cada criança;

- Centra-se nas áreas fortes de cada criança;

- Adapta-se à funcionalidade de cada criança;

- Envolve toda a família e os técnicos intervenientes no processo educativo.

Assim, tal metodologia se baseia em um ensino estruturado que aos poucos proporciona aos sujeitos a absorção de estratégias para serem adotadas fora do ambiente escolar, por meio do aprimoramento da linguagem, da aprendizagem de conceitos e da transformação dos comportamentos, tendo como foco educacional "[...] o ensino das capacidades de comunicação, organização e prazer na partilha social" (FERNANDES apud CRUZ, 2018, p. 5).

Vale ressaltar, que o trabalho pedagógico da sala regular deve sofrer mudança apenas na metodologia e não nos conteúdos programáticos, assim, os componentes curriculares propostos pelo Ministério da Educação devem ser ensinados de maneira significativa, por meio de um ambiente e materiais estruturados.

Ferreira (apud CRUZ, 2018) aponta para a necessidade de planejamento estrutural do ambiente educativo, predispondo uma organização espacial com orientações com pistas visuais que auxiliem na compreensão e execução das atividades propostas pelo educador.

Levando em consideração o que o teste PEP-R aponta em relação aos níveis de execução de determinadas atividades, mostrando o nível de maturidade para tal realização, pois há aquelas que conseguem fazer sozinha, as que não conseguem e as que precisam de auxílio, por isso, um ambiente amplo com espaços determinados seria o ideal para a aprendizagem. Infelizmente, sabemos que a maioria das escolas regulares públicas não possuem uma variedade de espaços para a execução de atividades diversas.

O recomendado é que exista um local para a aprendizagem de atividades novas, outro para atividades já conhecidas (para que sejam realizadas de forma independente) e um espaço para atividades livres. Tal diferenciação nos ambientes é explicada pelo fato de que os comportamentos e as regras envolvidos nas diversas situações são diferentes, portanto exigem espaços visualmente distintos, facilitando a compreensão por parte da criança (GONÇALVES, apud CRUZ, 2018, p. 6).

Por isso, os diversos autores apontam a importância de espaços diferentes, como ambiente de jogos, de brincadeiras, de computadores, de música, leitura entre outros. 
Vale ressaltar que um ambiente não poluído visualmente é essencial para a concentração das pessoas com o espectro autista, pois a poluição do ambiente interfere no processo de desenvolvimento destes. Por isso, também ressaltamos a importância desta recomendação de ambientes diversificados para que essa multiplicidade não acumule muitas informações em um único espaço e assim, proporcione uma organização melhor do pensamento dos envolvidos. No entanto, sabemos da dificuldade enfrentada pelos profissionais das redes públicas de ensino em encontrar ambientes diversos, assim, precisamos adaptar nossas salas de maneira eficiente, buscando torná-la um ambiente propício para o ensino estruturado.

\section{Planejamento educacional: PECs}

Através das pesquisas de Nunes e Santos (2015), tivemos ciência que os primeiros estudos a respeito do PECS surgiram com os pesquisadores Bondy e Frost, em meados dos anos 1994, sendo realizado em seis fases, buscando estimular as crianças não verbais ou com pouca verbalização a se comunicarem por um sistema que utiliza figuras/ fotografias de acordo com suas vivências, por isso, o responsável, geralmente fonoaudiólogos, realizam um levantamento léxico para a implementação adequada do programa com as crianças/ adolescentes ou adultos.

Segundo Nunes e Santos (2015, p. 60) “[...] o programa tem seus pressupostos teóricos apoiados na análise experimental do comportamento, que considera a linguagem como um comportamento como qualquer outro, adquirido a partir de contingências". Assim, através dos estímulos adequados, as crianças autistas não verbais ou com pouca verbalização conseguirão as coisas que desejam e provavelmente, diminuir as ações inadequadas, pois, grande parte dos autistas quando não conseguem ser compreendidos tendem a realizar ações vistas como inadequadas para tentar expressar seus desejos e necessidades.

As seis fases citadas acima são descritas por Ferreira et. al (2016, p. 2) da seguinte forma:

[...] Fase I (Troca física: como comunicar): a criança é incentivada a usar os cartões com o objetivo de solicitar/ mostrar o seu desejo por um objeto que lhe é atrativo. Na fase II (distância e persistência), o objetivo é que a criança compreenda efetivamente a importância do uso dos cartões e persista em usá-los em qualquer situação 
comunicativa. Na fase III (discriminação de figuras), a criança é incentivada a selecionar uma figura alvo dentre várias opções. Ela deve discriminar os cartões e entregar ao parceiro de comunicação aquele adequado à situação. Na fase IV (estrutura da sentença), aprende-se a construir frases com os cartões, utilizando verbos de ação (ex: querer) e atributos dos objetos (ex; cor, tamanho). Na fase $\mathrm{V}$ (responder ao o que você quer?), há incentivo de resposta para a pergunta "O que você quer?, por meio de frases simples construídas com os cartões. Na fase VI (comentar) há respostas às perguntas tais como "o que você está vendo?", “O que você está ouvindo?”, "o que é isso?", utilizando frases simples com os cartões.

Algumas pesquisas demonstram que, ao ter contato com o sistema PECs algumas crianças aprenderam a verbalizar aquilo que ouviam nos sistemas pictográficos e a ampliaram a frequência de interações sociais (NUNES; SANTOS, 2015). Desta forma, percebemos que este sistema pode contribuir para o trabalho do professor nas atividades diárias e educativas no ambiente escolar. Por isso, insistimos na premissa de que os órgãos responsáveis precisam realizar formações continuadas para os profissionais da Educação para que possamos alcançar uma verdadeira inclusão.

\section{Planejamento educacional: ABA}

Esta intervenção vem crescendo, assim como outras, no espaço clínico e educacional para trabalhar com os autistas, tendo em vista que ela busca analisar os comportamentos e desenvolver estratégias para aplicar com os mesmos, visando estimular através de reforços o que for considerado adequado e evitar a prática do que venha a ser considerado inadequado no comportamento social destas crianças ou adultos.

Carmargo e Rispoli (2013, p. 642) apontam que ABA pode ser “[...] definida como uma tecnologia que é aplicada em situações de vida reais, onde comportamentos apropriados e inapropriados podem ser melhorados, aumentados ou diminuídos”, assim, o terapeuta/ psicólogo/ educador que seja responsável pela intervenção ABA precisa está bem preparado em relação ao processo para que estimule o desenvolvimento da criança para uma vida mais autônoma, haja vista, que os comportamentos apropriados não se restrinjam apenas à clínica ou escola, mas que possam ser observados em todos os ambientes que a pessoa com autismo conviva. 
Ao fazer uma análise científica do comportamento humano, Skinner o definiu como comportamento operante, que é um mecanismo de aprendizagem de novo comportamento, no qual a resposta do indivíduo opera no ambiente e produz consequências que agem de novo sobre ele, podendo influenciar a probabilidade do fato ocorrer novamente [...]. Desta forma, se essa consequência, após um comportamento (reforço), a frequência desse comportamento vai aumentar. Esse reforço pode ser positivo (um elogio, prêmio ou recompensa) ou negativo (ação que reprime uma consequência indesejada). Sendo assim, é possível a alteração do comportamento humano por meio da concessão de reforços (na manutenção de comportamentos) ou da extinção de reforços (ao eliminar comportamentos inadequados) (RIBEIRO, 2016, p. 12).

Desta forma, é de fundamental importância que todos os envolvidos tenham ciência que alguns comportamentos podem servir de gatilho para estimular comportamentos adequados ou vistos como inadequados ao comportamento social, por isso, é necessário investigar detalhadamente o que ocasionou eventos agradáveis e desagradáveis no comportamento da criança ou do adulto autista, por isso, a intervenção ABA parte muito da observação. Schoen (apud CAMARGO e RISPOLI, 2013, p. 641) destaca que "[...] ABA torna-se uma intervenção bem-sucedida para crianças com TEA que tipicamente respondem bem a rotinas e diretrizes claras e planejadas". Partindo do pressuposto da observação, salientamos as palavras de Camargo e Rispoli (2013) quando enfatizam que,

[...] ABA é caracterizada pela coleta de dados antes, durante e depois da intervenção para analisar o progresso individual da criança e auxiliar na tomada de decisões em relação ao programa de intervenção e estratégias que melhor promovem a aquisição de habilidades especificamente necessárias para cada criança (CAMARGO e RISPOLI, 2013, p. 641).

Essa coleta de dados, assim como os resultados e os estímulos utilizados para a intervenção, mudança ou persistência de determinados comportamentos devem ser devidamente registrados e analisados pelo aplicador ABA, para que seja possível alcançar resultados positivos. Carmargo e Rispoli (2013) ainda destacam que, para a intervenção ser considerada ABA é necessário que elas tenham sete dimensões, são elas "[...] aplicada, comportamental, analítica, tecnológica, conceitualmente sistemática, efetiva e generalidade" (p. 644-645). 
Assim, estas dimensões guiam o processo desde os comportamentos ou situações que realmente devem ser focadas até as reais mudanças que se procura obter para a vida cotidiana e longínqua e não apenas para situações momentâneas. Por isso, é necessária observação, elaboração de estratégias claras e detalhadas de todo processo para que os procedimentos positivos sejam reaplicados e possam contribuir significativamente na mudança social, vistas por todos que convivem diariamente com os envolvidos.

\section{CONSIDERAÇÕES FINAIS}

Percebemos que ao longo dos anos uma luta pela qualidade da educação especial no Brasil vem sendo delineada, com leis e estudos na área que visam garantir uma melhoria na Educação, salientamos que muito ainda precisa ser efetivado.

As instituições de ensino precisam constantemente atualizarem seu pessoal com formação na área. Vemos um anseio dos profissionais da Educação em garantir uma melhor qualidade de ensino, no entanto, nem sempre possuem recursos adequados e algumas formações nem sempre são ofertadas pelas instituições e se seus custos são altos para muitos profissionais as fazerem particularmente. Assim, vemos que a inclusão também precisa iniciar com a formação dos profissionais que atuam diariamente com o processo educacional das crianças, adolescentes e adultos com necessidades especiais.

Neste trabalho buscamos direcionar olhares para os processos educacionais das crianças com autismo, mostrando que um direcionamento e uma capacitação adequada possibilitará um processo eficiente que garanta a autonomia e a absorção de conhecimentos pedagógicos e sociais, garantindo assim, uma educação de qualidade e realmente inclusiva. Muitos estudos estão sendo realizados e que, de maneira adequada, podem garantir que as práticas pedagógicas atendam às individualidades encontradas nas redes regulares, mas para isso, é necessário um investimento maior na área de formação continuada.

Assim, compreendemos que a garantia de uma educação inclusiva de qualidade perpassa também pela capacitação continuada do corpo docente, sendo responsabilidade dos governantes e um direito das pessoas com necessidades especiais e dos profissionais em Educação. 


\section{REFERÊNCIAS}

BRASIL. Lei n ${ }^{\circ}$ 12.764/2012: Direitos da Pessoa com Transtorno do Espectro Autista. 2012.

CAPOBIANGO, R. S. Hoffert. Criatividade, ludicidade, inclusão: uma mistura assertiva para aprendizagem de alunos com Transtorno do Espectro Autista no ensino de Ciências. 2017b. No prelo.

CAMARGO, Síglia Pimentel Hoher; RISPOLI, Mandy. Análise do comportamento aplicada como intervenção para o autismo: definição, características e pressupostos filosóficos. In.: Revista Educação especial. Vol. 26. n.47. p.639-650. Set./dez. 2013.

CRUZ, Marcos Cezar Simioni da. Método Teacch: Bases filosóficas e conceituais. In.: Anais da Semana Pedagógica. Paraná/PR: Secretaria de educação. Anexo 3.2018.

FERREIRA, Renata de Souza Capobiango. Contribuições das neurociências para a formação continuada de professores visando a inclusão de alunos com transtorno do espectro autista. Ouro Preto/MG: Universidade Federal de Ouro Preto. 2017.

FERREIRA, Carine (et.al). Seleção de vocábulos para implementação do Picture Exchange Communication System -PECS em autistas não verbais. 2016.

GIKOVATE, C. G. ; MOUSINHO, R. Autismo: Conceito, Diagnóstico e Quadro Clínico. In: LAMOGLIA, A. (Coord.). Temas em inclusão: saberes e práticas Rio de Janeiro: Synergia/ UNIRIO, 2004.

LEON, Viviane Costa de. Estudo das propriedades psicométricas do Perfil Psicoeducaccional PEP-R: elaboração da versão brasileira. Porto Alegre/RS: Universidade Federal do Rio Grande do Sul. Instituto de Psicologia. Dissertação. 2002.

LEON, Viviane Costa de; BOSA, Cleonice; HUGO, Cristina; HUTZ, Claudio S. Propriedades Psicométricas do Perfil Psicoeducacional Revisado: PEP-R. In. Avaliação Psicológica, 2004, p.39-52.

MIRANDA, Arlete Aparecida Bertoldo. História, Deficiência e Educação Especial. (s.d.).

NUNES, Débora Eegina de Paula; SANTOS, Larissa Bezerra dos. Mesclando práticas em comunicação alternativa: caso de uma criança autista. In.: Revista Quadrimestral da Associação Brasileira de Psicologia Escolar e Educacional, SP, vol.19, Janeiro/Abril de 2015. p. 59-69.

PETEERS,T. Autismo: Entendimento teórico e intervenção educacional. Rio de Janeiro: Cultura Médica,1998. 
RIBEIRO, Elza Maria Alves. Uma revisão sobre as propostas de intervenção com crianças autistas em sala de aula. In.: Os desafios da escola pública paranaense na perspectiva do professor PDE: produções didático-pedagógicas. Paraná/PR: Secretaria de educação. Cadernos PDE. Volume II. 2016.

TARCITANO, Ana Maria. Autismo: desafio na alfabetização e no convívio escolar. 2008. 


\section{SOBRE OS ORGANIZADORES}

PAIVA, Luciano Luan Gomes: Mestre em Música (com ênfase em Educação Musical) pela Universidade Federal do Rio Grande do Norte (UFRN). Licenciado em Música, Técnico em Guitarra Elétrica, todos pela Universidade Federal do Rio Grande do Norte (UFRN). Está cursando a Especialização em Tecnologias Educacionais e Educação à Distância pelo Instituto Federal de Educação, Ciência e Tecnologia (IFRN). Como professor, atua em projetos sociais e em aulas particulares de música, assim como já atuou em escolas especializadas. Foi bolsista do PIBID Música Universidade Federal do Rio Grande do Norte (UFRN). No âmbito da pesquisa, produz artigos científicos abordando temas como: Tecnologias digitais, Formação docente e aprendizagem de guitarra elétrica. É membro do Grupo de Estudos e Pesquisa em Música - GRUMUS (UFRN).

FREITAS, Dayana Lúcia Rodrigues De: Mestra em Ciências da Educação pelo Centro de Educação Continuada e Aperfeiçoamento Profissional (CECAP). Especialista em Mídias na Educação pela Universidade Estadual do Rio Grande do Norte (UERN). Especialista em Tecnologias Educacionais e Educação a Distância pelo Instituto Federal de Educação Ciências e Tecnologia do Rio Grande do Norte (IFRN). Especialista em Metodologia do ensino de Biologia e Química pelo Instituto Pedagógico de Minas Gerais (IPEMIG/MG). Especialista em Educação Ambiental e Geografia do semiárido pelo Instituto Federal de Educação Ciências e Tecnologia do Rio Grande do Norte (IFRN). Especialista em Ensino de Ciências Naturais e Matemática pelo Instituto Federal de educação Ciências e Tecnologia do Rio Grande do Norte (IFRN). Especialista em Língua Portuguesa, Matemática e Cidadania pelo Instituto Federal de Educação Ciências e Tecnologia do Rio Grande do Norte (IFRN). Graduada em Licenciatura Plena em Biologia pelo Instituto Federal de Educação Ciências e Tecnologia do Rio Grande do Norte (IFRN). Técnica em Meio Ambiente pelo Serviço Nacional de Aprendizagem Comercial (SENAC/RS). Palestrante. Pesquisadora. Professora do curso de Pós-Graduação e Graduação pela Rede Privada. Atuou como professora orientadora de TCC da turma de Pós-Graduação da Rede Privada, Macau/RN. Atua como professora Orientadora de TCC e Orientadora de Estágio da Escola Técnica Fanex Rede de Ensino - Macau/RN. Professora da Educação Básica do município de Guamaré/RN. 


\section{SOBRE OS AUTORES}

AGUIAR, Marileyde Leôncio De Moura: Especialista em Gestão Escolar e Coordenação Pedagógica pelo Instituto Superior de Educação de Pesqueira/PE. Graduada em Pedagogia pela Universidade Estadual Vale do Acaraú/CE (UVA). Professora da Educação Básica.

ARAÚJO, Layze Rose De Melo Fonseca: Estudante do Curso de Especialização em Educação Ambiental e Desenvolvimento Sustentável pela Faculdade de Venda Nova do Imigrante (FAVENI/ES). Licenciada em Ciências Biológicas pela Universidade do Estado do Rio Grande do Norte (UFRN). Professora da Educação Básica do município de Macau/RN.

ARAÚJO, Micilane Pereira De: Mestranda do curso de Educação na linha de pesquisa: Política Educacional, Planejamento e Gestão da Educação pela Universidade Federal de Pernambuco (UFPE). Possui Graduação em Letras com habilitação em Língua Portuguesa pela Universidade Federal de Pernambuco (UFPE). É professora do quadro efetivo da Rede Estadual de Educação, onde atuou na formação de jovens e adultos e no Programa de Educação Integral de Pernambuco (2005-2018). Coordenou o Núcleo de Estudos sobre Gênero e Violência contra a Mulher na Escola de Referência em Ensino Médio Nóbrega em parceria com a Secretaria Estadual da Mulher, (20142016). A partir de 2018, passou a integrar a Coordenadoria do Projeto de Extensão Acadêmica Ouvidoria Coletiva: uma Experiência em Roda de Fogo e a compor as atividades do grupo de Pesquisa GESTOR - Pesquisa em Gestão da Educação e Políticas do Tempo Livre, ambos, vinculados à Universidade Federal de Pernambuco.

BRÁS, Regina Maria: Mestranda do Curso de Ciências da Educação pela Faculdade do Estado do Maranhão (FACEM). Especialista Educação Infantil e Ensino Fundamental pela Faculdade Católica Nossa Senhora das Vitórias/RN. Especialista em Ludopedagógica na Educação Infantil pela Faculdade de Educação e Tecnologia da Região Missioneira/RS (FETREMIS). Especialista em Gestão Escolar e Coordenação Pedagógica pela Faculdade Maciço de Baturité (FMB). Graduada em Pedagogia pela Universidade Estadual Vale do Acaraú/CE (UVA). Professora da Educação Básica dos municípios de Macau/RN e Guamaré/RN.

CAFÉ, Joana Darc De Melo: Mestranda do Curso de Ciências da Educação pelo Centro de Educação Continuada e Aperfeiçoamento Profissional (CECAP). Especialista em Educação Infantil pela Faculdade De Educação Regional Serrana (FUNPAC). Especialista em Educação Infantil e Anos Iniciais Com Ênfase Em Alfabetização e Letramento pela Faculdade De Educação da Serra (FASE). Especialista em Educação Inclusiva pela Faculdade Venda Nova do Imigrante (FAVENI/ES). Especialista em Arte na Educação pela Faculdade de Educação da Serra Fase. Graduada em Licenciatura em Pedagogia pela Universidade do Estado do Rio Grande do Norte (UERN). Atuou como Professora da Educação Básica no Estado do Rio Grande do Norte e no Estado do Espírito Santo.

CARLOS, Camila Ursulla Batista: Mestra em Educação pelo Programa de Pós-Graduação da Universidade Federal do Rio Grande do Norte (UFRN). Especialista 
em Ensino da Educação Física Escolar pela Universidade Federal do Rio Grande do Norte (UFRN). Graduada em Educação Física Universidade Federal do Rio Grande do Norte (UFRN). Membro do Grupo de Estudos Cultura Corporal, Educação e Desenvolvimento Humano (UERN). Pesquisadora da Rede CEDES/RN. Professora do Departamento de Educação Física da UERN, Campus Central. Tem experiência e interesse na área de Educação Física, com ênfase em Educação física escolar, esporte escolar, práticas corporais e lazer.

CORREIA, Júlia Vieira: Mestranda do Curso em Estudos de Linguagem pela Universidade Federal Fluminense (UFF). Especialista em Educação pelo Colégio Pedro II. Estudante do Curso de Especialização em Língua Portuguesa pela Universidade Federal Fluminense (UFF). Graduada em Letras - Português/Literatura (Licenciatura) pela Universidade Federal Fluminense (UFF). Graduação em andamento em Pedagogia pela Universidade Federal do Estado do Rio de Janeiro (UNIRIO). Atuou como Professora residente do Colégio Pedro II/RJ. Professora da rede privada de Niterói/RJ. Tutora da graduação em Letras da Universidade Federal Fluminense (UFF).

DANTAS, Ana Lívia Moura De Paiva: Graduada em Licenciatura em Educação Física pela Universidade do Estado do Rio Grande do Norte (UERN). Egressa do Programa de Residência Pedagógica-RESPED. Monitoria no Laboratório de Alfabetização Motora (LAM). Graduanda do curso de Educação Física (Bacharelado) pela Universidade do Estado do Rio Grande do Norte (UERN). Tem experiência e interesse na área de Educação Física, com ênfase em Educação física escolar.

FAUSTINO, Weverson Waldones: Mestrando do Curso de Ciências da Educação pela Faculdade do Estado do Maranhão (FACEM). Especialista em Língua Brasileira de Sinais (Libras) pela Faculdade do Complexo Educacional Santo André (FACESA). Especialista em Psicopedagogia Clínica, Institucional e Hospitalar pela Faculdade do Complexo Educacional Santo André (FACESA). Especialista em Educação Infantil e Anos iniciais; Especialista em Atendimento Educacional Especializado (AEE) e Educação Inclusiva; Especialista em Coordenação Pedagógica e Gestão Escolar; Especialista em Alfabetização e Letramento, todos pela Faculdade Venda Nova do Imigrante (FAVENI/ES). Graduado em Licenciatura em Pedagogia pela Universidade do Estado do Rio Grande do Norte (UERN). Graduada em Ciências Econômicas pela Universidade do Estado do Rio Grande do Norte (UERN). Lecionou como Professor da Educação Infantil no município Guamaré/RN. Atualmente é Professor dos anos iniciais da Rede Estadual no município de Ipanguaçu/RN.

FERNANDES, Ylka De Carvalho: Especialista em Educação Inclusiva pela Faculdade Kennedy/RN. Graduada em Licenciatura em Pedagogia pela Universidade do Estado do Rio Grande do Norte (UERN). Professora da Educação Básica.

FIGUEIREDO, Nilza Tavares De: Especialista em Educação Infantil pela Universidade Federal do Rio Grande do Norte (UFRN). Especialista em Ludopedagógica na Educação Infantil pela Faculdade de Educação e Tecnologia da Região Missioneira/RS (FETREMIS). Graduada em Licenciatura em Pedagogia pela Universidade Federal do Rio Grande do Norte (UFRN). Professora da Educação Básica dos municípios de Macau/RN e Guamaré/RN. 
FONSECA, Silvinha De Melo: Mestranda do curso de Ciências da Educação pelo Centro de Educação Continuada e Aperfeiçoamento Profissional (CECAP). Especialista em Educação Especial e Inclusiva e Metodologia de Ensino pela Faculdade Venda Nova do Imigrante (FAVENI/ES). Especialista em Psicopedagogia Institucional e Clínica pela Faculdades Integradas de Patos (FIP). Graduada em Licenciatura em Pedagogia pela Universidade Federal do Rio Grande do Norte (UFRN). Professora da Educação Básica dos municípios de Macau/RN e Guamaré/RN.

FREITAS, Dayana Lúcia Rodrigues De: Mestra em Ciências da Educação pelo Centro de Educação Continuada e Aperfeiçoamento Profissional (CECAP). Especialista em Mídias na Educação pela Universidade Estadual do Rio Grande do Norte (UERN). Especialista em Tecnologias Educacionais e Educação a Distância pelo Instituto Federal de Educação Ciências e Tecnologia do Rio Grande do Norte (IFRN). Especialista em Metodologia do ensino de Biologia e Química pelo Instituto Pedagógico de Minas Gerais (IPEMIG/MG). Especialista em Educação Ambiental e Geografia do semiárido pelo Instituto Federal de Educação Ciências e Tecnologia do Rio Grande do Norte (IFRN). Especialista em Ensino de Ciências Naturais e Matemática pelo Instituto Federal de educação Ciências e Tecnologia do Rio Grande do Norte (IFRN). Especialista em Língua Portuguesa, Matemática e Cidadania pelo Instituto Federal de Educação Ciências e Tecnologia do Rio Grande do Norte (IFRN). Graduada em Licenciatura Plena em Biologia pelo Instituto Federal de Educação Ciências e Tecnologia do Rio Grande do Norte (IFRN). Técnica em Meio Ambiente pelo Serviço Nacional de Aprendizagem Comercial (SENAC/RS). Palestrante. Pesquisadora. Professora do curso de Pós-Graduação e Graduação pela Rede Privada. Atuou como professora orientadora de TCC da turma de Pós-Graduação da Rede Privada, Macau/RN. Atua como professora Orientadora de TCC e Orientadora de Estágio da Escola Técnica Fanex Rede de Ensino - Macau/RN. Professora da Educação Básica do município de Guamaré/RN.

GREGÓRIO, Maria Irani: Especialista em Neuropsicopedagogia, Educação Especial e Inclusiva pela Faculdade Venda Nova do Imigrante (FAVENI/ES). Graduada em Pedagogia pela Universidade Estadual Vale do Acaraú/CE (UVA). Professora da Educação Básica do município de Guamaré/RN.

HONORATO, Hercules Guimarães: Doutor e Mestre em Política e Estratégia Marítimas pela Escola de Guerra Naval/RJ (EGN), ambiência do Sistema de Ensino Naval. Mestre em Educação pela Universidade Estácio de Sá (UNESA), na linha de pesquisa de Políticas Públicas e Gestão. Especialista em Logística e Gestão Internacional pelo Instituto COPPEAD de Administração, da Universidade Federal do Rio de Janeiro (UFRJ). Especialista em Docência do Ensino Superior pelo Instituto A Vez do Mestre (AVM) da Universidade Cândido Mendes (UCAM). Bacharel em Ciências Navais, com habilitação em Administração de Sistemas, pela Escola Naval. Oficial da reserva da Marinha do Brasil e ex-professor da Escola Naval, das disciplinas de Metodologia da Pesquisa e Introdução à Logística Naval. Atualmente integrante do corpo docente da Escola Superior de Guerra (ESG). Autor do livro "Relato de uma experiência acadêmica: o 'eu' professor pesquisador”, vol. 1, lançado em 2019, e o vol. 2, no prelo. 
JULIÃO, Márcia Aparecida Da Silva Oliveira: Especialista em Educação Infantil pela Faculdade de Tecnologia Módulo Paulista/SP. Especialista em Gestão Escolar e Coordenação Pedagógica pelo Instituto Superior de Educação de Pesqueira/PE. Especialista em Atendimento Educacional Especializado pela Faculdade Maciço de Baturité (FMB). Graduada em Pedagogia pela Universidade Estadual Vale do Acaraú/CE (UVA). Professora da Educação Básica dos municípios de Macau/RN e Guamaré/RN.

LIMA, Jorge Luís de Freitas: Doutor e Mestre em Sociedade e Cultura na Amazônia pela Universidade Federal do Amazonas (UFAM). Especialista em Linguística Aplicada ao Ensino de Língua Inglesa pela FAP/RO. Possui graduação em Direito pela Universidade Federal de Rondônia (UNIR). Graduado em Letras pela Universidade Federal de Rondônia (UNIR). É docente na Universidade Federal do Amazonas (UFAM) no Instituto de Natureza e Cultura (INC). Exerceu atividade docente na área de Língua Portuguesa no ensino fundamental e médio por mais de vinte anos. Foi docente de Língua Portuguesa e Metodologia da Pesquisa nos cursos de graduação (Letras, Direito, Pedagogia, Ciências Contábeis, Administração de Empresas, Economia, Sistemas de Informação e Psicologia) e especialização das Faculdades Integradas de Cacoal/UNESC. Exerceu a docência como professor substituto nos cursos de graduação na Universidade Federal de Rondônia, campus de Cacoal-RO. Como pesquisador tem desenvolvido pesquisas nos seguintes temas: Linguística Aplicada, formação de professores e Processos Socioculturais em Regiões de Fronteira, com ênfase na região amazônica. Exerceu a função de Coordenador Acadêmico do Instituto de Natureza e Cultura da Universidade Federal do Amazonas (INC/UFAM) no quadriênio 2010-2014. Foi Coordenador de área do subprojeto de Língua Portuguesa do Programa Institucional Bolsa de Iniciação à Docência PIBID no Instituto de Natureza e Cultura da Universidade Federal do Amazonas por 4 anos. Tem publicações de livro e capítulos, bem como artigos em revista científica e em anais de congressos na área de Letras e Linguística, educação e estudos fronteiriços. Poeta e membro fundador da Academia de Letras de Cacoal/RO. Atualmente, exerce a função de coordenador do Curso de Letras do Instituto de Natureza e Cultura (INC) da Universidade Federal do Amazonas (UFAM) e atua como membro da Câmara de Ensino de Graduação da Universidade Federal do Amazonas. É vice-líder do grupo de Pesquisa Práticas Discursivas na Amazônia CNPq/IFRO. Pesquisador do grupo de pesquisa Infâncias, Criança e Educação na Fronteira Amazônica CNPq/UFAM e pesquisador no grupo de pesquisa Observatório de Ensino de Línguas da Universidade Federal do Amazonas CNPq/UFAM.

LOPES, Francisca Patrícia Da Silva: Acadêmica do Curso de graduação em Enfermagem da Universidade Federal de Campina Grande (UFCG). Pesquisadora do Programa de Voluntários de Iniciação Científica (PIVIC) nas áreas de educação, Psicologia e desenvolvimento humano. Membro da Linha de Pesquisa Tecnologias Cuidativo-Educacionais na Infância e Adolescência do Laboratório de Tecnologias de Informação e Comunicação em Saúde (LATICS) da Universidade Federal de Campina Grande (UFCG-Cajazeiras). ORCID: 0000-0002-7478-7358.

MASSAGLI, Silvia Carla Conceição: Doutora em educação pela Faculdade de Educação da Universidade de São Paulo (FEUSP). Mestra em Psicologia Escolar e do 
Desenvolvimento Humano pelo Instituto de Psicologia da Universidade de São Paulo (IPUSP). Licenciada em Psicologia e Pedagogia. Professora Adjunta de Psicologia da Educação nos cursos de Licenciatura da Universidade Federal da Fronteira Sul (UFFSLaranjeiras do Sul). Coordenadora da Linha de Pesquisa Tecnologias CuidativoEducacionais na Infância e Adolescência do Laboratório de Tecnologias de Informação e Comunicação em Saúde (LATICS) da Universidade Federal de Campina Grande (UFCG-Cajazeiras). ORCID: 0000-0003-3608-4261.

MELO, Janelene Rita Teixeira de: Mestranda no curso de Ciências da Educação pela Faculdade do Estado do Maranhão (FACEM). Especialista em Atendimento Educacional Especializado (AEE) pela Faculdade Do Vale Elvira Dayrell/MG. Especialista em Psicopedagogia pela Universidade Vale Do Acaraú/CE (UVA). Graduada em Pedagogia pela Universidade Vale Do Acaraú/CE (UVA). Professora da Educação Básica do município de Guamaré/RN.

MELO, Manoel Gilvan De: Mestrando do curso de Ciências da Educação pelo Centro de Educação Continuada e Aperfeiçoamento Profissional (CECAP). Especialista em Matemática pela Faculdade da Aldeia de Carapicuíba (FALC). Licenciado em Matemática pela Universidade do Estado do Rio Grande do Norte (UERN). Graduando em Pedagogia pela Faculdade Complexo Educacional Santo André (FACESA). Exerceu cargo de Gestor escolar no município de Ipanguaçu/RN. Atualmente é professor efetivo dos Municípios de Itajá/RN e Ipanguaçu/RN.

NASCIMENTO, Kamila Alkmim: Especialista em Filosofia e Sociologia pela Faculdade FARESE. Especialista em Direito Público Material pela Universidade Gama Filho/RJ. Possui MBA em Gestão em Segurança pela Faculdade Boas Novas/AM. Bacharel em Direito pelas Faculdades Integradas Pitágoras/MG. Bacharel em Ciências Militares e Segurança Pública pela Universidade Estadual do Amazonas (UEA). Graduação em Pedagogia pela Faculdade de Administração, Ciências, Educação e Letras (FACEL). Atualmente é Oficial da Polícia Militar do Estado do Amazonas.

NASCIMENTO, Lidja Caroline Do: Licenciada em Educação Física pela Universidade do Estado do Rio Grande do Norte (UFRN). Graduanda do curso de Bacharel em Educação Física, na Universidade do Estado do Rio Grande do Norte (UFRN). Técnica em Radiologia pela Universidade Potiguar (UNP). Atualmente trabalha com projetos na área de Educação e gênero, além de assistência terapêutica no Método Denver de Intervenção Precoce. Possui experiência com dança, psicomotricidade e autismo.

NEVES, Magda Lúcia: Especialista em Alfabetização e Letramento pelo Instituto Superior de Educação Elvira Dayrell/MG. Especialista em Educação Ambiental e Geografia do Semiárido pelo Instituto Federal de Educação Ciências e Tecnologia do Rio Grande do Norte - IFRN. Especialista em Educação Infantil e Anos Iniciais pela Faculdade de Educação e Tecnologia da Região Missioneira/RS (FETREMIS). Especialista em Psicopedagogia pelo Instituto Superior de Educação Elvira Dayrell/MG. Licenciada em Pedagogia pela Universidade do Estado do Rio Grande do Norte (UFRN). Professora da Educação Básica do município de Guamaré/RN. 
NEVES, Maria Inês Branquinho Da Costa: Mestra em Direito com especialização em Direito Internacional e Europeu pela Universidade Católica do Porto (Portugal). Formada em Direito pela Universidade de Coimbra (Portugal). O seu trabalho enquanto jurista foca-se no estudo da proteção dada ao meio ambiente ou, como prefere, à Natureza, pelo Direito. Na sua Dissertação de Mestrado explorou o que representa uma mudança radical do paradigma dominante ocidental de direito, que é antropocêntrico: os Direitos da Natureza.

NOGUEIRA, Josefa Uérica De Araujo: Mestranda do Programa de Pósgraduação em Educação da Universidade Federal de Pernambuco (UFPE), na linha de pesquisa: Política Educacional, Planejamento e Gestão da Educação. Graduada em Licenciatura em Educação Física pela Universidade Federal de Pernambuco (CAV/UFPE), tendo obtido láurea Universitária. Participante do grupo de Pesquisa GESTOR - Pesquisa em Gestão da Educação e Políticas do Tempo Livre, vinculado ao CNPq. Atualmente, servidora pública da Rede Estadual de Educação de Pernambuco na qualidade de Professora efetiva de Educação Física.

OLIVEIRA JÚNIOR, Alexandre Tiago De: Acadêmico do curso de graduação em Enfermagem da Universidade Federal de Campina Grande (UFCG). Membro da Linha de Pesquisa Tecnologias Cuidativo-Educacionais na Infância e Adolescência do Laboratório de Tecnologias de Informação e Comunicação em Saúde (LATICS) da Universidade Federal de Campina Grande (UFCG-Cajazeiras). ORCID: 0000-0003-3615-5293.

OLIVEIRA NETO, Benjamim Machado De: Especialista em Psicopedagogia Clínica e Institucional pela Faculdade Kurius (FAK/CE). Especialista em Gestão Escolar e Coordenação Pedagógica pela Instituição Kurius (FAK/CE). Bacharel em Direito pela Faculdade Católica Rainha do Sertão (Unicatólica/CE). Graduado em Licenciatura Plena em Pedagogia pela Universidade Estadual do Ceará (UECE). Desenvolve pesquisas na esfera do Direito, da Educação e da Psicologia. Áreas de atuação: Educação Infantil; Psicologia da Educação; Psicopedagogia Clínica e Institucional; Gestão e Coordenação Escolar; Avaliação Educacional; Metodologia da Pesquisa Científica; Teoria e Prática do Currículo Escolar; Didática Geral; Estágio Supervisionado; Direito Penal; Direito Processual Penal; Direito da Criança e do Adolescente; Direito da Família; Direito do Consumidor; Direito Administrativo; Direito Eleitoral; Psicologia Jurídica. Educador; Pesquisador; Pedagogo; Psicopedagogo; Escritor; Palestrante; Consultor Acadêmico, Pedagógico e Psicopedagógico.

OLIVEIRA, Glycia Melo De: Mestra em Educação Física pelo Programa Associado de Pós-Graduação da Universidade de Pernambuco e Universidade Federal da Paraíba. Especialista em Corpo e Cultura de Movimento pela Universidade Federal do Rio Grande do Norte (UFRN). Graduada em Educação Física pela Universidade Federal do Rio Grande do Norte (UFRN). Docente da Universidade do Estado do Rio Grande do Norte (UERN/FAEF). Membro do Grupo de Pesquisa Cultura Corporal, Educação e Desenvolvimento Humano (UERN) e do Grupo de Pesquisa Corpo, Educação e Linguagens (UEPB). Pesquisadora da Rede CEDES/RN. Tem experiência na área de Educação Física, com ênfase em Educação Física Escolar. 
OLIVEIRA, Vanessa Maria Araújo De: Graduada em Licenciatura em Pedagogia pela Universidade Estadual do Ceará (UECE). Atuou como bolsista do CEI Antônio Valdinar De Carvalho Custódio - CEI/CE. Professora da Educação Básica/CE.

PASSOS, Geillany Aurina Da Silva: Especialista em Educação Infantil pela Faculdade de Tecnologia Módulo Paulista/SP. Especialista em Gestão Escolar e Coordenação Pedagógica pelo Instituto de Educação de Pesqueira/PE. Graduada em Licenciatura em Pedagogia pela Universidade Estadual Vale do Acaraú/CE (UVA). Professora da Educação Básica.

SANTOS, Maria Da Conceição Dos: Especialista em Estudo da Língua Portuguesa pela Faculdade Venda Nova do Imigrante (FAVENI/ES). Especialista em Língua Portuguesa e Literatura Brasileira pela Faculdade Futura/SP. Especialista em Língua Brasileira de Sinais (Libras) pelo Instituto Superior de Educação de Pesqueira/PE. Graduada em Licenciatura em Letras pela Universidade do Estado do Rio Grande do Norte (UERN). Atualmente, leciona nos municípios de Guamaré/RN e Galinhos/RN exercendo a função de Professora de Língua Portuguesa com alunos de Ensino Fundamental II e Educação de Jovens e Adultos - EJA.

SATT, Jorge Antônio De Oliveira: Mestre em Educação Ambiental pelo Programa de Pós Graduação em Educação Ambiental da Universidade Federal do Rio Grande (UFRN). Especialista em Supervisão Escolar pela Escola Superior Aberta do Brasil (ESAB). Especialista através do curso de pós-graduação Formação de Professores na Narrativa da Docência. Graduado em História Licenciatura Plena pela Fundação Universidade Federal do Rio Grande (FURG). É professor da rede pública municipal e estadual de ensino da cidade do Rio Grande/RS. Atualmente desempenha a função de Diretor da Escola Municipal de Ensino Fundamental Prof. João de Oliveira Martins. Os trabalhos de pesquisa mais recentes estão embasados na metodologia das Histórias de vida, com ênfase na pesquisa narrativa de cunho autobiográfico e as contribuições desta para a formação de professores. Atua também em Programas, Projetos e Grupos de Pesquisa sobre a Formação Continuada de Professores e de Gestores Escolares.

SILVA, Anailde Varela Da: Especialista em Educação Ludopedagógica pela Faculdade do Vale Elivira Dayrell/MG. Especialista em Língua Brasileira de Sinais (Libras) pela Faculdade do Vale Elivira Dayrell/MG. Especialista em Educação Infantil pela Universidade Federal do Rio Grande do Norte (UFRN). Graduada em Licenciatura em Pedagogia pela Universidade Federal do Rio Grande do Norte (UFRN). Professora Aposentada da Educação Básica do município de Macau/RN; Professora da Educação Básica do município de Guamaré/RN.

SILVA, Daiane Leal Da: Especialista em Educação Infantil e Anos Iniciais pelo Centro Universitário Leonardo da Vinci/SC. Pedagoga pela Universidade Federal do Rio Grande (FURG- RS). Formação inicial no Magistério pelo Instituto de Educação Juvenal Muller - Rio Grande/RS. Atualmente é professora na Escola Municipal de Ensino Fundamental Professor João de Oliveira Martins/RS, nos Anos Iniciais. 
SILVA, Francisco Clécio Araújo: Especialista em Educação Infantil pela Faculdades Integradas de Patos/CE (FIP). Graduado em Licenciatura Plena e Pedagogia pela Universidade Estadual Vale do Acaraú/CE (UVA). Professor de Educação Básica do município de Guamaré/RN.

SILVA, Francisco Mário Carneiro Da: Graduando do Curso de Pedagogia pela Universidade Estadual do Ceará (UFCE). Foi integrante do Programa de Ensino Tutorial vinculado ao curso de Pedagogia da Universidade Estadual do Ceará (UFCE). Desempenha atividades de Ensino, Pesquisa e extensão.

SILVA, Ida Letícia Gautério Da: Mestra em Educação Ambiental pela Universidade Federal do Rio Grande (FURG/RS). Química Licenciada com habilitação em Ciências pela Universidade Federal do Rio Grande (FURG/RS). Atualmente professora de Ciências dos Anos Finais na EMEF Dom Frederico Didonet em São José do Norte/RS. Já atuou como coordenadora pedagógica na EMEF Prof. João de Oliveira Martins onde atualmente atua como Vice- Diretora.

SILVA, Jamerson Antônio De Almeida Da: Pós-Doutor pela Universidade do Estado do Rio de Janeiro (UERJ). Doutor em Educação pela Universidade Federal da Bahia (UFBA). Mestre em Educação pela Universidade Federal de Pernambuco (UFPE). Graduado em Educação Física pela Universidade de Pernambuco (UPE). Membro permanente do Programa de Pós-Graduação em Educação (UFPE/CE), Núcleo de Política Educacional, Planejamento e Gestão da Educação. Membro permanente do Programa de Pós-Graduação em Educação (UFPE/ CAA), Linha de Pesquisa Educação, Estado e Sociedade. Professor Associado 2 do Curso de Pedagogia da UFPE/ CAA/ NFD. No âmbito da graduação ministra as seguintes disciplinas: Estado, Política e Educação; Organização Educacional e Gestão da Educação; Legislação e Financiamento da Educação. É líder do grupo de Pesquisa GESTOR - Pesquisa em Gestão da Educação e Políticas do Tempo Livre e pesquisador do CNPq. Coordenou as pesquisas: Jovens e Educação Integral no Ensino Médio: analisando programas em implementação no Estado de Pernambuco, a partir do novo ordenamento legal do Estado Brasileiro (CNPq, Edital de Ciências Humanas - 2012-2015) e Educação Integral no contexto da intersetorialidade: avaliando o Programa Mais Educação em Pernambuco (CNPq, Edital de Ciências Humanas - 2009-2012). Também possui experiência em gestão pública nas áreas de Educação, Esporte e Lazer, tendo sido Diretor Geral de Esporte da Prefeitura do Recife (2001 a 2004), Diretor Presidente da Autarquia Ginásio de Esportes Geraldo Magalhães da Prefeitura do Recife (2007 a 2008). Publicou artigos nos seguintes periódicos: Educação em Revista (2014); Revista Práxis Educativa (2014); Revista Brasileira de Estudos Pedagógicos RBEP INEP (2013); Germinal: Marxismo e Educação em Debate (2013) e outros. Publicou, em coautoria, os livros: Educação Integral no Brasil de Hoje. Curitiba: Editora CRV, 2012 e Círculos Populares de Esporte e Lazer - por uma educação no e para o tempo livre. Recife: Bagaço, 2004. Organizou o livro Recreação, Esporte e Lazer - Espaço, Tempo e Atitude. Recife: Instituto Tempo Live, 2007, além de ter publicado vários capítulos de livros.

SILVA, João Carlos Marinho da: Mestrando no curso de Ciências da Educação pelo Programa de Mestrado Internacional da University Grendal (EUA). 
Especialista em Psicologia da Educação pela Universidade Estadual do Maranhão (UEMA). Especialista em História e Cultura Afro-Brasileira pela Faculdade de Tecnologia Antonio Propício Aguiar Franco (FAPAF/SP). Especialista em Metodologia do Ensino de Filosofia e Sociologia pela Faculdade de Ciências de Wenceslau Braz/PR. Possui graduação em Filosofia pela Universidade Estadual do Maranhão (UEMA). Graduado em História pela Universidade Estadual do Maranhão (UEMA). Professor do Ensino Fundamental e Médio. Tem experiência na área de História, com ênfase em Cultura Africana e Afro-Brasileira. Tem experiência na área de Filosofia, com ênfase em Existencialismo de Jean-Paul Sartre. Psicanalista Clínico - SBPMA.

SILVA, Johnny Jonas Do Nascimento: Estudante do curso de Especialização do Ensino de Música em Múltiplos Contextos pela Universidade Federal do Rio Grande do Norte (UFRN). Estudante do curso de Especialização em Metodologia do Ensino de Música pela Faculdade UniBF. Técnico em Guitarra Elétrica pela Universidade Federal do Rio Grande do Norte (UFRN). Técnico em Violão Popular pela Universidade Federal do Rio Grande do Norte (UFRN). Graduado em Educação Musical pela Universidade Federal do Rio Grande do Norte (UFRN). Professor de música do Centro Suzuki de Natal/RN. Professor de música pela Prefeitura do município de Guamaré/RN. Professor de Guitarra e teoria musical da Escola Bateras Beat Music School em Natal/RN. Arranjador e produtor musical. Tem experiência na área de Artes, com ênfase em Educação Musical.

SILVA, Josevane Francisco Da: Mestrando Profissional do Curso de História pela Universidade Católica de Pernambuco (UNICAP). Especialista em Metodologia do Ensino Superior pela Universidade Mauricio de Nassau/PB. Bacharel em Serviço Social pela Universidade Norte do Paraná (UNOPAR). Atualmente, professor do Curso de Serviço Social da Universidade Norte do Paraná, pólo Recife/PE.

SILVA, Rozenilda Maria Silva Da: Mestranda do curso de Ciências da Educação pelo Centro de Educação Continuada e Aperfeiçoamento Profissional (CECAP). Especialista em Formação de Professores pela Universidade do Estado do Rio Grande do Norte (UERN). Especialista em Educação Especial e Inclusiva com ênfase em deficiências pela Faculdade Futura/SP. Especialista em Psicopedagogia Institucional e Clínica pela Faculdade Futura/SP. Licenciada Em Pedagogia pela Universidade do Estado do Rio Grande do Norte (UERN). Professora da Educação Básica dos municípios de Guamaré/RN e Assú/RN.

SILVA, Selma Gomes Da: Estudante do Curso de Especialização em Ensino De Ciências pela Faculdade Venda Nova do Imigrante (FAVENI/ES). Graduanda do Curso de Ciências Biológicas pela Universidade Federal do Rio Grande do Norte (UFRN). Participou do Projeto de Pesquisa dos manguezais pela Universidade Federal do Rio Grande do Norte (UFRN). Professora estagiária da Educação Básica do município de Guamaré/RN.

SIMÃO, Gleice Kelly Freire: Mestranda no curso de Ciências da Educação pelo Centro de Educação Continuada e Aperfeiçoamento Profissional (CECAP). Especialista em Psicopedagogia Institucional e Clínica pelo Instituto Superior de Educação de Pesquisa (ISEP/CE). Especialista em Alfabetização e Letramento Pela 
Faculdade Futura, mantida pelo Instituto de Ciência, Educação e Tecnologia de Votuporanga/SP. Especialista em Educação Infantil e Anos Iniciais pela Faculdade de Venda Nova do Imigrante (FAVENI/ES). Especialista em Educação Especial e Inclusiva com Ênfase em Deficiência Intelectual e Múltipla pela Faculdade Futura/SP. Graduada em Licenciatura Plena em Pedagogia pela Universidade Estadual Vale do Acaraú/CE (UVA). Professora da Educação Básica do município de Pendências/RN.

SIMÃO, Gleika Magaly Freire: Mestranda no curso de Ciências da Educação pelo Centro de Educação Continuada e Aperfeiçoamento Profissional (CECAP). Especialista em Gestão Escolar e Administrativa pela Faculdade de Venda Nova do Imigrante (FAVENI/ES). Especialista em Metodologia do Ensino de Língua Inglesa pela Faculdade de Venda Nova do Imigrante (FAVENI/ES). Especialista em Ensino de Língua Inglesa pela Faculdade de Venda Nova do Imigrante (FAVENI/ES). Licenciada em Letras com habilitação em Língua Inglesa pela Universidade Estadual do Rio Grande do Norte (UERN). Professora da Educação Básica do município de Pendências/RN e Guamaré/RN.

SOUSA, Jefferson Martins De: Licenciado em Educação Física pela Universidade do Estado do Rio Grande do Norte (UFRN). Docente Efetivo da Rede Municipal de Ensino da cidade de Patos/PB e, também, da Rede Estadual de Ensino do Governo do Estado da Paraíba com lotação no município de Sousa/PB. Experiência em educação infantil e fundamental e trabalhos com crianças dotadas de necessidades educativas especiais - especialmente TEA, e em treinamento anaeróbico.

SOUSA, Josélia Isidio Rodrigues De: Especialista em Alfabetização e Letramento pelo Instituto Faculdade Venda Nova do Imigrante (FAVENI/ES). Especialista em Educação Infantil e Anos Iniciais pela Faculdade Futura/SP. Especialista em Educação e Sustentabilidade em Unidade de Conservação). Graduada em Licenciatura em Pedagogia pela Universidade do Estado do Rio Grande do Norte (UFRN). Atualmente, leciona nos municípios de Guamaré/RN e Macau/RN exercendo a função de Professora Polivalente com alunos de Ensino Fundamental Nível I.

SOUSA, Paulo Ricardo Cordeiro De: Acadêmico do Curso de graduação em Enfermagem da Universidade Federal de Campina Grande (UFCG). Membro da Linha de Pesquisa Tecnologias Cuidativo-Educacionais na Infância e Adolescência do Laboratório de Tecnologias de Informação e Comunicação em Saúde (LATICS) da Universidade Federal de Campina Grande (UFCG-Cajazeiras). ORCID:0000-00018139-3616.

SOUZA, Idayane Carla De: Mestranda em Ciências da Educação pelo Centro de Educação Continuada e Aperfeiçoamento Profissional (CECAP). Especialista Em Língua Brasileira de Sinais (Libras) pela Faculdade Venda Nova do Imigrante (FAVENI/ES). Especialista em Psicopedagogia com educação especial pela Faculdade Venda Nova do Imigrante (FAVENI/ES). Especialista Atendimento Educacional Especializado (AEE) pela Faculdade Venda Nova do Imigrante (FAVENI/ES). Graduada em Licenciatura em Pedagogia pela Faculdade do Maciço de Baturité (FMB). Professora de Educação Especial no município de Guamaré/RN e Professora de Atendimento Educacional Especializado no município do Alto do Rodrigues/RN. 
VALE, Francisca Antonia De Souza: Especialista em Psicopedagogia Clínica e Institucional pelo Instituto de Educação de Pesqueira/PE. Especialista em Gestão Educacional e criatividade na solução de desafios pela Faculdades Integradas de Patos (FIP). Possui Aperfeiçoamento em Atendimento Educacional Especializado (AEE) pela Faculdade Metropolitana/SP. Graduada em Licenciatura em Pedagogia pela Universidade Federal do Rio Grande do Norte (UFRN). Professora Auxiliar de Educação Especial no município de Guamaré/RN.

VIEIRA, Menetem Ferreira: Especialista em Educação de Jovens e Adultos pela Universidade do Paraná (UNOPAR). Pedagoga pela Universidade Federal de Pelotas, UFPEL/RS. Atualmente é coordenadora dos Anos Finais na Escola Municipal de Ensino Fundamental Professor João de Oliveira Martins/RS.

VIRGíNIO, Regina Maria Araújo: Mestranda em Ciências da educação pelo Centro de Educação Continuada e Aperfeiçoamento Profissional (CECAP). Especialista em Gestão Escolar e Coordenação Pedagógica pelo Instituto Superior de Educação de Pesqueira/PE. Graduada em Pedagogia pela Universidade Estadual Vale do Acaraú/CE (UVA). Professora da Educação Básica do município de Guamaré/RN. 